The topic of evolution and its potential clash with the mainstream teachings of Islam is one of the most contentious and charged issues of our times. How does a person of faith who also respects science reconcile between what science has almost definitively concluded as a fact with the claims of truth made by the Quran? In this comprehensive and highly readable monograph, Shoaib Ahmed Malik has done a commendable job of summarising the various approaches taken by modern Muslim thinkers. The text is accessible to even non-specialists and has enough in-depth analysis to be of interest to specialists in science and religion, theology, and philosophy. I believe this work is essential reading for anyone interested in the topic of Islam and evolution.

Dr. Yasir Qadhi, The Islamic Seminary of America, USA

Evolution has presented a serious challenge to traditional Abrahamic faiths. The responses have too often fallen short of the rigours exhibited by modern science and the resulting assertions of evolutionists. Here is a serious Muslim response by Shoaib Ahmed Malik who understands that the science of evolution and the faith of Islam and has no difficulty straddling both worlds without losing his faith in either.

Dr. Hamza Yusuf, Zaytuna College, USA

Shoaib Ahmed Malik's work is timely, thought-provoking, and stimulating. He marries the classical, theological framework of Ash'arism and modern evolution. The book's focus on the metaphysical and hermeneutic approaches of al-Ghazālī, a globally known Muslim figure, will fill a huge gap in the literature and answer the many questions in the public's mind and academia on the status of evolutionary thought in Islam. Malik's book is a well-written, exemplary work for scholars from a wide range of disciplines who wish to explore evolution in other Sunn̄̄, Shi ì̃, and Ismā̄îlī theological schools, among others.

Dr. Majid Daneshgar, University of Freiburg, Germany

Evolution is one of the most discussed and misrepresented theories among Muslims today. The discussions are usually motivated by emotional reactions, which only obscures the debate's multi-faceted nature and prevents us from seeing what the problem really is. To analyse the link between evolution and Islam carefully, one must differentiate the scientific foundation of evolution from its various philosophical glosses and have a consistent methodology for interpreting religious texts. Only with such sensitivity can one discuss to what extent evolution and Islam are compatible. Shoaib Ahmed Malik's book is an outstanding 
contribution to this debate/question while exemplifying the required sensitivity. He takes one of the giants of Islamic intellectual history, al-Ghazālī, and analyses the issue in terms of his commitments in metaphysics and hermeneutics. Thus, he gives life to a medieval thinker's ideas and brings him into dialogue with a contemporary problem. The result is a text that is a rare example of multi-faceted, critical, and innovative thinking.

Dr. Nazif Muhtaroğlu, Bahcesehir University, Turkey

This fascinating book is a pivotal source for anyone interested in Islam and evolution debate. Shoaib Ahmed Malik, first, provides careful, nuanced, and comprehensive examination of contemporary landscape of ideas on this important debate. Then, he presents his own fresh and thought-provoking perspective on whether a reconciliation between Islam and evolution can be reached by starting from the general principles of Ash'arite school al-Ghazālī's thought. Tracing the implications of medieval Islamic thought for a contemporary discussion is difficult and complex. Malik's book masterfully navigates the challenges and demands of this task.

Dr. Özgür Koca, Claremont School of Theology, USA

Shoaib Ahmed Malik's book is one of the very rare works that takes an accurate understanding of evolutionary biology and engages with is it according to the terms of the Islamic tradition (in this case, the Ash arite theology of al-Ghazālī) to determine what a viable faithbased stance could be. Rigorously researched, it explores with sensitivity the genuine theological issues that are confronted when biological evolution is considered in a religious light. It is indispensable reading on the subject.

Dr. David Solomon Jalajel, Prince Sultan Research Institute, Saudi Arabia

Evolution has been a dynamite in the science-and-religion debate since the time of Darwin, in spite of many serious and intelligent proposals to resolve the problems. Here is one of the most serious and intelligent yet. Shoaib Ahmed Malik makes a highly original case for peace by examining the foundational Muslim thinker, al-Ghazālī, and showing how his thought can shed light where so far there has been much heat. This is a book which all theists who are worried about the evolution wars need to read.

Prof. Mark Harris, University of Edinburgh, UK 
Sometimes a book is a total revelation. You realise just how very much you did not know. Those of us who work on the science-religion discourse too often assume that all of the Abrahamic religions - Judaism, Christianity, Islam - present the same challenges and opportunities. Shoaib Ahmed Malik's remarkable book, Islam and Evolution: Al-Ghazāli and the Modern Evolutionary Paradigm, shows how very wrong we have been. In clear, careful, non-condescending language, Malik teaches us about Islam and its varieties, and the challenges posed by modern evolutionary science. He writes in a constructive and confident manner, not avoiding problems, but showing how there is much for all of us to learn, and leads us from the narrow, Eurocentric vision that restricts so much of our thinking.

Prof. Michael Ruse, Florida State University, USA

For many writers on Islam and science, the medieval scholar and theologian al-Ghazāli is associated with a theory of causality inimical to the requirements of modern science. In exploring the scope for compatibility between Islam and the science of evolution, Shoaib Ahmed Malik takes a very different view, contending that the metaphysics and hermeneutics of al-Ghazāi permit the acceptance of much of the modern evolutionary narrative - with the critical exception of wholly naturalistic accounts of the origins of a unique and parentless Adam. I gladly recommend his book because it also paves the way for serious comparative studies of the receptivity of Islamic and Christian cultures to scientific innovation.

Prof. John Hedley Brooke, University of Oxford, UK 


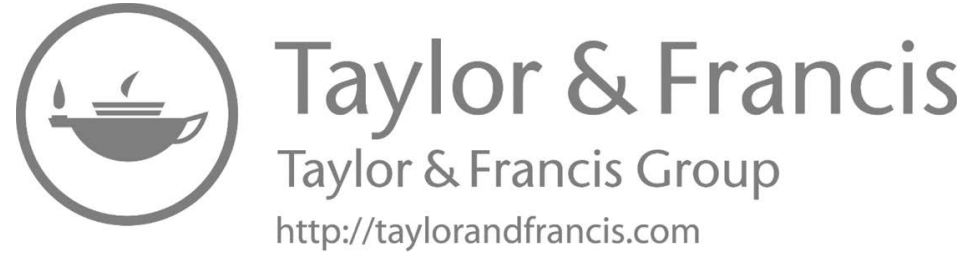




\section{Islam and Evolution}

This book attempts to equip the reader with a holistic and accessible account of Islam and evolution. It guides the reader through the different variables that have played a part in the ongoing dialogue between Muslim creationists and evolutionists.

This work views the discussion through the lens of al-Ghazāli (1058-1111), a widely known and well-respected Islamic intellectual from the medieval period. By understanding al-Ghazālī as an Ash'arite theologian, a particular strand of Sunnī theology, his metaphysical and hermeneutic ideas are taken to explore if and how much Neo-Darwinian evolution can be accepted. It is shown that his framework can be used to reach an alignment between Islam and Neo-Darwinian evolution.

This book offers a detailed examination that seeks to offer clarity if not agreement in the midst of an intense intellectual conflict and polarity amongst Muslims. As such, it will be of great interest to scholars of Science and Religion, Theology, Philosophy of Religion, Islamic Studies, and Religious Studies more generally.

Shoaib Ahmed Malik is an Assistant Professor of the Natural Sciences at Zayed University, Dubai. He researches exclusively on the topics of science and religion, atheism, and Islamic theology. He is the author of Atheism and Islam: A Contemporary Discourse (2018), and has book chapters and articles with various publishers and journals. 


\section{Routledge Science and Religion Series}

Series editors:

Michael S. Burdett, University of Nottingham, UK

Mark Harris, University of Edinburgh, UK

Science and religion have often been thought to be at loggerheads but much contemporary work in this flourishing interdisciplinary field suggests this is far from the case. The Science and Religion Series presents exciting new work to advance interdisciplinary study, research, and debate across key themes in science and religion. Contemporary issues in philosophy and theology are debated, as are prevailing cultural assumptions. The series enables leading international authors from a range of different disciplinary perspectives to apply the insights of the various sciences, theology, philosophy, and history in order to look at the relations between the different disciplines and the connections that can be made between them. These accessible, stimulating new contributions to key topics across science and religion will appeal particularly to individual academics and researchers, graduates, postgraduates, and upper-undergraduate students.

God, Evolution, and Animal Suffering

Theodicy without a Fall

Bethany N. Sollereder

Ramified Natural Theology in Science and Religion

Moving Forward from Natural Theology

Rodney Holder

Intersections of Religion and Astronomy

Edited by Aaron Ricker, Christopher J. Corbally, and Darry Dinnell

Divine and Human Providence

Philosophical, Psychological, and Theological Approaches

Edited by Ignacio Silva and Simon Maria Kopf

\section{Islam and Evolution}

Al-Ghazālī and the Modern Evolutionary Paradigm

Shoaib Ahmed Malik

For more information and a full list of titles in the series, please visit: https://www.routledge.com/religion/series/ASCIREL 


\section{Islam and Evolution}

Al-Ghazālī and the Modern Evolutionary Paradigm

\section{Shoaib Ahmed Malik}


First published 2021

by Routledge

2 Park Square, Milton Park, Abingdon, Oxon OX14 4RN

and by Routledge

605 Third Avenue, New York, NY 10158

Routledge is an imprint of the Taylor \& Francis Group, an informa business

(C) 2021 Shoaib Ahmed Malik

The right of Shoaib Ahmed Malik to be identified as author of this work has been asserted by him in accordance with sections 77 and 78 of the Copyright, Designs, and Patents Act 1988.

The Open Access version of this book, available at www.taylorfrancis.com, has been made available under a Creative Commons Attribution-Non Commercial-No Derivatives 4.0 license.

Trademark notice: Product or corporate names may be trademarks or registered trademarks, and are used only for identification and explanation without intent to infringe.

British Library Cataloguing-in-Publication Data

A catalogue record for this book is available from the British Library

Library of Congress Cataloging-in-Publication Data

A catalog record has been requested for this book

ISBN: 9780367364137 (hbk)

ISBN: $9781032026572(\mathrm{pbk})$

ISBN: 9780429345753 (ebk)

Typeset in Sabon

by KnowledgeWorks Global Ltd. 
"The definitive obligation in [investigating] the foundations of belief is to maintain moderation and steadiness on the straight path, for either extreme in pursuing the matter is reprehensible."

Abū Ḥāmid al-Ghazālī 
Dedicated to my beloved wife and son 


\section{Contents}

Acknowledgements xiii

Transliteration, Referencing, and Reused Material xv

Introduction 1

PART 1

$\begin{array}{ll}\text { Setting the context } & 19\end{array}$

1 What evolution is and isn't 21

2 Christian responses to evolution 66

PART 2

Islamic perspectives on evolution $\quad 85$

3 Islamic scripture and evolution $\quad 87$

4 Muslim opinions on evolution 106

5 Old texts, new masks: misreading evolution onto historical Islamic texts

PART 3

Metaphysical considerations

6 Chance, naturalism, and inefficiency 179

7 Intelligent design $\quad 212$

8 Morality and evolution 237 
xii Contents

PART 4

Hermeneutic considerations

9 Al-Ghazālī's hermeneutics 267

10 Creationism or evolution in Islamic scripture? 296

Conclusion $\quad 338$

Index 344 


\section{Acknowledgements}

This was a colossal project and could not have been possible without the help, encouragement, constructive feedback, and incredible discussions that I've had with so many people over the past few years. These include Usman Ali, Hamid Mahmood, Sohaib Saeed, Safaruk Chowdhury, Marzuqa Akrima, Edward Moad, Malek Zuaiter, Moamer Yahia Ali Khalayleh, Nadda Khan, Sara Sherbaji, Nour Skaf, Abbas Ahsan, Nidhal Guessoum, Rana Dajani, Mehmet Bulgen, Enis Doko, Caner Taslaman, Kelly James Clark, Jeffrey Koperski, Sajjad Rizvi, Martin Whittingham, Abdullah Galadari, Nazir Khan, Yasir Qadhi, Sarah Qidwai, Glen Moran, Jamie Turner, Carl Sharif El-Tobgui, Ramon Harvey, Majid Daneshgar, Michael Ruse, John Hedley Brooke, Alan C. Love, Derek Turner, Laura Hassan, Özgür Koca, Joseph Lumbard, Hira Amin, Elvira Kulieva, Rezart Beka, Shams Ad-Duha Muhammad, Muntasir Zaman, Imran Iqbal, Sarah Lane Ritchie, Jamie Collin, and Joshua Ralston.

During the course of writing this book, I have been sharing and discussing my ideas on several online platforms. Participants, who are too simply many to mention, have either directly or indirectly helped me refine my points as I deliberated over the ideas for this project. There are also numerous instances where people flew into Dubai from various countries and were able to bring several materials that were not available in my immediate vicinity. Appreciably, some kind souls - you know who are - also sent me copies of what are otherwise rare, out-of-print materials that were crucial for my work. I thank you all for your help, kindness, and fruitful engagement.

The diagrams that I felt were necessary for this project are all thanks to Muhammad Rusydi Azmi. He was exceedingly tolerant with the constant iterations that I requested during the course of this undertaking. I am also grateful to Routledge and its editors, Rebecca Shillabeer and R Yuga Harini, for their patience and helping me get this book to completion. I am also very thankful to my friend, who wishes to remain anonymous, for making this work open access. I cannot thank you enough for making this book accessible to the world. God bless you!

There are four people who I would like to acknowledge in particular. Mark Harris has been a mentor to me since I formally started my journey 
in science and religion. I am also very thankful and grateful to my teacher, Ali Laraki, who has been absolutely catalytic in my development of learning Islamic theology. Without their continuous encouragement, helpful counsels, and constructive feedback, I don't think this work would have ever come into fruition. David Solomon Jalajel and Nazif Muhtaroğlu have been dedicated partners in crime and were kind enough to review every single chapter, sometimes spending time well into the late hours to get back to me in the set deadlines. Both were incredibly helpful with sharpening the arguments, teasing out ambiguities, saving me from embarrassing errors, and directing me to crucial references that I missed out on. The quality of this work was raised tremendously by their unswerving support. I am in debt to them both. Of course, any errors that do seep through are entirely my own.

I would also like to acknowledge my family. Starting with my parents, Saleem Ahmed Malik and Fauzia Malik. I could not have reached where I am today without your hard work, sweat and tears. From the mischievous little boy that you once knew, I had no idea that I would come to write a book like this. I am grateful for everything you have sacrificed for me, mom and dad! My brother, Altamash, has been a nuisance since he was born, but every rose has its thorns. Jokes aside, you and your wife, Mahnoor, has made the writing process all the more fun in the past year with your timely, pre-Corona marriage.

Last but not least, I would like to thank the two precious human beings that have completely transformed my life: my wife, Elnaz Alipour, and my son, Jonah. Elnaz bore the difficulties of being a patient spouse and mother as I scrambled for time writing this book alongside the crushing workload of teaching online during the Corona pandemic. Her love, untiring support, understanding, and kindness were invaluable in the process to which I owe the success of this work. Similarly, I had to shun several fun opportunities with my little tyke. However, whatever moments that we spent and laughed together made the whole thing much easier to bear. Thank you both for being in my life and for helping me get to where I am today.

A friend of mine once remarked: "We all too often forget to thank God." This statement has lasted with me. This endeavour has simultaneously been an academic exploration as well as a personal journey. I thank and praise God with all my heart for making it happen and for helping me through it: "... Be thankful to God: whoever gives thanks benefits his own soul ..." (Qửān 31:120). 


\section{Transliteration, Referencing, and Reused Material}

I have followed the transliteration guidelines as set by the International Journal of Middle East Studies. All English renditions of Qur'ānic verses taken from are Mohammed Abdul Haleem's translation of the Qur'ān. For ease of searching, most hadīth translations were acquired from www. sunnah.com with single-number referencing. Some hadīth translations were obtained from other references, which have been mentioned in the endnotes and bibliography. All dates are in the Common Era.

Some of the material in this book was published elsewhere. All of chapter 5 was published as an independent article under the same name with Zygon. Some of the material in chapter 6 was also published with Zygon under the title, "Does Belief in Human Evolution Entail Kufr (Disbelief)? Evaluating the Concerns of a Muslim Theologian." I would like to thank Zygon's editor, Arthur C. Petersen, who kindly gave me permission to reuse the material for this book. 


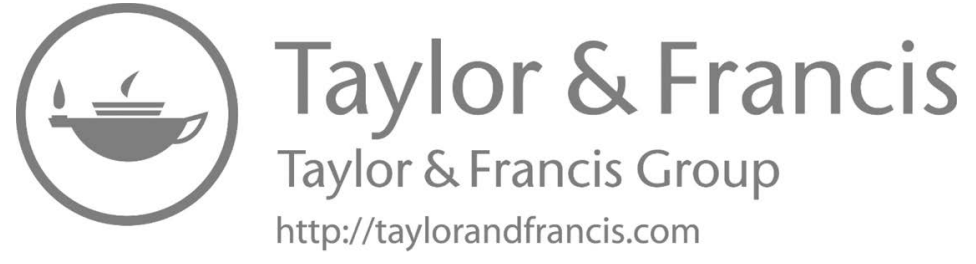




\section{Introduction}

The field of Islam and science has been steadily developing over the past few decades with many dimensions of the discourse gaining contemporary interest. These include divine action models, quantum mechanics, evolution, bioethics, science, and scripture, and many more (Jalajel 2009; Guessoum 2011a; Yazicioglu 2013; Bigliardi 2014; Altaie 2016; Malik 2019a; Koca 2020; Al-Akiti and Padela 2021; Salim and Malik 2021; Padela and Moosa 2021). Undoubtedly, the specific interface of Islam and evolution is one of the most interesting yet polarising discussions in this territory (Mabud 1992; Iqbal 2003; Jalajel 2009; Hameed 2011; Guessoum 2011a; Ibrahim and Baharuddin 2014; Bigliardi 2014; Qadhi and Khan 2018). The theory of evolution states that every biological entity, humans included, are all historically related through interconnecting lineages. Humans, then, are descendants of an earlier species and were not simply created into existence instantaneously. This entails that Adam and Eve, who are generally and traditionally considered to be the first parentless couple of humankind in Islam, must have had a mother and a father. Here, tension starts to brew, and it is the conceptual starting point for the entire discourse of Islam and evolution.

As we shall see in the coming chapters, there have been various responses to the theory of evolution by Muslim thinkers (Guessoum 2016; Malik $2019 b)$. This particular work attempts to look at the discussion from a theological perspective through the lens of a medieval Muslim theologian called Abū Hāamid al-Ghazālī. But why theology? Who is al-Ghazālī? And what's his importance when it comes to evolution? This chapter will aim to answer these questions and simultaneously set the stage for the entire book.

The structure of this chapter is as follows. I will first discuss the challenges one faces when looking at the interface of Islam and evolution. This is followed by an exposition of the methodology adopted in this work, an introduction to al-Ghazālī, and the rationale for adopting his framework. The third section is an outline of the coming chapters followed by some final remarks. 


\section{Introduction}

\section{Difficult landscape}

Before we get into the details, it is first important to acknowledge the various hurdles surrounding the landscape. In trying to address the (in)compatibility of Islam and evolution, one cannot but face a horde of unnecessary and cumbersome baggage that has stigmatised the conversation. Moreover, the discussion is inherently complex due to its interdisciplinary nature, making it very difficult for some to follow, and appreciate the different vantages points and nuances that form part and parcel of the conversation. The following are some observations that reflect these assertions.

\section{Navigating Islam and science}

On the one hand, we have adamant scientists stating that evolution is the best and well-substantiated science of our bio-historical diversity, with humans being no exception to the process. On the other hand, we see how the narrative of Adam's creation occupies an important place in Islamic scripture. It has generally been understood that Adam and Eve were created miraculously without parents, and they were the first of humankind. This has been the standard narrative amongst Muslims (Mabud 1992; Nadvi 1998). Thus, we very quickly see an emerging conflict of ideas leaving many Muslims to choose what may appear to be a binary choice, that of Islam or evolution, which in turn leads to sweeping statements and conclusions. Some will choose to reject or doubt the science of evolution because they deem the creation narrative provided by their Islamic teachings to be on firmer grounds. By contrast, some Muslims begin to question their commitments to Islam because they think science gives more robust answers. This has resulted in some individuals leaving Islam altogether (the new atheist movement has played a part in this as I shall highlight shortly; Cottee 2015). Others maintain their Muslim identity but find their own ways of reconciling Islam with evolution. Indeed, the landscape is heterogeneous.

There is also the question of authority (Tayob 2009; Determann 2015; Shavit 2017). Science has been incredibly successful in advancing human knowledge. Viewed superficially, Islamic discourse seems to be stagnant since its inception in comparison to the progressive and dynamic world of the natural sciences. Given this apparent discrepancy, it is not necessarily a surprise to see how science's authority begins to overshadow the authority of Islam (and any other domains of knowledge as a matter of fact). This creates a conflict of authority where the theologian is pitted against the scientist; each one will have his/her own sensitivities when it comes to external imposition and/or appropriation. Accordingly, one can reasonably understand how the reception of evolution amongst Muslims, particularly theologians, pushes them to re-evaluate their scripture and how that can, to some extent, be seen as a kind of intrusion upon a 1,400-year-old tradition. The combination of age-old precedents, theological scholarly authority 
(be it old or new), and general scepticism towards any kind of external incursion on traditional Islamic discourse makes for a very uneasy setting. Subsequently, when some individuals do try to present compatible theses, sometimes labels such as progressionist, revisionist, sellout, and modernist (among others) are pejoratively thrown around. On other occasions, when theologians inform scientists that certain domains of knowledge are outside the purview of science, e.g. miracles such as Adam's creation, it can create a tensive relationship, as some scientists may not be able to entertain such ideas. Depending on how science as a method is differentiated from science as an ideology, i.e. scientism, in its various shades and forms, one will see a spectrum of opinions ranging from conflict to concord (Porter 2001; Smedes 2004; Bolger 2012).

It also needs to be made explicit that evolution is a modern idea, and so it could never have been entertained by Muslim theologians before the nineteenth century; simply relying on age-old precedents to disregard evolution altogether may not be helpful nor appropriate since previous Muslim scholars never had to deal with such inquiries. The same goes with other modern dilemmas such as organ transplantation, cryogenics, and quantum mechanics, among others. This is not to say that ideas that have been crystallised should be rejected or ignored in light of modern developments, but there should be an open attitude to help understand how sturdy these ideas are in light of new intellectual challenges. Understandably, there is a lingering worry by some that catering for such approaches may lead to diluting or blending religious ideas due to transient intellectual fads of the time, which in turn may morph longstanding religious frameworks into self-serving, incoherent, inconsistent, and perhaps even unrecognisable paradigms (Tayob 2009; Zaidi 2011; Hughes 2015; Hallaq 2018; Daneshgar and Hughes 2020; Murad 2020). This is an appreciable concern that comes with entertaining any modern inquiry in light of one's religious tradition. With this apprehension in mind, the approach taken in this book is a dialogical one. I will attempt to highlight the fixtures and flexibilities in both domains (Islam and science), put them into the conversation, and determine the possibilities that can be arrived at, leaving it to the reader which option they prefer to entertain.

My aim with this (very brief) discussion is to show how various sensitivities come to the fore when looking at the interface of Islam and evolution. Experts of different kinds will have their respective set(s) of commitments which they cannot compromise and expects others to acknowledge them and appreciate them. Scientists expect the non-scientist to appreciate the nuances of the scientific discussions involved in this dialogue, and Muslim theologians expect the same consideration for the metaphysics and hermeneutics involved. Friction is generated when either side is made impotent and simplified to arrive at a predisposed conclusion. I don't believe that we can please everyone, but it goes a long way to understand where each person is coming from. 


\section{Introduction}

\section{Misconceptions}

The dialogue becomes even more convoluted when various "isms" are associated with evolution. One will find evolution being equated with, or derived from, or leading to atheism, naturalism, Marxism, communism, nihilism, capitalism, fascism, colonialism, imperialism, secularism, scientism among many others (Nadvi 1998; Yahya 2001). This makes it sometimes impossible to talk about evolution strictly as a scientific theory. Appropriately, one has to do a lot of groundwork to clarify what evolution is not before establishing what it is. But even if one can successfully disentangle evolution from the negative connotations it is usually associated with, this is but half the hurdle. There are the added difficulties of explaining the science of evolution to non-scientists. Public communication of evolution is generally a challenge for the scientific community (Jones and Reiss 2009; Kampourakis 2020). The common trope of humans evolving from monkeys is still widespread, which only shows how easy it is to confuse and misguide people (Hatcher 2018). In other instances, the education delivery is problematised because of the social context; there are several studies which indicate how evolution is viewed negatively, suspiciously or with hostility in Muslim pedagogical settings due to religious and cultural sensitivities (Mansour 2011; BouJaoude 2018; Fouad 2018; Lay et al. 2018; Muğaloğlu 2018; Osman et al. 2018; Guhin 2020). ${ }^{1}$ While some faults can be traced to problematic educational configurations, another factor seems to be misinformed statements of prominent Muslim theologians and apologists. Consider Zakir Naik - one of the most popular apologists in the Muslim world - who still describes evolution as "just a theory," conflating the term's colloquial designation for the scientific one (Gardner et al. 2018). Furthermore, the Muslim world has its own hosts of hardcore creationists that see no fruits to bear from evolution and consider it the antithesis of Islam. Harun Yahya (2001), which is a pen name for the individual known as Adnan Oktar, ${ }^{2}$ is a prominent Muslim apologist on a creationist bent who has made it his mission to dismantle evolution as a shoddy worldview. He argues that evolution is a baseless narrative that is geared for destroying religion. He has written dozens of books to this effect which seem to be, at times, an exact replication of creationist material produced by American institutions (Solberg 2013). Collectively, the false connotations and the misrepresentations of evolution make the entire discussion unnecessarily difficult and cumbersome.

\section{Problematic bifurcations}

Richard Dawkins, Daniel Dennett, Sam Harris, and Christopher Hitchens otherwise known as the "four horsemen" of the new atheism movement - have made significant strides in creating a wedge between the religious and the scientific community (Elsdon-Baker 2009; 2017). They polarise the discussion with the conflict narrative. Essential to their message is how evolution 
makes a strong claim against religious beliefs, particularly God's existence. By explaining how evolution undermines believers' beliefs in God via genes and memes, religion becomes a baseless worldview. It is in this light that Dennett calls Darwinian evolution a "universal acid" and Dawkins refers to religious ideas (like belief in God) as viruses (Malik 2018). In effect, they are forcing a binary choice: either evolution or religion (Islam in this case) is correct, but both cannot be true at the same time. Some impressionable Muslims who are heavily influenced by the works of new atheists will not likely see beyond this false bifurcation.

Related to this point are judgements by some Muslim theologians that only amplify the divide between Islam and evolution. Nuh Ha Mim Keller (2011) is a prominent contemporary theologian who asserts that belief in human evolution $^{3}$ is tantamount to unbelief $(k u f r$; the adoption of an idea or enaction of behaviour that is tantamount to leaving the fold of Islam; the person considered to be in this state, i.e. an unbeliever, is called a $k \bar{a} f i r)$. He believes that Islam and human evolution are fundamentally at odds with one another and thus warrants this judgement. He highlights many reasons for his position, which I will not entertain here. Regardless of the details, other theologians have noted that this seems like an unnecessary harsh measure. Consider Salman Younas (2017), another contemporary Muslim theologian, who says that Keller is mistaken to apply such a taxing label to a devout Muslim who believes in evolution. For him, an evolutionary reading of the Qur'ān is at best is an erroneous one, but as long as one believes that God created Adam, even if under an evolutionary narrative, it does not warrant the strong charge of $k u f r$. To be clear, my point with mentioning this difference in judgement is only to point out how even theologians have disagreements over the dialogue of Islam and evolution, and judgements like $k u f r$ or sweeping dismissals of evolution may aggravate the discourse unnecessarily and result in simplistic binaries, which in turn into the unhelpful narrative of new atheists. The need for nuances and thinking outside of strict either/or categories is much needed to help reduce the conversation's polarity.

\section{Emotions}

Aside from the intellectual component, the conversation of Islam and evolution is very value laden. Emotions run high when it is suggested that humans are biologically connected with the rest of the biological kingdom. It is not uncommon - at least in my experience - for one to hear contemptuous retorts like: "Do you think I come from a monkey?" Apart from the misunderstanding of evolution, the notion that we have any biological relationships to animals seems like an alien and unfathomable idea that the theory is sometimes dismissed purely on emotional terms. It may have religious roots since, after all, Islamic scripture does indicate that God created man with honour and dignity. But it can also be seen as an insult according to one's culture. I remember once talking to an old Arabic teacher of 


\section{Introduction}

mine who was simply disgusted at the thought of the theory. Without even quoting scripture, he felt it was an insult to humankind to have any biohistorical dependence on other "lesser" animals.

There is another episode that accentuates the sensitivity of this topic. After getting newly appointed by an institution in a Muslim-majority country, I went through induction week alongside a cohort of other new faculty members. The reader might be surprised to learn, as I was back then, that the lead instructor made it very explicit how the topic of evolution should be handled very cautiously with students. The instructor informed us of a faculty member who raised this discussion in a classroom which rubbed some students the wrong way. Within three days, the faculty member was fired from the job. Given this episode, the instructor jokingly remarked that instructors teaching biology would do well by referring to evolution as the "theory of change." Students hardly get irked by this kind of terminology in the instructor's experience with teaching the subject. In other words, evolution is not just a hot topic; it is a loaded term and should be tread very carefully. While these events may seem trivial, as both scientific and theological truths are supposed to be judged independently of our emotional biases, it highlights another layer of difficulty associated with the conversation: evolution is neither socially nor culturally neutral (Laats 2020).

\section{The nature of this book}

Given these complexities of the landscape, navigating the discourse of Islam and evolution can be confusing, difficult and, at times, hostile. However, I don't mean to suggest that the discourse is all that bad or stagnant. The reception of evolution in the Muslim world is very mixed, and depending on when, where, and who you ask, you will get different responses. As it stands, the discussion has undoubtedly started to mature, and a spectrum is very visibly developing. Some Muslims see evolution very comfortably and find it unproblematic with Islam. On the other end, some see the two as irreconcilable. There are also people in between with various, partial leanings to either side. These opinions are emerging in various formats, including articles, books, videos and conferences (Hameed 2011; Bigliardi 2014; Ibrahim and Baharuddin 2014; Guessoum 2016; Malik 2019b).

The material in this book hopes to contribute towards this growing literature. It works with the broad assumption that the Islamic tradition has something to offer for contemporary issues in Islam and science. What makes this book distinctive to other works is its focus on theology. To be clear, by theology I mean what metaphysical (can God do/create it?) and hermeneutic commitments (does it conflict with scripture?) a Muslim needs to acknowledge to determine whether evolution can conflict with one's beliefs in the first place. This isn't the first attempt which tries to create an interface between Islamic theology and evolution. Several others have come before. As examples, consider Mabud (1992) and Nadvi (1998) 
who after having investigated the science of evolution and the hermeneutic considerations primarily, i.e. they don't go too much into the metaphysical issues, come to the conclusion that Islam cannot be reconciled with evolution. David Solomon Jalajel $(2009 ; 2018)$ goes a step beyond these works and focuses on the conversation from the broad overview of the different theological schools that come to define Sunnī orthodoxy, which include Ash 'arism, Māturīdism, and Atharism (Nagel 2000; Winter 2008; Jackson 2009; Yusuf 2009; Schmidtke 2014; Khan 2020). Using ideas from a range of scholars representing these groups and grappling with metaphysical and hermeneutic issues head-on, Jalajel suggests there is no inherent theological conflict between Islam and evolution. He argues that it is only Adam and Eve that are miraculous creations, but there is nothing in Islamic scripture that denies the possibility of there being pre/co-Adamic human beings who could have been products of evolution. So Adam and Eve's descendants could have integrated with these other humans, thus forging a human lineage with an evolutionary history. Subsequently, Muslims can happily accept evolution as devout Muslims save for Adam and Eve who were excluded from the process. Yasir Qadhi, a prominent American theologian, has also discussed his take from a theological perspective over the past decade (Moran 2020). He recently penned his thoughts with Nazir Khan (Qadhi and Khan 2018). Focusing primarily on scripture, and adopting an Atharī perspective on the matter, they take the creation narrative of Adam/humans as is described in Islamic scripture, i.e. Adam was created miraculously, but make the case that Adam had all the right biological properties as is demanded by evolution. Thus, from a scientific perspective, which is blind to miracles, there is a seamless continuation as demanded by evolution from which it follows that reconciliation is entirely possible. More will be discussed of these perspectives in Chapter 4.

In the same vein as Qadhi, Khan, and Jalajel, this book assumes that Islamic theology has something to offer to the discussion. It also takes the vantage point of a Sunnī perspective on the discussion. But unlike Jalajel, who takes a broad approach from all Sunnī schools, and unlike Qadhi and Khan who focus on the discussion from an Atharī perspective, this work concentrates exclusively on the Ash'arite standpoint. Ash'arites are wellknown for adopting occasionalism, atomism, and divine command theory; they also stress on the radical contingency of creation, God's transcendence and omnipotence (these things will be expanded on in the coming chapters; Jackson 2009; al-Ghazālī 2016; Malik 2019a). To be sure, the adoption of Ash arism should not be taken as a dismissal of the other theological schools and perspectives (Sunnī or otherwise). There may very well be detailed treatments of Māturīdism, Atharism, and non-Sunnī evaluations and/or appropriation of evolution, but this will be left to other researchers to follow up on. Furthermore, I should add that I am not trying to convince the reader that the Ash'arite perspective is the only correct Islamic perspective, nor am I trying to convince the reader that Ash arism should be 


\section{Introduction}

espoused. I am also not trying to claim that Ash 'arism is problem-free. Like every other theological and philosophical system, Ash'arism has its own host of issues, some of which will be highlighted during the course of this book. I simply take the Ash arite school as a given and evaluate evolution metaphysically and hermeneutically accordingly. In effect, I entertain the following question: if evolution is true, how much of it can be theologically accepted as per the principles of the Asharite school of thought?

Exploring an issue like evolution in light of classical theological schools, though they were founded many centuries ago, is a relevant endeavour, since these schools have a living continuity right up to the modern period, and thus still define religious adherence, and indeed religious identity, for a large percentage of Muslims today (Gesink 2009; Halverson 2010; Hamid 2011; Bano 2018; Nahouza 2018; Bano 2020; El-Shamsy 2020). Of course, there might be some artefacts of these theological systems that may need updating, or there might be new elements that need to be coupled with these systems in light of contemporary developments, which this book attempts to do. ${ }^{4}$ But these are widely held belief systems that Muslims occupy today and are taught at some of the leading institutions in the world, e.g. Al-Azhar (Egypt), Zaytuna College (USA), and Cambridge Muslim College (UK). Therefore, adopting schools that have their origins in the medieval period does not diminish their relevance for exploring contemporary Muslims' faith issues. However, some researchers have expressed reservations to such an approach. ${ }^{5}$ This work tries to strike a healthy balance between absolute ossification and total relinquishment of the Islamic intellectual heritage.

\section{Al-Ghazālī}

Having clarified the general direction of this book, I shall now attempt to justify a particular strategy that I've adopted. Many Ash'arite scholars have contributed and developed the principles and ideas specific to the school. Famous examples (non-exhaustively) include Abū Hasan al-Asharī (d. 936; the founder of the school), Abū Bakr al-Baqillān̄i (d. 1013), Dhia ul-Dīn al-Juwayn̄̄ (d. 1085), Abū Ḥāmid al-Ghazālī (d. 1111), Fakhr al-Dīn al-Rāzī (d. 1210), Sayf al-Dīn al-Amidī (d. 1233), and 'Aḍud al-Dīn al-İjī (d. 1355). In this work, I shall mainly be using ideas derived from the works of al-Ghazālī when evaluating evolution, which further distinguishes this work from earlier treatments of Islam and evolution.

Al-Ghazālī was born in 1058 in Tus, Khorasan, what is now modern Iran. He showed amazing potential as a young student and was eventually under the tutelage of al-Juwayni, a distinguished theologian and jurist of his time. After the death of al-Juwayn̄i in 1085, al-Ghazālī eventually surpassed his teacher's status and was made the lead instructor/professor at the then prestigious Nizamiyya seminary in Baghdad. It is during this period that he faced spiritual crises. He mastered most if not all the theoretical sciences 
of the day (logic, philosophy, jurisprudence, theology) of his times, yet he felt something was missing. In 1095 al-Ghazālī took on a long hiatus from his role at the Nizamiyya seminary and went into periods of seclusion and spiritual retreats (though not absolutely as he still had community, familial, and pedagogical arrangements), eventually transforming his lifestyle into an ascetic one before passing away in 1111 (Watt 1963; Al-Ghazālī 1980; Frank 1994; Ormsby 2007; Griffel 2009; Campanini 2019). He was a masterful thinker and penned many books on a diverse number of topics like logic (mantiq), jurisprudence (fiqh), scholastic theology $\left(\right.$ kala $\left.m^{6}\right)$, and spirituality (tasawwuf). ${ }^{7}$ Since this book is a theological endeavour, I will primarily utilise his ideas related to scholastic theology.

I have intentionally decided to focus on al-Ghazālì for several reasons:

1 Al-Ghazāli is unquestionably one of the most respected scholars in Muslim history such that he was (and still is) referred to as the "Proof of Islam" (huijat al-Islam). His work is influential and respected till today in both Muslim seminaries and academia. This is important to acknowledge because if it can be shown that using his ideas one can comfortably accept evolution (albeit with qualifications as we shall see) without impinging one's theological commitments (at least if committed to the Ash arite school), then this can significantly dilute the negative connotations surrounding the discourse of Islam and evolution;

2 As we will come to see shortly, al-Ghazālī has a well-articulated metaphysical system that is tightly knit with his hermeneutic principles. Collectively, his ideas make for a united and consistent framework - at least how I have interpreted him - for when evaluating concerns related to evolution;

3 Much of al-Ghazālī's primary works have been translated into the English language. Furthermore, there is a vast amount of secondary literature on his ideas. So the unfamiliar reader can easily access the material that discuss his thoughts and works.

Having said all this, I want to mention four caveats. First, adopting al-Ghazālī for this project doesn't intend to slight other Ash'arite scholars. One could just as easily utilise their works for the project at hand with their respective idiosyncrasies. I have selected al-Ghazāli for the reasons already mentioned. Second, I don't intend for this project to be a strict and blind application of al-Ghazālī's ideas. I intend to use his ideas in conjunction with developments in the contemporary literature that can be easily integrated into the Ash'arite framework even though al-Ghazālī may have never used them (though this doesn't entail that he could not have conceived of them). Thus, this work should be seen, to some extent, as a form of development of Ash'arite theology as penned by al-Ghazālī alongside its application. Whether this is successful or not is something I leave the reader to decide. As an extension of this point, I am unsure 
what al-Ghazāli himself would have thought of evolution had he been alive today. I don't claim that this work's conclusion is something al-Ghazāli himself would conclude (though it remains possible) but only what I can conclude given how I have interpreted his ideas. Third, the modern debate over al-Ghazālī's metaphysical orientation needs to be highlighted. Over the past few decades, some academics have proposed that al-Ghazāli is not the Ash 'arite he is claimed to be. Some suggest that al-Ghazālī was influenced by Avicenna's ideas and was a covert Neoplatonist. Others argue that perhaps he was broadly an Ash'arite thinker but still idiosyncratic in some ways. Suffice to say, scholars are divided over this issue (Frank 1992; Gianotti 2001; Marmura 2002; Dallal 2002; Moosa 2005; Griffel 2009; Zarkasyi 2010). I acknowledge this debate's complexities and leave it to the intellectual historians (which I am not) to make their cases. For this study, I am simply taking for granted the classical interpretation of al-Ghazāli as an Ash arite thinker, which is still a reasonable option. ${ }^{8}$ However, it is perfectly acceptable to redo the project entertained in this book with other interpretations. Finally, and still on the point of looking at al-Ghazālī historically, I acknowledge that some of the works that I will be looking at were written within a particular intellectual milieu. I am not intending to historicise these works (except on a few occasions for providing clarity). Neither am I intending to draw analogies between evolution and the intellectual challenges al-Ghazāli was facing in his time. My approach is simply to identify and extract the relevant ideas that he developed, which are pertinent to the Ash arite perspective and then use them for a contemporary discussion on Islam and evolution. ${ }^{9}$

\section{Outline of the book}

Having qualified my approach for this book, the following is a brief outline of what the reader can expect in the coming chapters. The book is divided into four parts.

\section{Part 1 - setting the context (two chapters)}

Chapter one intends to capture the scientific perspective on evolution. It includes a review of the scientific principles of evolution, the evidence that supports it followed by a brief historical overview. It also covers some objections which are raised against evolution that unnecessarily clutter the discussion. Chapter two will look at the Christian responses to evolution. This will cover the positions of young-earth creationism, old-earth creationism, intelligent design, and theistic evolution. This chapter aims to illustrate the differences between these popular positions; some of the justifications for these positions will resonate with the Islamic tradition while others will not have any parallels. It is against this background that Muslim perspectives on evolution are discussed in Part 2 of this book. 


\section{Part 2 - Islamic perspectives on evolution (three chapters)}

Chapter three will trace and cover all the Qurānic verses (that are scattered all across the Qur'ān) and hadīths relevant to the Islamic narrative of genesis with minimal commentary (as that will be left for later chapters) to get an overview. This chapter will provide the scriptural context for Chapter 4 and the hermeneutic discussion in Part 4 of this book. Chapter four is a review that explains the various positions of how and why Muslims either accept, reject, or remain accommodative in their stance on evolution. It will be highlighted how thinkers in the same camp may reach similar conclusions, but their justification for their stances may differ. These will act as interlocutors for later chapters. A classification is adopted that summarises the different positions:

1 Creationism - everything is instantaneously created by God (complete rejection of evolution ${ }^{10}$;

2 Human exceptionalism - everything is created through the processes of evolution save humans;

3 Adamic exceptionalism - everything is created through the processes of evolution save Adam (and Eve $\left.{ }^{11}\right)$;

4 No exceptions - everything is created through the process of evolution.

Chapter five reviews how various contemporary authors suggest or read evolution onto historical texts written by medieval Muslim thinkers. It is demonstrated how this reading is incorrect because it relies on truncating selective paragraphs that are divorced from their thematic and historical contexts. It is argued how their works were framed from the perspective of the great chain of being rather than evolution.

\section{Part 3 - metaphysical considerations (three chapters)}

Chapter six introduces the metaphysical framework of the Asharite perspective as outlined by al-Ghazālī. The Ash'arite framework is then compared to a recent development in science and religion known as the Divine Action Project (DAP). This is to highlight the differences between Ash arism and the DAP framework in the contemporary context. Following this, we will look at the problem of naturalism, the problem of chance, and the problem of inefficiency (wasteful process) within the context of evolution. It is demonstrated that none of these ideas is problematic within the Ash'arite paradigm. Furthermore, it is concluded that al-Ghazālī's framework is metaphysically compatible with creationism, human exceptionalism, Adamic exceptionalism, and no exceptions. Chapter seven evaluates the design argument as portrayed by the intelligent design (ID) camp in relation to evolution. Using the metaphysical framework of Ash arism, it is demonstrated that regardless of whether biological organisms - or even the 


\section{Introduction}

whole universe as a matter of fact - shows overt design, it is a secondary contention. What matters in the Ash'arite paradigm is contingency, which can cater for any kind of existence, be it designed, complex, simple, or chaotic. Accordingly, committing oneself to ID as an alternative to evolution because it seems more "God-friendly" holds no weight in the Ash'arite paradigm. Chapter eight visits the question of morality in light of evolution. This chapter shows how al-Ghazālī believes morality isn't innate, i.e. humans don't occupy any fixed moral codes in their innate nature, and is instead social inculcations absorbed through habit. Furthermore, al-Ghazāli adopts divine command theory, which is the idea that it is solely God's command which determines what is morally good and bad. Given the problems associated with morality in light of evolution, I demonstrate that al-Ghazālî̀s ideas on morality are compatible with evolution.

\section{Part 4 - hermeneutic considerations (two chapters)}

Chapter nine will introduce al-Ghazālī’s hermeneutic framework. This will include his understanding of the balance between reason and revelation, the relationship between science and scripture, how to distinguish literal readings from figurative ones, and a discussion on hadīths. It will be made apparent that al-Ghazālī's hermeneutic framework is tightly welded to his metaphysical framework within which miracles are possible. This will set the stage for when we review the Muslim perspectives that were encountered in Chapter 4. Chapter ten evaluates the attempts that have been made to argue for and against evolution using scripture through al-Ghazālī's hermeneutic framework. It is concluded that al-Ghazālī's hermeneutic framework is hermeneutically compatible with creationism, human exceptionalism, and Adamic exceptionalism but not with no exceptions. The scriptural reading of Adam being created miraculously would be somewhat difficult to overcome, and al-Ghazāli would have no problem accepting that Adam was created miraculously in his metaphysical and hermeneutic framework.

\section{Final thoughts}

This book is the result of a journey that attempted to explore the challenging and sensitive territory of Islam and evolution. Looking back at the start now, I do not hesitate to admit that I was initially quite naïve about certain elements in this discourse (isn't anyone in the beginning?). I myself have learnt so much since embarking on this path. On my way, I have met, listened to, and exchanged ideas with several individuals from various specialisations (theology, philosophy, and science) and backgrounds (university settings and seminaries) who have helped me understand the numerous dimensions of this critical conversation. I have also tried my utmost best to listen to the worries and concerns of the Muslim laity who find evolution difficult to understand and/or to be incompatible with Islam. The collective 
culmination of these experiences has led me to change my opinion since the start of this project. I was initially in the no exceptions camp, but I have since changed my stance to believing that Adamic exceptionalism is the best alignment one can maintain in light of the respective methodologies of science and al-Ghazālī’s Ash'arite framework. Subsequently, this book has evolved as much as I have.

When writing this book, the primary readership I had in mind was the Muslim community given the topic's sensitivity in that context. However, it is, in fact, open to multiple audiences. While working through the manuscript and several revisions that came after, I have tried my best to ensure that the reader with no background in either science and/or (Islamic) theology can pick it up and read it. Thus, it will help anyone interested in Islam and evolution, Islam and science, Islamic theology, and al-Ghazālī.

I am very aware that al-Ghazāli is a revered figure amongst some Muslim communities, and some may feel a sense of ownership in carrying his legacy. To individuals and communities who occupy such sensibilities, this work may seem like a confusing intrusion. After all, what does al-Ghazālī have to do with evolution? As stated earlier, this project works with the presumption that Islamic intellectual history is a repository that can be mined to address contemporary issues. Al-Ghazālī is undoubtedly an important figure whose works and ideas are discussed even today. Utilising al-Ghazālī to discuss evolution within this book's set parameter should not be seen as a confounding nor surprising matter. I have made my working interpretation of al-Ghazālī and justification of using him as clear as possible, and I hope to retain this clarity throughout this book. At times, I have inserted new suggestions that align with the Ash'arite perspective as discussed by al-Ghazālī. Perhaps some may see this as my attempt of moulding al-Ghazāli into a new cast. This isn't the case as I am merely suggesting ideas that could align with al-Ghazālī's ideas. I leave it to the reader to decide whether these have been done effectively or not.

All in all, I acknowledge that this is a risky endeavour since I am juxtaposing the thoughts of a medieval Muslim scholar with a novel issue, which has its respective challenges. As an author, I can only hope the ideas poured into this work offers the reader clarity on the broader discussion of Islam and evolution even if the reader might disagree with the adopted interpretation, methodology, and/or the particular conclusions arrived at through the lens of al-Ghazālī as an Ash'arite. If it has achieved this much, then I have considered this to be a successful project.

Happy reading!

\section{Notes}

1 I myself have experienced this at the administrative level. I was once rejected an ethical exemption application by an institution in a Muslim majority country to conduct research on the pedagogy of Islam and evolution. Not 
surprisingly, I applied for the same thing externally at a Western institution shortly after this incident, and it was accepted without any issue.

2 I should add, Harun Yahya was sentenced to prison for over 1000 years at the time of completing this manuscript for various crimes he was involved in.

3 The stress on human evolution will make sense in Chapter 4. But in short, he distinguishes between non-human evolution and human evolution. For him, the former is possible, but the latter is not.

4 Similar work has been done with Thomas Aquinas and Aristotle's ideas in contemporary science and religion discussions. See Simpson et al. (2017) and Feser (2019).

5 For instance, in a book review by Guessoum (2011b), he criticises Jalajel's work, calling his focus on Ash 'arism, Māturīdism, and Atharism "an agenda" because Jalajel seems to have restricted his analysis to Islamic orthodoxy, which, in Jalajel's work, refers to Sunnī Islam. Guessoum (2011b, 476) says: "And there lies the main issue I have with this work, namely the fact that the author limits the possible position(s) on evolution on the basis of what the 'mainstream' is, while noting that these 'orthodox' Islamic theologies (the word 'orthodox' comes back repeatedly in the book) were formulated many centuries ago." It is unclear what is Guessoum's issue. Is he uncomfortable with the designation of orthodoxy? If so, then it is unclear as to why this is the case. Or does he find Jalajel's proposal problematic because he relies on theological models that were developed many centuries ago, and thus outdated? This is somewhat erroneous if it is indeed his intention.

6 Scholastic theology may not capture the full gamut of kalām. For nuances on how the discipline of kaläm was understood, see Hassan (2020, 135-139).

7 Some have criticised al-Ghazālī for having demolished philosophy which then resulted in the decline of the Muslim world. For a critical treatment of this topic, see Malik (2021).

8 I believe al-Ghazālī wrote each work with a particular audience, discourse, and scope in mind, which can sometimes lead to potential or apparent tensions in his corpus. My personal opinion is that he was broadly an Ash arite in his scholastic theology, but he realised its limitations. See al-Ghazālī (1980; 2016, 35, 39) and Ormsby (2007).

9 In science, there is an artificial division between theoretical and applied science. If we entertain this division, this work could be seen as a form of applied theology.

10 For now, I am using evolution as a placeholder. As will become clear in Chapter 4, what I actually mean by this is common ancestry.

11 For the sake of convenience, I have subsumed Eve under Adamic exceptionalism.

\section{References}

Al-Akiti, Afifi, and Aasim Padela. 2021. Islam and Biomedicine. New York, NY: Springer.

Al-Ghazālī, Abū Hāmid. 1980. Deliverance from Error: An Annotated Translation of al-Munqidh min al-Dalāl and Other Relevant Works of al-Ghazālī. trans. by Richard J. McCarthy. Louisville, KY: Fons Vitae.

Al-Ghazālī, Abū Hāmid. 2016. Kitāb Qawāid al-'Aqāid: The Principles of the Creed - Book 2 of the Ihya ' 'Ulüm al-Dīn. trans. by Khalid Williams. Louisville, KY: Fons Vitae.

Altaie, Basil. 2016. God, Nature, and the Cause: Essays on Islam and Science. Abu Dhabi: Kalam Research and Media. 
Bano, Masooda, ed. 2018. Modern Islamic Authority and Social Change - Volume 2: Evolving Debates in the West. Edinburgh: Edinburgh University Press.

Bano, Masooda. 2020. The Revival of Islamic Rationalism: Logic, Metaphysics, and Mysticism in Modern Muslim Societies. Cambridge: Cambridge University Press.

Bigliardi, Stefano. 2014. Islam and the Quest for Modern Science: Conversations with Adnan Oktar, Mehdi Golshani, Mohammed Basil Altaie, Zaghloul El-Naggar, Bruno Guiderdoni and Nidhal Guessoum. Istanbul: The Swedish Research Institute.

Bolger, Robert. 2012. Kneeling at the Altar of Science: The Mistaken Path of Contemporary Religious Scientism. Eugene, OR: Wipf and Stock Publishers.

BouJaoude, Saouma. 2018. "Evolution Education in the Arab States: Context, History, Stakeholders' Positions and Future Prospects." In Hasan Deniz and Lisa A. Borgerding, eds. Evolution Education Around the Globe. Cham: Springer, 297-314.

Campanini, Massimo. 2019. Al-Ghazali and the Divine. Abingdon: Routledge.

Cottee, Simon. 2015. The Apostates: When Muslims Leave Islam. London: Hurst and Company.

Dallal, Ahmed. 2002. "Ghazali and the Perils of Interpretation." Journal of the American Oriental Society, 122(4): 773-787.

Daneshgar, Majid, and Aaron W. Hughes, eds. 2020. Deconstructing Islamic Studies. Cambridge, MA: Harvard University Press.

Determann, Jörg Matthias. 2015. Researching Biology and Evolution in the Gulf States Networks of Science in the Middle East. London: I.B. Tauris.

Elsdon-Baker, Fern. 2009. Selfish Genius: How Richard Dawkins Rewrote Darwin's Legacy. London: Icon Books.

Elsdon-Baker, Fern. 2017. "The Compatibility of Science and Religion?" In Anthony Carroll, and Richard Norman, eds. Religion and Atheism: Beyond the Divide. Abingdon: Routledge, 82-92.

El-Shamsy, Ahmed. 2020. Rediscovering the Islamic Classics: How Editors and Print Culture Transformed an Intellectual Tradition. Princeton, NJ: Princeton University Press.

Feser, Edward. 2019. Aristotle's Revenge: The Metaphysical Foundations of Physical and Biological Science. Neunkirchen-Seelscheid: Editiones Scholasticae.

Fouad, Khadija E. 2018. "Pedagogical Implications of American Muslims' Views on Evolution.” In Hasan Deniz and Lisa A. Borgerding, eds. Evolution Education Around the Globe. Cham: Springer, 15-40.

Frank, Richard M.1992. Creation and the Cosmic System: Al-Ghazālī and Avicenna. Heidelberg: Universitätsverlag.

Frank, Richard M. 1994. Al-Ghazālī and the Asharite School. Durham: Durham University Press.

Gardner, Vika, E. Carolina Mayes, and Salman Hameed. 2018. "Preaching Science and Islam: Dr. Zakir Naik and Discourses of Science and Islam in Internet Videos." Die Welt Des Islams, 58: 57-391.

Gesink, Indira. 2009. Islamic Reform and Conservatism: Al-Azhar and the Evolution of Modern Sunnī Islam. London: I.B. Tauris.

Gianotti, Timothy J. 2001. Al-Ghazall’’s Unspeakable Doctrine of the Soul: Unveiling the Esoteric Psychology and Eschatology of the Ihya $\vec{a}$. Leiden: Brill.

Griffel, Frank. 2009. Al-Ghazali's Philosophical Theology. New York, NY: Oxford University Press. 
Guhin, Jeffrey. 2020. Agents of God Boundaries and Authority in Muslim and Christian Schools. Oxford: Oxford University Press.

Guessoum, Nidhal. 2011. Islam's Quantum Question: Reconciling Muslim Tradition and Modern Science. London: I.B. Tauris.

Guessoum, Nidhal. 2011. "Islam and Biological Evolution: Exploring Classical Sources and Methodologies by David Solomon Jalajel." Journal of Islamic Studies, 22(3): 476-479.

Guessoum, Nidhal. 2016. "Islamic Theological Views on Darwinian Evolution". Oxford Research Encyclopedia of Religion. Accessed 1st of January 2020. https:// oxfordre.com/religion/view/10.1093/acrefore/9780199340378.001.0001/acrefore9780199340378-e-36

Hallaq, Wael B. 2018. Restating Orientalism: A Critique of Modern Knowledge. New York, NY: Columbia University Press.

Hameed, Salman. 2011. "Evolution and Creationism in the Islamic World." In Thomas Dixon, Geoffrey Cantor, and Stephen Pumfrey, eds. Cambridge: Cambridge University Press, 133-154.

Hamid, Sadek. 2011. Sufis, Salafis and Islamists: The Contested Ground of British Islamic Activism. London: I.B. Tauris.

Halverson, Jeffry R. 2010. Theology and Creed in Sunn̄ Islam: The Muslim Brotherhood, Ash'arism, and Political Sunnīsm. New York, NY: Palgrave Macmillan.

Hassan, Laura. 2020. Ash'arism Encounters Avicennism: Sayf al-Dīn al-Āmid̄̄ on Creation. New Jersey: Georgia Press.

Hatcher, Chris. 2018. "Evolution.” In Berry Billingsley, Manzoorul Abedin, and Keith Chappel, eds. A Teacher's Guide to Science and Religion in the Classroom. Abingdon: Routledge, 86-93.

Hughes, Aaron W. 2015. Islam and the Tyranny of Authenticity: An Inquiry into Disciplinary Apologetics and Self-Deception. Equinox: Sheffield.

Ibrahim, Abdul Halim, and Madiha Baharuddin. 2014. "Criticism of Darwin's Theory of Evolution by Muslim Scholars." Online Journal of Research in Islamic Studies, 1(1): 50-62.

Iqbal, Muzaffar. 2003. "Biological Origins: Traditional and Contemporary Perspectives." Islamic Herald. Accessed 1st of October 2019. Available at: http:// saif_w.tripod.com/curious/evolution/muz/biological_origins.htm

Jackson, Sherman. 2009. Islam and the Problem of Black Suffering. Oxford: Oxford University Press.

Jalajel, David Solomon. 2009. Islam and Biological Evolution: Exploring Classical Sources and Methodologies. Western Cape: University of the Western Cape.

Jalajel, David Solomon. 2018. "Tawaqquf and Acceptance of Human Evolution.” Yaqeen Institute. Accessed 1st of January 2020. Available at: https://yaqeeninstitute. org/dr-david-solomon-jalajel/tawaqquf-and-acceptance-of-human-evolution/\#. Xgw_HxczbPA

Jones, Leslie S, and Michael J Reiss, eds.2009. Teaching About Scientific Origins: Taking Account of Creationism. New York, NY: Peter Lang.

Kampourakis, Kostas. 2020. Understanding Evolution. Cambridge: Cambridge University Press.

Keller, Nuh Ha Mim. 2011. Sea Without Shore: A Manual of the Sufi Path. Amman: Sunna Books.

Khan, Faraz A. 2020. An Introduction to Islamic Theology: Imam Nūr al-Dīn al-Șabūnī’s al-Bidāya fī Ușūl al-Dīn. Berkeley, CA: Zaytuna Institute. 
Koca, Özgür. 2020. Islam, Causality, and Freedom: From the Medieval to the Modern Era. Cambridge: Cambridge University Press.

Laats, Adam. 2020. Creationism USA: Bridging the Impasse on Teaching Evolution. Oxford: Oxford University Press.

Lay, Yoon Fah, Eng Tek Ong, Crispina Gregory K. Han and Sane Hwui Chan. 2018. "A Glimpse of Evolution Education in the Malaysian Context." In Hasan Deniz and Lisa A. Borgerding, eds. Evolution Education Around the Globe. Cham: Springer, 357-374.

Mabud, Shaikh Abdul. 1992. Theory of Evolution: Assessment from the Islamic Point of View. Cambridge: Islamic Academy.

Malik, Shoaib Ahmed. 2018. Atheism and Islam: A Contemporary Discourse. Abu Dhabi: Kalam and Research Media.

Malik, Shoaib Ahmed. 2019a. "God, Information and the World: The Metaphysics of William Dembski and Al-Ghazālī." Philosophy, 94(4): 547-576.

Malik, Shoaib Ahmed. 2019b. "Evolution and Islam - A Brief Review." In Abdallah Schleifer, ed. The Muslim 500: The World's 500 Most Influential Muslims 2020. Jordan: The Royal Islamic Strategic Studies Centre, 207-212.

Malik, Shoaib Ahmed. 2021. "Al-Ghazālē.” In Stephen Bullivant and Michael Ruse, eds. The Cambridge History of Atheism. Cambridge: Cambridge University Press, forthcoming.

Mansour, Nasser. 2011. Science Teachers' Views of Science and Religion vs. the Islamic Perspective: Conflicting or Compatible? Science Education, 95(2): 281-309.

Marmura, Michael E. 2002. "Ghazali and Ash'arism Revisited.” Arabic Sciences and Philosophy, 12(1): 91-110.

Moosa, Ebrahim. 2005. Ghazāli and the Poetics of Imagination. Chapel Hill, NC: The University of North Carolina Press.

Moran, Glen. 2020. “The Final Domino: Yasir Qadhi, YouTube, and Evolution.” Zygon, 56(1): 34-53.

Muğaloğlu, Ebru Z. 2018. “An Insight into Evolution Education in Turkey.” In Hasan Deniz and Lisa A. Borgerding, eds. Evolution Education Around the Globe. Cham: Springer, 263-280.

Murad, Abdul Hakim. 2020. Travelling Home: Essays on Islam in Europe. Cambridge: The Quilliam Press.

Nadvi, Muhammad Shahabuddin. 1998. Evolution or Creation? trans. by Maqbool Ahmed Siraj. Bangalore: Furqania Academy Trust.

Nagel, Tilman. 2000. The History of Islamic Theology from Muhammad to the Present. Princeton: Markus Weiner Publishers.

Nahouza, Namira. 2018. Wabhabism and the Rise of the New Salafists: Theology, Power and Sunnī Islam. London: I.B. Taurus.

Ormsby, Eric. 2007. Ghazali: The Revival of Islam. London: Oneworld Publications.

Osman, Kamisah, Rezzuana Razali, and Nurnadiah Mohamed Bahri. 2018. "Biological Evolution Education in Malaysia; Where We Are Now." In Hasan Deniz and Lisa A. Borgerding, eds. Evolution Education Around the Globe. Cham: Springer, 375-390.

Padela, Aasim, and Ebrahim Moosa. 2021. Medicine and Shariah: A Dialogue in Islamic Bioethics. Notre Dame, IN: University of Notre Dame Press.

Porter, Andrew P. 2001. By the Waters of Naturalism: Theology Perplexed Among the Sciences. Eugene, OR: Wipf and Stock Publishers. 


\section{Introduction}

Qadhi, Yasir, and Nazir Khan. 2018. "Human Origins: Theological Conclusions and Empirical Limitations." Yaqeen Institute. Accessed 19th of August 2020. Available at: https://yaqeeninstitute.org/nazir-khan/human-origins-theologicalconclusions-and-empirical-limitations/

Salim, Emil, and Shoaib Ahmed Malik. 2021. "Creatio Continua and Quantum Randomness." In Kelly James Clark and Jeffrey Koperski, eds. Abrahamic Reflections on Randomness and Providence. New York, NY: Palgrave, forthcoming.

Schmidtke, Sabine, ed. 2014. The Oxford Handbook of Islamic Theology. Oxford: Oxford University Press.

Shavit, Uriya. 2017. Scientific and Political Freedom in Islam: A Critical Reading of the Modernist-Apologetic School. Abingdon: Routledge.

Simpson, William M. R., Robert C. Koons, and Nicholas J Teh, eds. 2017. NeoAristotelian Perspectives on Contemporary Science. Abingdon: Routledge.

Smedes, Taede A. 2004. Chaos, Complexity, and God: Divine Action and Scientism. Leuven: Peeters.

Solberg, Anna Ross. 2013. The Mahdi Wears Armani. Huddinge: Södertöns Högskola.

Tayob, Abdulkader. 2009. Religion in Modern Islamic Discourse. London: Hurst and Company.

Watt, Montgomery. 1963. Muslim Intellectual: A Study of al-Ghazali. Edinburgh: The Edinburgh University Press.

Winter, Timothy, ed. 2008. The Cambridge Companion to Classical Islamic Theology. Cambridge: Cambridge University.

Yahya, Harun. 2001. The Evolution Deceit: The Scientific Collapse of Darwinism and Its Ideological Background. Istanbul: Kültür Publishing.

Yazicioglu, Isra. 2013. Understanding the Qur'anic Miracle Stories in the Modern Age. Pennsylvania: The Pennsylvania State University.

Younas, Salman. 2017. “Am I a Disbeliever by Believing in Evolution?” Accessed 1st of January 2020. Available at: https://seekersguidance.org/answers/islamic-belief/ am-i-a-disbeliever-by-believing-in-evolution/

Yusuf, Hamza. 2009. The Creed of Imam al-Ṭahāwī. Berkeley, CA: Zaytuna Institute. Zaidi, Ali. 2011. Islam, Modernity, and the Human Sciences. New York, NY: Palgrave Macmillan.

Zarkasyi, Hamid Fahmy. 2010. Al-Ghazālī's Concept of Causality with Reference to His Interpretations of Reality and Knowledge. Kuala Lumpur: International Islamic University Malaysia Press. 
Part 1

Setting the context 


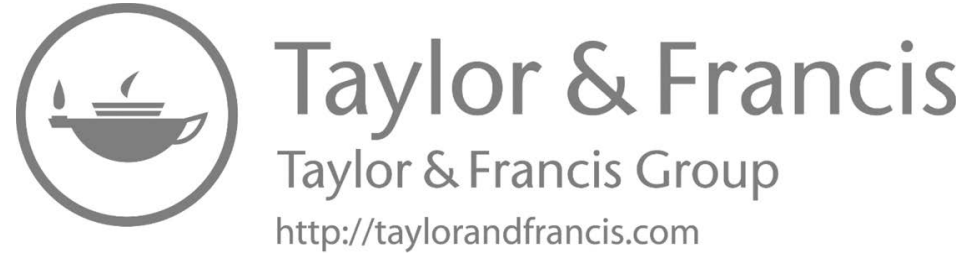




\section{What evolution is and isn't}

\section{Introduction}

Theodosius Dobzhansky (1973) famously stated that "nothing in biology makes sense except in light of evolution." While certain individuals and groups may disagree with this statement, as we shall see in Chapters 2 and 4 , it is first important to spell out what we actually mean by the term, particularly in its scientific context. This is a necessary undertaking because, unfortunately, evolution has been grossly misunderstood and misrepresented. As an example, consider Figure 1.1.

This diagram has become commonplace in the global and popular culture, and it wouldn't be inaccurate to claim that it has become the central token for representing evolution. While this may be, the diagram is erroneous. This diagram has played an important role in perpetuating the belief that humans are derivatives of monkeys (Hatcher 2018, 91). Given how such misconceptions are deeply entrenched in our societies, it is important to unpack evolution prudently and explain the various principles that underlie it in a stepwise fashion. The following, then, is a primer on the science of evolution. This chapter may seem like a revision of the topic or redundant for the reader already acquainted with the science of evolution. If so, it is recommended to skip to the next chapter (but going through the conclusion may help with the rest of the book). Critics or sceptics of evolution may find this chapter to be rudimentary. That may be so, but this chapter is written to clarify the science of evolution in simple terms so as to set the stage for the theological discussion. There are several references that have been cited in the main text and endnotes for the critical or intrigued reader.

This chapter has four parts. The first and second sections overview the scientific principles of evolution and the evidence for evolution, respectively. These sections will discuss the standard depiction of evolution called Neo-Darwinism or the Modern Synthesis. What separates Darwinism from Neo-Darwinism will be made clear when reviewing the history of the theory of evolution, which will be the third segment of this chapter. ${ }^{1}$ The historical overview of evolution is necessary to appreciate how Charles 

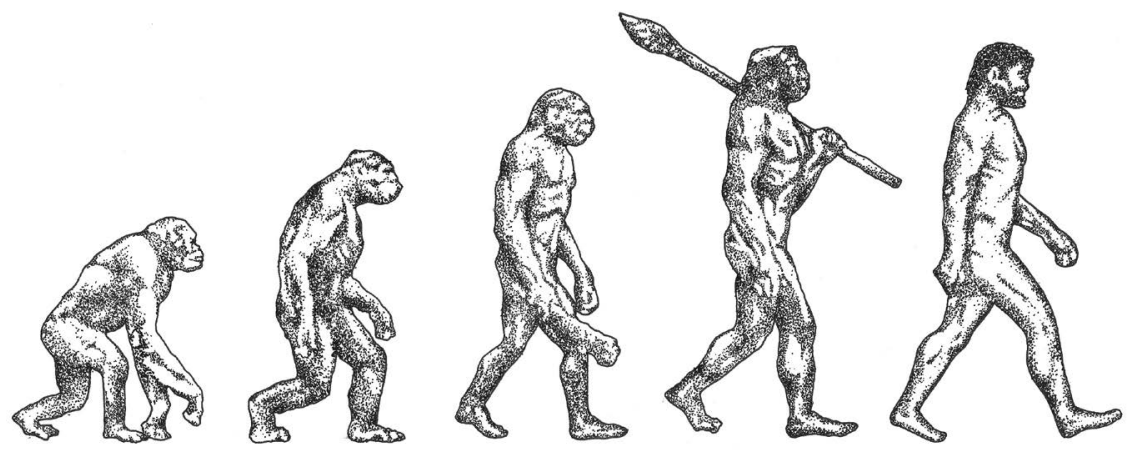

Figure 1.1 This picture depicts the common yet incorrect depiction in which an ape is transforming into a human linearly through intermediate stages.

Darwin's theory advanced and surpassed other competing theories. This section will also highlight some of the contemporary debates amongst evolutionary biologists some of whom are suggesting that Neo-Darwinism may need revising. Finally, the last section will review some of the major objections against evolution by critics.

\section{Principles of evolution}

Colloquially, the word "evolution" has a few connotations, but it generally invokes two possible (but non-exclusive) meanings. First, it means a form of change. To evolve entails a kind of transformation from one state to another. A second meaning associated with evolution is a development in a positive sense (Cambridge Dictionary 2020a; Oxford English Dictionary 2020a). This is contrasted with negative developments which would be termed devolution (Cambridge Dictionary 2020b; Oxford English Dictionary 2020b). These colloquial conceptions have some parallels with the scientific definition of evolution but are also somewhat different. Given this disparity, we need to unpack the scientific term carefully to avoid any confusion.

\section{The basic idea}

As a starting point, consider the different species that we are all familiar with. We have cats and dogs as pets, we see tigers in the zoos, we have flies that pester us daily, we have roses that we smell in gardens, we have trees to gives us shade on a bright sunny day, and we have ourselves, humans. All of these are different biological entities. Evolution tells us that even though we are all different, we share a lineage and a history. We are all biologically connected through the process of evolution. Consider a basic family unit. A child comes from his/her parents, who themselves come from grandparents, 
who themselves come from grand-grandparents, and so on. This is commonly observed and known. Where evolution goes a step further is that this same process applies to the entire biological kingdom. In other words, evolution informs us that humans came from a pre-human species that were just another product of an earlier species and so on. If we keep reverting in time, we will eventually start with the basic building blocks of life which started the process. Figure 1.2 captures this simple overview (notice the time span).

\section{Genotype and phenotype}

To understand the particulars of evolution, we need to create a distinction between the genotype and phenotype (Urry et al. 2016, 274). Let's go back to when parents have children. You'll notice that, on an average, when people have children, they look similar to them but are also distinct. Biology explains as to why this may be. All biological entities have a basic biological unit called genes, and they make up our DNA. These contain the blueprints which govern how we eventually come to look like (e.g. hair colour), what kind of dispositions we may have (e.g. eating habits), and well-being (e.g. whether we are healthy or born with a disease). DNA is transferred carried over in children as packages known as chromosomes, and is usually a split mix of the parents (Urry et al. 2016, 254-268). Half of it comes from the mother, and the other half of it comes from the father. Given this distribution, we can now see why kids look similar and also distinct from their parents. At this point, the distinction between genotype and phenotype becomes helpful. The genotype is what biological entitles are on the genetic level, and phenotype is what they are on the observable level. When the genotype forms the phenotype, it is called a gene expression (Urry et al. 2016, 335). ${ }^{2}$ For example, if a child has genetic coding for having black hair, it will express black hair. The expression of genotypes into phenotypes is ubiquitous in the biological kingdom. This is summarised in Figure 1.3.

Having clarified the general idea, it will be helpful at this stage to distinguish between the process of evolution (how it occurs) versus the pattern of evolution (what occurs). Let us start with the former.

\section{Process of evolution}

The process of evolution can be heuristically divided into two parts. Microevolution is referred to as the changes between individuals within a species, e.g. two cats with different colours. Macroevolution is the change across species, e.g. fish evolving to reptiles (Urry et al. 2016, 484-550; Futuyma and Kirkpatrick 2017, 16). Fundamentally, they are both governed by the same processes of heredity and variation. Heredity is what is genetically passed on from the parent generation to the daughter generation, 


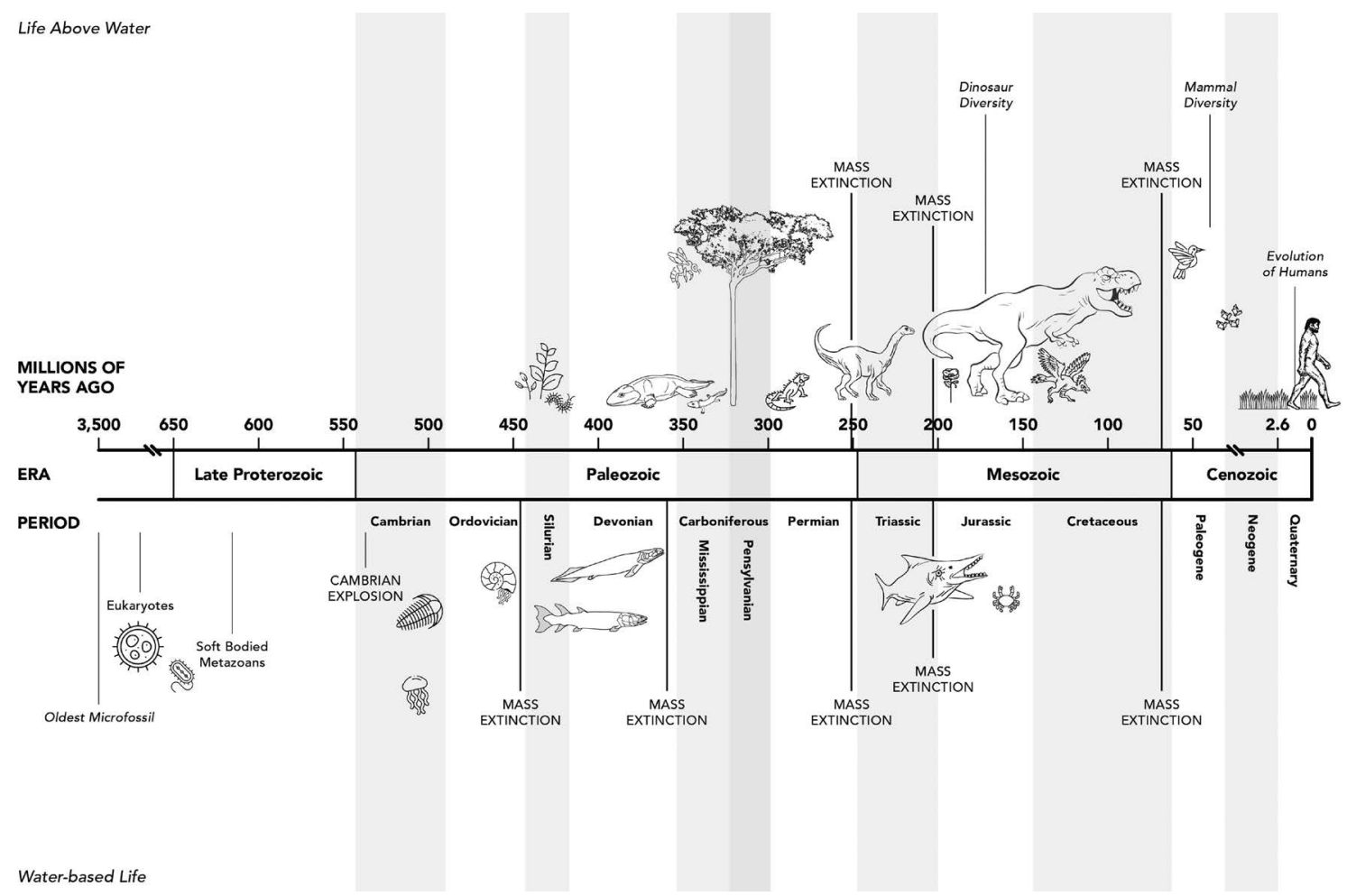

Figure 1.2 A timeline of evolution which shows the general development of life starting from 3.5 billion years ago. Between 3.5 billion years to 550 million years ago, we see elementary life forms such as bacteria. After the 550 million mark, which is known as the Cambrian explosion, we see a general increase in the complexity of life forms. These include fish, lizards, dinosaurs, birds, and humans arriving on the scene very recently. 


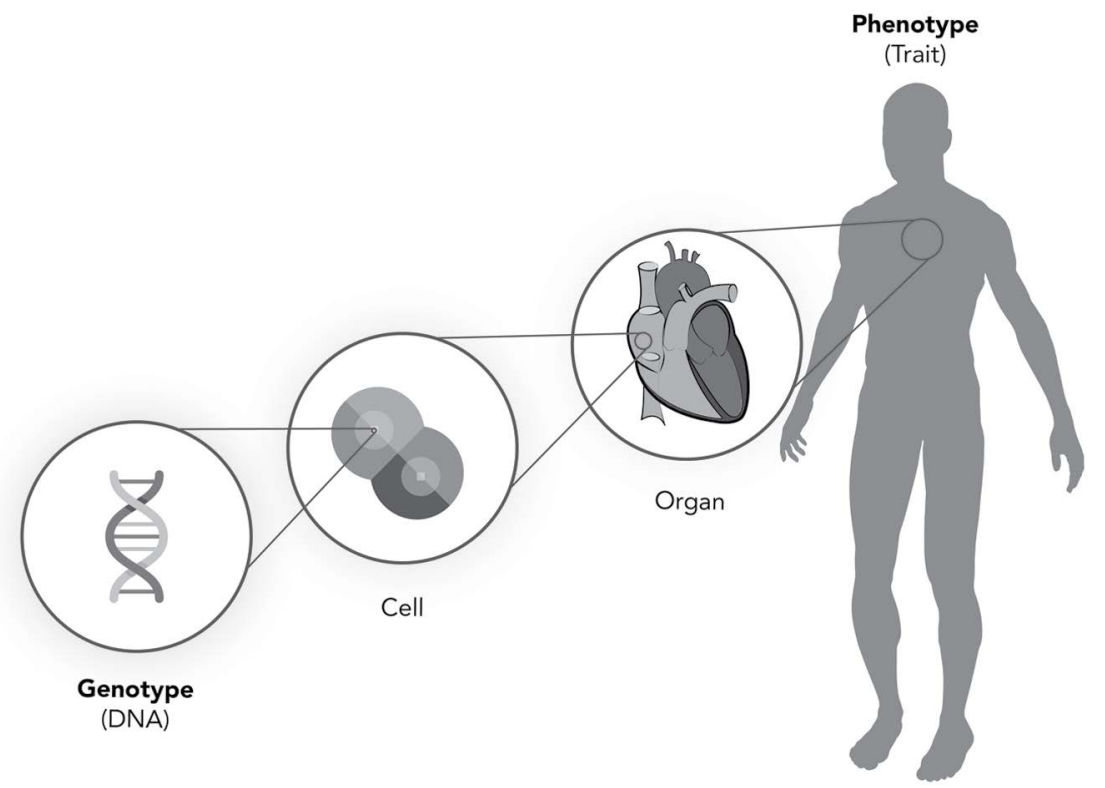

Figure 1.3 This is a depiction of biological scale on a human being. Starting with a human body, we zoom into the heart. The heart is then further magnified into cells, which are further magnified to show the DNA. The DNA is referred to as the genotype, which acts as a blueprint. When this DNA is expressed or manifested, it shows what properties a human being might have. These manifested properties are known as phenotypes.

while variation is what differs. How the genes are combined from the mother and father ${ }^{3}$ to create the genotype of the child is probabilistic, which means that the configuration of the child's genotype cannot be predicted down to every single gene (Urry et al. 2016, 273-291). Consider the following analogy. Imagine two people, each having a six-sided dice. We can compute all the possibilities of the different permutations that can occur when rolled, but we can never assert exactly which permutation will occur on a specific roll. The result is entirely premised on chance. However, it is important to stress that the permutations are limited and governed by what is contained in the dice. If each dice is numbered one to six, then having a combination of one and seven is impossible because seven is not an option in the dice used. Similarly, when parents have children, their resulting genotypes are based on chance but governed and limited by the existing genetic material contained within the parents' genotypes. ${ }^{4}$ This inherent probability associated with having offspring explains why the same two parents can have different children with varying traits, e.g. one with black hair and the other with blonde hair. In the context of evolution, if this process goes on long enough (again, think of millions of years), 


\section{Setting the context}

these tiny variations in the genotype lead to changes in the phenotype through accumulation. Accordingly, as species evolve, they begin to diversify in their phenotypic traits.

So far, we've looked at heredity and variation within the organism(s), but this isn't the complete picture as we haven't considered external factors. Part of evolution is the idea that the environment within which species are located in contributes to the overall process. Consider the scenario wherein there are two kinds of mice, black ones and white ones, and the terrain they live on is largely black. One predator species in the vicinity are eagles who feed on them. Given the context, the chance of survival for the black mice is significantly higher because they can easily camouflage with the terrain. In contrast, the white mice will stick out very clearly, making them easy targets for the eagles to prey on. Accordingly, the white mice population will decrease as they get picked out as food much more easily, while the black mice population will relatively and simultaneously increase. So, the genes responsible for the white colour in the white mice will eventually fade out, which, in turn, increases the likelihood of future generations having black colour since black mice are becoming the dominant population. This is illustrated in Figure 1.4.

The example we have just seen illustrates a process of evolution known as natural selection (Urry et al. 2016, 14). In simple terms, it is the idea that given the environmental context that species are located in, nature will choose the ones that are most suited to survive in that particular context. To make this clearer, consider another example where we have long trees and giraffes. Giraffes with relatively shorter necks will not survive if they

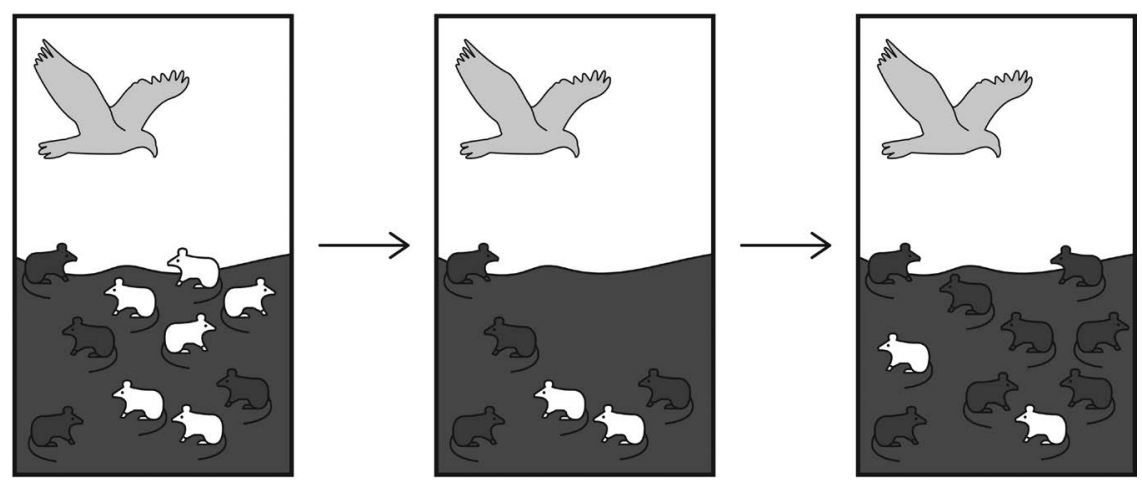

Figure 1.4 This image shows three stages. In the first stage, we see an eagle hovering over four black mice and six white mice. In the second stage in the middle image, we see four black mice and two white mice. In the final stage on the right, we see eight black mice and two white mice. This progression shows how the eagle is feeding off the white mice much more easily against the black landscape, which is simultaneously making the mice population statistically more black due to better survivability. 
cannot reach the tall trees as their food source. By contrast, the giraffes with longer necks will have a higher chance to survive because they have the necessary trait to endure in that specific context. In short, natural selection is like a sieve which flushes out what can survive versus what cannot in a given context, and it is this component where the slogan "survival of the fittest" comes from (we will look at this principle in its historical context shortly). Now that we have a rudimentary understanding of evolution, a few things need to be clarified and elucidated.

First, one should not be mistaken to think that evolution is as simple as what was mentioned. The examples illustrated earlier are basic scenarios; reality is much more complicated. The mice example showed how one predator affected the mice population, a simple one-to-one correlation. However, an environment may have several other predators and other relevant factors which can immensely complicate how future life will pan out. Accordingly, what gene or trait becomes dominant for a particular species in a given environment is not always straightforward to determine.

Second, the survival of the fittest shouldn't be taken to mean that only the ones with the better genes or trait actually survive. Evolution discusses things like these in probabilities (Urry et al. 2016, 291). So, while the black mice have a better chance to survive, this shouldn't be taken to imply that all the white mice will necessarily die out. It is possible but not guaranteed. A better descriptor of these particular examples would be that black mice are becoming dominant in the mice population.

Third, if a particular species obtains the necessary trait to survive in a given context, this is called adaptation (Urry et al. 2016, 470). So, if initially a population of mice were an equal mix of black and white, but over time became dominantly black, as the white mice are dying out due to the predators, this would be an example of adaptation, i.e. they became better suited to their environment (Stearns and Hoekstra 2005, 519).

Fourth, survival in evolution is a relative term. In other words, what is a good trait for survival in one time and place may not be for another time and place (Urry et al. 2016, 495-496). If we take an equal mix of black and white mice from a black terrain to a white one, e.g. a snowy area, then having a black trait will no longer help survival. After several generations, assuming one predator species which will feed on the black mice much more easily, and assuming no other external interference, we can expect to see the dominant colour of the mice population to be white eventually.

Fifth, the process of evolution has both a deterministic and a random aspect to it. Natural selection is the deterministic part. Given the particularities of a set environment, nature will flush out what entities are more likely to survive. This is a deterministic process. The random aspect comes from the mutations of the genotype (Stearns and Hoekstra 2005, 100). Mutations occur for a variety of reasons. Sometimes mutations are the result of exposure to radiation or chemicals. Other times it may be due 


\section{Setting the context}

to the copying errors in the genetic material during the course of reproduction. Mutations can occur on various scales across the genotype, i.e. they can be small or big changes, and they are the fundamental source of variation. Additionally, mutations can be advantageous, disadvantageous, or neutral. Depending on the frequency of mutations, when they occur, how they occur, where (on the genome) they occur, and what they result in can lead to various possible evolutionary pathways (Stearns and Hoekstra $2005,100-123)$. It is this openness in the nature of mutations that gives evolution its randomness component.

Sixth, given the mechanism outlined, evolution is a gradual process and requires a very long time. Before geology matured into the science as it is known today, the standard opinion for a long time was that the earth was very young, around 6,000 years old as the youngest estimation. This was primarily due to the Biblical narrative (Rogers 2011, 71). However, it has been determined from the geological record that earth existed much longer than that. Based on advanced dating methods, it has been determined that earth itself was formed around 4.6 billions of years ago (bya) and our earliest evidence of life on earth is from around 3.5 bya. Long periods of time like bya or millions of years ago (mya) in geological terms is referred to as deep time. So the timescales do seem to align with what we expect for evolution to have occurred (Rogers 2011, 73-80). For the unacquainted reader, such large time scales can be difficult to appreciate and understand (Trend 2002; Cotner et al. 2010). To help comprehend this concept, it might help treating them as if they are seconds, as shown in Table 1.1. As can be seen, if the earth was formed around 145.9 years ago, the earliest humans appeared on earth only 2.3 days ago!

Table 1.1 A brief chronology of the universe. ${ }^{5}$

\begin{tabular}{|c|c|c|}
\hline Years ago & $\begin{array}{l}\text { Equivalent to if } \\
\text { treated as seconds } \\
\text { (units change suitably) }\end{array}$ & Comment \\
\hline 1,430 & 23.8 minutes & Muhammed appears \\
\hline 2,000 & 33.3 minutes & Jesus appears \\
\hline 200,000 & 2.3 days & Earliest humans appear \\
\hline $7,000,000$ & 2.6 months & $\begin{array}{l}\text { Ancestral split between chimpanzee } \\
\text { and human lineages (see Figure 1.5) }\end{array}$ \\
\hline $225,000,000$ & 7.1 years & Dinosaurs \\
\hline $470,000,000$ & 14.9 years & First plants \\
\hline $570,000,000$ & 18.1 years & First animals \\
\hline $1,200,000,000$ & 38.1 years & First eukaryotic cells \\
\hline $3,500,000,000$ & 111 years & First prokaryotic cells \\
\hline $4,600,000,000$ & 145.9 years & When earth formed \\
\hline $14,000,000,000$ & 444.9 years & When the big bang started \\
\hline
\end{tabular}


So, to conclude, at least given what we've covered, evolution is the interplay of two primary mechanisms:

1 Random mutation;

2 Natural selection.

It is the conjunction and primacy of these two mechanisms that make evolution specifically Neo-Darwinian. ${ }^{6}$

\section{Pattern of evolution}

While having explained the process of evolution, it may still be unclear how we get different species. This is where the pattern of evolution comes in. However, let us first start with what we mean by species as this has been left unqualified until now. As a general understanding, species refers to organisms that can interbreed with one another. So, frogs breed with frogs, cats with cats, and humans with humans. When two organisms cannot interbreed, they are classed as two different species (Rogers 2011, 9). This is distinct to what we mean by speciation, which is the course of time it takes for a population of a parent species to evolve (however much) such that it leads to distinct offspring species that can no longer interbreed with the parent (and other) species (Urry et al. 2016, 521). Imagine a parent species that live in a particular habitat which survives an earthquake. Due to this disaster, the population is now split because of a massive crack in the land which cannot be crossed. Moreover, due to the aftermaths of the disaster, the ecosystem of both sides of the land no longer occupies the same initial setting. Given this new environment and the evolution processes we encountered earlier (random mutations and natural selection), the separated populations might ultimately lead to new species on both sides of the land. They will differ to such an extent that they can no longer breed with one another, i.e. they've undergone speciation. This is known as divergent evolution, where one parent species' lineage has successfully led to two (or more) different species over a large span of time (Urry et al. 2016, 564). ${ }^{7}$ As species evolve and branch out over several millions of years, we begin to see a very complicated network of branching relationships like tree branches. It is important to mention that it doesn't entail that the daughter species necessarily and completely replace the parent species when speciation occurs. While this is a possibility, speciation only requires that a subset (and thus not all) of the parent species picks up enough changes to evolve into a new species. This means that parent and daughter species can coexist at a given time (Urry et al. 2016, 504-522). In short, the point being conveyed here is that evolution is not a linear process. It's progressive in that things are changing over time, but they are based on probabilistic mechanisms that follow no clear path of predictability. 
It is because of this branching that evolution is usually depicted as the "tree of life." However, care needs to be taken when using this metaphor. Given the colloquial definition of evolution we looked at earlier, it is not uncommon for people to sometimes think of evolution as a ladder. ${ }^{8}$ Ladders convey a sense of direction that is linear and has a specific goal, i.e. going upwards. But the pattern of evolution is messy and splits into many directions like the branches of a tree, which is why trees depict evolution better than ladders. However, the trunk of a tree can convey a sense of something continuing through the process of evolution when, in fact, this isn't the case (except for time itself). Thus, a better metaphor for the pattern of evolution is more like a bush as is clearly seen in Figure $1.5,{ }^{9}$ and therefore, should suitably be termed as the "bush of life." 10

\section{Defining evolution}

Having cleared the general ideas that underlie evolution, we can now define it scientifically. Charles Darwin described it simply as descent with modification (Urry et al. 2016, 471-472).

This means that over time as entities successively reproduce, there are cumulative, gradual changes that lead to speciation, which in turn produce the biodiversity we see in our animal and plant kingdoms. Recall, the process rests on principles of heredity, variation, and natural selection. Mutations occur on the genetic level, which in turn affect the phenotype. Until now, the first colloquial understanding of evolution - a mere change in something - is similar to the scientific definition. However, the second colloquial understanding of evolution as a positive development doesn't strictly align with the scientific conception. Since the mutations are entirely random, there isn't any inherent direction towards anything. Thus, it wouldn't strictly be correct to say that evolution has a positive development since the entire process is radically contingent. It is this inherent randomness in the mechanics of evolution and contingency in its history that compelled the renowned evolutionary biologist, Stephen Jay Gould $(1989,289)$ to say, "Replay the tape [of life] a million times ... and I doubt that anything like Homo sapiens [i.e. humans] would ever evolve again." 11

Given what we have discussed so far, Neo-Darwinian evolution can be broken down into three core concepts (Fowler and Kuebler 2007, 28-29):

1 Deep time - a long period (millions and billions of years) has occurred (also known as geological time);

2 Common ancestry - all living entities are biologically connected and have a historical lineage, i.e. latter biological entities are derivatives of earlier biological entities;

3 Causal mechanics - random mutations and natural selection are the driving forces of the process. 


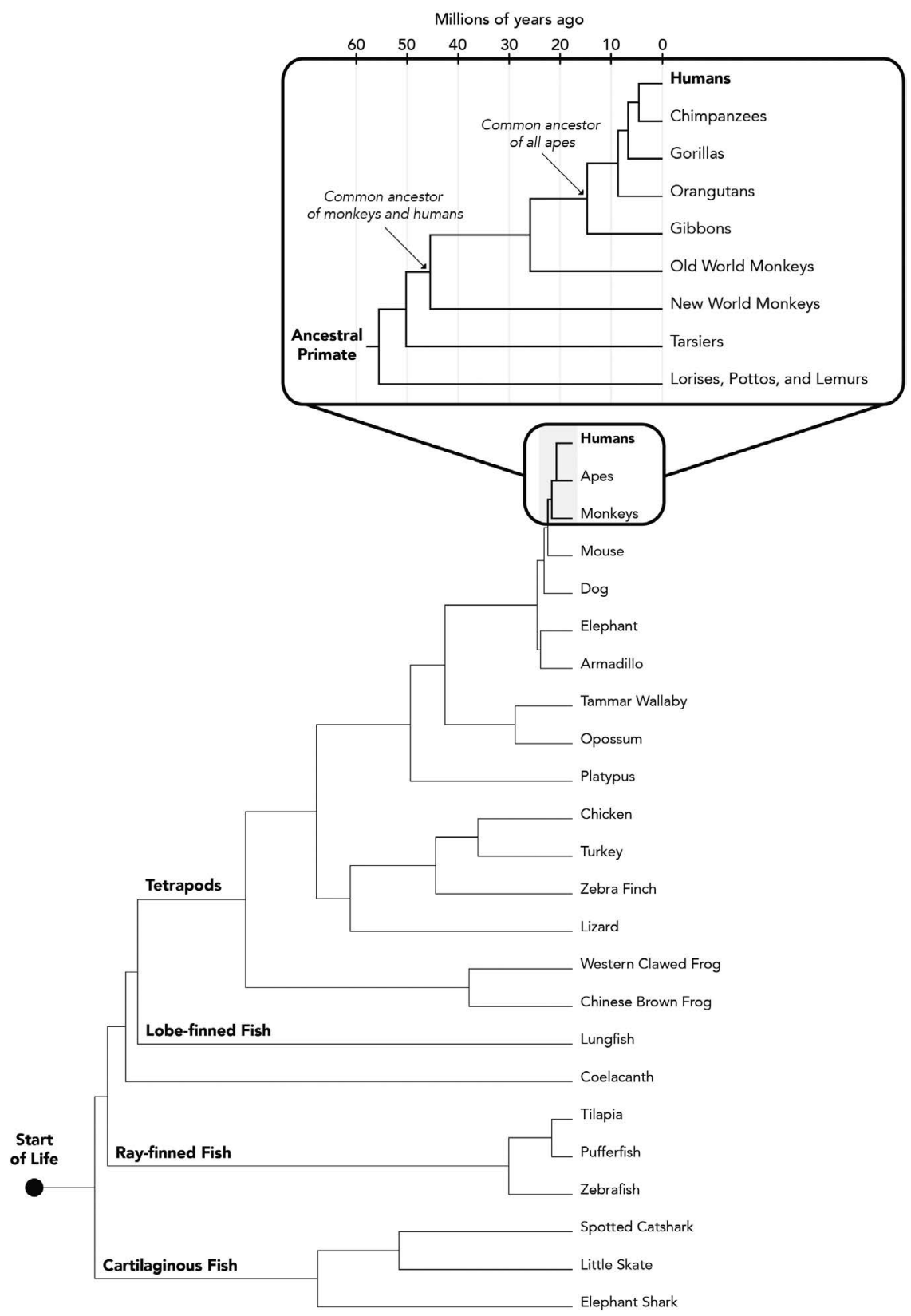

Figure 1.5 This is a bird's eye view of evolution. It shows a branching pattern as we see in a bush. After multiple branches since the start of the origin of life, we see different species appearing. The branches between humans, apes, and monkeys have been zoomed in to show the various intermediates leading up to their existence over the past 60 million years. 


\section{Setting the context}

It is important to note the logical relationships between these propositions. Going from point 1 to 3 , geological time doesn't necessarily entail common ancestry, and neither does common ancestry necessarily entail evolution via natural selection and random mutation. However, this isn't true for the reverse direction, i.e. point 3 to 1, i.e. Neo-Darwinian evolution relies on natural selection and random mutation, common ancestry, and geological time (van den Brink et al. 2017, 459).

\section{Evidence for evolution}

There are several lines of evidence for evolution which collectively make a case for the theory. Due to limitations of space, the focus shall only be on three evidence. These are the fossil record (or palaeontology), homology, and genetics.

\section{Fossil record}

The fossil record simply refers to the bones of past species that have been discovered. The earth's crust is stratified, which means that there are several layers in the ground. Each layer corresponds to a particular time in the history of the earth. We can figure this out by doing several geological and chemical analyses. Consequently, when a particular fossil is found in a specific layer, we usually associate the corresponding time period with the period of existence of that organism (within a given measurement resolution according to the methods used). With the fossil record, there are two general rules to keep in mind. First, older layers are deeper in the ground. So the deeper we dig, the further back in time we go. Second, there seems to be a broad increase in organisms' complexity as we move from the older strata to the more recent ones. In Darwin's time, the fossil record was comparatively weak. It was patchy and had many gaps. After more than a century and a half later, the fossil record has received significant substantiation which evinces gradual evolution of biological organisms. As an example, consider Figure 1.6. Here, we see the progressive record starting from the skeletal structure of Pakicetus - a fossil discovered in Pakistan (and hence the name) - towards modern whales (Rogers 2011, 18-21). As can be seen, over several million years and several minuscule changes, Pakicetus incrementally evolved to longer species with fins instead of legs.

Evolutionary biologists have also made predictions about certain species due to gaps. One famous example of such a specimen is the Tiktaalik as shown in Figure 1.7. Given the broad principles of evolution, the general narrative is that life started at sea. As several million years passed, and fish began to exist and evolve, they somehow developed properties that allowed them to access land. Evolutionary biologists predicted that there must have been some kind of specimen which had biological properties of both sea and land animals. This is where the Tiktaalik comes in. It was seen as an important discovery because it had the basic features seen with fish and 

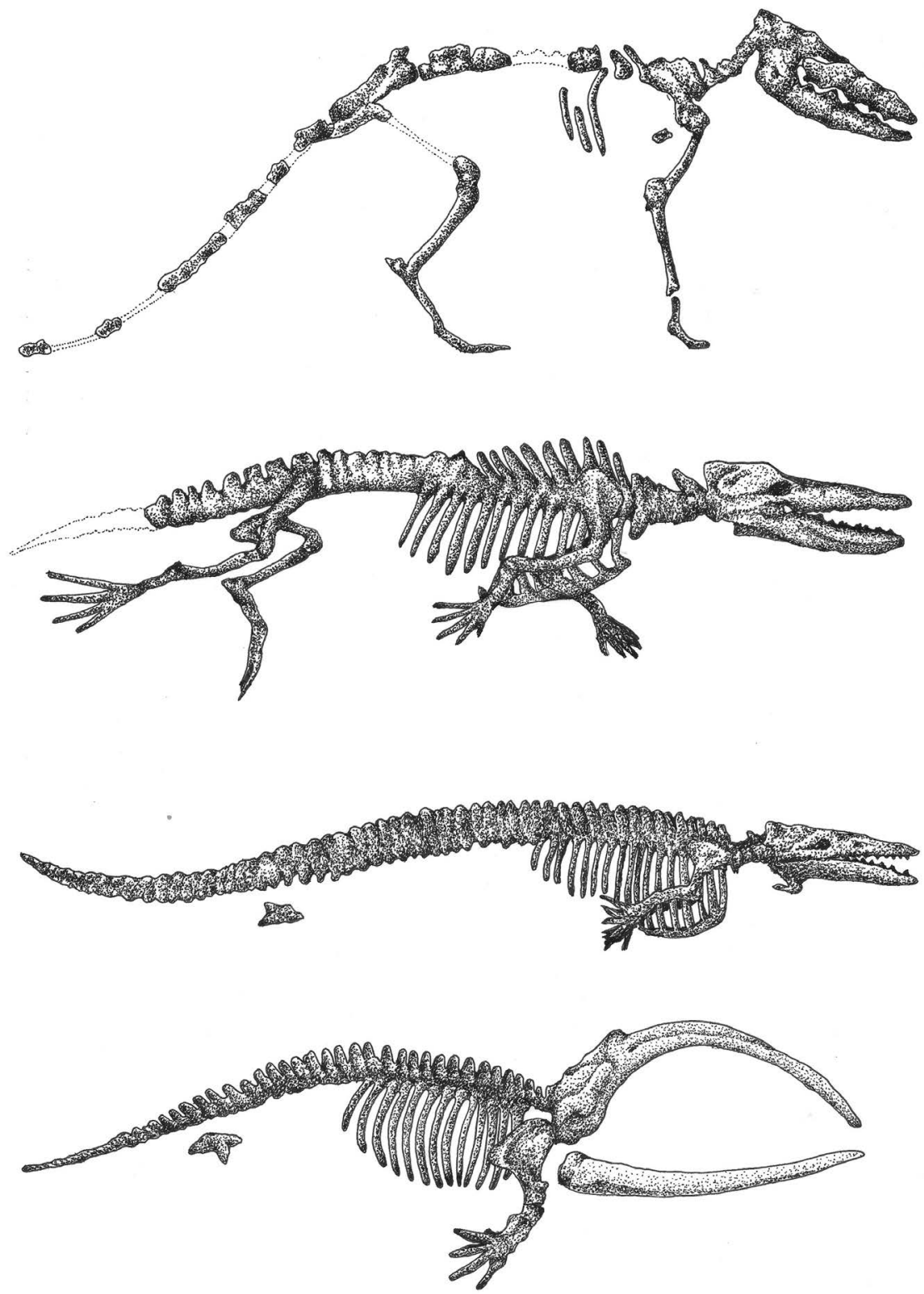

Figure 1.6 This is an example of how the fossil record evinces evolution. It shows the species' historical changes starting from the Pakicetus, a historical ancestor, to the modern whale with intermediates in-between. The Pakicetus resembles a four-legged animal. The succeeding intermediates begin to have shorter legs that resemble fins, and longer bodies, leading up to the modern whale. 


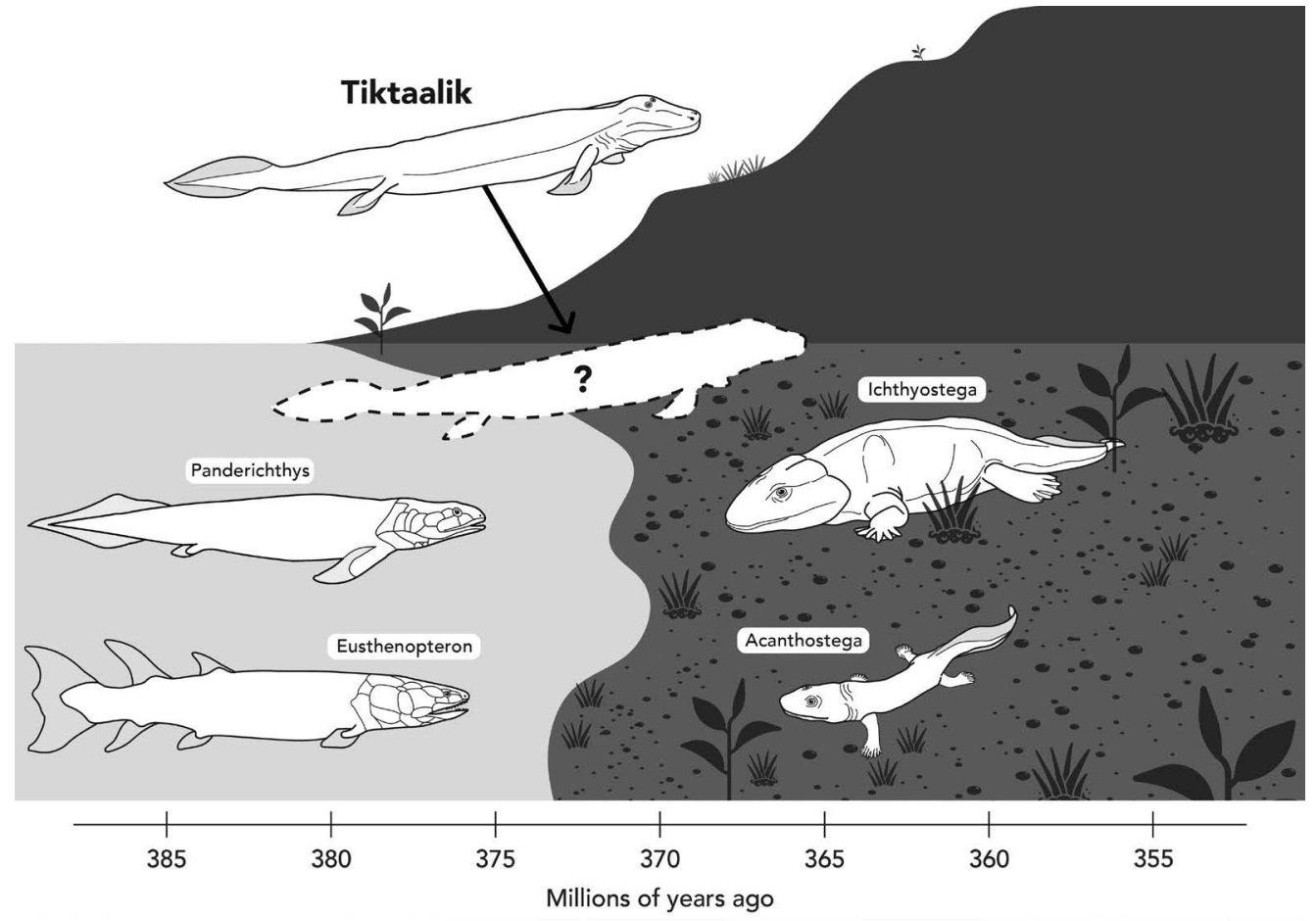

Figure 1.7 This image depicts the transition from water species to land animals with a timeline. On the left side is the sea with various fish species and the right is a landmass with some reptiles. The direction of the timeline is from left to right. This image depicts an empty silhouette at the interface of the sea and land. It represents an entity that must have had mixed biological traits of fish and reptiles. The Tiktaalik, a recent discovery, was found to fit this expectation. A drawing of the Tiktaalik points towards the silhouette to make this point. 
a primitive lung system required of land-based animals, clearly showing some kind of transition (Rogers 2011, 22-23; Futuyma and Kirkpatrick 2017, 447-449). This is one of the most famous examples illustrating how evolution provides the best narrative for such discoveries.

\section{Homology}

Biological homology is simply the study of shared features that exist in different species due to a common ancestor. When a parent species population evolves, the offspring species can evolve and branch into several directions resulting in several more distinguished generations of offspring species. However, it is still possible that some of the basic features that were once in the parent species have transformed in these offspring species depending on the different environmental pressures they have experienced. Consider Figure 1.8, where we see different skeletal structures of a human, a dog, a whale, and a bat. Humans have hands which are functionally different to dogs' legs, a whales' fin, and a bat's wing (Morvillo 2010, 192-194; Urry et al. 2016, 477-479). Given how these species differ in their overall anatomy, we can still observe similarities in their specific bone structure which can be seen in the black and white colour scheme. This indicates that these species once shared a common ancestor come from (however much time ago) even though they have each morphed differently since then. Homology helps evolutionary biologist to explain these striking similarities.

\section{Genetics}

Genetics is one of the most definitive pieces of evidence for evolution. Before we can look at the science, let us entertain a simple analogy. Imagine a teacher with a castle that is made out of simple lego blocks. The teacher tells her twenty students that they either add a single lego block, remove a single lego block, change one of the lego blocks already in the castle, or leave it as it is. Furthermore, they can only do this one student at a time. So, the first student walks up, chooses one of the options, and walks away. Once finished, the teacher takes a photo. The second student comes up does the same, and then the teacher takes another photo. This goes on successively for the remaining eighteen students. At the end of the process, the teacher has a historical record of how the castle morphed over time. Now imagine she gives this photo set to another class who hasn't done this exercise. Furthermore, she completely scrambles the arrangement. The class needs to use the cues in the pictures to determine their historical arrangement. Since each student was only allowed to make one change (or none at all), it won't be too hard for the students to come close to the sequence's actual arrangement. The study of genetics is crudely analogous to this.

We can use principles of genetics to determine a history based on the changes we see at the genetic level. Consider Figure 1.9, where we can track 

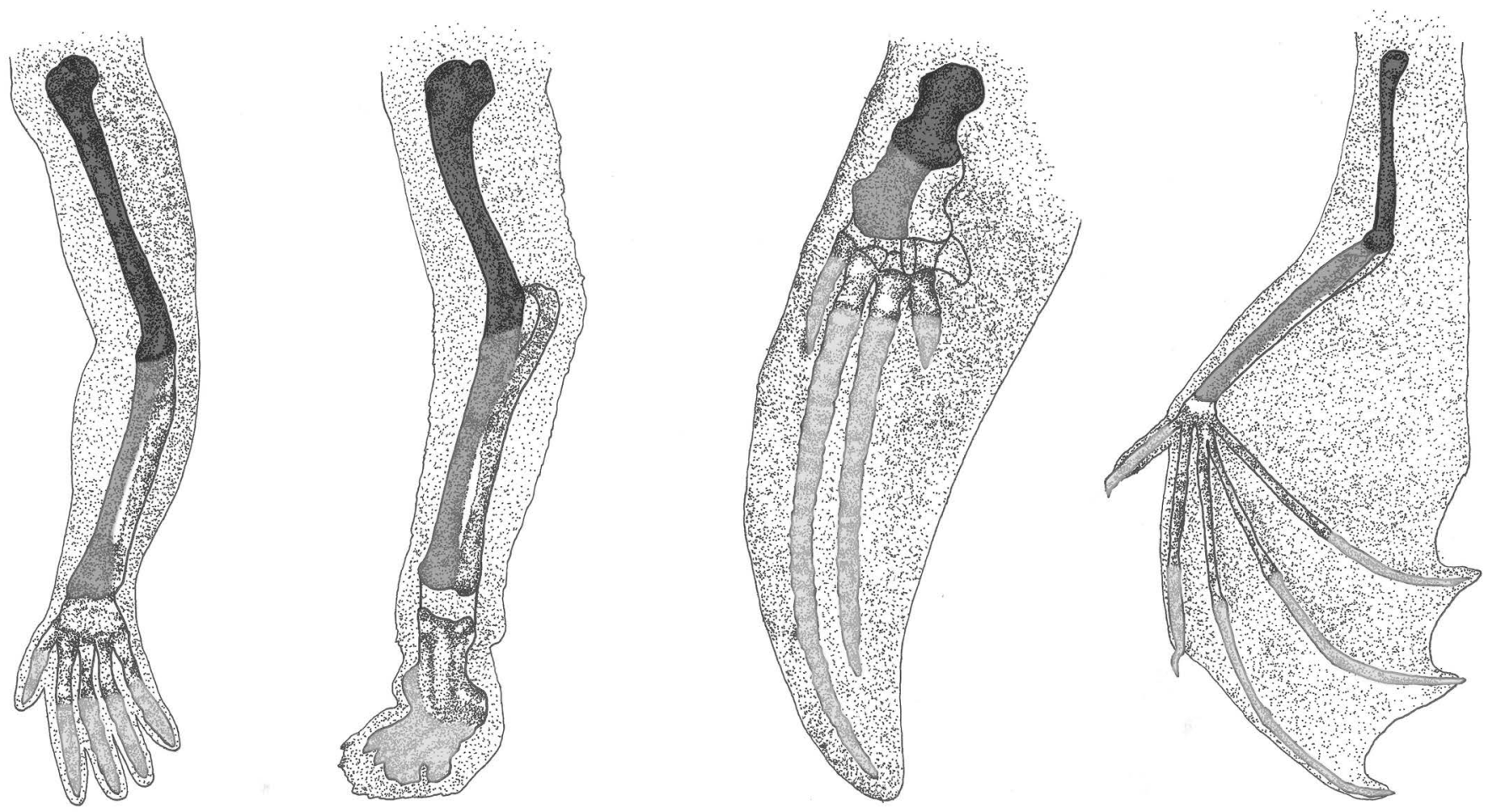

Figure 1.8 This image depicts the bone structure of a human's hand, a dog's leg, a whale's fin, and a bat's wing. While there are variations in the individual bones across these different biological specimens, e.g. the length and width, these bones have the same relative placement indicating they had common ancestors. This is known as homology, and is used as one piece of evidence for evolution. 


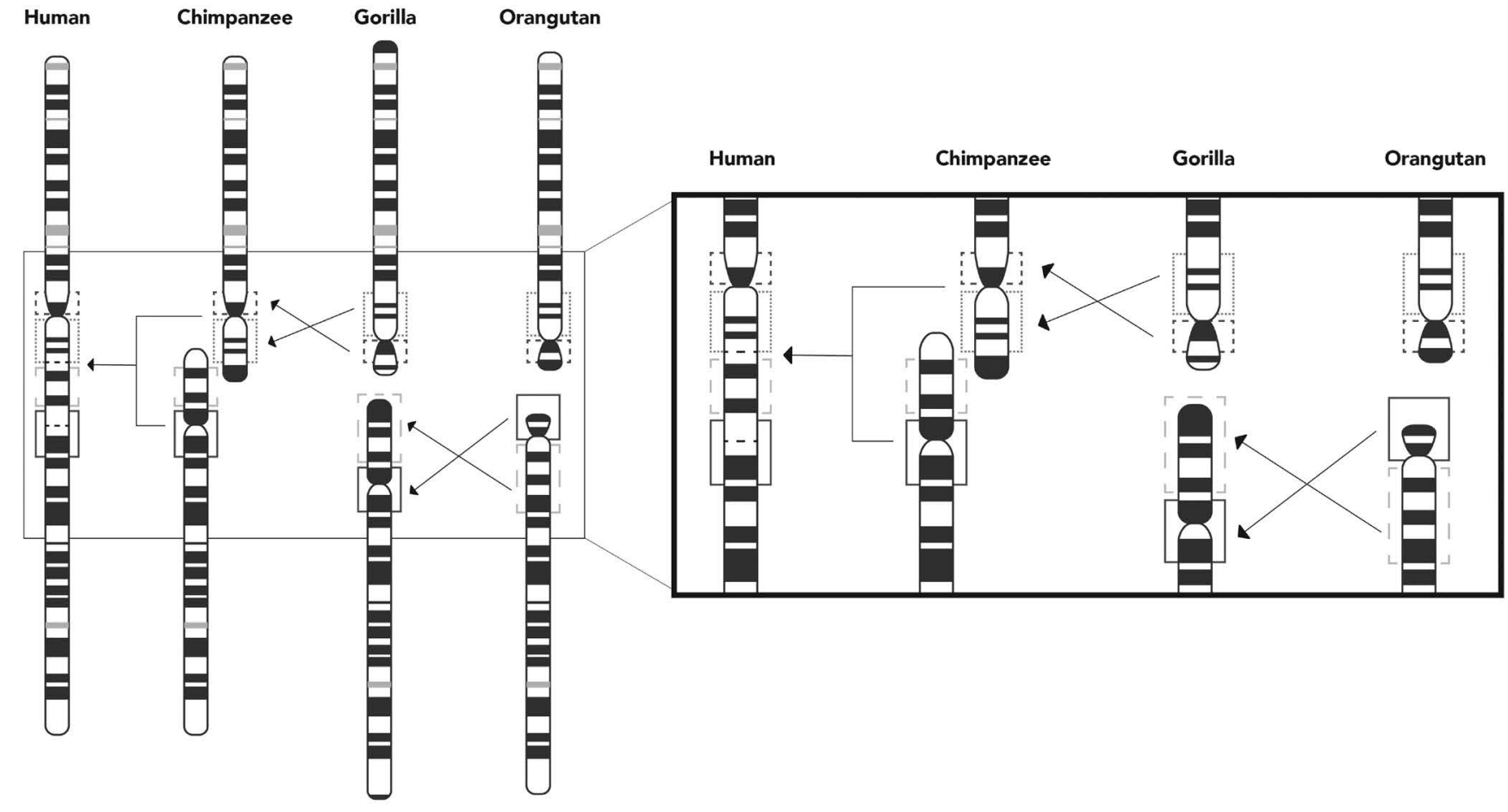

Figure 1.9 This shows the genetic evidence for evolution. It shows four chromosomes of four entities. These include orangutans, gorillas, chimpanzees, and humans. These chromosomes reveal historical changes in the chromosomes. These genetic markers correspond to what we expect if these are related through common ancestry. 
genetic changes from orangutans to humans in their chromosomes. But before we can analyse the figure, and thus acknowledge its importance, it is necessary to understand the scientific context. Orangutans, gorillas, and chimpanzees have 24 chromosomes, and geneticists have labelled them numerically, e.g. 1, 2, 3, etc. Humans, however, are the exception as they have 23 chromes, one less than the others. It is believed that two of the chromosomes of an earlier ancestor of chimpanzees and humans must have fused. Coming back to Figure 1.9, it shows two chromosomes of orangutans, gorillas, and chimpanzees. We can track historical changes on the chromosomes of these entities. However, unlike simple rearrangements, the difference between chimpanzee and human chromosomes is that the latter has a fusion of two chromosomes (Alexander 2008, 211-212; Fairbanks 2010, 17-30). The interesting thing about this finding is that we see the relative genetic similarities in the chromosomes of orangutans, apes, chimpanzees, and humans, which is a significant line of evidence suggesting common ancestry between them. ${ }^{12}$

Additionally, there are non-functional genes called pseudogenes that are carried over to successive generations and species. These can act as unique historical markers in the genes that indicate how different animals are connected through a biological lineage (Finlay 2013, 132-193; Futuyma and Kirkpatrick 2017, 345-367). Humans and chimpanzees carry very similar pseudogenes, which further corroborate the claim of humans and chimpanzees having a shared ancestor (Zhang 2014). Thus, there is substantial proof of evolution from genetics.

\section{Summary}

Evolution is well-substantiated. Individually, each line of evidence may be held tentatively. But when independent lines of inquiry point towards the same idea, known as consilience of induction, the conclusion becomes much more substantiated. This is the case with evolution (Ruse 2008, 25-51; Rieppel 2011, 127-133). While only three pieces of evidence were reviewed in this section, there are, in fact, many more. Covering all of these in sufficient depth is beyond the scope of this work, and the reader wanting more details should refer to the references (Stearns and Hoekstra 2005; Fowler and Kuebler 2007, 77-112; Rogers 2011; Finlay 2013; Bard 2017; Futuyma and Kirkpatrick 2017). ${ }^{13}$

\section{A very brief history of evolution}

The scientific principles of evolution discussed previously fall under what is known as Neo-Darwinism or the Modern Synthesis. However, what puts the "Neo" in Neo-Darwinism requires us to delve into the theory's history, and this is what will be covered here. This section will broadly show how the theory of evolution originated, developed, and the challenges it's facing 
today. That said, a caveat needs to be pointed out. The following is a simple sketch of what is otherwise a long-winded and complex history. Authors develop neat categories through which they think about history, which can sometimes distort reality. The following, then, should be taken as a very simple outline of the history of evolution. It will be left to the historians who have done much good work to fill in the gaps and increase the resolution on skimmed points (Moore 1981; Bowler 1983; Bowler 2007; Young 2007; Bowler 2009; Depew 2009; Spencer 2009; Bowler 2015; Johnson 2015; Jenkins 2019; Gribbin and Gribbin 2020). Finally, a point needs to be made about a particular approach that has been adopted in this section. The prevailing idea in Darwin's time was God created things with a specific design and purpose. With the advent of evolution, biodiversity was now explainable without appealing to God. This is why notions of design and evolution are sometimes thought to be in a tense relationship. While this discussion is critical, it will not be reviewed here. The particular conversation of design and its relationship with evolution has been postponed to Chapter 7 in its entirety. The related conversation of teleology will be discussed in Chapter 6 .

\section{Medieval ideas}

It would be a fair characterisation to say that the idea of having common ancestry was non-existent before the enlightenment period (roughly seventeenth to the nineteenth century). The dominant paradigm at the time was that animals remain fixed as they are. This was premised on a framework known as the Great Chain of Being (GCB). In short, this was a hierarchal, ladder-like worldview which established a gradient of perfection with God being the highest rank as He could never be imperfect. Everything below Him was the rest of the imperfect creation. At the bottom of the ladder were simple things like minerals, followed by plants, then by animals, then angels all the way up to God (Bowler 2009, 62-66). The uniqueness of the GCB was that it viewed the world as fixed ontological units. This entailed that biological change of one species converting into another was impossible (Morvillo 2010, 144). Cats would always be cats, lions would always be lions, and humans would always be humans. It would take several developments in science (and philosophy) to finally move away from this worldview. ${ }^{14}$ This particular idea will be picked up again in Chapter 5 in which will see how some contemporary Muslim thinkers try to read evolutionary ideas into historical Muslim thinkers' works while not realising they were, in fact, discussing the GCB.

\section{Pre-Darwinian ideas}

A common misconception about evolution is that Darwin was the first person to have conceived the idea of evolution. This is untrue as there were evolutionary ideas before Darwin. However, it is important to highlight 
that the conception and discipline of genetics did not exist until the $1930 \mathrm{~s},{ }^{15}$ which is beyond Darwin's time. ${ }^{16}$ So the ideas to follow should be understood with this context in mind.

One of the first thinkers to have proposed a coherent account of evolution (albeit different from today's understanding of evolution) was a French scientist named Jean-Baptiste Lamarck (d. 1829). His proposal rested on a few basic ideas. First, all animals have a fluid inside them that continuously develops them towards higher levels of complexity (Larson 2006, 41). In other words, biological entities are inherently driven towards higher sophistication. Accordingly, organisms have a progressive direction in their development, i.e. like a ladder (keeping in mind the point about metaphors discussed earlier). ${ }^{17}$ Second, the same fluid inside of them allowed them to acclimatise to the environment they were in. This adaptive force would develop particular organs used constantly by the specimen (and create new ones depending on the environmental stress). At the same time, those that weren't would atrophy (Bowler 2009, 92). This was aptly known as the law of use and disuse. For example, consider a giraffe that was constantly using its neck to reach foliage at the top of long trees. With time, the neck would get longer to help the animal adapt in that particular environment. Third, Lamarck adopted a principle known as the inheritance of acquired characteristics. In short, if an animal developed a particular adaptation during its lifetime, it would be passed on to its offspring. Going back to the giraffe example, its offspring would automatically start with a long neck rather than having to develop one for themselves. So traits or characteristics that were being acquired by the parent generation could be inherited by the offspring generation, hence the name, inheritance of acquired characteristics (Bowler 2009, 92). Fourth, Lamarck didn't strictly adopt the idea of common ancestry. He believed that life was constantly and spontaneously originating, leading to various, independent evolutionary pathways towards higher complexity. So rather than having an interconnected paradigm like a bush, he saw all lineages as disconnected strands that were all climbing up their own ladders towards higher sophistication (Larson 2006, 42; Waters 2009, 123; Morvillo 2010, 146). Thus, at any given moment in time, some species were at an early stage (and therefore historically younger). In contrast, others were much more developed, older, and thus at a much higher level in their ladder-like progression (Shanahan 2004, 14-17). This implied no such thing as the extinction of species (see the comparison between Lamarckian evolution and Darwinian evolution in Figure 1.10). The fossils that were being discovered were of individuals of particular species but did this not imply that species were dying out (Bowler 2009, 89). ${ }^{18}$ These ideas collectively came to be known as Lamarckism.

\section{Charles Darwin}

Darwin has a fascinating biography, and many accounts have looked into his works, historical setting, and possible influences to suggest how he 


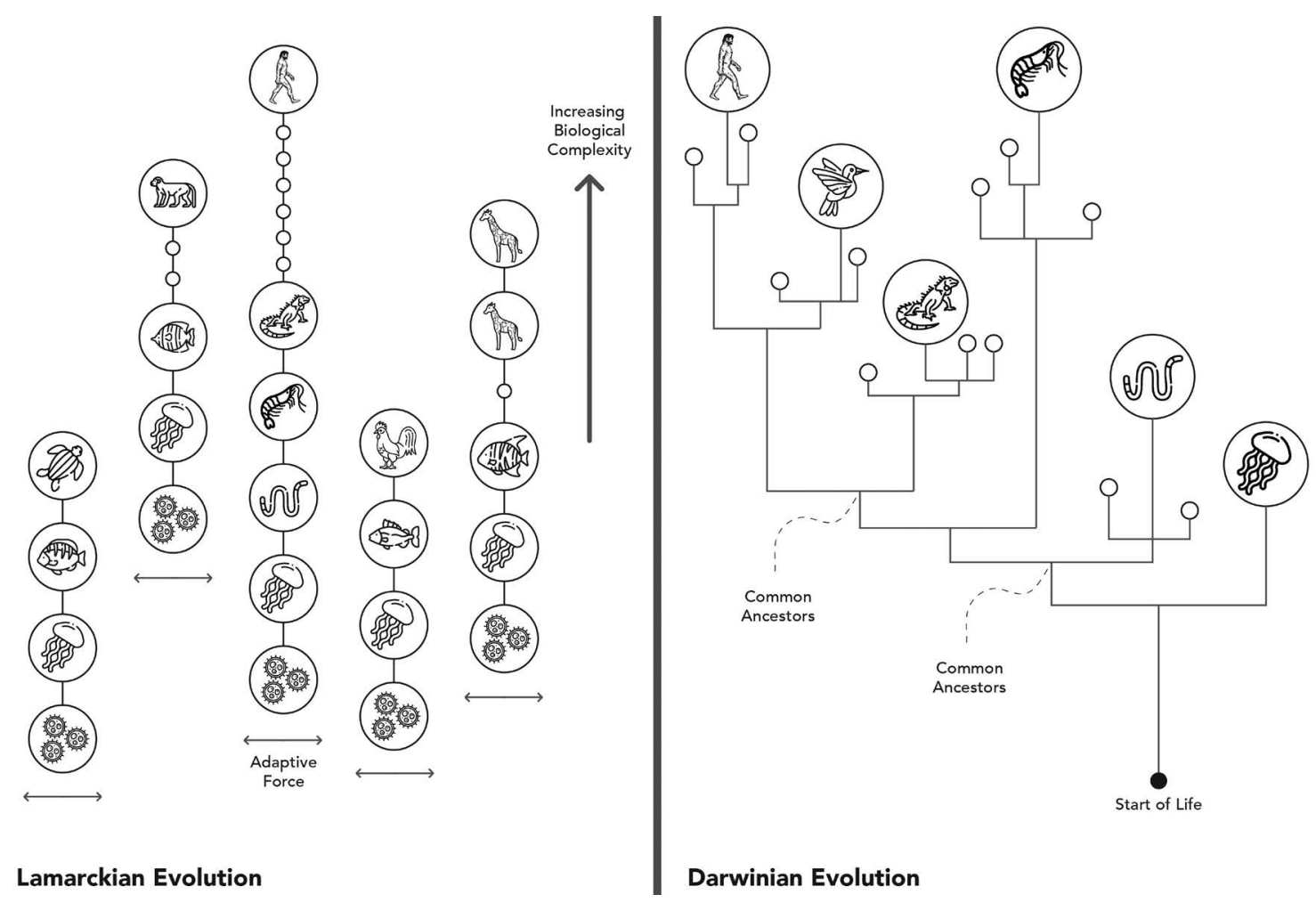

Figure 1.10 This contains two images which illustrate the differences between Lamarckian evolution and (Neo-)Darwinian evolution. Lamarckian has independent strands of evolutionary pathways, i.e. separated ladders with a progression. By contrast, (Neo-) Darwinian evolution has interconnected evolutionary pathways like a bush. 


\section{Setting the context}

arrived at this theory (Spencer 2009; Johnson 2015). This is a vast corpus and will not be entertained here. This section aims to primarily unpack what made Darwin's proposal unique in his time.

In 1859, Charles Darwin (d. 1882) published his outstanding book, On the Origin of Species by Means of Natural Selection, or the Preservation of Favoured Races in the Struggle for Life (hereon referred to as On the Origins of Species). ${ }^{19}$ There are three key things about his perspective that need to be highlighted. First, what made Darwin's proposal unique was his emphasis on natural selection. He took inspiration from artificial selection utilised by farmers (Larson 2006, 69; Waters 2009, 124). Artificial selection, also known as selective breeding, is the process whereby humans select which animals or plants they want to breed to induce a particular kind of trait in the offspring. As a simple example, horse breeders may want to focus on getting speedy male horses to mate with speedy female horses to have foals (baby horses) which will more likely have that trait. So, in this case, humans are actively interfering with the mating process for an intended outcome. Darwin took this idea but transposed it (analogically) to nature (Largent 2009). Since each environment has its own particularities, the individual organisms and species that were likely to survive were the ones best adapted to their localities. This should be understood as two connected principles. There is on the hand the requirement of species adapting to the environment itself. So, for example, animals with really thick fur that cannot get rid of heat quickly may die out in a scorching hot desert. Then there is the other component where species have to compete over the limited number of available resources in the environment they are situated in (Larson 2006, 85). In this compounded understanding of survival, nature was "selecting" which species got to succeed, which is where we get the term natural selection from. It is Darwin's stress on evolution being driven by natural selection that is referred to as Darwinism ${ }^{20}$ (which will be contrasted with Neo-Darwinism shortly).

Second, since Darwin didn't know about genetics, he speculated about how the daughter generation inherited traits from the parent generation. The theory he came up with was known as pangenesis (Endersby 2009, 82-86). To keep things simple, this theory relied on a basic idea that all the organisms in the body were shedding small entities called gemmules, which made their way to the parents' sex cells. Gemmules insured that the offspring would then inherit the traits which were in the parents. This theory had two implications. First, this theory had some alignment with Lamarckism, particularly the inheritance of acquired characteristics and the law of use and disuse (Larson 2006, 86). ${ }^{21}$ Consider a parent who was very slender in his younger age and then got muscular over time. If he had kids in the early period, then his children would also inherit that slenderness. But if he had children in his muscular days, then his kids would be so too. This is important to point out because it shows that Darwin's theory was as speculative as Lamarckism when it came to the question of inheritance. ${ }^{22}$ 
Second, this theory implied something known as blended inheritance. The mother and father's gemmules would have to combine and thus blend into some kind of average (like mixing colours), which would then be passed on in the offspring. As a crude example, offspring of parents with different hair colours would have an intermediate shade. However, some traits, e.g. gender, were exceptions and did not blend (Bowler 2009, 199). Regardless, this was problematic because it entailed that traits would eventually dilute over several offspring successions, but this ran counter to experience and experimentation, which led to its eventual rejection (Morvillo 2010, 152).

Finally, Darwin knew that his theory was circumstantial given the then available evidence (Lustig 2009). His theory required that evolution was a long and gradual process. But the physics known at the time made this somewhat difficult to accept (Larson 2006, 120). The prominent Lord Kelvin, one of the most celebrated physicists at the time, calculated that the earth could not be more than a maximum value of 500 million years old with a likely age of 200 million years (Hattiangadi 1971, 505). This was not enough time to give Darwin's theory traction, which is something he himself acknowledged (Hattiangadi 1971, 506). Also, it wasn't always clear how sufficient the fossil record really was to justify his theory (Shanahan 2004, 247-282; Herbert and Norman 2009). ${ }^{23}$ If evolution is a gradual process, then there should be several intermediate fossils that display a steady development of the history of life. Since these were lacking, the fossil record had "missing links," i.e. remained gappy, and thus was open to other interpretations (Larson 2006, 125; Rogers 2011, 5; Berry 2012, 26).

\section{Neo-Darwinism}

The reception of Darwin's ideas was mixed. Some were heavily against his theory, while others were much more open to it (Larson 2006, 177-218; Bowler 2009, 177-273; Brooke 2012). Regardless of the individuals and movements on the spectrum, what is important for this section is to note how Darwinism eventually crystallised into evolutionary orthodoxy. The scientific issues with Darwin's theory were raised earlier. There were also some theo-philosophical problems that contributed to the Darwinian paradigm's resistance.

One of the biggest issues was teleology. If evolution, as described by Darwin, is true, and the process is fundamentally dependent on environmental pressures and inheritance, then it punctures the traditional understanding of a purposeful universe, which in turn raises questions for God's providence (Berry 2012, 21-22). If survival value is contingent on the always fluctuating environments, the notion of a good adaptation versus a bad one was completely relative. A good adaptation or survival value one day may be completely useless or even detrimental on another day (Morvillo 2010, 153). The direction of evolution, then, is incredibly temperamental. Therefore, it is unsurprising that some perceived the 


\section{Setting the context}

appearance of humans as a lucky accident in Darwin's theory of evolution. This questioned God's planning, specifically if He created humans and this universe for a particular reason. It was for this reason that revised versions of Lamarckism, which were identified as Neo-Lamarckism, ${ }^{24}$ were seen as better perspectives because of the law of use and disuse through which biological entities at least had some control in their lifetimes to adapt (Bowler 1988, 200-201; Bowler 2009, 236-247). ${ }^{25}$ As stated by Bowler (2009, 367):

One of the most emotionally compelling arguments used by the neo-Lamarckians of the late nineteenth century was the claim that Darwinism was a mechanistic theory which reduced living things to puppets driven by heredity. The selection theory made life into a game of Russian roulette, where life or death was predetermined by the genes one inherited. The individual could do nothing to mitigate bad heredity. Lamarckism, in contrast, allowed the individual to choose a new habit when faced with an environmental challenge and shape the whole future course of evolution.

Second, natural selection questioned God's omnibenevolence. Scientists estimate that $99 \%$ of all species that ever lived are now extinct (Urry et al. 2016, 472). Why would a caring and loving God create such a process in which suffering and extinction of species are systematically inherent? It is too cruel of an operation befitting of an omnibenevolent God, which is why it was (and still is) a challenging conclusion to swallow for some (Larson 2006, 90-93).

Third, if humans are a product of evolution, then the notion of human uniqueness comes in to question (Bowler 2009, 207-223). Humans were thought to be categorically distinct to other entities similar to us in appearance, e.g. apes. But if evolution is true, then humans and apes are only different as a matter of degree not of kind (Moore 1981, 156; Larson 2006, 97-99). The particular implications Darwin's ideas had for humans' cognitive apparatus was a grave concern (Larson 2006, 95). If humans are nothing but the products of natural selection and random mutation that are geared for survival, it raises the concern of how humans can trust their own convictions (Brooke 2009, 397). As stated by Darwin (1881):

But then with me the horrid doubt always arises whether the convictions of man's mind, which has been developed from the mind of the lower animals, are of any value or at all trustworthy. Would any one trust in the convictions of a monkey's mind, if there are any convictions in such a mind?

Related to human uniqueness was the problem of morality. If evolution was all about "survival of the fittest," - a term that was not invented by Darwin 
but by Herbert Spencer (Larson 2006, 72) - then objective morality could be undermined (Larson 2006, 95). If survival instincts primarily drove our ancestors, then anything can be justified as being necessary for survival, including killing off the old, the disabled, and the poor. It is in this regard that evolution is linked to ideas like eugenics, communism, and capitalism, among others (Moore 1981, 153-173; Larson 2006, 70; Bowler 2015, 153-170). Another related problem is what we mean by "natural." If instincts are part and parcel of human nature as prescribed by evolution, then even things that are traditionally considered to be taboo or vices like prostitution, gambling, gluttony, drinking, and others could equally be considered part of our biological makeup (Morvillo 2010, 155; Huskinson 2020, 108-111). These are some of the perplexing issues surrounding human uniqueness and dignity when situated in an evolutionary context.

Despite scientific and theo-philosophical hurdles, some of which still are debated today, it was ultimately the science that paved the way for Darwin's paradigm getting accepted as evolutionary orthodoxy (Bowler 1983). With the resurfacing of Mendelian genetics in the 1930s and onwards, the question of inheritance was resolved (Bowler 1983; Bowler 1988, 105-130; Larson 2006, 153-174; Bowler 2015). ${ }^{26}$ The conjunction of Mendelian genetics and Darwin's paradigm of natural selection came to be identified as Neo-Darwinism or the Modern Synthesis, thereafter being recognised as a gene-centred narrative (Larson 2006, 221-243; Walsh and Huneman 2017, 4). ${ }^{27}$ The fossil record was also advancing and filling in the missing gaps that weren't available in Darwin's lifetime. Moreover, Darwin's worldview implied that not all evolutionary pathways continued until the present time. Some pathways had dead-ends which led to extinctions, unlike the Lamarckian perspective. The fossil record findings eventually favoured the Neo-Darwinian narrative (Larson 2006, 133-150). Finally, after the discovery of radioactivity, the age of the earth was pushed further than Lord Kelvin's estimates to around 4.6 billion years. All of these findings (and others) eventually eliminated the competing theories at the time and finally allowed Neo-Darwinism to take centre-stage as the best explanation for the accumulating evidence.

\section{Contemporary debates}

Despite the given success story of Neo-Darwinism, the scientific establishment has recently started to question it (Larson 2006, 267-286; Pigliucci and Müller 2010; Fodor and Piatelli-Palmarini 2011; Jablonka and Lamb 2014; Laland et al. 2014; Marshall 2015; Walsh and Huneman 2017; Uller and Laland 2019). The main problem seems to be with how much focus is given to the gene-centric narrative. As put by Laland et al. $(2014,162)$ :

In our view, this 'gene-centric' focus fails to capture the full gamut of processes that direct evolution. Missing pieces include how physical 
development influences the generation of variation (developmental bias); how the environment directly shapes organisms' traits (plasticity); how organisms modify environments (niche construction); and how organisms transmit more than genes across generations (extragenetic inheritance).

In other words, it seems that other mechanisms need to be considered, as having a gene-oriented process doesn't necessarily capture all the things that scientists expect evolution to be able to explain. Recall, the NeoDarwinian paradigm stresses natural selection and random mutation as the primary mechanisms of evolutionary processes. Critics argue that there needs to be an acknowledgement of other causal factors, which, if permitted, require a deeper explanation as to how to they all relate one another as drivers of evolution. This new revision of Neo-Darwinism or Modern Synthesis has been referred to as the Extended Evolutionary Synthesis. Understandably, advocates of the Neo-Darwinian paradigm remain unconvinced (Wray et al. 2014). For the purposes of this section, it is irrelevant to look into the specifics of this debate. The fundamental point that needs to be drawn from these advances is that there is now a healthy examination amongst scientists specifically about evolution's causal mechanics. Accordingly, the distinction between the following two questions needs to be kept in mind:

1 Whether evolution occurred?

2 How does evolution occur?

Advocates of Neo-Darwinism and the other scientific alternatives aren't debating over the first question, but have differing opinions over the second one (Rogers 2011, 3). In other words, most biologists hold onto common ancestry (Glansdorff et al. 2008; Koonin and Wolf 2010; Theobald 2010).28 So what is being called into question is the Neo-Darwinian paradigm and not evolution as a whole. It is important to point this out for two reasons. Some critics take any form of dissension amongst biologists to suggest that the entire edifice of evolution has been dismantled. This is simply untrue. Evolution is a multi-propositional theory, and so care needs to be taken in acknowledging what the disagreement seems to be on (Huskinson 2020, 149-151). As pointed out earlier, the point of contention is over the causal mechanics of evolution, not common ancestry. This distinction ties in with the second point. Some theists find evolution problematic because they see it conflicting with Adam and Eve's creation account mentioned in scripture, which has traditionally been understood as the first parentless couple of humankind. Therefore, whatever the outcome of the current debates over the nature of evolutionary causation, an important scriptural tension remains. ${ }^{29}$ 


\section{Summary}

To summarise, the theory of evolution has come a long way. Darwin's initial conception of evolution faced a lot of resistance. However, once it was merged with Mendelian genetics, and was supported with other accumulating evidence, it was able to surpass the then available alternative paradigms. This advancement came to be known as Neo-Darwinism. However, while Neo-Darwinism stands today as the main framework for understanding evolution, evolutionary biologists have raised questions over the efficacy of its causal mechanics. The outcome of the debate is currently uncertain, but this does not undermine the validity of evolution as a whole, i.e. deep time and common ancestry.

\section{The criticisms of evolution and their evaluation}

This section briefly reviews some of the main objections which critics of evolutions point out. Some of these are scientific, while others are philosophical/theological in nature. The responses to the latter kind may at times be short because they will be expanded on in later chapters. Furthermore, these are independent objections. So, one may read them in any order. Also, at times specific references are made to certain Muslim figures who make some of these claims. This is done intentionally. Readers familiar with the discourse will easily recognise these claims in the writings of Christian creationists (and apologists). The aim with the exclusive focus on Muslim thinkers is to showcase how some of the claims prevalent in Christian circles are equally available in Muslim circles. For the present purposes, these individuals will be mentioned in passing, but they will be discussed in detail in Chapter 4.

\section{Objection 1 - evolution is just a theory}

A common charge against evolution is the claim that it is "just a theory." Well-known preachers like Zakir Naik have been known to make such statements (Samuel and Rozario 2010, 428; Gardner et al. 2018, 383); such utterances unfortunately only illustrate a poor understanding of science (and the philosophy of science).

It is a commonplace in science to find colloquial terms as was seen earlier where we distinguished the colloquial concept of evolution with the scientific one. Similarly, there is a distinction between the colloquial and scientific understanding of the term "theory." In a colloquial sense, it means conjecture or a guess. Rightfully so, it gives the impression of mere plausibility or an opinion that may not be substantiated at a given moment. For instance, imagine a group of friends, none of whom are historians, talking about a particular war in the past. One person says, "it is my theory that the war happened because of $x$ " where $x$ can be a reason or several reasons. 
Being a non-historian, that individual's theory may or may not be credible but is presented as a possible explanation, a guess at best. We experience such conversations daily. However, in science, the word "theory" means something entirely different.

The following is a very crude sketch of what science looks like in practice but is sufficient to make the point. For a start, science needs facts or data to make claims. Without data, scientists cannot guess what's going on with the phenomena they are interested in. So once data is acquired, scientists start creating hypotheses. After a hypothesis is further reified through experimentation, scientists begin to develop laws in mathematical form to encapsulate an equation. Once those laws are understood, can be explained, and have been substantially tested, only then does it becomes a scientific theory (Scott 2009, 11-14). A scientific theory is a model that best explains the facts and makes testable predictions. If it continues to align with newly discovered facts and continues to make predictions that come true, it remains a valid theory. In other words, a valid theory is the highest level of substantiation you can get in science. The colloquial understanding of theory best aligns with the hypothesising stage but in no shape or form does it correlate to the scientific understanding of theory. Thus, it is a categorical error to claim that evolution is "just a theory," and therefore erroneous if used to dismiss evolution.

\section{Objection 2 - evolution isn't falsifiable}

A common objection which is usually thrown around is how evolution is an irrefutable theory as it insulates itself from any criticism. The claim is that evolution is not scientific because it is not falsifiable, a notion which is considered the hallmark of a scientific theory that was popularised by the eminent philosopher of science, Karl Popper. So, before we can discuss whether evolution is falsifiable, let us take a short but helpful detour on what we mean by the term to gather some precision.

Popper explains falsification by comparing three theories: Sigmund Freud's psychoanalytic theory, Alfred Adler's psychoanalytic theory, and Albert Einstein's theory of relativity. For Popper, the first two ideas are unscientific while the last one is a credible scientific theory. His reasoning is as follows. Freud's and Adler's psychoanalytical theories are so broad that they become self-validating. This means that any data considered under either theory somehow ends up supporting the theory, even when there are contradictory data points. Consider two polar opposite cases. The first when a man intentionally drowns a child and the second when a man sacrifices himself (and thus drowns) helps save a child. Both of these can be explained through Freud's and Adler's psychoanalytical theories (Popper 2002, 43-77). How so? Under Freud's understanding, the first case is an example of repression, and the latter is an example of sublimation (terms that are specific to Freud's framework). Adler's psychoanalytic framework 
can also equally explain both scenarios. For Adler, everything is premised on going beyond one's inferiority complexes to reach a superior state. Accordingly, the man in the first case wanted to drown the child to prove himself that he can commit the crime while the man in the second case wanted to prove himself that he was brave enough to save the child. The point here is that both theories can absorb data points which lead to perpetual self-validation. By contrast, Popper felt that Einstein's theory of relativity was different. Without getting caught up in the details, Einstein's general theory of relativity made a simple prediction: light bends around heavy celestial objects like the sun. If so, this could be tested, and this is exactly what happened in 1919 when it was found that light does indeed bend around celestial bodies. The difference between Einstein's theory and Freud and Adler's psychoanalytical theories was that it was open to being wrong and didn't absorb everything that was thrown at it. This is what Popper identified as being falsifiable (Popper 2002, 57-73).

Now that we've unpacked what the term means, we can determine whether evolution is falsifiable or not. Given the science of evolution that was covered earlier, evolution is absolutely falsifiable (Isaak 2007, 21). One example could be to find a complex species in a stratum within which it shouldn't exist. To make this clearer, the theory of evolution states that as we progress in time, the complexity and biodiversity of the species generally increase. In other words, the fossils we expect to find in older strata should be simpler than the ones in more recent strata. The theory of evolution could be refuted when an advanced species expected to be in a later time period, i.e. earlier stratum, is found in an older stratum. Put simply, finding a rabbit before the Cambrian explosion (see the 550 mya ago mark in Figure 1.2) - an event in history where there was a sudden appearance of complex organisms which weren't seen before - could be a game-changer (Pigliucci 2002, 216-231; Sober and Elgin 2017, 46). ${ }^{30}$ Or finding out the gene sequences doesn't match up with our predictions. These are some examples which could have easily falsified evolution as a theory. Thus, claiming that evolution isn't falsifiable and therefore unscientific is completely mistaken.

Concerning this point, it might also help clarify Popper's own stance on evolution since he is used as a reference criticise evolution (Bakar 1984; Sonleitner 1986; Ibrahim and Baharuddin 2014). Indeed, Popper did at one point remark on evolution's scientific status (quoted from Sonleitner 1986, 11): "I have come to the conclusion that Darwinism is not a testable scientific theory, but a metaphysical research programme - a possible framework for testable scientific theories." However, he very clearly withdrew from his stance later on (quoted from Sonleitner 1986, 11): "I have changed my mind about the testability and logical status of the theory of natural selection; and I am glad to have an opportunity to make a recantation ..." So even if Popper is being used a reference for rejecting evolution, i.e. an argument form authority, then this is mistaken because Popper himself eventually agreed that evolution is indeed falsifiable. ${ }^{31}$ 


\section{Objection 3 - the fossil record is gappy}

Nuh Ha Mim Keller (2011), a prominent theologian, argues that the fossil is gappy, and because of this, it can be interpreted many other ways. Accordingly, each interpretation is only probable at best and never certain. The first problem with Keller's scientific contentions has to do with the probability associated with the evidence. Keller wouldn't be wrong to think this way. Scientists recognise that the fossil record is necessarily incomplete and even explain why this is the case. Bone and tissue preservation can occur in a very limited number of conditions, so even if any initial biological specimens are buried or fossilised, they could have eventually eroded or decomposed (Berra 1990, 31-51; Futuyma and Kirkpatrick 2017, 432-435). Moreover, from the samples we find, the amount we obtain in their fully-fledged form is somewhat rare. Usually, parts of the biological specimens are found, e.g. finger bones, which further limits the kind of data we can get from the fossil record (Futuyma and Kirkpatrick 2017, 435). So, the gaps in the fossil record are not surprising for scientists and instead have scientific reasons for their existence (Padian and Angielczyk 2007). Despite the difficulties and complexities associated with the fossil record, scientists have still been able to obtain an overwhelmingly large number of fossils which were unknown before. Examples include the ones we reviewed earlier, e.g. Pakicetus and Tiktaalik (Rogers 2011, 18-25).

The second issue with Keller's scientific disputations against evolution is his lack of awareness of the other sources of evidence which support the theory of evolution. While the fossil record on its own could be considered uncertain if interpreted in isolation, there are independent lines of evidence which corroborate the theory of evolution (van den Brink et al. 2017, 463). Evolution is now supported by genetics, biogeography, homology and many other distinctive fields (Morvillo 2010, 185-210; Rogers 2011; Futuyma and Kirkpatrick 2017). Independent sources of evidence lead to the same conclusion, i.e. consilience of induction, gives us strong epistemic support that evolution is true. ${ }^{32}$

\section{Objection 4 - scientists disagree about evolution}

This claim rests on the observation that scientists disagree over some of the principles and/or evidence of evolution, which, apparently, demonstrates that the theory is in crisis. As shown before, evolutionists (and philosophers of biology) wholeheartedly acknowledge various other issues with the science of evolution. For instance, scientists still have different conceptions of what it means to be a species. While it seems trivial, this can seem like a major problem because one needs a robust definition to understand when speciation has occurred (Mayr 1991, 26-34; Ershefsky 2017). Another example is the gene comparison problem between chimpanzees and humans. Since the chromosomes of chimpanzees are longer, 
it is somewhat difficult to assess which parts can be correlated with the human chromosome. In short, classifying the chromosomes to make a case for genetic similarity non-arbitrarily is an issue (Marks 2002, 23-50; Castle 2017). These and a host of other issues are known by the experts and are discussed extensively (Sober 2006; Gee 2013; Thompson and Walsh 2017).

However, what needs to be acknowledged is that science, like most disciplines, never comes with complete answers, and it will always be a work in progress. Critics treat these as opportunities to reject evolution while scientists see these as prospects for further investigation. With this categorical misalignment between the two, scientific debates problematically become religio-political ammunition. As observed by Bowler (2009, 348):

To the critics outside the scientific community, these disagreements are heaven-sent. For them, the failure of the synthesis to impose a lasting consensus reveals the weakness of its claim to offer a truly scientific account of the development of life. Most scientists see the debates as a sign of vitality indicating that they are still grappling with significant issues and trying to resolve their differences. But to anyone not actively engaged in scientific research, an admission that theories cannot be immediately verified looks like a sign of weakness. Religious thinkers, convinced that God created the world directly in its modern form, exploit any sign of dissent among scientists as evidence that the materialistic worldview has major flaws.

Dissensions amongst scientists indicate that perhaps things need to be mulled over and further work needs doing. But drawing strong conclusions (particularly religious ones) on tentative and pocketed scientific disagreements will not help anyone in this discourse. At best, one should remain agnostic about the outcome because what is disagreed over today may result in a concrete response tomorrow (or not). Accordingly, critics of evolution have nothing to celebrate about over these disagreements. ${ }^{33}$

\section{Objection 5 - evolution can't explain the origin of life}

This is a common objection against the theory of evolution. There are a few problems with this argument. Many conjectures have been proposed that seek to illustrate how life originated from basic inert matter. While scientists have tried to speculate the possible conditions and mechanisms for the origins of life, the science behind this remains speculative (Walker 2017; Kitadai and Maruyama 2018; Maruyama et al. 2019; Schreiber and Mayer 2020). However, this shouldn't be taken to suggest that an adequate explanation will never come to fruition (Lazcano 2007; Ruse 2008, 52-71). History is indicative of how what was once thought to be scientifically impossible is now in the realm of plausibility, e.g. sending a man to the moon. 


\section{Setting the context}

However, let's say that scientists did eventually successfully come up with a scientifically plausible scenario through which life originates. Why would this be problematic? Some may see this to be an issue because it makes God (even more) unnecessary in the process. The problem with this line of reasoning is that it presumes nature (or science) and God are competing explanations for life's origins, which would be problematic from an Islamic perspective. The distinction between primary and secondary causation will help here (Pope 2007; Rieppel 2011, 47, 52). A scientific explanation attempts to understand how nature operates (secondary causation), which is always directed and sustained by God (primary causation). To collapse the distinction between these two results in treating God and nature (or science) as competitors, which results in the God of the gaps narrative (Pennock 2007). This is the idea that natural phenomena that were once believed to be explained by God are now replaced by scientific explanations. So God is receding as our science progresses. In short, God is only useful when we have gaps in our knowledge, but once those are filled, God is removed from the equations. This is a problematic perspective, and we shall see this issue in more detail in Chapter 6.

Much more importantly, however, this is a completely misplaced objection. Care needs to be taken in distinguishing between the origin of life and the origin of species. The former attempts to explain how life started while the latter explains how species exist (Rau 2012, 82-152). Evolution only addresses the latter (hence the name of Darwin's book, On the Origins of Species). Evolution is the scientific explanation of the origin of species. It is only viable given that life has started but it in of itself makes no claims about how life started. To be clear, evolution as an explanation of the origins of species logically relies on a credible explanation of the origins of life, but it doesn't govern it. Thus, to critique evolution because it doesn't explain how life started is a misdirected criticism of evolution.

\section{Objection 6 - evolution is random which undermines God's omnipotence and omniscience}

As we saw earlier, since the mutations in the genes are unpredictable - they can be either positive, negative or neutral - this potentially undermines a teleological worldview. As it says in the Qur'ān (51:56), "I created jinn and mankind only to worship Me" This verse is obvious in stating the purpose of man which is to worship God. If evolution is inherently random, then it could be claimed that humans are a lucky production, i.e. humans weren't necessarily a product of evolution. Stephen Jay Gould's statement implies that all organisms that we know, humans included, are not guaranteed to come into existence if we rewind the tape of life,. This makes for an uncomfortable perspective because of two reasons. One is metaphysical and the other is scriptural. Metaphysically, it could suggest that God operates in a trial by error basis, i.e. He is experimenting with his creation and doesn't 
seem to know what he is doing. This kind of deity seems dumb and not befitting of the omnipresent and omniscient God which Muslims generally believe in. Scripturally, it seems to go against the quoted verse indirectly if not directly.

Two things can be said about this. First, scientifically speaking, some advocates claim the course of evolution isn't really as open-ended as Gould seems to suggest. Several developments suggest physical and biological constraints that automatically limit what kind of traits can (eventually) come to exist (McGhee 2008). Convergent evolution, which is when a trait is produced through evolution in multiple evolutionary pathways, seems to be commonplace. As an example, if the tape of life were to rewind, we would inevitably see some form of eyes (be they primitive or advanced) to come about. In fact, in our own evolutionary history, eyes have been found throughout evolution in different strands independent of one another, showing its inevitability (Morris 2003, 147-196). This, of course, is but one example, and there are many more in the literature (Morris 2003, 283-310; McGhee 2011). Whether this suggests that teleology is made more apparent, however, is debatable (Morris 2008).

Second, let us assume for the sake of the argument that convergent evolution is invalid. Even in such a scenario, the aforementioned worries aren't cogent. Having a probabilistic or chance-like operation in the universe doesn't entail God doesn't know what He is doing, nor does it undermine divine planning. It is perfectly within God's powers to create a universe which works stochastically that needn't negate God's omniscience nor His omnipotence. To think that it does is only a false imposition of a human vantage point onto God, which is inherently problematic. These and other issues related to randomness will be looked into in Chapter 6.

\section{Objection 7 - evolution is naturalistic and atheistic}

Harun Yahya (2006), which is the pen name of Adnan Oktar, a famous Turkish apologist who has made debunking evolution his life's mission, argues that evolution is naturalistic and atheistic. The notion that evolution is naturalistic is problematic because in Islamic thought there is the conception of supernatural agency and forces such as God and angels. If evolution is considered an exhaustive explanation, it eliminates God's integration in the overall perspective, which then ends up becoming a godless enterprise. Three things can be said of this.

As a start, not only are such claims untrue, but they display a lack of understanding of what it means to be a scientific theory. Scientific theories uncover and explain the laws of nature or regularities which are identifiable in the universe. From an Islamic viewpoint, these observable regularities are instilled and sustained by God (Malik 2019). So, on a fundamental level, how we come to identify a scientific theory to equate to godlessness is an immediate problem. Muslims have generally had no 


\section{Setting the context}

problem doing science because they understood it as unveiling how God runs the universe.

It is also important to note how evolution is almost exclusively criticised with the charge of naturalism and atheism. Simultaneously, the notion of atoms, quarks, chemical reactions, gravity, forces and other scientific phenomena remain somewhat unscathed. If one wants to deny evolution with this line of argument, then they should equally deny the technological products that rely on scientific laws too, e.g. laptops, phones, and the internet, among others. Consider the following comment by Robert Pennock $(1999,333)$ in which he criticises Philip Johnson, a well-known critic of evolution, that highlights this double standard:

Evolutionary theory is naturalistic in just the same way that all scientific theories are, in that they proceed without any appeal to any supernatural entities or powers. Given that this is true of science generally, why should evolution be any special worry to the theist? If it is science's naturalistic methodology that is inherently problematic, then Johnson should be equally worried about chemistry and meteorology and electrical engineering. He should also be concerned about automobile mechanics, for this field too proceeds under the naturalistic assumption that God does not intervene in the workings of the motor. But surely no one thinks that these naturalistic sciences imply that God does not exist.

Finally, an important distinction that can help this particular worry is philosophical naturalism (PN) and methodological naturalism (MN). PN is a metaphysical position that states that nature is all there is while $\mathrm{MN}$ is a position that defines epistemic limits and praxis of science. It can only understand the natural world while remaining silent on the existence of supernatural agencies. Theists can then comfortably adopt MN and treat evolution as a descriptive account of how nature works to create different species without negating the underlying orchestration that can be attributed to God. ${ }^{34}$ More will be discussed on the distinction between PN and $\mathrm{MN}$ in Chapter 6.

\section{Objection 8 - evolution undermines morality}

This objection was seen as a problem in Darwin's time and resurfaces today with critics like Harun Yahya. There are two worries with morality in the context of evolution. The first worry is that morality depends on nature and may have some force as to what a natural behaviour is even though it may seem odd to us. So, if things like incest have some kind of evolutionary basis - say our ancestors practised this - then it may lend to some kind of justification as to why it may be deemed as appropriate. The second worry associated with morality is that under an evolutionary framework morality loses its objectivity. The idea here is that if life was to be replayed then 
what we consider to be moral principles, e.g. not lying, may not turn out to be true (given the different evolutionary pressures that may have arisen). Therefore, moral principles are completely contingent on life's history, and thus aren't set in stone (Ruse 2008, 202-207). The discussion of evolution and ethics will be discussed in detail in Chapter 8. But in short, the theological framework espoused in this work entails that morality is entirely dependent on God's will and not on the natural world. God reveals the moral code He wishes for us to follow through revelation. This also implies that there isn't anything intrinsically objective about morality. The will of God determines entirely what is morally right and wrong, and He can designate and define them as He so pleases.

\section{Objection 9 - Charles Darwin was an atheist}

A common way to refute an argument is by referring to the idea's origins. The claim that is usually charged against evolution is that it came from an atheist, which in this case is Charles Darwin, and therefore Muslims should not adopt it. This is an example of what is known as the genetic fallacy. Just because an idea has a certain an origin that we disagree with doesn't necessarily entail that what is being said is false. If dictators like Hitler, Stalin, or Mao (or even Satan if we want to push this example to the extreme) uttered the statement that two plus is equal to four, their personal temperaments have no bearing on the truthfulness of what they are saying. Similarly, if Darwin was indeed an atheist and came up with the theory of evolution, his atheism has no bearing on what evinces the theory of evolution.

Additionally, and more to the point, Darwin was not, in fact, an atheist, or at least not in the sense that critics claim him to be. Before he arrived at his conception of evolution, he was on track to getting ordained as a priest (Brooke 2009, 393; Osborn 2017, 26-28). He eventually lost some sense of religion and faith in God, but this doesn't entail Darwin was an outright atheist (Bowler 2009, 146). Against the backdrop of the prevailing natural theology in his time, the loss of several family members, including his daughter Anne who he had a very personal connection with, and the implications of evolution being a merciless process, eventually made him lose belief in an omnibenevolent God (Brooke 2009, 396; Spencer 2009, 100). Read charitably, Darwin had fluctuating thoughts but seemed to have been content as an agnostic (Brooke 2009, 394; Spencer 2009, 101). Critics who want to claim Darwin's loss of faith as some kind of victory and basis for rejecting evolution are simply mistaken and misinformed.

\section{Conclusion}

In this chapter, we looked at the science of evolution, the history of the theory, and some criticisms that people usually raise against it. The theory of evolution, which Charles Darwin proposed it more than a 150 years 
ago, stood the test of time with some modifications, and remains with us as the best explanation of our biodiversity. Darwin's theory was merged with Mendelian genetics through developments in science and came to be known as Neo-Darwinism or the Modern Synthesis, and has since been the standard interpretation of evolution. Neo-Darwinian rests on three principles:

1 Deep time;

2 Common ancestry;

3 Natural selection and random mutation.

Despite the success of Neo-Darwinian evolution, there are several scientific debates over the causal mechanics, i.e. the third principle. The critics have aptly referred to this potential revision of Neo-Darwinian evolution or Modern Synthesis as the Extended Evolutionary Synthesis. Regardless of whether the scientific establishment will take this up doesn't undermine common ancestry, which entails that every biological entity, including Adam and Eve, had parents. Naturally, this will raise scriptural tensions for some people (as we shall see in Chapter 4). Finally, care needs to be taken in delineating the science of evolution with the other philosophical, historical, and socio-political concerns that unnecessarily cloud the understanding of the theory.

\section{Notes}

1 When explaining the science of evolution, many textbooks refer to Charles Darwin, given that he was the founder of the theory. Some may notice that my reference to him in the first two sections are non-existent. This is done for two reasons. First, to avoid muddling the historical development of the theory with the science as it stands today. I prefer to keep the explanation of the science ahistorical. The third section, which covers the historical development, will make Darwin's significance and contribution abundantly clear. Second, we are living at a time where our substantiation of evolution has far surpassed the time and conceptions of Darwin (who wrote on evolution nearly 150 years ago). Credit must be given and acknowledged where it is due, and Darwin does indeed deserve the title and fame people give him. However, relying on Darwin's primary works to understand evolution in the twenty-first century is, in my opinion, obsolete. When looking at Darwin's theory in hindsight as developed by him in his own time, we will come to see that it was incomplete. See Shanks (2007, 71-72) for similar observations.

2 It is important to note that there are many layers between the genotype and the phenotype with increasing scale. When genotypes are expressed, there is a whole host of biological complexity taking place, which hasn't been discussed here (Urry et al. 2016, 335-398).

3 Nature also has examples of asexual production. One example is the dandelion (Futuyma and Kirkpatrick 2017, 263). In such species, the genetic material is inherited from a single parent.

4 Of course, this analogy should be taken with some caution. It precludes the possibility of mutation in the genetic material during the course of reproduction, which is possible. 
5 For a similar table, see Kampourakis $(2020,134)$.

6 Recall from the beginning of this chapter, the difference between Darwinism and Neo-Darwinism will be made apparent in the history section.

7 Also see convergent evolution, which is briefly discussed in one of the objections in the last section (Morris 1998; Morris 2003; Urry et al. 2016, 479).

8 It is important to stress that evolution has no direction and nor does it behave linearly. Some interpret evolution simplistically as a linear change in which species in a given time all evolve progressively towards a final goal. This is incorrect. Evolution doesn't state that a species' entire population will evolve but only some might, depending on genetic and environmental pressures. Evolution also isn't goal oriented. The upcoming quote by Stephen Jay Gould should help better understand this point.

9 That said, one should generally remain prudent with metaphors that convey scientific concepts (Bowler 2009, 12-13).

10 This metaphor can also be straining. With new insights like horizontal gene transfer, one could argue that a better metaphor is the "web of life." See Olendzenski and Gogarten (2009).

11 As we shall in a later section, this isn't entirely accurate. Some constraints limit what can and cannot be produced in the history of life through evolution.

12 This should not be confused as a linear and temporal sequence from orangutans to humans. Instead, these are the end products of ancestry lines going through successive mutations. Keep Figure 1.5 in mind when reading the following. Orangutans and gorillas had a common ancestor, which resulted in certain genetic dissimilarities due to mutations. This is what is shown between the two chromosomes of orangutans and apes. A later ancestor of apes and chimpanzees went through something similar. An even later ancestor of humans and chimpanzees follows suit, but with the two chromosomes being fused for the humans. We can see relative genetic similarities that are being carried over in time through which we can suggest orangutans, apes, chimpanzees, and humans as being linked by common ancestry.

13 For specific references on human evolution, see Lewin and Foley (2004), Ayala and Cela-Conde (2017), and Delisle (2017).

14 Moore (1981, 193-216) notes how such ideas were still influential until Darwin's time.

15 This isn't strictly true. Historically, the founder of genetics was Gregor Mendel (d. 1884), a Czech scientist who developed ideas about genetic inheritance (now known as Mendelian genetics) in the mid-nineteenth century. However, his work didn't get much acknowledgement from the scientific community at the time. It was only resurfaced later on in the early decades of the twentieth century and was acknowledged to be an important contribution, particularly in the context of evolution (Bowler 2009, 260-268; Bowler 2015).

16 As we will see shortly, this is one of the key differences between Darwinism and Neo-Darwinism.

17 In the literature of evolution studies, this position is known as Orthogenesis. It should be stated that Lamarckism and Orthogenesis were two different frameworks which were competing with Darwinism. They had overlapping similarities but also had their respective differences (Bowler 1983).

18 Historically, this was known as transmutation. Before Darwin, this was the general reference to evolution. See Eldredge (2008) and Galera (2016).

19 To be historically accurate, Darwin was not alone in discovering this theory. $\mathrm{He}$, in fact, co-founded the theory of evolution with Alfred Russel Wallace (d. 1913). I have intentionally avoided referring to Wallace in the main text to maintain ease of reading. Since this isn't a historical work as such, and given Darwin's almost exclusive association with evolution in the Islamic context, 
my priority was simplicity. However, I believe that Wallace has been a somewhat marginalised figure, and I don't intend to further his absence from the discussion by ignoring him altogether. For the intrigued reader, I recommend Flannery (2018) as an excellent historical treatment of Wallace, where Darwin and Wallace agreed, and how they differed in their interpretations.

20 As a point of caution, the term "Darwinism" has multiple connotations. Historically, it is context-specific (Depew 2009, 326): “... one must constantly bear in mind that what the term 'Darwinism' means in a particular context is deeply affected by what it is contrasted with on that occasion: species fixity? common descent? inner drives? gradualism?"

21 See Nei's $(2013,2)$ observation of how this may have blurred the lines between Lamarckism and Darwinism: "If one accepts any form of inheritance of acquired characters as he [Darwin] did, the difference between the cause of variation and the result of natural selection necessarily becomes unclear. This is because the Lamarckian doctrine generates new heritable variations which are similar to the results of natural selection and the variations may be reverted to original characters when the environmental condition changes back to the original status ... This situation becomes worse if one accepts the blending inheritance to which Darwin subscribed."

22 Considered by some to be a refutation of Lamarckism, August Weisman, a well-known evolutionary biologist, famously cut several mice's tails over several successive generations to show how latter offspring didn't see develop loss nor shrinking of tails (Bowler 2009, 255). However, it is disputed how decisive this experiment really was (Gauthier 1990; Larson 2006, 123-124).

23 Discovery of fossils leading up to humans and theories of human evolution was just beginning to develop at the time (Bowler 1986).

24 When first conceived, Lamarckism fell out of favour with some academics for being too materialistic (Jenkins 2019, 107-195). However, in comparison to Darwin's natural selection, reincarnations of Lamarckism, also known as Neo-Lamarckism, fared better because it provided a sense of order and direction in nature, which is why it gained renewed traction (Bowler 2009, 236-238; Brooke 2012, 56). To be sure, Neo-Lamarckism carried other connotations too. Moore $(1981,175)$ notes that individuals who minimised the role of natural selection were also called Neo-Lamarckians.

25 There were other non-Darwinian and non-Lamarckian theories at the time (Bowler 2009, 207).

26 Interesting to note is that Mendelian genetics wasn't brought up to plug the holes in Darwin's theory. It was initially thought to be an alternative paradigm (Bowler 1983; Walsh and Huneman 2017, 3). However, scientists eventually realised that Mendelian genetics and Darwin's theory was indeed compatible and overlapped (Bowler 2009, 266-273; Bowler 2015).

27 For extensive readings on the Modern Synthesis, see Smocovitis (1996), and Mayr and Provine (1998).

28 It is important to acknowledge the difference between logical dependence and evidential dependence. While common ancestry and causal mechanisms are logically independent propositions, they are evidentially connected. Hypothetically speaking, if no causal mechanics are warranted, it can lend to questioning the validity of common ancestry (Sober and Orzack 2003; van den Brink et al. 2017).

29 I raise this point because Adam and Eve's creation narrative is definitively one of the central concerns amongst Muslims as we shall see in Chapter 4. The only other possible implication that the evolutionary causation debate may have for Islamic thought is the inherent randomness in the process, at least as far as I can tell. Regardless, even if randomness is inherent in the process, 
this poses no threat within the theological parameters adopted in this book, as will be seen in Chapter 6 .

30 However, even in such a scenario, it would not be inconceivable to think of a cataclysmic event where the stratum buckled causing buried fossils to be displaced from their original subterranean settings (assuming there is scientific evidence to back this up) (Isaak 2007, 133). Moreover, in such a scenario, one would have to find alternative explanations for the other evidence obtained from genetics, biogeography, homology, and other fields that point towards the same direction. For historical examples of similar scenarios, see Rudwick (1985), Rudwick (2010), and Montgomery (2012). To be sure, this is not to say that evolution is insulated from criticism but rather the evidence for evolution is so overwhelming that finding a single anomaly wouldn't necessarily entail an immediate refutation of the entire theory. Evolution has significant epistemic inertia. Thus, one would have to revise a lot to account for all the available evidence that can't be sweepingly forsaken for just a few anomalies as is common in science. For example, consider how Newtonian mechanics was unable to account for Uranus's motion (Smith 1989; Ladyman 2002, 88). Rather than dropping Newton mechanics altogether, scientists suggested that another planet was perturbing Uranus' trajectory, which was why their calculations were not aligning with the data. Upon further examination, Neptune, a planet unknown back then, was eventually discovered and explained the discrepancy they had with Uranus' trajectory.

31 For direction quotations, see Popper (1978). Critical perspectives on Popper's understanding of evolution can be found with Stamos (1996) and Sober and Elgin (2017).

32 As an analogue in Islamic theology, consider the field of hadīths. While the Qur'ān is, Islamically speaking, believed to have been preserved without error (Qadhi 1999; Al-A'zamī 2003; Usmani 2007), the same cannot be said of hadīths (Siddiqui 2008; Brown 2011). This is why there is a whole independent discipline within which hadīths are analysed for their veracity and integrity. One principle within this domain is that if several transmission chains are individually weak but corroborate the same message, then the epistemic status of that hadīth becomes stronger (Brown 2011, 92-95). This idea of corroboration is the same principle used to substantiate the theory of evolution.

33 If Muslims are criticising evolution because of a mere difference of opinion, then it only opens problems for themselves. For instance, within Sunnī Islamic discourse, there are different schools of jurisprudence - Hanafī, Hanbalī, Mālikī, Shāfíī - and creed - Ash arism, Māturīdism, and Atharism (Jackson 2009; Abu Zahra 2012). At times there are pretty substantial disagreements between them. Given this point, if the objection of mere disagreement is applied on to Islamic discourse, it would entail that Islamic jurisprudence and creed are equally problematic. Since this isn't a desirable conclusion, criticising evolution on the same grounds should seriously be reconsidered.

34 Thus, theistic evolution - the thesis that God directed the evolutionary process is a position that Muslims can happily occupy. To be clear, theistic evolution isn't a scientific position. It is simply a position given to theists who adopt evolution but know that it is orchestrated and directed by God. In the same spirit of Pennock's aforementioned comment, I personally don't see the necessity of this term because to be consistent we would equally need theistic physics, theistic electrical engineering, theistic chemistry, and so on. None of this is necessary. I am only using this is a term because of its prevalence in the literature. 


\section{References}

Al-A'ẓamī, Muhammad Muștafā. 2003. The History of the Qur'ānic Text, from Revelation to Compilation: A Comparative Study with the Old and New Testaments. Leicester: UK Islamic Academy.

Alexander, Denis. 2008. Creation or Evolution: Do We Have to Choose? Michigan: Monarch Books.

Ayala, Francisco J., and Camilo J. Cela-Conde. 2017. Process in Human Evolution: The Journey from Early Hominins to Neanderthals and Modern Humans. Oxford: Oxford University Press.

Bakar, Osman. 1984. "The Nature and Extent of Criticism of Evolutionary Theory." In Osman Bakar, ed. Critique of Evolutionary Theory: A Collection of Essays. Kuala Lumpur: The Islamic Academy of Science and Nurin Enterprise, 123-152.

Bard, Jonathon. 2017. Principles of Evolution Systems, Species, and the History of Life. Abingdon: Routledge.

Berra, Tim M. 1990. Evolution and the Myth of Creationism: A Basic Guide to the Facts of Evolution Debate. Stanford, CA: Stanford University Press.

Berry, R. J. 2012. “Biology Since Darwin.” In Andrew Robinson, ed. Darwinism and Natural Theology: Evolving Perspectives. Newcastle Upon Tyne: Cambridge Scholars Publishing, 12-38.

Bowler, Peter J. 1983. The Eclipse of Darwinism. Baltimore, MD: The John Hopkins University Press.

Bowler, Peter J. 1986. Theories of Human Evolution: A Century of Debate, 1844-1944. Baltimore, MD: The John Hopkins University Press.

Bowler, Peter J. 1988. The Non-Darwinian Revolution: Reinterpreting A Historical Myth. Baltimore, MD: The John Hopkins University Press.

Bowler, Peter J. 2007. Monkey Trials and Gorilla Sermons: Evolution and Christianity from Darwin to Intelligent Design. Cambridge, MA: Harvard University Press.

Bowler, Peter J. 2009. Evolution: The History of an Idea. Berkeley, CA: University of California Press.

Bowler, Peter J. 2015. The Mendelian Revolution: The Emergence of Hereditarian Concepts in Modern Science and Society. London: Bloomsbury Academic.

Brooke, John Hedley. 2009. "Darwin and Religion: Correcting the Caricatures." Science and Education, 19: 391-405.

Brooke, John Hedley. 2012. "Christian Darwinians.” In Andrew Robinson, ed. Darwinism and Natural Theology: Evolving Perspectives. Newcastle Upon Tyne: Cambridge Scholars Publishing, 47-67.

Brown, Jonathon A. C. 2011. Hadith: Muhammad's Legacy in the Medieval and Modern World. Oxford: Oneworld.

Cambridge Dictionary. "Evolution.” Accessed 14th of June 2020a. Available at: https://dictionary.cambridge.org/dictionary/english/evolution

Cambridge Dictionary. "Devolution.” Accessed 14th of June 2020b. Available at: https://dictionary.cambridge.org/dictionary/english/devolution

Castle, David. 2017. "DNA Barcoding and Taxonomic Practice." In R. Paul Thompson, and Denis M. Walsh, eds. Evolutionary Biology: Conceptual, Ethical, and Religious Issues. Cambridge: Cambridge University Press, 87-106.

Cotner, Sehoya, D. Christopher Brooks, and Randy Moore. 2010. "Is the Age of the Earth One of or 'Sorest Troubles?' Students' Perceptions About Deep Time Affect Their Acceptance of Evolutionary Theory" Evolution, 64(3): 858-864. 
Darwin, Charles. 1881. “Letter to William Graham, Down, July 31, 1881.” In Francis Darwin, ed. The Life and Letters of Charles Darwin Including an Autobiographical Chapter. Volume 1. London: John Murray, 315-316.

Delisle, Richard G. 2017. Debating Humankind's Place in Nature 186-2000: The Nature of Paleoanthropology. Abingdon: Routledge.

Depew, David. J. 2009. "Darwinian Controversies: An Historiographical Recounting." Science and Education, 19: 323-366.

Dobzhansky, Theodosius. 1973. "Nothing in Biology Makes Sense Except in the Light of Evolution." American Biology Teacher, 35(3): 125-129.

Eldredge, Niles. 2008. "Experimenting With Transmutation: Darwin, the Beagle, and Evolution." Evolution: Education and Outreach, 2: 35-54.

Endersby, Jim. 2009. "Generation, Pangenesis and Sexual Selection.” In Jonathon Hodge, and Gregory Radick, eds. The Cambridge Companion to Darwin. Cambridge: Cambridge University Press, 73-95.

Ershefsky, Marc. 2017. "Consilience, Historicity, and the Species Problem.” In R. Paul Thompson, and Denis M. Walsh, eds. Evolutionary Biology: Conceptual, Ethical, and Religious Issues. Cambridge: Cambridge University Press, 65-86.

Fairbanks, Daniel J. 2010. Relics of Eden: The Powerful Evidence of Evolution in Human DNA. New York, NY: Prometheus Books.

Finlay, Graeme. 2013. Human Evolution: Genes, Genealogies, and Phylogenies. Cambridge: Cambridge University Press.

Flannery, Michael A. 2018. Nature's Prophet: Alfred Russel Wallace and His Evolution from Natural Selection to Natural Theology. Tuscaloosa, AL: The University of Alabama Press.

Fodor, Jerry, and Miassimo Piatelli-Palmarini. 2011. What Darwin Got Wrong. London: Profile Books.

Fowler, Thomas, and Daniel Kuebler. 2007. The Evolution Controversy: A Survey of Competing Theories. Ada, MI: Baker Academic.

Futuyma, Douglas J., and Mark Kirkpatrick. 2017. Evolution. Sunderland, MA: Sinauer Associates, Inc.

Galera, Andrés. 2016. “The Impact of Lamarck's Theory of Evolution Before Darwin's Theory." Journal of the History of Biology, 50: 53-70.

Gardner, Vika, E. Carolina Mayes, and Salman Hameed. 2018. "Preaching Science and Islam: Dr. Zakir Naik and Discourses of Science and Islam in Internet Videos." Die Welt Des Islams, 58: 357-391.

Gauthier, Peter. 1990. “Does Weismann's Experiment Constitute a Refutation of the Lamarckian Hypothesis? Bios, 61(1/2): 6-8.

Gee, Henry. 2013. The Accidental Species: Misunderstandings of Human Evolution. Chicago, IL: The University of Chicago Press.

Glansdorff, Nicholas, Ying Xu, and Bernard Labedan. 2008. “The Last Universal Common Ancestor: Emergence, Constitution and Genetic Legacy of an Elusive Forerunner." Biology Direct, 3(29): 1-35.

Gould, Stephen Jay. 1989. Wonderful Life: The Burgess Shale and the Nature of History. New York: W. W. Norton and Company.

Gribbin, John, and Mary Gribbin. 2020. On the Origin of Evolution: Tracing 'Darwin's Dangeous Idea' from Aristotle to DNA. London: William Collins.

Hatcher, Chris. 2018. "Evolution.” In Berry Billingsley, Manzoorul Abedin, and Keith Chappel, eds. A Teacher's Guide to Science and Religion in the Classroom. Abingdon: Routldege, 86-93. 


\section{Setting the context}

Hattiangadi, J. N. 1971. "Alternatives and Incommensurables: The Case of Darwin and Kelvin.” Philosophy of Science, 38(4): 502-507.

Herbert, Sandra, and David Norman. 2009. "Darwin's Geology and Perspective on the Fossil Record." In Michael Ruse, and Robert Richards, eds. The Cambridge Companion to the Origin of Species. Cambridge: Cambridge University Press, 129-152.

Huskinson, Benjamin L. 2020. American Creationism, Creation Science, and Intelligent Design in the Evangelical Market. Cham: Palgrave Macmillan.

Ibrahim, Abdul Halim, and Madiha Baharuddin. 2014. "Criticism of Darwin's Theory of Evolution by Muslim Scholars." Online Journal of Research in Islamic Studies, 1(1): 50-62.

Isaak, Mark. 2007. The Counter-Creationism Handbook. Berkeley, CA: The University of California Press.

Jablonka, Eva, and Mariion J. Lamb. 2014. Evolution in Four Dimensions: Genetic, Epigenetic, Behavioural, and Symbolic Variation in the History of Life. Cambridge, MA: The MIT Press.

Jackson, Sherman A. 2009. Islam and the Problem of Black Suffering. Oxford: Oxford University Press.

Jenkins, Bill. 2019. Evolution Before Darwin. Theories of the Transmutation of Species in Edinburgh, 1804-1834. Edinburgh: Edinburgh University Press.

Johnson, Curtis. 2015. Darwin's Dice: The Idea of Chance in the Thought of Charles Darwin. New York, NY: Oxford University Press.

Kampourakis, Kostas. 2020. Understanding Evolution. Cambridge: Cambridge University Press.

Keller, Nuh Ha Mim. 2011. Sea Without Shore: A Manual of the Sufi Path. Amman: Sunna Books.

Kitadai, Norio, and Shigenori Maruyama. 2018. "Origins of Building Blocks of Life: A Review.” Geoscience Frontiers, 9(4): 1117-1153.

Koonin, Eugene V., and Yuri I. Wolf. 2010. “The Common Ancestry of Life.” Biology Direct, 5(64): 1-5.

Ladyman, James. 2002. Understanding Philosophy of Science. London: Routledge.

Laland, Kevin, Tobias Uller, Marc Feldman, Kim Sterelny, Gerd B. Müller, Armin Moczek, Eva Jablonka, and John Odling-Smee. 2014. "Does Evolutionary Theory Need a Rethink? Yes, Urgently.” Nature, 514: 161-164.

Largent, Mark A. 2009. "Darwin's Analogy Between Artificial and Natural Selection in the Origin of Species." In Michael Ruse, and Robert Richards, eds. The Cambridge Companion to the Origin of Species. Cambridge: Cambridge University Press, 14-29.

Larson, Edward J. 2006. Evolution: The Remarkable History of a Scientific Theory. New York, NY: Modern Library.

Lazcano, Atonio. 2007. "Creationism and the Origin of Life: Did It All Begin in a Warm Little Pond." In Andrew J. Petto and Laurie R. Godfrey, eds. Scientists Confront Creationism: Intelligent Design and Beyond. New York, NY: W.W. Norton and Company Inc, 180-196.

Lewin, Roger, and Robert A. Foley. 2004. Principles of Human Evolution. Oxford: Blackwell Publishing.

Lustig, A. J. 2009. “Darwin's Difficulties.” In Michael Ruse, and Robert Richards, eds. The Cambridge Companion to the Origin of Species. Cambridge: Cambridge University Press, 109-128. 
Malik, Shoaib Ahmed. 2019. "God, Information and the World: The Metaphysics of William Dembski and al-Ghazālī." Philosophy, 94(4): 547-576.

Marks, Jonathon. 2002. What It Means to Be 98\% Chimpanzee? Apes, People, and Their Genes. California: University of California Press.

Marshall, Perry. 2015. Evolution 2.0: Breaking the Deadlock Between Darwin and Design. Dallas, TX: Benbella Books.

Maruyama, Shigenori, Ken Kurokawaac, Toshikazu Ebisuzakid, Yusuke Sawakief, Konomi Sudag, and M. Santosh. 2019. "Nine Requirements for the Origin of Earth's Life: Not at the Hydrothermal Vent, but in a Nuclear Geyser System." Geoscience Frontiers, 10(4): 1337-1357.

Mayr, Ernst. 1991. One Long Argument: Charles Darwin and the Genesis of Modern Evolutionary Thought. Cambridge, MA: Harvard University Press.

Mayr, Ernst, and William B Provine, eds. 1998. The Evolutionary Synthesis: Perspectives on the Unification of Biology. Cambridge, MA: Harvard University Press.

McGhee, George. 2008. "Convergent Evolution: A Periodic Table of Life? In Morris Simon Conway, ed. The Deep Structure of Biology: Is Convergence Sufficiently Ubiquitous to Give a Directional Signal? Conshohocken, PA: Templeton Foundation Press, 17-31.

McGhee, George. 2011. Convergent Evolution: Limited Forms Most Beautiful. Cambridge, MA: The MIT Press.

Montgomery, David R. 2012. The Rocks Don't Lie: A Geologist Investigates Noab's Flood. New York, NY: W. W. Norton \& Company.

Moore, James R. 1981. The Post-Darwinian Controversies: A Study of the Protestant Struggle to Come With Darwin in Great Britain and America 1870-1900. Cambridge: Cambridge University Press.

Morris, Simon Conway. 1998. The Crucible Creation: The Burgess Shale and the Rise of Animals. Oxford: Oxford University Press.

Morris, Simon Conway. 2003. Life's Solution: Inevitable Humans in a Lonely Universe. Cambridge: Cambridge University Press.

Morris, Simon Conway, ed. 2008. The Deep Structure of Biology: Is Convergence Sufficiently Ubiquitous to Give a Directional Signal? Conshohocken, PA: Templeton Foundation Press. Morvillo, Nancy. 2010. Science and Religion: Understanding the Issues. West Sussex: Wiley-Blackwell.

Muhammad, Abu Zahra. 2012. The Four Imams. trans. by Aisha Bewley. London: Dār al-Taqwa.

Nei, Masatoshi. 2013. Mutation-Driven Evolution. Oxford: Oxford University Press.

Olendzenski, Lorraine, and J. Peter Gogarten. 2009. "Evolution of Genes and Organisms: The Tree/Web of Life in Light of Horizontal Gene Transfer." Annals of the New York Academy of Sciences, 1178(1): 137-145.

Osborn, Ronald E. 2017. Humanism and the Death of God. Oxford: Oxford University Press.

Oxford English Dictionary. "Evolution.” Accessed 14th of June 2020a. Available at: https://www.oed.com/view/Entry/65447

Oxford English Dictionary. "Devolution.” Accessed 14th of June 2020b. Available at: https:/www.oed.com/view/Entry/51549

Padian, Kevin, and Kenneth D. Angielczyk. 2007. “Transitional Forms’ Versus Transitional Features.” In Andrew J. Petto and Laurie R. Godfrey, eds. Scientists 


\section{Setting the context}

Confront Creationism: Intelligent Design and Beyond. New York, NY: W.W. Norton and Company Inc, 197-230.

Pigliucci, Massimo. 2002. Denying Evolution: Creationism, Scientism, and the Nature of Science. Sunderland, MA: Sinauer Associates Inc.

Pigliucci, Massimo, and Gerd B. Müller. 2010. Evolution: The Extended Synthesis. Cambridge, MA: The MIT Press.

Pennock, Robert T. 1999. Tower of Babel: The Evidence Against the New Creationism. Cambridge, MA: The MIT Press.

Pennock, Robert T. 2007. "God of the Gaps: The Argument from Ignorance and the Limits of Methdological Naturalism.” In Andrew J. Petto and Laurie R. Godfrey, eds. Scientists Confront Creationism: Intelligent Design and Beyond. New York, NY: W.W. Norton and Company Inc, 309-338.

Popper, Karl. 1978. "Natural Selection and the Emergence of Mind.” Dialectica, 32: 339-355.

Popper, Karl. 2002. The Logic of Scientific Discovery. Abingdon: Routledge.

Qadhi, Yaser. 1999. An Introduction to the Sciences of the Quran. Birmingham: Al Hidaayah Publishing and Distribution.

Rau, Gerald. 2012. Mapping the Origins Debate: Six Models of the Beginning of Everything. Westmont, IL: InterVarsity Press.

Rieppel, Olivier. 2011. Evolutionary Theory and The Creation Controversy. Berlin: Springer.

Rogers, Alan R. 2011. The Evidence for Evolution. Chicago, IL: The University of Chicago Press.

Rudwick, Martin J. S. 1985. The Great Devonian Controversy: The Sharping of Scientific Knowledge Among Gentlemanly Specialists. Chicago, IL: The University of Chicago Press.

Rudwick, Martin J. S. 2010. Worlds Before Adam: The Reconstruction of Geohistory in the Age of Reform. Chicago, IL: The University of Chicago Press.

Ruse, Michael. 2008. Darwinism and Its Discontents. Cambridge: Cambridge University Press.

Samuel, Geoffrey, and Santi Rozario. 2010. "Contesting Science for Islam: the media as a Source of Revisionist Knowledge in the Lives of Young Bangladeshis." Contemporary South Asia, 18(4): 427-441.

Schreiber, Ulrich, and Christian Mayer. 2020. The First Cell: The Mystery Surrounding the Beginning of Life. Switzerland: Springer.

Scott, Eugenie C. 2009. Evolution vs. Creationism. Berkley, CA: University of California Press.

Shanahan, Timothy. 2004. The Evolution of Darwinism: Selection, Adaptation, and Progress in Evolutionary Biology. Cambridge: Cambridge University Press.

Shanks, Niall. 2007. God, the Devil, and Darwin: A Critique of Intelligent Design Theory. Oxford: Oxford University Press.

Siddiqui, Muhammad Zubayr. 2008. Hadith Literature: Its Origin, Development and Special Features. Cambridge: The Islamic Texts Society.

Smith, Robert W. 1989. "The Cambridge Network in Action: The Discovery of Neptune." The University of Chicago Press on behalf of The History of Science Society, 80(3): 395-422.

Smocovitis, Vassiliki Betty. 1996. Unifying Biology: The Evolutionary Synthesis and Evolutionary Biology. Princeton, NJ: Princeton University Press. 
Sober, Elliott, and Steven Orzack. 2003. "Common Ancestry and Natural Selection." The British Journal for the Philosophy of Science, 54(3): 423-437.

Sober, Elliott, ed. 2006. Conceptual Issues in Evolutionary Biology. Massachusetts: The MIT Press.

Sober, Elliott, and Mehmet Elgin. 2017. "Popper's Shifting Appraisal of Evolutionary Theory." Hopos: The Journal of the International Society for the History of Philosophy of Science, 7(1): 31-55.

Sonleitner, Frank J. 1986. "What Did Karl Popper Really Say About Evolution?" Creation/Evolution, 6(2): 9-14.

Spencer, Nick. 2009. Darwin and God. London: SPCK.

Stamos, David N. 1996. "Popper, Falsifiability, and Evolutionary Biology." Biology and Philosophy, 11: 161-191.

Stearns, Stephen, and Rolf Hoekstra. 2005. Evolution: An Introduction. Oxford: Oxford University Press.

Theobald, Douglas L. 2010. "A Formal Test of the Theory of Universal Common Ancestry." Nature, 465: 219-222.

Thompson, R. Paul, and Denis M. Walsh. 2017. Evolutionary Biology: Conceptual, Ethical, and Religious Issues. Cambridge: Cambridge University Press.

Trend, Roger David. 2002. "Developing the Concept of Deep Time.” In Victor J. Mayer, ed. Global Science Literacy. London: Kluwer Academic Publishers, 187-202.

Uller, Tobias, and Kevin N. Laland, eds. 2019. Evolutionary Causation: Biological and Philosophical Reflections. Cambridge, MA: The MIT Press.

Usmani, Muhammad Taqi. 2007. Uloomul Quran: An Approach to the Quranic Sciences. Karachi: Darul-Ishaat.

van den Brink, Gijsbert, Jeron de Ridder, and René van Woudenberg. 2017. "The Epistemic Status of Evolutionary Theory.” Theology and Science, 15(4): 454-472.

Walker, Sara Imari. 2017. "Origins of Life: A Problem for Physics, A Key Issues Review.” Reports on Progress in Physics, 80(9): 1-21.

Walsh, Denis M., and Philippe Huneman. 2017. Challenging the Modern the Modern Synthesis: Adaptation, Development, and Inheritance. Oxford: Oxford University Press.

Waters, C. Kenneth. 2009. "The Arguments in Origins of Species." In Jonathon Hodge, and Gregory Radick, eds. The Cambridge Companion to Darwin. Cambridge: Cambridge University Press, 120-143.

Wray, Gregory A., Hopi E. Hoekstra, Douglas J. Futuyma, Richard E. Lenski, Trudy F. C. Mackay, Dolph Schluter, and Joan E. Strassmann. 2014. "Does Evolutionary Theory Need a Rethink? No, All Is Well.” Nature, 514: 161-164.

Yahya, Harun. 2006. The Dark Spell of Darwinism: How Darwinists Twist the Truth to Turn People Away from God. Istanbul: Global Publishing.

Young, David. 2007. The Discovery of Evolution. Cambridge: Cambridge University Press.

Zhang, Qu. 2014. "Using Pseudogene Database to Identify Lineage-Specific Genes and Pseudogenes in Humans and Chimpanzees." Journal of Heredity, 105(3): 436-443. 


\section{Christian responses to evolution}

\section{Introduction}

The theory of evolution was developed in a largely Christian context. Subsequently, when Charles Darwin first published his book, On the Origin of Species, in 1859, the most immediate reaction and longstanding engagement with the theory has been through Christian lenses. Since then, Christian thinkers have responded to it in many different ways, resulting in complicated historical trajectories that in turn has led to an incredibly heterogeneous religious, political, and social landscape in the contemporary period (Livingstone 1984; Artigas et al. 2006; Numbers 2006; Bowler 2007; Livingstone 2008; Bowler 2009; McGrath 2011; Matthew 2013; Livingstone 2014; Rios 2014; Kaden 2019; Houck 2020; Huskinson 2020; Kemp 2020; Laats 2020; Matheison 2020). Some wholeheartedly accept(ed) evolution without deeming it to be theologically problematic, while others saw (and still see) several problems with it. This chapter briefly tries to capture the thoughts of four popular, predominant responses that have varying levels and kinds of (dis)agreements with evolution. These include young-earth creationism (YEC), old-earth creationism (OEC), intelligent design (ID), and theistic evolution (TE). To be sure, this is by no means an exhaustive review. These specific groups (and their respective representative thinkers) were chosen because of their clear dissimilarities, making it easier to contrast their intra-religious differences in this chapter, and for highlighting inter-religious similarities and differences when compared with Muslim perspectives in Chapters 3 and $4 .^{1}$

The structure of this chapter will review the groups in the aforementioned order. Given the extensive amount of material on these responses (collectively and individually), this chapter should be treated only as a summary. Each position will be reviewed to the extent of presenting the core ideas. The strengths and weaknesses of each position will not be discussed. Occasionally, an inter-group analysis does occur, but this is primarily done to sharpen the distinctions between the different positions. For convenience, the views being presented in this chapter are primarily, but not exhaustively, relying on the book, Four Views on Creation, Evolution, 
and Intelligent Design. This book takes the leading scholars of each camp to present their positions alongside their critiques of the other positions followed by rejoinders. Accordingly, it makes for an excellent resource on Christian perspectives on evolution.

The purpose of this chapter is primarily to understand how some Christians may have certain theological and philosophical reservations that may or may not have parallels in Islamic thought as we shall see in Chapters 3 and 4.

\section{Young-earth creationism (YEC)}

YEC is the least friendly position on evolution that one can get on the spectrum. Advocates reject evolution primarily because they stress the Bible as the literal word of God, which conflicts with the evolutionary narrative. Once this conflict is established, they find evolution scientifically problematic and try to identify several holes in the theory (Nieminen et al. 2014). The initial ideas nucleated in the late nineteenth century and early twentieth century with the rise of Christian fundamentalism, but gained significant traction after the publication of The Genesis Flood published by John Whitcomb and Henry Morris in 1961 (Numbers 2006; Trollinger and Trollinger 2018; Huskinson 2020). Currently, one of the leading voices of YEC is Ken Ham, an Australian advocate who moved to America and founded one of the largest institutions that promote YEC, Answers in Genesis (AiG). The following is the position of YEC as presented by Ken Ham.

To start with, Ham criticises evolution because of what the Bible informs its readers. Four main propositions are relevant to evolution:

1 God created the universe in six literal 24-hour days ${ }^{2}$ around 6,00010,000 years ago;

2 Noah's flood was a year-long global event;

3 God created all natural kinds without common ancestry; and

4 Evolution problematises Adam's fall and salvation through Jesus.

The first proposition rests on the idea that Genesis is a historical account of how life started. As stated by Ham (2017a, 19), "Genesis 1-11 is history not poetry, parable, prophetic vision, or mythology." However, his interpretation clearly contradicts the evolutionary narrative. As discussed in Chapter 1, science informs us that the universe is around 14.6 billion years old. The earth was formed 4.6 bya with the earliest life forms existing 3.5 bya (according to our latest findings). Modern humans themselves have arrived relatively late on the scene with estimates claiming around 200,000 years ago. This is many magnitudes of difference between YEC and modern science. Another point that supports the young-earth narrative is genealogical details. The Bible discusses genealogies from Adam to Abraham 
in Genesis 5 and 11. The genealogy in itself is taken as a literal chronology used as further supporting evidence to indicate a young earth (Ham 2017a, 23-24). ${ }^{3}$

Noah's flood contradicts science because it asserts a monumental largescale geological event occurred that should have had clear empirically verifiable consequences, which we have now observed. According to YEC, the Bible informs the reader that Noah was instructed about a coming flood. So he was assigned with creating an ark big enough that could hold two of every species. Once built, the catastrophic event ensued in which all entities other than the ones on Noah's ark were destroyed. Given this catastrophic flood, Ham $(2017 \mathrm{a}, 29)$ supports this position with scientific data:

Now what would we expect to find from this flood? As I often say, billions of dead things, buried in rock layers, laid down by water, all over the earth. All the continents are covered with sedimentary rock layers containing billions of fossils, and we find marine creatures on the topic of our highest mountains, including Mt. Everest.

In other words, given the flood as outlined in the Bible, finding several fossils is expected even in the highest peak point on earth, Mount Everest, because it was once covered in water. So the fossil record, which is usually taken as evidence for evolution, is being taken by YEC to corroborate their creationist narrative (Scott 2009, 69; Nieminen et al. 2014).

The third proposition that YEC advocates claim is that God created all the kinds, i.e. the original forms, of all animals without any common ancestry (Ham 2017a, 41). They admit God created these kinds with inbuilt potentialities so that there is tremendous room for biological diversity. For example, there can be many variations of cats, but this doesn't entail common ancestry as suggested by evolution. Evolutionists, claim YEC, presuppose common ancestry rather than prove it, which is why there is a fundamental conflict between the Bible and the theory of evolution. ${ }^{4}$ As stated on AiG's website, "Dogs, for example, exhibit tremendous variety. Yet diverse breeds of dogs can produce offspring with each other - indicating that all dogs are of the same kind. Dogs will not interbreed with cats, however, since they are a different kind" (Purdom 2010). Accordingly, YEC accepts microevolution but denies macroevolution.

The final proposition requires us to look into the basic doctrines of Christian theology. The sin and fall of Adam is a significant point for Christian thought. It is widely held that Adam was made in the "image of God" (Imago Dei) which entails that he was morally upright, dignified, and free from weaknesses and disabilities like death (McGrath 2016, 328-329). Thus, Adam was in perfect communion with God as he was in God's grace. Furthermore, it is thought that the world was good before Adam and Eve's sin, i.e. eating from the tree. This is an important point 
because God created the world with goodness, and hence evil is not attributable to him. As mentioned by Harris $(2013,132)$ :

... if there is only one God and this God is good, the creation must be good too, since such a God cannot be the source of evil. And the basic 'goodness' of creation was enshrined as one of the foundational propositions of the doctrine of creation.

After the sin, however, two things happened. First, Adam and Eve fell from God's grace. Second, the world became cursed and filled with pain, difficulty, and death as reflected in various passages in the Bible, e.g. farming becoming toilsome and childbirth becoming more painful for women (Ham 2017a, 25). ${ }^{5}$ Because of Adam's error, the whole world now errs and suffers, and humans are prone to committing sin, which they inherited from Adam and Eve. This is commonly known as the original sin. Accordingly, the world needed saving, and human sin needed removing. It is at this point that Jesus Christ becomes an important figure because he is the saviour who came to remove evil and sin from the world, and only he can do that because of his dual nature of simultaneously being God and man (McGrath 2016, 246-269). However, while he died on the cross and assumed the burden of humanity's sins, he could not complete his work as he didn't remove all evil. This incompletion leads to the idea of Jesus' second coming in the eschaton (McGrath 2016, 424-447).

Given this very brief overview of the Christian understanding of Adam and Jesus's role in the history of life, Christians face two problems on a very fundamental level if evolution is true. First, evil and suffering had existed long before humans arrived on earth, i.e. there was evil in the prefall creation. As mentioned in Chapter 1, scientists estimate that $99 \%$ of all species that ever existed have gone extinct. This problematises the fall and original sin (Harris 2013, 131-132; Ham 2017a, 24-25). Second, which is an extension of the first problem, the whole paradigm of Jesus's role in Christian thought becomes questionable (Harris 2013, 132-133; Ham 2017a, 26). If the account of Adam's fall is false, i.e. not historically real, then the very necessity of Jesus and redemption becomes redundant. It is why Ham $(2017 \mathrm{a}, 27)$ remarks:

So, to accept millions of years of animal death, disease, and extinction as well as earthquakes, hurricanes, tornadoes, and tsunamis requires a conscious or unconscious rejection of (or superficial attention to or failure to apply one's orthodox belief in) the Bible's clear teaching about the 'very good' pre-fall creation, the cosmic impact on the whole of creation (not just mankind), and Christ's redemptive work in the cosmos.

Thus, from the perspective of YEC, it can be seen that evolution has a massive impact not only on the hermeneutic details but also on a substantial 
portion of the edifice that is central to Christianity. The trilemma of balancing original sin, Jesus' redemption, and evolution is fittingly summarised by Houck (2020, 5): "Denying original sin obscures the universal need for redemption. Affirming original sin and the Fall seems incompatible with evolution. And affirming original sin without a Fall seems to compromise the goodness of creation."

YEC also couple their narrative with non-Biblical claims against evolution. These include philosophical charges, e.g. equating evolution to atheism and naturalism (Ham 2017a, 33); and identifying scientific problems with evolution, such as issues with dating procedures that scientists rely on to construct a timeline of life (Ham 2017a, 42). Collectively, given the worrying implications that evolution has for Christian thought, YEC is adamant on reading the Bible literally and rejecting evolution. For Ham (2017a, 44-45), in particular, it seems there is a question of authority between God's word and science, with the latter slowly chipping away from orthodox Biblical positions resulting in Christians inclining towards unbelief (Huskinson 2020; Laats 2020).

\section{Old-earth creationism (OEC)}

As the name suggests, OEC has no problem with an old earth, which brings it into stark contrast with YEC. However, this is a big camp with several nuances under its umbrella, but we can safely demarcate three different sub-positions. These include gap creationism (also known as ruinrestoration creationism), day-age creationism, and progressive creationism (Numbers 2006). An old-earth reading unites these, but what makes them distinctive is how differently each interprets a long period of creation as discussed in the Bible (Trollinger and Trollinger 2018, 217-219). ${ }^{6}$ Let us review each one.

Gap creationism is the closest one gets to YEC in OEC. They adopt the six days literally as 24 -hour days. However, they permit an old-earth reading based on a distinction between two verses in Genesis 1 . The first and second verse in Genesis 1 (NIV) says, "In the beginning God created the heavens and the earth. Now the earth was formless and empty, darkness was over the surface of the deep, and the Spirit of God was hovering over the waters." YEC take these two verses as referring to the same event, but gap creationism differs in their reading by permitting the possibility of a time gap between these two verses, hence the name. So in this account, these verses are referring to two different creation events. The duration of the time between these events is not specified, but it permits a reading of an old earth (Scott 2009, 68).

Day-age creationism takes a different approach to gap creationism. Rather than permitting a time gap between verses, day-age creationists widen the semantic scope of the word for "day" $(y \mathrm{om})$. Instead of assuming it to be literal 24-hour days, they suggest it could be any span of time from 
thousands to millions of years. To be clear, they don't necessarily deny the possibility of a 24-hour day reading, but state it is not the only possible rendition. Accordingly, there is no problem with the universe's age or the earth being really old (Scott 2009, 68).

Progressive creationism is very similar in its stance to day-age creationism. Instead of focusing on the six days with semantic openness to accommodate long passages of time, they bypass the entire issue by suggesting that the six days reveal a pictorial description. So creation wasn't actually created in six literal days but is only depicted as such. Accordingly, they assume that several outbursts of life were introduced gradually and intermediately over millions of years. Each spurt involved introduced all kinds of animals and plants. This position adheres well to the fossil record where life started with simplicity and gets complex over time (Scott 2009, 69).

Having reviewed each sub-position in OEC, it is important to restate that what combines them is that an old-earth reading is Biblically possible, unlike YEC. That is as far as they go to match modern science. However, like YEC, they reject common ancestry and macroevolution. One of the leading advocates of OEC in the contemporary period is Hugh Ross. He defends day-age creationism and is founder of Reasons to Believe (RtB). The following is the OEC narrative as depicted by him.

To help better appreciate OEC, recall that YEC believes in the following propositions:

1 God created the universe in six literal 24-hour days around 6,00010,000 years ago;

2 Noah's flood was a year-long global event;

3 God created all natural kinds without common ancestry;

4 Evolution problematises Adam's fall and salvation through Jesus.

From what was mentioned earlier, OEC will concur with YEC that God directly creates natural kinds and hence agree with the third proposition. However, day-age creationism has no problem with the six-day issue because the semantic scope is wide enough for word yom to carry other meanings (Ross 2017a, 73). The related issue of Biblical genealogies is also not an issue for them because several generations may have been masked under a single name, like a telescope when it collapses into a simpler unit. As stated in an online article on RtB's website (Millam 2003):

Understanding the Genesis genealogies requires a systematic understanding of the nature, style, and purpose of genealogies in the Bible. Even a cursory study of Biblical genealogies shows that Biblical genealogies are very different from their modern counterparts. Looking closer, we find that Biblical genealogies are commonly telescoped by leaving out less important names and that it is usually impossible to tell if a genealogy is complete simply by looking at it. 


\section{Setting the context}

So genealogy isn't strictly an issue as a case for the age of the earth. As for Noah's flood, Ross rejects YEC's global reading. For him, it seems that the reference of the flood taking over the world isn't a geographical reference, but instead one of the people who were localised and were the only humans there at the time (Ross 2017a, 85):

Humanity was not yet globally dispersed Gen (10-11). In Peter 2:5 we read that 'the world of the ungodly' was flooded. Second Peter 3:6 says 'the world of that time' ... was flooded. These are references to people rather than land. The flood's extent was determined by how far people had spread. Genesis 11 gives us a clue when it reveals the unwillingness of humans - even long after the flood - to spread out and fill the earth. When Bible writers made reference the 'the worlds,' their focus most often was on people, not on the planet.

So, Ross has no problem rejecting the second proposition. Finally, Ross would disagree with YEC's interpretation of no evil existing before the fall. He contends that scripture only indicates the inauguration of death for humans after Adam's sin, but this doesn't entail death for all life, which leaves open the possibility of animals dying before Adam's fall (Ross 2017a, $86-87) .^{7}$ Furthermore, he puts a positive spin on the creation of the universe and the redemption of Jesus. He stresses that the laws of the universe are fixed. Thus, things like entropy - which, roughly put, entails the constant decay of the universe over time - are an inherent part of the universe. Given this fixity of the laws of nature in which decay is intrinsic and the nature of human hardship, which was a result of Adam's sin, Ross argues for a positive interpretation of hardship and death as an integral part of God's plan towards building a heaven better than Eden as promised by him (Ross 2003). The following comments reveal this combinatory affliction realism and eschatological optimism (Ross 2017a, 86-87):

Physical death, though grievous, yields valuable redemptive benefits. Death of nonhuman life blessed humanity with a treasure chest of more than seventy-six quadrillion tons of biodeposits (e.g. coal, oil natural gas, limestone) from which to build a global civilisation and facilitate the fulfilment of the Great Commission ${ }^{8}$ in mere thousands, rather than millions of years, of years. Christ's crucifixion and resurrection demonstrate ... that only through death can we truly live, both now and forever ... Death and decay's temporary necessity aligns with the day-age vision of the future creation, the new heavens and the new earth, which Scripture describes as perfect in every way ... The current creation serves its purpose as the best possible realm in which God efficiently, rapidly, and permanently conquers evil and suffering while allowing free-will humans to participate in his redemptive process and plan. 
Given this interpretation, Ross would not have an issue with Adam's fall and salvation through Christ despite the old age of creation.

\section{Intelligent design (ID)}

This is the most recent movement to have come to the stage. The basic idea with ID is not that it offers a Biblical interpretation and therefore a rival religious position to evolution, but rather presents itself as a scientific alternative to evolution. ID believes that evolution is scientifically inadequate because some aspects of creation are so complex that it cannot be attributed to natural selection and random mutation. Such instances, they believe, are evidence of intelligence. Therefore, entities which reflect highly designed features indicate an intelligent designer created them.

Before going any further, it might help to clarify a few things at the onset. First, design arguments aren't really novel (Jantzen 2014). Such ideas have existed long before the ID movement came to the scene. The most famous example is William Paley, who came up with the infamous clock-world analogy in the late eighteenth century. What makes ID distinctive, however, is how advancements in science, namely biology and physics, ${ }^{9}$ offer new avenues in which design arguments are being refreshed and localised (Kojonen 2016, 33-72; Ratzsch and Koperski 2020). Second, the ID crowd is highly diverse (Numbers 2006, 373-398; Avise 2010, 25; Kojonen 2016, 18-21). ${ }^{10}$ Some Christian advocates are the main proponents and founders of the movement, and include Protestants (Phillip Johnson, William Dembski, and Stephen Meyer), a Roman Catholic (Michael Behe), and a member of the Unification Church (Jonathon Wells). Additionally, the movement is supported by well-known agnostics, including Michael Denton and David Berlinski. Furthermore, Paul Nelson is a proponent of YEC, but supports ID. This makes it very difficult to generalise about the movement, particularly about what they concede are the merits of evolution. So, for example, Meyer is sceptical (though not dismissive) about common ancestry, but Behe has no problem accepting it (Behe 2007, 64-83; Meyer 2017b, 113-119). Nonetheless, they all seem to agree on the basic idea that the causal mechanics of evolution (natural selection and random mutations) are scientifically inadequate; intelligent design offers a better alternative. Finally, none of the members explicitly claim who or what the intelligent designer is (Kojonen 2016, 19). For instance, Behe $(2003,277)$ clearly mentions that the designer could be “an angel - fallen or not; Plato's demiurge; some mystical new-age force; space aliens from Alpha Centauri; time travellers; or some utterly unknown intelligent being." So the designer can have any properties one chooses to believe in. That said, barring Denton and Berlinski, the Christian proponents believe that the impregnation of the universe with marks of intelligence results from the Christian God, and perhaps even motivated by this. Still, all that is needed from a strictly scientific perspective is the mere recognition of an intelligent designer (Avise 
2010, 25). This forces us to make a useful distinction between ID as a neutral argument/position, which can be aligned with any worldview (theism, agnosticism, and even atheism - this point will be expanded on in Chapter 7), and the personal worldviews of ID advocates. Accordingly, ID isn't inherently a Christian position but can be couched into one.

We will be going through the ID movement in detail in Chapter 7, so the following is only meant to be a summary, which is Stephen Meyer's presentation of ID. He is the Program Director of the Center for Science and Culture at the Discovery Institute, the ID movement's headquarter. ${ }^{11}$

As a starting point, the following paragraph encapsulates how ID is seen in comparison to evolution (Meyer 2017a, 180):

... the theory of intelligent design holds that there are telltale features of living systems and the universe - for example, the digital code in DNA, the miniature circuits and machines in cells, and the fine-tuning of the laws and constants in physics - that are best explained by an intelligent cause rather than an undirected material process. The theory does not challenge the idea of evolution defined as either change over time or common ancestry, but it does dispute the Darwinian idea that the cause of biological chance is wholly blind and undirected. Either life arose as the result of purely undirected material processes or guiding intelligence played a role. Design theorists affirm the latter option and argues that living organisms look designed because they really were designed.

This paragraph highlights the two main problems that ID has with NeoDarwinian evolution (what Meyer refers to as Darwinian evolution above), which is how random and material processes cannot adequately explain creation. Aspects of creation display complexities, but it seems problematic to assert that they are products of evolution. Note that Meyer doesn't decisively argue for this, but conveys ID as alternative hypotheses which needs to be considered in light of the evidence. Therefore, he relies on abduction to make his case.

Meyers presents his argument for ID through probabilities (Meyer 2009; Meyer 2013; Meyer 2017a, 185-197). He argues that the chance-like process which Neo-Darwinian evolution relies on is so incredibly indeterminate, that the likelihood of getting complex biological properties is absolutely minuscule. To cut the scientific jargon, consider the following analogy instead. Imagine two people, let's call them Sara and Adam, with equipment for Scrabble. Adam asks Sara to put on a blindfold. After she does that, Adam takes the bag of letters and turns it upside down, so all the letters fall out of the bag, which Sara hears falling. Adam then asks here to take off the blindfold. On the floor, she sees the scrambled letters. However, she identifies three letters forming the word "CAT." She thinks to herself whether this is by chance or if Adam messed around with the letters to form that word before she took off the blindfold. She convinces herself that perhaps this was a one-time fluke. The 
same thing is repeated but this time she sees the word "WATCH." Now she is more sceptical of this being a chance scenario. Perhaps Adam did it? The scenario is repeated once more, and now she sees the word "CATASTROPHE." Now she is certain that this cannot be by chance and Adam is playing with the letters. She reasons that out of all the ways which the letters could have scrambled on the floor, it is hard to believe that this particular formation occurred by chance. By extension, as the word grows in size, it becomes harder to reconcile it with chance-based scenarios. ID advocates take the same line of reasoning to assert that biological structures like amino acids, proteins, cellular assemblies, and organisms are designed so precisely, against the vast array of possibilities that don't give them functionality and complexity (in random simulations as suggested by Neo-Darwinism), that it is akin to believing the impossible. In other words, these cannot be the products of chance processes, and therefore there must be an intelligent designer who or which is coordinating these highly improbable scenarios.

Meyer supports his case by giving examples of other scientific arenas. By looking into the difficulties with the origins of life, even though it doesn't come under the umbrella of evolution (see Chapter 1), Meyer argues that the required coordination for all the initial proteins to come into place to kickstart life is equally improbable through random and material causes. Thus, it makes more sense to accept an intelligent designer not just for the origin of species (evolution), but for the origin of life too (Meyer 2017a, 197-198). Meyer gives examples of research enterprises that rely on and utilise these principles to show how this isn't an invalid move. Archaeology and the search for extra-terrestrial intelligence (SETI) rely on using complex patterns in creation to argue for intelligent causes (Meyer 2017a, 203). So if these are indeed genuine research enterprises, then ID should be seen as no threat to science, and therefore should be considered as a valid, scientific alternative to evolution. ${ }^{12}$

As can be seen from the preceding discussion, the nature of the ID movement is vastly different from YEC and OEC. No reference is made to the Bible, nor does the group identify the designer with the Christian God, which is why advocates of YEC and OEC find ID somewhat problematic (Nieminen et al. 2014; Ham 2017b; Ross 2017b). But ID advocates clearly affirm this since ID is put forward as a scientific theory, not a religious outlook, and they leave it to the individual as to how they want to square ID with their personal worldviews (Meyer 2017a, 179):

... the theory of intelligent design does not offer an interpretation of the book of Genesis, nor does it posit a theory about the length of the biblical days of creation or the age of the earth. Consequently, intelligent design proponents may have a variety of positions on such issue (or none at all).

It is then not surprising that many different voices from different backgrounds can come under one banner seeing that ID advocates categorically emphasise their outlook as a scientific one. 


\section{Theistic evolution (TE)}

This brief review of TE will be based on the thoughts of Deborah Haarsma, who is the president of BioLogos, one of the largest American institutions that promote reconciliation between Christianity and modern science. Haarsma refers to this position as evolutionary creationism. While some individuals see some kind of distinction between evolutionary creationism and TE (Scott 2009, 69-71), I understand them synonymously in this chapter.

In comparison to the three positions we just looked at, TE is the easiest position to characterise. It accepts everything evolution has to offer with the single caveat that God orchestrates the process. So whatever the findings scientists develop on evolution (discussed in Chapter 1) is taken as a given. In this regard, TE clashes with ID on the scientific front. Haarsma doesn't see the exclusive binary which ID presents, i.e. it's either undirected material processes or intelligent design (Haarsma 2017, 221). For her, these aren't explanations that compete (Haarsma 2017, 222):

... we can perceive design in nature even when scientists have a complete natural explanation ... Evolutionary creationists delight in natural mechanisms as descriptions of the ongoing, regular activity of God in the natural world. Without God's sustained action, all natural laws and matter itself would cease to exist. God also works in non-regular (i.e. miraculous) ways at times, most notable in the incarnation and resurrection of Christ. Yet a completely natural explanation never negates God as the designer.

In other words, laws of nature are sustained by God, and scientists are simply discovering them. Even in the case of miracles, which are considered changes or violations of regularity, a natural account of them wouldn't undermine God as the designer. Framed this way, ID is seen as creating a false bifurcation because it comes very close to a God of the gaps narrative (Haarsma 2017, 223):

If scientists discover a natural explanation for the phenomenon attributed to design, then the ID argument fails ... the God of the Bible is the sovereign designer of both the phenomena that science can explain and what science cannot explain.

In other words, if there are improbable mechanisms and complex structures in our biology that can be viably explained through natural explanations, which ID contends are best explained by an intelligent designer, then it undermines the claim that ID is a competing scientific explanation. ${ }^{13}$ Given this possibility, ID arguments rest on contingent knowledge within which there are potential gaps. So even if something is not known today, there might be yet unexplored new ideas, pieces of evidence, and mechanisms that could fill in those gaps. For example, the Extended Evolutionary Synthesis discussed in Chapter 1 could shed some light on the matter. Thus, 
from the perspective of TE, unless science has categorically ruled out the plausibility of such scenarios, which it hasn't, ID jumps to a conclusion too quickly, and therefore rests on very tentative foundations.

Regarding how TE is reconciled with the Bible and Christian thought, Haarsma tries to tackle several issues. These include:

1 The nature of Adam/Eve;

2 Death before the fall;

3 The nature of evil; and

4 Randomness.

Her overall approach to some of these issues is suggestive, and offers options without mentioning which perspective(s) she herself adopts. For the first proposition, she suggests two broad potential routes. These include the possibility of there being other humans alongside Adam and Eve, so they aren't the sole progenitors, or interpreting Genesis as metaphorical stories in light of the historical context and language of the Bible. ${ }^{14}$ Either of these scenarios doesn't undermine the core message of the Bible (Haarsma 2017, 149-150). As for the second proposition, Haarsma offers two suggestions. One is the same as OEC, which suggests that Adam's sin resulted in the death of humans and not animals. Hence, the idea of there being millions of years of the death of species before Adam's fall is unproblematic. A second option is reading death as a spiritual one rather than physical in which case evolution is entirely unproblematic (Haarsma 2017, 150). She finds the third proposition to be nothing new. She correctly points out that regardless of whether evolution is true or not, Christians still need to deal with the problem of evil. If so, several proposals have been developed prior to the discussion of evolution which people can freely choose from (Haarsma $2017,151)$. On the issue of randomness, she clearly points out that randomness in the sciences means something unpredictable, but it doesn't entail that something is also meaningless. God can easily orchestrate his creation through random processes with a purpose in mind. So randomness isn't a problem in her outlook (Haarsma 2017, 152).

Evidently, Haarsma offers a very flexible approach in which multiple resolutions can be catered for. She accepts the difficulties that evolution may pose for the Bible and Christian thought, but she believes several options can be looked at to arrive at sensible reconciliations..$^{15}$ That said, YEC and OEC see this approach as giving too much credibility to science and not enough weight to the Bible (Ham 2017c; Ross 2017c).

\section{Conclusion}

This chapter attempted to broadly capture the main principles behind four Christian responses to evolution. Representatives from each camp differ on how much weight and flexibility they want to give to the Bible and/or science (keeping ID's silence over the Bible in mind), resulting in varying 
conclusions. YEC stands on one side of the pole and interprets the Bible as the literal word of God. They take a very non-flexible stance on the interpretation of the Bible, which presses the belief in a young earth, the rejection of common ancestry, and therefore evolution. Accordingly, the only science that they accept is the one that corroborates their creationist narrative. OEC go one step further and allow the hermeneutic and theological possibility of an old earth, but share the rejection of common ancestry and evolution with YEC due to Biblical reasons. The ID movement presents itself as a scientific alternative to evolution. However, just because it doesn't strictly have a religious outlook, advocates acknowledge that it can be aligned with one or none. The huge diversity of its participants from various (non)religious outlooks makes it challenging to characterise what they concede with respect to the science of evolution. As mentioned before, some members are creationists, e.g. Paul Nelson is an advocate of YEC, and therefore rejects an old-earth interpretation and common ancestry. By contrast, others are sceptical about common ancestry, e.g. Stephen Meyer. Still, there are individuals like Michael Behe who completely accept common ancestry. So it is hard to generalise about the movement. That said, the ID movement is clear in its collective rejection of Neo-Darwinian's causal mechanics being an adequate explanation for the history of life. TE is on the opposite side of the pole and completely accepts what evolution offers. It presents Biblical, theological, and philosophical nuances to arrive at various kinds of reconciliatory positions.

In light of what has been said, Table 2.1 summarises the views of the four positions. As a reminder to the reader, this tabulation is neat and tidy while the groups it is characterising are not always so. There will always be some porosity between the positions and variation amongst individuals within each camp (some of which has been attempted to be captured here). So Table 2.1 should be taken as an approximate summary rather than a defining map of the territory.

Finally, a point on terminology needs to be cleared. These four positions are usually referred to as "creationists" in some of the literature (Ruse 2018). However, this term can refer to an umbrella term and a narrower one. Broadly, creationism means that God has played a part in creating the world and its constituents. Muslims, Jews, and Christians are all creationists in these sense. The four positions we looked at could also be described this

Table 2.1 Summative comparison of YEC, OEC, ID, and TE

\begin{tabular}{lcccc}
\hline & YEC & OEC & $I D$ & $T E$ \\
\hline Deep time & $x$ & $\checkmark$ & $x / \mathfrak{}$ & $\checkmark$ \\
Common ancestry & $x$ & $x$ & $x / \mathfrak{}$ & $\checkmark$ \\
Natural selection and random & $x$ & $x$ & $x$ & $\checkmark$ \\
causation (Neo-Darwinism) & & & & \\
\hline
\end{tabular}


way (except for maybe some non-religious proponents of ID). Creationism in a narrower sense entails being created by God de novo (absolutely new, from nothing/scratch). ${ }^{16}$ YEC and OEC would clearly fit the description under this narrower definition because they believe species were created instantaneously by God. But it would be incorrect to call ID and TE creationists this way. This is being pointed out because the word "creationism" is sometimes used pejoratively as a rival understanding of evolution. Thus, any position carrying this label is considered an unscientific position (Huskinson 2020; Laats 2020). YEC and OEC would be unscientific in this sense since they deny all major aspects of evolution. But clearly, adopting ID and TE doesn't entail a rejection of all components of evolution. Both can happily accept deep time and common ancestry (barring some ID advocates), which is the main point of difference in this narrower definition (Kojonen 2016, 20). So care needs to be taken with how creationism is being used and understood. For the rest of the book, the word "creationism" is used in this narrower sense unless and otherwise stated.

\section{Notes}

1 For other detailed treatments on the topic from other vantage points, see Peters and Hewlett (2003), Życińkski (2006), Pope (2007), Haught (2008), Nevi (2009), Cunningham (2010), Plantinga (2011), Harris (2013), and van den Brink (2020).

2 The word for "day" in the Bible is yom.

3 This is actually the main reason why the upper limit for YEC is around 10,000 years. The sources used for calculating the chronologies and the assumptions used when guessing the timeline, e.g. possible gaps in the chronology, can vary, impacting the resulting calculation. For more information on this, see articles on the AiG website (Pierce and Ham 2010; Hodge 2019).

4 Interestingly, as an alternative to evolutionists' classifications, YEC has its own taxonomy based on Biblical presumptions called "baraminology." See Patterson (2007).

5 The verse that motivates this reasoning is in Romans 5:12 (NIV): “Therefore, just as sin entered the world through one man, and death through sin, and in this way death came to all people, because all sinned."

6 For an excellent visual aid that depicts these positions, see Numbers (2006, 10-11).

7 Interestingly, he supports this point on RtB's website, where he suggests that Satan's first sin was when he beguiled Eve (Ross 2003). So for him, Satan's sin predates Adam's.

8 This simply means spreading the message of Christ.

9 We should distinguish between biological design arguments and cosmological design arguments. The latter encompasses the entire creation, e.g. the fine-tuning argument, and is the territory of physics. The former is a design located in the corners of biological entities, e.g. the complex nature of DNA.

10 For a general reference which discusses the key profiles, places, and events relevant to evolution, see Moore and Decker (2009).

11 All of the aforementioned individuals are working with or had worked with the Discovery Institute. An example of the latter is Phillip Johnson because he recently passed away in 2019. 
12 It is also in this spirit that ID advocates criticise methodological naturalism. We shall look further into point in Chapters 6 and 7.

13 It is why some see ID as a metaphysical interpretation rather than as a scientific one. We shall look into this in more detail in Chapter 7.

14 For contrasting interpretations of Adam and Eve in the Bible, see Barrett (2013).

15 The same approach is taken in her book, which she co-wrote with her husband. See Haarsma and Haarsma (2011).

16 See Ruse's (2018) entry on creationism with Plato Stanford: “At a broad level, a Creationist is someone who believes in a god who is absolute creator of heaven and earth, out of nothing, by an act of free will. Such a deity is generally thought to be 'transcendent' meaning beyond human experience, and constantly involved ('immanent') in the creation, ready to intervene as necessary, and without whose constant concern the creation would cease or disappear. Christians, Jews, and Muslims are all Creationists in this sense. Generally, they are known as 'theists,' distinguishing them from 'deists,' that is people who believe that there is a designer who might or might not have created the material on which he (or she or it) is working and who does not interfere once the designing act is finishing. The focus of this discussion is on a narrower sense of Creationism, the sense that one usually finds in popular writings (especially in America today, but expanding world-wide rapidly). Here, Creationism means the taking of the Bible, particularly the early chapters of Genesis, as literally true guides to the history of the universe and to the history of life, including us humans, down here on earth ... Creationism in this more restricted sense entails a number of beliefs. These include, first, that a short time has elapsed since the beginning of everything. 'Young Earth Creationists' think that Archbishop Ussher's sixteenth-century calculation of about 6000 years is a good estimate. Second, that there are six days of creation - there is debate on the meaning of 'day' in this context, with some insisting on a literal twenty-four hours, and others more flexible. Third, that there was a miraculous creation of all life including Homo sapiens - with scope for debate about whether Adam and Eve came together or if Eve came afterwards to keep Adam company. Fourth, that there was a world-wide flood sometime after the initial creation, through which only a limited number of humans and animals survived."

\section{References}

Artigas, Mariano, Thomas F. Glick, and Rafael A. Martinez. 2006. Negotiating Darwin: The Vatican Confronts Evolution: 1877-1902. Baltimore, MD: The Johns Hopkins University Press.

Avise, John C. 2010. Inside the Human Genome: A Case for Non-Intelligent Design. Oxford: Oxford University Press.

Behe, Michael. 2003. "The Modern Intelligent Design Hypothesis: Breaking Rules.” In Neil Manson, ed. God and Design: The Teleological Argument and Modern Science. London: Routledge, 276-290.

Behe, Michael. 2007. The Edge of Evolution: The Search for the Limits of Darwinism. New York, NY: Free Press.

Bowler, Peter J. 2007. Monkey Trials and Gorilla Sermons: Evolution and Christianity from Darwin to Intelligent Design. Cambridge, MA: Harvard University Press. 
Bowler, Peter J. 2009. Evolution: The History of an Idea. Berkeley, CA: University of California Press.

Cunningham, Conor. 2010. Darwin's Pious Idea: Why the Ultra-Darwinist and Creationists Both Get It Wrong. Grand Rapids, MI: William B. Eerdmans Publishing Company.

Haarsma, Deborah B., and Loren D. Haarsma. 2011. Origins: Christian Perspectives on Creation, Evolution, and Intelligent Design. Grand Rapids, MI: Faith Alive Christian Resources.

Haarsma, Deborah B. 2017. "Evolutionary Creation” In J. B Stump, ed. Four Views on Creation, Evolution, and Intelligent Design. Grand Rapids, MI: Zondervan, 124-153.

Ham, Ken. 2017a. "Young Earth Creationism” In J. B Stump, ed. Four Views on Creation, Evolution, and Intelligent Design. Grand Rapids, MI: Zondervan, 17-48.

Ham, Ken. 2017b. "Response from Young Earth Creationism” In J. B Stump, ed. Four Views on Creation, Evolution, and Intelligent Design. Grand Rapids, MI: Zondervan, 101-106.

Ham, Ken. 2017c. "Response from Young Earth Creationism” In J. B Stump, ed. Four Views on Creation, Evolution, and Intelligent Design. Grand Rapids, MI: Zondervan, 154-160.

Harris, Mark. 2013. The Nature of Creation: Examining the Bible and Science. Croydon: Acumen.

Haught, John F. 2008. God After Darwin: A Theology of Evolution. Boulder, CO: Westview Press.

Hodge, Bodie. 2019. "Chapter 4: How Old Is the Earth?” Answers in Genesis. Accessed 28th of June 2020. https://answersingenesis.org/age-of-the-earth/howold-is-the-earth/

Houck, Daniel W. 2020. Aquinas, Original Sin, and the Challenge of Evolution. Cambridge: Cambridge University Press.

Huskinson, Benjamin L. 2020. American Creationism, Creation Science, and Intelligent Design in the Evangelical Market. Cham: Palgrave Macmillan.

Jantzen, Benjamin C. 2014. An Introduction to Design Arguments. Cambridge: Cambridge University Press.

Kaden, Tom. 2019. Creationism and Anti-Creationism in the United States. Cham: Springer.

Kemp, Kenneth W. 2020. The War That Never Was: Evolution and Christian Theology. Eugene: Cascade Books.

Kojonen, Erkki Vesa Rope. 2016. The Intelligent Design Debate and the Temptation of Scientism. Abingdon: Routledge.

Laats, Adam. 2020. Creationism USA: Bridging the Impasse on Teaching Evolution. Oxford: Oxford University Press.

Livingstone, David N. 1984. Darwin's Forgotten Defenders: The Encounter between Evangelical Theology and Evolutionary Thought. Baltimore, MD: The John Hopkins University Press.

Livingstone, David N. 2008. Adam's Ancestors: Race, Religion and the Politics of Human Origins. Baltimore, MD: The John Hopkins University Press.

Livingstone, David N. 2014. Dealing with Darwin: Place, Politics, and Rhetoric in Religious Engagements with Evolution. Baltimore, MD: The John Hopkins University Press. 


\section{Setting the context}

Matheison, Stuart. 2020. Evangelicals and the Philosophy of Science: The Victoria Institute, 1865-1939. Abingdon: Routledge.

Matthew, Barrett, ed. 2013. Four Views on the Historical Adam. Grand Rapids, MI: Zondervan.

McGrath, Alister E. 2011. Darwinism and the Divine: Evolutionary Thought and Natural Theology. West Sussex: Wiley-Blackwell.

McGrath, Alister E. 2016. Christian Theology: An Introduction. West Sussex: Wiley-Blackwell.

Meyer, Stephen C. 2009. Signature in the Cell: DNA and the Evidence for Intelligent Design. New York, NY: HarperOne.

Meyer, Stephen C. 2013. Darwin's Doubt: The Explosive Origin of Animal Life and the Case for Intelligent Design. New York, NY: HarperOne.

Meyer, Stephen C. 2017a. "Intelligent Design.” In J. B Stump, ed. Four Views on Creation, Evolution, and Intelligent Design. Grand Rapids, MI: Zondervan, 177-208.

Meyer, Stephen C. 2017b. "Response from Intelligent Design" In J. B Stump, ed. Four Views on Creation, Evolution, and Intelligent Design. Grand Rapids, MI: Zondervan, 113-119.

Millam, John. 2003. "The Genesis Genealogies.” Reasons to Believe. Accessed 29th of June 2020. Available at: https://reasons.org/explore/publications/tnrtb/read/ tnrtb/2003/01/01/the-genesis-genealogies

Moore, Randy, and Mark D. Decker. 2009. More Than Darwin: The People and Places of the Evolution-Creationism Controversy. Berkley, CA: University of California Press.

Nevi, Norman C, ed. 2009. Should Christians Embrace Evolution? Biblical and Scientific Responses. Phillipsburg, NJ: P\&R Publishing.

Nieminen, Petteri, Anne-Mari Mustonen, and Esko Ryökäs. 2014. “Theological Implications of Young Earth Creationism and Intelligent Design: Emerging Tendencies of Scientism and Agnosticism" Theology and Science, 12(3): 260-284.

Numbers, Ronald. 2006. The Creationists: From Scientific Creationism to Intelligent Design. Cambridge, MA: Harvard University Press.

Patterson, Roger. 2007. “Chapter 2: Classifying Life.” Answers in Genesis. Accessed 28th of June 2020. Available at: https://answersingenesis.org/creation-science/ baraminology/classifying-life/

Peters, Ted, and Martinez Hewlett. 2003. Evolution from Creation to New Creation: Conflict, Conversation, and Convergence. Nashville, TN: Abingdon Press.

Pierce, Larry, and Ken Ham. 2010. "Chapter 5: Are There Gaps in the Genesis Genealogies?” Answers in Genesis. Accessed 28th of June 2020. Available at: https:// answersingenesis.org/bible-timeline/genealogy/gaps-in-the-genesis-genealogies/

Plantinga, Alvin. 2011. Where the Conflict Really Lies: Science, Religion, and Naturalism. Oxford: Oxford University Press.

Pope, Stephen J. 2007. Human Evolution and Christian Ethics. Cambridge: Cambridge University Press.

Purdom, Georgia. 2010. "Variety Within Created Kinds." Answers in Genesis. Accessed 28th of June 2020. Available at: https://answersingenesis.org/creationscience/baraminology/variety-within-created-kinds/

Ratzsch, Del, and Jeffrey Koperski. 2020. "Teleological Arguments for God's Existence." The Stanford Encyclopedia of Philosophy. Accessed 1st of July. 
Available at: https://plato.stanford.edu/archives/sum2020/entries/teleologicalarguments/

Rios, Christopher M. 2014. After the Monkey Trial: Evangelical Scientists and a New Creationism. New York, NY: Fordham University Press.

Ross, Hugh. 2003. “The Physics of Sin.” Reasons to Believe. Accessed 29th of June 2020. Available at: https://reasons.org/explore/publications/facts-for-faith/read/ facts-for-faith/2002/01/01/the-physics-of-sin

Ross, Hugh. 2017a. “Old Earth Creationism” In J. B Stump, ed. Four Views on Creation, Evolution, and Intelligent Design. Grand Rapids, MI: Zondervan, 71-100.

Ross, Hugh. 2017b. "Response from Old Earth Creationism” In J. B Stump, ed. Four Views on Creation, Evolution, and Intelligent Design. Grand Rapids, MI: Zondervan, 161-166.

Ross, Hugh. 2017c. "Response from Old Earth Creationism” In J. B Stump, ed. Four Views on Creation, Evolution, and Intelligent Design. Grand Rapids, MI: Zondervan, 214-220.

Ruse, Michael. 2018. "Creationism." The Stanford Encyclopedia of Philosophy. Accessed 18th of December 2020. Available at: https://plato.stanford.edu/archives/ win2018/entries/creationism/

Scott, Eugenie C. 2009. Evolution vs. Creation. Berkley, CA: University of California Press.

Trollinger, Susan L., and William Vance Trollinger Jr. 2018. "The Bible and Creationism" In Paul C. Gutjahr, ed. The Oxford Handbook of the Bible in America. Oxford: Oxford University Press, 216-228.

van den Brink, Gilsjbert. 2020. Reformed Theology and Evolutionary Theory. Grand Rapids, MI: William B. Eerdmans Publishing Company.

Życińkski, Jozef. 2006. God and Evolution: Fundamental Questions of Christian Evolutionism. Washington: The Catholic University of America Press. 


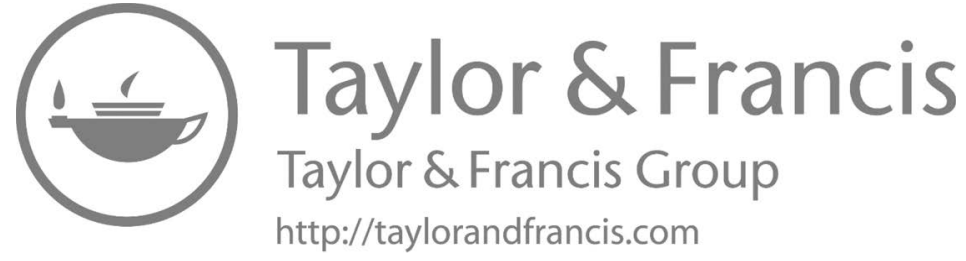


Part 2

Islamic perspectives

on evolution 


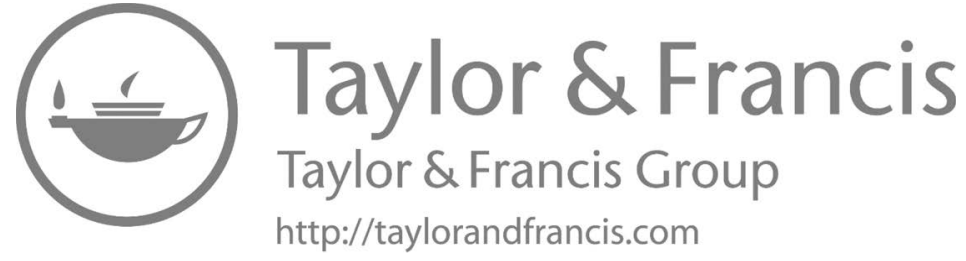




\section{Islamic scripture and evolution}

\section{Introduction}

Many Muslims believe that there are two primary sources of scripture. The first is the Qur'ān. This is the revealed word of God and not Prophet Muhammed's own expression or inspiration of it. The second is the hadīth corpus. Hadīths are accompanying scriptures which contain the actions and the sayings of the Prophet Muhammed. According to many Muslims, the authority of the Prophet is licensed by God through Qur'ān, which is why hadiths occupy an important role alongside the it. Some of the subject matters of the Qur'ān and the hadīth corpus overlap. Both contain varying levels of instructions of jurisprudence, doctrine, prophetic stories, and moral guidance, but they work in tandem (Totolli 2020). For instance, the Qur'ān in several instances instructs Muslims to pray, but the details of how to pray come from the hadīths (through various principles of interpretation). Sometimes a group of verses are linked to a particular historical episode in the Prophet's life, which is contextualised by the hadīths (Görke 2020). Another fundamental difference between them is that the Qur'ann is recited in rituals, whereas the hadīths are not (Michot 2009; Graham 2020). To be clear, hadiths generally have two components. The first is the historical transmission (isnad), a list of names of all the narrators in the chain. After this comes the content (matn). The historical transmission is not recited in rituals, but the content may or may not have words of supplication. Accordingly, many Muslims see hadīths as historical repositories which contain details of the Prophet's life, which in of themselves may or may not contain supplications that may be used in prayer.

Finally, a major difference between the sources is the variation in historical integrity. Most Muslims generally believe the Qur'ān is the unadulterated word of God as revealed to the Prophet since the inception of Islam 1,400 years ago. It has been transmitted through time by so many channels and people that to think it is a conspired and colluded project would be nonsensical. It is why the Qur'ān's historical veracity has not been questioned by most Muslims (Graham 2020). However, the hadīths are a different matter altogether. The saying and the actions of the Prophet were 
recorded and transmitted by hadīth narrators (muhaddithīn). However, according to many Muslims, hadìths occupy varying levels of historical integrity and authenticity. Muslim scholars recognised early on in Islamic history that some people could forge hadīths for personal, social or political gain (Brown 2009, 1-66). This triggered the development of an entire discipline of evaluating hadīths (uṣul al-hadìth or also known as muștalah al-hadīth). Within this discipline, hadīth specialists developed a variety of methodological principles, nomenclature, and grading schemes to differentiate strong hadīths from weak ones (Abdul-Jabbar, 2020a). We shall be looking at some of these details in Chapter 9. But sufficient for now is to note that the Qur'ān's historical transmission has not been questioned, but the integrity of the hadiths has, which is why there are various grades of hadīth (Brown 2009).

A final point on hadiths is the notion of canonisation (Abdul-Jabbar, $2020 \mathrm{~b})$. As the process of hadīth verification solidified over time, Muslim scholars codified hadīths into collected volumes. These act as indexed utilities for Muslim scholars so they can look up verified hadīths without starting from scratch. Sunnīs and Shi î̃s differ in their hadīth structure and corpus. Since the focus of this work is on al-Ghazālī, who was a Sunnī scholar, the focus will exclusively be on the Sunnī hadīth corpus. Sunnī Muslims came to identify six books (al-kutub al-sitta) as the most reliable books in the Sunnī hadīth canon, which were named after their compilers (for most of them; Abdul-Jabbar, 2020b):

1 Șaḥịh Bukhārī (compiled by Imām Bukhārī);

2 Șạ̄ị Muslim (compiled by Imām Muslim);

3 Sunan al-Sughrā (compiled by Imām Nisầ̄);

4 Sunan Abu Dawood (compiled by Imām Abū Dāūud);

5 Jāmi al-Tirmidhī (compiled by Imām al-Tirmidh̄i);

6 Muwațtả Imām Mālik (compiled by Imām Mālik) or Sunan Ibn Mājah (compiled by Imām Ibn Mājah). ${ }^{1}$

To be clear, these aren't the only hadīth compilations that exist; rather, they are the most popular and the most reliable ones in comparison. Finally, of these six compilations, Bukhārī and Muslim are the two the most authentic (commonly known as șahihayn, literally meaning the two authentic ones) with the former occupying the highest level of robustness (Brown 2009, 31-32). As we shall see, most of the hadīths pertinent to Adam's creation narrative (and thus relevant to evolution) come from both of these compilations, which is why questioning or dismissing their authenticity can become a very sensitive issue. For brevity, the discussion on the classification of hadiths will be postponed to Chapter 9. This chapter is mainly focused on making all the relevant scriptural details as accessible as possible without any technical jargon.

This chapter aims to achieve two things. First, we will review the various verses in the Qur'àn and the hadīths that are relevant to the discussion of 
Islam and evolution. This shall set the stage for Chapter 4 when we review the various ways Muslim thinkers have tried to oppose or reconcile Islam's compatibility with evolution. The conjunction of Chapters 3 and 4 will then provide the foundational backdrop for Chapter 9 where al-Ghazali's hermeneutic methodology is established through which attempts at reconciling Islam with evolution are then evaluated in Chapter 10. The second objective is to compare the relevant Islamic scripture with some Christian concerns highlighted in Chapter 2. As we shall see, some issues might be important in certain Christian narratives, but they do not have a strict parallel in Islamic scripture and thought. These two objectives map the structure of this chapter in the stated order.

\section{Creation in Islamic scripture}

In this section, we shall review the verses and hadiths related to creation. For clarity, this discussion is divided into three parts. This includes the creation of the heavens and the earth, non-human life, and Adam's creation. We shall review the relevant verses and hadiths in the stated order.

\section{Creation of the heavens and the earth}

The Qur'ān is similar to the Bible in that it mentions God having created everything in six days. The following are two examples:

Your Lord is God, who created the heavens and earth in six days (sitta ayyām), then established Himself on the throne; He makes the night cover the day in swift pursuit; He created the sun, moon, and stars to be subservient to His command; all creation and command belong to Him. Exalted be God, Lord of all the worlds! (Qur'ān 7:54)

Your Lord is God who created the heavens and earth in six days (sitta ayyām), then established Himself on the Throne, governing everything; there is no one that can intercede with Him, unless He has first given permission: this is God your Lord so worship Him. How can you not take heed? (Qur'ān 10:3)

These verses give an apparent reading of the heavens and the earth being created by God in six days. However, in classical Arabic, the word for days (ayyām) is semantically elastic. It could mean 24-hour days, or it could mean six spans of time with any duration (Mabud 1991, 54-57; Jalajel 2009, 36). The Qurān itself utilises this semantic elasticity in other places:

They will challenge you [Prophet] to hasten the punishment. God will not fail in His promise - a day (yawm) with your Lord is like a thousand years by your reckoning. (Qur'ān 22:47) 
In addition to the ambiguity embedded in the word for days (ayyām), there is also uncertainty about the duration of each of the six days. They could be the same lengths, or they could be very different from one another. There is nothing explicit in Islamic scripture that warrants a definitive conclusion for either case (Jalajel 2009, 36).

Finally, one could question the sequence of things and determine if Islamic scripture makes any point on this matter. The first two verses seem to be neutral as they mention heaven and earth with a conjunction, i.e. they mention heavens and earth in six days. ${ }^{2}$ So they don't seem to indicate any chronology. That said, in another part of the Qur'ān, there seems to be a chronological sequence:

Say, 'How can you disregard the One who created the earth in two days? How can you set up other gods as His equals? He is the Lord of all the worlds!' He placed solid mountains on it, blessed it, measured out its varied provisions for all who seek them - all in four days. Then (thumma) He turned to the sky, which was smoke - He said to it and the earth, 'Come into being, willingly or not,' and they said, 'We come willingly' and in two days He formed seven heavens, and assigned an order to each. We have made the nearest one beautifully illuminated and secure. Such is the design of the Almighty, the All Knowing. (Qur'ān 41:9-12)

In these verses, we can clearly see that earth with its surface and mountains were created first followed by the heavens. The connective, "Then (thumma) He turned to the sky ...," suggests that this is a chronological sequence. However, the connective is not as restrictive as it seems. It could be read as a chronological sequence, but it can also be read to illustrate a degree of difference, which, if interpreted this way, could suggest the heavens are grander than the earth (Mabud 1991, 58; Jalajel 2009, 38). For example, when a music teacher reprimands an arrogant student of music and says to him: "There's you, then there's Beethoven." The connective "then" in this sentence is not a connective of chronology but one of a point of continuation from a lesser valued subject to a higher one. The same reading could be applied to the verse referring to the sky. To be sure, this is not an isolated case in the Qur'ān. Imam al-Bayḍāwīi, a well-known classical exegete, gives an example from another part of the Qur'ān with a similar context. Consider the following verse:

It was He who created all that is on the earth for you, then (thumma) turned to the sky and made the seven heavens; it is He who has knowledge of all things. (Qur'ān 2:29)

On this verse, he comments with the following (Al-Bayḍāwī 2016, 499): "Thumma is probably the disparity between the two creations and the superiority of the creation of the sky over the creation of the earth." Given 
this plausibility, there is no definitive statement in the Qurān which suggests a chronology.

There is a hadīth in Muslim (2789), however, which seems to have a conclusive chronology and even seems to against the Qur'ān:

God created the dust on Saturday. He created the mountains on Sunday. He created the trees on Monday. He created the despised things on Tuesday. He created the light on Wednesday. He scattered the beasts throughout it on Thursday. He created Adam in the late afternoon on Friday as the last creation on the last hour of Friday, between the late afternoon and the night. ${ }^{3}$

This hadith is suggesting that things were created over a seven-day period, which apparently contradicts the six days mentioned in the Qur'ān. How to go about analysing hadīths will be discussed in detail in Chapters 9 and 10 . For now, the following points expressed aptly by Jalajel (2009, 38-42) will suffice. First, there are issues with the hadīth's authenticity as pointed out by the scholars of hadīth. Second, there are variations of this hadīth in other hadith compilations which differ and sometimes contradict one another in details, e.g. what was created on what day. Accordingly, this reduces the confidence in how far the details of this hadith can be taken at face value. Third, even if this hadīth were to be taken apparently, it doesn't contradict the six-day claim in the Qur'ān because of the semantic elasticity discussed earlier. The Qur'ān's six days could be referring to any six periods of time, which could make it compatible with this hadīth. Fourth, this hadīth isn't straightforwardly relevant to the creation of the heavens and the earth. Indeed, there is mention of dust being created on the Saturday and light on a Friday, but to conclude these as definitive references to the earth (Surface? Crust? Tectonic Plates?) and heaven (Sun? Celestial bodies? Supernova?), respectively, would be problematic. This is one possible (and valid) reading but not the only one. For these reasons, this hadīth doesn't give us any decisive chronology.

To conclude this section, Islamic scripture doesn't seem to give us any definitive readings of a six 24-hour day creation of the universe and earth, and neither does it contain details of these six epochs' uniformity. Consequently, there doesn't seem to be any conclusive chronology. More can be said on other verses related to the creation of the heavens and earth, ${ }^{4}$ but the key emphasis here was on the timing. The rest of the details do not seem to be relevant to the discussion of evolution.

\section{Creation of (non-human) life}

It is mentioned throughout the Qur'ann that God is the creator of everything. However, Islamic scripture seems to be vague about the creation details of living things (barring Adam's/human creation for now). This includes the 


\section{Islamic perspectives on evolution}

origins of life as well as the origins species. There is a verse in the Qur'ān which indicates that life seems to have started with water:

Are the disbelievers not aware that the heavens and the earth used to be joined together and that We ripped them apart, that We made every living thing from water? Will they not believe? (Qur'ān 21:30)

In another verse, this is further qualified:

And God created each animal out of [its own] fluid: some of them crawl on their bellies, some walk on two legs, and some on four. God creates whatever He will; God has power over everything. (Qur'ān 24:45)

While both of these links living things to water, the process through which this happens is not mentioned. ${ }^{5}$

The Qur'ān also makes references to plants:

Another of His signs is this: you see the earth lying desolate, but when We send water down on to it, it stirs and grows. He who gives it life will certainly give life to the dead. He has power over everything. (Qur’ān 41:39)

In this verse, we can see that God is referring to his creative powers such that when rain is sent down on barren land, it can grow with life, i.e. vegetation. There is another verse where the theme of life and death is linked with plant seeds:

It is God who splits open the seed and the fruit stone: He brings out the living from the dead and the dead from the living - that is God - so how can you turn away from the truth? (Qur'ān 6:95)

The Qur'ān is also replete with mention of animals such as ants (Qur'ān 27:18), dogs (Qur'ān 7:176), birds (Qur'ān 6:38; 16:79), spiders (Qur'ān 29:41), donkeys (Qur'ān 16:8; 31:19), and many more. These are referred to either as a parable or as actors in stories, either in relation to prophets or ordinary folks. The Qur'ān makes a specific reference to cattle which is mentioned alongside God's hands:

Can they not see how, among the things made by Our hands, We have created livestock they control (Qur'ān 36:71)

In another verse, the Qur'ān mentions that cattle were sent down by God for humankind:

He created you all from a single being, from which He made its mate; He gave (nazala) you four kinds of livestock in pairs; He creates you in 
your mothers' wombs, in one stage after another, in threefold depths of darkness. Such is God, your Lord; He holds control, there is no god but Him. How can you turn away? (Qur'ān 39:6)

However, neither of these contain any difficulties when viewed through the lens of evolution. As we shall see in the next section, there is a verse which mentions that God created Adam with his two hands. Some have used it to deny that Adam was a part of evolution, claiming that it signifies a special creation (Keller 2011, 350-364). But the mere mention of God's hands isn't exclusive to Adam. In another place, the Qur'ān mentions God's hand when an allegiance was made between two parties (Qur'ān 48:10). Collectively, what these indicate, at best, is an important element associated with these things. Still, it doesn't necessarily nor definitively entail a decisive rejection of evolution by reading them as a reference to instantaneous creation.

As for the second verse related to cattle (Qur'ān 39:6), Jalajel (2009, 44-47) observes a difference of opinion over what is meant by "He gave" (nazala). Literally, it means to send down. If taken this way, it could be mean that cattle descended from heaven, which, in turn, could entail a conflict with evolution. However, as Jalajel $(2009,45)$ points out:

[Exegetes] provide numerous suggestions based on various linguistic conventions, but none of their suggestions are definitive. Some of their suggestions imply that the creation being referred to is the initial creation of these cattle. Other interpretations point instead to their continual creation and sustenance.

Given these various opinions on the matter, the second verse of the cattle doesn't negate the possibility of cattle being created through evolutionary processes. ${ }^{6}$

Finally, there are verses which mention that God created things in pairs:

Glory be to Him who created all the pairs of things that the earth produces, as well as themselves and other things they do not know about. (Qur'ān 36:36)

And We created pairs of all things so that you [people] might take note. (Qur'ān 51:49)

These verses could be taken to mean that animals and/or plants can only be in a binary gender, i.e. male or female. The first verse doesn't restrict itself to gender binaries. The mention of "other things they do know about" indicates a suggestion of there being things beyond the male-female classification. As for the second verse, exegetes did not see this interpretation as the only specification. Since there is no qualification, they were open to interpreting this as other binary categories, e.g. hot and cold, dry and wet, night and day, sweet and sour, etc. (Shafi 2008a, 385-386; Nasr 2015, 


\section{Islamic perspectives on evolution}

1076, 1278). So, it could include gender binaries but isn't restricted to it. The reason why is this is important to point out is because such references may be taken to indicate that Islamic scripture only alludes to animals and plants in strict a strict gender binary. Given that there are species which do not fit this classification, e.g. some lizards are unisexual, this could have seen to be problematic. However, this needn't be the case given the range of (com)possible interpretations as indicated here.

From this brief review, it is reasonable to conclude that there doesn't seem to be anything conclusive in Islamic scripture that warrants a rejection of plant or animal evolution. We can even see this amongst some thinkers who distinguish between non-human evolution and human evolution and having no problems with the former, e.g. Keller (2011, 350-364) and Qadhi and Khan (2018) who we will be reviewing in detail in Chapter 4.

\section{Creation of Adam}

Elements related to the creation of Adam is mentioned throughout the Qur'ān. These don't follow any chronological order (the Qur'ān itself isn't arranged in chronological order and does not map history chronologically). To begin with, the Qur'ān makes general claims about humankind's creation from base materials such as dust, earth, clay (of various kinds, e.g. dry or sticky), dark mud, and seminal fluid:

People, [remember,] if you doubt the Resurrection, that We created you from dust, then a drop of fluid, then a clinging form, then a lump of flesh, both shaped and unshaped: We mean to make Our power clear to you ... (Qur’ān 22:5)

To the Thamud, We sent their brother, Salih. He said, 'My people, worship God. You have no god other than Him. It was He who brought you into being from the earth and made you inhabit it, so ask forgiveness from Him, and turn back to Him: my Lord is near, and ready to answer.' (Qur'ān 11:61)

He is the one who created you from clay and specified a term [for you] and another fixed time, known only to Him; yet still you doubt! (Qur'ān 6:2)

So [Prophet], ask the disbelievers: is it harder to create them than other beings We have created? We created them from sticky clay. (Qur'ān 37:11)

We created man out of dried clay formed from dark mud (Qur'ān 15:26)

Man should reflect on what he was created from. He was created from a fluid, ejected, then he emerges from between the backbone and breastbone (Qur'ān 86:5-8) 
There is also a hadīth which explicitly states that God took a handful of soil from the earth and fashioned Adam's lifeless body (Muslim 2611). This narrative aligns with some verses which mention how God created Adam from these base materials and then injected into Adam a spirit $(r \bar{u} h)$ :

Such is He who knows all that is unseen as well as what is seen, the Almighty, the Merciful, who gave everything its perfect form. He first created man from clay, then made his descendants from an extract of underrated fluid. Then He moulded him; He breathed from His Spirit (rühihi) into him; He gave you hearing, sight, and minds. How seldom you are grateful! (Qur'ān 32:6-9)

Your Lord said to the angels, 'I will create a mortal out of dried clay, formed from dark mud. When I have fashioned him and breathed My spirit (rūhī) into him, bow down before him.' (Qur'ān 15:28-29)

Your Lord said to the angels, 'I will create a man from clay. When I have shaped him and breathed from My Spirit (rūhī) into him, bow down before him.' (Qur'ān 38:71-72)

Another hadīth explicitly mentions that people are known as the children as Adam while Adam himself was created from dust: "People are all the children of Adam, and Adam was [created] from dust" (Tirmidhī 3955). The notion of humanity referred to as Adam's children (bani Adam) is also found in the Qur'ān $(7: 27 ; 36: 60)$.

Furthermore, there are hadiths that mention Adam as the father of humanity:

On the Day of Resurrection the Believers will assemble and say, 'Let us ask somebody to intercede for us with our Lord.' So they will go to Adam and say, 'You are the father of all the people, and God created you with His Own Hands, and ordered the angels to prostrate to you, and taught you the names of all things; so please intercede for us with your Lord, so that He may relieve us from this place of ours.' Adam will say, 'I am not fit for this (i.e. intercession for you).' (Bukhārī 4476)

People, your Lord is one, and your father is one. Indeed, there is no superiority of an Arab over a non-Arab, or a non-Arab over an Arab, or of a red man over a black man, or of a black man over a red man, except in terms of God-consciousness ${ }^{7}\left(\mathrm{Ahmad}^{8} 23479\right)$

These tie in with hadīths that are less explicit, but they indirectly maintain Adam's significance for humanity. The hadīth we looked at earlier wherein it states that Adam was created on a Friday contributes to this narrative. 
There are also verses in the Qur'ān which make it apparent that humanity can be traced down to a single couple, i.e. Adam and Eve:

People, be mindful of your Lord, who created you from a single soul (nafsin wähidatin), and from it created its mate, and from the pair of them spread countless men and women far and wide; be mindful of God, in whose name you make requests of one another. Beware of severing the ties of kinship: God is always watching over you. (Qur'ān 4:1)

It is He who created you all from one soul (nafsin wähidatin), and from it made its mate so that he might find comfort in her ... (Qur'ān 7:189)

People, We created you all from a single man and a single woman, and made you into races and tribes so that you should recognise one another. In God's eyes, the most honoured of you are the ones most mindful of Him: God is all knowing, all aware. (Qur'ān 49:13)

To be sure, the mention of "its mate" in the first two verses is referring to Eve. ${ }^{9}$ Interestingly, there are two interpretations of the first verse (Qur'ān $4: 1)$. It comes down to how one interprets what is meant by "from it," which gives us two slightly different accounts of how Eve was created. Haleem $(2011,135)$ aptly summarises the difference between the two positions:

'From it' is an ambiguous expression in Arabic, which has resulted in two interpretations, each of which has supporting arguments: one takes it to mean 'part of the soul [nafs],' without any specification as to which part exactly; the other interpretation takes it to mean 'of the same kind.'

In the first interpretation, a part of Adam was taken to create Eve. This could tie in with the popular account of Eve being created from Adam's rib. The second interpretation suggests that Eve was created in the same essence as Adam. So, this is not a physical interpretation as such, but more of a metaphysical point. Either way, both of these interpretations indicate that Eve was created miraculously in some relation to Adam, and these are generally recognised as the two possible interpretations of this verse (Al-Rāzi 2000, 131; Ibn al-Jawzī 2002, 253; Nasr 2015, 189).

Additionally, the narrative of the fall is clearly mentioned in the Qur'ann in several places. The following is one group of verses which describes the event:

[Prophet], when your Lord told the angels, 'I am putting a successor on earth,' they said, 'How can You put someone there who will cause damage and bloodshed, when we celebrate Your praise and proclaim Your holiness?' but He said, 'I know things you do not.' He taught Adam all the names [of things], then He showed them to the angels and said, 'Tell 
me the names of these if you truly [think you can].' They said, 'May You be glorified! We have knowledge only of what You have taught us. You are the All Knowing and All Wise.' Then He said, 'Adam, tell them the names of these.' When he told them their names, God said, 'Did I not tell you that I know what is hidden in the heavens and the earth, and that I know what you reveal and what you conceal?' When We told the angels, 'Bow down before Adam,' they all bowed. But not Iblis, who refused and was arrogant: he was one of the disobedient. We said, 'Adam, live with your wife in this garden. Both of you eat freely there as you will, but do not go near this tree, or you will both become wrongdoers.' But Satan made them slip, and removed them from the state they were in. We said, 'Get out, all of you! You are each other's enemy. On earth you will have a place to stay and livelihood for a time.' Then Adam received some words from his Lord and He accepted his repentance: He is the Ever Relenting, the Most Merciful. We said, 'Get out, all of you! But when guidance comes from Me, as it certainly will, there will be no fear for those who follow My guidance nor will they grieve - those who disbelieve and deny Our messages shall be the inhabitants of the Fire, and there they will remain.' (Qur'ān 2:31-39)

The is the general outline of Adam's fall from the garden. It starts with Adam being created by God who appoints him as a vicegerent upon the earth (the previous verses in which it was mentioned that Adam was created through clay and then injected with the soul should be kept in mind here). Upon seeing this, the angels present remarked why God created an entity that would cause damage and bloodshed. God reminds the angels that He knows things they don't. This is then followed by God teaching Adam names and being asked to name things. The angels are then asked to bow to Adam. Satan refused to do so out of arrogance. Adam and his wife are then instructed to not eat from the tree, but Satan makes them slip, and they end up going against the command of God, after which $\mathrm{He}$ expels them from the garden (Wheeler 2002, 15-35; Shafi 2008b, 159-187; Mikulicová, 2014; Kaltner and Mirza 2018, 16-20).

Concerning this episode, there is a verse in the Qur'ann where Adam is specifically mentioned as being created by God's two hands. This reference of God creating Adam with his two hands is juxtaposed with Satan (named Iblīs in Islamic scripture) who refused to bow down to Adam when commanded by God:

God said, 'Iblīs, what prevents you from bowing down to the man I have made with My own [two] hands? Are you too high and mighty?' (Qur'ān 38:75)

As mentioned earlier, some thinkers use this verse to apply exclusivity to Adam's special creation (Keller 2011, 350-364; Qadhi and Khan 2018). To 
be sure, while the mere mention of God's hands in of itself doesn't warrant exclusivity, the fact that this verse mentions God's two hands (in comparison to the singular, i.e. God's hand, and the plural, i.e. God's hands ${ }^{10}$ ) is exclusive to Adam. Classical thinkers like Ibn Taymiyya, al-Bayhaqī, and al-Bayḍāwī all agree that this point illustrates the uniqueness of Adam's creation in comparison to other creations (Jalajel 2009, 150-152). However, the exact nature of this distinctiveness remains unclear. This point will be picked up again in Chapter 10.

One key verse that makes interpreting Adam having parents difficult is the following:

In God's eyes Jesus is just like Adam: He created him from dust, said to him, 'Be', and he was. (Qur'ān 3:59)

While the verse on the face of it seems unproblematic, this verse's context gives an apparent reading that Adam was created without any parents. This verse is located in the third chapter of the Qur'ān (Sürah al-'Imrān), which, broadly speaking, is a critique of Christianity. It sporadically disapproves associating any divine status (though not prophethood) to Jesus throughout the chapter (Ayoub 1992). The similarity being alluded to here is that both were created miraculously (Al-Qurțubī 2019, 243-244). The mention of "'Be' and it was" refers to God manifesting whatever He wills, including being able to violate laws of nature. This is a common motif in the Qur'ān. Furthermore, Mary's miraculous conception of Jesus is discussed in another part of the Qur'ān (19:16-21). The Archangel Gabriel informs Mary that she will have a son to which she responds (Qur'ān 19:20): "How can I have a son when no man has touched me? I have not been unchaste". Given that Muslims don't consider Mary to have lied, this is taken as clear scriptural evidence of Jesus' miraculous conception. ${ }^{11}$ However, this doesn't entail that Jesus and Adam are completely isomorphic. There is an extra clause that qualifies Adam's creation with respect to Jesus. The mention of "creating him from dust," which refers to Adam in light of the verses we looked at earlier, suggests that Adam was created without any parental agency, unlike Jesus who was born with a mother. So, putting all these verses together, the similitude established between Jesus and Adam in this verse is them not having a father.

Additionally, this verse has a specific historical context to it (asbāb al-nuzūl). The following is one variation of this episode (An-Naisaburi 2010, 139):

Two monks from Najrān came to [the] Holy Prophet. The Messenger of [God] said to them: 'Accept Islam.' They then said: 'We have accepted Islam already before you.' He [the Prophet] said: 'You Lie. There are three things which prevent you from accepting Islam. Your prostrating in front of the cross, your saying that [God] has taken a son, and your drinking wine.' They asked: 'What do you say regarding Jesus?' The Prophet kept silent and the following verse was revealed to him [i.e. Qur'ān (3:59)].12 
The crux of that episode is a back and forth between Prophet Muhammed and some Christian monks. These monks weren't accepting Islam because of their belief that Jesus was born miraculously without a father, and hence a divine figure. ${ }^{13}$ This verse was revealed in light of this episode (Al-Qurțubī 2019, 244; Al-Gharnāțī 2002a; Al-Gharnāțī 2002b). Taking the thematic and historical context together, this verse reveals an argument based on the comparison of Jesus and Adam, and it goes as follows. If Christians believe that Jesus is divine because of his miracle birth, then Adam is even more divine and miraculous since he was born without a mother and a father. It is for this reason many exegetes and Muslim scholars have interpreted this to mean that Adam had no parents (Ayoub 1992, 183-188; Jalajel 2009, 48-52; Seoharvi 2009a, 316-317; Haleem 2011, 135; Nasr 2015, 147; Al-Qurțubī 2019, 243-244). The verses and hadīths we looked at earlier refer to Adam's creation in general terms, e.g. dust, clay, and the father of humanity. They did not strictly rule out any parental agency of Adam, and could be interpreted in other ways, like referring to Adam's creation in heaven, or to the constituents of his bodily makeup. However, this verse seems to get to the heart of the issue. It presents an argument against the divinity of Jesus, and the logic of the argument is built upon the premise of Adam's miraculous creation, i.e. not having parents. For this reason, it is arguably the most important verse in the context of Islam and evolution.

Finally, there is one more hadīth that is of relevance. It discusses Adam's description with a specific mention of his height. The hadith states that Adam was 60 cubits (around 30 metres) tall (Bukhārī 6277). While this in of itself isn't strictly related to evolution, i.e. it's not really related to common descent, it has come up in the literature of Islam and evolution, which is why it deserves attention (Mabud 1991, 91; Guessoum 2010, 829; Majid 2015, 104-105). Even if evolution wasn't true, this hadīth is problematic because it conflicts with physics and biology, i.e. humans cannot be that tall with the anatomy they occupy (Zaman 2020). The details of this hadīth will be an important case study when we critically evaluate various proposals that attempt to reconcile Islam with evolution in Chapter 10.

In short, by looking at all these verses and hadīths collectively, Muslim scholars did not seem to question the miraculous creation of Adam, nor the idea that humankind's lineage can be traced back to him (however absent the intermediate details as we shall shortly see). To reconcile Islam with evolution, a consistent and coherent hermeneutic framework must be needed where these verses and hadīths can be read non-arbitrarily. The various ways people have tried to achieve this will be reviewed in Chapter 4 .

\section{Key differences between Christian and Islamic narratives}

Having gone through a brief review of the pertinent Qur'ānic verses and hadīths, we are now in a better position to highlight the differences between the Christian and Islamic narratives. In Chapter 2, we noted some of the 
sensitivities that troubled some Christian thinkers (primarily young-earth creationism, YEC) when it came to the topic of evolution. These include original sin, age of the universe/earth, prophetic lineage, and Noah's flood. Let us review them in the stated order.

\section{Original Sin}

In Chapter 2, we learnt that before Adam ate from the tree, the world was believed to be in a state of goodness. However, once Adam committed the act and fell from grace, evil, suffering, and death came upon the world. This is the concept of original sin. This idea does not exist in the Islamic narrative. As we saw earlier, when God commanded the angels to bow down to Adam, Satan refused and was disobedient. He rejected a command of God, and hence Adam was not the first to sin. ${ }^{14}$ Another possible reference which makes this somewhat apparent is the questioning of the angels. When Adam was created, the angels immediately asked God: "How can You put someone there who will cause damage and bloodshed, when we celebrate Your praise and proclaim Your holiness?” (Qur'ān 2:30). The interesting thing to note is why did the angels ask this question? There are narratives which suggest that this is about creatures before Adam/humans that caused bloodshed and mischief on earth. Some say these could be Satan and his minions who occupied earth before humans; others suggest it's referring to pre-Adamic (perhaps pseudo-human) entities; still, others say it simply reflects a curiosity of the angels which was addressed by God (Ayoub 1984, 71-92; Nadvi 1998, 29-74; Nasr 2015, 21-22; Al-Bayḍāwī 2016, Al-Qurtubi 2018, 117-118). Whatever the truth may be, the notion that evil is linked to Adam eating from the tree doesn't exist in the Islamic narrative. Indeed, both the Christian and Islamic narrative agree on a fall of Adam and Eve from the garden, but the notion of original sin is a fundamental theological difference between the two (Ayoub 1984, 71-92; Burrel 2011; Khalil 2012; Winter 2017).

\section{Age of the Universe/Earth}

The age of the universe is an important point of difference for YEC. They believe that the Bible should be taken literally through which it is suggested that that earth can only be 6-10,000 years old. There is a refusal on their part to interpret this in any other way semantically and thematically. As was seen earlier in this chapter, the Qur'ān does contain verses which mention that the heavens and the earth were created in six days. While these could be interpreted as six 24-hour days, the word for days (yawm) is semantically flexible. It entails any span of time. For this reason, Islamic scripture doesn't have any tension with an old age of the universe/earth, and it is probably why there is no YEC in the Muslim world (although this has to be stated tentatively). 


\section{Prophetic lineage}

Concerning the age of the universe, the prophets' lineage plays an important role, as was seen in Chapter 2. YEC believe that the prophetic lineages can be traced back to Adam, who came to earth when it first existed. Islamic scripture undoubtedly contains mention of prophets, some more than others. But the Qur'ān contains minimal details when it comes to the history of their genealogy. There are hadīths which mention the genealogy of the Prophet Muhammed and the preceding Arab tribes, as this was an important part of the culture of Arabs. But the historical reliability of a genealogy leading up to Noah and beyond that to Adam drastically withers (Jalajel 2009, 54; Ibn Kathīr 2010, 34). Islamic scripture and the Bible may agree on some patriarchs that come in-between, but there isn't any reliable source which Muslims commit to when it comes to the genealogy leading up to Adam (Varisco 1995).

\section{Noab's flood}

The last consideration that played a part in Biblical sensitivities was the flood of Noah. The Qur'ān mentions Noah in several places, and the general outline is the same as the Bible. God instructs Noah to build an ark and asks him to call people to heed to His message. Some joined Noah while most declined. Additionally, God instructs Noah to gather pairs of each kind of animal (Wheeler 2002, 49-62; Kaltner and Mirza 2018, 36-140). The main detail that is specific to the conversation of evolution is the scale of the flood. Was it local or global? In Chapter 2, we saw that Christian thinkers differ over this question. There contains no definitive statement about this issue in Islamic scripture. Undoubtedly, there are different opinions on the matter. Some suggest a local flood, while others argue for a global one (Seoharvi 2009b, 70). But there is no scriptural decisiveness over this issue (Ibn 'Ațiyya 2002, 946). Given this ambiguity, Islamic scripture is compatible with either opinion.

\section{Conclusion}

This chapter attempted to introduce and review the pertinent source materials from Islamic scripture relevant to evolution. Three specific creation narratives were reviewed and discussed. The first was the creation of the universe and earth. It was concluded that Islamic scripture is ambiguous about the length of this process. The second creation conversation was about non-human life. While Islamic scripture does indicate that life started with water, the exact mechanics of how plant life or animals were brought in existence are not mentioned. The third creation narrative we looked at was the creation of Adam. Islamic scripture seems to give an overwhelming number of verses and hadīths that discuss Adam's miraculous creation. 
Furthermore, Adam is described as the father of humanity, and humans are referred to as Adam's children. Collectively these indicate that our genealogy does go back to Adam. So, if thinkers want to reconcile Islam and evolution, they must engage with these texts through a consistent and coherent hermeneutic procedure that is neither arbitrary nor whimsical such that scripture is masked with a forced evolutionary reading.

Finally, the differences between the Biblical and Islamic narratives were highlighted. The concept of original sin does not exist in Islamic thought. While the Qur'ān and the Bible agree on the fall of Adam and Eve from the garden, the notion of evil starting with Adam sinning is not a theological axiom in Islamic thought. Furthermore, it was mentioned that the age of the universe/earth, prophetic lineages, and Noah's flood are non-issues in the Islamic narrative. There is nothing explicit in the texts that results in a contradiction with modern science in these areas.

\section{Notes}

1 There is a disagreement over the sixth book, hence the two possibilities.

2 There is another verse where the order is reversed: "A revelation from $\mathrm{He}$ who created the earth and highest heavens ..." (Qur'ān 20:4). But this is still referring to a conjunction, and therefore not a definitive sequence.

3 This translation is taken from Jalajel $(2009,38)$.

4 For example, the Qur'ān mentions the notion of seven heavens in some places, e.g. Qur'ann $(2: 29 ; 3: 129 ; 6: 73)$. Or consider the different words that the Qur'ān uses to describe the heavens, e.g. bina $\bar{a}^{\prime}$ (canopy) or saqf (roof). These can have various meanings or maybe emphasising specific aspects depending on the etymology, rhetoric, and context. See Mabud (1991, 60-64) and Nasr (2015).

5 Interesting to note that the search for extraterrestrial intelligence is predicated on finding water in other planets, which resonates with the idea being alluded to in these verses (Wilkinson 2017).

6 For an alternate viewpoint see Nadvi (1993, 202-217).

7 This hadīth was not available on www.sunnah.com. This particular hadīth was taken from al-Arna'ūt and Murshid (2001, 474). It conveys an excerpt from the well-known speech of the Prophet called the farewell or final sermon (khutbat ul-widā').

8 Important to note that this hadīth compiler is not in the famous six compilations identified at the beginning of this chapter.

9 In the Islamic narrative, it is generally considered that Adam was created first, after which Eve was made (Wheeler 2002, 15-35; Mikulicová, 2014; Kaltner and Mirza 2018, 16-20).

10 Unlike the English language, which has single and plural nouns only, words are either singular, dual, or plural in the Arabic language.

11 The reader might find it interesting to note that because of this miracle given to Mary, there was a whole debate amongst Muslim scholars on whether women can be prophets or not. See Seoharvi (2009a, 289-296) and Nasr (2015, 769).

12 The translation was slightly modified.

13 For excellent resources on the miraculous, virginal conception of Jesus as seen and discussed by Christian scholars, see Brown (1973; 1993). 
14 This is similar to what Hugh Ross, the representative of old-earth creationism, we looked at in Chapter 2 believes. See Note 7 in Chapter 2.

\section{References}

Abdul-Jabbar, Ghassan. 2020a. “The Classical Tradition.” In Daniel W Brown, ed. The Wiley Blackwell Concise Companion to the Hadith. West Sussex: Wiley Blackwell, 15-38.

Abdul-Jabbar, Ghassan. 2020b. "Collections.” In Daniel W Brown, ed. The Wiley Blackwell Concise Companion to the Hadith. West Sussex: Wiley Blackwell, 137-158.

Al-Arna'ūt, Sho'ayb, and 'Ādil Murshid, eds. 2001. Musnad al-Imām Aḥmad Ibn Hanbal. Volume 38. Beirut: Mu’assasat al-Risāla.

Al-Bayḍāwī, 'Abdullah Ibn 'Umar. 2016. The Lights of Revelation and the Secrets of Interpretation: Hizb One of the Commentary on the Qur'ann. trans. by Gibril Fouad Haddad. Manchester: Beacon Books.

Al-Gharnāṭ̂̄, Abū Ḥayyān Athīr ad-Dīn, 2002a. “Tafsīr al-Baḥr al-Muhīị.” Al-Tafāsīr. Accessed 8th of November. Available at: https://www.altafsir.com/Tafasir.asp? $\mathrm{tMadhNo}=0 \& \mathrm{tTafsirNo}=19 \& \mathrm{t} \mathrm{SoraNo}=3 \& \mathrm{t}$ AyahNo=59\&tDisplay=yes \&Page= $10 \&$ Size $=1 \&$ LanguageId $=1$

Al-Gharnāṭ̣̂, Abū Ḥayyān Athīr ad-Dīn, 2002b. "Tafsīr al-Baḥr al-Muhīị." Al-Tafāsīr. Accessed on 8th of November. Available at: https://www.altafsir.com/Tafasir.asp? $\mathrm{tMadhNo}=0 \& \mathrm{tTafsir} \mathrm{No}=19 \& \mathrm{t}$ SoraNo=3\&tAyahNo=59\&tDisplay=yes\&Page= $11 \&$ Size $=1 \&$ LanguageId $=1$

Al-Qurțubi, Abū 'Abdullah Muhammad. 2018. Tafsīr al-Qurțbi. Volume 1. trans. by Aisha Bewley. Bradford: Diwan Press.

Al-Qurțubī, Abū 'Abdullah Muhammad. 2019. Tafsīr al-Qurțub̄i. Volume 2. trans. by Aisha Bewley. Bradford: Diwan Press.

Al-Rāzī, Muḥammad Ibn 'Umar (Fakhr al-Dīn). 2000. Mafātīh al-Ghayb. Volume 9. Beirut: Dār al-Kutub al-'Ilmiyya.

An-Naisaburi, Abdul Hassan. 2010. Reasons of Revelation of the Noble Qur'ann. trans. by Aiman Saleh Sha'aban and Muhammad Ismail. Selangor Darul Ehsan: Dakwah Corner Bookstore.

Ayoub, Mahmoud M. 1984. The Qur'ān and Its Interpreters. Volume 1. New York, NY: The State University of New York Press.

Ayoub, Mahmoud M. 1992. The Qur'àn and Its Interpreters. Volume 2. New York, NY: The State University of New York Press.

Brown, Raymond E. 1973. The Virginal Conception and Bodily Resurrection of Jesus. New York, NY: Paulist Press.

Brown, Raymond E. 1993. The Birth of the Messiah: A Commentary on the Infancy Narratives in the Gospels of Matthew and Luke. New York, NY: Doubleday.

Brown, Jonathon A. C. 2009. Hadith: Muhammad's Legacy in the Medieval and Modern World. New York, NY: Oneworld Publications.

Burrel, David B. Towards a Jewish-Christian-Muslim Theology. West Sussex: Wiley-Blackwell.

Graham, William A. 2020. “Revelation.” In Daniel W Brown, ed. The Wiley Blackwell Concise Companion to the Hadith. West Sussex: Wiley Blackwell, 59-74.

Görke, Andreas. 2020. “Muhammad.” In Daniel W. Brown, ed. The Wiley Blackwell Concise Companion to the Hadìth. West Sussex: Wiley Blackwell, 75-90. 
Guessoum, Nidhal. 2010. "Religion Literalism and Science-Related Issues in Contemporary Islam.” Zygon, 45(4): 817-840.

Haleem, Muhammad Abdel. 2011. Understanding the Qur'ann: Themes and Style. London: I.B. Tauris.

Ibn al-Jawzī, 'Abdur Rahmān. 2002. Zād al-Masīr fī 'Ilm al-Tafsīr. Beirut: Dār Ibn Ḥazm.

Ibn 'Ațiyya, 'Abd al-Haqq. 2002. Al-Muharrar al-Waj̄̄z fī Tafsīr al-Kitāb al-Azīz. Beirut: Dār Ibn Hazm.

Ibn Kathīr, Abū l-Fidā’ Ismā 'îl Ibn 'Umar. 2010. The Life of Prophet Muhammad. Trans. by Rafiq Abdur Rehman. Karachi: Darul-Ishaat.

Jalajel, David Solomon. 2009. Islam and Biological Evolution: Exploring Classical Sources and Methodologies. Western Cape: University of the Western Cape.

Kaltner, John, and Younus Mirza. 2018. The Bible and the Qur'ān: Biblical Figures in the Islamic Tradition. London: Bloomsbury.

Keller, Nuh Ha Mim. 2011. Sea Without Shore: A Manual of the Sufi Path. Amman: Sunna Books.

Khalil, Mohammad Hassan. 2012. Islam and the Fate of Others. Oxford: Oxford University Press.

Mabud, Shaik Abdul. 1991. Theory of Evolution: An Assessment from the Islamic Point of View. Cambridge: The Islamic Academy.

Majid, DS Adnan. 2015. "Qur'ānic Interpretative Latitude and Human Evolution: A Case Study.” Al-Bayan - Journal of Qur'ān and Hadīth Studies, 12: 95-114.

Michot, Yahya. 2009. “Revelation.” In Tim Winter, ed. The Cambridge Companion to Classical Islamic Theology. Cambridge: Cambridge University Press, 180-196. Mikulicová, Mlada. 2014. “Adam's Story in the Qur’ān.” Theologica, 4(2): 277-296.

Nadvi, Khurshid. 1993. Darwinism on Trial. London: Ta-Ha Publishers.

Nadvi, Mohammed Shihabuddin. 1998. Evolution or Creation? Bangalore: Furqani Academy Trust.

Nasr, Seyyed Hossein. ed. 2015. The Study Qurāan: A New Translation and Commentary. New York, NY: HarperOne.

Qadhi, Yasir, and Nazir Khan. 2018. "Human Origins: Theological Conclusions and Empirical Limitations." Yaqeen Institute. Accessed 19th of August 2020. Available at: https:/yaqeeninstitute.org/nazir-khan/human-origins-theological-conclusionsand-empirical-limitations/

Seoharvi, Muhammad Hifzur Rehman. 2009a. Stories from the Qur'än. Volume 2. trans. by Rafiq Abdur Rahman and Muhammad Saeed. Karachi: Darul-Ishaat.

Seoharvi, Muhammad Hifzur Rehman. 2009b. Stories from the Qur'än. Volume 1. trans. by Rafiq Abdur Rahman and Muhammad Saeed. Karachi: Darul-Ishaat.

Shafi, Muhammad. 2008a. Ma'ariful Qur'ān: A Comprehensive Commentary on the Holy Qur'ann. Volume 7. trans. by Muhammad Taqi Usmani. Karachi: Maktaba-e-Darul-Uloom.

Shafi, Muhammad. 2008b. Ma'ariful Qur'ān: A Comprehensive Commentary on the Holy Qur'ann. Volume 1. trans. by Muhammad Taqi Usmani. Karachi: Maktaba-e-Darul-Uloom.

Totolli, Robert. 2020. “Genres.” In Daniel W. Brown, ed. The Wiley Blackwell Concise Companion to the Hadith. West Sussex: Wiley Blackwell, 187-202.

Varisco, Daniel Martin. 1995. "Metaphors and Sacred History: The Genealogy of Muhammad and the Arab 'Tribe.' Anthropological Quarterly, 68(3): 139-156. 
Wheeler, Brannon M. 2002. Prophets in the Qur'ann: An Introduction to the Qur'ann and Muslim Exegesis. New York, NY: Continuum.

Wilkinson, David. 2017. Science, Religion, and the Search for Extraterrestrial Intelligence. Oxford: Oxford University Press.

Winter, Timothy. 2017. "Islam and the Problem of Evil." In Chad Meister, and Paul $\mathrm{K}$ Moser, eds. The Cambridge Companion to the Problem of Evil. Cambridge: Cambridge University Press, 230-248.

Zaman, Muntasir. 2020. At the Crossroads of Science and Scripture: An Analysis of the Hadith on Prophet Adam's Height (Unpublished manuscript). 


\section{Muslim opinions on evolution}

\section{Introduction}

In Chapter 2, we looked at four predominant positions in the Christian context. This was compared and contrasted with the Islamic narrative in Chapter 3, where we reviewed the various verses and hadīths pertinent to the topic of evolution. We noted some sensitivities that are more important with some Christian thinkers and groups than in the Islamic context. Here we build upon Chapter 3 and review the various lines of reasoning that Muslim thinkers have provided when evaluating the (in)compatibility of Islam and Evolution. However, it will be useful to review the numerous ways people have tried to classify or conceptualise these things. Undoubtedly, each systemisation works with certain points of emphasis that the classifier wants to highlight. But this may come with the risk of imposing a classification that may not be applicable in other contexts. As we shall see, some classifications are highly sensitive to the American context, which may be awkward to apply in the Muslim context. With this in mind, this chapter is divided into two parts. The first part is a review of the different classification schemes and the criticisms that have been or can be levelled against them. It will conclude with the adoption of a classification system that solely focuses solely on common ancestry. The rationale behind this will be explained. The second part involves taking the adopted classification system and applying it on the Muslim perspectives found in the literature. This will include a summary table that highlights what each thinker accepts or rejects as part of common ancestry with accompanying expositions of their reasons.

\section{Review of classifications}

Deciding how to frame and classify people's opinions on Islam and evolution can be an arduous task. We saw in Chapter 1 that evolution is multipropositional theory. In other words, there are many aspects which come together to define evolution. Deep time and common ancestry are two of them, with the mechanics of random mutation and natural selection giving 
it a Neo-Darwinian rendition. Therefore, when people are asked whether they believe or reject evolution as a lumped term, there is a danger of resorting to simplistic binaries. What exactly are they accepting or rejecting? Deep time? Common ancestry? The mechanics? A combination of these principles? This gets masked if evolution is used as an umbrella term to capture all these propositions. ${ }^{1}$ In addition to this lumping problem, there is also the problem of connotations. Evolution and (Neo-)Darwinism are very loaded terms in some contexts. As was alluded to in Chapter 1, and as we shall see later in this chapter, evolution and (Neo-)Darwinism immediately connote things like naturalism and atheism (among others) when these are in fact logically independent positions. Belief in evolution does not logically entail naturalism nor atheism. But because evolution has been heavily tied up in theism-atheism polemics historically and sociologically, the terms "evolution" and "(Neo-)Darwinism" may lose their neutrality. It does not help that famous new atheists like Richard Dawkins see belief in evolution and atheism as one and the same thing, which is why he emphasises that one can either be a believer or an evolutionist (Elsdon-Baker 2009; 2017). Such polemical language and simplistic binaries unnecessarily obfuscate the discussion. Another layer of confusion is the general understanding of science by the wider populous. Recall from Chapter 1, the term "theory" in a scientific context does not mean the same thing as in the colloquial one. But individuals unaware of these distinctions may treat evolution as mere guesswork, and therefore find it very easy to brush it aside.

With these concerns in mind, polling data and surveys of Muslim perceptions of evolution should be reviewed critically and not be taken at face value. For instance, Hassan (2007) conducted a wide-ranging survey of Muslim-majority countries, including Egypt, Kazakhstan, Indonesia, Pakistan, Turkey, and Malaysia. A question that was asked in this survey was the following: "Do you agree or disagree with Darwin's theory of evolution?" This item was rightly criticised by Carlisle et al. $(2019,152)$ :

This survey item is problematic for a number of reasons. First, it assumes a working knowledge of Darwinian evolution. Second, it uses the word theory, which could be perceived by members of the public as implying uncertainty, regardless of how well established evolution science may be within the scientific community. Third, it historicises a contemporary field of research by linking it with Darwin. Thus, this study is indifferent to the potential negative associations between the name 'Darwin' and an assertion of Western, scientific supremacy/materialism ... Finally, this question did not differentiate between human and non-human evolution.

The final criticism raised by Carlisle et al. (2019) is important to take note of. Some Muslims thinkers make a distinction between non-human evolution and human evolution, as we shall come to see. But others unaware of 
this distinction might reject evolution in one stroke, a problem which can be observed in the Pew World Muslim Poll (2013). The following is the question and options list that was presented to participants:

Q.20 Thinking about Evolution, which comes closer to your view?

- Humans and other living things have evolved over time

- Humans and other living things have existed in their present form since the beginning of time

- Don't Know

Elsdon-Baker (2015) notes how this is a problematic way of framing the question. From her perspective, this question is heavily influenced by the American landscape, which is predicated by an all or nothing scenario. She points out how this survey item does not consider the option of accepting non-human evolution but not human evolution, which entails that anything that is not considered to be a process of evolution forces respondents to subscribe to "a hardline anti-evolutionist stance" (Elsdon-Baker 2015, 434). She aptly highlights that we end up creating creationists through artefacts of our surveys.

Accordingly, distinguishing between non-human and human evolution may help because it may entail partial acceptance of evolution if not wholesale rejection. As a case in point, Unsworth and Voas (2018) distinguish between the two in their surveys when measuring the responses various religious groups with a sample size of 815 Muslims. Their data revealed that when it came to non-human (plants and animals) evolution, $42.4 \%$ of the Muslims participants strongly agreed with it while only $26.2 \%$ strongly disagreed (with the rest being neutral). However, when it came to human evolution, $26.9 \%$ strongly agreed while $44.2 \%$ strongly disagreed with it (with the rest being neutral). If this data is anything to go by, it shows that the distinction between non-human evolution and human evolution is an important variable in the discussion (also see Elsdon-Baker et al. 2017).

Elsdon-Baker's point on how things are framed in the American landscape also needs some unpacking. As we saw earlier in Chapters 2 and 3, some things are more sensitive in some Christian circles than Muslim ones. Thus, having a shared classification that relies on wholesale transplantation of those sensitivities from one context to another may not be helpful. For instance, consider the following classification by Eugenie Scott (2002) in Table 4.1, which is a spectrum of opinions based on the sensitivities found in the American context.

The top and bottom of Table 4.1 represent the two sides of the spectrum. She starts with flat earthers and ends with materialist evolution, the latter entailing a rejection of God. This may make sense in the American landscape within which some religious groups are largely questioning the whole territory of science. It may be why Scott felt the need to add flat earthers and geocentrists on a creationism-evolution spectrum. But whether such considerations are applicable to the Muslim context need to be carefully 
Table 4.1 A spectrum of opinions on the creationism-evolution divide adapted from Eugenie Scott $(2009,64) .^{2}$

\begin{tabular}{|c|c|c|}
\hline & Flat Earthers ${ }^{3}$ & \\
\hline & Geocentrists $^{4}$ & \\
\hline \multirow{5}{*}{$\begin{array}{l}\text { Compatible with Intelligent } \\
\text { Design (ID) }\end{array}$} & $\begin{array}{l}\text { Young-Earth Creationism } \\
\text { (YEC) }\end{array}$ & \\
\hline & Gap Creationism & \multirow{3}{*}{$\begin{array}{l}\text { Old-Earth Creationism } \\
\text { (OEC) }\end{array}$} \\
\hline & Day-Age Creationism & \\
\hline & Progressive Creation & \\
\hline & Evolutionary Creationism $^{5}$ & \\
\hline & Theistic Evolution (TE) & \\
\hline & Agnostic Evolution & \\
\hline & Materialist Evolution & \\
\hline
\end{tabular}

determined before they can be applied. This is not to say that flat earthers and geocentrists do not exist in the Muslim world. They may very well do. In fact, there was a scandal in 2017 in which a Tunisian student submitted a thesis, stating that the earth was young $(13,500$ years old), stationary, and at the centre of the universe (Guessoum 2017). But whether this is an isolated case or a widespread belief needs to be determined before it can be affirmed and applied in the Muslim context. Returning to the study of Unsworth and Voas $(2018,82)$, they note that $50 \%$ of the Muslim participants strongly agreed that the earth is billions of years old while only $5.5 \%$ said they strongly disagreed (with the rest being neutral). This suggests that perhaps flat earthism might not be as prevalent or a concern in Muslim contexts, but this can only be stated tentatively.

Another problem with this classification is the lumping of scientific beliefs with (a)theistic ones. The spectrum moves simultaneously from the least conformity with science and religious beliefs on the one end with absolute conformity with science and a rejection of God on the other (Huskinson 2020, 9). This dual gradient embedded in this spectrum highlights the same issue of the bifurcation tendency noted earlier with Dawkins. It suggests that to be scientific one must abandon belief in God. The conclusion of these observations is care needs to be taken how a classification developed in one locality is applied to another context.

Some Muslim thinkers who have looked at the discourse of Islam and evolution seem to have classified things differently. Guessoum (2016) adopts a three-tier system, which includes rejectionists, moderates, and pro-evolutionists. Malik $(2018 ; 2019)$ seems to have followed Guessoum with a similar scheme but uses the terms rejection, accommodative, and acceptance instead. A notable difference between Malik and Guessoum on the one hand, and Scott on the other, is that the former's classification doesn't require a rejection of God to believe in evolution. Another benefit 
of this classification is that one can put in many different reasons for each camp. As we shall shortly see, sometimes thinkers who completely reject or accept evolution have various reasons for doing so. These may be scientific, theological, hermeneutic in nature, or even a combination of them. So Guessoum's and Malik's method of classification can help manage these differences of opinions. However, one downfall with this scheme is that what counts as rejection and acceptance is largely dependent on how the classifier views the positions he or she is evaluating. For instance, both put David Solomon Jalajel, whose position we shall review shortly, in the rejection camp (Guessoum 2016; Malik 2019, 210). But reviewed on his own terms, Jalajel (2018) says his proposal is perfectly compatible with evolution. So there can be a conflict between how the classifier conceives the positions and the people who are being classified see themselves. Another possible problem is that with such a broad classification, a comparison can be, at times, difficult to manage. The reasons for (dis)agreement(s) can cut across various lines of reasoning, including the determination or interpretation of the science, metaphysical principles, and hermeneutic commitments. So it may be challenging to determine what common denominator these differences or agreements can be made on.

Another classification that can be found in the literature is one by Ghafouri-Fard and Mohammad Akrami (2011). They have four divisions in their taxonomy with a focus on scripture and science. The first group believes that evolution is just a theory, but there are ways to interpret the creation of humans through other ways to make them compatible. The second group believes the veracity of the texts are clear and the creation of humans cannot be reinterpreted. So even if evolution is true, humans are an exception to it. The third group believes that Qur'ān and science function on two very different planes, i.e. not communicable. ${ }^{6}$ The Qur'ān is not a book of science, so belief in scientific theories shouldn't matter. The fourth group believe that human evolution can be determined from the Qur'ann. The difference between this group and the first one is a commitment to the veracity of the science and the resolute determinability of human evolution from Islamic scripture. While this scheme seems to focus more on human evolution, the fundamental problem with this setup is that it's trying to lump various considerations under one rubric. This way of classifying involves merging epistemic commitments to science, hermeneutic commitments, and the relationship between science and scripture, which can lead to arbitrary positional differences. The first and fourth positions, for instance, seem to be differences in degree rather than of kind. It also excludes options that thinkers may have where evolution is being rejected or accepted based on one discipline rather than a conjunction of the two. Consider the hypothetical position of an individual who rejects evolution simply because the science doesn't convince them. He or she has no opinion on the scriptural side of things. It's difficult to see how such individuals may fit in this scheme. 
Finally, and by their own admission, some thinkers might accept or reject evolution for reasons beyond science and scripture (Ghafouri-Fard and Mohammad Akrami 2011, 24). Seyyed Hossein Nasr, whose opinion we shall see shortly, is one example. His primary reason for rejecting evolution is based on a metaphysical worldview that he occupies within which evolution is impossible. So the science and hermeneutics have little or no bearing on his position, making it difficult to determine where he would fit in this classification.

Undoubtedly, each way of classifying things rests on what the classifier thinks is important to highlight. For Guessoum (2016) and Malik (2018; 2019), it seems to be taking a broad classification that can absorb all the ideas in the literature with a focus on reconciliation or lack thereof. For Ghafouri-Fard and Mohammad Akrami (2011), it appears to be focusing on science and scripture. Each has its merits and difficulties. The classification adopted here takes the problems identified with both of these seriously alongside the rest of the considerations looked at earlier. Three main principles have guided the adopted classification. The first principle is to focus on common ancestry. Since the primary concern seems to be human evolution, it was decided that common ancestry should be the sole, underlying denominator for classifying the various positions. The second principle is to separate the reasons for why people accept or reject evolution from what they accept to be part of common ancestry. Since thinkers can reject or agree with evolution from various vantage points, i.e. science, metaphysics, and hermeneutics, it was thought to best separate this from the classification. It keeps it simple and easy to manage when it comes to comparing various thinkers. The third and final principle is to separate the question of reconciliation from the classification. This may seem like it's a regurgitation of the second principle. This isn't the case. Belief (or lack of it) in evolution is one thing and reconciling it with one's religion (or not) is another. Adopting this principle avoids the conflict of interpretation between the classifier and who is being classified in their own terms (exactly how this is the case will be shown shortly). Table 4.2 is the classification system adopted here in light of these considerations.

Table 4.2 Adopted classification.

\begin{tabular}{lccc}
\hline & $\begin{array}{c}\text { Are non-humans } \\
\text { products of } \\
\text { evolution? }\end{array}$ & $\begin{array}{c}\text { Are bumans } \\
\text { products of } \\
\text { evolution? }\end{array}$ & $\begin{array}{c}\text { Is Adam a } \\
\text { product of } \\
\text { evolution? }\end{array}$ \\
\hline Creationism & $\mathbf{x}$ & $\mathbf{x}$ & $\mathbf{x}$ \\
Human exceptionalism & $\checkmark$ & $\mathbf{x}$ & $\mathbf{x}$ \\
Adamic exceptionalism & $\checkmark$ & $\checkmark$ & $\mathbf{x}$ \\
No exceptions & $\checkmark$ & $\checkmark$ & $\checkmark$ \\
\hline
\end{tabular}




\section{Islamic perspectives on evolution}

What is and isn't part of common ancestry boils down to three things: non-humans, humans, and Adam. For simplicity, Eve is coupled with Adam in Adamic exceptionalism since both of them are considered to be created miraculously. If thinkers reject every entity being a part of evolutionary processes, then this is creationism. Human exceptionalism permits non-human evolution, but believes Adam (who in this position is context is considered the first human) and humanity is rejected as a product of evolution. Adamic exceptionalism is the idea that nonhumans and humans are a product of evolution, but only Adam is an exception to that process (which then entails that Adam is not considered to the be the first human). Finally, the no exceptions stance is the position that there are, as the name suggests, no exemptions from the process. So non-humans, humans, and Adam are all products of evolutionary processes. In the next section, we shall see how various thinkers fit in this scheme.

\section{The Muslim spectrum}

With the increasing development of Islam and evolution as an academic discourse, many opinions (distinctive and overlapping) are coming to the fore. One can identify opined literature on the topic from scholars around the world including America, India, Pakistan, Turkey, Middle East, Malaysia, and Iran (Ziadat 1986; Nadvi 1998; Hanioğlu 2005; Riexinger 2009; Howard 2011; Kaya 2011; Elshakry 2013; Bigliardi 2014; Ibrahim, and Baharuddin 2014; Bilgil 2015; Determann 2015; Varisco 2018; Ibrahim et al. 2019; Qidwai 2019; Daneshgar 2020). Due to limitations of space, not all of this literature will be discussed. Three principles were used to identify which opinions were to be in this chapter (and in Chapter 10, where they will be evaluated through al-Ghazāli’s hermeneutic framework). First, contemporary thinkers were given priority. Second, only thinkers who have a sufficient amount of writing to their name were reviewed (save for Zakir Naik who was the one exception, and for good reason). Some thinkers wrote very briefly about their opinions on evolution in a paragraph or a footnote. This made it very difficult to determine what exactly they were agreeing or disagreeing with (evolution in general? human evolution? deep time? mechanics?). Third, thinkers were chosen for where they showed relative uniqueness in their approach or reasoning for why they either accepted or rejected (aspects of) evolution. This is to highlight the contrasting approaches people may have towards the topic. As we shall see, sometimes people arrive at the same position but for different reasons, and may occupy different strategies for reconciliation (or not). With these considerations in mind, a total of 20 thinkers were selected, as shown in Table 4.3. There are eight thinkers in the creationism and no exceptions camp each. Human exceptionalism has three thinkers, and Adamic exceptionalism has 
Table 4.3 List of thinkers sorted by the adopted classification.

\begin{tabular}{|c|c|c|c|c|}
\hline Position & $\begin{array}{l}\text { Are non-humans } \\
\text { products of evolution? }\end{array}$ & $\begin{array}{c}\text { Are humans products } \\
\text { of evolution? }\end{array}$ & $\begin{array}{l}\text { Is Adam a product } \\
\text { of evolution? }\end{array}$ & Thinker \\
\hline Creationism & $x$ & $x$ & $x$ & $\begin{array}{l}\text { Zakir Naik (Samuel and Rozario } \\
\text { 2010; Gardner et al. 2018, 383) } \\
\text { Seyyed Hossein Nasr (2006) } \\
\text { Osman Bakar (1984) } \\
\text { Muzaffar Iqbal (2009) } \\
\text { Shaikh Mabud (1991) } \\
\text { Muhammad Sa īd Ramad̄ān Al-Būṭī } \\
\text { (2017) } \\
\text { Mohammed Shihabuddin Nadvi } \\
\text { (1998) } \\
\text { Harun Yahya (2006) }\end{array}$ \\
\hline Human exceptionalism & $\checkmark$ & $x$ & $x$ & $\begin{array}{l}\text { Nuh Ha Mim Keller (2011) } \\
\text { Yasir Qadhi and Nazir Khan (2018) }\end{array}$ \\
\hline Adamic exceptionalism & $\checkmark$ & $\checkmark$ & $x$ & David Solomon Jalajel (2009; 2018) \\
\hline No exceptions & $\checkmark$ & $\checkmark$ & $\checkmark$ & $\begin{array}{l}\text { Rana Dajani }(2011 ; 2016) \\
\text { Mohamed Iqbal }(2012) \\
\text { Nidhal Guessoum }(2008 ; 2010 ; \\
\text { 2011a) } \\
\text { Israr Ahmad }(2013) \\
\text { T.O. Shanavas }(2010) \\
\text { Basil Altaie }(2018) \\
\text { Daud Abdul-Fattah Batchelor } \\
\text { (2017) } \\
\text { Caner Taslaman (2020) }\end{array}$ \\
\hline
\end{tabular}




\section{Islamic perspectives on evolution}

one thinker. With this cleared, we can now briefly review each of the thinkers in these positions.

\section{Creationism}

Advocates in this camp believe that common ancestry is entirely untrue. There are various reasons why people believe this to be the case, some of which were mentioned in Chapter 1. A single thinker sometimes provides multiples reasons for rejecting evolution, while others only give one or two. For the sake of brevity, as we review the various thinkers, criticisms raised against the theory of evolution by one thinker will not be repeated unless to show a common theme that can be found amongst some of them.

To start with, some people reject evolution simply because they believe it's "just a theory." Zakir Naik, a globally famous Muslim preacher, is wellknown for stating this point several times. He assumes that the colloquial understanding of the term "theory" means the same thing as the scientific one (Samuel and Rozario 2010; Gardner et al. 2018, 383). To be clear, this might be because he thinks evolution isn't compatible with Islamic scripture. So while the argument that is being presented is that evolution is "just a theory," i.e. evolution is not robust or simply a hypothesis simply on its own merits, there may be an underlying religious reason for rejecting it. The others that come under the creationist camp either follow Naik in his approach or eliminate evolution as a valid scientific theory because it contains many scientific problems. These charges are generally similar to those posed by American creationists which were reviewed in Chapter 2. For the sake of brevity, these will not be repeated here.

Others reject evolution because they find the science itself to be untenable. Seyyed Hossein Nasr (2006), an Iranian-American physicist-turnedreligious scholar, and Osman Bakar (1984), a Malaysian religious scholar who was under the tutelage of Nasr, criticise the components related to the science of evolution such as the chance-like mechanism embedded in the process; there being holes in the theory; the constant revisions that the theory has gone through historically, which further suggests that it is a theory in crisis; and the problems associated with the science of the origins of life. Uniquely, however, Nasr (2006) and Bakar (1984) also criticise evolution on metaphysical grounds. Both adopt a Neoplatonic worldview within which essences are fixed. Accordingly, essences can't change. Nasr $(2006,183)$ gives the example of the triangle which he then compares to life forms:

A triangle is a triangle, and nothing evolves into a triangle; until a triangle becomes a triangle, it is not a triangle. So if we have three loose lines that gradually meet, even if there is one micron of separation, that is not a triangle. Only a triangle is a triangle. And life forms also have a finality of their own. 
Elsewhere, Bakar (1984) elucidates Nasr's paradigm:

A species is an 'idea' in the Divine Mind with all its possibilities. It is not an individual reality but an archetype, and as such it lies beyond limitations and beyond change. It is first manifested as individuals belonging to it in the subtle state where each individual reality is constituted by the conjunction of a 'form' and a subtle 'proto-matter,' this 'form' referring to the association of qualities of the species which is therefore the trace of its immutable essence. This means that different types of animals, for example, pre-existed at the level immediately above the corporeal world as non-spatial forms but clothed with a certain 'matter' which is of the subtle world. These forms 'descended' into the material world, wherever the latter was ready to receive them, and this 'descent' had the nature of a sudden coagulation and hence also the nature of a limitation or fragmentation of the original subtle form. Thus species appear on the plane of physical reality by successive 'manifestations' or 'materialisations' starting from the subtle state. This then is the 'vertical' genesis of species of traditional metaphysics as opposed to the 'horizontal' genesis of species from a single cell of modern biology.

Accordingly, Nasr and Bakar deem that everything has fixed archetypes, which lends them to believe that evolution isn't possible. To be clear, their perspective doesn't deny microevolution but only macroevolution (Nasr 2006, 184-185):

There is the possibility of micro-evolution, but not of macro-evolution. Now micro-evolution is still within the possibilities of the archetype or form of a particular being in the philosophical sense in the same way that you and I are human beings, and the Chinese and the Japanese are also human beings. Our eyes are one way; their eyes are another way. If we migrate to Zimbabwe, our skin grows darker; if we go to Sweden, it would grow a bit lighter. But we are all within the possibilities of the human form. That kind of micro-evolution is possible. Flies can become a bit bigger and when there is a certain kind of light, plants can do this and that, and this is mistaken by some for change of species. That is not change of species; that is 'evolution' within a single species. Each species has a width, a range, a reality greater than a particular individual in that species. And so other individuals can appear in that species with other characteristics and even change according to environmental conditions, without one species becoming another.

In addition to these criticisms, they also have philosophical problems with the theory of evolution. The primary issues they raise in this regard are the problems of naturalism and reductionism. Evolution is a materialistic theory that cuts off the hand of God from the process. It thus reduces humans 
(which are more than just material beings) solely to productions of genes and the environment. Collectively, these make evolution all the more problematic (Nasr 2006, 190-191):

Obviously human beings have a more complicated life form than the monkey, but possess also some of those characteristics we see in the monkey, but this does not mean that we have evolved from the monkey. That is the whole problem. If you function in a universe of discourse where there is nothing but the material world as claimed by modern science, then there is no choice but to explain higher life forms as the evolution of lower forms and reducible ultimately to material aggregates. But if you live in a universe in which you accept the unique creative power of God ...then it is easy to accept that Divine creative power can create something including living forms, can bestow life, and can also endow human beings with the spirit.

However, despite these various criticisms, evolution is problematic primarily because of the Neoplatonic paradigm that Nasr and Bakar have adopted (Bagir 2005, 49). So no matter how much scientific impetus the theory may have, and even if the scientific criticisms they have levied against evolution could be surmounted, it seems their worldview simply doesn't allow any kind of transformation of species. ${ }^{7}$

Muzaffar Iqbal (2008; 2009), a chemist-turned-theologian, relays the same concerns as Nasr and Bakar. ${ }^{8}$ However, Iqbal (2003) also emphasises the notion of design that is prevalent in the Islamic tradition, which seems to go against the notion of chance as propounded by the theory of evolution:

One of the main characteristics of various theories of evolution is their reliance on 'Chance' as means of evolution rather than a 'Design.' For if it could be proved that there exists no design in the emergence of species (or individual organs) and that each species and organ becomes perfect through gradation, as Darwin proposed, then one can eliminate not only the Design, but also the Designer. However, if on the contrary, it can be shown that there exists no possibility of chance evolution of perfect organs and species, because of their complexity, and then Darwin's theory will break down.

Argument against Design often marshals so-called facts from the natural world in its support with the underlying assumptions that these have been recently discovered. But in piling these mounds of 'facts,' it is often overlooked that no amount of hair-splitting can make hair anything but hair. To be sure, what we know today about the physical world far exceeds than what was known eight hundred years ago, but most of it is in a quantitative sense. Medieval scientists were not innocent of these facts that are often claimed to have been discovered yesterday. Just one source, our Kitāb al-Dalä'il, accumulates hundreds of 
details from plant biology, zoology, human physiology, and psychology in support of its argument from Design ... One can continue to quote examples of teleological arguments from this tradition ad infinitum. Suffice it to say that Islamic intellectual tradition was not only aware of the need for formulating the argument for Design independent of the ontological premises which were at the heart of Islamic faith but it also carried it out to its ultimate limits with increasing refinement. One.

It is then of no surprise that Iqbal (2003) quotes the works of ID advocates such as Michael Behe and William Dembski, who we briefly looked at in Chapter 2, to strengthen his case for design-like arguments based on the complexity found in nature.

He also claims that evolutionary readings of the Qur'ān have no traction. In particular, he critiques individuals who argue for a metaphorical reading of Adam's creation narrative in the Qur'ān, which we shall review shortly (Iqbal 2009, 28). He also criticises attempts to read evolution into isolated verses without considering Islamic scripture holistically (Iqbal 2009, 33-34). For instance, consider the following verse:

when He has created you stage by stage (ațwāran)? (Qur'ān 71:14)

Some have read this verse as indicating of evolution being readable in the Qur'ān. Iqbal (2009) is highly critical of any such approaches because they aren't based on holistic textual evidence and go against Muslims' widely held beliefs for the past 1,400 years. For all these reasons, he questions the validity of any theistic renditions of evolution, e.g. theistic evolution (which we encountered in Chapter 2; Iqbal 2010).

Shaikh Mabud (1991) also stresses on the hermeneutic dimension. ${ }^{9} \mathrm{He}$ takes the Qur'ān to be categorically clear that plants, animals, and humans are distinctive, non-gradual creations. As for plants, he states (1991,71):

... according to the Qur'ān all different kinds of plants, no matter how similar they are, should be taken to be all separately created, i.e. they did not evolve from one another because over the vast span of time because there is not a single verse in the Qur'ān that refers even indirectly to evolution.

He makes his case by alluding to verses in the Qur'ann which indicate the production of independent and distinctive creations, such as the following:

It was He who spread out the earth for you and traced routes in it. $\mathrm{He}$ sent down water from the sky. With that water We bring forth every kind of plant. (Qur'ān 20:53)

In the case of animals, Mabud argues similarly that there are no verses which indicate gradual creation. This is part and parcel of Mabud's 
$(1991,73)$ framework within which there needs to be a general, consistent, non-evolutionary reading of the Qur'ān:

... if we accept evolution of the animal kingdom ... we will also have to include human beings in the animal lineage. But if we do so, we will contradict the Qur'ān ... [Also] when the Qur'ān does not explicitly say that Mankind or plants have evolved, why should we accept evolution in the case of animals?

In another place, he points out another piece evidence for creationism by referring to the example of demons (jinn), which are referred in the Qur'ān as being created out of smoke (Qur'ān 55:15). On this point, he notes (Mabud 1991, 74):

Here is a clear example of a being which has been separately and distinctly created, not from any pre-existing species through evolution, but from matter through a discontinuous process. I am sure no theistic evolutionist will try to link jinn's ancestry to the amoeba.

So for Mabud, it is clear that the Qur'ann does not allude to any kind of gradual creation, and instead provides a clear creationist worldview. In this vein, he adopts the miraculous, parent-less reading of Adam's creation from which humans sprang forth.

The late Syrian Sunnī theologian, Muhammad Sa īed Ramaḍān Al-Būṭī, is also well-known for being critical of evolution. He had two broad criticisms against the theory. One is scriptural and the other is scientific (2017, 311-342). The scientific contentions parallel those that were mentioned earlier, e.g. evolution is just a theory. From the scriptural side, al-Būṭi takes Adam's creation narrative, which was reviewed in Chapter 3, as a given. He also highlights the uniqueness and nobility of humans, as highlighted in the Qur'ān:

We have honoured the children of Adam and carried them by land and sea; We have provided good sustenance for them and favoured them specially above many of those We have created. (Qur'ān 17:70)

We create man in the finest state. (Qur'ān 95:4)

Al-Būți $(2017,314)$ couples these verses with arguments such as the uniqueness of the human soul, focusing on the intellectual powers that humans possess. Furthermore, al-Būṭī $(2017,314)$ uses other verses to demonstrate that the universe and all its elements were made for the service of man:

He has subjected all that is in the heavens and the earth for your benefit, as a gift from Him. There truly are signs in this for those who reflect. (Qur’ān 45:13) 
Collectively, these suggest that humans are a superior creation through which al-Būṭi disqualifies man's origin from evolutionary processes when coupled with his negative evaluation of evolution as a scientific theory.

The late Indian theologian, Mohammed Shihabuddin Nadvi (1998, 20-22), claimed that evolution is a myth. Moreover, he asserted that evolution is part and parcel of a Jewish makeup with a hidden Zionist agenda (Nadvi 1998, 24-24):

More than scientists, the protagonists of atheism and their organisations have been active in backing up the evolution theory. Even the Marxists, Zionists and Freemasons have taken a lead role in fulfilling this task. The Jews have always been keen to root out religion and religious values. The Jews have secretly harboured ambitions to rule over the world. Their protocols bear the testimony to such long cherished dreams. Its quest has prompted them to work for uprooting of religious and ethical values and promotion of all secular atheistic beliefs, materialistic philosophies and 'isms.' They believe that its achievement should precede with striking at the moral foundations of each nation. Even a cursory glance over the world intellectual scene would reveal that Jews have dominated it during the last two centuries. Karl Marx, the founder of Marxism; Freud, who advocated sexual liberalism and Durkheim who conceived the collective materialism, rose from among the Jews. Although Darwin was not a Jew, but his theory of evolution fitted ideally into the Jewish scheme of things. Jews therefore became its chief propagators. Propagation of Darwinism and Marxism enjoyed a high priority in the Zionist agenda and was included in their protocols as obligatory. ${ }^{10}$

He also argued against allegorical interpretations of Adam (Nadvi 1998, 75-97). For him, Adam is a historical actor, and the Qur'ann makes this very clear (Nadvi 1998, 107-116). To say otherwise has consequences, which includes rendering other prophets in Islam to be mythical realities. Consider the following verses in which Adam is mentioned alongside Noah, Abraham, and Jesus:

God chose Adam, Noah, Abraham's family, and the family of Imran, over all other people. (Qur'ān 3:33)

In God's eyes Jesus is just like Adam: He created him from dust, said to him, 'Be', and he was. (Qur'ān 3:59)

Nadvi $(1998,99-106)$ points out that if Adam is interpreted as an allegory, then what is to stop interpreting the other prophets mentioned in such verses to be allegories as well. It would be arbitrary to call Adam an allegory and not the others, making for an inconsistent, ad hoc, and whimsical reading. 
Finally, Harun Yahya, which is a pen name for Adnan Oktar, is a selfmade Turkish preacher who shot to fame after publishing several wellknown books on evolution and its incompatibility with Islam with titles such as The Atlas of Creation and The Evolution Deceit (Solberg 2013).11 Out of all the thinkers presented so far, Yahya provides the largest number of compounding arguments against accepting evolution. He rejects the science altogether, claiming that every piece of evidence, be it the fossil record, molecular biology, and homology among others fails on every turn by their own merits (Yahya 2001a; Yahya 2003a; Yahya 2006a). Furthermore, he claims that evolution is inherently a naturalistic worldview which is antithetical to the Islamic perspective. He does this by tracing evolution back to the "pagan origins" of the Greek thinkers like Thales, Anaximander, Empedocles, Heraclitus, and Aristotle because they attempted to explain the origins of life in material terms (Yahya 2003b, 28-33). Furthermore, Yahya (2003b, 33-34) makes it very clear that chance-like mechanisms are fundamentally incompatible with Islam:

Looking at the matter as a devout Muslim and thinking about it in the light of the Qur'ān, a theory that is fundamentally based upon chance clearly cannot have anything common with Islam. Evolution sees chance, time, and inanimate matter as divine, and ascribes the title 'creator' to these weak and unconscious concepts. No Muslim can accept such a pagan-based theory, for each Muslim knows that Allah, the sole Creator, creating everything from nothing. Therefore, he uses science and reason to oppose all beliefs and ideas that conflict with that fact.

Adding to this point, he asserts that the theory of evolution was the brainchild of Charles Darwin, who was an atheist (Yahya 2003b, 52-54). Yahya even claims that Darwin tried concealing his faith so that his theory would not be considered an obstacle in light of his disbelief in God (Yahya 2003b, 54-56). ${ }^{12}$ This seems to be important for Yahya $(2003 \mathrm{~b}, 56)$ because he sees atheism and evolution as two sides of the same coin, such that any support for Darwin's theory equates to atheism:

In fact, atheists have supported Darwin for the last 150 years and irreligious ideologies have backed Darwinism precisely because of his atheism. Thus, given the fact of Darwin's atheism, Muslims must not make the mistake of thinking that he was religious, or at least not opposed to religion, and continue to support him, his theory, and those who think like him. If they do, they place themselves alongside atheists.

It is therefore unsurprising that Yahya relies on ID literature in some of his works. Like Iqbal, he refers to the works of Michael Behe to make his case (Yahya 2006, 98-101) Additionally, Yahya (2001b) claims that evolution is responsible for spurring the various socio-political "isms" of the past 
century or so which includes communism, fascism, capitalism, racism, and also traces the moral degradation of the world back to evolutionary thinking. Yahya (2003b, 94-121) also maintains the creationist reading of the Qur'ān and negates any attempts to find evolutionary narratives within it. To be clear, and this somewhat interesting for someone who is very critical of evolution, Yahya (2003b, 108-109) maintains God could have created life through evolutionary processes, but the data (scripture and science) simply do not yield this conclusion:

It is evident that God, the Almighty, created the whole universe and life. It is His decision whether creation should be instantaneous or by stages. We can only understand how it happened by means of the information God has given us (in other words, from the verses of the Qur'ān), and the scientific evidence apparent in nature. When we look at these two sources, we see no case for 'creation by evolution.'

This ends our review of the creationist camp. As can be seen from this very brief tour, thinkers sometimes put forward very distinctive reasons for why they reject evolution. These could be scientific, philosophical, theological, hermeneutic, and/or socio-political in nature. Some thinkers have overlapping ideas, e.g. not seeing the tenability of metaphorical readings of Adam. At other times they differ. Sometimes, even when arguing from a particular discipline, thinkers may have intradisciplinary differences or points of emphasis. Taking science as an example, some disqualify evolution as being meritless because they see it as "just a theory," e.g. Zakir Naik, while others have a collection of scientific criticisms against it, e.g. Harun Yahya.

\section{Human exceptionalism}

In Table 4.3, we noted three different thinkers who adopt human exceptionalism; Nuh Ha Mim Keller, Yasir Qadhi, and Nazir Khan. The latter two co-authored a paper in which they pen their thoughts. So we shall, in fact, be reviewing two pieces of work that argue for human exceptionalism written by three authors. Let us start with Keller.

In 1995, a biologist named Suleman Ali was stirred by a local pamphlet within which it was claimed that evolution is synonymous with shirk (associating partners with God - an idolatrous association of another entity that shares any divine status alongside God, e.g. idol-worshipping - is the highest magnitude of sin in Islamic thought) or unbelief. With this plight, he sent a fax to Keller, a Muslim theologian, asking for his understanding of Islam and evolution (Keller 2011, 350). It is in response to this query that Keller advances his critique of evolution. Keller raises several issues with evolution, but they can be broken down to three different categorical criticisms for simplicity. The first is science. Keller admits that he felt evolution was unchallengeable but changed his opinion after reading Charles Darwin's On the 


\section{Islamic perspectives on evolution}

Origins of Species. He raises two specific points in this regard. His first issue is with the falsifiability of the theory of evolution (Keller 2011, 351-352):

"The ninth chapter [of Darwin's book] ... made it clear, from what Darwin modestly calls the 'great imperfection of the geological record,' that the theory was not in principle falsifiable, though the possibility that some kind of evidence or another should be able in principle to disprove a theory is a condition (if we can believe logicians like Karl Popper) for it to be considered scientific. By its nature, fossil evidence of intermediate forms that could prove or disprove the theory remained unfound and unfindable. When I read this, it was not clear to me how such a theory could be called 'scientific.' If evolution is not scientific, then what is it? It seems to me that it is a human interpretation, an endeavor, an industry, a literature, based on what the American philosopher Charles Peirce called abductive reasoning, which functions in the following way:

1 Surprising fact A.

2 If theory B were the case, then A would naturally follow.

3 Therefore B.

Here, (1) alone is certain, (2) is merely probable (as it explains the facts, though does not preclude other possible theories), while (3) has only the same probability as (2). If you want to see how ironclad the case for the evolution of man is, make a list of all the fossils discovered so far that 'prove' the evolution of man from lower life forms, date them, and then ask yourself if abductive reasoning is not what urges it, and if it really precludes the possibility of quite a different (2) in place of the theory of evolution.

From these statements, it becomes apparent that Keller believes evolution is an all-absorbing theory which doesn't seem to have any internal falsification criteria. The reference to Karl Popper suggests that Keller has something like Sigmund Freud's and Alfred Adler's psychological theories in mind that could explain any data set because they were too broad and vague according to Popper (2002a, 43-77). These two theories - Freud and Adler's - are being mentioned because these were thinkers and ideas that Popper reviewed and contrasted with other more substantial scientific theories - like Einstein's theory of relativity - when he developed his famous falsification criterion in the demarcation of science and pseudoscience (this was discussed in Chapter 1; Popper 2002b, 57-73)..$^{13}$

The second scientific issue which Keller has with evolution is the lack of evidence for macroevolution. Rhetorically, Keller conveys his doubts (Keller 2011, 352):

Is the analogy from micro-evolution within a species (which is fairly well-attested to by breeding horses, pigeons, useful plant hybrids, and 
so on) applicable to macro-evolution, from one species to another? That is, is there a single example of one species actually evolving into another, with the intermediate forms represented in the fossil record?

In both points, it seems clear that Keller believes evolution isn't epistemically robust. For him, the theory is only probable and therefore uncertain and seems to be masked on to the data rather inferred from it.

Second, Keller raises metaphysical issues with evolution. Metaphysically, evolution could be problematic because of the underlying naturalism and the randomness that governs the process. There are two particular assertions that Keller believes leads one to go beyond the fold of Islam (Keller 2011, 359-360):

... belief in macro-evolutionary transformation and variation of non-human species does not seem to me to entail kufr (unbelief) or shirk (ascribing co-sharers to Allah) unless one also believes that such transformation came about by random mutation and natural selection, understanding these adjectives as meaning causal independence from the will of Allah. You have to look in your heart and ask yourself what you believe. From the point of view of tawhid, Islamic theism, nothing happens 'at random,' there is no 'autonomous nature,' and anyone who believes in either of these is necessarily beyond the pale of Islam.

Third, Keller believes that the creationist account found in Islamic scripture clearly contradicts human evolution. Keller acknowledges the distinction between the evolution of humans and the evolution of every other species. ${ }^{14} \mathrm{He}$ makes two points in this regard. His first point is that Adam was created in heaven and therefore not on earth (Keller 2011, 355):

Regarding ... whether the Qur'ānic account of creation is incompatible with man having evolved; if evolution entails, as Darwin believed, that 'probably all the organic beings which have ever lived on this earth have descended from one primordial form, into which life was first breathed'... I apprehend that this is incompatible with the Qur'ānic account of creation. Our first ancestor was the prophet Adam (upon whom be peace), who was created by Allah in janna, or paradise, ${ }^{15}$ and not on earth ...

His second point is that the process of creation is also of special significance which marks an important distinction between Adam (and humans by extension) and the rest of the biological world (Keller 2011, 355):

... but [Adam was] also created in a particular way that He describes to us: 


\section{Islamic perspectives on evolution}

When your Lord said to the angels: 'Verily, I am to create a man from clay; So when I have formed him well, and blown into him a-kindling of My spirit, fall you down to him prostrate.' So all the angels bowed down to him as one; Except Satan: he waxed proud, and was of the utter disbelievers. He said, 'O Satan, what prevented you from bowing down to what I created with My own hands; Were you too haughty Or too exalted?' He replied, 'I am better than he: You created me of fire, and created him of clay' (Qur’ān 38:71-76).

Now, the God of Islam is transcendently above any suggestion of anthropomorphism, and Qur'ānic exegetes like Fakhr al-Dīn al-Rāzī explain the above words created with My own [lit. 'two'] hands as a figurative expression of Allah's special concern for this particular creation, the first human, since a sovereign of immense majesty does not undertake any work 'with his own hands' unless it is of the greatest importance ... I say 'the first human,' because the Arabic term bashar used in the verse 'Verily, I am to create a man from clay' means precisely a human being and has no other lexical acceptation.

Thus, he concludes (Keller 2011, 356):

All of which shows that, according to the Qur'ān, human beings are intrinsically - by their celestial provenance in paradise, by their specially created nature, and by the $r \bar{u} h$ or soul within them - at a quite different level in Allah's eyes than other terrestrial life, whether or not their bodies have certain physiological affinities with it, which are the prerogative of their Maker to create.

In short, Keller seems to be very clear that non-humans could have been created through the process of evolution, even though he has his reservations about the science; but humans are categorically excluded from the process. This ends our review of Keller's thoughts on evolution.

Qadhi ${ }^{16}$ and Khan co-authored a paper for Yaqeen Institute ${ }^{17}$ in which they spell out their take on Islam and evolution. ${ }^{18}$ While there is much that overlaps with Keller, there is also much that differs, which is why we need to unpack their ideas carefully. At the very beginning of the article, Qadhi and Khan summarise the situation at hand. They divide the current participants of the discourse into two categories. The first category refers to individuals who have completely abandoned anything that traditional Islamic scholarship has to offer on the subject (Qadhi and Khan 2018, 4):

One group has attempted to jettison all traditional theological commitments in favor of a wholesale embrace of the conclusions of evolutionists. 
Through radical hermeneutical gymnastics, they have claimed to unearth specific Qur'ānic passages that allegedly discuss natural selection, abiogenesis, and other similar concepts. Not only does this compromise the truth-value of a scripture such that it becomes infinitely malleable to mean whatever one desires but it is also worth noting that history has not looked kindly upon such attempts in the past.

Apparent from this paragraph is that Qadhi and Khan deem all approaches of reading evolution into scripture problematic. In their opinion, it seems to be an imposition of the reader onto Islamic texts rather than letting scripture speak for itself. Interestingly, at no point do they mention anyone by name, but, presumably, have candidates in mind who come under the no exceptions camp, which we will review shortly.

Qadhi and Khan also highlight the opposing extreme position which entails rejecting anything science has to offer on biological diversity (Qadhi and Khan 2018, 5):

On the other extreme are those Muslim creationists who reject all evolutionary science as falsehood, attempting to dispute every piece of data in genetics, population dynamics, and paleontology. This position is not only unreasonable in that it requires Muslims to believe that the entire scientific community is participating in a massive conspiracy, but it is also theologically unrequired since there is nothing in Islamic scripture to necessitate such a stance. Moreover, it burdens the average lay Muslim with abstruse matters of empirical research, telling him or her that the only way to be a committed Muslim is by undertaking the task of challenging an entire community of scientific experts on the very subject matter of their expertise. It also places many Muslim scientists in a position of supposed tension between their religious beliefs and their scientific research.

Here Qadhi and Khan make their concerns apparent. They want the Muslim community not to be tempted by conspiracy narratives and be fettered to a position that challenges the entire scientific community. Their motivation seems to be squarely in preserving Muslim believers' faith against any apparent conflicts between science and religion. However, their article makes it apparent that this does not entail a total acceptance of what science has to say on theological matters.

With the extremes made explicit, Qadhi and Khan then make it very clear that a balanced approach is direly needed, which is presumably the gap their article seeks to fill (Qadhi and Khan 2018, 5):

What has been sorely needed, and thus far missing, is a critical evaluation and academic engagement that attempts to integrate scripture 
and science. Such an approach would entail acknowledging the credibility of the scientific research, while criticising pseudoscientific excesses in the public domain. It would also entail a deeper reflection on the precise theological conclusions that can be derived from Islamic scripture on humanity's origins and status vis-a-vis other creatures.

After summarising the landscape, Qadhi and Khan then discuss three different hermeneutic approaches that can be found in the classical Islamic tradition. These include the hermeneutic frameworks of Avicenna, alGhazālī, and Ibn Taymiyya.

Qadhi and Khan begin by discussing Avicenna, who represents the philosophical tradition (Neoplatonic-Aristotelian) in Islamic intellectual history. For them, Avicenna's approach represents a Pandora's box in hermeneutics. Avicenna claimed that prophetic language is an expression of philosophical truths in (largely) symbolic terms which is comprehensible for the masses. ${ }^{19}$ Entities like heaven and hell, which Muslims regard as true and real, should be taken as symbols for realities beyond imagination $($ takhy $\bar{l} l)$. Moreover, if ever philosophical truths (which include scientific information) conflict with Islamic texts, they should be interpreted allegorically (Qadhi and Khan 2018, 8-9). It is why Qadhi and Khan $(2018,9)$ state: "There are no hermeneutic limits to this approach; one could extend this method to argue that prayer, fasting, and even the concept of God are mere symbols."

Qadhi and Khan then move on to al-Ghazālī, who represents the kalām tradition. Al-Ghazālī is well-known for having been critical of Avicenna on several fronts. One specific point that al-Ghazālī criticises Avicenna on is his allegorical interpretations of miracle stories in the Qur'ān. Al-Ghazālī is completely supportive in the use of reason in situations of apparent conflicts since it is reason itself that allows one to establish the veracity of the Qur'ān (this will be expanded on in Chapter 9). As for how one should go about reading scripture, his framework involves taking Islamic scripture at face value unless and otherwise there is a valid logically deductive argument $(b u r h \bar{a} n)$ that requires a non-literal interpretation $\left(t a^{3} w \bar{l} l\right)$ (we shall see this in detail in Chapter 9; Qadhi and Khan 2018, 9). Taking the Qur'ānic verses mentioning God's hands as an example, al-Ghazāli would claim that such references cannot be literally referring to a hand since God is atemporal and non-spatial. It would be illogical to say God literally has hands. But entities that Avicenna believed were symbolic, e.g. heaven and hell, are taken at face value because there is no reason to reject them. Qadhi and Khan don't seem to criticise al-Ghazāli on any point, which suggests they do not have issues with this approach.

Finally, Qadhi and Khan move on to their preferred scholar, Ibn Taymiyya. In his framework, neither the methods of takbyīl nor $t a^{\prime} w \bar{l} l$ is necessary. In moments of conflict, Ibn Taymiyya opts for giving revelation 
preference. Like al-Ghazālī, they point out that Ibn Taymiyya agrees that reason establishes revelation, but after that one should submit to what "scripture states unconditionally and without challenging it on the basis of fallible and fundamentally limited human reasoning" (Qadhi and Khan $2018,10)$. Revelation is also externally corroborated by the fitra (primordial nature) rather than philosophical arguments, which is a famous and distinctive position in the Taymiyyan framework. ${ }^{20}$ So revelation is ontologically heavier than reason in the Taymiyyan paradigm. Qadhi and Khan also point out that the bipartite division between rationality and revelation is non-existent in the Taymiyyan paradigm since reason is intrinsic to religion. This is a major point of difference between Ibn Taymiyya, and Avicenna, and al-Ghazālī. Hence, “... what is relevant is the definitive (qat $\bar{\imath}$ ) nature of a proof, regardless of whether it is scriptural or rational. When it comes to textual evidence which is explicit and unequivocal, there can be no recourse to reinterpretation" (Qadhi and Khan 2018, 10). In cases of ambiguity, which may have multiple meanings, then one can adopt any reading as long as it falls under the linguistic constraints of language, reason, and science. However, Qadhi and Khan $(2018,10)$ make it clear that "this is not a case of figurative interpretation, but rather selecting one of a variety of established lexical meanings of a word based on definitive proofs." As a case in point, they give the example of the mention of sittati ayyām in the Qur'ān (7:54), which is usually translated as six days. However, the word ayyam is ambiguous and can refer to any span of time, as was discussed in Chapter 3. So one could validly interpret this as six 24-hour days or six spans of time (Qadhi and Khan 2018, 11).

The implications of the different perspectives are significant for Qadhi and $\operatorname{Khan}(2018,11)$ :

In the case of the story of human origins, we have such an explicit narrative, one that is deeply rooted in countless passages throughout the entire Qur'ann and numerous prophetic statements, that there is no choice other than to accept that this is what Allah intended for us to believe. The sheer quantity and diversity of nouns, adjectives, and verbs used simply makes any linguistic reinterpretation (or $\left.t a^{3} w \bar{l} l\right)$ implausible. Meanwhile, attempts to describe the entire account as symbolic or allegorical (takhyīl) may be tempting for some contemporary Muslim scientists, but it leads to logically incoherent theological ramifications and contradicts the Qur'ān's own emphasis that these accounts are literally true narratives (3:62). Developing an epistemologically sound foundation upon which both scriptural and scientific truths work in concert is a far more fruitful endeavour.

In this passage, Qadhi and Khan explicitly state that neither $t a^{3} w \bar{l} l$ nor takhyīl can help with evolutionary readings of the Qur'ān as they would be 


\section{Islamic perspectives on evolution}

internally consistent. It is important to note here that it is not the individuals (Avicenna and al-Ghazālī) as such that are being criticised by Qadhi and Khan, but specifically, their approaches that could be instrumentalised for evolutionary readings.

For Qadhi and Khan, the creation narrative, as outlined in Chapter 3, is a given. Collectively these scriptural indications make it very difficult to allow for any kind of parental agency for Adam. However, this doesn't entail a wholesale rejection of evolution. While the evolution of Adam and his descendants are out of the question, they make it very clear that Muslims can accept an array of other things that are part and parcel of evolution (Qadhi and Khan 2018, 12):

... there is nothing in Islamic scripture that explicitly negates the concepts of abiogenesis, genetic mutation and diversification, natural selection, the existence of hominid species, or a common ancestor for all biological life on earth, excluding only the descendants of Adam.

Since scripture makes it difficult to argue against Adam's miraculous creation, it seems that Qadhi and Khan adopt human exceptionalism similarly to Keller. However, unlike Keller, they do not deny the possibility of an alignment between Islam and human evolution, and it is here where Qadhi and Khan mark their novelty.

Key to Qadhi and Khan's position is philosophical deliberations over scientific realism, a critical discussion in philosophy of science about what our scientific equations and theories posit, and how much we can believe in them. But to see why this is the case, we first need to understand an important distinction they make between direct and indirect observations. From their perspective, any propositions that are predicated on direct observations are empirically adequate and therefore the same as truth. However, indirect observations are bound by various "interpretations, inferences, models, extrapolations, and postulations" that aim to be empirically adequate (Qadhi and Khan 2018, 15). So the latter has lesser epistemic weight, and it seems no matter which position one adopts on the scientific realism spectrum, it cannot be the same as direct observation. It is why they say: "... what we can affirm as truth when it comes to the unobservable is considerably limited" (Qadhi and Khan 2018, 15). It is this specific juncture of unobservable entities in science that invigorate the discussion of scientific realism, which is relevant for our conversation. To what extent can we confer existence or justify our belief in the existence of entities posited by science that have not been observed? There are a variety of positions on this matter which form a spectrum. At one end of this spectrum is scientific realism, which suggests a strong commitment to what scientific theories and equations posit even though they have never been empirically realised. On the opposite side of the spectrum, there are variations 
of antirealism. One example is instrumentalism which sees science as mere instruments that cater to functionality but aren't necessarily truthdepicting. So long as “it works" it's fine, but it doesn't obtain some grand understanding of nature as such (Chakravartty 2017). The discussion over multiverses, some of which are an artefact of string theory, could be an example that highlights these differences (Wolt 2007; Kragh 2011). Should we accept multiverses simply because they are suggestive even though there is no proof for them? Or should we treat them as mathematical artefacts? As one moves between the various positions on the matter, the discussion becomes even more challenging (Chakravartty 2017; Ladyman 2020). Does science uncover things (entity realism) or structures (structural realism)? Are these epistemic commitments or ontological ones? Realising that there is a broad spectrum of opinions on the issue, Qadhi and Khan $(2018,15)$ make it very clear that they are not advocates of any hard form of scientific realism:

When it comes to things that are directly observable, then empirical adequacy becomes the same as truth. As for matters that are unobservable, then we rely on interpretations, inferences, models, extrapolations, and postulations that aim only to be empirically adequate. Attempting to retreat from many of the unwarranted metaphysical excesses of scientific realism, there emerged a diverse set of offshoots of scientific realism including empiric structural realism (both direct and indirect), ontic structural realism, semi-realism, etc. However, a key theme acknowledged by almost all groups is that what we can affirm as truth when it comes to the unobservable is considerably limited.

With this clarified, Qadhi and Khan then move on to the theological discussion of the ghayb (matters of the unseen), e.g. entities such as heaven, hellfire, and God. Concerning the origins of human beings, they go on to say: "No human being can go back in time and determine precisely what happened at the time of Adam and Eve, and thus it constitutes something empirically unobservable, a matter of the unseen (ghayb)" (Qadhi and Khan 2018, 15). To make better sense of this statement, we need to qualify what the term ghayb means here since there are two sub-divisions one can make, as discussed by Ibn Taymiyya, which Qadhi and Khan do not mention. On the one hand, there is ghayb mutlaq (absolute unseen), which is unseen by all, like heaven and hell. Then there is ghayb muqayyad (qualified unseen), which are things that were seen by some people first hand but are knowable to others only by way of revelation (see Jalajel 2018). This includes stories of the distant past that leave no empirical evidence, like the stories of the prophets of old. For us in the modern-day and age, Adam's creation is squarely under 
the category of ghayb since we cannot know of a specific individual named Adam and his miraculous creation through human capacities alone. However, it was not ghayb for his wife and children who saw him and interacted with him. Accordingly, Adam is under the category of ghayb muqayyad.

Qadhi and Khan connect the discussion of scientific realism and the ghayb to make their case of Adam's empirical irrelevance and theological significance. Since Adam is ghayb muqayyad, Adam, by definition, cannot be known by science. Accordingly, science can neither prove nor disprove the existence of Adam (Qadhi and Khan 2018, 15-18):

In constructing theories about what took place at an unseen time hundreds of thousands of years ago, we can only make inferences based on interpretations of the data that have survived until today. We cannot design an experiment that could reach back thousands of years and directly determine what took place.

This point has also been made by David Solomon Jalajel, who we will review shortly. If this is the case, then how can there be an alignment? At this point, Qadhi's famous domino analogy comes into play, which he has mentioned several times in his video presentations (Moran 2020). The idea here is of a domino row. If you topple the first one, the rest topple sequentially. However, imagine that you have a row that's already been toppled, but then someone adds a toppled domino at the very end of the row. A third person who looks at the toppled row would not be able to guess that the final domino tablet was not a part of the sequential toppling of the entire row. Similarly, Qadhi and Khan argue it is possible that as evolution was progressing, at the time where there was an expectation of humans to emerge, arrive or evolve on the scene, Adam miraculously appeared, as seen in Figure 4.1. This is completely plausible from a theological perspective and unfalsifiable from a scientific perspective (Qadhi and Khan 2018, 12):

... one can certainly imagine a scenario wherein hominid species were gradually evolving on earth, and right at the point when evolutionists would predict the emergence of modern humans, God miraculously inserted the children of Adam. Let us suppose that these 'Adamic species' are biologically, anatomically, physiologically, and genetically indistinguishable from the would-be species one would have predicted to have emerged based on the preceding population of species in evolutionary history. They appear to occupy the exact same position on the phylogenetic tree. The occurrence of such a scenario is theologically plausible and would be impossible to disprove empirically since it is a metaphysical assertion. 

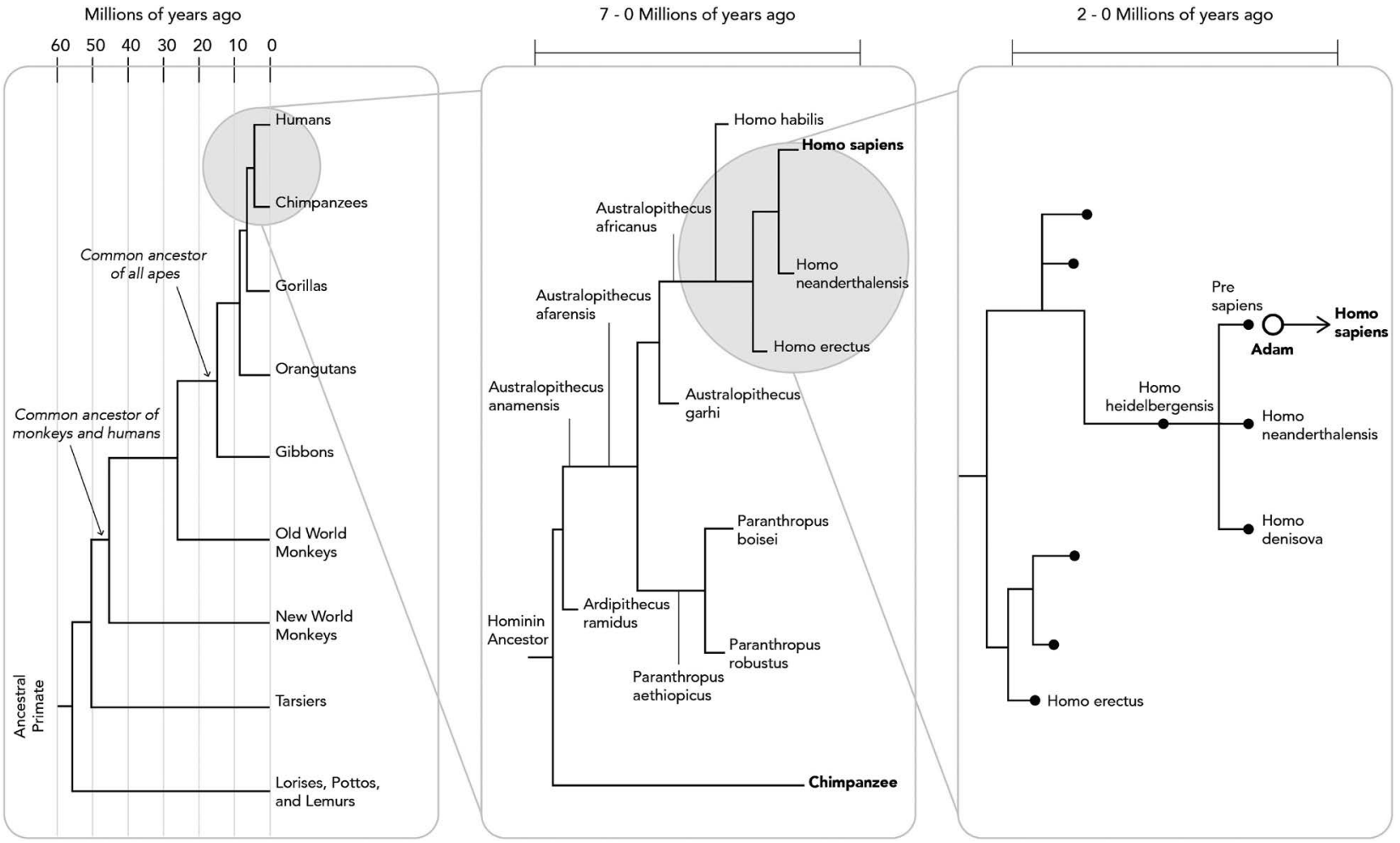

Figure 4.1 This image is showing human exceptionalism as argued by Yasir Qadhi and Nazir Khan. It shows the branching process of hominins, which lead up to human beings. However, there is no connecting lineage between preceding species and Homo sapiens. It shows Adam appearing into existence from which the Homo sapien line starts and continues. 


\section{Islamic perspectives on evolution}

In this narrative, Adam was created with the right biology at the right time, making it seem like Adam was a seamless part of the evolutionary process.

However, it could be asked if this is a form of divine deception. They foresee this question and provide two lines of responses. First, they contend that if this is a bone of contention then this is no longer the territory of science, i.e. it is no longer a scientific contention. Rather, it becomes a theological issue which isn't the domain of scientists. However, this response of theirs doesn't seem to be directed to scientists as such but more so to a category of people they refer to as "anti-religionists" (Qadhi and Khan 2018, 13):

An opponent of religion might object that it is deceptive for God to create human beings to resemble other biological organisms in a manner compatible with evolution. But this is a bizarre objection for an anti-religionist, since it represents a weak theological objection (regarding what God would or would not do) rather than a scientific objection.

Given this statement, it makes sense to understand this term as a reference to certain atheists who have issues with religion and see evolution as a defeater for it, e.g. Richard Dawkins and Daniel Dennett. Since they do not believe in God, why are they dabbling in theology and determining what God can and cannot do to begin with?

Their second contention deals with the objection head-on. By their lights, Qadhi and Khan see nothing problematic with God informing humanity through revelation about the miraculous starting point of humanity even though it might not be determinable from science; both are valid sources of knowledge which can complement each other. As seen from the previous discussion on scientific realism and ghayb, human capacities cannot necessarily determine some ideas that are part of the unseen unless informed by revelation. So revelation contains determinations which God gives to humans that they cannot arrive at on their own, which is why "from a theological standpoint, there is nothing deceptive whatsoever about God informing us through scripture of our heavenly origin while reminding us biologically of our terrestrial sojourn" (Qadhi and Khan 2018, 13).

Consider the discussion of miracle stories mentioned in the Qur'ān which contemporary science may never accept: the change of Moses' wooden staff into a snake, Abraham being thrown in the fire and surviving, Muhammad splitting the moon, etc. Or consider entities such as angels, demons, heaven, and hell, which are not necessary or generally understood to be part of the spatiotemporal world, and therefore outside the scope of science, but which has been part and parcel of the Islamic creed. Within the framework of science, these things are deemed to be indeterminable if not impossible to 
know. If so, these events and entities that most Muslims deem to be real and true, as stated by Qadhi and Khan, can never be conceived through science. So revelation can help with the blind spots of science (Yazicioglu 2013). This point feeds into their discussion of scientific realism.

In short, Qadhi and Khan's position preserves the generally understood narrative of Adam the Qur'ān and stops the natural sciences from overstepping their disciplinary boundaries. So while they adopt human exceptionalism like Keller, they deny this entails a rejection of evolution. This is a clear example of the third principle used for adopting the classification discussed earlier. Thinkers can reject the entirety or aspects of evolution but can still develop reconciliatory scenarios. ${ }^{21}$

\section{Adamic exceptionalism}

David Solomon Jalajel is the only one who argues for what is coined as Adamic exceptionalism. His proposal requires careful elucidation. As mentioned before, Malik $(2018 ; 2019)$ and Guessoum $(2011 b ; 2016)$ seem to think he should be in the creationist camp, but Jalajel suggests that a Muslim can perfectly believe in the compatibility of Islam and evolution. That said, Malik (2020) has recently retracted his earlier evaluation of Jalajel's proposal.

Jalajel makes it very clear that he is advancing a proposal extrapolated from the methodology of the Sunni theological schools of Islam. These include Ash'arism, Māturīdism, and Atharism (Jalajel 2009, 3-8). ${ }^{22}$ If these schools are taken as the prism through which the discussion is viewed, Jalajel argues we can arrive at an opinion that doesn't warrant such a harsh and frankly unnecessary rejection of evolution. But what about Adam? Jalajel determines that the Sunnī hermeneutical methods he is examining cannot provide a reading of scripture where Adam has parents. In other words, Adam is a miraculous creation and was born without any parental agency. This is an uncontroversial position in Sunnī schools because such Muslims believe that miracles are possible. God can do whatever He pleases. But if Adam is born without a father and a mother, how can this be reconciled with evolution? It is at this juncture that Jalajel utilises the principle of tawaqquf, which is his novel contribution.

The term tawaqquf needs unpacking. Generally, this means the suspension of belief. For example, when an individual is stuck on a question with multiple answers that are all plausible, and he or she doesn't decide to answer due to uncertainty, then that individual is doing tawaqquf. When it comes to Islamic scripture, however, it should be made clear that the term tawaqquf has two usages, one in the field of Islamic law and hadīth criticism, and the other in theology, i.e. matters of faith.

The first usage, i.e. in Islamic law and hadīth criticism, is to refrain from making a judgement due to being unable to resolve conflicting evidence. It is a form of vacillating. It is temporary while waiting for evidence or an 


\section{Islamic perspectives on evolution}

argument that will tip the scales in favour of one possibility or another (Farahat 2019, 177). An example of this is when we have two conflicting hadīths. A particular hadīth scholar may not know how to do it, so he or she reserves judgement. But this doesn't eliminate the possibility of another scholar coming along and being able to reconcile the two. So in this type of tawaqquf, a solution is determinable, but the judgement is postponed for another individual or later time.

This should be contrasted with theological tawaqquf, which is an obligatory, permanent epistemological stance of declaring a matter unknowable, e.g. when the scriptures are totally silent about something (Ghamdi 2016, 32). For instance, consider the case of dinosaurs. Islamic scripture makes no claim either for or against dinosaurs, so one cannot argue a case for or against dinosaurs on behalf of scripture since it is silent on this matter. Thus, arguing for or against dinosaurs through or by scripture is prohibited and sinful (harām) because one is claiming something on behalf of God which He himself hasn't said. To make the implications of this matter clearer, it is prohibited and sinful to say Islam denies dinosaurs. It is also prohibited and sinful to say belief in dinosaurs is mandatory in Islam. Both are unwarranted scripturally. Dinosaurs are just one example, but one can think of several variations, e.g. animals having souls and demons' fate in the eschaton. Since there is no defining answer, as we have nothing to go by, whether one accepts dinosaurs or doesn't accept dinosaurs, or suspends making any judgement on the matter, it makes no theological difference. Subsequently, all are valid possibilities since they are all compatible with Islamic scripture. The take-home message with theological tawaqquf is that a Muslim cannot affirm nor negate such things using scripture because scripture itself isn't saying anything. If so, all options are possible to take up since all are compatible with Islamic scripture. It is this particular understanding of tawaqquf that Jalajel uses to make his case for there being no conflict between Islam and evolution.

Theological tawaqquf should also be contrasted with the deferment of interpretation (tafwīd al-maina $)$. This is used where a text's apparent meaning is problematic for one reason or another and needs to be re-interpreted to arrive at a non-problematic meaning. The interpreter can decide to suggest a plausible interpretation $\left(t a^{3} w \bar{l} l\right)$ that removes the difficulty. Otherwise, the interpreter can defer the interpretation of the text's meaning to God while negating the text's apparent meaning and affirming belief in the text on whatever meaning God intended. This is a stance for interpreting a problematic text that one is faced with. Theological tawaqquf (hereon simply referred to as tawaqquf), by contrast, is to refrain from having any opinion due to the complete absence of textual evidence on that topic. We will return to these points in Chapters 9 and 10.

With these ideas in place, we can now understand how Jalajel advances his novel proposal. Most Muslims assume that Adam is the first human being. So the origin of humanity is generally thought to have started with 
Adam. Keller (2011), and Qadhi and Khan (2018) are examples of proponents of this opinion who we looked at earlier. They are human exceptionalists precisely because they believe Adam was the first human being and was born miraculously, and therefore humans cannot be a product of evolution. Jalajel (2018) uniquely divorces the connection between the creation of Adam with the start of humanity. ${ }^{23}$ In this narrative, when Adam descended to earth from heaven (as opined by most scholars), the Qur'ān doesn't affirm nor negate the idea of there being already-existing humans on earth. In other words, the Qur'ān is silent on there being humans on earth before Adam's descent. If this is the case, we have to adopt theological tawaqquf on this issue. This entails that there is equally the possibility of there being humans before Adam's descent and there not being humans before Adam's descent. Both are valid possibilities since Islamic scripture is silent on the matter. If we go by this argument, then there is a plausible scenario of Adam descending to earth and there being humans on earth who were created through the process of evolution. Adam's descendants might or might not have (again, tawaqquf) mingled with these other humans leading to established lineages right up to our time, with the former possibility allowing for all people thereafter to share in common descent with all life on Earth as well as a lineage going back to Adam. The point here is that Adam is a miracle beyond doubt because of scripture. But scripture doesn't deny the possibility of co-existing humans at the moment of Adam's descent who could be a product of evolution. So it would be incorrect to call Jalajel's account creationism because he accepts non-human evolution. It would also be incorrect to call his position human exceptionalism since he believes in the possibility of all humans today having a lineage that predates Adam all the way back to the origin of life. But it would be incorrect to put this position in the no exceptions camp because Adam is an exception to common ancestry due to his miraculous creation. It is for this reason that Adamic exceptionalism is a suitable term. The various possibilities under this position have been illustrated in Figure 4.2.24

In short, for Jalajel, Adam is not a point of scientific enquiry, but one of faith. This is not just because Adam is a miraculous entity, but, more importantly, because he is a single individual from pre-history revealed to us by scripture. As such, his existence cannot be established by science. Consequently, he does not have to impact the scientific claims of evolutionary theory. Adam's miraculous creation has no explanatory relevance to human origins from a scientific vantage point, nor does it negate the possibility of common descent for human beings since tawaqquf must be exercised regarding the marriage practices of Adam's earliest descendants, which the scriptures are silent about. Accordingly, he asserts that Muslims are free to accept or reject human evolution on its scientific merits without reference to the story of Adam (Jalajel 2009, 157-153; Jalajel 2018). ${ }^{25}$ 

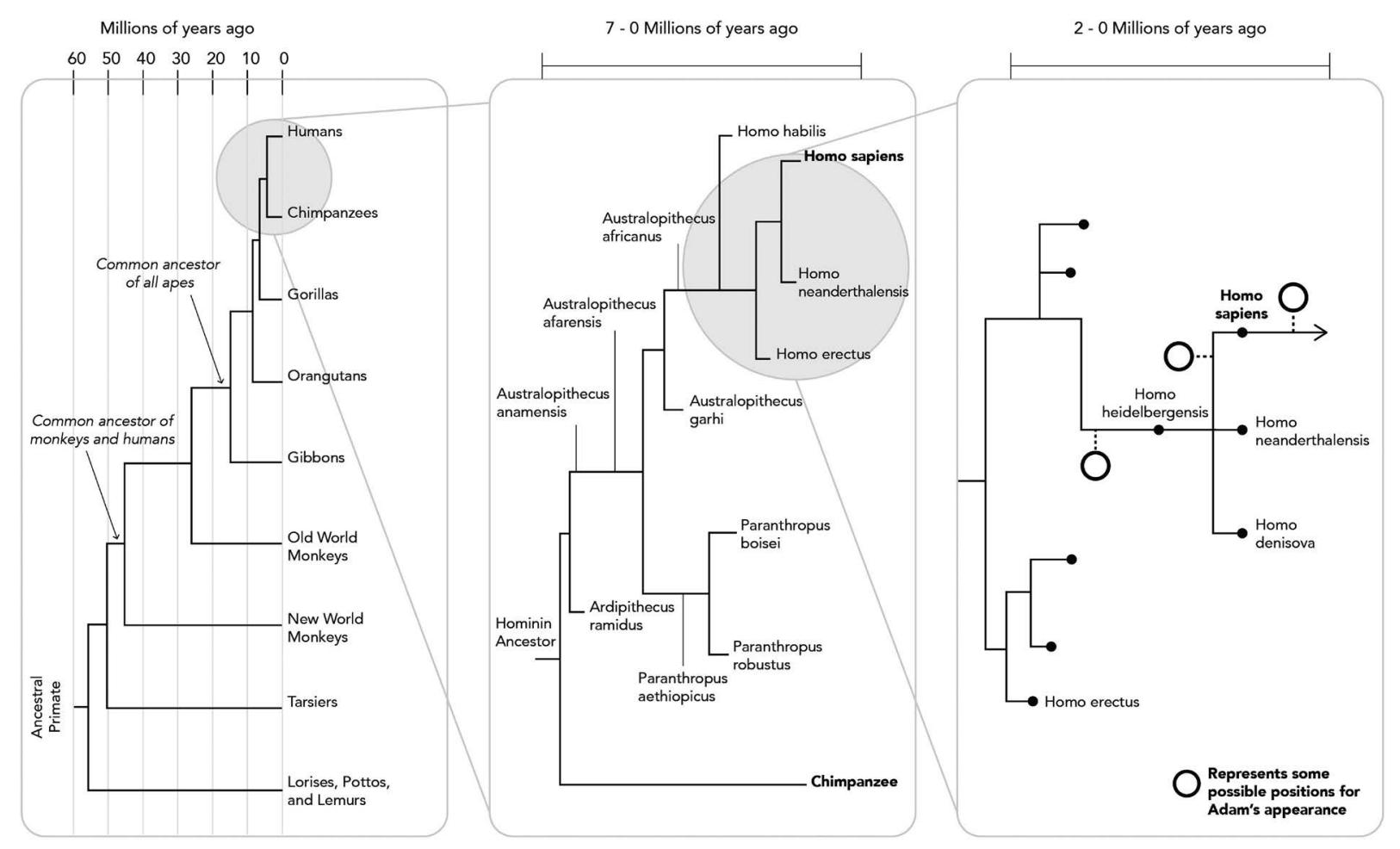

Figure 4.2 This image is showing Adamic exceptionalism as argued by David Solomon Jalajel. It shows the branching process of hominins which lead up to human beings. In this scenario, humans do have a connecting linkage to human ancestors. It shows Adam appearing into existence at multiple possibilities between Homo heidelbergensis and Homo sapiens, illustrating that only Adam was a miracle creation. ${ }^{26}$ 


\section{No exceptions}

Proponents in this camp assert that there are no exceptions to the process of evolution. Non-humans, humans, and Adam (at least for those who presume he existed) are part and parcel of common ancestry. Accordingly, this group takes the science for granted, which completely contrasts with the creationists camp, but then faces the challenge of making this case given the creation narrative outlined in Chapter 3.

Some individuals go straight for a metaphorical track. Rana Dajani, a molecular biologist, is one advocate of this strategy. She rests her case on two principles. First, she clearly says that the Qur'ān is not a book of science. Instead, she writes, "it is a guide how to live our lives. Therefore, we don't look into it for evidence for every scientific discovery" (Dajani 2016, 146). Second, she stresses on human limitations. Since interpretation is a human activity, and humans are bound by time and space, one must be careful not to be too strict in holding on to their interpretation. As time progresses and more scientific knowledge is accumulated, it may bring fresh insights to understanding scripture. She emphasises the role of ijtiha $\bar{d}$ (scholarly attempt to arrive at an educated opinion), and quotes the following hadīth of the prophet to make the point that making mistakes is fine (Dajani 2012, 346; Dajani 2016, 146): “When a judge gives judgment and strives to know a ruling (ijtiha $\bar{a}$ ) and is correct, he has two rewards. If he gives judgment and strives to know a ruling, but is wrong, he has one reward" (Bukhārī 7352). From these two premises, she concludes that (Dajani 2016, 146):

The story of Adam in the Qur'ān as well as other stories should not be taken literary $[s i c]$. They are metaphors to learn lessons. The process of human evolution was gradual and concerned groups of humans who evolved from former ancestors.

In supporting her case, she makes two other points on how certain words in the Qur'ān are misunderstood, which causes unnecessary tension between evolution and Islam, but, if corrected, it can be used to provide possible space for evolutionary readings. The first comment is related to the word khalaqa (create) (Dajani 2016, 145-146):

... the word create does not necessarily mean spontaneous it could be interpreted as over a period of time. Muslims don't have a problem with the sun and stars taking billions of years to be created but they do have an issue with living things or specifically humans taking millions of years to be created ... Time is a dimension and Allah is above all dimensions. Hence, Allah is not governed by time. Therefore, Muslims should not have any problem with creation taking a long time. 


\section{Islamic perspectives on evolution}

In effect, she says that the word "khalaqa" is broad in its meaning and could encompass instantaneous creation or a long evolutionary process. If the latter, then it is no problem for God because He is outside of time anyways. Indeed, the word "khalaqa" does occupy different modalities in Islamic scripture. ${ }^{27}$

The second issue Dajani deals with is how to understand the word "ahsan." She refers to two verses which, if understood correctly, can support evolution. Quoting the verses directly from her, these are (Dajani 2012, 349):

He Who has made everything which He has created (ahsan) most good: He began the creation of man with (nothing more than) clay (Qur'ān 32:7)

We have indeed created man in the (ahsan) best of moulds (Qur'ān 95:4)

She gives her interpretation to illustrate how they've been wrongly understood (Dajani 2012, 349):

In these two verses, Allah states that he created all creatures and man in the (ahsan) way. He uses the word absan, meaning 'most fit,' not the word (afdal), which means 'the best.' Although, as can be seen from the translation, the word (ahsan) has been translated as 'most good' in the first verse and as 'the best' in the second verse. Both translations hold a totally different meaning in this context. In the Sajdeh [first quoted] verse, Allah states that he created all organisms to be the best fit and even man was created from mud, which is the origin of all creatures. In the [second quoted] verse in Al teen, Allah states that man was created to be fit for his environment. To me, this supports evolution and is an example of misinterpretation of the meaning of words in religious texts for lack of the scientific knowledge on the issue by the interpreters.

Another advocate who follows a similar strategy is the famous Pakistani poet and philosopher, Muhammad Iqbal. He takes his cues from other civilisations as a point of reference where instead of reading the fall as a literal event, he reads it symbolically (Iqbal 2012, 65):

But the clue to a better understanding of our difficulty is given in the legend relating to what is called the Fall of Man. In this legend the Qur'ān partly retains the ancient symbols, but the legend is materially transformed with a view to put an entirely fresh meaning into it. The Qur'ānic method of complete or partial transformation of legends in order to besoul them with new ideas, and thus to adapt them to the advancing spirit of time, is an important point which has nearly always 
been overlooked both by Muslim and non-Muslim students of Islam. The object of the Qur'ān in dealing with these legends is seldom historical; it nearly always aims at giving them a universal moral or philosophical import.

Accordingly, he suggests that Adam isn't a real historical actor as such but more of a symbol for humankind (Iqbal 2012, 66):

Indeed, in the verses which deal with the origin of man as a living being, the Qur'ān uses the words Bashar or Insān ${ }^{28}$ not Adam, which it reserves for man in his capacity of God's vicegerent on earth. The purpose of the Qur'ān is further secured by the omission of proper names mentioned in the Biblical narration - Adam and Eve. The word Adam is retained and used more as a concept than as the name of a concrete human individual.

Others don't (solely) take the metaphorical track but seem to find evolutionary readings in the Qur'ān. Nidhal Guessoum, an Algerian astronomer, is one such example. He advances three hermeneutic principles to make his case for a compatible reading between evolution and Islamic scripture. First, he adopts Ibn Rushd's (also known as Averroes) no possible conflict principle. ${ }^{29}$ This is the simple position that there can be no tension between scripture and reality, which is similar to Avicenna's ideas we looked at earlier. For him, this is a defining principle when looking at the intersection of science and Islam (Guessoum 2008, 429):

In practice this principle can be turned into a 'no objection' or 'no opposition' approach, whereby one can persuade the Muslim public of a given idea (say, the theory of biological evolution) not by proving that it can be found in the Qur'ān but rather by showing that at least one intelligent reading and interpretation of various passages is fully consistent with the scientific theory.

Second, he makes a case against literalism. For Guessoum, literalism is the central problem because it dominates the hermeneutic narrative, which forbids any other reading. Following through with this reasoning, Guessoum argues that creationism is, in fact, a derivative of literalism. In his own words (Guessoum 2010, 828):

This rejection [of evolution] is based on a literalistic reading and understanding of the sacred texts ... Adam is the central issue for Muslims with regard to evolution, at least today. Many contemporary religious scholars find it so impossible to conceive of a pre-Adam species or even of a possible multiplicity of Adams, lineages that ended up disappearing (like Neanderthals and Java men), that they reject the theory of 
evolution wholesale for that reason ... The literalist mindset has led to a simplistic conception of the creation of humanity, and sometimes of animals, a conception that insists that humans and animals were created in roughly the forms they presently have, that they have undergone little or no evolution. (A somewhat more intelligent variant of this is the 'microevolution' standpoint, which accepts the evolution of species as species but no transformation from one into another.) Creationism is a literalistic religious movement.

Third, Guessoum argues for interpretive pluralism. This is simply the idea that one can arrive at different meanings of scripture as long as it is intelligible and informed by various tools with science being one of them (Guessoum 2011a, 64):

The position I advocate is simply a rejection of all extreme positions ... Instead, I have emphasised and promoted a multiplicity of readings (with multilayered nuances) of most, if not all, of the Qur'an, an approach which allows for an intelligent enlightenment of one's interpretation of Qur'ānic verses, using various tools, including scientific knowledge, at one's disposal.

To be sure that this captures his view, the following paragraph is taken from the conclusion of his chapter on evolution, which is the largest chapter in his book, where it is clear that these three principles govern his hermeneutics (Guessoum 2011a, 323-324):

The first major idea that must be reiterated and re-emphasised here is that the process of evolution is an established fact of nature. I have devoted a long section of this chapter in an attempt to provide succinct but multiple lines of evidence of observational support for evolution ... No one can ignore or reject the facts of evolution (on any grounds) and expect to be taken seriously; this applies equally to the special area of human evolution and to the general field of biology. One cannot repeat that Islam (or any other religion) does not contradict science while rejecting a whole part of natural science, dismissing it as 'a hoax' ... evolution is highly important in the science-religion/ Islam debates, for it is there that one sees the clear difference between those who adopt a simplistic, literalistic reading of the scriptures (in all areas of life and thought) and those who accept the application of hermeneutics and the principle of multiple, multilayered reading of the Texts.

Given these principles, Guessoum provides us with his take on how to go about navigating Islamic scripture with compatible readings of Islamic scripture. As for hadīths, such as Adam being 60 cubits (30 metres) tall, 
and others which he identifies to be relevant, Guessoum $(2010,829)$ states the following:

These hadīths present us with serious challenges if we try to fit them within our scientifically correct view of creation (of humans or of life more generally). The only solution is to advocate a metaphorical reading of these statements, assuming of course that they were indeed uttered by the Prophet. (The Islamic tradition universally considers the al-Bukhārī collection as the most genuine and reliable volume of hadiths ever assembled.) One must then take the allegorical route, which is in fact a rather common approach adopted by Muslim scholars whenever a contradiction is (apparently) found between the foundational texts or between the scriptures and reason.

Thus, for Guessoum, hadīths that conflict with the science of evolution must be interpreted metaphorically. As for the Qur'ān, Guessoum seems to suggest, if not adopt, a reading where an evolutionary reading is possible. He follows the well-known thinker, Muhammed Shahrour, ${ }^{30}$ whose reading relies on a semantic distinction between bashar and insān, which usually refers to humans or humankind in Arabic. Here's what he says (Guessoum 2011a, 313-314):

He [Shahrour] starts by declaring that the Arabic/Qur'ānic words insān, usually understood as 'man', and bashar, usually rendered as 'human being', must be distinguished; they refer to two very different stages of human evolution. Indeed, in reviewing the story of Adam in the Qur'ān, he shows that each time the word insān ('man') is used, there is a clear connotation of 'comprehension' (mental capacity), 'abstract conception' (of metaphysical entities, in particular) and 'intelligence.' By contrast, the word bashar is used only in the context of its creation, well before it has evolved to insān and become mentally capable. One could simply say that Shahrour wants to identify the bashar stage with hominid (or even Homo) and insān with modern man. He finds support for this idea in the fact that the Qur'ān refers to the 'breathing of God's Spirit' into the hominid/homo ... Shahrour summarises the whole story by emphasising two things: (1) there were many hominid/homo creatures before Adam; (2) God then 'selected' Adam and breathed into him from His Spirit; this later action is the transformative act that produced the jump from the animal state to the human one.

In short, Guessoum believes there is a meaningful distinction in the Qur'ān between bashar and insān, with the former being a wider category of Homo and the latter reserved from Homo sapiens. To him, this reading seems to be compatible with evolution. 


\section{Islamic perspectives on evolution}

The late Pakistani exegete, Israr Ahmad, also takes on the basharinsān approach (Arien 2019). ${ }^{31}$ For him, the human is a combination of the immaterial soul and the physical human body. Ahmad finds this in consonance with Islamic scripture with the words bashar and insān. In his perspective, the word bashar could refer to any biological species belonging to the genus of Homo, including Homo sapiens, while insān refers to Homo sapiens with the infusion of the soul. Consider the following verses:

Your Lord said to the angels, 'I will create a man (bashar) from clay.' (Qur'ān 38:71)

Your Lord said to the angels, 'I will create a mortal (bashar) out of dried clay, formed from dark mud. (Qur'ān 15:28)

Ahmad $(2013,46)$ comments on these verses as follows:

The word bashar used in these verses can refer to Homo, the genus of primates of which, according to evolutionary theory, modern humans (Homosapiens) are the present-day representative. The genus Homo is believed to have existed for at least two million years and modern humans first appeared in the Upper Palaeolithic. In this sense, bashar can denote hominid (or hominoid) - a primate of a group that includes humans (only in the sense of living physical body prior to the breathing of Divine spirit into it), their fossil ancestors, and the bipeds.

He then goes further and suggests one bashar was chosen and was cast into Adam (Ahmad 2013, 46-47):

There is very strong insinuation in the Qur'ān that Adam was one chosen bashar and he became Adam after Allah blew into him out of His spirit - a primordial truth to which atheistic evolutionists turn a blind eye.

He substantiates his claim by resorting to the following verses which indicate divine selection of particular members of the bashar species to become prophets:

God chose (aștafa $\left.\bar{a}^{32}\right)$ Adam, Noah, Abraham's family, and the family of Imran, over all other people (Qur'ān 3:33)

We created you, We gave you shape, and then We said to the angels, 'Bow down before Adam,' and they did. But not Iblīs: he was not one of those who bowed down. (Qur'ān 7:11) 
Ahmad $(2013,47)$ then finally concludes his perspective with the following:

Adam's being chosen by Allah and similarly creation of a multitude of human primates and crowning one individual with the title and status of 'Adam' is quite significant. This essential difference is definitely due to the addition of spiritual soul - a new and highest metaphysical element - to the animal part of man. And this, of course, was the result of Allah's breathing into him out of His own spirit and thus infusing in him the metaphysical element of soul ... It is in this perspective that we can appreciate ... [when] Allah says that He created Adam with 'His two Hands' (yadayya). This perhaps is a subtle allusion to the fact that as Adam is a composite being of material/physical body and a spiritual soul ...

Still, others don't adopt the bashar-insān dichotomy nor the metaphorical option. Instead, these thinkers find other ways of reading evolution into the Qur'ān. T.O. Shanavas, an Indian-American paediatrician, takes a different approach. His motivation for an evolutionary reading seems to stem from the problem associated with genetic bottlenecks, which is when a population is so small that it doesn't have enough genetic diversity. Genetic diversity is important in evolution because it leads to several health issues in offspring and potential extinction. As a result, he rejects the idea that humanity started with a single couple, i.e. Adam and Eve. Shanavas believes that the entire creation narrative of Adam, as discussed in Chapter 3, is referring to a mental state. God divinely selected Adam amongst many humans that were already present on earth. In this framework, Adam isn't strictly the first human, but he is the first "spiritual" father of humanity (Shanavas 2010, 153-160). He then supports his position by arguing for an earthly garden from which Adam fell and finding evolution-friendly readings of Qur'ānic verses looked at earlier, e.g. "when He has created you stage by stage?" (Qur'ān 71:14). It is interesting to note that he arrives at the same opinion as Israr Ahmad but without the bashar-insān distinction.

The Iraqi physicist, Basil Altaie, also readily reads human evolution into the Qur'ann. He takes the creation narrative highlighted in Chapter 3 at face value, but divides the narrative into three parts. The first part refers to Adam's creation from elemental materials, e.g. dust and mud. For Altaie $(2018,131)$, the references to these base materials mean they have been there for a very long time and are being assimilated to create man. The second stage refers to the construction of man's physical features (Altaie $2018,132)$. The third and final stage is when God blew His spirit into humans who gave him consciousness and a will. This led to the civilisation of humanity (Altaie 2018, 134):

... the breathing of the Holy Spirit into the body, as presented in the third stage of creating a human being, was a turning point in the 
evolution process. The creature was transformed from the uncivilised stages where he had no developed mind into a stage where he could think and deduce using an advanced intellect. This, I believe was imparted by Allah through His Spirit. His breath altered man from being an upper animal into a human being. Following this stage, the angels (which here is a metaphor standing for the laws of nature) were ordered to be at the disposal of humankind, to enable him to explore the world, discover it and exploit it positively for his own welfare.

However, Altaie $(2018,135)$ is careful to note that there might be mysterious components to the creation of Adam mentioned discussed in Islamic scripture that might be difficult to determine:

... I am not claiming that our understanding of the Qur'ānic image is a comprehensive one; on the contrary, there must be an unknown, metaphysical aspect to the image which involves the creation of Adam in the Garden. It cannot be a clear-cut conclusion that the Garden is moved from the Garden and sent down to Earth was only meant to serve a spiritual purpose. Ultimately, the unintelligible passages in the Holy Qur'ān are in need of further analysis in order to devise solutions and decipher their mysteries.

The Malaysian thinker, Daud Abdul-Fattah Batchelor (2017) proposes a very novel reading of the following verse:

People, be mindful of your Lord, who created you from a single soul (nafsin wähidatin), and from it created its mate, and from the pair of them spread countless men and women far and wide; be mindful of God, in whose name you make requests of one another. Beware of severing the ties of kinship: God is always watching over you. (Qur'ān 4:1)

He suggests that the mention of a single soul (nafsin wähidatin) in this particular verse might be referring to monozygotic twins from one fertilised egg. He argues that perhaps this initial zygote went through a rare genetic mutation which led one twin being a male and other a female, i.e. Adam and Eve, which is scientifically plausible (Batchelor 2017, 496-497). This makes Batchelor unique in that he argues of there being an explicit reference in the Qur'ān of Adam and Eve having parents. The others argue for compatibility with evolution through which it is implicitly suggested that Adam and Eve had parents.

Finally, Caner Taslaman, a Turkish philosopher, offers another unique perspective of what he refers to as "theological agnosticism." This concept is the same as Jalajel's tawaqquf we reviewed earlier. The only difference between the two thinkers is that while Jalajel suggests suspension of judgement over co/pre-Adamic human beings, Taslaman makes this the case 
for Adam as well. In other words, Taslaman argues that there is nothing definitive in Islamic scripture which either affirms or negates evolution in toto, including Adam. He advances three things to make his case. The first part of his argument involves a rejection of hadiths related to evolution because they are fabrications which crept their way into Islamic sources from Judeo-Christian influences (Taslaman 2020, 29-30):

The literature of hadīth, which is the collection of the sayings and actions of the Prophet Mohammed contains fabricated statements ... about the universe and living things, often falsely attributed to Prophet Mohammad. These fabrications have sneaked into literature as hadīth particularly as a result of interactions between Muslim societies and Judeo-Christian cultures and the consequent assimilation of their narrations (referred to as Israilliyyah and Masehiyyah).

Taslaman also makes a distinction between mutawātir hadīth and $\bar{a} h \bar{a} d$ hadīth, which for now we shall simply understand as strong and weak hadīths, respectively (we will look at this distinction in detail in Chapter 9). This distinction is important for Taslaman because they have theological consequences. Tenets of faith can only be based on strong hadīths, i.e. mutawätir hadīth. Accordingly, since the details of creation and origins of non-human and human life are based on weak hadīths, i.e. ăhād hadīth, the hadīth corpus is irrelevant for evolution. This is why "the content of the Qur'ān would suffice to determine whether the theory of evolution conflicts with Islamic beliefs" (Taslaman 2020, 30), which leads us to the second argument.

Taslaman's second strategy involves demonstrating that the Qur'annic verses related to evolution, which we reviewed in Chapter 3, are open to interpretation. For instance, the verse we looked at earlier that mentions a single soul (nafsin wähidatin), which Batchelor renders as a zygote, Taslaman $(2020,66)$ interprets this to mean a genus. So instead of saying, "... who created you from a single soul (nafsin wähidatin) ...," it should instead say, "... who created you from a single kind/entity (nafsin wähidatin) ..." This implies that God is not referring to a specific individual, but is instead referring to a category which qualifies all humans. Additionally, Taslaman (2020, 72-75) interprets Adam's garden as an earthly one. In another place, Taslaman also suggests that the verse which discusses the similitude between Adam and Jesus doesn't warrant a reading of Adam's miraculous creation. Taslaman $(2020,63)$ claims that the Qur'ān itself makes it clear that "Jesus had a mother and was born through the normal and natural processes of pregnancy and delivery." 33 If this is the case, the analogy between Jesus and Adam suggests that Adam had a mother and was born through natural processes too. In other words, he inverts the general reading of the verse as discussed in Chapter 3.

His third and final argument involves making a case for an agnostic stance on miracles. Taslaman claims that the Qur'àn is silent in on the 
nature of miracles. Furthermore, believers aren't privy to God's intentions (on whether he suspends or violates the laws of nature or not - we shall be looking at the nature of miracles in Chapter 6). Taslaman suggests that what are considered miracles are possible under the laws of nature, which were perhaps unknown when they were performed (Taslaman 2020, 92). The conjunction of these points leads to an uncertain stance on miracles (Taslaman 2020, 93):

Religious believers can agree that divine intervention can happen with or without the suspension of laws. Whichever position is chosen, the other remains a possibility. A Muslim cannot sensibly claim that 'God cannot create species by suspending the laws of nature;' nor can a Muslim sensibly claim that 'God cannot create species without suspending the laws of nature.' Both options are possible and, since we lack epistemic access to God's intentions, we should withhold belief about which is actual. The content of the Qur'ān does not force us to make a choice. Likewise, as with the theory of evolution, I suggest the adaption of 'theological agnosticism' regarding the matter of miracles.

The rejection of weak hadīths, the hermeneutic openness of the pertinent verses related to evolution, and the agnosticism displayed towards miracles lead Taslaman to his stance of theological agnosticism on evolution. This entails that evolution has no bearing on claims made by Islamic scripture, which then makes room for compatibility.

This ends our tour of the no exceptions camp. Having completed this review, we can see that just as there are various arguments in the creationism camp, there is equally a diverse number of opinions in the no exceptions camp. In Chapter 10, we shall review which opinions are compatible with al-Ghazālī's hermeneutical framework.

\section{Conclusion}

This chapter attempted to review and discuss how classifications in the context of Islam and evolution have been developed. Having highlighted some problems with the current classification systems, this chapter adopts a particular classification which focuses solely on common ancestry with four positions under its umbrella: creationism, which is the position that all kinds of life are directly created; human exceptionalism, which is the position that humans are an exception to the process of evolution; Adamic exceptionalism, which is the position that only Adam is an exception to the process; and finally, no exceptions, which admits no omissions from the processes evolution. Following this, we reviewed a variety of interlocutors in each camp.

Of those who reject evolution partially if not entirely, there are three broad ranges of criticisms that are usually presented. These are scientific, metaphysical (philosophical), and hermeneutic. The scientific criticisms 
involve dismissing evolution because it's "just a theory" alongside identifying scientific problems with it. Since this book is concerned with assessing evolution from a theological angle, these scientific criticisms will not be entertained any further. There are a host of responses to these claims, some of which were reviewed in Chapter 1. It is the prerogative of the relevant thinkers to deny evolution if they see it that way, but the motivation of this book is to determine how far one can theologically accept evolution assuming it is scientifically valid, which will be the presumption hereon.

On the metaphysical level, critics of evolution raised a variety of complaints. These include evolution being equivalent to atheism and naturalism. Furthermore, some of them highlighted the problems associated with chance and the moral consequences of evolution. Also, some see evolution undermining design. These discussions will be taken up in Part 3 of this book. Chapter 6 will discuss review the concerns of atheism, naturalism, and chance. Chapter 7 is dedicated to seeing how the notion of design might be undermined theologically and scientifically in the framework of evolution. Chapter 8 will discuss how the discussion of morality is affected by evolution.

There are various considerations that need to be entertained on the hermeneutic plane. While some have argued that non-human evolution isn't determinable from the Islamic scripture, e.g. Mabud, and therefore should be rejected, from Chapter 3 it was concluded that the verses and hadiths are in fact ambiguous on this point. It is not scripturally clear whether non-humans were created instantaneously or through gradual processes. Consider Keller, Qadhi, and Khan, all of whom are trained theologians, don't have any (theoretical or actual) issue with non-human evolution. Accordingly, adopting non-human evolution will be seen as non-problematic hereon, which then focuses the discussion on human evolution. There are there three comments that were noted in this regard. These include the garden of Adam (heaven or earth?), the notion of the nobility of man, and the mention of God's hands. These are individually and/or collectively taken as reasons to reject the possibility of human evolution scripturally.

As for the no exceptions camp, there are three methods that were identified on how thinkers reconcile human evolution with Islamic scripture. The first is the metaphorical approach, e.g. Dajani. Here thinkers take the creation narrative of Adam non-literally. The second approach relies on the bashar-insān distinction, e.g. Guessoum. The third and final approach is that scripture either has readily available possibilities for evolutionary readings, e.g. Altaie; or is unclear and therefore compatibility can be made, e.g. Taslaman. Finally, there is also the consideration of how much hadīths play a part in the discussion. Are they weak or strong? If the latter, can they be plausibly interpreted any other way within the confines of Islamic hermeneutics?

All of these hermeneutic considerations will be entertained in Part 4 of this book, which contains Chapters 9 and 10. Chapter 9 will set up alGhazāli's hermeneutic framework, which will then be used to evaluate the 
said approaches and opinions in Chapter 10. Before moving on to Part 3, we shall review how some contemporary thinkers are claiming that historical Muslim thinkers were discussing evolutionary or proto-evolutionary ideas. This will be evaluated in the Chapter 5 .

\section{Notes}

1 Huskinson (2020, 149-152) observes how the intelligent design camp has resorted to dissent amongst scientists to claim that evolution is in crisis. However, the dissent is, in fact, over the causal mechanics (recall Chapter 1), not common ancestry. But for the layman who is unfamiliar with evolution, and thus may not realise the importance of these distinctions, may think the entire theory is scientifically bankrupt.

2 It should be noted that Scott changed this diagram between the first and second edition of her book. In the first edition, there was no mention of evolutionary creationism, and instead of materialist evolution, it said atheistic evolution.

3 The position that the earth is flat instead of a sphere is believed by a sizeable number of people even today (Scott 2002, 64).

4 The position that earth is at the centre of the universe. Historically, geocentrism was the main belief. But with advancements in science, geocentrism was abandoned for heliocentrism, which is why the sun is instead at the centre (Scott 2002, 65).

5 Evolutionary creationism is indistinguishable from theistic evolution in the scientific realm. According to Scott $(2002,69)$, the difference between the systems is a theological one. The former states that God directs evolution to achieve his purposes while theistic evolution seems more open-ended.

6 This is equivalent to the non-overlapping magisteria of Stephen Jay Gould (2002).

7 For alternative perspectives on evolution with similar metaphysical outlooks, see de Beer (2018) and Austin (2019).

8 It is unclear in my reading of Iqbal whether he adopts the Neoplatonic worldview of Nasr and Bakar.

9 However, he does criticise the science of evolution extensively. See Mabud (2007).

10 It should be noted that neither I, the author, nor the editors of this series advocate the antisemitism conveyed in this quotation.

11 For an alternative viewpoint on Harun Yahya's popularity, see Moran (2019).

12 As we saw in Chapter 1, this is untrue. Darwin was an agnostic. Interestingly, this narrative was and has been reinforced by a popular myth which asserts that Darwin eventually abandoned the theory of evolution and had a deathbed conversion to Christianity. The historical veracity of this claim has been debunked by Moore (1994).

13 For a critical assessment of the relation between falsification and evolution, see Lee (1969).

14 To be clear, this distinction isn't novel nor specific to Keller. Others also recognise this difference, e.g. Ahmad (2013).

15 Given this comment, and in the absence of any further details, I interpret Keller to believe that the place of Adam's creation is synonymous with the garden from which he was expelled from and descended to earth.

16 Qadhi has written an entire book on the subject of Islamic hermeneutics. See Qadhi (1999).

17 This is a well-known American-based Muslim think tank. 
18 The article can be found online but I shall be quoting from the downloadable PDF.

19 For more detailed treatments of Avicenna's hermeneutics, see Heath (1989; 1992).

20 For an excellent treatment on the Taymiyyan hermeneutic framework, see El-Tobgui (2019).

21 Even creationists who we looked at earlier could resort to the discussion of scientific realism to make their case (Chakravartty 2017). They could adopt and/or argue for antirealist interpretations such as instrumentalism. To be clear, I am not arguing for this but simply stating the possibilities.

22 The interpretation of al-Ghazālī's adopted here is that he is from the Ash'arite school.

23 Interestingly, Mabud (1991, 76), the creationist we looked at earlier, admits the Qur'ān isn't explicit on Adam being the first member of humankind. However, in his reading, all the Qur'annic verses related to the creation of Adam point to the idea that Adam was the first member of humankind (Mabud 1991, 76-78).

24 Also see Jalajel (2009) for other possibilities that align with Qadhi and Khan's perspective. This point will be upon again in Chapter 10.

25 Jalajel's position is very similar to S. Joshua Swamidass (2019).

26 The following is Jalajel's (2018) justification for the various possibilities of Adam's appearance as shown in Figure 4.2: "In the absence of any unequivocal textual evidence describing Adam's earliest descendants in detail, there would be no way to gauge the extent or rate of genetic and phenotypic change that has taken place among Adam's later progeny. Therefore, scriptural evidence cannot be used by theologians to indicate whether Adam's earliest descendants would have been classified biologically as Homo sapiens or possibly as some earlier human species. This means that theologians would not attempt answers to questions like whether Homo neanderthalensis were from Adam's descendants, any more than they could argue whether or not creatures that scientists would classify as being biologically Homo sapiens had already evolved on Earth and were populating it before Adam's arrival upon it. All the evidence for hominid evolution, up to and including the evolution of Homo sapiens in a direct line of descent, is empirical, and there is nothing in Islamic scriptures that confirms or contradicts the existence of those hominids." See also the diagram in Jalajel $(2009,155)$ for other possibilities under his framework.

27 The Qur'ān uses the word “khalaqa” in various ways. See Qur'ān $(2: 228$; $6: 2 ; 49: 13 ; 26: 166 ; 22: 5 ; 75: 37-39 ; 23: 14 ; 74: 11-12 ; 21: 33 ; 37: 96 ; 67: 2 ; 3: 49$; $5: 110 ; 29: 17)$.

28 Bashar and insān are two commonly used Arabic terms to refer to humans or humankind in the Qur'ān. But as we shall see shortly, there is a strand of thinking that sees these as distinctive terms which can pave the way for evolutionary readings. It seems that Iqbal doesn't take this track.

29 The details of this position can be found in Ibn Rushd (2017).

30 For more information on Shahrour, see Christmann (2009).

31 It should be pointed out that Ahmad (2013, 35-44) categorically rejects certain aspects of Neo-Darwinism. Furthermore, he was tentative about the connecting lineage between modern man and primates (Ahmad 2013, 44). However, he presents his case as if common ancestry for modern man is true, as seen in the upcoming quotations.

32 See the thoughts of Ahmed Hamdi Akseki who refers to this particular verse when making a case for divine selection in Kaka (2011).

33 He refers to the Qur'ān (19:19-27) for this point. 


\section{References}

Ahmad, Israr. 2013. The Process of Creation: A Qur'annic Perspective. trans. by Absar Ahmad. Lahore: Shirkat Printing Press.

Altaie, Basil. 2018. The Divine Word and The Grand Design: Interpreting the Qur'an in the Light of Modern Science. Manchester: Beacon Books.

Al-Būṭī, Muhammad Sa îd Ramaḍān. 2017. The Greatest Universal Sureties: The Creator's Existence and The Creature's Function. trans. by Nicholas Walter Mogiliansky Lock. Damascus: Dār al-Fikr.

Arien, Muhammad Ramzan. 2019. "Contribution of Dr. Israr Ahmad in the Interpretation of Qur'ān (As a Mudarris and Mufassir).” The Islamic Culture, 41: 119-140.

Austin, Christopher J. 2019. Essence in the Age of Evolution: A New Theory of Natural Kinds. Abingdon: Routledge.

Bagir, Zainal Abidin. 2005. "Islam, Science, and 'Islamic Science:' How to 'Integrate' Science and Religion." In Zainal Abidin Bagir, ed. Science and Religion in a Post-Colonial World: Interfaith Perspectives. Hindmarsh: ATF Press, 37-64.

Bakar, Osman. 1984. "The Nature and Extent of Criticism of Evolutionary Theory." In Osman Bakar, ed. Critique of Evolutionary Theory: A Collection of Essays. Kuala Lumpur: The Islamic Academy of Science and Nurin Enterprise, 123-152.

Batchelor, Daud Abdul-Fattah. 2017. "Adam and Eve's Origin: A Theory Harmonising Scientific Evidence With the Qur'ānic Text.” Theology and Science, 15(4): 490-508.

Bigliardi, Stefano. 2014. Islam and the Quest for Modern Science: Conversations with Adnan Oktar, Mehdi Golshani, Mohammed Basil Altaie, Zaghloul El-Naggar, Bruno Guiderdoni and Nidhal Guessoum. Istanbul: The Swedish Research Institute.

Bilgil, Alper. 2015. “An Ottoman Response to Darwinism: Ismail Fenni on Islam and Evolution." British Journal for the History of Science, 48(4): 565-582.

Carlisle, Jessica, Salman Hameed, and Fern Elsdon-Baker. 2019. “Muslim Perceptions of Biological Evolution: A Critical Review of Quantitative and Qualitative Research.” In Stephen H. Jones, Tom Kaden, and Rebecca Catto, eds. Science, Belief and Society: International Perspectives on Religion, Non-Religion and the Public Understanding of Science. Bristol: Bristol University Press, 147-172.

Chakravartty, Anjan. 2017. "Scientific Realism." The Stanford Encyclopedia of Philosophy. Accessed 19th of August 2020. Available at: https://plato.stanford. edu/archives/sum2017/entries/scientific-realism

Christmann, Andreas. 2009. The Qur'àn, Morality and Critical Reason: The Essential Muhammad Shahrour. Leiden: Brill.

Dajani, Rana. 2012. “Evolution and Islam's Quantum Question.” Zygon, 47(2): 343-353.

Dajani, Rana. 2016. "Evolution and Islam: Is There a Contradiction?” In Muslim World Science Initiative: Islam and Science: Muslim Responses to Science's Big Questions, Islamabad, February 12-13, 2015, 142-151.

Daneshgar, Majid. 2020. "Uninterrupted Censored Darwin: From the Middle East to the Malay-Indonesia World.” Zygon. https://doi.org/10.1111/zygo.12644.

de Beer, Wynand. 2018. From Logos to Bios: Evolutionary Theory in Light of Plato, Aristotle, and Neoplatonism. New York, NY: Angelico Press. 
Determann, Jörg Matthias. 2015. Researching Biology and Evolution in the Gulf States Networks of Science in the Middle East. London: I.B. Tauris.

Elsdon-Baker, Fern. 2009. Selfish Genius: How Richard Dawkins Rewrote Darwin's Legacy. London: Icon Books.

Elsdon-Baker, Fern. 2015. “Creating Creationists: The Influence of 'Issues Framing' on Our Understanding of Public Perceptions of Clash Narratives Between Evolutionary Science and Belief." Public Understanding of Science, 24(4): 422-439.

Elsdon-Baker, Fern. 2017. “The Compatibility of Science and Religion?” In Anthony Carroll and Richard Norman, eds. Religion and Atheism: Beyond the Divide. Abingdon: Routledge, 82-92.

Elsdon-Baker, Fern, Carola Leicht, Will Mason-Wilkes, Emma Preece, and Laura Piggot. 2017. "Summary Report of Preliminary Findings for a Survey of Public Perspectives on Evolution and the Relationship Between Evolutionary Science and Religion." Science and Religion: Exploring the Spectrum. Accessed 1st of November 2020. Available at: https://sciencereligionspectrum.org/wp-content/ uploads/2017/09/SRESYouGov-survey-preliminary-findings-5.9.17.pdf

Elshahat, Ibrahim, Abdullatif Ahmadi Ramchahi, Mohd Yakub, and Zulkifli Mohd Yusoff. 2019. "Theistic Evolutionists' Views of the Words Bashar and Insān in the Qur'ān: A Critical Analysis.” Afkār, 21: 103-140.

Elshakry, Marwa. 2013. Reading Darwin in Arabic, 1860-1950. Chicago, IL: The University of Chicago Press.

El-Tobgui, Carl Sharif. 2019. Ibn Taymiyya on Reason and Revelation: A Study of Dār' Ta'ārud al-'Aql wa-l-Naql. Leiden: Brill.

Eugenie, Scott. 2009. Evolution vs. Creationism: An Introduction. Berkley, CA: University of California Press.

Farahat, Omar. 2019. The Foundation of Norms in Islamic Jurisprudence and Theology. Cambridge: Cambridge University Press.

Gardner, Vika, E. Carolina Mayes, and Salman Hameed. 2018. "Preaching Science and Islam: Dr. Zakir Naik and Discourses of Science and Islam in Internet Videos.” Die Welt Des Islams, 58: 57-391.

Ghafouri-Fard, Soudeh, and Seyed Mohammad Akrami. 2011. "Man Evolution: An Islamic Point of View.” European Journal of Science and Theology, 7(3): 17-28.

Ghamdi, Badr. 2016. Al-Tawaqquf fi-l-'Aqīda. London: Takween.

Gould, Stephen Jay. 2002. Rocks of Ages: Science and Religion in the Fullness of Life. New York, NY: Penguin Random House.

Guessoum, Nidhal. 2008. "The Qur'ān, Science and the (Related) Contemporary Muslim Discourse.” Zygon, 43(2): 411-431.

Guessoum, Nidhal. 2010. "Religion Literalism and Science-Related Issues in Contemporary Islam.” Zygon, 45(4): 817-840.

Guessoum, Nidhal. 2011a. Islam's Quantum Question: Reconciling Muslim Tradition and Modern Science. London: I.B. Tauris.

Guessoum, Nidhal. 2011b. "Islam and Biological Evolution: Exploring Classical Sources and Methodologies by David Solomon Jalajel." Journal of Islamic Studies, 22(3): 476-479.

Guessoum, Nidhal. 2016. "Islamic Theological Views on Darwinian Evolution." Oxford Research Encyclopedia of Religion. Accessed 1st of January 2020. https:// oxfordre.com/religion/view/10.1093/acrefore/9780199340378.001.0001/acrefore9780199340378-e-36 


\section{Islamic perspectives on evolution}

Guessoum, Nidhal. 2017. "PhD Thesis: The Earth is Flat." Gulf News. Accessed 1st of November 2020. https://gulfnews.com/opinion/op-eds/phd-thesis-the-earthis-flat-1.2009202

Hassan, Riaz. 2007. "On Being Religious: Patterns of Religious Commitment in Muslim Societies.” The Muslim World, 97(3): 437-476.

Hanioğlu, M.Şükrü. 2005. "Blueprints for a Future Society: Late Ottoman Materialists on Science, Religion, and Art." In Elisabeth Özdalga, ed. Late Ottoman Society: the Intellectual Legacy. Abingdon: Routledge, 27-116.

Heath, Peter. 1989. "Creative Hermeneutics: A Comparative Analysis of Three Islamic Approaches." Arabica, 36(2): 173-210.

Heath, Peter. 1992. Allegory and Philosophy in Avicenna (Ibn Sina): With a Translation of the Book of the Prophet Muhammad's Ascent to Heaven. Philadelphia, PN: University of Pennsylvania Press.

Howard, Damian A. 2011. Being Human in Islam: The Impact of the Evolutionary Worldview. Abingdon: Routledge.

Huskinson, Benjamin L. 2020. American Creationism, Creation Science, and Intelligent Design in the Evangelical Market. Cham: Palgrave Macmillan.

Ibrahim, Abdul Halim, and Madiha Baharuddin. 2014. "Criticism of Darwin's Theory of Evolution by Muslim Scholars." Online Journal of Research in Islamic Studies, 1(1): 50-62.

Ibn Rushd, Abū-l-Walīd Muhammad Ibn 'Ahmad. 2017. Averroes, the Decisive Treatise: The Connection Between Islamic Religious Law and Philosophy. trans. by Massimo Campanini. Piscataway: Gorgias Press.

Iqbal, Muzaffar. 2003. "Biological Origins: Traditional and Contemporary Perspectives." Islamic Herald. Accessed 1st of October 2019. Available at: http://saif_ w.tripod.com/curious/evolution/muz/biological_origins.htm

Iqbal, Muzaffar. 2008. "Darwin's Shadow: Context and Reception in the Western World.” Islam and Science, 6(2): 99-152.

Iqbal, Muzaffar. 2009. "Darwin's Shadow: Context and Reception in the Muslim World.” Islam and Science, 7(1): 9-50.

Iqbal, Muzaffar. 2010. "Darwin's Shadow: Evolution in an Islamic Mirror.” Islam and Science, 8(1): 11-32.

Iqbal, Mohammad. 2012. Reconstruction of Religious Thought in Islam. Stanford, MO: Stanford University Press.

Jalajel, David Solomon. 2009. Islam and Biological Evolution: Exploring Classical Sources and Methodologies. Western Cape: University of the Western Cape.

Jalajel, David Solomon. 2018. "Tawaqquf and Acceptance of Human Evolution.” Yaqeen Institute. Accessed 1st of January 2020. Available at: https://yaqeeninstitute. org/dr-david-solomon-jalajel/tawaqquf-and-acceptance-of-human-evolution/\#. Xgw_HxczbPA

Kaya, Veysel. 2011. “Can the Qur’ān Support Darwin? An Evolutionist Approach by Two Turkish Scholars after the Foundation of the Turkish Republic.” The Muslim World, 102(2): 357-370.

Keller, Nuh Ha Mim. 2011. Sea Without Shore: A Manual of the Sufi Path. Amman: Sunna Books.

Kragh, Helge. 2011. Higher Speculations: Grand Theories and Failed Revolutions in Physics and Cosmology. Oxford: Oxford University Press. 
Ladyman, James. 2020. "Structural Realism." The Stanford Encyclopedia of Philosophy. Accessed 19th of August. Available at: https://plato.stanford.edu/ archives/spr2020/entries/structural-realism

Lee, K. K. 1969. “Popper's Falsifiability and Darwin's Natural Selection.” Philosophy, 44(170): 291-302.

Mabud, Shaikh Abdul. 1991. Theory of Evolution: Assessment from the Islamic Point of View. Cambridge: Islamic Academy.

Mabud, Shaikh Abduk. 2007. "The Theory of Evolution: Teaching the Whole Truth.” In Leslie S. Jones and Michael J. Reiss, eds. Teaching About Scientific Origins: Taking Account of Creationism. New York, NY: Peter Lang Publishing.

Malik, Shoaib Ahmed. 2018. Atheism and Islam: A Contemporary Discourse. Abu Dhabi: Kalam and Research Media.

Malik, Shoaib Ahmed. 2019. "Evolution and Islam - A Brief Review.” In Abdallah Schleifer, ed. The Muslim 500: The World's 500 Most Influential Muslims 2020. Jordan: The Royal Islamic Strategic Studies Centre, 207-212.

Malik, Shoaib Ahmed. 2020. "Islam and Evolution: The Curious Case of David Solomon Jalajel.” In Abdallah Schleifer, ed. The Muslim 500: The World's 500 Most Influential Muslims 2021. Jordan: The Royal Islamic Strategic Studies Centre, 251-255.

Moore, James. 1994. The Darwin Legend. Grand Rapids, MI: Baker Books.

Moran, Glen. 2019. "Harun Yahya's Influence in Muslim Minority Contexts: Implications for Research in Britain, Europe, and Beyond.” Zygon, 54(4): 837-856.

Moran, Glen. 2020. "The Final Domino: Yasir Qadhi, YouTube, and Evolution.” Zygon, 56(1): 34-53.

Nadvi, Muhammad Shahabuddin. 1998. Evolution or Creation? trans. by Maqbool Ahmed Siraj. Bangalore: Furqania Academy Trust.

Nasr, Seyyed Hossein. 2006. "On the Question of Biological Origins." Islam and Science, 4(2): 181-197.

Pew Research Centre. 2013. "The World's Muslims: Religion, Politics and Society.” The Pew Forum on Religion and Public Life. Accessed 2nd of November 2020. Available at: http://assets.pewresearch.org/wp-content/uploads/sites/11/2013/04/ worlds-muslims-religion-politics-society-fullreport.pdf

Popper, Karl. 2002a. Conjectures and Refutations. Abingdon: Routledge.

Popper, Karl. 2002b. The Logic of Scientific Discovery. Abingdon: Routledge.

Qadhi, Abu Ammar Yasir. 1999. An Introduction to the Sciences of the Qur'aan. Birmingham: Al-Hidaayah Publishing and Distribution.

Qadhi, Yasir, and Nazir Khan. 2018. "Human Origins: Theological Conclusions and Empirical Limitations." Yaqeen Institute. Accessed 19th of August 2020. Available at: https://yaqeeninstitute.org/nazir-khan/human-origins-theological-conclusionsand-empirical-limitations/

Qidwai, Sarah. 2019. "Darwin or Design: Sir Sayyid Ahmad Khan's Views on Human Evolution.” In Yasmin Saikia, and Raisur Rahim, eds. The Cambridge Companion to Sayyid Ahmad Khan. Cambridge: Cambridge University Press, 214-232.

Riexinger, Martin. 2009. "Responses of South Asian Muslims to the Theory of Evolution." Die Welt des Islams, 49: 212-247.

Samuel, Geoffrey, and Santi Rozario. 2010. "Contesting Science for Islam: The Media as a Source of Revisionist Knowledge in the Lives of Young Bangladeshis." Contemporary South Asia, 18(4): 427-441. 


\section{Islamic perspectives on evolution}

Shanavas, T. O. 2010. Islamic Theory of Evolution: The Missing Link Between Darwin and the Origin of Species. USA: Brainbow Press.

Solberg, Anna Ross. 2013. The Mahdi Wears Armani. Huddinge: Södertöns Högskola. Swamidass, S. Joseph. 2019. The Genealogical Adam and Eve: The Surprising Science of Universal Ancestry. Downers Grove, IL: IVP Academic.

Taslaman, Caner. 2020. Can a Muslim Be an Evolutionist? Istanbul: Istanbul Yayınevi.

Unsworth, Amy, and David. Voas. 2018. "Attitudes to Evolution Among Christians, Muslims and the Non-Religious in Britain: Differential Effects of Religious and Educational Factors." Public Understanding of Science, 27(1): 76-93.

Varisco, Daniel. 2018. "Darwin and Dunya: Muslims Responses to Darwinian Evolution." Journal of International and Global Studies, 9(2): 14-39.

Wolt, Peter. 2007. Not Even Wrong: The Failure of String Theory and the Search for Unity in Physical Law. New York, NY: Basic Books.

Yahya, Harun. 2001. The Evolution Deceit: The Scientific Collapse of Darwinism and Its Ideological Background. Istanbul: Kültür Publishing.

Yahya, Harun. 2001. The Disasters Darwinism Brought to Humanity. Toronto: al-Attique Publishers Inc.

Yahya, Harun. 2003a. The Collapse of the Theory of Evolution in 20 Questions. New Delhi: Idara Isaat-e-Diniyat (P) Ltd.

Yahya, Harun. 2003b. Why Darwinism Is Incompatible with the Qur'ān. Istanbul: Seçil Ofset.

Yahya, Harun. 2006. The Dark Spell of Darwinism: How Darwinists Twist the Truth to Turn People Away From God. Istanbul: Global Publishing.

Yazicioglu, Isra. 2013. Understanding the Qur'anic Miracle Stories in the Modern Age. University Park, PA: The Pennsylvania State University Press.

Ziadat, Adel. 1986. Western Science in the Arab World. New York, NY: St. Martin's Press. 


\section{Old texts, new masks: misreading evolution onto historical Islamic texts}

\section{Introduction}

In Chapter 3, we reviewed all the relevant Qur'annic verses and hadīths that are relevant and discussed in the context of evolution. In Chapter 4, we examined the various ideas that people have brought forward when discussing the (in)compatibility of Islam and evolution. But a thorough review of how Muslims perceive evolution cannot be complete without evaluating how some contemporary Muslim thinkers suggest that historical Muslim thinkers were actually thinking and writing about evolution (or a protoevolutionary theory) as it is understood today. The motivation behind this chapter is to demonstrate that this is an anachronistic reading. In fact, it can be stated at the onset said that all the thinkers we shall review here do not discuss evolution, but are rather speaking under the broad framework of scalae naturae or what is known as the great chain of being (GCB). ${ }^{1}$ Before we begin, it will help juxtapose the GCB with the modern conception of evolution to make the differences between these two frameworks as clear as possible.

The GCB is a metaphysical framework derived from Plato and Aristotle's works, and particularly flourished in Neoplatonism as a spiritual and philosophical account of reality (Lovejoy 2009, 61-63). It was incredibly influential in Islam and Christianity because it established an ontological hierarchy of all beings, a principle and worldview that was theistic-friendly (Wildberg 2016). When the GCB was introduced into the Muslim world, it was appropriated to fit under an Islamic rubric, though not necessarily with any homogeneity, which is why we sometimes see differences amongst Muslim thinkers (Twetten 2017). This is being stressed because it establishes that this idea was prevalent in the collective Muslim psyche, and it was a major frame reference at the time (Kruk 1995, 31). Broadly speaking, at the top of the chain was God (or the Absolute Good, The First Principle, or The One depending on the adopted account), which represented the highest level of perfection. After God, it was simply a downward degradation to lesser perfect beings. These included various tiers (such as the Universal Intellect or the Soul), angels/demons, celestial bodies, man, 
animals, plants, and rocks/minerals in that order (Netton 1991, 36-37; Netton 2003). By contrast, the increasing complexity from the lower levels to the higher levels demonstrated the increasing qualities of perfection. Where minerals only had existence, plants had life and existence, and animals were better because they had existence, life, and movement, and so forth with increasing ascension. Each category also had its various subdivisions. For example, animals that demonstrated advanced levels of intelligence, mobility and strength such as the elephant or lion were considered much higher in rank than, say, oysters in the animal tier (Nasr $1978,70)$. Or take another example where avian animals were considered superior to aquatic ones because of the increased mobility in the air in contrast to water. So the establishment of these tiers or ranks were not due to some temporal or material dimension; rather, it was to do with the metaphysical progression of perfection (Nasr 1978, 69; Lovejoy 2009, 24-98). On a more spiritual rendering, the lower-level entities lacked the perfection found in the highest level and yearned for that reunion with God. That displacement between the lower entities and God creates a gradient that induces the creative or spiritual potential that yearns for "reunion" (Morewidge 1992). The exact mechanics and referents of this process varied from one thinker to another. Still, the underlying denominator in all of the variations of the GCB was the idea of an ontological gradation where each tier was a "fixed" unit.

By contrast, modern-day evolution seeks to explain the biodiversity that we see in the animal and plant world from a strictly scientific framework. Recall from Chapter 1, evolution rests on the principles of deep time, common descent, natural selection, and random mutations. In essence, evolution explains that biological traits can be passed down from the parent generation to the offspring's generation but never with absolute similarity. This is because the genetic information is never carried over as an exact copy, leading to degrees of similarity and differences in the parent and offspring generations. Species carrying biological traits which are stressed from the external environment that help with food and competitive survival tend to reproduce successfully. But with the constant flux found in nature, those stresses also vary through time and space. Branching of species occurs because certain members of the parent species diverge from the original group and adapt to different localities due to different environmental pressures (Stearns and Hoekstra 2005). So there is a constant dialectic landscape between the genes and the environment where chance-like events, i.e. no long-term purposes in mind, can equally lead to positive, negative, or neutral traits to be expressed. Such chance-like events can be external, e.g. natural disasters, or internal, e.g. random genetic mutations. Through several generations of change and adaption over deep time, we begin to see the biodiversity we recognise today (Futuyma and Kirkpatrick 2017). In this account, humans are but one product of a long and complicated evolutionary pathway. 
It would be an unfair anachronism if one were to criticise historical works of biology or zoology due to not employing the particular language and concepts that current evolutionary biologists use. But this is not the argument being presented here. Rather, it is simply that the historical scholars we will review were not discussing through the broad lens of modern-day evolution in their works. More specifically, the argument is that none of the works we will review indicate any notion of ancestry, neither Lamarckian nor Neo-Darwinian (see Figure 1.10 in Chapter 1). The GCB is a metaphysical framework premised on the ascending perfection of beings, while evolution is a temporal and material explanation of plant and animal biodiversity. These are fundamentally different viewpoints. Without pushing the metaphor too far, the GCB is a "vertical" scheme whereas modern-day evolution is "horizontal" one. So even though these scholars refer to potential similarities between species or observe (or utilise) the language of biological sequential order, their underlying principles are embedded in some variation of the GCB, not evolution, as we shall observe shortly. There may very well be some similarities in the language and schemes of these accounts, but these would not be due to any substantial sense; rather, they would be merely superficial or accidental similarities. Having cleared this preamble, let us review how various contemporary scholars have attempted to understand historical works as evolutionary (or proto-evolutionary) accounts.

Ironically, one of the earliest accounts which praises historical Muslim scholars' works for thinking of evolution was by John William Draper (Hameed 2011, 143). He is generally held responsible for nucleating a very aggressive confrontation between Christianity and science (or what is known as the conflict thesis) when he wrote his infamous History of the Conflict between Religion and Science in 1875. ${ }^{2}$ However, the book has been criticised for its lack of historical accuracy (Russel 2002; Principe 2016). Adding to this list of inaccuracies is the following quote (Draper 1875, 188):

[Christian] Theological authorities were therefore constrained to look with disfavor on any attempt to carry back the origin of the earth to an epoch indefinitely remote, and on the Mohammedan theory of the evolution of man from lower forms, or his gradual development to his present condition in the long lapse of time.

In one place, he goes on to praise the Muslims for going further than the Christians by teaching evolution in their institutions (Draper 1875, 118):

Sometimes, not without surprise, we meet with ideas which we flatter ourselves have originated in our own times. Thus our modern doctrines of evolution and development were taught in their [Muslim] schools. In fact, they carried them much farther than we are disposed to do, extending them even to inorganic or mineral things. 
Resorting to historical authors is a strategy that is utilised by contemporary advocates who want to demonstrate that Islam and evolution are non-conflicting. For example, after claiming that Darwin took the idea of evolution from Muslim scholars, Shanavas $(2010,126-127)^{3}$ praises Draper for his acknowledgement:

The abundant evidence ... demonstrates that Muslims are the originators of the theory of evolution, and William Draper is correct when be calls it the Muslim Theory of Evolution. The only difference one can cite between the Muslim scholars and Darwin is that Muslims believed that the existence of the ladder of nature was the result of divine will and providence.

Consider a recent article titled, An Untold Story in Biology: The Historical Continuity of Evolutionary Ideas of Muslim Scholars From the 8th century to Darwin's Time, which contains an argument for the unappreciated acknowledgement of Muslim scholarship on the topic of evolution (Malik et al. 2017). The authors review eight Muslim scholars - three of which will also be looked at in this article including Ibn Khāldun, The Brethren of Purity and al-Jāhiz - and concluded that "all eight Muslim scholars suggested that humans underwent some type of phenotypic evolution. Some of them specifically wrote about similarities between humans and apes/monkeys, in many cases stating that humans derived from an ape/monkey ancestor" which is why "their theories were evolutionary because they supported the notion that species change over time" (Malik et al. 2017, 13). Such perspectives are rampant (Hamad 2007; Kaya 2011; Dajani 2016; Iqbal 2012, 121).

Other authors are much more implicit in their position. Nidhal Guessoum, undoubtedly one of the more leading voices of evolution in the dialogue of science and Islam, is a bit more cautious. He introduces the idea of the GCB when relaying historical accounts of (apparent) evolution amongst Muslim thinkers while not clearly clarifying nor stipulating his own position (Guessoum 2011, 305-308). However, on sending a letter to an editor as a reaction to the promotion of creationism, he indicates that they could be discussing evolution when he writes (Guessoum 2011, 320):

People may be surprised that many Muslims scholars of the golden era of the Islamic civilisation, scholars like al-Farābi, al-Jāhiz, Ikhwān al-Ṣafā and Ibn Khaldūn, all noted the 'gradation' or even 'evolution', of organisms in nature. How much have we regressed!

Aside from suggesting that historical Muslim could be discussing evolution, it raises the question as to why would someone refer to such historical Muslim authors to make a point for contemporary evolution. And if regressed as he says, regressed from what exactly? There are other points that Guessoum and Malik et al. have mentioned in their reading of historical thinkers, but they will be postponed for the coming and relevant sections. 
Despite the aforementioned worries, one can understand the need for making evolution a more amenable position. Because of the negative associations linked with evolution in the Muslim world, a possible motive in positing evolution onto historical Muslim scholars (knowingly or unknowingly) might be due to inducing the idea that Muslims are only re-embracing age-old ideas from their tradition. This was the position of Jamāl al-Dīn al-Afghānī, for instance (Shah 2010, 159). So this isn't a contemporary worry, and seems to be a lasting historical precedent (Elshakry 2014, 161-218). The motivation behind this line of thinking seems to be diminishing the highly charged polarity directed towards evolution found in the Muslim world. Though such a strategy might help reduce Muslims' social anxieties, and thus potentially help them embrace evolution, it resorts to a false stimulus (for a similar observation see footnote 10 in Chittick 2013, 88). Regardless of whether one is implicit or explicit in seeking an ideological footprint of evolution in historical works, the underlying issue with all these perspectives is that they approach them with a modern lens. The historical works we will look at were written in the framework of some version of the GCB. Unfortunately, they have been interpreted as works of evolution when the relevant paragraphs or couplets have been isolated and truncated from the wider text, which then conveniently provide an evolution-friendly reading. So what seems like indications of evolution are in fact decontextualised interpretations.

Finally, it could be contended that though this may be true, these thinkers had some novel ideas that were not available in other intellectual traditions such as Christian Europe, that anticipated modern-day evolution. It should be pointed out that there are, unquestionably, some ideas and observations in some of these works and thinkers that can easily correlate with our current conceptions under the broad umbrella of evolution (or even biology in general), e.g. al-Jāhị discussed food chains as we will come to see shortly. Such observations are not being negated, nor are they being downplayed in this study. Instead, the purpose here is to provide context for these thinkers to explicitly define the conceptual foundations of these works. This way, we can pinpoint the isolated ideas that do have similarities with contemporary evolution without reducing their entire worldviews to an evolutionary framework through highly selective (and thus erroneous) readings. Thus, this work is a philological attempt which is "the discipline of making sense of texts" (Pollock 2009, 934). Accordingly, the analysis to follow will look at the language of the texts and their textual and contextual settings.

\section{Reading evolution onto historical works}

We will review four scholars in this chapter which include Ibn Khaldūn, Jalāl ad-Dīn Rūmī, al-Jāhịiz, and the Ikhwān al-Ṣafā (Brethren of Purity); and the specific works that we will be looking at are Muqaddimah (Prolegomena), Mathnawi (The Spiritual Couplets), Kitāb al Hayawān (The Book of Animals), and the Ris $\bar{a}^{\prime} i l$ Ikhwān al-Safā (Epistles of the Brethren of Purity), respectively. The specific focus on these three thinkers and one group have 
been maintained for two reasons. First, these seem to be the most widely quoted. Second, there is a large amount of material available on them from various other perspectives, including the historical, philosophical, and theological aspects in English, making them very accessible to the avid reader.

\section{Ibn Khaldūn}

From his famous Muqaddimah, Ibn Khaldūn $(2005,75)$ is oft-quoted with the following:

One should then look at the world of creation. It started out from the mineral and progressed, in an ingenious, gradual manner, to plants and animals. The last stage of minerals is connected with the first stage of plants, such as herbs and seedless plants. The last stage of plants such as palms and vines, is connected with the first stage of animals, such as snails and shellfish which have only the power of touch. The word 'connection' with regard to these created things means that the last stage of each group is fully prepared to become the first stage of the next group. The animal world then widens, its species become numerous, and, in a gradual process of creation, it finally leads to man, who is able to think and reflect. The higher stage of man is reach from the world of monkeys, in which both sagacity and perception are found, but which has not reached the stage of actual reflection and thinking. At this stage we come to the first stage of man. This is as far as our (physical) observation extends.

One can easily surmise from this quote that Ibn Khaldūn is very likely talking about evolution. Two points indicate this. First, the initial sentences discuss a linear biological process from simpler entities to more complex ones, which falls in line with contemporary evolution. Of particular interest is the specific point on the relationship between man and monkeys towards the end. Second, in the last part of the paragraph, a specific point is made regarding the extent of physical observation. This is important because it seems to indicate an empirical account, a point also in line with modern-day evolution. Malik et al. $(2017,12)$ quote this very paragraph and state:

It is fascinating to see ... Ibn Khaldūn most clearly professed his belief that humans themselves evolved specifically from an ape/monkey ancestor - a concept that a majority of both Muslims and people of other religions, including Christian creationists, find particularly difficult to accept.

However, probing further into the text reveals otherwise. The first indicator of an alternative reading is the title of the section under which this quote is situated: The Real Meaning of Prophecy. If not obvious, at the 
very least, it should instigate the reader to think about the possible connection between the title and the previous quote. The second and much more explicit evidence for the case that he is not speaking about evolution are the following paragraphs that come right after (Ibn Khaldūn 2005, 75):

... In the world of creation there are certain influences of the motions of growth and perception. All this is evidence of the fact that there is something that exercises in influence and is different from the bodily substances. This is something spiritual ... The soul ... must be prepared to exchange humanity for angelicality, in order actually to become part of the angelic species at certain times in the flash of a moment ... The soul is connected with the stage next to it, as are all the order of the existentia, as we have mentioned before. It is connected both upward and downward. Downward it is connected with the body, thus acquiring the sense perceptions by which it is prepared for actual intellection. Upward, it is connected with the stage of the angels. There, it acquires scientific and supernatural perceptions, for knowledge of things to that come into being exists timelessly in the intellections of the angels.

In the first few sentences in this paragraph, Ibn Khaldūn discusses influences in creation that is "different from bodily substances," which he refers to as the soul right after. It is the entity that connects the realm of man with angels. So, it seems that there is a continuation of being after the realm of man. The previous paragraph truncates with man in its finality and thus seems to be very evolution-friendly. However, when we situate these two paragraphs together, we see a different picture. Three points need highlighting. First, if this is truly a reading of evolution, then its advocates would have to demonstrate what relevance souls and angels have to do in this account seeing that these are immaterial entities as traditionally understood by Muslims, and thus also Ibn Khaldūn. Second, recall the point made earlier regarding the comment on "the extent of observation." If that statement is read and contained only within the first paragraph, it will give the false impression of it being an empirical account of reality. However, on continuing with the second paragraph, it seems that Ibn Khaldūn is still developing that point to prepare the link between man and angels through the soul, which is unobservable, and thus contrary to all the entities mentioned in the first paragraph, e.g. minerals, plants, animals, and man. This is a subtlety that is lost that renders a polar opposite (i.e. evolutionary) reading when the first paragraph is truncated from the second. Now the question is why this link between man and angels is being established. This can be answered through the following paragraph (Ibn Khaldūn 2015, 78):

They [prophets] thus move towards the angelic, sloughing off humanity at will, by virtue of their natural constitution, and not with the help of 
any acquired faculty or craft. The prophets move in that direction ... and once among the highest group of angels, learn all that may there be learned. They then bring what they have learned back down to the level of powers of human perception, as this is the way in which it can be transmitted to human beings.

Recall that angels occupy a higher tier than man in the GCB. Furthermore, within each tier, there are sub-ranks. The highest rank in humanity is none other than the prophets in Islam because they can transcend their human status in the spiritual sense (Netton 1991, 36). Finally, it should be pointed out again that the title of this section is The Real Meaning of Prophecy. Keeping these three points in mind, the purpose of establishing the link between man and angels is to demonstrate how prophets, who occupy the highest ranks amongst humans, can transcend the rank of man into the realm of angels to learn spiritual truths (revelation) and then come back down to the realm of humans to share that knowledge with the rest of humanity. Thus, what becomes clear is that Ibn Khaldūn was not discussing evolution. Rather, he discussed the gradation of beings in the GCB with particular focus on what discriminates prophets from ordinary men and how prophecy itself operates, hence the importance of the title and the discussion of the soul being responsible for the possible transformation from "humanity to angelicality."

Thus, it can be conclusively said that Ibn Khaldūn is not talking about evolution in this paragraph, and it would be an interpretative fallacy to state that he is. As pointed out earlier, to maintain an evolutionary reading of Ibn Khaldūn one would have to answer how the points of the soul and angels would fit in that narrative, which is not possible under a scientific outlook like evolution. More importantly, one would have to entertain serious thematic gymnastics of the first quoted paragraph to make a case for evolution. Neither of these options seem tenable.

\section{Jalāl ad-Dīn Rūmī}

A similar mistake is masked onto several couplets taken from Rūmī's famous poetry work, the Mathnawi. Take the following as an example (Rūmī 2003, 218):

I died to the inorganic state and became endowed with growth, and (then) I died to (vegetable) growth and attained to the animal.

I died from animality and became Adam (man): why, then, should I fear? When have I become less by dying?

Up to this point, it may seem like a perfectly acceptable account of evolution with the progressive sequence of the inorganic state to the vegetable state, from there to the animal state, and finally to man as mentioned in 
these two couplets. However, the immediate subsequent couplets indicate something else (Rūmī 2003, 219):

At the next remove I shall die to man, that I may soar and lift up my head amongst the angels;

And I must escape even from (the state of) the angel: everything is perishing except His Face [God].

In continuing with the phase-changing storyline, the next phase seems to be from man to angel with a final pointer to the imperishable God. Since angels do not take part in any modern understanding of evolution, as a matter of fact, this clearly refers to a non-evolutionary account. However, before we can convincingly dismiss this as an evolutionary reading, we need some context to understand what is being implied here to make an alternative reading plausible. To begin with, it must be pointed out at the onset that Rūmī was one of the most noteworthy mystics in Islamic history. Keeping this critical point in mind, let us view William Chittick's (2013, 84 ) - one of the most respected, contemporary scholars on Islamic spirituality (and by extension Rūmī) - remarks on the contextual background of Rūmī's passages on "evolution:"

When Rumi and others talk about what has been labelled as 'evolution,' they are talking about the manner in which human beings go back to God ... The idea of a 'return' is meaningless unless we begin by acknowledging that creation has come from God in the first place. In other words, every 'evolution' demands a prior 'devolution' ... The basic principle in all Islamic discussions of 'evolution' is that the human soul needs to undergo a synthetic and unifying growth by which it can go back in happiness and wholeness to the unitary realm from which it arose.

The idea here is that there has been a separation, disintegration and dispersion of the human soul and the creator. So there is a longing and a process to unite with God. Thus "the goal is to awaken the intelligent and the intelligible light of God that the Qur'ān calls the 'spirit'” (Chittick 2013, 84) or what is known as "origin and return" (mabd $\bar{a}^{3}$ wa ma'a $d$ ) in Sufi literature. Accordingly, Chittick $(2013,86)$ notes:

... the return to God is a gradual ascent on a ladder whose steps mark the increasing unification and intensification of the spiritual and intellectual light. This can only happen because human beings came into this world by successive degrees of darkening and obscuration. The integrative movement of the return to God is the reversal of the dispersive movement of creation. 
Thus, what seems to be physical stages of evolutionary development are actually just spiritual states expressed in Sufi/mystical and metaphorical expressions. As explained by Chittick (2017):

It is because people have descended from God in stages ... that they are then able to ascend from the mineral and plant stages (in the womb), to the animal stage (in infancy and childhood), to the human level (as adults observing the necessities of human goodness), and then to even higher levels, following Mohammad in his Night Journey ...

So, similar to the erroneous reading of Ibn Khaldūn, the quoted couplet seems to be a truncated and selective reading of Rūmī. Another oft-quoted stanza is the following (Guessoum 2011, 308):

Man first appeared at the level of inanimate matter,

Then it moved to the level of plants,

And lived years and years a plant among the plants,

Not remembering a thing from its earlier inanimate life.

And when it moved from plant to animal,

It did not remember anything from its plant life,

Except the longing it felt for plants,

Especially when spring comes and beautiful flowers bloom,

Like the longing of children to their mothers,

They don't know the reason for longing to their breasts,

The Creator pulled Man - as you known - from its animal state,

To this human state,

And so Man moved from one natural state,

To another natural state,

Until he became wise, knowledgeable, and strong as he is now,

But he does not remember anything from his earlier states,

And he will change again from his current state.

Again, this quotation seems to very plausibly imply that Rūmī is discussing evolution. However, this specific quotation is from Guessoum, who translated this couplet himself from Arabic. ${ }^{4}$ The problem here is that the Mathnawi was originally written in Persian so this is the output of a double translation. Reynold Nicholson, who was a leading expert on Rūmī, translates the same couplet from Farsi as the following (Rūmī 2003, 472):

First he came into the clime (world) of inorganic things, and from the state of organic things he passed into the vegetable state.

(Many) years he lived in the vegetable state and did not remember the inorganic state because of the opposition (between them);

And when he passed from the vegetable into the animal state, the vegetable state was not remembered by him at all, 
Save only for the inclination which he has towards that (state), especially in the season of spring and sweet herbs -

Like the inclination of babes towards their mothers: it (the babe) does not know the secret of its desire for being suckled;

$(\mathrm{Or})$ like the excessive inclination of every novice towards the noble spiritual Elder, whose fortune is young (and flourishing).

The particular intelligence of this (disciple) is derived from the Universal intelligence: the motion of this shadow is derived from that Rose-bough.

His (the disciple's) shadow disappears at last in him (the Master); then he knows the secret of his inclination and search seeking.

How should the shadow of the other's (the disciple's) bough move, O fortunate one, if this Tree move not?

Again, the Creator, whom thou knowest, was leading him (Man) from the animal (state) towards humanity.

Thus did he advance from clime to clime (from one world of being to another), till he has now become intelligent and wise and mighty.

He hath no remembrance of his former intelligences (souls); from this (human) intelligence also there is a migration to be made by him.

Two things need to be pointed out. First, the translation by Nicholson does not seem to be as mechanical as Guessoum's. For example, Nicholson is careful to add that the intelligence mentioned in the second last couplet is referring to a spiritual state and not necessarily intelligence in the cognitive sense, which aligns with Chittick's remarks mentioned earlier. Also, the point of forgetting former intelligences (i.e. from plant to animals and then to humans) is an analogy of the stages of human development in which the latter does not remember the previous stages, and not in the sense of physical transformations as is understood in evolution: "This is ... a spiritual climb, like that of an embryo to intelligence" (Chittick 2017). ${ }^{5}$ Second, and more important than the first, Guessoum's translation is missing four couplets as emphasised in the quotation. ${ }^{6}$ This could be because his source material for this translation is an Arabic PhD dissertation on this topic rather than the original work. It is plausible that the author of the dissertation happened to have missed these couplets. Alternatively, it may be countered that Nicholson's translation which has been relied on, might be in error. This is not the case as these missing couplets can be easily found in the original text. ${ }^{7}$ Furthermore, Jawid Mojaddedi $(2017,216)$, a contemporary expert on Sufism, has also translated Rūmī's Mathnawi, includes these four couplets, and offers a very similar of this stanza in his translation. ${ }^{8}$ So it seems that the real error stems from the dissertation which Guessoum has relied on.

Having cleared the problem of translation and selective readings, the use of terms like "Universal intelligence," which is one of the immaterial tiers in the Neoplatonic framework as pointed out earlier, found in the complete 
stanza is a clear indicator that it is premised on the GCB. But Rūmī also utilises explicit terms like "spiritual Elder" and implicit ones like "disciple" and "master" which are common terms and ideas used in mystical writings. This should not be surprising because, as indicated earlier, Rūmī was well-known for being one of Islam's most vivid and impacting mystic. In fact, Rūmī premised his entire worldview on the notion of love. It is the single principle that drives the entirety of creation, be it cosmic, geographical, material, mental or spiritual interactions. Ultimately, every entity is trying to reach a state whereby one is united with the Ultimate, which is God. In mystical terms, since a lover (creation) yearns for the beloved (God), it does anything it can to assimilate and ascend towards that unity in the higher realms from its multiplicity in the lower realms to the unity "above" (Nasr 1978, 53). Thus, as has been highlighted and stressed earlier, he discusses or rather alludes to a spiritual account of nature within the GCB that has no resemblance to the mechanical forces of natural selection as in evolution. The differences between the two accounts have also been pointed out by others (Hakim 1959, 32-42; Ghafouri-Fard and Akrami 2011, 26; Kartenegara $2016,80)$. It is then fair to conclude that Rūmī's work "has only superficial resemblance to evolution in any modern sense" (Chittick 2013, 87).

\section{Al-Jāhiz}

Al-Jāhiz̧'s Kitāb al-Hayawān is an encyclopaedic seven-volume tome which discusses various aspects of the natural world. The problem with it is that it entangles theological, philosophical and empirical perspectives into one matrix, making it an interpretive challenge (Montgomery 2013). Furthermore, al-Jāhiz utilises poetry, religious scripture, and accounts from local and distant cultures in addition to his empirical observations. This further complicates determining what the overall objective or motivation in his work is. Nevertheless, it unquestionably contains a lot of empirical content "including the influences of various climates and diets on men, animals and even plants of different geographical regions; as well as discussions of animal mimicry, intelligence, and social organisation" (Elshakry 2014, 268). Al-Jāhiz is also known to have compared humans with various other animals as noted by Mansūr $(1977,279)$ in his detailed and masterful study of Kitāb al-Hayawān:

Al-Jāhiz notices the similarities seen in physical structure; for example, the face, the eye, the hand, the fingers, and the way they are raised, moved, and used to supply the mouth with food. In other respects also there is resemblance between monkeys and men as for insurance in marriage, jealousy, the way of laughing and imitating ... Even the cat in the general view of al-Jăhiz is thought to resemble man in her sneezing, yawning and cleaning herself. 
Or consider the following observation made by Bayrakdar (1983, 311):

He [al-Jāhiz] says, 'People said different things about the existence of al-miskh (= original form of quadrupeds). Some accepted its evolution and said that it gave existence to dog, wolf, fox, and their similar. The members of this family came from this form (al-miskh).

From such statements, some have gone on to contend how this is the first zoological account which discusses biological evolution in the Muslim world (Bayrakdar 1983; Shah 2010, 142). Two points need to be addressed here. First, it has been argued that the treatise itself is not strictly a biological account of nature even though it contains empirical observations. Consider Elshakry $(2014,269)$ who believes that al-Jāhiz's book "is not so much a zoological treatise as ... its emphasis was on philosophical and religious edification," and points out how some thinkers have read al-Jāhiz’s work selectively while ignoring his other points such as "the transformation by God of sinful nations or peoples into pigs, apes, and other 'lower creatures." Similarly, but much more potently, Mansūr (1977, 299-301) astutely highlights that al-Jāhiz discussed the broader ontological interconnectedness between metaphysical entities such as God, angels and demons with the animal kingdom (while, of course, also acknowledging their differences), clearly indicating a broader purpose rather than a simple treatise on zoology. Egerton $(2002,143)$ also remains unconvinced of a zoological reading, but he points out that al-Jāhiz does deserve the credit for mentioning the ideas of food chains (even though they were incorrect on some occasions ${ }^{9}$ ):

The mosquitoes go out to look for their food as they know instinctively that blood is the thing which makes them live. As soon as they see the elephant, hippopotamus or any other animal, they know that the skin has been fashioned to serve them as food; and falling on it, they pierce it with their proboscises, certain that their thrusts are piercing deep enough and are capable of reaching down to draw the blood. Flies in their turn, although they feed on many and various things, principally hunt the mosquito ... All animals, in short, cannot exist without food, neither can the hunting animal escape being hunted in his turn.

Second, Bayrakdar's claim that al-Jāhị believed in evolution based on the quote he provides does not actually indicate that he actually does. Careful attention to Bayrakdar's quotation reveals that it isn't actually al-Jāhiz's opinion; rather, al-Jāhiz is relaying an account of what others believed. More importantly, when the primary text is read carefully, it becomes apparent that Bayrakdar actually mistranslated and selectively quoted 
sentences from a wider paragraph. The full paragraph reads as follows (Al-Jāḥiz 1938a, 68):

The people said different things about the miskh. Some of them said that the miskh doesn't reproduce or doesn't remain (or survive) except as a lesson to mankind, and they [the people] were sure about that evidence. And some of them said that the miskh does remain. So they considered lizards, eels, rabbits, dogs, and other animals from the descendents of those that were metamorphosed into that form [miskb]. They say the same of snakes. ${ }^{10}$

Having quoted the original text, it is noteworthy to clarify three things. First, Bayrakdar translates miskh as quadrupeds, which is incorrect. Miskh actually translates into the transformation or the metamorphosis of an entity into an animal (Cowan 1976, 908). It is derived from a well-known account in the Qur'ān in which a certain group of people were transformed into apes and pigs by God as divine punishment (Qur'ān 5:60; 2:65; 7:166) ${ }^{11}$ Bayrakdar's translation of it as quadruped seems to be idiosyncratic. Second, in light of the correction of miskh, the discussion of animals evolving is strictly within the subject domain of the miskb and not a general discussion that applies to all creatures. Third, it should be evident that in this paragraph, al-Jāhiz compares two perspectives and doesn't mention his own stance. So to characterise al-Jāhị as a pro-evolutionary thinker based on this paragraph is erroneous.

By contrast, al-Jāhiz rejected any kind of evolution from one species into another (Mansūr 1977, 280-281):

$\ldots$ in spite of a certain resemblance ... with man the monkey does not pass beyond the limitations of the monkeys to enter the boundaries of man. This means also that the monkey is confined to its own species. The similarity between man and animal ... does not go beyond the limit of resemblance in al-Jāhiz's outlook. It may happen that a thing possesses an element similar to something else, but this does not mean at all that either of the two things will depart from the rules and limits of its own nature. Nothing that resembles man is ever able actually to cross the boundary of human nature and become man. What is true of animals holds also of man; man does not forsake his nature to take on theirs. It is clear ... that al-Jāhiz completely rejected the possibility of the transformation of one species to another. Furthermore, he rejected the gradual development in animal life. ${ }^{12}$

Interestingly, Mansūr $(1977,282)$ takes al-Jāḥiz’s rejection and indicates that some proto-evolutionary ideas could have been present and discussed at the time. 
In summary, even though al-Jāhiiz may have described various observations of the animal and plant kingdom in terms of food chains, environmental factors and physical similarities, it does not follow that he believed in macroevolution (Stott 2012, 55). His empirical observations may be similar to what we believe and know today, but he does not provide any grand narrative that parallels with any kind of explanation where species evolve from one to the other. On the contrary, he believed in the fixation of species which is an immediate indication that he developed or adopted a version of the GCB. This is further substantiated with his inclusive mention and discussion of metaphysical entities, as highlighted earlier. Restricting al-Jāhiż's work to selective empirical observations or evolution-friendly quotations insulates the reader from his wider framework, which makes it impossible to draw an alternative reading, and is where the confusion arises. Nonetheless, it can be concluded that al-Jāhiz, like the thinkers discussed before, did not adopt an evolutionary framework.

\section{Ikbwān al-Ṣafā (Brethren of Purity)}

The Brethren of Purity are, by far, one of the more interesting cases. They have been quoted with similar paragraphs as discussed of Ibn Khaldūn and Rūmī (Shanavas 2010, 118; Guessoum 2011, 271; 307), so we needn't repeat the criticism here. It is well-known that the Brethren of Purity were Neoplatonists, and their worldview was saturated with all sorts of hierarchal structures and relationships (Netton 1991, 36; El-Bizri 2014). So such quotations are undoubtedly about the GCB. However, the most interesting feature of the Brethren of Purity is that in addition to the ontological hierarchy there seems to be a temporal aspect to their worldview unlike the previous thinkers we've looked at (Fakhry 2004, 177-178):

... according to the Brethren, there is in addition a certain chronological order which they follow, amounting almost to an anticipation of Darwinian evolution. Thus plants precede animals in the order of their appearance in the world, since they are to them what matter is to form. Similarly the lower animals 'have preceded the more perfect, at the beginning of creation, in so far as they take a shorter time to develop, compared with the more perfect, which take a longer time ... Moreover, sea animals have preceded land animals by a long stretch, because water came before earth, and the sear before dry land, at the beginning of creation.' The appearance of animals generally upon the globe must therefore have come after plants, and prepared the ground for the appearance of man, for whose sake not only the animal kingdom but everything else beneath it were created.

It is this particular feature which makes interpreting them tractable to evolutionary readings. For example, Malik et al. $(2017,7)$ mention the 
following quote from the Brethren of Purity as evidence of them being evolutionists:

Plants come before (taqaddama) animals in the series of beings and serve them as material for the forms of animals and food for the nutrition of their bodies. From this point of view, plants would be like a mother who eats raw food, digests it, assimilates it and transforms it into pure milk which is absorbed very gently by those who drink it. The plants subsequently present this to the animals considered as their sons ... Plants occupy an intermediate position-necessary and salutary-between the four elements and the animals. All the parts of the vegetables which the animals consume such as seeds, leaves, fruit, and so on, come from the four elements digested and transformed by the plants ...

However, to fully appreciate such quotations from their work, we must carefully unpack their worldview before we can decisively render any evolution-friendly interpretations. Neoplatonists believed in an ontological hierarchy with man in the centre, the midpoint between the material and immaterial world. There are three kingdoms within the material world: minerals, plants, and animals. Each tier acts as sustenance for the ranks above it. So minerals fed plants which in turn fed animals. The culmination of these ranks and sustenance end with man, beyond which there will be no further gradation of physical forms. Once man reaches a state of spirituality that allows him to enter that reunion with God, the "process" ends. Thus, Nasr $(1978,73)$ states:

Man's 'evolution' is therefore inward; God does not create something after man as he created man after the animals, because man, by virtue of being able to return to his origin, fulfills the purpose of the whole of creation. All the other orders of beings were created in order that this final stage of reunion might take place. Once the reunion has occurred, there is no metaphysical necessity for another form to be created. Man is the link between the three kingdoms and the heavens and therefore the channel of grace for the terrestrial environment; the three kingdoms depend upon him, and man in turn has the right to make use of them.

It can be gathered from this that the Brethren of Purity spoke largely in spiritual and teleological terms that aligned with the GCB. So the previous quote by Malik et al. (2017) has to be situated within a broader metaphysical scheme rather than a simple material observation. Up to this point, it can be argued that this can perfectly align with evolution. It can, but the Brethren of Purity do not stop there. As Neoplatonists, they believed in the fixation of species or natural kinds in the world of "ideas" that manifest 
into particulars in this shadow-like world. This is explicitly mentioned in their own words (quoted in Nasr 1978, 73):

The species and genus are definite and preserved. Their forms are in matter. But the individuals are in perpetual flow; they are neither definite nor preserved. The reason for the conservation of forms, genus and species, in matter is the fixity of their celestial cause because their efficient cause is the Universal Soul of the spheres instead of the change and continuous flux of individuals which is due to the variability of their cause.

In other words, there is fluidity in particulars, but not essences. It follows from this that the Brethren of Purity occupied no conception of the biological derivation of latter species from earlier ones since every species is fixed; each one is an ontological and immutable designation defined by God who has set the spatial, temporal and adaptive boundaries of each kind (Goodman and McGregor 2012, 31). Each species is elected (rather than naturally selected) to manifest a certain function in the grand scheme of things in coordination with the heavenly spheres (Goodman and McGregor 2012, 30):

Every creature's tenure is no more than God has allotted. Animals, humans, jinn - every kind has its domain and its moment. Each species has its habitat and mode of life, the implements and skills it needs to carry on - to reproduce, in the case of higher animals; or to be reborn, for those that seem to arise by spontaneous generation. Ants and bees industriously stow their stores and guard their young. But even the careless grasshopper and negligent ostrich are looked after. So their kinds persist - but not forever. Each kind endures or flourishes for just the era God has allotted, marked out by the revolutions of the planets and the spheres.

Accordingly, there is no temporal sequence in the biological sense but instead atemporal divine prescriptions of ontological slots in alignment with the GCB that happen to have temporal implications. Even ideas such as "adaption" need to be carefully understood as divine settings rather than material correlations (Nasr 1978, 74):

... 'Adaptation to the environment' is not the result of struggles for life or 'survival of the fittest,' but comes from the wisdom of the Creator, Who has given to each creature what corresponds to its need. In the deepest sense, what separates all these ideas of the Ikhwān from their modern counterparts is that for the Ikhwān the hands of God were not cut off from creation after the beginning of the world-as is the case with the deists. On the contrary, every event here 'below' is performed from 'above' by the Universal Soul, which is God's agent. 
This makes the terrestrial similarities, e.g. plants coming before animals, observed between the worldview of the Brethren of Purity and evolution accidental and not correlative in any substantial sense. It is indeed astonishing that even as early as 1903 a philosopher by the name of Tjitze de Boer (1903, 91-92) noted the problem of mischaracterising the Brethren of Purity as evolutionists, and attempted to rectify this reading:

They [Brethren of Purity] have been represented as the Darwinists of the tenth century, but nothing could be more inappropriate. The various realms of nature, it is true, yield according to the Encyclopaedia an ascending and connected series; but the relation is not bodily structure, but by the inner form of substance. The form wanders in mystic fashion from the lower to the higher and vice versa, not in accordance with inner laws of formation, or modified to suit external conditions, but in accordance with the influences of the stars, and, in the case of man at least, in accordance with practical and theoretical behaviour. To give a history of evolution in the modern of the term was very far from the thought of the Brethren. For example, they expressly insist that the horse and the elephant resemble man more than the ape does, although the bodily likeness is greater than the last-named. In fact in their system the body is a matter of quite secondary consideration: the death of the body is called the birth of the soul. The soul alone is an efficient existence, which procures the body for itself.

It can be concluded that with the constant imbuement of God or His agents (e.g. Universal Soul) as proximate causes, the terminology and the frame of reference for the Brethren of Purity is largely teleological and spiritual in nature rather than a mechanical one (Hameed 2014; Shah 2010, 148-149). More importantly, they denied any transformations of species, which is a marked difference with evolution. So there is no evolution of species over time as advocated in the latter even though a temporal chronology can be found in their works. Relying simply on their broad terrestrial chronology renders an evolution-friendly reading that is acontextual, ahistorical and anachronistic. At best, the observed similarities between evolution and the worldview of the Brethren of Purity are nothing but superficial.

\section{Conclusion}

From the preceding analysis of the three thinkers and one group, it seems, that their quotations have been taken in isolation without realising their underlying themes and context. These works are premised on the GCB, which is remarkably different in terms of its conceptual underpinnings when compared to modern evolution. Thus, these works only suggest an evolutionary reading when read selectively. This is evidenced by the language used and the consistent conceptual schemes that join physical entities, 
e.g. plans, animals and man, with metaphysical ones such as angels found in their works. Reading evolution onto such historical works of Muslim authors is erroneous, and contemporary thinkers need to be aware of it from falling prey to such errors. If these texts are being used to have some respectful connection between modern science and Islamic intellectual history, then this is not the best way to go forward.

It could be countered that they could be read as evolutionary texts but aren't because of bad renderings of the translations since most of these are in Arabic or Farsi as in the case of Rūmī (Hameed 2014). This is a plausible argument but not necessarily a strong one. It is very difficult to believe that entire conceptual schemes can be reduced to bad translations. It is possible to stretch a word to certain renderings, but it is negligent to divorce an entire worldview, a conceptual infrastructure which these works are premised on. When viewed holistically, it seems that these works here have been read superficially and selectively, as has been demonstrated here (also see Iqbal 2003)..$^{13}$

That said, the possibility of historical documents revealing a close parallel to modern-day evolution is not being dismissed. It may very well be that there remain yet undiscovered manuscripts that genuinely discuss some prototype theories of evolution as it is understood today, i.e. species changing over time, but as far as the author is concerned such works have not yet materialised. At least for the works that have been reviewed here, readers should remain cautious.

\section{Notes}

1 For an excellent historical overview of this concept, see Lovejoy (2009).

2 However, see Ungureanu (2019), which offers a different perspective of this narrative.

3 He isn't alone in thinking this. Shah $(2010,153-154)$ believes that Darwin knew Arabic and was familiar with these historical works, which laid down the foundations for his theory.

4 See footnote 79 in chapter 9 in Guessoum $(2011,393)$.

5 Recall the quote earlier by Chittick (2017).

6 It is surprising to find the same misquotation in the work of the iconoclast, Muhammad Iqbal (2012, 121-122). It can even be found in the works of contemporary authors such as Dajani (2016).

7 The following is the original text in Farsi with the missing couplets emphasised:

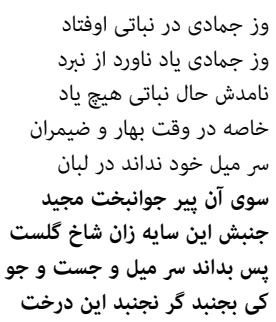

وز جمادى در نباتى اوفتاد

وز جمادى ياد ناورد از نبرد

خاصه در وقت بهار و ضيمران

سر ميل خود نداند در لبان

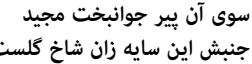

كى بجنبد كر نجنبد اين درخت

$$
\begin{aligned}
& \text { آدمه اول به اقليم جماد } \\
& \text { سالها اندر نباتى عمر كرد } \\
& \text { وز نباتى جون به حيوانى فيلى فئاد } \\
& \text { جز همين ميلى كه دارد سوى آن } \\
& \text { همجيو ميل كودكان با مادران } \\
& \text { همجيو ميل مفرط هر نو مريد ادريد } \\
& \text { جزو عقل اين از آن عقل كلست مرت مريل } \\
& \text { سايهاش فانى شود آخر درو آن آن } \\
& \text { سائُ شاخ دكر ای نيكبخت }
\end{aligned}
$$




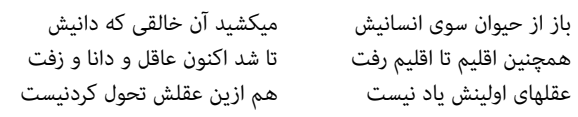

8 The following is his Mojadedi's translation of the missing couplets:

"Like what disciples feel fill up inside Drawing them to the Sufi Master's side. The Universal Intellect's the source Of this: the shadow trails its source of course.

The shadow fades in him eventually And he attains the strong pull's mystery.

How can another branch's shadow shake If this tree doesn't move. That's a mistake."

9 For example, Egerton $(2002,143)$ notes that al-Jāhiz claimed that the lizard could hunt snakes down.

10 The following is the original text in Arabic:

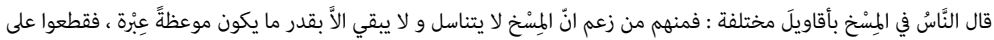

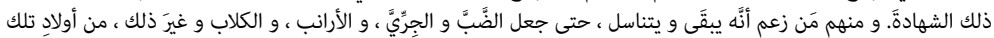

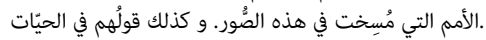

11 For an excellent historical analysis of metamorphosis in Islamic thought, see Cook (1999).

12 See al-Jāhiz (1938b, 211-215).

13 It is interesting to note that Wilczynski (1959) wrote a similar critique for people reading Darwinism in al-Birūn̄̄'s works. This is one of the eight scholars that Malik et al. (2017) looked at when claiming that historical Muslim scholars discussed evolutionary theories.

\section{References}

Al-Jāḥiz. 1938a. Kitāb Al Hayawān. Volume 4. Cairo: Muṣtafā al-Bābī al-Halabī. Al-Jāḥiž. 1938b. Kitāb Al Hayawān. Volume 1. Cairo: Muṣtafā al-Bābī al-Halabī. Bayrakdar, Mehmet. 1983. "Al-Jāhiz and the Rise of Biological Evolutionism.” Islam Quarterly, 21: 149-155.

Chittick, William C. 2013. “The Evolutionary Psychology of Jalal al-Dīn Rumī.” In Peter J. Chelkowski, ed. Crafting the Intangible: Persian Literature and Mysticism. University of Utah Press: Salt Lake City, 70-90.

Chittick, William C. 2017. "RUMĪ, JALĀL-AL-DĪN vii. Philosophy," Encyclopcedia Iranica. Accessed 5th February 2019. Available at: http://www.iranicaonline.org/ articles/rumi-philosophy

Cook, Michael. 1999. "Ibn Qutayba and The Monkey.” Studia Islamica, 89: 43-74.

Dajani, Rana. 2016. "Evolution and Islam: Is There a Contradiction?" Paper Presented at Islam and Science: Muslim Responses to Science's Big Questions, London and Islamabad.

de Boer, Tjitze J. 1903. The History of Philosophy in Islam. London: London Luzac. Draper, John William. 1875. History of the Conflict between Religion and Science. New York, NY: D. Appleton and Company.

Egerton, Frank N. 2002. "A History of the Ecological Sciences, Part 6: Arabic Language Science: Origins and Zoological Writings." Bulletin of the Ecological Society of America, 83(2): 142-146. 
El-Bizri, Nader. 2014. The Ikhwan al-Safa and Their Rasail. Oxford: Oxford University Press.

Elshakry, Marwa. 2014. Reading Darwin in Arabic, 1860-1950. Chicago, IL: The University of Chicago Press.

Fakhry, Majid. 2004. A History of Islamic Philosophy. New York, NY: Columbia University Press.

Futuyma, Douglas J., and Mark Kirkpatrick. 2017. Evolution. Sunderland: Sinauer Associates, Inc.

Ghafouri-Fard, Soudeh, and Seyed Mohammad Akrami. 2011. "Man Evolution: An Islamic Point of View." European Journal of Science and Theology 7(3), 17-28.

Goodman, Lenn E., and Richard McGregor. 2012. The Case of Animals Versus Man: Before the King of the Jinn - A Translation from the Epistles of the Brethren of Purity. Oxford: Oxford University Press.

Guessoum, Nidhal. 2011. Islam's Quantum Question: Reconciling Muslim Tradition and Modern Science. London: I.B. Tauris.

Hakim, Khalifa Abdul. 1959. The Metaphysics of Rumi: A Critical and Historical Approach. Lahore: The Institute of Islamic Culture.

Hamad, Mawieh. 2007. "Islamic Roots to the Theory of Evolution: The Ignored History." Rivista di Biologia, 100(2): 173-178.

Hameed, Salman. 2011. "Evolution and Creationism in the Islamic World." In Thomas Dixon, Geoffrey Cantor, and Stephen Pumfrey, eds. Science and Religion: New Historical Perspective. Cambridge: Cambridge University Press, 133-154.

Hameed, Salman. 2014. "Evolution of Species, Islamic Ideas.” In Amils R. et al. eds. Encyclopedia of Astrobiology. Berlin: Springer.

Ibn Khaldūn, Abū Zayd 'Abd ar-Raḥmān Ibn Muhammad. 2005. The Muqaddimah. trans. by Franz Rosenthal. New Jersey, NY: Princeton University Press.

Iqbal, Muzaffar. 2003. "Biological Origins: Traditional and Contemporary Perspectives.” Islamic Herald. Accessed 1st of October 2019. Available at: http://saif_ w.tripod.com/curious/evolution/muz/biological_origins.htm

Iqbal, Muhammad. 2012. The Reconstruction of Religious Thought in Islam. New Delhi: Kitab Bhavan.

Kartenegara, Mulyadhi. 2016. "Rumi on the Living Earth: A Sufi Perspective.” In Mohammad Hashim Kamali, Osman Bakar, Dauf Abul-Fattah Batchelor, and Rugayah Hashim, eds. Islamic Perspectives on Science and Technology: Selected Conference Papers. Singapore: Springer.

Kaya, Veysel. 2011. "Can the Quran Support Darwin? An Evolutionist Approach by Two Turkish Scholars after the Foundation of the Turkish Republic.” The Muslim World, 102: 357-370.

Kruk, Remke. 1995. "Traditional Islamic Views of Apes and Monkeys.” In Frank Spencer, Raymond Corbey, and Bert Theunissen, eds. Ape, Man, Apeman: Changing Views Since 1600. Leiden: Leiden University.

Lovejoy, Arthur Oncken. 2009. The Great Chain of Being: A Study of the History of an Idea. New Jersey, NY: Transaction Publishers.

Malik, Amina H., Janine M. Ziermann, and Rui Diogo. 2017. “An Untold Story in Biology: The Historical Continuity of Evolutionary Ideas of Muslim Scholars From the 8th Century to Darwin's Time." Journal of Biological Education, 52(1): $1-15$.

Mansūr, Sa īd H. 1977. The Worldview of al-Jāhiziz in Kitāb al-Hayawān. Alexandria: Dār al-Ma'ārif. 
Mojaddedi, Jawid. 2017. The Masnavi: Book Four. Oxford: Oxford University Press. Montgomery, James E. 2013. Al-Jāhiz: In Praise of Books. Edinburgh: Edinburgh University Press.

Morewidge, Parviz. 1992. "The Neoplatonic Structure of Some Islamic Mystical Doctrines.” In Parviz Morewedge, ed. Neoplatonism in Islamic Thought. Albany, NY: State University of New York Press.

Nasr, Seyyed Hossein. 1978. An Introduction to Islamic Cosmological Doctrines. Bath: The Pitman Press.

Netton, Ian R. 1991. Muslim Neoplatonists: An Introduction to the Thought of the Brethren of Purity. Edinburgh: Edinburgh University Press.

Netton, Ian R. 2003. “The Brethren of Purity (Ikhwān Al-Ṣafā).” In Seyyed Hossein Nasr and Oliver Leaman, eds. The History of Islamic Philosophy. New York, NY: Routledge.

Pollock, Sheldon. 2009. "Future Philology? The Fate of a Soft Science in a Hard World.” Critical Inquiry, 35(4): 931-961.

Principe, Lawrence M. 2016. "Scientism and Religion of Science." In Richard N. Williams and Daniel N. Robinson, eds. Scientism: The New Orthodoxy. London: Bloomsbury, 41-62.

Rūmī, Jalāl ad-Dīn. 2003. The Mathnawi. Volume IV. trans. by Reynold A. Nicholson. Karachi: Darul Ishaat.

Russel, Colin A. 2002. "Conflict of Science and Religion.” In Gary B. Ferngren, ed. Science and Religion: A Historical Introduction. Baltimore, MD: The John Hopkins University Press, 3-12.

Shah, Muhammad Sultan. 2010. Evolution and Creation: Islamic Perspective. Mansehra: Society for Interaction of Religion, Science and Technology.

Shanavas, T. O. 2010. Islamic Theory of Evolution: The Missing Link between Darwin and the Origin of Species. USA: Brainbow Press.

Stearns, Stephen C., and Rolf F. Hoekstra. 2005. Evolution: An Introduction. Oxford: Oxford University Press.

Stott, Rebecca. 2012. Darwin's Ghost's: The Secret History of Evolution. New York, NY: Spiegel and Grau.

Twetten, David. 2017. “Arabic Cosmology and the Physics of Cosmic Motion.” In Richard C. Taylo, and Luis Xavier López-Farjeat, eds. The Routledge Companion to Islamic Philosophy. Abingdon: Routledge, 156-167.

Ungureanu, James C. 2019. Science, Religion, and the Protestant Tradition: Retracting the Origins of the Conflict. Pittsburgh, PA: University of Pittsburgh Press.

Wehr, Hans, and Cowan, J. Milton. 1976. A Dictionary of Modern Written Arabic. New York: Spoken Language Services, Inc.

Wilczynski, Jan Z. 1959. "On the Presumed Darwinism of Alberuni Eight Hundred Years Before Darwin.” History of Science Society, 50(4): 459-466.

Wildberg, Christian. 2016. "Neoplatonism." The Stanford Encyclopaedia of Philosophy. Accessed 3rd of November 2020. Available at: https://plato.stanford. edu/archives/spr2016/entries/neoplatonism/ 
Part 3

Metaphysical considerations 


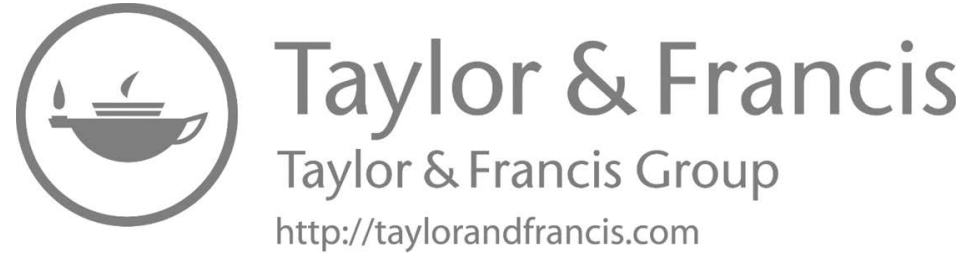




\section{Chance, naturalism, and inefficiency}

\section{Introduction}

There were many strands of thought in Islamic intellectual history. A particular strand is known as kalām - loosely translated as scholastic theology (though not exhaustively ${ }^{1}$ ) - was primarily represented by three schools of thought: Mu'tazilism, Ash 'arism, and Māturīdism (Jackson 2009). For various reasons, Ash arism and Māturīdism came to be historically recognised as Sunnī orthodoxy (alongside a non-kalāmic group known as Atharism; Winters 2008; Schmidtke 2014). Al-Ghazālī (2000; 2013; 2016) belonged to the Ash arite school and wrote several treatises that systematically developed and codified the edifice of the Ash arite creed. In this chapter, we shall be reviewing some of the central tenets of this perspective insofar they aid us with addressing the concerns related to evolution. The specific problems that will be dealt with in this chapter are the problem of naturalism (PON), the problem of chance (POC), and the problem of inefficiency (POI). To this end, the structure of the chapter is as follows.

First, we shall briefly outline and review the general ideas of the Ash arite perspective. This will set the stage for this chapter as well as Chapters 7 and 8 . The next section will introduce the recent developments in science and religion, namely the Divine Action Project (DAP). This will serve as a useful point of comparison for understanding the Ash'arite paradigm. The following section will deal with the PON. As we saw in Chapter 4, some thinkers associate evolution with naturalism and atheism, so it is important to determine if this is the only way to understand evolution. The second contention that will be dealt with is the POC. There are two dimensions to this particular problem. One concern is how chance relates to God. If God operates in a chance-like manner, does this entail He doesn't know what $\mathrm{He}$ is doing? Or does chance somehow undermine His omnipotence and omniscience? The second concern is related to chance is teleology, i.e. purposes in nature. If the entire creation process of life was based on a chancebased process like evolution, does that mean humans were accidental or lucky creations? How does this relate to Islamic scripture wherein it states that God created humans to worship Him? The third and final issue we 
shall be dealing with is the POI. It seems God hasn't optimised the world for maximal efficiency; many animals have suffered died in this enduring process. Couldn't God could have created biological entities without such a long and arduous process that led to so much biological waste? In other words, the general concern with this problem is that God's design of the world is poor, and $\mathrm{He}$ could have done a much better job.

It shall be shown that none of these concerns are issues within the Ash'arite framework. Each of these issues can be qualified in a certain way that can make them unproblematic. However, these questions do have a bearing on other issues such as the idea of design and issues related to morality. These discussions will be postponed to Chapters 7 and 8, respectively, since they deserve an independent treatment. Finally, this chapter uses many abbreviations. These have been summarised and tabulated in the Note affixed at the end of this sentence. ${ }^{2}$

\section{The Ash'arite school}

The specific worldview of Ash 'arite kalām rests on two different philosophical constructs that were systematically and creatively merged together by practitioners of kaläm (mutakallimün). These are occasionalism and atomism (Malik 2019). Occasionalism is a divine action model which informs us how God interacts with the world. In this perspective, God is the primary cause of absolutely everything. All of creation, e.g. atoms, plants, animals, humans, planets, universe, galaxies, and even multiverses (alongside everything else in creation), fundamentally rely on God for their existence as well as their active and passive causal properties. It is usually contrasted with deism, which is where creation runs independently without any further sustainment from God once created by Him (Larmer 2014, 7-23). In this perspective, creation becomes independent from the creator similar to how a watch becomes independent from its watchmaker once built and functioning. Between occasionalism and deism are various divine action models that have been explored in contemporary dialogues of science and religion (Lee 2020).

Atomism is a position of ontology and informs us about the world's furniture (Koca 2020, 29-32). As the name suggests, Ash arites believe that created entities can be broken down into fundamental atomistic units. Atomism was employed to ensure that creation stayed limited and avoided absurdities; they rationalised that an eventual endpoint in how far creation could be divided into its constituents was needed, else the universe could be divided ad infinitum which was illogical. Shlomo Pines $(1997,15)$ provides an example of such an illogical implication that can be commonly be found in the works of the practitioners of kalām: "If bodies were infinitely divisible, then a seed of mustard ... would necessarily consist of as many parts as a mountain." To be clear, Ash 'arites not only understand matter to be atomistic, but every other categorical unit as well. So it's not just matter, but categories like time are also atomistic. The main point to take from 
all this is they viewed creation in discrete terms (Pines 1997; Altaie 2016, 16-18; Hassan 2020; Ibrahim 2020).

Both occasionalism and atomism were utilised for different reasons. The primary motivation for holding on to occasionalism was to make sure that God's absolute power could not be locked out by any natural laws as a matter of causal necessity as held by rival worldviews, ${ }^{3}$ and to ensure that His involvement would not be expelled from the constant affairs of the world at any moment. Furthermore, occasionalism was a position that attracted the practitioners of kala $m$ because it eliminated the idea of any intrinsic power (i.e. power in virtue of its essence) that was thought to belong to nature in the ontological sense, thus treating nature (including humans themselves) as the manifestation, an interface of some sort, of God's absolute will. Atomism was adopted to show that creation was fundamentally a limited thing over which God had absolute control. By directly forging a link between God and the fundamental units of the world, Ash 'arites maintained that there is no intrinsic power in nature and instead is under God's total and extrinsic control. In this framework, God is (re-)creating the entire universe from nonexistence into existence every moment (Koca 2020, 32-34). By way of analogy, the world is like the refresh rate on a computer screen where God is controlling every pixel in every time slice. Creation, then, is fundamentally contingent and is constantly being (re-)created.

It does need to be pointed out that occasionalism and atomism are logically independent of one another. Occasionalism doesn't entail atomism and nor does atomism entail occasionalism. In relation to the aims of this work, the main emphasis will be on occasionalism. Atomism played a significant role in the development of Ash arism historically (and perhaps even now $^{4}$ ) but it isn't significantly important for this presentation except for heuristic purposes. ${ }^{5}$ To get specifics on the Ash arite paradigm, we will be using al-Ghazālì's account to understand God's nature, His capabilities, the nature of creation, and the laws of nature.

\section{God's will, knowledge, and power}

In the Ash arite paradigm, God is understood to have essential characteristics, three of which are directly relevant to the question of creation. There is His will (irāda), knowledge ('ilm), and power (qudra). Al-Ghazālī $(2000,22)$ defines his conception of God's will as follows:

The world came to existence whence it did, having the description with which it came to exist, and in the place in which it came to exist, through will, will being an attribute whose function is to differentiate a thing from its similar. If this were not its function, then power would be sufficient. But since the relation of power to two contraries is the same and there was an inescapable need for a specifying [agent] that would specify one thing from its similar, it was said: 'The Eternal has, 
beyond power, an attribute that has as its function the specifying of one thing from its similar.' Hence, someone's statement, 'Why did the will specifically relate to one of the two similars?' is akin to the statement, 'Why does knowledge entail as a requirement the encompassing of the object of knowledge as it is?' For [to the latter] one would reply, 'This is because 'knowledge' stands as an expression for an attribute that has this as a function.' Similarly, 'Will stands as an expression for an attribute whose function-nay, its essence-is to differentiate a thing from its similar.'

In this paragraph, al-Ghazāli defines the will as the function that can distinguish between several alternatives. If this were not the case, then power would be sufficient on its own. But power doesn't have the capacity to choose; rather, it enacts or manifests the selected option. For example, a heavyweight lifter may have the power to lift a hundred kilograms, but on a particular day, he may choose to lift five, ten, fifty or a hundred. The will, then, is different to power. But somewhat not explicitly clear in this paragraph is how knowledge is a prerequisite of will. If one doesn't know the alternatives, one cannot choose one among others (Al-Ghazālī 2016, 8-10).

In another place, al-Ghazālī $(2013,104)$ effectively writes how God "chooses" from an infinite number of possible worlds:

It might be asked: "Is there an end to what He knows?" We say "No, for although the existents at the present are finite, the possible existents in the future are infinite. He knows with respect all the possible things that do not exist now whether He will bring them into existence or not. Therefore, what He knows is infinite. In fact, if we want to multiply the aspects of a single object by considering different relations and magnitudes, these aspects would exceed any finite limit; and God knows of these.

Of course, the "choosing" of God is far removed from any conception of human choices. Since God is eternal, atemporal, and non-spatial, His choice is unlike any human endeavour (Al-Ghazālī 2016, 4-6; Kraft 2016).

\section{Divine capabilities}

A fundamental principle in the Ash arite paradigm is God can do anything that is logically possible. So God could if He wanted to create threeheaded human beings, unicorns, vampires, and anything else that we can render to be logically possible are all within the power of God (Al-Ghazālī 2000, 175):

The impossible is not within the power [of being enacted]. The impossible consists in affirming a thing conjointly with denying it, affirming 
the more specific while denying the more general, or affirming two things while negating one [of them]. What does not reduce to this is not impossible, and what is not impossible is within [divine] power.

What is logically impossible is not within divine power (Al-Ghazālī 2000, 38):

For, in supposing the world larger or smaller than it is by a cubit, ${ }^{6}$ the mind is not supposing what is akin to conjoining blackness and whiteness in one and the same place: namely, existence and nonexistence. The impossible consists of conjoining negation and affirmation. All impossibilities reduce to this.

Thus, al-Ghazālī's understanding of divine power was that it had to be bound by the law of non-contradiction: united contraries are not realisable because they are impossible, but all else is realisable and therefore possible. This means whatever God creates is bound by logical possibility (Kukkonen 2000a; Kukkonen 2000b; Kukkonen 2006). Things like a squared circle to which divine power does not apply are not possible because they are illogical. Related to divine capabilities is the notion of what God can morally command. This will be dealt with in Chapter 8. But in short, moral considerations do not trump God's capabilities in the Ash'arite paradigm.

\section{The contingency of the creation}

Regarding creation, everything that God has created or could create is fundamentally contingent (Ormsby 2017, 52-55). Think of a car. A car can be customised in several different ways. It could have a different engine, colour, seating arrangement, internal display, and many other variables for car design. The same point can be extrapolated to the whole universe. The universe, like the car, is a contingent thing. However, we should keep in mind two different types of contingencies.

The first kind of contingency is related to mere existence versus nonexistence. God has the absolute power to bring things into existence or keep them in nonexistence. The universe did not have to be created, but He chose to bring our universe into existence instead of nonexistence. Al-Ghazālī (2013, 28-29) writes:

For we mean by 'occurrent' that which was non-existent and then became existent. Thus we say: 'Was its existence before it existed impossible or contingent?' It is false that it was impossible, since what is impossible can never exist. If it was contingent, then we mean by 'contingent' only that which is possible to exist and is possible not to exist. However, it was not a necessary existent, because its existence is not necessitated by its essence; for if its existence were necessitated by its essence, it would be necessary, not contingent. In fact, its existence 
was deprived of that which would give it preponderance over nonexistence preponderance, which would change nonexistence into existence. If its nonexistence continues, then that is because there is nothing that gives preponderance to existence over nonexistence; for so long as there is nothing that gives this preponderance, existence does not come about.

The second kind of existence is related to how things are once they do exist. The universe has a particular configuration. It has specific laws of nature that govern our planets, biology, and chemistry. But God could have created a different universe with different laws. Think of the periodic table as another example. Currently, there are 118 chemical elements in the periodic table. But God could have created a universe in which there are different elements or perhaps even no elements. Al-Ghazālī $(2000,37)$ makes a similar argument with the size of the universe as an example:

'Did it lie within God's power to create the highest heaven greater in thickness by one cubit than the one He had created?' If they say, 'No' this would be [the attribution to Him of] impotence. If they say, 'Yes,' then [it follows that God could have created it] greater by two cubits, three cubits, and so on, ascending ad infinitum.

So here al-Ghazāli is alluding to the idea that there is nothing intrinsically necessary in creation. ${ }^{7}$ Everything is contingent, and it is completely up to how God wants to arrange or create his creation (Davidson 1987, 154-212; Kukkonen 2000a; Al-Ghazālī 2016, 14). ${ }^{8}$

\section{Laws of nature}

The previous points need to be tied to the discussion on the laws of nature. In the Ash 'arite paradigm, God doesn't merely create, but He also actively sustains every moment. Accordingly, the laws of nature are not just contingent with respect to the universe, i.e. they could be different from what they are now, but also from one moment to another. If we think of the universe as a collection of moments (atomic time?), each moment is sustained by God. At each moment, God chooses what to manifest. So He can choose to sustain the same activity, which gives us our laws of nature, or He can choose to change those laws which give us things like miracles. In other words, the causal connections between physical things that science aims to understand are contingent upon the will of God (Al-Ghazālī 2000, 166):

The connection between what is habitually believed to be a cause and what is habitually believed to be an effect is not necessary, according to us ... Their connection is due to the prior decree of God, who creates them side by side, not to its being necessary in itself, incapable of 
separation. On the contrary, it is within [divine] power to create satiety without eating, to create death without decapitation, to continue life after decapitation, and so on to all connected things.

Two things need to be highlighted about this point. First, we should distinguish between logical necessity and physical necessity. An example of the former are things like mathematics. One plus one must necessarily equal to two, and this is logically necessary. It cannot be anything else, and to say otherwise is illogical. However, to say things like fire causes cotton to burn is not intrinsically necessary. These things are determined through habitual experimentation. They are open to what the experiences and experiments yield to us. We could have lived in a different universe where perhaps cotton does not burn when exposed to fire due to different laws of nature. So in that world, we wouldn't take it for granted that fire necessarily causes cotton to burn. Therefore, physical necessity isn't as sturdy as a logical necessity, which is why we do experiments in the first place. However, it should be made clear that while al-Ghazālī denies the stricter logical necessity between physical phenomena, he does not deny constant conjunction between physical phenomena (Koca 2020, 240). It is this repetitive element sustained by God (known as sunnat Allāh or ' $\bar{a} d a$ ) which is formed in our minds as laws of nature as expressed by al-Ghazālī $(2000,170)$ : “... the continuous habit of their occurrence repeatedly, one time after another, fixes unshakably in our minds the belief in their occurrence according to past habit." So occasionalism does not entail a rejection of science. Rather, it unearths the underlying metaphysical foundations of physical phenomena that are solely dependent on God's will. This is why Frank Griffel (2020) observes that a world governed by occasionalism of Ash arism is indistinguishable from a world governed by physical laws. ${ }^{9}$

Second, since God is an absolutely free agent that can do anything logically possible, God can create universes where there are no laws of nature. Imagine total chaos with no regularity whatsoever. In those kinds of worlds, science is not even possible since a basic requirement of science is that things occur regularly (be it deterministically or indeterministically, a distinction we shall unpack shortly). In other words, science relies on induction. For example, if we mixed two chemicals and get a different product every time, and thus no one reaction ever gives us the same product, we wouldn't be able to generalise a chemical law. Science rests on regular behaviour in nature (be it deterministic or indeterministic) without which science is impossible. But as mentioned by al-Ghazālī, physical causation is entirely contingent and dependent on the will of God. So determinations of science which in turn depend on the laws of nature are dependent on the will of God, but the reverse is not true. In other words, all scientific possibilities come under theological possibilities, but not all theological possibilities are scientifically possible. ${ }^{10}$ This is summarised in Figure 6.1. 


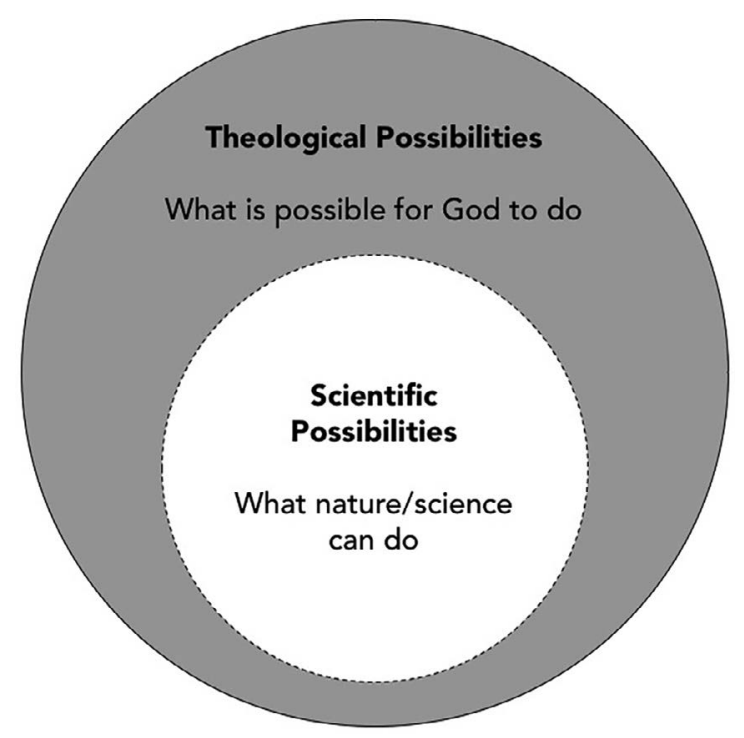

Figure 6.1 This shows two circles, one bigger than the other. The smaller one is a subset of the bigger one. The bigger circle represents theological possibilities while the smaller circle represents scientific possibilities. It is trying to illustrate that what God can do is much broader than what is scientifically possible.

\section{Free will}

While the question of free will is not strictly related to our treatment, a few things should be said on this matter. The key problem with occasionalism is that if God is the primary and absolute cause of everything, human free will comes into question. What does free will really mean if God controls and knows everything? It is challenging to reconcile God's omnipotence, omniscience and authentic free will of human beings. Therefore, Ash'arites are stuck with a massive theological conundrum.

In response to this problem, Ash arites developed a position known as the theory of acquisition (kasb) (Al-Ghazālī 2001, 36; Koca 2020, 34-38). In this theory, there seems to be a dual composition of human action. Humans will what they want to do, but the enaction of that will comes from God. So if a person wants to raise their hand and wills it, that comes from the individual, but the hand's actual moving is God doing it. The problem with this perspective is that if Ash arites believe God is in control of everything, what sense does it make to say that humans do the willing? Isn't God the fundamental anchor for all creations' activities? If so, then the willing done by humans is also under God's control. Given this problematic outcome of occasionalism, it is of no surprise to find that al-Ghazālī didn't know how to address this tension. For him, it seems, this matter is something that could perhaps be understood in spiritual 
terms, as not everything can be reduced to empiricism or ratiocination (Al-Ghazālī 2001; Marmura 2004; De Cillis 2016, 96-166; Al-Ghazālī 2016, 45-47; Rouzati 2018). As noted by Kurt $(2012,130)$, “... the essence of the spirit, as well as the quality of its relation to the body, remains unknown. According to classical theology, this relationship is a 'mystery' confined to the divine knowledge."

Despite this shroud of mystery, there have been philosophical attempts to salvage free will in light of occasionalism (Muhtaroglu 2010). Furthermore, there have been recent developments in analytical theology, namely contradictory theology, which could serve some kind of utility to address such theological discussions (Ahsan 2019; Chowdhury 2020; Ahsan 2021). Determining whether these proposals and research lines are valid or useful, and whether they can be incorporated in the Ash'arite paradigm is beyond the scope of this work. The key thing to note is that there is a known tension between authentic human free will and occasionalism in the Ash arite paradigm (Koca 2020, 247-249).

\section{The divine action project}

The DAP is a recent and ambitious endeavour that took place over the past three decades. It was an exciting project which involved the cooperation and coordination of the Centre of Theology and Natural Science and the Vatican Observatory. Participants included well-known Christian philosophers, theologians, and scientists. These include Ian Barbour, Thomas Tracy, Philip Clayton, John Polkinghorne, Wesley Wildman, Nancey Murphy, Keith Ward, William Dress, and William J. Stoeger to name a few. Through a series of conferences, they published several books on the interface of science and theology in various localised scientific contexts, e.g. evolution, neuroscience, quantum mechanics, chaos theory, etc. (Russel et al. 1995; Russel et al. 1996; Russel et al. 2001; Russel et al. 2008). Robert Russell was one of the main coordinators of this project, and edited every volume that came into production alongside other co-editors which varied with each book.

Fundamental to this entire project was giving serious attention to the natural sciences and rejecting the idea of miracles. Wildman (2008, 141) summarises the general atmosphere ${ }^{11}$ of the project:

...the idea of God sustaining nature and its law-like regularities with one hand while miraculously intervening, abrogating, or ignoring those regularities with the other hand struck most members as dangerously close to outright contradiction. Most participants certainly felt that God would not create an orderly world in which it was impossible for the creator to act without violating the created structures of order.

To this end, developing divine action models that are compatible with the natural sciences and yet safeguard God's involvement in creation has been 
the focus of this group's attention (hence the name, DAP). They have developed and adopted four different categories of useful distinctions that have since set the stage for the discussion (there are more but these are sufficient for our purposes). It will be helpful to spell these out to better situate the Ash'arite perspective in the current dialogue.

\section{1 - General divine action and special divine action}

The first categorical distinction is between general divine action (GDA) and special divine action (SDA). While these definitions are somewhat fluid, since they depend on the thinker being looked at, but one way of defining them is as follows (Wildman 2008, 140):

General divine action ... is the creation and sustaining of all reality in so far as this does not necessarily presume any specific providential divine intentions or purposes. Special divine action ... is specific providential acts, envisaged, intended, and somehow brought about in this world by God, possibly at particular times and places but possibly also at all times and places.

In simpler terms, "GDA is a theological restatement of the laws of nature" (Ritchie 2019, 40). By contrast, SDA "departs from the default scenario of what would have occurred had Got not chosen to act at a given moment" (Ritchie 2019, 41). To be clear, SDA should not be confused with miracles. SDA consists of intentional non-miraculous events that cause active changes in the structures or functions of the universe that are still governed by the laws of nature. Miracles are events which defy, work against, or go beyond the laws of nature. The distinction between SDA and miracles will be clearer in light of the next conceptual division.

\section{2 - Interventionism and non-interventionism}

The second distinction is between interventionism and non-interventionism. Interventionism is the idea that God's acts "involves abrogating, suspending, or ignoring created structures or order and regularity within nature," while non-interventionism is when God's acts "accord with created structures or order and regularity within nature" (Wildman 2008, 141). Fundamentally, this division is about God's relationship with the affairs of the world or the laws of nature. Interestingly, Koperski (2020, 3-5) identifies a third position that can be situated between these two, which he calls non-violationism, and is not visible in the writings of the DAP. This position agrees with interventionism insofar that God can merely intervene, but it also agrees with non-interventionism to the extent that the laws of nature don't have to be violated. God can still intervene but use the existing laws to enact whatever He so wishes. ${ }^{12}$ These distinctions have been summarised in Table 6.1. 
Table 6.1 Differences between interventionism, non-violationism, and non-interventionism.

\begin{tabular}{lcc}
\hline Position & $\begin{array}{c}\text { Can/does God intervene in } \\
\text { the affairs of the world? }\end{array}$ & $\begin{array}{c}\text { Can/does God violate } \\
\text { the laws of nature? }\end{array}$ \\
\hline Interventionism & Yes & Yes \\
Non-violationism & Yes & No \\
Non-Interventionism & No & No \\
\hline
\end{tabular}

\section{3 - Compatibilism and incompatibilism}

To appreciate the third classification, it will be helpful to demarcate between physical determinism and indeterminism. Physical determinism is the idea that once creation was made, the laws of motion are fixed and set. So the world is like a domino row where previous enacted physical causes have fixed outcomes and effects. By contrast, indeterminism has a looser arrangement. Here, causes don't have linear outputs but may manifest differently from one event to another. Accurately put, this is where the domain of probabilistic or stochastic laws come into the picture. In a deterministic world, one cause will have one effect, whereas in an indeterministic world one cause may have multiple effects that are bound by probability and likelihoods (Briggs 2016). As a rudimentary example, consider dice rolls. We know all the available possibilities in each roll, i.e. we know all the numbers we can get on the dice, but each roll is indeterminate to us until we roll the dice and find out what we get in a given round. If this setup is taken to govern all or parts of reality, then perhaps there are indeterminate features in the fabric of the nature that gives the universe an open-ended framework.

Recall the DAP's motivation was to try and determine how natural sciences can work with a God who doesn't intervene/violate the laws of nature. However, God shouldn't (or isn't to) be set to the sides while nature runs its course. Hence their affinity to theological models in which God is still able to interact with the natural world through SDA but in a non-intervening or non-violent manner (and hence safeguards the natural sciences). With this in mind, alongside the aforementioned distinction between determinism and indeterminism, the third classification between compatibilism and incompatibilism can be elucidated. Compatibilism is the position in which it doesn't matter whether the universe is bound by physical determinism or indeterminism, as there might be ways to reach compatibility with noninterventionism/non-violationism through SDA. Incompatibilism is the thesis that physical determinism rules out the possibility of SDA through non-interventionism/non-violationism. Hence, incompatibilists try to identify routes through indeterminacy in nature (Wildman 2008, 143). It is why scientific developments like quantum mechanics, chaos theory, emergence, 
and evolution, which have an indeterminate interpretation or component, are useful utilities and attractive loci for incompatibilists.

\section{4 - Prescriptive and descriptive}

The last distinction which is of importance for us is the interpretation over laws of nature. There is a prescriptive interpretation and a descriptive one. If the laws of nature are understood prescriptively, it commits one to the idea that they have ontological weight that science can discover. By contrast, if the laws of nature are understood descriptively, then science is only in the business of approximating patterns in nature (Wildman 2008, 144). Miracles are significantly affected by this distinction. If laws of nature are descriptive, then miracles may be possible as they are simply outside or beyond our descriptions. But if one adopts the prescriptive interpretation, miracles may be harder to justify. In fact, the entire DAP motivation would seem unnecessary if laws are descriptive. As stated by Ritchie $(2019,48)$ :

... if so-called laws were merely descriptions of contingent regularities, the interventionism/noninterventionism debate would simply disappear. The very idea of intervention requires an ontological, prescriptive view of physical laws; otherwise, there would be no laws for God to violate in the first place. ${ }^{13}$

Another point related to this discussion is how exhaustive our scientific theories really are in explaining the structures of nature. There is a distinction that can be created between our current understanding of nature versus how nature really is. The former can be referred to as the laws of science and the latter as laws of nature. Seen this way, science gives us approximations of nature. However, this approximationist approach is equally compatible with the prescriptive and descriptive interpretation (Ritchie 2019, 51-54).

It seems somewhat unclear where participants stand with respect to these distinctions. For instance, Russel (2008, 151-211) spends a lot of energy in trying to determine divine action through quantum theories. However, in another place, he says that he adopts a descriptive interpretation (Russel $2008,119)$. With this observation in mind, Ritchie $(2019,50)$ makes the following point: "This common tendency to presume a prescriptive view and still claim the descriptive position is one of the most fascinating (and confusing) aspects of divine action.”

\section{Putting it all together}

The DAP is motivated by safeguarding and respecting the claims of the natural sciences. Accordingly, God cannot work against regularities of the natural world and instead must work with them, and hence miracles are 
ruled out the equations from the onset. However, keeping God out of the affairs of the world entirely would lead us to deism, which participants of the DAP don't (or do not want to) commit to. Identifying theological models in which both of these constraints are satisfied is the holy grail of the DAP. It is why the SDA and non-interventionism or non-violationism are adopted. These positions still allow God to manoeuvre through the fabric of the universe but within scientific parameters. However, physical determinism is seen as a restriction on what God can and cannot do. It is why scientific theories that are indeterminate in nature (or in interpretation) are attractive loci for participants of the DAP, and hence they adopt incompatibilism. But for this project to gain any stimulus, the laws of nature must be understood as having some kind of prescriptive weight. Otherwise, if they are descriptive, then violations of the laws of nature make no sense. In this regard, it seems to be unclear what the stances really are, as noted earlier.

There is a vast corpus on the DAP which can be mined for further details. But these are the main points which are relevant for us. We are now better able to situate Ash arism in light of these developments.

\section{Ash'arism and the DAP}

As can be guessed from the preceding two sections, Ash'arism and the DAP are fundamentally at odds with one another. Members of the DAP want to safeguard the respect of natural sciences and therefore avoid miracles. The contradiction which propels this project is not being able to reconcile the irregularity of miracles on the one hand with the unvarying laws of nature on the other. This is understandable since in the modern-day and age science has become an important cultural force, and any talk about miracles may seem almost embarrassing. Plantinga $(2011,71)$ quotes the Christian theologian John Macquarrie in observing this point:

The way of understanding miracle that appeals to breaks in the natural order and to supernatural interventions belongs to the mythological outlook and cannot commend itself in a post-mythological climate of thought ... The traditional conception of miracle is irreconcilable with our modern understanding of both science and history. Science proceeds on the assumption that whatever events occur in the world can be accounted for in terms of other events that also belong within the world; and if on some occasions we are unable to give a complete account of some happening ... the scientific conviction is that further research will bring to light further factors in the situation, but factors that will turn out to be just as immanent and this-worldly as those already known.

Accordingly, the DAP is a modern project, and perhaps could be considered an extension of the Enlightenment project of theology in response to the 
increasing cultural force and pressures of modern science (Placher 1996). Langdon Gilkey, another Christian theologian, expresses this point (quoted in Plantinga 2011, 69):

Thus contemporary theology does not expect, nor does it speak of, wondrous divine events on the surface of natural and historical life. The causal nexus in space and time which the Enlightenment science and philosophy introduced into the Western mind ... is also assumed by modern theologians and scholars; since they participate in the modern world of science both intellectually and existentially, they can scarcely do anything else.

Ash'arites would categorically reject the idea of using science as a starting point to understand God's involvement in the natural world. This premise, which acts foundationally for the DAP, is not something which Ash'arites would entertain as an axiom. The starting point for Ash'arism is the radical contingency of creation (and its structural features) and God's absolute omnipotence. His creative capabilities aren't restricted by considerations of what he creates (the world) nor of what $\mathrm{He}$ commands (i.e. morals, which we shall see in Chapter 8). Under occasionalism, miracles and laws of nature are equally the results of God exercising His will and power. To then use science as a form of restriction for what God can and cannot do, and to simultaneously reject miracles, would be seen as a form of lip service to scientism - loosely defined as an ideology through which everything is measure by science, which should be distinguished by science itself which is a methodology through we attempt to understand the world (Stenmark 2001; Williams and Robinson 2016; Boudry and Pigliucci 2018; de Ridder et al. 2018) - in the Ash arite paradigm. ${ }^{14}$ The fundamental point of difference between the DAP and Asharism is that God is seen as a cause among causes by the former, whereas the latter sees God as the Cause of causes. In other words, the DAP project seems to suggest a causal or explanatory bifurcation, i.e. God or the laws of nature. This contrasts with the Ash arites who see God as a radically different entity than his creation. The Ash'arite paradigm sees God and nature as two as different categorical explanations with God being the primary cause and nature being the secondary one. So explanations are always understood as conjunctions, i.e. God and creation.

As for the classifications, Ash'arites would reject any form of division between GDA and SDA since it wouldn't make sense to distinguish between general or special events, as all effects are causally rooted in God's will under occasionalism. ${ }^{15}$ Even the discussion of interventionism and non-interventionism is somewhat meaningless in the Ash'arite perspective. This distinction presumes that laws of nature have some kind of ontological activity which are independently ongoing and God either steps back or interferes when need be. Within the Ash arite perspective, God 
Table 6.2 Summary of the differences between the DAP and Ash 'arism.

\begin{tabular}{|c|c|c|c|}
\hline Category & Classification & $D A P$ & Ashiarism \\
\hline Divine action & $\begin{array}{l}\text { GDA } \\
\text { SDA }\end{array}$ & $\begin{array}{l}\text { Both are applicable, } \\
\text { but the focus is on } \\
\text { SDA }\end{array}$ & Inapplicable \\
\hline $\begin{array}{l}\text { God's } \\
\text { intervening } \\
\text { with the laws } \\
\text { of nature }\end{array}$ & $\begin{array}{l}\text { Interventionism } \\
\text { Non-violationism } \\
\text { Non-interventionism }\end{array}$ & $\begin{array}{l}\text { All are applicable, } \\
\text { but the focus is on } \\
\text { non-interventionism/ } \\
\text { non-violationism }\end{array}$ & $\begin{array}{l}\text { Inapplicable or } \\
\text { hyper-interventionism }\end{array}$ \\
\hline $\begin{array}{l}\text { Compatibility } \\
\text { question }\end{array}$ & $\begin{array}{l}\text { Compatibilism } \\
\text { Incompatibilism }\end{array}$ & $\begin{array}{l}\text { Mostly } \\
\text { incompatibilism }\end{array}$ & $\begin{array}{l}\text { Compatibilism but } \\
\text { not necessarily } \\
\text { through SDA }\end{array}$ \\
\hline $\begin{array}{l}\text { Laws of } \\
\text { nature }\end{array}$ & $\begin{array}{l}\text { Prescriptive } \\
\text { Descriptive }\end{array}$ & $\begin{array}{l}\text { Unclear but for the } \\
\text { DAP to be a valid } \\
\text { research line, stress } \\
\text { has to be given to a } \\
\text { prescriptive } \\
\text { interpretation }\end{array}$ & $\begin{array}{l}\text { Prescriptive insofar } \\
\text { that laws of God are } \\
\text { the will of God; } \\
\text { descriptive in that } \\
\text { science attempts to } \\
\text { describe these laws }\end{array}$ \\
\hline
\end{tabular}

is actively willing and sustaining those laws and entities every moment atemporally. So the very idea of framing the choice as a form of intervention or not is somewhat inapplicable. However, if there is a common language that is being used to compare different theological models, then perhaps hyper-interventionism could be a useful designation. As for the compatibilism-incompatibilism dichotomy, Ash'arites would fall under compatibilism with the caveat that this is not necessarily done through SDA. We will shortly see that it makes no difference whether the universe is physically determinate or indeterminate in the Ash'arite perspective. Finally, with respect to the laws of nature, it could be said that there are elements of both. The previously referred distinction between the laws of nature and the laws of science will be helpful here. The laws of nature are prescriptive insofar they are willed by God. But the laws of science are descriptive attempts of those laws of nature. So there is an element of both that Ash'arites would find useful to explain their position. The differences between the DAP and the Asharite paradigm has been summarised in Table 6.2.

\section{Evaluating contentions of naturalism, chance, and inefficiency}

Having cleared how Ash'arism stands with respect to the DAP, and familiarising ourselves with the relevant terminology, we can now entertain the three problems associated with evolution set out at the beginning of this chapter. In the following, the PON, the POC, and the POI will be addressed in that order. 


\section{Problem of naturalism}

As was seen earlier in Chapter 4, some individuals think evolution, specifically natural selection, entails that God's hands are cut off from the natural world. For instance, Nuh Ha Mim Keller, a human exceptionalist, highlights the problems associated with consciousness if it is the product of evolution. He argues that since evolutionists assume that "human consciousness" "is also governed by evolution," then all "categories such as number, space, time, measurement, logic, causality and so forth are mere physiological accidents of random mutation and natural selection in a particular species" (Keller 2011, 351). This allows him to say that "every statement within the theory thus proceeds from the unreflective, unexamined historical forces that produced 'consciousness"' (Keller 2011, 351). In effect, Keller expresses his scepticism of evolution because of its implications for the integrity of human consciousness. A similar concern was also raised by the American philosopher, Alvin Plantinga, who questioned the implications of human cognition if produced through the process of evolution (Plantinga 2011, 311). However, Plantinga doesn't believe evolution on its own is the problem; Plantinga's full argument states that it is impossible to believe in scientific evolution strictly from a naturalistic perspective because it is the conjunction of the two, i.e. evolution and naturalism, that leads one to question the trust put in one's cognitive apparatus. This is Plantinga's famous evolutionary argument against naturalism (EAAN; Plantinga 2011, 307-350). As an alternative, Plantinga suggests that if one accepts evolution from a theistic perspective, i.e. not naturalistically, then the issue dissolves. ${ }^{16}$

To make our concern of this particular section lucidly apparent, two distinctive points need to be untangled in this regard. First, there is the epistemic concern of the conjunction of naturalism and evolution, which, if true, possibly undermines the veracity of consciousness as highlighted both by Keller and Plantinga. Second, there is the metaphysical question of whether naturalism itself is true or not. It is the second question that is of interest here, because if it can be shown that evolution doesn't have to be interpreted in absolute naturalistic terms, then it simultaneously eases the tension in the epistemic department. Plantinga also makes this distinction evidently clear. When criticizing the epistemic problems with evolution and naturalism, he launches his EAAN. When trying to assess naturalism in of itself as a metaphysical position, he distinguishes between philosophical naturalism and methodological naturalism to show how Christians can easily accept evolution under the latter but not the former (Plantinga 2011, $168-177)$, and this is exactly what is being suggested here when looked at from the lens of Ash'arism.

At this point, it may be useful to distinguish between the two types of naturalism. Philosophical, metaphysical, or ontological naturalism (hereon referred to a PN) implies the denial of the existence of supernatural entities 
(Draper 2005, 279). This denial proposes alternatives answers for the inquiries which traditionally occupied the domain of religion, e.g. Is there a creator? Are there angels? Is there a life after death? Etc. From the perspective of philosophical naturalism, the answers to all these questions are negative because there is only the natural world that is restricted by time and space dimensions, and it is the ultimate reference for seeking any answers. Methodological naturalism (MN) implies that scientists solely focus on natural phenomena, and they do not try to connect it with the supernatural. In other words, under the umbrella of $\mathrm{MN}$ science is strictly the methodological study of the natural world, leaving aside the question of whether there are any supernatural entities (Draper 2005, 279). MN, then, is an epistemic or a methodological position. Thus, with $\mathrm{MN}$ one can be a theist and a scientist while this option is ruled out with PN.

Returning to Keller, he asserts that for believers the material world is separated from the supernatural through a "seamless veil of light manifesting the Divine through the perfection of creation," while for those who allow the possibility of evolution (which, recall, in this context means naturalism for him) in relation to Adam it is "a perfect nexus of interpenetrating causal relations in which there is no place for anything that is not material" (Keller 2011, 357). It seems, then, that Keller fails to make the useful distinction between PM and MN. By contrast, Plantinga only sees a problem when additional "philosophical gloss" - i.e. interpreted through PN - is added to science, namely when it is though that "evolution is undirected, unguided, unorchestrated by God" (Plantinga 2011, xii). If evolution is viewed through the prism of $\mathrm{MN}$, then God is not necessarily cut off from the natural world, and thus allows for the possibility of theistic-friendly interpretations of evolution like intelligent design or theistic evolution (Scott 2009, 53-76). ${ }^{17}$

\section{Evolution exclusionism}

In addition to aiding the discussion by positing the distinction between $\mathrm{PN}$ and $\mathrm{MN}$, it is important to note that some thinkers look at evolution as the exclusive scientific theory which comes under PN. Everything else such as chemistry, physics, engineering, geography, and many other disciplines seem to be either ignored or neglected. It is inconsistent to believe that evolution has the PON while everything like electrons, atoms, waves, genes, and every scientifically determinable entity is safeguarded by it. The quote of Robert Pennock (1999, 333) from Chapter 1, in which he criticises Phillip Johnson, a well-known creationist, is important to regurgitate here:

Evolutionary theory is naturalistic in just the same way that all scientific theories are, in that they proceed without any appeal to any supernatural entities or powers. Given that this is true of science 
generally, why should evolution be any special worry to the theist? If it is science's naturalistic methodology that is inherently problematic, then Johnson should be equally worried about chemistry and meteorology and electrical engineering. He should also be concerned about automobile mechanics, for this field too proceeds under the naturalistic assumption that God does not intervene in the workings of the motor. But surely no one thinks that these naturalistic sciences imply that God does not exist.

In other words, evolution is equally methodologically naturalistic like other disciplines. There is nothing intrinsic to evolution that makes it part and parcel of PN just like there isn't anything intrinsic in an electron, an atom or a gene that make them products of PN.

\section{What kind of methodological naturalism?}

While MN is compatible with the Ash arite framework, there is a further distinction that has been developed in the literature between intrinsic methodological naturalism (heron referred to as IMN) and pragmatic or provisory methodological naturalism (heron referred to as PMN; Boudry et al. 2010; Fishman and Boudry 2013). As defined by Boudry et al. (2010, 227), IMN is "a self-imposed or intrinsic limitation of science, which means that science is simply not equipped to deal with claims of the supernatural." By contrast, PMN is "a provisory and empirically grounded attitude of scientists, which is justified in virtue of the consistent success of naturalistic explanations and the lack of success of supernatural explanations in the history of science." This is because "[A]ppeals to the supernatural have consistently proven to be premature, and science has never made headway by pursuing them" (Boudry et al. 2010, 230). The question that arises is: which perspective fares better in the Ash arite paradigm?

The simple answer is either. To appreciate this point, it needs to be stressed that $\mathrm{MN}$ is fundamentally an epistemic and/or methodological position about the disciplinary borders and capabilities of science as a field of study. Accordingly, however, scientists (and perhaps philosophers of science) want to mark the boundaries and capabilities of science is entirely up to them. What matters theologically, however, is God not being bound by scientific measures. As stated earlier, in the Ash'arite paradigm, God isn't restricted to what science can or cannot methodologically determine. Laws of nature are nothing but the manifestation of God's will that run consistently. Thus, it is these regularities that science is determining as the laws of nature, but nothing is stopping God from being able to change those regularities either locally or globally if $\mathrm{He}$ so wished.

Under the auspice of IMN, science is categorically blind to miracles. So if a miracle did indeed occur, it would be scientifically indeterminable according to this position. Under PMN miracles may or may not be 
scientifically determinable depending on the nature of the event. Some miracles might have some scientific merit, e.g. a yet unknown force that can be generated to split the seas like in the episode of Moses. Others might be categorically impossible, e.g. turning a human into a monkey within a second (recall the incident of the miskh in Chapter 5). Either way, the modality of scientific possibilities is a subset of theological possibilities.

These points are being stressed because it may be said that the adoption of MN (either IMN or PMN) entails a rejection of miracles. This is not the case. Miracles may be rejected through the lens of science, but not theology. However, if one sees only through the lens of science and cannot accept anything beyond that, then this entails that one is committed to either PN or a form of scientism. To be clear, this is not meant to undermine science as a discipline. Science is respectable enterprise, but it has its scope and limits. Furthermore, regularities in nature are also important for Islamic jurisprudence; jurisprudence would not be able to function if there were no natural laws (Opwis 2012; Eissa 2017; Malik 2021). Islamic laws pertaining to wills, family and lineage are premised on regularities of biological processes. The only point being made here is that miracles are not categorically impossible unless one adopts PN or scientism when looked at through the prism of Ash'arism. ${ }^{18}$

\section{The problem of chance}

Having a chance-like mechanism has a few implications, which may be theologically problematic. But if we are to review the evolutionary process seriously from a theological angle, it would not be unhelpful then to seek a short detour on what is actually meant by "chance." It is a notoriously ambivalent term. "Synonyms or words that may be substituted include accident, randomness, uncaused, fortune or fortuity, happenstance, likelihood (or probability), unpredictability, coincidence, spontaneity and serendipity ..." (Johnson 2015, 1-2). It will also be helpful to see what chance is contrasted with ".. determinism, necessity, caused, predictability, skill, free will, purpose, design and uniformity to name a few" (Johnson $2015,2)$. For the purposes of this chapter, it is unnecessary to look into every synonym-antonym pair's details. The specific concern that will be looked at here is how chance is contrasted with predictability (with respect to God) and purpose. Let's start with the former.

\section{Chance and God}

It is possible to look at chance from two philosophical perspectives. The first is epistemic chance, which reflects our lack of knowledge of a system, and so it seems chance-based to us. This can be divided into two types. The first is when we are uncertain (hereon referred to as $\mathrm{EC}_{1}$ ) about 
a system. For example, we know that a coin toss can be either heads or tails, but why is it heads or tails in a specific toss is uncertain. If we had all the relevant information of a coin toss, e.g. the physics of the coin and the environment, then it could be possible to determine what side the coin would land on in that particular toss. Another kind of epistemic chance is an unknowable one (hereon referred to as $\mathrm{EC}_{2}$ ). This is referring to the impossibility for an agent to have epistemic accessibility for a given event. For example, as human agents we can never claim to know what Julius Caesar wore in the 37th last hour of his life; we don't have any historical documentation that tells us this information, and given that time travel is impossible (at least for now), this insight will be permanently inaccessible to us. Crossing over to evolution, if there were (several) chance events in the past, e.g. a particular mutation or sets of mutations that led to divergent species, it would be unknowable by us today because there are a range of explanations for why mutations occur, e.g. copying errors in the genes or radiation. We cannot go back in time and identify the exact mechanism that caused a particular mutation. Both $\mathrm{EC}_{1}$ and $\mathrm{EC}_{2}$ are fundamentally reflections of what we can and cannot know.

Chance can also be looked at ontologically, and it can also be viewed from two perspectives. The first kind of ontological chance (hereon referred to as $\mathrm{OC}_{1}$ ) is when something doesn't have a prior physical cause. So, things popping in and out of physical existence without a prior physical cause would be interpreted as chance-like phenomena. Another version of ontological chance is when there is no physical and no metaphysical cause (hereon referred to as $\mathrm{OC}_{2}$ ). In this perspective, chance is no longer solely an operational feature of the physical world but a metaphysical one too. In a very strong form, it can even mean God doesn't know the prior causes of things or how things are to unfold and thus are indeterminate even to God. $\mathrm{OC}_{1}$ and $\mathrm{OC}_{2}$ are positions of what reality is fundamentally like.

Having cleared these distinctions, it is now easy to see that $\mathrm{EC}_{1}, \mathrm{EC}_{2}$ and $\mathrm{OC}_{1}$ are entirely unproblematic in the Ash arite framework. $\mathrm{EC}_{1}$ and $\mathrm{EC}_{2}$ are reflections of human ignorance and therefore non-conflicting. Just because we (as humans) can't determine the particular cause for a natural event doesn't mean that God also doesn't know too. We have stochastic laws alongside chaos theory which are indications of our limited capabilities in understanding any given system in toto (Polkinghorne 1995; Polkinghorne 2001; Briggs 2016). So when a mutation occurs, evolutionists don't necessarily know why it occurred or when it occurred on a specific occasion. Still, they usually have a range of possible explanations, e.g. copying error in the genes. The main area of contention seems to be when evolutionists claim that a mutation can be advantageous, disadvantageous, or neutral, and it could be open to any direction depending on the dialectics between genes, species, and their environments through extensive periods of time. This openness in the evolutionary paradigm gives evolution the 
chance-like appeal. Again, this could be cast under $\mathrm{EC}_{1}$ or $\mathrm{EC}_{2}$, i.e. reflects human ignorance. Consider Sweetman (2015, 124-125), who says:

We overlook the fact that for every effect that occurs in biology, there is a specific cause for this effect, including every supposedly ('chance' or 'random') mutation, and for every environmental change, right back to the beginning of time. Evolutionary theorists sometimes forget this, or ignore it, when they are talking about the process of evolution.

So while the process of evolution seems like chance to humans, it doesn't entail God doesn't know what He is doing. It could easily be that God orchestrates the entire process, i.e. has complete knowledge and control over it, but executes it in a way that appears indeterministic to us.

As for $\mathrm{OC}_{1}$, and given occasionalism, it is also unproblematic since God isn't bound by any natural law fixation. It is completely possible for God to create a new species from no prior physical material and even dissolve a species into nothing, thus making it seem chance-based process to us. But it's not that chance is just apparent, it is also ontologically real in the physical plane. In this framework, it is still completely plausible that God knows and controls everything in this scenario. It is similar to a graphics animator who can pop things into existence from nothing from one frame to another. The animator knows how the animation is to proceed as a whole even though there are instantaneous "disruptions." The only real difficulty arises when chance is understood as $\mathrm{OC}_{2}$. This kind of chance wouldn't work with the Ash arite outlook because it makes for a limited God who doesn't know how creation proceeds or operates. So for example, consider Polkinghorne who in the context of quantum mechanics, which also shares an indeterminate structure as evolution (at least according to the Copenhagen interpretation), says:

... I believe that God who is the creator of the world of becoming must be a God who possesses a temporal pole as well as an eternal pole. Because the future of such a world is not yet formed, even God does not yet know it. This is no imperfection in the divine nature. God knows all that can be known but the future is still inherently unknowable. (Polkinghorne 1995, 156)

This would be a severe breach in the Ash arite paradigm because the idea of God not knowing the future would be incredibly problematic. Arguably, however, this is beyond the purview of science if evolution is interpreted under the auspice of $\mathrm{MN} .{ }^{19}$ Given the nuances of chance mentioned here, evolution could be compatible even with the Ash arite paradigm except for when chance is taken as $\mathrm{OC}_{2}$. Subsequently, whether the universe is determinate or indeterminate makes no difference to the Ash arite paradigm provided it's not interpreted as $\mathrm{OC}_{2} \cdot{ }^{20}$ 


\section{Chance and purpose}

Chance is troubling from a teleological perspective because it seems to imply that there really is no ultimate purpose in nature. If life's history is fundamentally based on chance, and thus relies on several contingencies, then humans seem to be a lucky accident. This seems to contradict the narrative found in the Quran (51:56), which clearly says that man's purpose is to worship God. To address this apparent conflict, we need to be careful with the terminology that is sometimes utilised in the discourse. Some thinkers make a useful distinction between proximate goals and the ultimate goals (Kurt 2012, 46-48). Proximate goals are localised explanations for why things occur or behave the way they do, e.g. function of a gene or adaptation of an animal to its environment. Ultimate goals are explanations on a cosmic scale. For instance, what is the purpose of human beings, and why did God create the world and its inhabitants.

But it gets slightly confusing because the terms "proximate" and "ultimate" have been "biologicised." Ernst Mayr (1961), one of the leading evolutionists of the past century, used these terms to refer to two different aspects of biological explanations. Using bird migration as an example, he distinguished between them as follows (Mayr 1961, 1503):

Now, if we look over the ... causations of the migration of this bird once more we can readily see that there is an immediate set of causes of the migration, consisting of the physiological condition of the bird interacting with photoperiodicity and drop in temperature. We might call these the proximate causes of migration. The other ... causes, the lack of food during winter and the genetic disposition of the bird, are the ultimate causes. These are causes that have a history and that have been incorporated into the system through many thousands of generations of natural selection. It is evident that the functional biologist would be concerned with analysis of the proximate causes, while the evolutionary biologist would be concerned with analysis of the ultimate causes. This is the case with almost any biological phenomenon we might want to study. There is always a proximate set of causes and an ultimate set of causes; both have to be explained and interpreted for a complete understanding of the given phenomenon.

These distinctions seem to correlate with definitions that Okasha $(2018,16)$ provides, what he refers to as type 1 and type 2 telos:

In type 1 , the telos belongs to an evolved organism ...; the point of treating the organism as agent-like is to capture the fact that its evolved traits, including its behaviour, are adaptive, hence conduce towards the goal of survival and reproduction. In type 2 , by contrast, the putative telos belongs to the evolutionary process itself ('mother nature'); the 
suggestion is that natural selection has an inherent tendency to move the population in a particular direction, so is goal-directed in that sense. Thus in the former case the teleological description applies to the products of evolution, while in the latter case it applies to the evolutionary process itself.

Given these nuances, to have a constructive conversation about chance and teleology within the context of evolution and religion, we need to demarcate between three tiers or categories of teleology, which will be referred to as macroteleology (MAT), mesoteleology (MET), and microteleology (MIT).

MAT is what we can refer to as the ultimate goals of creation in total, i.e. the non-biologicised understanding of the ultimate. It answers questions such as the purpose of life. MET is a structural and a global kind of teleology which is embedded in our laws of nature. It explains the ways laws of nature lead to or cause somethings to occur. This is equivalent to Mayr's biologicised rendition of ultimate causes and Okasha's type 2 telos. MIT constitutes of immediate and localised explanations of things, e.g. chemical reactions, signalling of genes, causes of sickness, functions of the heart, etc. This is equivalent to Mayr's proximate goals and Okasha's type 1 telos. If we accept this framework, we can then easily point the interdependencies. MIT and MET seem to be co-dependent. How an organism or a biological entity behaves today may have been impacted by its evolutionary history by some shape and/or degree. Simultaneously, the future evolutionary pathways of a certain species at a particular point in time will significantly depend on its survivability and gene pool. Scientists can discuss and debate these things.

However, it remains unclear how we can deduce MAT by observing nature. As a point of reference, consider the debates over design arguments (which we shall be looking at in detail in Chapter 7). There is extensive literature over whether the universe seems designed or not, which helps navigate the question of MAT. Interestingly, even some theists are not entirely convinced by the nature of design arguments. Within the context of biological design, Plantinga (2011, 264), for instance, says the following: "Taken not as arguments but as design discourses they fare better ... The proper conclusion to be drawn, I think, is that ... design discourses do support theism, although it isn't easy to say how much support they offer." The iconoclast Richard Dawkins (1995, 131-133) offers a stronger, though negative, interpretation:

The total amount of suffering per year in the natural world is beyond all decent contemplation. During the minute that it takes me to compose this sentence, thousands of animals are being eaten alive, many others are running for their lives, whimpering with fear, others are slowly being devoured from within by rasping parasites, thousands of all kinds are dying of starvation, thirst, and disease. It must be so. If 
there ever is a time of plenty, this very fact will automatically lead to an increase in the population until the natural state of starvation and misery is restored ... In a universe of electrons and selfish genes, blind physical forces and genetic replication, some people are going to get hurt, other people are going to get lucky, and you won't find any rhyme or reason in it, nor any justice. The universe that we observe has precisely the properties we should expect if there is, at bottom, no design, no purpose, no evil, no good, nothing but pitiless indifference.

Moving beyond biological design, consider the words of Steven Weinberg (1993, 149), an eminent physicist and an atheist, who said: "The more the universe seems comprehensible, the more it also seems pointless." In the same vein, the late Christopher Hitchens $(2007,91)$ stresses the coincidental creation of humans and the lack of apparent MAT in nature:

Our place in the cosmos is so unimaginably small that we cannot, with our miserly endowment of cranial matter, contemplate it for long at all. No less difficult is the realization that we may also be quite random as presences on earth. We may have learned about our modest position on the scale, about how to prolong our lives, cure ourselves of disease, learn to respect and profit from other tribes and other animals, and employ rockets and satellites for ease of communication; but then, the awareness that our death is coming and will be succeeded by the death of the species and the heat death of the universe is scant comfort.

Given this diversity, it seems to be clear that it is harder to agree on MAT than MET and MIT. From an Ash arite perspective, MAT can only be informed by God, which is why it is revelation-bound (Frank 2005, 135-138; Al-Ghazālī 2013, 157-198). To know the purpose of why man is created is not dependent on the natural setup of the world. Consider how the purpose of man to worship God, i.e. MAT, would be valid regardless of whether man was created instantaneously or through evolution. So it doesn't seem to affect MAT which one is true. But if we reverse the order and try to determine MAT from MET and/or MIT, it creates a challenging task that can be highly speculative. This is because we are trying to guess the grand goal of things from limited and proximate explanations, and the results can vary from one person to another, as was seen with the earlier quotations. Therefore, it is doubtful that MAT, as intended by God, can be conclusively determined or undermined by indeterminate natural processes such as evolution. ${ }^{21}$

It follows that even if humans arrived on the scene through a chance-like mechanism such as evolution, the fact that humans cannot construct an overarching purpose from proximate or structural foundations of the world is not something that should be a worry. Just because MAT cannot be obtained 
from MET and/or MIT, it does not entail that there is no grand purpose. God may have an ultimate purpose in mind, but how this is done through structural pathways of the universe may not make any immediate nor apparent sense. ${ }^{22}$ Wildman $(1998,148)$ seems to offer a similar perspective:

... there is no sound chain of implications from analysis of apparent ends in nature ... to estimations of the locus in nature of fundamental teleological principles, and then to specification of the modes of divine action. In fact, the implications run more smoothly in the reverse direction. In the order stated, the chain breaks down at each link, at least when biological evolution remains the sphere of discussion. Additional premises are needed to move from apparent ends in nature to the affirmation of real ends, from there to metaphysical theories affirming a fundamental teleological principle consistent with divine action, and from any such teleological theory to the reality of divine action in particular modes ... None of these missing premises are furnished by biological evolution ...

In short, chance does not undermine teleology, specifically MAT, but may impact the discussions related to MET and MIT, which MAT is independent of.

\section{The problem of inefficiency}

The argument of the inefficiency of evolution is very closely linked with the problem of evil, which shall be addressed in Chapter 8. God could have made a process where the production of humans did not have to come from such an arduous and time-consuming mechanism that simultaneously involves so much suffering and death. However, efficiency and evil, though both are evaluative, are two different categorical evaluations. Efficiency is linked to the idea of how well something is achieved given certain spatiotemporal constraints. The constraint could be time-bound. For example, imagine a comparison between two very similar factories with the same resources responsible for producing the same product. Factory A produces 100 items in an hour while Factory B produces 250. In this example, Factory $B$ would be considered as being more efficient. The constraint could also be material bound. If two carpenters are given the same amount of wood and asked to construct a table, the carpenter that discards the least amount of wood would be deemed as the more efficient one. The constraint could also be space-bound. Consider a fixed room that is to be converted into a kids' bedroom for a large family. If the family is smart, they can use convertible sofa-beds to maximise the number of kids who can sleep in there compared to having a sofa and a bed as two different items. The former option utilises the designated space much more efficiently. The question is: how can we measure efficiency when it comes to God's work? The answer 
is we can't since spatiotemporal elements don't constrain God. Alexander $(2012,238)$ articulates this laconically:

[Evolution is] wasteful compared to what? ... It is difficult to know what 'waste' means to be God who is the ground for all existence. Equally with those who wonder why evolution has taken 'so long' before arriving at humans ... God in his transcendence is not encompassed by space nor by time, so the question 'why long' hardly seems relevant to such a creator.

This understanding of God is in resonance with the Ash'arites. God isn't a material thing, and nor is He in time, as both imply a limited being (Al-Ghazālī 2016, 59-68). Time, space, and matter are creations ${ }^{23}$ that were brought into existence, and, as highlighted by Alexander, God is the ground for their existence. For this reason, the argument from inefficiency does not actually have any substantial weight because efficiency is an anthropocentric construct that cannot be applied to God. Thus, arguments that promote the incompatibility between evolution and Islam because of the resulting biological waste and its lengthy mechanism cannot be considered serious contentions.

\section{Conclusion}

In this chapter, we established the Ash arite framework from the works of al-Ghazālī, which was then compared with the DAP. From this exercise, it was concluded that Ash arism is fundamentally at odds with the DAP. The DAP is seen as a form of scientism from an Ash'arite perspective. Thereon, three problems were evaluated: the PON, the POC, and the POI. The PON is not an issue as long as evolution (and science more broadly) is understood through the lens of MN. The POC had two dimensions. One was in relation to God's knowledge and power. It was concluded that under the banner of occasionalism Ash arites could go as far as embracing $\mathrm{EC}_{1}, \mathrm{EC}_{2}$, or $\mathrm{OC}_{1}$. However, strong ontological chance, $\mathrm{OC}_{2}$, would make no theological sense in the Ash arite framework. The second dimension of the POC was the issue of teleology. It seems that MAT is not strictly dependent on the MET nor MIT. While the latter two may be affected in terms of how the universe operates, MAT seems to be independent of it. Finally, the POI was seen as an inapplicable to God since He is not an evaluative being. Subsequently, He isn't constrained by resources like time, space, and matter to then be charged with being a wasteful or an inefficient creator.

In light of all these points, al-Ghazālīs metaphysical framework is entirely compatible with creationism, human exceptionalism, Adamic exceptionalism, and no exceptions.

\section{Notes}

1 For nuances on how kalām is and/or was understood, see Hassan (2020, 135-139). 
2 Summary of abbreviations used in this chapter.

\begin{tabular}{lc}
\hline Name & Abbreviation \\
\hline Problem of naturalism & PON \\
Problem of chance & POC \\
Problem of inefficiency & POI \\
Divine Action Project & DAP \\
Evolutionary Argument Against Naturalism & EAAN \\
Epistemic chance (uncertain) & $\mathrm{EC}_{1}$ \\
Epistemic chance (unknowable) & $\mathrm{EC}_{2}$ \\
Ontological chance (physical) & $\mathrm{OC}_{1}$ \\
Ontological chance (physical and metaphysical) & $\mathrm{OC}_{2}$ \\
Macroteleology & $\mathrm{MAT}_{\text {Mesoteleology }}$ \\
Microteleology & $\mathrm{MIT}$ \\
\hline
\end{tabular}

3 One example of a rival worldview was the one developed by Avicenna, a philosopher who tried to merge Neo-Platonic and Aristotelian elements with Islam. His metaphysical paradigm is known as emanationism. In this position, creation is a necessary by-product, i.e. God didn't will it to come into existence, but rather it had to come to existence because of God's nature. An extension of this point is that nature behaves in fixed, necessary ontological trajectories that do not permit the viability of miracles (Richardson 2020). This perspective was problematic from an Ash arite perspective (Zarkasyi 2010; Hassan 2020). In fact, al-Ghazālī (2002) wrote a whole treatise criticizing some of the features of this perspective in his famous work, Incoherence of the Philosophers (Tahäfut al-Falāsifa).

$4 \mathrm{I}$ am hesitant with asserting this since there have been several developments in contemporary philosophy in the metaphysics of time and matter (Koons and Pickavance 2017). Determining whether atomism as laid out by the Ash'arites holds under scrutiny in light of these new developments would be a fruitful inquiry, but it is beyond the scope of this work.

5 I am also inclined towards Hassan's (2020,152-153) observations regarding al-Ghazālī's attitudes towards atomism: "His discussions ... show that he is far more interested in the metaphysics of the process of causation, given its theological implications, rather in the formation and constitution of the physical world per se. In al-Ghazālī's thought, we see a radical reduction in attention given to questions of physical theory, as compared with classical Ash'arism. Al-Ghazālī does not hold physical theory to have much place within theological discussion, nor in the refutation of views which he considers heretical. Neither is her interested in physical theory as a separate field of inquiry. This makes sense against the background of theological pragmatism - al-Ghazāli is interested in protecting the belief of ordinary folk by providing evidence for theological doctrine which is simple and convincing. For al-Ghazālī, natural philosophy is not an end unto itself, and the theologian should focus on matters which strictly serve the cause of defending sound doctrine." For detailed treatments of al-Ghazālī's metaphysics and physical theory, see Frank (1994) and Zarkasyi (2010).

6 Cubit is simply a unit of measure. The point that al-Ghazāli is making here is that the universe could have been bigger or smaller. 
7 The kind of modalities applicable to God's creations which Ash'arites held on to were temporal in nature. See al-Ghazālī (2013) and Hassan (2020) for more details. This is a technical point that needn't affect our conversation on the topic of evolution.

8 For an excellent, contemporary treatment on the necessary being, see Pruss and Rasmussen (2018).

9 Koperski (2020, 86-108) has an excellent review of different interpretations of laws of nature. The Ash'arites' stance on laws of nature would most likely fall under the position known as decretalism. Also see Plantinga (2016).

10 From all the preceding sections, note how this metaphysical worldview radically differs from Bakar (1984) and Nasr (2006) who we looked at in Chapter 4.

11 This point should be taken cautiously, as it is a general claim. There are notable exceptions.

12 It may be helpful to note that Koperski $(2020$, 5) himself concedes that non-violationism could be seen as a kind of soft interventionism. So nonviolationism and non-interventionism could be seen as a difference in degree than kind.

13 A related conversation is the question of scientific realism and antirealism. This is a vibrant discussion in the philosophy of science. When we develop scientific theories and equations, what are committing ourselves to metaphysically and epistemically when it comes to unobserved or unobservable entities? For instance, take the notion of string theory. If true, it requires us to believe ten dimensions, six of which we can't observe. Without any clear empirical evidence, how should we commit ourselves to this? Same goes for the multiverse. This is a larger conversation which is beyond the scope of this chapter. Still, it is important to recognise that scientific (anti)realism does play a massive part in how we come to understand science in light of theology.

14 To be more precise, this, in fact, would be seen as a form of religious scientism. This is where religion is primarily viewed from a scientific lens that distorts or conforms religious ideas to scientific ones. See Porter (2001), Smedes (2004), and Bolger (2012).

15 Niels Gregersen (2008) highlights further issues with the GDA/SDA distinction that Ash'arites would agree to. One problem is that we think that we can guess how nature would operate in the absence of SDA. This seems like a strong conclusion and may be difficult to justify. Put differently, how do we know when God is performing a GDA rather than SDA? It is not an easy question to answer. The other related problem is assuming a strong prescriptive commitment to the laws of nature. This could be questionable.

16 In case this is misunderstood, the EAAN is not an argument against evolution; rather, it is an argument against evolution when combined with the metaphysical perspective of naturalism. If evolution is couched in another metaphysical framework, e.g. theism, then the problems with the EAAN are dissolved.

17 Keller doesn't explicitly mention this point, but I feel he might also be thinking of the problem of reductionism, which is the idea that everything can be explained by reducing it to its most fundamental constituents. Given Keller's Sufi background, which entertains the idea that the soul is an immaterial realty that cannot be reduced to the material world, he might see reductionism as a problem. However, even here, one can create a distinction between philosophical reductionism and methodological reductionism. See Pope (2007, 56-75).

18 Osborn's $(2017,68)$ point is of relevance: “There is a need, I am suggesting, for a kind of apophatic science that makes clear not the empirical challenges to Darwin's theory in the manner of dubious 'creation science' but rather the limitations of naturalistic methods and assumptions in the face of certain questions and realities." 
19 But it does raise the important question of how we are to proceed with drawing metaphysical conclusions based on science. As Monton (2011) demonstrates with clear lucidity, it is possible to arrive at contradictory metaphysical worldviews based on patchy scientific frameworks. It opens the question of whether metaphysics should be dependent or independent of science.

20 Another way of appreciating the compatibility of chance-like processes in nature within a theistic framework is by creating a table of possibilities that intersect between physical and theological (in)determinism. Theological determinism is the position in which God determines (knows and controls) everything, while theological indeterminism states that God is partially determining things. The latter position would be intolerable in the Ash'arite framework. Theological determinism is the position of Ash'arism which is compatible with physical determinism and indeterminism. Chance-like operations are in the category of physical indeterminism, which can be theologically determined. Hence, chance-like features in the natural world are not incompatible with God. These ideas have been summarised in the following table.

\begin{tabular}{lcc}
\hline & $\begin{array}{c}\text { Theological } \\
\text { Determinism }\end{array}$ & $\begin{array}{c}\text { Theological } \\
\text { Indeterminism }\end{array}$ \\
\hline Physical Determinism & $\checkmark$ & $\mathbf{x}$ \\
Physical Indeterminism & $\checkmark$ & $\mathbf{x}$ \\
\hline
\end{tabular}

21 Furthermore, physical explanations or causes are incomplete from a theological perspective as God has set both physical and metaphysical mechanics in place to do His bidding. For example, in some verses, God mentions that $\mathrm{He}$ has set certain tasks for angels (e.g. Qur'ān 79:1). Since we have very limited information as to what exactly the metaphysical world contains and how it operates, and since science strictly deals with the physical world, and even if we could construct a complete narrative of the physical world, it seems like nothing but speculative leaps can lead us from MET and/or MIT to MAT. However, this information can only be known after revelation. The concept of angels being co-responsible for natural world phenomenon before the getting revelation would be nothing but speculation.

22 On such occasions, scripture can provide us with information that cannot be derived from nature, lending to a complementary unison.

23 This needs to be qualified. Some entities are directly existentiated while others emergent properties of those that are existentiated. For instance, time is considered a relational category while atoms are seen as existential categories in Ash arism. See Sabra (2009) and Ibrahim (2020).

\section{References}

Ahsan, Abbas. 2019. "The Paradox of an Absolute Ineffable God of Islam." Philotheos, 19(2): 227-259.

Ahsan, Abbas. 2021. "The Logical Inconsistency of Making Sense of an Ineffable God in Islam.” Philotheos, 20(1): 68-116.

Alexander, Denis. 2012. “Creation and Evolution.” In J. B Stump and Alan G Padgett, eds. The Blackwell Companion to Science and Religion. West Sussex: Blackwell Publishing, 233-245. 


\section{Metaphysical considerations}

Al-Ghazāīi, Abū Hāmid. 2000. The Incoherence of the Philosophers. trans. by Michael E. Marmura. Utah: Brigham University Press.

Al-Ghazālī, Abū Hāmid. 2001. Faith in Divine Unity and Trust in Divine Providence: Book XXXV of The Revival of the Religious Sciences. trans. by David B. Burrell. Louisville, KY: Fons Vitae.

Al-Ghazālī, Abū Ḥāmid. 2013. Moderation in Belief. trans. by Aladdin M. Yaqub. Chicago: University of Chicago University Press.

Al-Ghazālī, Abū Hāmid. 2016. Kitāb Qawāi id al-'Aqāid: The Principles of the Creed - Book 2 of the Ihyä' 'Ulüm al-Dìn. trans. by Khalid Williams. Louisville, KY: Fons Vitae.

Altaie, Basil. 2016. God, Nature, and the Cause: Essays on Islam and Science. Abu Dhabi: Kalam Research and Media.

Bakar, Osman. 1984. "The Nature and Extent of Criticism of Evolutionary Theory." In Osman Bakar, ed. Critique of Evolutionary Theory: A Collection of Essays. Kuala Lumpur: The Islamic Academy of Science and Nurin Enterprise, 123-152.

Bolger, Robert. 2012. Kneeling at the Alter of Science: The Mistaken Path of Contemporary Religious Scientism. Oregon: Wipf and Stock Publishers.

Boudry, Maarten, Stefaan Blancke, and Johan Braeckman. 2010. "How Not to Attack Intelligent Design Creationism: Philosophical Misconceptions About Methodological Naturalism.” Foundations of Science, 15(3): 227-244.

Boudry, Maarten, and Massimo Pigliucci. 2018. Science Unlimited? The Challenges of Scientism. Chicago, IL: University of Chicago Press.

Briggs, William. 2016. Uncertainty: The Soul of Modelling, Probability and Statistic. Dordrecht: Springer.

Chowdhury, Safaruk. 2020. "God, Gluts and Gaps: Examining an Islamic Traditionalist Case for a Contradictory Theology." History and Philosophy of Logic, DOI:10.1080/01445340.2020.1797449.

Davidson, Herbert A. 1987. Proofs for Eternity, Creation and the Existence of God in Medieval Islamic and Jewish Philosophy. Oxford: Oxford University Press.

Dawkins, Richard. 1995. River Out of Eden: A Darwinian View of Life. London: George Weidenfeld \& Nicolson Ltd.

De Cillis, Maria. 2016. Free Will and Predestination in Islamic Thought: Theoretical Compromises in the Works of Avicenna, al-Ghazāli and Ibn 'Arabī. Abingdon: Routledge.

de Ridder, Jeroen, Rik Peels, and Rene van Woudenberg, eds. 2018. Scientism: Prospects and Problems. Oxford: Oxford University Press.

Draper, Paul. 2005. “God, Science, and Naturalism.” In William J Wainwright, ed. The Oxford Handbook of Philosophy of Religion. Oxford: Oxford University Press, 272-303.

Eissa, Mohamed. 2017. The Jurist and the Theologian: Speculative Theology in Shāfi $\bar{\imath}$ Legal Theory. Piscataway, NJ: Georgia Press.

Fishman, Yonatan I., and Maarten Boudry. 2013. "Does Science Presuppose Naturalism (or Anything at All)? Science and Education, 22(5): 921-949.

Frank, Richard. 1994. Al-Ghazālī and the Ash'arite School. Durham: Duke University Press.

Frank, Richard. 2005. "Reason and Revealed Law: A Sample of Parallels and Divergences in Kalām and Falsafa.” In Dimitri Gutas, ed. Philosophy, Theology and Mysticism in Medieval Islam: Texts and Studies on the Development and History of Kalām. Volume 1. Abingdon: Routledge, 123-138. 
Griffel, Frank. 2020. “Al-Ghazali.” The Stanford Encyclopedia of Philosophy. Accessed 26th of September 2020. https://plato.stanford.edu/archives/sum2020/ entries/al-ghazali/

Gregersen, Niels Henrik. 2008. "Special Action and the Quilt of Laws: Why the Distinction Between Special and Divine Action Cannot Be Maintained.” In Russel, Robert John, Nancey Murphy, and William R. Stoeger S. J., eds. Scientific Perspectives on Divine Action: Twenty Years of Challenge and Progress. Indiana: Vatican Observatory and the Centre for Theology and the Natural Sciences, 179-200.

Hassan, Laura. 2020. Ash'arism Encounters Avicennism: Sayf al-Dīn al-Āmid̄̄ on Creation. New Jersey: Georgia Press.

Hitchens, Christopher. 2007. God Is Not Great. New York, NY: Twelve Books.

Ibrahim, Bilal. 2020. "Beyond Atoms and Accidents Fakhr al-Dīn al-Rāzī and the New Ontology of Postclassical Kalām.” Oriens, 48: 67-122.

Jackson, Sherman. 2009. Islam and the Problem of Black Suffering. Oxford: Oxford University Press.

Johnson, Curtis. 2015. Darwin's Dice: The Idea of Chance in the Thought of Charles Darwin. New York, NY: Oxford University Press.

Keller, Nuh Ha Mim. 2011. Sea Without Shore: A Manual of the Sufi Path. Amman: Sunna Books.

Koca, Özgür. 2020. Islam, Causality, and Freedom: From the Medieval to the Modern Era. Cambridge: Cambridge University Press.

Koons, Robert C., and Timothy Pickavance. 2017. The Atlas of Reality: A Comprehensive Guide to Metaphysics. West Sussex: Wiley Blackwell.

Koperski, Jeffrey. 2020. Divine Action, Determinism, and the Laws of Nature. Abingdon: Routledge.

Kraft, András. 2016. “A Nominalist Deliverance from Error: On al-Ghazālī’s Concept of Modality." The Czech and Slovak Journal of Humanities: Philosophica, 1: 26-36.

Kukkonen, Taneli. 2000a. "Possible World in the Tahāfut al-Falāsifa: al-Ghazālī on Creation and Contingency." Journal of the History of Philosophy, 38(4): 479-502.

Kukkonen, Taneli. 2000b. "Plenitude, Possibility and the Limits of Reason: A Medieval Arabic Debate on the Metaphysics of Nature." Journal of the History of Ideas, 61(4): 539-560.

Kukkonen, Taneli. 2006. "Mind and Modal Judgement: Al-Ghazāl̄̄ and Ibn Rushd on Conceivability and Possibility." In Vesa Hirvonen, Toivo Holopainen, and Miira Tuominen, eds. Mind and Modality Studies in the History of Philosophy in Honour of Simo Knuuttila. Leiden: Brill, 121-139.

Kurt, Erkan M. 2012. Creation: The Principles of Nature in Islamic Metaphysics. New York, NY: Blue Dome Press.

Larmer, Robert A. 2014. The Legitimacy of Miracle. Plymouth: Lexington Books.

Lee, Sukjae. 2020. "Occasionalism." The Stanford Encyclopedia of Philosophy. Accessed 26th of September 2020. Available at: https://plato.stanford.edu/ archives/fall2020/entries/occasionalism/

Malik, Shoaib Ahmed. 2019. "God, Information and the World: The Metaphysics of William Dembski and al-Ghazālī.” Philosophy, 94(4): 547-576.

Malik, Shoaib Ahmed. 2021. "Al-Ghazālīs Divine Command Theory - Biting the Bullet." Journal of Religious Ethics, revised and resubmitted.

Marmura, Michael E. 2004. "Al-Ghazālē.” In Peter Adamson and Richard C. Taylor, eds. The Cambridge Companion to Arabic Philosophy. Cambridge: Cambridge University Press, 137-154. 
Mayr, Ernst. 1961. "Cause and Effect in Biology: Kinds of Causes, Predictability, and Teleology Are Viewed by a Practicing Biologist." Science (American Association for the Advancement of Science), 134(3489): 1501-1506.

Monton, Bradley. 2011. "Prolegomena to Any Future Physics-Based Metaphysics." In Jonathan L Kvanvig, ed. Oxford Studies in Philosophy of Religion. Volume 3. Oxford: Oxford University Press, 142-165.

Muhtaroglu, Nazif. 2010. “An Occasionalist Defence of Free Will.” In A-T Tymieniecka and Nazif Muhtaroglu, eds. Classic Issues in Islamic Philosophy and Theology Today. Dordrecht: Springer, 45-62.

Nasr, Seyyed Hossein. 2006. "On the Question of Biological Origins." Islam and Science, 4(2): 181-197.

Okasha, Samir. 2018. Agents and Goals in Evolution. Oxford: Oxford University Press.

Opwis, Felicitas. 2012. "Attributing Causality to God's Law: The Solution of Fahr Ad-Dīn Ar-Rāzī.” In Hans Daiber, Anna Akasoy, and Emilie Savage-Smith, eds. Islamic Philosophy, Science, Culture, and Religion: Text and Studies. Leiden: Brill.

Ormsby, Eric. 2017. Ghazali: The Revival of Islam. London: Oneworld Academic.

Osborn, Ronald E. 2017. Humanism and the Death of God. Oxford: Oxford University Press.

Pennock, Robert T. 1999. Tower of Babel: The Evidence Against the New Creationism. Cambridge, MA: The MIT Press.

Pines, Shlomo. 1997. Studies in Islamic Atomism. Jerusalem: The Hebrew University.

Placher, William C. 1996. The Domestication of Transcendence: How Modern Thinking About God Went Wrong. Kentucky: Westminster John Knox Press.

Plantinga, Alvin. 2011. Where the Conflict Really Lies: Science, Religion, and Naturalism. Oxford: Oxford University Press.

Plantinga, Alvin. 2016. "Law, Cause, and Occasionalism.” In Michael Bergmann and Jeffrey E Brower, eds. Reason and Faith: Themes from Swinburne. Oxford: Oxford University Press, 126-144.

Polkinghorne, John. 1995. "The Metaphysics of Divine Action.” In Robert John Russell, Nancey Murphy, and Arthur R. Peacocke, eds. Chaos and Complexity: Scientific Perspectives on Divine Action. Berkley: Center for Theology and the Natural Sciences, 147-156.

Polkinghorne, John. 2001. "Physical Process, Quantum Events, and Divine Agency.” In Robert John Russell, Philip Clayton, Kirk Wegter-McNelly, and John Polkinghorne, eds. Quantum Mechanics: Scientific Perspectives on Divine Action. Berkley: Center for Theology and the Natural Sciences, 181-190.

Pope, Stephen J. 2007. Human Evolution and Christian Ethics. Cambridge: Cambridge University Press.

Porter, Andrew P. 2001. By the Waters of Naturalism: Theology Perplexed Among the Sciences. Eugene, Oregon: Wipf and Stock Publishers.

Pruss, Alexander R., and Joshua L. Rasmussen. 2018. Necessary Existence. Oxford: Oxford University Press.

Richardson, Kara. 2020. "Causation in Arabic and Islamic Thought." The Stanford Encyclopedia of Philosophy. Accessed 10th of November 2020. Available at: https://plato.stanford.edu/archives/fall2020/entries/arabic-islamic-causation/

Ritchie, Sarah Lane. 2019. Divine Action and the Human Mind. Cambridge: Cambridge University Press. 
Rouzati, Nasrin. 2018. "Evil and Human Suffering in Islamic Thought - Towards a Mystical Theodicy." Religions, 9(47): 1-13.

Russel, Robert John, Nancey Murphy, and Arthur R. Peacocke, eds. 1995. Chaos and Complexity: Scientific Perspectives on Divine Action. Bloomington, IN: Vatican Observatory and the Centre for Theology and the Natural Sciences.

Russel, Robert John, Nancey Murphy, and C. J. Isham, eds.1996. Quantum Cosmology and the Laws of Nature: Scientific Perspectives on Divine Action. Bloomington, IN: Vatican Observatory and the Centre for Theology and the Natural Sciences.

Russel, Robert John, Nancey Murphy, and William R. Stoeger S. J., eds. 2008. Scientific Perspectives on Divine Action: Twenty Years of Challenge and Progress. Bloomington, IN: Vatican Observatory and the Centre for Theology and the Natural Sciences.

Russel, Robert John, Philip Clayton, Kirk Wegter-McNelly, and John Polkinghorne, eds. 2001. Quantum Cosmology and the Laws of Nature: Scientific Perspectives on Divine Action. Bloomington, IN: Vatican Observatory and the Centre for Theology and the Natural Sciences.

Russel, Robert John. 2008. Cosmology: From Alpha to Omega - The Creative Mutual Interaction of Theology and Science. Minneapolis, MN: Fortress Press.

Sabra, A. I. 2009. “The Simple Ontology of Kalam Atomism: An Outline.” Early Science and Medicine, 14: 68-78.

Schmidtke, Sabine, ed. 2014. The Oxford Handbook of Islamic Theology. Oxford: Oxford University Press.

Scott, Eugenie. 2009. Evolution vs. Creationism: An Introduction. Berkeley, CA: University of California Press.

Smedes, Taede A. 2004. Chaos, Complexity, and God: Divine Action and Scientism. Leuven: Peeters.

Stenmark, Mikael. 2001. Scientism: Science, Ethics and Religion. Abingdon: Routledge.

Sweetman, Brendan. 2015. Evolution, Chance, and God. New York, NY: Bloomsbury.

Weinberg, Steven. 1993. The First Three Minutes: A Modem View of the Origin of the Universe. New York, NY: Basic Books.

Wildman, Wesley J. 1998. "Evaluating the Teleological Argument for Divine Action.” In Robert J Russell, William. R Stoeger S. J., and Francisco J Ayala, eds. Evolutionary and Molecular Biology: Scientific Perspectives on Divine Action. Notre Dame, IN: University of Notre Dame Press, 117-150.

Wildman, Wesley J. 2008. “The Divine Action Project, 1988-2003.” In Russel, Robert John, Nancey Murphy, and William R. Stoeger S. J., eds. Scientific Perspectives on Divine Action: Twenty Years of Challenge and Progress. Bloomington, IN: Vatican Observatory and the Centre for Theology and the Natural Sciences, 133-178.

Williams, Richard N. and Daniel N. Robinson. 2016. Scientism: The New Orthodoxy. London: Bloomsbury Academic.

Winter, Timothy, ed. 2008. The Cambridge Companion to Classical Islamic Theology. Cambridge: Cambridge University.

Zarkasyi, Hamid Fahmy. 2010. Al-Ghazālì's Concept of Causality with Reference to His Interpretations of Reality and Knowledge. Kuala Lumpur: Islamic International University of Malaysia. 


\section{$7 \quad$ Intelligent design}

\section{Introduction}

In Chapter 2, we briefly reviewed the intelligent design (ID) movement and saw how it compared to other Christian responses, namely young-earth creationism, old-earth creationism, and theistic evolution. In Chapter 4, we saw how some Muslim thinkers like Muzaffar Iqbal and Harun Yahya rally behind the ID narrative - both quote from Michael Behe - and have sometimes taken it on as an exclusive theistic alternative to evolution. This is due to understanding evolution as either a Godless or a materialist theory, or because of the idea of randomness in Neo-Darwinism is seen as vexing. It was argued in Chapter 6 that God is still open to orchestrate the process of evolution under methodological naturalism (MN), and randomness (save strong ontological chance, $\mathrm{OC}_{2}$ ) isn't problematic under occasionalism. Furthermore, it was demonstrated in Chapter 6 that evolution isn't inherently atheistic nor naturalistic. While the exclusivity between atheism, naturalism, and evolution was shown to be untrue, it's time to evaluate ID on its own merit, and determine whether it is exclusively theistic. To this end, this chapter intends to clarify how ID stands scientifically, and theologically from an Ash'arite perspective.

This chapter is divided into four sections. The first section goes through some preliminary remarks. The second part is an overview of a specific kind of argument presented by Michael Behe, an ID proponent. The third section reviews the challenges ID faces in gaining credibility as a scientific alternative to evolution. The fourth section shows the irrelevance of ID from the Ash arite standpoint. To help the reader with the many abbreviations used in this chapter, they have been summarised and tabulated in the Note appended to this sentence. ${ }^{1}$

\section{Preliminary comments}

To fully appreciate the discussions to follow, three preliminary points need to be mentioned. These include the various presentations of the design argument, the perspectival difference between bottom-up and top-down approaches, and the distinction between cosmological design(ers) and biological design(ers). Let's review them. 


\section{Different presentations of design arguments}

First, design arguments are logically framed in one of two ways. One is through an analogical argument, and the other is through inference to the best explanation, or what is known as abduction. ${ }^{2}$ According to some, the analogical argument was used by William Paley (d. 1805) when he discussed his famous clock analogy (Nagasawa 2010, 71-73). ${ }^{3}$ He took the clock as a designed object because it is known to have a designer, i.e. a clockmaker, and then transposed it to apparently designed features in creation. If there are elements in creation which are designed like a clock, then there should be a designer of those features like the clockmaker. Abduction works differently. This approach involves identifying various scenarios or explanations for a phenomenon, and then through the accumulation of evidence and process by elimination tries to reason which possibility best explains it. ID arguments are presented in the abductive format where evolution's adequacy to explain biological complexity is rivalled with an intelligent designer, with the latter considered being a superior explanation by its advocates (Jantzen 2014, 189-225).

\section{Top-down and bottom-up differences}

Second, we need to distinguish between a top-down approach and a bottom-up approach when understanding designs and designers. A top-down approach is what a designer can and cannot create given the designer's capabilities. Say an architect is known to be really good with designing houses made of wood and nothing else. Based on this information, we know what he can do, i.e. create good wooden houses, and what he cannot do, e.g. create houses made out of concrete.

By contrast, a bottom-up approach determines the designer's capabilities based on what is deemed to be designed. Imagine two tables that show very different levels of intricacy. One table is very basic with just a plain surface and four simple legs but with an excellent finish. The other table is much grander with very sophisticated patterns on the legs and the surface, and moving parts, e.g. drawers. The question is, what can we infer about the designer of each table. Due to the simplicity of the first table, the only thing that can be conclusively inferred about the designer is he/she can design simple tables. From this, it naturally follows that he/she should have certain knowledge and physical makeup to be able to make that table. This information is knowable. But what isn't knowable are things like whether this is the designer's first table or the best one he's designed so far, or what colour hair he/she has. Perhaps the individual is indeed a very creative designer and decided to create a simple table on this particular occasion (for whatever reason, e.g. sickness). Still, in the absence of knowing this and anything else about the designer, and simply judging him/her based on the table, the only thing that we can definitively ascertain is he/she is a simple designer; everything else is speculative. 


\section{Metaphysical considerations}

The same cannot be said of the designer of the second table, however, because of the added sophistication in the craftsmanship. The second designer can create more refined tables, and therefore it makes sense to ascribe higher-level table-making capabilities to him/her. Moreover, it would be rational to assume that the designer of the more sophisticated table could create the simpler table since this requires more know-how and better craftsmanship capabilities, but we cannot state for sure that the designer of the simpler table can create the more sophisticated one.

Finally, until now we've assumed the designer is a human, but it is also perfectly possible that the designer of either table is a machine. Since both humans and machines can create tables, and barring extra information, both are plausible candidates. It is also unclear whether there was one or many designers. Perhaps different designers were responsible for different parts of the table's assembly, or it could involve a combination of machine and human designers. Just by using the tables as our only available evidence, the designer's identity is uncertain, and it also unclear how many designers were involved. We can definitively determine that at least one designer was involved. Unless the seller of those tables informs us that the table was a human or a machine, and how many were involved in the process, we can't clearly rule out those possibilities.

The distinction between the top-down approach and the bottom-up approach will be helpful for when analysing ID theologically.

\section{Cosmological versus biological design}

Finally, it will be helpful to acknowledge the difference between cosmological design and biological design (Barr 2003, 69-70). Cosmological design arguments are inferences made to a designer due to the features of the entire universe. The fine-tuning argument - the idea that the universe is set up with certain physical constants which fall under an incredibly narrow life-permitting range - is an example of this kind (Waller 2020). This is contrasted with biological design, which infers a designer based on the complex features found in the biological world. This is the main but not exclusive territory of ID. One important thing to note about this difference is the designer's capabilities from each kind of argument. Just from the sheer difference in scale, the designer of the cosmos should be much more intelligent and powerful than the designer of the biological world (similar to the table-designer example we looked at earlier). This is important to highlight because it demonstrates the viability of designer candidates for each argument. For example, consider an advanced alien civilisation which originated on another planet earlier than life originated on earth. They could have to come to earth and interfere with its history of life that resulted in today's biochemical diversity and complexity. ${ }^{4}$ In this case, they would correctly be called the designers of earth's biological world. But they 
wouldn't necessarily be the logical candidates for the designer of the universe seeing that they relied on the universe (its physical constants and laws) for their existence to come about. If an entity did design the universe, it could have the capacity to design the biological complexity which is seen on earth. ${ }^{5}$ It is worth mentioning this to illustrate the logical relationship(s) between the cosmological designer (CD) and the biological designer (BD). The CD, e.g. God or some entity that lives in the multiverse (or beyond it), could be the BD but the reverse isn't necessarily true. In other words, the BD doesn't automatically entail a CD. This is an important to raise, and it will have implications for when evaluating ID theologically as we shall shortly see. ${ }^{6}$

\section{Michael Behe's irreducible complexity}

ID rests on the thesis that there are incredibly sophisticated markers of intelligence in the biochemical world, which gives us warrant for a belief in some kind of designer. As mentioned in Chapter 2, advocates of ID make it very clear that what they are presenting is a scientific alternative to evolution, not a religious one. There are two popular formulations by ID proponents. One presentation is framed by Michael Behe, who is famous for promoting the idea of "irreducible complexity" (IRC) (Behe 2006; 2007; 2019). The other way of arguing for ID is presented by William Dembski $(1998 ; 1999 ; 2002 ; 2004)$, which takes on a very technical and mathematical formulation, and is a general framework that can be applied to all systems, biological or otherwise. Despite the different ways these arguments are presented, the net result is the same. The main contention which advocates of ID bring forward is the incapability of natural selection and random mutation, i.e., Neo-Darwinian mechanics, to bring about some of the complexities seen in the biological kingdom. Thus, Neo-Darwinian evolution is a weaker explanation than an intelligent designer. For the sake of simplicity, only Behe's argument will be reviewed here, but the reader can refer to the references to follow up on Dembski's and others' thoughts (Johnson 1993; Johnson 1995; Johnson 1997; Johnson 2000; Wells 2000; Wells 2006; Meyers 2009; Berlinski 2010; Wells 2011, Meyers 2013; Denton 2016; Wells 2017).

Behe's formulation for an intelligent designer rests on IRC. But what exactly is meant by this? Behe uses a mousetrap as an analogy to explain what he means by the term (Behe 2019, 227-252). As shown in Figure 7.1, a mousetrap has several individual components that perform the function of a mousetrap only when they come together. So even if one component is removed, the entire function of the mousetrap is lost. In other words, IRC systems rely on the aggregation of individual components, each of which is necessary, and collectively yield a specific function. With this understanding in place, Behe then moves to the biological world to give examples of IRC. 


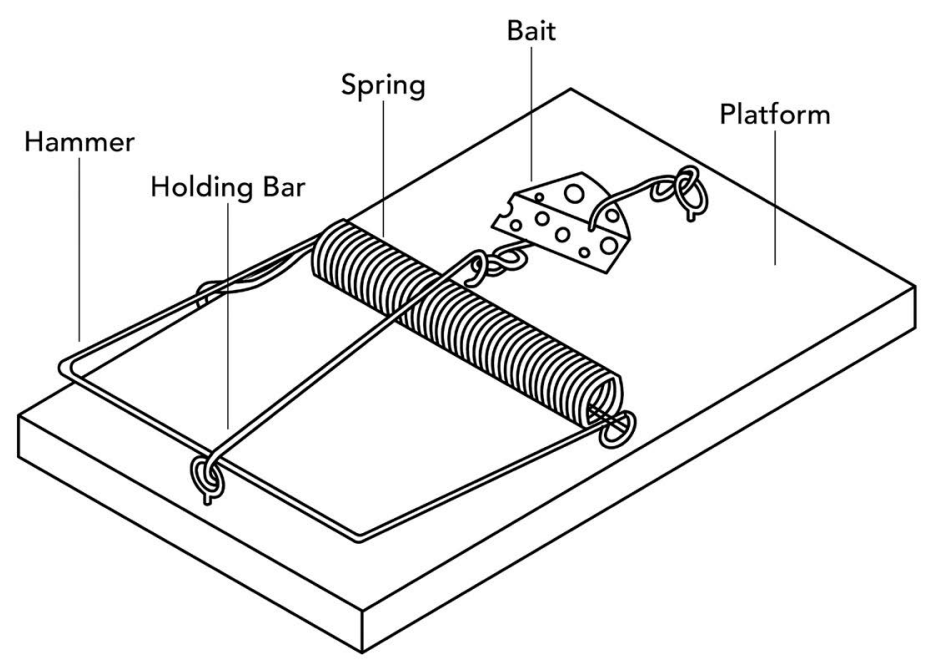

Figure 7.1 This image shows a mousetrap with all its various components, which is Michael Behe's famous example used to illustrate how multiple elements need to come together for a particular and collective function.

One of his favourite examples is the bacterial flagellum (Behe 2019, 283-287). The flagellum is a structure that has a protruding tail which gives it locomotive capabilities as shown in Figure 7.2. The flagellum is connected to a motor-like structure (based on the collective configuration of the various proteins involved) that allows it to rotate. For more details, the reader is advised to read Behe's descriptions in his work. What matters with this example is that if even one component were out of place, the assembly would lose locomotion. If this is indeed a case of IRC, then what are we to conclude from this? Behe $(2006,39)$ puts it as follows:

An irreducibly complex system cannot be produced directly (that is, by continuously improving the initial function, which continues to work by the same mechanism) by slight, successive modifications of a precursor system, because any precursor to an irreducibly complex system that is missing a part is by definition nonfunctional. An irreducibly complex biological system, if there is such a thing, would be a powerful challenge to Darwinian evolution. Since natural selection can only choose systems that are already working, then if a biological system cannot be produced gradually it would have to arise as an integrated unit, in one fell swoop, for natural selection to have anything to act on.

To be clear, what Behe is implying by this statement is that it is an all or nothing situation. Neo-Darwinian evolution (which, to be clear, Behe refers to as Darwinian in the quote above) relies on stepwise development. This means 


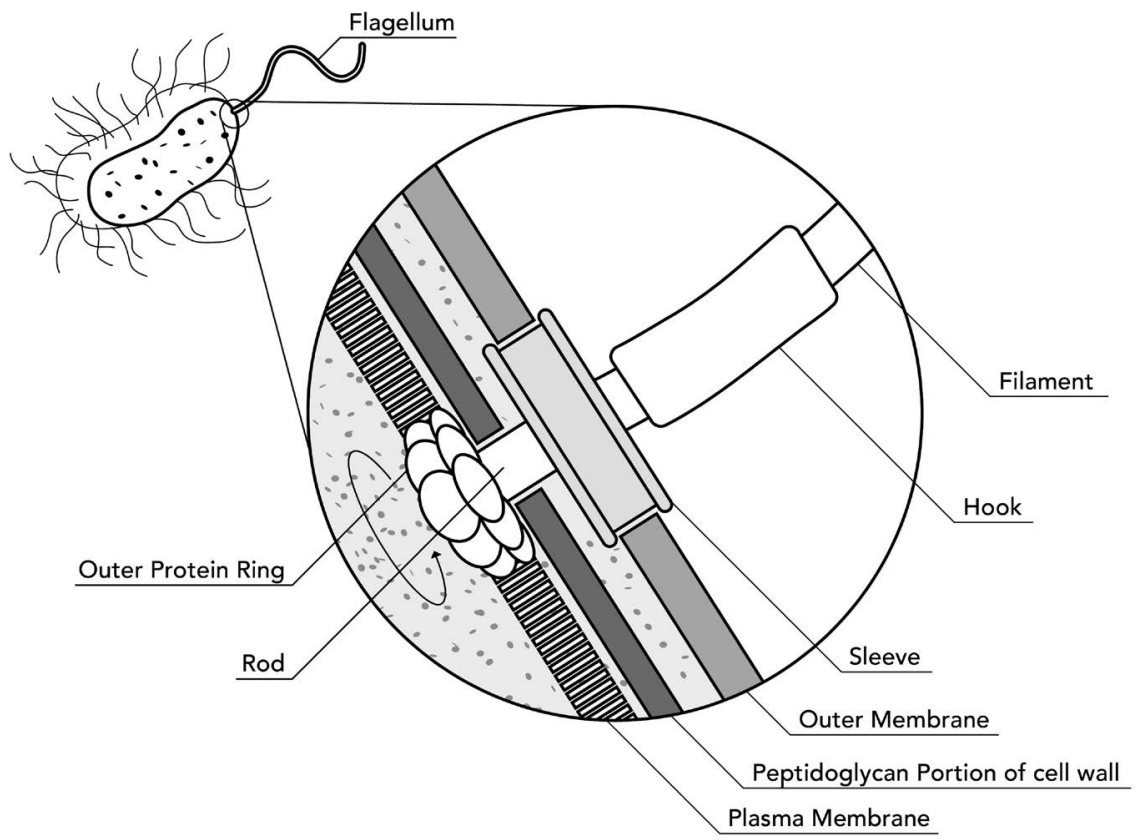

Figure 7.2 This image shows a bacterial flagellum. The internal architecture of the flagellum looks very similar to the design of a motor. Michael Behe uses this as an example of irreducible complexity because the bacterial flagellum has multiple components that need to be intricately combined to attain locomotion just like a motor.

that new biological structures rely on their precursors, i.e. they need previous templates to work off. But even if one of the necessary components is not there, then there is no pre-existing bacterial flagellum because it would lose its functionality, and therefore not exist. So, all the necessary components need to be there simultaneously, or else the entire thing fails. Behe takes this line of reasoning to conclude that random mutations and natural selection alone are statistically improbable for all the components to be there in the right circumstances. A better explanation, then, is to consider an intelligent designer. By extension, as IRC systems get more complicated by requiring more necessary components to acquire a collective, specific function, their existence through Neo-Darwinian mechanics becomes even more statistically improbable, and thus more likely through an intelligent designer. ${ }^{7}$

Critics have not found this line of reasoning convincing. Setting aside the idea that improbability doesn't necessarily entail impossibility, critics argue that Behe has framed the discussion in a binary lens, which doesn't seem to be warranted (Miller 2002, 131-164; Miller 2003). It is definitely conceded that many basic but necessary parts need to come together like for structures like the bacterial flagellum. However, what is being questioned 


\section{Metaphysical considerations}

is the "all or nothing" approach presented by Behe. Perhaps the individual components might be available in a way that increases the probability or the likelihood of IRC systems. The individual components originally could have had different functions in their developmental history, but those functions might have changed over time, leading to complex entitles like the bacterial flagellum. Accordingly, while there might not be pre-existing or proto bacterial flagellums, the components might have been readily available that could have led to their existence.

Think about the mousetrap again. Minimally, it has a spring mechanism, a hammer of some kind, a holding bar, and a base platform (see Figure 7.1). If you were in your house and suddenly had the idea to create a mousetrap, it would be very unlikely to find all these parts ready as they should be for your mousetrap. But imagine if you could identify equivalents of those parts in house items that you already possess. You could get a spring mechanism from an old toy, a hammer from a clothes hanger, and the base from scrap wood. They may have had different functions when taken individually, but if brought together and arranged in a specific configuration, they can be used to create a mousetrap. Critics of Behe argue for evolutionary developments of IRC systems in the same way.

Given these contentions, the question becomes of evidence. For clarity, we need to distinguish between two questions:

1 Is there any scientific evidence of biological entities generally changing function?

2 Is there any scientific evidence of evolutionary pathways of individual components leading to IRC systems?

One response to the first question would be feathers initially used for thermal insulation that eventually gained functionality for aviation capability (McLennan 2008). As for the second question, there have been several suggestions of experiments, mechanisms, and theoretical simulations which can lead to IRC systems (Gishlick 2005; Doolittle et al. 2008; Durett and and Schmidt 2008; Näsvall et al. 2012; Chou et al. 2015; Good et al. 2017; Lang and Rice 2019; Lents et al. 2019). However, in his most recent book, Darwin Devolves, Behe (2019, 287-294) reviews the various studies over past two decades that have tried to argue along those lines, and concludes that none of them deliver. The following is his summary (Behe 2019, 294):

Almost all work on the evolution of flagella consists in comparing sequences, a method that - although it can support interesting conjectures about who descended from whom - says nothing about the mechanism of evolution. The very little work that has been done that's relevant to the mechanism strongly supports the arguments of this book. ${ }^{8}$

He believes that so far no evidence sufficiently warrants the case that evolutionary pathways for IRCs have occurred. Adding to this point, Behe 
$(2019,232)$ has a serious issue with how critics demand evidence from him (and ID in general) for a categorical negation of such possibilities:

... many critics ... force skeptics like myself into trying to prove a negative. 'Demonstrate,' they insist, that a functioning trap 'could not possibly' arise gradually; prove that it's somehow logically impossible. But that's a completely unsuitable standard. Although it uses logic, science judges the success of a theory by the weight of empirical evidence. The appropriate straightforward criterion is this: if there are good physical reasons to think [Neo-]Darwinian routes wouldn't work and if after a diligent search no evidence is found that they do, then the theory has failed. There's no obligation to pretend otherwise, no requirement to hunt forever for the Loch Ness monster.

In other words, Behe finds it incredibly problematic that he is being asked to deliver an absolute rule-out of any possibility of complex features ever coming out of natural selection and random mutation. In his view, this is an impractical demand. Others disagree with Behe's arguments and conclusion (Lang and Rice 2019; Lents et al. 2019).

This debate won't be entertained further than this. The key point to note here is that Behe thinks IRC systems cannot be adequately explained through Neo-Darwinian mechanics, and a better explanation is an intelligent designer. Critics argue that this approach jumps to a conclusion too quickly without giving enough credence to arguments that have been presented and potential scenarios, which, even if are yet not known or known but not empirically validated, could one day be empirically established (Musgrave 2005; Ussery 2005; Young 2005; Dorit 2007; Elsberry 2007). In other words, a designer isn't necessarily the automatic answer when there is no current answer. Fundamental to this issue is how the available and prospective evidence anchors the relevant possibilities and probabilities. This is one of several things that divides critics and advocates of ID.

\section{Evaluating ID as a science}

The question of ID being a valid scientific explanation has been a long and constant battle. To make sense of this multifaceted discussion, we can divide the areas of contention into three different points. These include the demarcation of science from pseudoscience, $\mathrm{MN}$, and science's cultural context. Each of these points should not be thought of as distinctive things since they are all interrelated; rather, they should be seen as highlighting different parts of the discussion on the question of ID being a scientific theory.

The question of demarcating science from non-science or pseudoscience has a long historical standing starting from 1935 when Karl Popper (who we looked at in Chapter 1) first talked about the demarcation criteria. Since then, many suggestions have been made to show how one can 
sharply distinguish between science and everything else. Almost all such proposals have been deemed unsatisfactory either because they become so abstract that they are impractical for scientists, i.e. they become overly prescriptive in what scientists do or ought to do, or because there are always exceptions which can be identified (Hansson 2017; McIntyre 2019; Reeves 2019). Furthermore, what science means can vary from one time to another (Brooke 2014; Harrison 2017). For example, what would be considered scientific before and after the computer generation would be very different. Before the invention of computers, scientists were largely seen to be involved with experimental procedures. However, today there are some disciplines which are solely computational. Theoretical physics is one example. Such disciplines don't have a historical parallel. Finally, given the hyper-specialisation of science today, it is challenging to identify a single set of criteria which satisfies all of them. What would be the underlying denominator of evolutionary biology, astronomy, psychology, and sociology? And is mathematics a science? These are difficult questions that would need addressing. In short, identifying a single set of criteria which successfully demarcates between science and non-science or pseudoscience that is transhistorical and transdisciplinary is a vexing philosophical question. It is why some have tried to identify a multi-criterial approach rather than a mono-criterial one (Hansson 2017). None of this should be taken to mean that everything goes in science. Currently, no one treats astrology - the study of horoscopes - as a science because it lacks scientific appeal. It doesn't give us specified predictive power, simplicity, an explanatory or research scope, and falsification criterion among others. Prudentially, all this indicates is that each discipline is assessed on a case-by-case basis before it is welcomed under the umbrella of science. ${ }^{9}$

Given what has been mentioned, the question is how ID fares as a scientific theory. A useful starting point is the Kitzmiller v. Dover Area School District court case, also known as the Dover Panda Trial, which took place in 2005. This was an important time in the legal, social, and pedagogical acceptance of ID. The case was brought to the fore because ID was being taught in certain schools. A book by the name Of Pandas and People (from which part of the name for the Dover Panda Trial comes from) was circulated as a textbook. But this was questioned by many, and eventually led to a court hearing. After hearing defences from both sides, Judge Jones, who presided over the court case, eventually denied ID as a scientific theory (Kitzmiller v. Dover 2005).

Central to the debate is the scope of science and its relationship to naturalism (Koperski 2015, 202-214). Recall from Chapter 6, MN is contrasted with philosophical naturalism (PN) in that the latter is an ontological position and the former is an epistemic one. MN makes no assertions about the world's total ontological furniture, and simply limits science as a method of inquiry of the natural world. Despite MN's neutral appeal, which comfortably explains how atheists and theists can both come to do excellent 
science, this is, nonetheless, being criticised by advocates of ID. Proponents of ID point out that this is an unnecessary restriction on science. They argue that science shouldn't be restricted by a priori principles which automatically rule out explanations that may be plausible. If the investigation of natural phenomenon points to some kind of designer, which recall isn't specified by the ID theorist, then it should be taken seriously. If scientists aren't willing to give credence to such valid explanations, goes the ID theorist, then it shows science isn't truly an open enterprise since valid suggestions are being criticised due to prior commitments as to what science should be. Since ID theorists consistently emphasise that the designer isn't specified, and can easily be natural entities like aliens, then the criticism of ID being an argument for a supernatural designer loses force. So what, then, is the issue?

The ID movement lost their impartiality and neutrality after the infamous Wedge document that was leaked from the Discovery Institute and surfaced on the net in 1999 (Forrest and Gross 2007). It was a manifesto that clearly outlined a plan to overtake the materialistic framework of science. In it was the blueprint of the ID movement, which involved establishing a scientific alternative to evolution that was God-friendly (Pigliucci 2002, 68-72; Kitzmiller v. Dover 2005, 720). This revealed the underlying motivations of the ID movement, which played a significant role when Judge Jones made his decision against countenancing ID as a scientific theory. Since the document made it very clear that ID was a religiously-motivated movement, and God was indeed the designer, the appeal to an unspecified designer was seen as mere lip-service for public neutrality (Kojonen 2016, 91). Thus, because it was clearly established that ID members identify the designer with a supernatural entity, it was considered to be unscientific based on the aforementioned criterion (Kitzmiller v. Dover 2005, 737). Had the Wedge document not been released, who knows how the legal, social, and pedagogical framing of ID might have looked like today.

Unsurprisingly, advocates of ID have retorted with claiming that their personal beliefs should not necessarily undermine the merits of the arguments they are presenting. God is a possible candidate of the designer in light of their worldview, but it can equally be a terrestrial or galactic designer. Thus the warrant for a designer isn't negated simply because their personal beliefs have been identified to be with God (Kojonen 2016, 91-93). As put by Behe $(2003,276)$,

... while I argue for design, the question of the identity of the designer is left open. Possible candidates for the role of designer include: the God of Christianity; an angel - fallen or not; Plato's demiurge; some mystical new-age force; space aliens from Alpha Centauri; time travelers; or some utterly unknown intelligent being. Of course, some of these possibilities may seem more plausible than others based on information from fields other than science. 


\section{Metaphysical considerations}

Interestingly, Behe $(2006,241)$ remarks that even if a supernatural designer was permitted, it doesn't entail a full-on acceptance of every supernatural explanation and breakdown of science:

No one can predict the behaviour of human beings, but it seems to me that the fear of the supernatural popping up everywhere in science is vastly overblown. If my graduate student came into my office and said that the angel of death killed her bacterial culture, I would be disinclined to believe her. The Journal of Biological Chemistry is unlikely to start a new section on the spiritual regulation of enzyme activity.

But if this is conceded, it might raise more questions than answers. Say for the sake of the argument that supernatural designers and even natural designers are accepted as viable explanations. It remains unclear, and perhaps even more perplexing, as to how scientists could ever successfully demarcate between explanations calling for supernatural designer(s) versus natural designer(s) versus natural claims (Ratzsch 2001, 27-39; Pigliucci 2002, 64-68).

A broader worry with entertaining designers as viable explanations is potential research lines could very easily be short-circuited if a current natural explanation can't be found. If Neo-Darwinian mechanics make it improbable to explain some complex features, as proponents of ID claim, it doesn't by default entail a designer. There are perhaps other proposals which could be considered. As mentioned in Chapter 1, currently there is a debate amongst evolutionary biologists over Neo-Darwinian mechanics through which suggestions of alternative mechanisms have been made for phenomena which, it is claimed, Neo-Darwinian evolution can't explain (recall the Extended Evolutionary Synthesis). Perhaps these new developments may shed some new light on how some biologically complex features came about (Koperski 2015, 218). Thus, the worry with such thinking is it may stifle research activity all too quickly. Denis Alexander (2008, 306-307), a wellknown Christian molecular biologist, criticises ID on this point:

The idea of 'irreducible complexity', with its associated idea of a 'design inference', is actually very sterile for science and indeed forms no part of scientific thought. Imagine that I have a PhD student in my laboratory, to whom I have given the task of working out a complex biochemical signalling pathway in the white blood cells that defend our bodies against viruses, but after a couple of years of hard work the student comes into my office saying 'I'm terribly sorry, I've worked on this project really hard for two years, but the signalling pathway just has too many components to analyse properly, so I think it's irreducibly complex and must be designed.' I will leave the subsequent conversation to your imagination, but the outcome would certainly include the student being sent back to the laboratory to try a 
bit harder! Calling something 'designed' would not help to generate a set of experiments to test the hypothesis. How would my PhD student test the idea in the laboratory that the biochemical signalling pathway in question is designed? How could such an idea be falsified? Unless ideas in the biological sciences field are testable, leading on to a fruitful research programme, then they are sterile and in fact form no part of the scientific enterprise.

In effect, positing a designer seems problematic for science and borders on the edge of unfalsifiability if presented as the default alternative to Neo-Darwinian (and alternative explanations of) evolution. These added difficulties with accepting supernatural or natural designers as a viable scientific explanation explicate the resistance scientists have with accepting ID as a science.

Evident in this entire discussion is that there are background commitments that inescapably affect how one evaluates ID (and in fact anything presented as science). As we saw earlier, theories are judged by certain scientific virtues. Koperski $(2015,25-29)$ calls them metatheoretical shaping principles (MSPs), and he distinguishes broadly between two types: metaphysical and epistemic MSPs. Examples of metaphysical MSPs include uniformity of nature, causation, and realism; examples of epistemic MSPs include justification, induction, and MN. These are some of several principles which scientists adopt when guiding their judgements and assessments of scientific theories and data. All these have been debated over (Pigliucci 2010; Koperski 2015, 11-57). We have already seen how $\mathrm{MN}$ is a major point of contention. However, missing or not explicitly mentioned by Koperski is how values affect scientific endeavours.

Scientific activities are never done in a vacuum; they are always part of a larger cultural context. Sometimes, the values held by that society affect how science plays out in practice. Imagine a time and place in which cutting up a dead body is highly tabooed. Scientists who may be curious in determining what is inside a human body would think twice before performing any surgery given such associations with this particular activity. So in this instance, we have a particular value or norm that impedes a particular line of inquiry. While this may be a hypothetical scenario, such instances are not uncommon in reality. As mentioned in Chapter 1, Darwinian evolution was initially viewed negatively because it broke away from the then highly valued teleological alternatives (Bowler 1983; Bowler 2009; Behe $2019,81-86)$. Or take the example of how in the early part of the twentieth century, some scientists provided evolutionary explanations for the differences between white and black people. These included black people having smaller brain sizes and were even deemed descendants of non-Adamic lineages, which justified their primitiveness compared to white people (Livingstone 2008). These are clear examples of how values and biases affect scientific practice. To be sure, this isn't meant to imply that scientists 


\section{Metaphysical considerations}

are entirely or reductively shaped by their societal norms. All that is being highlighted is that background values (societal or individual) are intricately entangled with how MSPs are adopted and utilised. ${ }^{10}$

Given this point, it seems that the current pedagogical and social context does not favour ID. Before the ID movement's arrival on the scene, creationist movements (young and old earth creationism) made a lasting but negative impact on the legal, political, and educational landscape with their own shares of court cases and socio-political clashes with the scientific community (Numbers 2006; Bowler 2007; Nagasawa 2010, 51-54; Phy-Olsen 2010; Caudill 2013; Rios 2014; Kaden 2015, 1-66). Worrying over creationist criticisms against science, several thinkers and bodies responded with nationwide clampdowns on creationist ideas wiggling their way into education settings (Berkman and Plutzer 2010). These included coordination of education bodies, e.g. National Academy of Science, to develop guidelines that clarify what kind of science can be taught in classrooms, and the publications of several books and training programs that respond to creationists claims. Against this tensive environment, ID is seen as another creationist camp, ${ }^{11}$ albeit more sophisticated, and hence is dealt with extreme suspicion. For instance, Forrest's and Gross's (2007) detailed study of the Wedge document and the ID movement behind it is named Creationism's Trojan Horse. It is then no wonder that the scientific community resents anything that comes even remotely close to creationism. This isn't an excuse to justify the scientific validity of ID; rather, what is merely being highlighted are the value systems that enwrap the current discussion on ID that has deeply entrenched historical roots. This suggests one reason why ID is very unwelcomed in the current day and age. Though not necessarily with the aforementioned points in mind, Sean Carroll's $(2005,631)$ following statement sheds some light on how ID-styled developments could have had viability in a different time and era, but it isn't the case with the contemporary period:

A few centuries ago, for example, it would have been completely reasonable to observe the complexity and subtlety exhibited in the workings of biological creatures, and conclude that such intricacy could not possibly have arisen by chance, but must instead be attributed to the plan of a Creator. The advent of Darwin's theory of evolution, featuring descent with modification and natural selection, provided a mechanism by which such apparently improbable configurations could have arisen via innumerable gradual changes.

Whether ID will ever be taken seriously is heavily dependent on the fruits of scientific labours and the scientific community's consensus. As it stands, ID is seen as either being unscientific altogether or simply bad science. As seen earlier, this objection comes from scientists who are atheists (e.g. Sean Carroll) and Christians (e.g. Denis Alexander). But because of the issues we 
have looked at, namely the demarcation criterion, $\mathrm{MN}$, and the cultural context of the scientific community, it remains unclear which side ID seems to be on. Treading this evaluation with caution, Yujin Nagasawa (2011, 100) summarises the situation well: “... it is much more difficult to show that intelligent design is not science than to show it has not been established as a good viable scientific theory." In short, ID is currently seen as a questionable scientific explanation for biological design, and only time will tell if and how this might change.

\section{Evaluating ID theologically and philosophically}

In this section, four problems with ID are discussed in light of al-Ghazālì's metaphysical framework as outlined in Chapter 6. These are the localisation problem, the specification problem, the tentative abduction problem, and the contingency problem. The motivation behind this section is to elucidate why ID is an unsatisfactory position from an Ash arite perspective.

\section{Localisation problem}

ID advocates make it very clear that that they are only arguing for a designer based on some entities that have complex features in nature. The other parts of the biological kingdom could easily be produced from NeoDarwinian mechanics. As stated by Behe $(2011,356)$ :

... Intelligent Design can happily coexist with even a large degree of natural selection. Antibiotic and pesticide resistance, antifreeze proteins in fish and plants, and more may indeed be explained by a [Neo-] Darwinian mechanism. The critical claim of ID is not that natural selection doesn't explain anything, but that it doesn't explain everything.

Dembski $(2004,63)$ makes a similar statement elsewhere:

The design theorist is not committed to every biological structure being designed. Naturalistic mechanisms like mutation and selection do operate in natural history to adapt organisms to their environments ... Nonetheless, naturalistic mechanisms are incapable of generating the highly specific, information-rich structures that pervade biology.

So Behe and Dembski concede here that evolution can explain some things through natural selection and random mutations, but complex features seem better explained by a designer (or designers). Put this way, it seems the designer is allocated a very limited and localised role in the universe. But the God of al-Ghazālī isn't a localised designer as such. Instead, the God of al-Ghazālī is responsible for everything, everywhere, all the time. 


\section{Metaphysical considerations}

As mentioned in Chapter 6, al-Ghazālī’s Ash'arism prescribes an occasionalist outlook. This entails that regardless of whether entitles are complex, somewhat complex, or very simple (non-designed or rudimentary), they are all created and sustained by God. Therefore, limiting God to be responsible only for complex features while ignoring everything else is astoundingly inconsistent.

\section{Specification problem}

This next issue with ID fundamentally boils down to the lack of specification of the designer. Since ID by their own admission concede that the designer could be an array of things, it makes it very unclear whether God is the actual designer or not. Given ID and what can be determined from the argument, the best that can be determined is that all entities that exhibit complexity have a designer of some sorts. By extension, as the sophistication of such entities increases, so does the designer's intellectual requirements and capabilities. This does not, however, logically land us to God, who is omniscient and omnipotent. One would need extra premises or arguments to show how the designer is God rather than someone or something else. So God could be a candidate, but he isn't the only one, and it is far from clear how biological design alone can lead us to God as an explanation or a designer. Behe $(2003,277)$ also acknowledges this point:

The most important difference [between my intelligent design argument and William Paley's traditional design argument for the existence of God] is that my argument is limited to design itself; I strongly emphasise that it is not an argument for the existence of a benevolent God, as Paley's was. I hasten to add that I myself do believe in a benevolent God, and I recognise that philosophy and theology may be able to extend the argument. But a scientific argument for design in biology does not reach that far.

Given what has been stated, it is then perfectly possible for the designer to be some kind of a terrestrial or galactic entity, e.g. aliens. Just on this point alone, then, $\mathrm{BD}$ is perfectly compatible with atheism, agnosticism, and theism. This is very important to note. As disturbing this might be to some Muslim thinkers, e.g. Harun Yahya, but BD is not restricted to theism. This is a glaring problem with adopting $\mathrm{BD}$ if it is being instrumentalised merely for the sake of being God-friendly. With BD alone, theists and atheists are in the same boat. Some might contend that this seems to be a bit of a jump since the cosmological design arguments make it unlikely that the designer can be an intra-cosmic entity. Therefore, atheism is ruled out. This very well may be true. However, as mentioned in the preliminary section earlier, this contention presumes that the BD and the $\mathrm{CD}$ are one and the same. This is not argued for and instead simply asserted. Since ID in the context 
of the evolution debate is strictly a biological argument, the best one can attain is a $\mathrm{BD}$, but the jump to the $\mathrm{CD}$ needs extra argumentation to make the case. How this can be done is unclear. Furthermore, and as stated earlier, just from the sheer size of scale, the CD has to be more powerful, knowledgeable, and capable than the BD to be able to produce and sustain something like the universe. Therefore, one can easily argue that the $\mathrm{CD}$ could be the $\mathrm{BD}$, but the reverse isn't necessarily true.

However, let's assume for the sake of the argument that the BD and $\mathrm{CD}$ are the same, and this is a significant concession, what implications might this have? For one, it may rule out atheism as a valid option in the atheism-theism divide, which might favour and impress those who latch on to ID as an alternative to evolution because for them it equates to atheism (something which was clearly stated isn't the case in Chapters 1 and 6). But even at this point, it remains unclear whether this designer is God or not. Again, what can definitively be ascertained is the CD has to have the required knowledge, power, and capabilities to create and construct something like the universe. But this is still far from saying that this designer is an omnipotent and omniscient being that al-Ghazāli holds on to. Given the possibilities of multiverses and potential entities living in those multiverses, it is entirely conceivable that a pre-cosmos civilisation created this universe. Just by relying on design alone doesn't guarantee that God is the designer.

These issues with ID make sense seeing that this a bottom-approach. Design arguments could suggest a designer, but the designer's identity may fit with any entity that fits the required criteria. As has been repeatedly pointed out, the designer in design arguments doesn't definitively lead to God since it remains unspecified. So it would be presumptuous to conclude that God is the exclusive and sole candidate. Some Muslim thinkers automatically presume that ID leads to God, but this is merely asserted and never demonstrated. To make a case for this claim, one would need to step outside of design arguments and argue for an entity like God, e.g. the contingency argument. Only then could the designer of ID arguments be correlated much more strongly with God. If this is the case, then it simply raises the question of why ID is being latched on to if it doesn't necessarily entail God. As highlighted earlier, some thinkers perceive ID as an alternative to evolution because they see the latter as being atheistic and ID as being God-friendly. But this is a false bifurcation. As we have seen, the $\mathrm{BD}$ is compatible with atheism, agnosticism, and theism. So not only does this strategy fail to live to its mark, but it also relies on an exclusive binary which unfairly treats evolution as atheistic and ID as theistic.

\section{Tentative abduction problem}

The next issue with ID theologically is the abductive nature of the argument. Recall from the preliminary section earlier, abduction is when there are multiple explanations, and the one that is adopted is the best 


\section{Metaphysical considerations}

explanation in light of the evidence and its strength in comparison to others. Advocates promote ID in a way that makes it a better explanation than Neo-Darwinism in light of scientific evidence. Let us concede to this and agree that complex features in the biological world are incredibly improbable. Therefore, a designer is a better alternative. Furthermore, let us assume that this designer is God. The problem with this position is that it is premised on current knowledge that evolutionary biologists occupy. Regardless of the improbability of complex biological features arising through NeoDarwinian mechanics, it still leaves open the possibility of there being a natural process which does not rely on a designer, i.e. perhaps scientists can come up with an explanation that explains complex features which is scientifically adequate through evolutionary processes currently yet not understood or entertained. Unless this has been categorically ruled out, which it hasn't, this makes ID as some kind of an argument for God tentative. This would be extremely problematic within an Ash'arite paradigm. Al-Ghazālī would never place God in a provisional position that could one day be undermined in light of new scientific evidence (no matter how improbable) since God and natural explanations can never compete. God is the primary cause of all creation and could never enter such an opposing relationship with his own creation. Within the Ash'arite paradigm, it is always God (primary cause) and scientific explanations (secondary cause) and never God or scientific explanations. In short, God can never be a placeholder for our tentative scientific ignorance. So unless all alternative explanations can be categorically ruled out, which would be exceedingly hard to do, from an Ash arite perspective identifying God with the BD is indeed a "God of the gaps" narrative even though ID proponents don't claim this to be the case.

\section{Contingency problem}

Despite all that has been said thus far, it is probably the contingency problem that may be the most contentious issue al-Ghazāli might have with ID. The previous objections are based on a bottom-up perspective, i.e. what can one infer of the designer-based elements that display complexity in creation. By contrast, the contingency problem is predicated on a top-down perspective. The key thing here is trying to understand what God's creative capabilities are. What can God do? Can he create all sorts of worlds? Or is he restricted to a certain few?

Recall from Chapter 6 that in the Ash arite paradigm God can create anything so long as it is not logically contradictory. So God can create three-headed human beings, dragons, a universe with different laws and so on. However, divine power does not apply to illogical things. Examples include a square circle. This isn't a limitation on God as such, but more how such things are intrinsically nonsensical. It's equivalent to asking when did the numbers sleep? Or saying things like the colours were 
walking yesterday. Numbers aren't the kind of entities that sleep, and colours don't walk. These are illogical and nonsensical statements. The contrast between the two sets of examples should make evident what God can and cannot do.

In light of this point, God can easily create worlds that are equally complex/designed as this world, more complex/designed than this world (i.e. more finely tuned or more improbable scenarios), and even less complex/ designed than this world. Alternatively, we can even look at the kind of worlds God can create in terms of laws of nature. God can create completely deterministic worlds. So everything is fixed and going according to motion, and there is no room for probabilistic laws. God could also create universes with some degree of indeterminacy in them. Our universe is an example which contains evolutionary and quantum mechanical laws that have a probabilistic nature to them. On the opposite side of the pole, God can create universes which are so chaotic such that even science cannot be done in them since there is no underlying regularity.

Having mapped out these possibilities about God's creative powers, what do we make of design or complex features in light of what God can do? From an Ash'arite perspective, while design/complexity is a possible element of creation, it is unnecessary. If we map all the possible creations that God could create, design/complexity doesn't seem to be an intrinsically necessary feature in all creations since God can equally create totally simple worlds or even totally chaotic worlds. This then raises the more fundamental question of what grounds all creative possibilities. The Ash arite response to this is simply contingency. This has two meanings. One meaning is something that could either exist or not exist. So humans, prophets, the world, the universe, angels, heaven, and earth could easily not have come into existence. But God chose to bring them into existence instead of nonexistence. The starting point of the Ash'arite paradigm is that everything that exists in the universe is contingent, so its nonexistence is conceivable. The second meaning of contingency is if something could have different properties. This text could be any size, format, and colour. There isn't anything intrinsically necessary for it to be a particular way over another. Take another example. The neighbour's car colour could be a white Toyota, or it could be a yellow Beagle. Again, there is nothing intrinsic to the car that makes it necessary to be in a certain way. Broadly, both definitions rely on the idea things could be other than they are. Things could exist or not exist, and if they do exist, they can occupy a variety of features, e.g. size, shape, or colour.

In the Ash arite paradigm, all of creation is fundamentally contingent. This means that God can equally bring the universe and all its constituents into existence and bring them into nonexistence. They are equally possible. If God does bring them into existence, they can occupy any features so long as it is logically possible for God to do so. Accordingly, God could create worlds where laws of nature are radically different to ours, he could have 
created humans without ever having thirst, he could have created worlds where fires don't burn, etc. Pertinent to this chapter, it makes no difference to God if his creation is fine-tuned, designed, not designed, or simple. These are secondary points entirely. Given this framework, is there anything intrinsically in creation which requires God to make it complex or finetuned? The answer is no. God can equally create simple and complex worlds. In short, design is unnecessary in all possible worlds that God can create, while contingency is necessary for all possible worlds that God can create.

The implication this has for the ID-evolution divide should now be evident. If some thinkers are latching on to ID because they think that it is God friendly and evolution is atheistic or naturalistic are relying on a false binary. But even if this was conceded, rejecting evolution because design is more appealing is, as we have seen, irrelevant to the Ash'arite paradigm. It is why things like chance, randomness, or lack of design don't really matter theologically. The key point is that contingency is much more foundational than design in the Ash'arite paradigm. Given this, al-Ghazālî̀s framework would have no problem accepting any kind of scientific theory that has chance elements or lack of design in it. ${ }^{12}$

\section{Conclusion}

This chapter intended to assess ID on its own merit from a scientific and theological angle. ID's scientific status seems to be unclear for the moment. Critics and proponents have had their exchanges, and it's not certain what the future may hold. As it stands, the scientific community isn't acknowledging ID as a scientific theory. From a theological angle, we assessed ID from a bottom-up approach and a top-down approach. From a bottom-up approach, neither the BD nor the CD strictly guarantees God as the designer. To jump from a designer to God requires extra arguments, which design arguments on their own cannot facilitate, and this is the problem with design arguments in general. Significantly, the BD is equally compatible with theism, agnosticism, and atheism. The motivation behind pointing this out is demonstrating how treating evolution as equivalent to atheism and ID being God-friendly has no basis. This is sometimes done because some thinkers want to reject evolution altogether, and the only alternative they see is ID. However, both evolution and ID can be accommodated within a theistic framework. Atheism isn't intrinsic to evolution and nor is theism intrinsic to ID. From a top-down approach, we observed that God could equally create designed and simple things. He can create universes simpler than ours or even more than designed than ours. In the array of possibilities available to God's creative capabilities, there is nothing fundamental to the idea of design that definitively makes it exclusively linked to God. Consequently, whether elements in creation are designed or not are irrelevant. This feeds back into breaking the inherent connection some thinkers have between design and God. To be sure, this isn't to 
undermine the existence of design in creation as such, but only to place it in the larger Ash arite paradigm within which design is not necessary for God to create. ${ }^{13}$

\section{Notes}

1 Summary of abbreviations used in this chapter.

\begin{tabular}{lc}
\hline Name & Abbreviation \\
\hline Methodological Naturalism & MN \\
Philosophical Naturalism & PN \\
Intelligent Design & ID \\
Cosmological Designer & CD \\
Biological Designer & BD \\
Irreducible Complexity & IRC \\
\hline
\end{tabular}

2 For a detailed study of the various ways the design argument has been formulated, see Ratzsch and Koperski (2020).

3 This hasn't gone uncontended. For instance, Jantzen (2014, 118-135) argues that Paley doesn't seem to be arguing for a designer using the analogical argument.

4 The 2012 movie Prometheus directed by Ridley Scott comes to mind here.

5 Of course, this depends on whether the designer intended to create life on earth, to begin with. If it was intentional, this could be done either directly or indirectly (these terms are somewhat dependent on which divine action model is adopted). A direct approach could be intervening in the course of life on earth such that once biological life began to exist, in turn, guided the course of evolution. An indirect approach could be front-loading the creation of the universe with the exact initial configurations, i.e. laws and constants of the universe, such that life on earth was guaranteed. It is also possible that the designer of the universe intended to create an alien civilisation that was instructed to create life on earth. If the designer did not intend for life to occur when creating the universe, then life on earth could simply have formed and evolved through the laws of nature (however improbable). Another unintentional scenario might include the designer intending to create aliens who, in turn, created life on earth but which wasn't part of the designer's plan. The purpose of this exercise was to exhibit various possibilities depending on how the designer's (un)intentionality and remoteness from the universe are navigated.

6 This is not without disagreement. See Sober (2007), Dougherty (2008), Sober (2008), and Beaudoin (2008).

7 Recall the scrabble analogy from Chapter 1.

8 For a response to Behe's remarks, see Lang and Rice (2019) and Lents et al. (2019).

9 For a recent and extensive treatment on the demarcation problem by various authors, see Pigliucci and Boudry (2013).

10 For an excellent resource that discusses how background ideologies affect scientific practice, see Alexander and Numbers (2010).

11 Recall from Chapter 2 that this isn't strictly correct. Creationism in a narrower sense implies a rejection of common ancestry that not all ID advocates necessarily do. 


\section{Metaphysical considerations}

12 Some readers might be surprised by this comment, and this chapter in general, given that al-Ghazālī discusses design-like notions in some of his works. As noted by Guessoum (2011, 228-230), al-Ghazālī (1987) wrote a treatise called The Wisdom of the Creation of God (Al-Hikma fī Makblūqāt-Allāh) within which he marvels at the world and shows its design-like features (see El Shamsy 2016, 96 for a brief question on the authenticity of this work). However, as I have stressed before, I am viewing al-Ghazāli as a theologian. Given this book's language and structure, it is not a book of theology but one of spirituality and reads like a confessional piece. Compared to his other theological treatises in which he gives detailed definitions, propositions, and arguments, this work pales in comparison, suggesting that it is not meant to be seen as a theological work. One can, for instance, find similar spirituallyimbibed design observations in his other works like the Alchemy of Happiness (Al-Ghazālī 2008). However, as stated before, al-Ghazālī has been known to wear many hats, one of them being a mystic. Accordingly, the argument I have presented here is from a theological standpoint, not a mystical one. That said, one can even identify design-like arguments in his theological works. In his Moderation in Belief, al-Ghazālī $(2013,83)$ mentions: "We claim that the Originator of the world is powerful, since the world is a product that is well-designed, well-ordered, exquisite, and well-composed, and contains all kinds of wonders and marvels; and this is a demonstration of power." Two points can be made in this regard. First, this argument is only presented after al-Ghazālī presents an argument for God based on contingency discussed in an earlier part of the book, suggesting that design arguments are themselves predicated on contingency (Al-Ghazālī 2013, 27-40). That said, it may very well be that al-Ghazālī sees design as a strong argument from a theological standpoint, and I am simply imposing my own perspective onto him. I concede this possibility. However, I do not think al-Ghazālī would deny that contingency is a first-order principle and design is a second-order one, i.e. design is predicated on contingency and not vice versa. Second, while there may be design-like elements in this world, the point being illustrated here is that from God's vantage point and creative capabilities, complex creations are equivalent to simple ones given that they are both logically possible. Accordingly, lacking conspicuous design would not undermine God's existence (see Goodman 1971a; Goodman 1971b). For an excellent overview of al-Ghazālī's epistemology in light of these considerations, see Heck (2019, 108-151).

13 There is a related concern that I have not addressed in this chapter, namely, the problem of the best of all possible worlds, i.e. theological optimism. If Ash'arism is true, God could have created any kind of world, which entails that there is nothing intrinsically "good" in any creative possibility for it to be better than the others. However, al-Ghazāli $(2001,45-46)$ is well-known for having made the statement the following in his magnum opus, Revival of the Religious Sciences (Ihy $\bar{a}^{\prime}$ 'Ulüm al-Dīn): "Indeed, all this [the constituency and order of this creation] happens according to a necessary and true order, according to what is appropriate as it is appropriate and in the measure that is proper to it; nor is anything more fitting, more perfect, and more attractive within the realm of possibility." This statement galvanised an entire debate concerning al-Ghazālī's metaphysical worldview, as it seems to contradict the Ash arite paradigm (Ormsby 1984). The question of whether this is reconcilable with Ash'arism is beyond the scope of this work. However, even if this statement were taken at face value, which I am only conceding for the sake of the argument, what matters for this book is that it is compatible with the four different positions looked at in Chapter 4, i.e. creationism, human exceptionalism, Adamic exceptionalism, and the no exceptions camp. 


\section{References}

Al-Ghazālī, Abū Ḥāmid. 1987. Al-Hikkma fī Makhluqāt-Allāh. Beirut: Dār Iḥyā̄ al-Ulūm.

Al-Ghazālī, Abū Hāmid. 2001. Faith in Divine Unity and Trust in Divine Providence: Book XXXV of The Revival of the Religious Sciences. trans. by David B. Burrell. Lousville, KN: Fons Vitae.

Al-Ghazālī, Abū Ḥāmid. 2008. Alchemy of Happiness. Volume 2. trans. by Jay R. Crook. Chicago, IL: Great Books of the Islamic World.

Al-Ghazālī, Abū Ḥāmid. 2013. Moderation in Belief. trans. by Aladdin M. Yaqub. Chicago, IL: University of Chicago University Press.

Alexander, Denis. 2008. Creation or Evolution? Do We Have to Choose? Michigan: Monarch Books.

Barr, Stephen. 2003. Modern Physics and Ancient Faith. Notre Dame, IN: University of Notre Dame.

Beaudoin, John. 2008. "Sober on Intelligent Design Theory and the Intelligent Designer." Faith and Philosophy, 25(4): 432-442.

Behe, Michael J. 2003. "The Modern Intelligent Design Hypothesis.” In Neil A. Manson, ed. God and Design: The Teleological Argument and Modern Science. Abingdon: Routledge.

Behe, Michael J. 2006. Darwin's Black Box: The Biochemical Challenge to Evolution. New York, NY: Free Press.

Behe, Michael J. 2007. The Edge of Evolution: The Search for the Limits of Darwinism. New York, NY: Free Press.

Behe, Michael J. 2011. “Irreducible Complexity: Obstacle to Darwinian Evolution.” In William A. Dembski and Michael Ruse, eds. Debating Design: From Darwin to DNA. Cambridge: Cambridge University Press, 352-370.

Behe, Michael J. 2019. Darwin Devolves: The New Science About DNA That Challenges Evolution. San Francisco, CA: HarperOne.

Berkman, Michael and Eric Plutzer. 2010. Evolution, Creationism, and the Battle to Control America's Classrooms. Cambridge: Cambridge University Press.

Berlinski, David. 2010. The Deniable Darwin. Washington: Discovery Institute.

Bowler, Peter J. 1983. The Eclipse of Darwinism. Baltimore, MD: The John Hopkins University Press.

Bowler, Peter J. 2007. Monkey Trials and Gorilla Sermons: Evolution and Christianity from Darwin to Intelligent Design. Cambridge, MA: Harvard University Press.

Bowler, Peter J. 2009. Evolution: The History of an Idea. California: University of California Press.

Brooke, John Hedley. 2014. Science and Religion: Some Historical Perspectives. Cambridge: Cambridge University Press.

Carroll, Sean M. 2005. "Why (Almost All) Cosmologists Are Atheists." Faith and Philosophy, 22(5): 622-635.

Caudill, Edward. 2013. Intelligently Designed: How Creationists Built the Campaign Against Evolution. Champaign, IL: University of Illinois Press.

Chou, Seemay, Matthew D. Daugherty, S. Brook Peterson, Jacob Biboy, Youyun Yang, Brandon L Jutras, Lillian K Fritz-Laylin, Michael A Ferrin, Brittany N Harding, Christine Jacobs-Wagner, X Frank Yang, Waldemar Vollmer, Harmit S Malik, and Joseph D Mougous. 2015. "Transferred Interbacterial Antagonism Genes Augment Eukaryotic Innate Immune Function.” Nature, 518(7537): 98-101.

Dembski, William A. 1998. The Design Inference: Eliminating Chance Through Small Probabilities. Cambridge: Cambridge University Press. 


\section{Metaphysical considerations}

Dembski, William A. 1999. Intelligent Design: The Bridge Between Science of Theology. Westmont, IL: InterVarsity Press.

Dembski, William A. 2002. No Free Lunch: Why Specified Complexity Cannot Be Purchased Without Intelligence. Lanham, MD: Rowman \& Littlefield.

Dembski, William. A. 2004. The Design Revolution: Answering the Toughest Questions About Intelligent Design. Westmont, IL: InterVarsity Press.

Denton, Michael. 2016. Evolution: Still a Theory in Crisis. Washington: Discovery Institute.

Dorit, Robert. 2007. "Biological Complexity." In Andrew J. Petto and Laurie R. Godfrey, eds. Scientists Confront Creationism: Intelligent Design and Beyond. New York, NY: W. W. Norton and Company, 231-249.

Doolittle, Russell F., Yong Jiang, and Justin Nand. 2008. "Genomic Evidence for a Simpler Clotting Scheme in Jawless Vertebrates." Journal of Molecular Evolution, 66(2): 185-196.

Dougherty, Trent. 2008. “A User's Guide to Design Arguments.” Religious Studies, 44(1): 99-110.

Durrett, Rick, and Deena Schmidt. 2008. "Waiting for Two Mutations: With Applications to Regulatory Sequence Evolution and the Limits of Darwinian Evolution." Genetics, 180(3): 1501-1509.

El Shamsy, Ahmed. 2016. "Al-Ghazālī’s Teleology and the Galenic Tradition: Reading The Wisdom in God's Creation (Al-Hikma fī Makblūqāt-Allāh).” In Frank Griffel, ed. Islam and Rationality: The Impact of al-Ghazālī Papers Collected on His 900th Anniversary. Volume 2. Leiden: Brill, 90-112.

Elsberry, Wesley R. 2007. "Logic and Math Turn to Smoke and Mirrors: William Dembski's 'Design Inference'.” In Andrew J. Petto and Laurie R. Godfrey, eds. Scientists Confront Creationism: Intelligent Design and Beyond. New York, NY: W. W. Norton and Company, 250-271.

Forrest, Barbara, and Paul R. Gross. 2007. Creationism's Trojan Horse: The Wedge of Intelligent Design. Oxford: Oxford University Press.

Gishlick, Alan D. 2005. "Evolutionary Paths to Evolutionary Systems: The Avian Flight Apparatus.” In Matt Young and Taner Edi, eds. Why Intelligent Design Fails: A Scientific Critique of the New Creationism. New Brunswick, NJ: Rutgers University Press, 58-71.

Good, Benjamin H., Michael J. McDonald, Jeffrey E. Barrick, Richard E Lenski, and Michael M Desai. 2017. "The Dynamics of Molecular Evolution Over 60,000 Generations.” Nature, 551(7678): 45-50.

Goodman, Lenn E. 1971a. "Ghazālī's Argument from Creation (I).” International Journal of Middle East Studies, 2(1): 67-85.

Goodman, Lenn E. 1971b. “Ghazālī’s Argument from Creation (II).” International Journal of Middle East Studies, 2(2): 168-188.

Guessoum, Nidhal. 2011. Islam's Quantum Question: Reconciling Muslim Tradition and Modern Science. London: I.B. Tauris.

Hansson, Sven Ove.Sven Ove. 2017. "Science and Pseudo-Science." The Stanford Encyclopedia of Philosophy. Accessed 22nd of July 2020. Available at: https:// plato.stanford.edu/archives/sum2017/entries/pseudo-science

Harrison, Peter. 2017. The Territories of Science and Religion. Chicago: University of Chicago Press.

Heck, Paul. L. 2019. Skepticism in Classical Isla: Moments of Confusion. Abingdon: Routledge. 
Jantzen, Benjamin C. 2014. An Introduction to Design Arguments. Cambridge: Cambridge University Press.

Johnson, Philip E. 1993. Darwin on Trial. Westmont, IL: InterVarsity Press.

Johnson, Philip E. 1995. Reason in the Balance: The Case Against Naturalism in Science, Law \& Education. Westmont, IL: InterVarsity Press.

Johnson, Philip E. 1997. Defeating Darwinism by Opening Minds. Westmont, IL: InterVarsity Press.

Johnson, Philip E. 2000. The Wedge of Truth: Splitting the Foundations of Naturalism. Westmont, IL: InterVarsity Press.

Kaden, Tom. 2015. Creationism and Anti-Creationism in the United States: A Sociology of Conflict. Switzerland: Springer.

Koperski, Jeffrey. 2015. The Physics of Theism: God, Physics, and the Philosophy of Science. West Sussex: Wiley-Blackwell.

Kojonen, Erkki Vesa Rope. 2016. The Intelligent Design Debate and the Temptation of Scientism. Abingdon: Routledge.

Kitzmiller v. Dover. 2005. Kitzmiller v. Dover, 400 F. Supp. $2 d 707$ (M.D. Pa., 2005).

Lang, Gregory I., and Amber M. Rice. 2019. "Evolution Unscathed: Darwin Devolves Argues on Weak Reasoning That Unguided Evolution Is a Destructive Force, Incapable of Innovation.” Evolution, 73: 862-868.

Lents, Nathan H., S. Joshua Swamidass, and Richard E. Lenski. 2019. "The End of Evolution?" Science, 363(6427): 590.

Livingstone, David N. 2008. Adam's Ancestors: Race, Religion and the Politics of Human Origins. Baltimore, MD: The John Hopkins University Press.

McIntyre, Lee. 2019. The Scientific Attitude: Defending Science from Denial, Fraud, and Pseudoscience. Cambridge, MA: The MIT Press.

McLennan, Deborah A. 2008. "The Concept of Co-Option: Why Evolution Often Looks Miraculous." Evolution: Education and Outreach, 1: 247-258.

Meyers, Stephen C. 2009. Signature in the Cell: DNA and the Evidence for Intelligent Design. New York, NY: HarperOne.

Meyers, Stephen C. 2013. Darwin's Doubt: The Explosive Origin of Animal Life and the Case for Intelligent Design. New York, NY: HarperOne.

Miller, Kenneth. 2002. Finding Darwin's God: A Scientist's Search for Common Ground Between God and Evolution. New York, NY: HarperCollins Publishers.

Miller, Kenneth. 2003. “Answering the Biochemical Argument from Design.” In Neil A. Manson, ed. God and Design: The Teleological Argument and Modern Science. Abingdon: Routledge, 292-307.

Musgrave, Ian. 2005. "Evolution of the Bacterial Flagellum.” In Matt Young and Taner Edi, eds. Why Intelligent Design Fails: A Scientific Critique of the New Creationism. New Brunswick, NJ: Rutgers University Press, 72-84.

Nagasawa, Yujin. 2011. The Existence of God: A Philosophical Introduction. Abingdon: Routledge.

Näsvall, Joakim, Lei Sun, John R. Roth, and Dan I. Andersson. 2012. "Real-time Evolution of New Genes by Innovation, Amplification, and Divergence.” Science, 338(6105): 384-387.

Numbers, Ronald. L. 2006. The Creationists: From Scientific Creationism to Intelligent Design. Massachusetts: Harvard University Press.

Ormsby, Eric Linn. 1984. Theodicy in Islamic Thought: The Dispute Over al-Ghazali's Best of All Possible World. Princeton: Princeton University Press. 


\section{Metaphysical considerations}

Phy-Olsen, Allene. 2010. Evolution, Creationism, and Intelligent Design: Historical Guides to Controversial Issues in America. Oxford: Greenwood.

Pigliucci, Massimo. 2002. Denying Evolution: Creationism, Scientism, and the Nature of Science. Sunderland, MA: Sinauer Associates Publishers.

Pigliucci, Massimo. 2010. Nonsense on Stilts: How to Tell Science from Bunk. Chicago, IL: University of Chicago Press.

Pigliucci, Massimo and Maarten Boudry, eds. 2013. Philosophy of Pseudoscience. Chicago, IL: The University of Chicago Press.

Ratzsch, Del. 2001. Nature, Design and Science: The Status of Design in Natural Science. New York, NY: State University of New York Press.

Ratzsch, Del, and Jeffrey Koperski. 2020. "Teleological Arguments for God's Existence." The Stanford Encyclopedia of Philosophy. Accessed 17th of July 2020. Available at: https://plato.stanford.edu/archives/sum2020/entries/teleologicalarguments/

Reeves, Josh. 2019. Against Methodology in Science and Religion: Recent Debates on Rationality and Theology. Abingdon: Routledge.

Rios, Christopher M. 2014. After the Monkey Trial: Evangelical Scientists and a New Creationism. New York, NY: Fordham University Press.

Sober, Elliott. 2007. "The Intelligent Design Theory and the Supernatural - The 'God or Extra-Terrestrials' Reply." Faith and Philosophy, 25(4): 72-82.

Sober, Elliott. 2008. "Intelligent Design, Irreducible Complexity, and Minds - A Reply to John Beaudoin.” Faith and Philosophy, 24(1): 443-446.

Ussery, David. 2005. "Darwin's Transparent Box: The Biochemical Evidence for Evolution.” In Matt Young and Taner Edi, eds. Why Intelligent Design Fails: A Scientific Critique of the New Creationism. New Brunswick, NJ: Rutgers University Press, 48-57.

Young, Matt. 2005. "Grand Design and Facile Analogies: Exposing Behe's Mousetrap and Dembski's Arrow." In Matt Young and Taner Edi, eds. Why Intelligent Design Fails: A Scientific Critique of the New Creationism. New Brunswick, NJ: Rutgers University Press, 20-31.

Waller, Jason. 2020. Cosmological Fine-Tuning Arguments: What (If Anything) Should We Infer from the Fine-Tuning of Our Universe for Life? Abingdon: Routledge.

Wells, Jonathon. 2000. Icons of Evolution: Science or Myth? Why Much of What We Teach About Evolution Is Wrong. Washington: Regnery Publishing.

Wells, Jonathon. 2006. The Politically Incorrect Guide to Darwinism and Intelligent Design. Washington: Regnery Publishing.

Wells, Jonathan. 2011. The Myth of Junk DNA. Washington: Discovery Institute Press.

Wells, Jonathan. 2017. Zombie Science More Icons of Evolution. Washington: Discovery Institute Press. 


\section{Morality and evolution}

\section{Introduction}

In Chapter 6, we developed al-Ghazālī's occasionalist framework. This was then used to evaluate the problems of chance, naturalism, and efficiency. It was concluded that chance is non-problematic except if interpreted in the strong sense $\left(\mathrm{OC}_{2}\right)$. Evolution (and any other science in fact) is something al-Ghazālī’s framework will not accept under philosophical naturalism, but will have no issues with if interpreted under methodological naturalism. Finally, it was shown that the question of efficiency is inapplicable to the God of Ash'arism. In Chapter 7, we took Ash arism one step further to demonstrate that design is irrelevant in the theological worldview of Ash'arism. Contingency is fundamental to all of God's creations. So if evolution is being negated because design seems to be in question or undermined, which in turn seems to be a problem because it is less or not Godfriendly, then this an irrelevant matter in the Ash'arite framework. In this chapter we will look at the moral ${ }^{1}$ dimension of the discussion. The abbreviations that have been used in this chapter are summarised and tabulated in the Note appended to this sentence. ${ }^{2}$

In Chapters 1 and 4, we saw how some thinkers believe evolution has problematic moral implications and raises concerns for God's omnibenevolence. There are two key problems related to morality that will be discussed in this chapter. These are the problem of evil (POE) and the problem of objective morality (POM).

The POE is a well-known issue for theological schools in general. An important and relevant division is between moral and natural evil. The former is usually referred to as evil acts done by moral agents since they have autonomy, e.g. one human killing another for fun. The latter is referred to natural events that lead to death and suffering, e.g. earthquakes and widespread disease leading to many humans dying. The key distinction between them is human control. Moral evil is within the autonomy of human beings, but natural evil is not. Having cleared this distinction, the POE and its relation to theism are usually best summarised by the statement attributed to Epicurus (quoted in Hickson 2013, 6): "Is God willing 


\section{Metaphysical considerations}

to prevent evil, but not able? Then he is not omnipotent. Is he able, but not willing? Then he is malevolent. Is he both able and willing? Then from whence comes evil?" In other words, how do we understand God who is omnipotent, omniscient, and omnibenevolent in light of the prevalent evil that we see in creation. Squaring these points is problematic. It needs to be stressed that the POE is an issue regardless of whether evolution is true or not. However, the POE becomes amplified because the theory of evolution informs us of a systematic process in the structure of life that is perceived as inherently cruel as it results in the unnecessary suffering of animals. In other words, it is a type of natural evil but one that is intrinsic to the laws of nature in biology. As mentioned in Chapter 1, 99\% of all species that have existed since the dawn of life 3.5 bya are extinct. This is an enduring process through which several animals have suffered and died (Murray 2008; Francescotti 2013). Nagasawa $(2018,153-154)$ identifies this issue as the problem of systemic evil:

The problem of evil standardly focuses on specific events that are considered evil (e.g. the Holocaust, the Rwandan Genocide, the Boxing Day tsunami in Southeast Asia, etc.) or the specific types of events (e.g. wars, murders, rapes, earthquakes, floods, etc.). But the problem in question suggests that not only that are specific events or specific types of events are evil, but the entire biological system which nature is based is fundamentally evil, too. Hence, I call it the 'problem of systemic evil.' The problem of systemic evil is more forceful than the standard problem of evil because, again, it is focused on something more fundamental than specific events or type of events that are deemed evil.

So Nagasawa clearly believes that evolution amplifies the POE. Given these points, it raises the question: why would an omnibenevolent God allow this to occur?

The POM questions the objectivity of moral principles. If what we believe in and what we are capable of believing in are governed by the processes of evolution, then it is conceivable of us occupying a different moral framework if the story of life were to be replayed. This puts morality on very tentative foundations, and suggests that there really isn't anything intrinsically good and bad. We simply believe in good and bad things because of historical evolutionary pressures which are entirely contingent. In other words, what we understand to be good and bad are at the mercy of chance, and thus there is no such thing as objective morality.

The intention of this chapter is to assess these problems in light of al-Ghazālī's moral framework. To this end, we need to break the conversation down into four distinctive parts, which form this chapter's structure. The first part will explain some useful terminology that will prove to be helpful for the discussion. The second part will look at the scientific and philosophical developments in the discipline known as evolutionary ethics. 
Taking this detour is necessary because it will further the resolution of the connection between evolution and morality, and bring forth nuances behind the POE and POM. Some conceptual distinctions in this territory can also help better express al-Ghazālī's ideas, and show where and how he might (dis)agree with some of the points discussed in this area. The third part will involve unpacking al-Ghazālī's moral framework and the associated points. Finally, the fourth section will evaluate the POE and the POM in light of al-Ghazālī's perspective.

\section{Terminology}

When it comes to the topic of evolution and morality, it is helpful to have the following distinctions in mind (Fitzpatrick 2016): descriptive evolutionary ethics (DEE), normative evolutionary ethics (NEE), and evolutionary metaethics (EM). ${ }^{3}$ Let us briefly review each one.

\section{Descriptive evolutionary ethics}

With evolution being the predominant narrative that explains our biological history and diversity, it is of no surprise to find that scientists have tried to understand how various features can be explained within its purview, including morality. DEE is simply the empirical study of biological organisms that describes their moral behaviour and capabilities. Examples include: what is a moral making capacity? How do species develop moral-making capacities? What kind of moral judgements do individuals make in a given situation? Are moral judgements particular to the biological entity being studied, or can they be generalised to the whole species? In short, DEE looks at descriptive accounts of morality in an evolutionary context.

\section{Normative evolutionary ethics}

NEE may be more controversial than DEE. NEE looks at how evolution can be used to explain, justify, or rationalise moral prescriptions. In other words, NEE is deliberation over whether the principles of evolution or findings from it can be used to determine what is morally permissible and impermissible, and thus how we should live. For example, does evolution tell us that some species are more valuable or honourable than others? Is killing for food bad? Is group protection or personal safety better? In other words, NEE helps us determine whether evolution provides us with any moral repository through which we can regulate our moral makeup.

\section{Evolutionary metaethics}

EM is as controversial as NEE, if not more so, because this discourse seems to have implications for the topic of moral realism/antirealism. It asks us to 
consider whether evolution negates moral objectivity or not. Some thinkers claim, as we shall see shortly, that evolution entails morality is relative, which is why it has become a contentious topic. Fundamentally, this domain forces us to ask if morality is dependent on nature. Since morality is contingent upon evolutionary forces, it follows that morality is causally dependent somehow on the natural world. The POM we looked at earlier is related to this domain.

\section{Summary}

Ideas bearing relation to these three will be crop up throughout this chapter. For simplicity, the reader should just keep in mind the distinctions between what things are like (DEE), what things ought to be like (NEE), and what grounds our sense of morality (EM).

\section{Evolution and morality}

The intersection of evolution and morality has two components to it. One is the scientific dimension, and the other is the philosophical interpretation. We shall start with what the science of evolution has to say about ethics.

\section{Science of evolutionary ethics}

The empirical study of morality from an evolutionary perspective has led to interesting developments. Recall from Chapter 1 that evolution is about the preservation of genes. This is a selfish driving force - from a gene's functional point of view and not in the sense that genes have motives in biological advancement and reproduction. Theoretically, it should land us in a situation where we see egoists in all parts of the biological world. However, this is something we simply do not observe. Aside from the cooperative behaviours we see from humans (most of the time), we observe cooperative comportment amongst animals. Take the example of bees. In the scenario of a predator attacking the hive, bees will sting the predator, but at the cost of their lives, i.e. bees die after stinging their target (James 2011, 27). This seems very much like self-sacrifice, i.e. giving one's life for others, a moral virtue in our understanding (arguably). One can find many more examples in the animal kingdom, but this example should suffice. The point is that to observe altruism and cooperation amongst animals developing within an evolutionary framework within which the selfish behaviour could have been much more predominant is strange, at least perfunctorily.

However, scientists seem to have some explanation as to how this all started. Seeing that evolution is a gene-centric narrative, it is no surprise that scientists have suggested genes as the root of morality too (Wilson 1995; Dawkins 2006). Let's see how this works. Scientists have suggested that morality started with some kind of developmental cooperation schemes between and within species. But how can this be given that genes aren't "conscious" beings? How do we go from genes to cooperation? To 
explain this, it will be helpful to recall the difference (from Chapter 1) between the gene of an individual (genotype) and the individual itself (phenotype). From a gene's perspective, all that matters is that it passes through to the next generation through reproductive succession. This means that it is not so much the individual's survival that matters, but instead it is the underlying genes that are important. Since genes are available in the individual and familial members, it doesn't matter who survives so long as the genes survive from the relative familial circle. To make this work, it is then important that the individual recognises and cooperates with family members because the survival of the genes transcends the survival of the individuals who make up the group. There's even a simple equation that governs this behaviour called Hamilton's rule (Hamilton 1964).

\section{$\mathrm{C}<\mathrm{R} \times \mathrm{B}$}

This equation is relatively simple to understand. $C$ is the cost of the action that benefits a relative, $R$ is the genetic relation between the individual, and the recipient of the act ( 0.5 for parents, 0.25 for grandparents and grandchildren, etc.), and $B$ is the (biological) benefit that comes out of the act which the recipient receives. In effect, this equation states that so long as the product of the genetic relation and the benefit is higher than the cost of the act, the action is a good act in terms of reproductive success. This kind of cooperation is termed inclusive fitness or kin selection. Returning to the bee example, it is now easy to see how it can be explained from an evolutionary perspective. If a bee stings a predator and dies, it doesn't matter because its action helps preserve the gene pool of the bee's family. In other words, the dying bee gives the genes in the other family members a greater chance to survive. But what about cooperation that is observed outside of family members? How does evolution explain that?

Explaining cooperation between non-kin members is known as reciprocity or reciprocal altruism (Trivers 1971; Trivers 2002). In essence, it's a "tit for tat" world where if you scratch someone's back, they'll scratch yours. It's the same principle as kin selection. Instead of helping genetically related members, a biological entity (also) helps non-genetic members (non-familial members and/or members of a different species). The only difference is that instead of direct genetic success, reciprocity helps with survival indirectly. Think of food, shelter and other kinds of resources linked to survival. The expectation here is that a cost in resources at one point in time by the donor will be regained by the recipient at some point in the future. This can be illustrated with vampire bats. They need to feed within 2-3 days; otherwise, they will die. Since they feed on blood, and given the short time span within which they can survive without nourishment, it has been observed that bats share regurgitated blood with non-familial members (James 2011, 41; Carter and Wilkinson 2013). This seems like an excellent survival mechanism, and is particularly helpful when many non-kin members are available compared to a few genetically related members. Such exchanges can be 


\section{Metaphysical considerations}

found in various other settings, and provide some experimental basis for cooperation between non-kin members.

Of course, there are limits as to how far this can work. For reciprocity to succeed as a useful survival mechanism, such encounters need to be frequent and require some kind of filtering system to push out the cheaters (James 2011, 66-86). Frequency is important because a one-time exchange or a few exchanges will hardly be seen as a potential long-term benefit. Consistent encounters will more likely lead to sustainable cooperation. As for cheats, this is just basic calculus. Consider the vampire bats again. Imagine if one bat keeps taking blood from others but without ever giving anything back to the group members. From its point of view, it is reaping all the benefit without any cost to itself. However, others in the group will (or should) come to eventually realise that exchanging blood with it is not leading to any positive gain. This realisation should lead to the eventual lockout of exchanging any further blood with such cheating bats, which in turn could translate into cheating bats eventually dying out. So reciprocity is a good explanation for non-kin behaviour provided that frequency and cheat filters are maintained.

Both of these theories, kin selection and reciprocity, are examples of biological altruism. They explain how altruism occurs from a biological perspective and for biological reasons, which in this case is evolutionary fitness. However, while they may explain how cooperation may have started, it still raises the question: are they really moral behaviours? More to the point, are they really altruistic? Let's go back to the vampire bat. If a vampire bat regurgitates blood in hopes of getting some kind of help in the future, is it really fair to call it an altruistic act? Arguably not, since the mere appearance of a helpful act isn't sufficiently a moral act. Consider a thief who acts nicely on the surface only to deprive his victim of a prized possession. Thus, apparent good behaviour doesn't necessarily guarantee a moral act. This then takes us to the longstanding question of what a moral act is. Philosophers and theologians have answered this in various ways, e.g. virtue ethics or categorical imperatives, in the context of evolution, e.g. Clark (2014). I don't intend to distract us into what is otherwise a complex and fascinating field. For the purposes of this chapter, it is enough to point out that biological altruism is usually contrasted with psychological altruism, which is the idea that real altruism is more to do with motivations of helping others without expecting anything back. In other words, real altruism is a conscious decision to help someone at one's expense without an expectation of return. Neither kin selection nor reciprocity neatly fits under this kind of altruism. This, in turn, implies that a lot of animals aren't really altruistic (Okasha 2020):

If by 'real' altruism we mean altruism done with the conscious intention to help, then the vast majority of living creatures are not capable of 'real' altruism nor therefore of 'real' selfishness either. Ants and 
termites, for example, presumably do not have conscious intentions, hence their behaviour cannot be done with the intention of promoting their own self-interest, nor the interests of others. Thus the assertion that the evolutionary theories reviewed above show that the altruism in nature is only apparent makes little sense. The contrast between 'real' altruism and merely apparent altruism simply does not apply to most animal species.

Given this discrepancy, then, how can we explain the kind of psychological altruism observed in humans? More importantly, how did humans eventually come up with a moral sense and/or capacity? It is here where speculations have been offered. Recall that with kin selection and reciprocity, species cooperate because of an uncritical, behavioural stimulus to preserve one's genes. So it is not so much that they believe what they are doing is right, it's just that such alliances help their survival, without them even consciously being aware of it. However, with such proto-moral foundations, it is still possible that individuals can be egotistical and survive of the group's benefits. Accordingly, something must have occurred which caused individuals - and here I mean the early cognitively developed ancestors of humans - to actively and stressfully think that a particular act was wrong if it went against a cooperative alliance. Such an internal tensor would then allow an individual to attain an active conscious about crossing boundaries and the implications it could have, e.g. being ostracised from the group. In other words, morality would ensure a stronger form of commitment towards a group's conventions. So somewhere down the evolutionary timeline socio-moral pressures and principles developed (emerged?) into a moral fabric as a product of evolution, an adaptation perhaps, which ended up helping maintain cooperative alliances. As put by James $(2011,59)$, "cooperating is not merely something to be desired ... it's something we regard as required."

\section{Moral nativism}

At this point, it may be worthwhile to introduce the discussion of moral nativism (or innatism). ${ }^{4}$ This is the notion that there are inbuilt moral capacities, ideas, and/or principles humans are born with. Of course, the discussion of whether there are any such foundational elements in the human being far predates evolution (Samet and Zaitchik 2017; Samet 2019). But evolution provides a new frame of reference. If we as human are products of evolution, then our cognitive structures must have been shaped by that process, too, by some degree. ${ }^{5}$ The key question is: are there any systematic accounts of moral cognition which we can identify and develop in the context of evolution?

A helpful distinction between capacity nativism and content nativism may help us address this question (Sripada 2008a, 321; Sripada 2008b, 


\section{Metaphysical considerations}

362-363). Capacity nativism is the idea that agents have an inbuilt cognitive architecture that allows them to make moral determinations. Consider the steps one has to take to make a moral judgement. An agent has to look at an action, ensure that it is being done by an intentional agent rather than an inanimate object like trees rustling, and then come to an evaluation. So even before a moral principle is adopted and applied, an agent needs to have the capability of acknowledging and understanding actions, behaviours, and intentionality. Without these prerequisites in place, an agent cannot make any moral evaluations. By contrast, content nativism is the position in which moral norms, e.g. prohibitions and permissions such as "killing is wrong" or "helping one another," are believed to be innate.

While the specifics of the mechanics and evolutionary processes behind capacity nativism seem to be unclear (Dwyer 2008; Harman 2008; Prinz 2008; Tiberius 2008), Sripada (2008b, 363) suggests a general agreement over its importance and necessity for morally conscious beings. By contrast, and more importantly, thinkers tend to disagree over content nativism (Mikhail 2008; Prinz 2008; Sripada 2008b). The fundamental dispute seems to be over the lack of empirical support of universal norms held by civilisations across time and space. Consider the harm principle, i.e. the idea that it is wrong to harm others, which is usually considered a good candidate for a universal moral principle. Sripada and Stich (2006) and Prinz (2009) point out the heterogeneity of the kinds, limits, and degrees of harm determined historically and globally in the current climate. As summarised by Prinz $(2008,373)$ :

Is there a universal prohibition against harm? The evidence is depressingly weak. Torture, war, spousal abuse, corporal punishment, belligerent games, painful initiations, and fighting are all extremely widespread. Tolerated harm is as common as its prohibition. There is also massive cultural variation in who can be harmed and when. Within our own geographic boundaries, subcultures disagree about whether capital punishment, spanking, and violent sports are permissible. Globally, every extreme can be found.

So if there is such widespread variation and disagreement over the application and scope of something as basic as the harm principle, how can we explain it? This is where moral (content) non-nativists can claim their stake. Rather than rooting moral principles as an intrinsic thing to humans through their genes, ideas like the harm principle can be explained extrinsically via social institutions. So perhaps these are cultural norms for the sake of social stability which "may not be underwritten by moral sentiments" (Prinz 2008, 375). Adopting certain moral principles may not have been directly or exclusively driven by genes. It may have been informed by non-genetic sources such as institutionalised cultures in part if not completely. ${ }^{6}$ 
Everything that has been said thus far should be treated with some caution. Evolutionary psychology and the related field cognitive science of religion are still relatively young disciplines, and it can be tempting to make claims that sometimes go beyond the data and even the discipline (Jones 2016; Clark 2019). Furthermore, there seem to be disagreements between philosophers, theologians, and scientists over how and if ever evolutionary psychology can indeed be scientifically informative (Rose and Rose 2000; Scher and Rauscher 2003; Smith 2020). However, despite these difficulties, the presented ideas give us some direction for seeing how morality could be explained from an evolutionary perspective.

\section{Evolution, normativity and moral realism}

In the previous section, we looked at a potential scenario whereby a moral consciousness could have emerged in the history of life. In other words, we were looking at a discussion of DEE. However, evolutionary ethics doesn't end there. There have been attempts by some thinkers who have taken up the evolutionary narrative to explain how we can justify certain social and political programs, i.e. NEE. The stock example of this is Herbert Spencer who was a catalytic figure in the rising tide of Social Darwinism in the early twentieth century (Peters and Hewlett 2003, 52-55; Ruse 2008, 203-204). Having coined the phrase "survival of the fittest" to capture what he thought was the essence of evolution, Spencer applied evolutionary principles to social dynamics (Ruse 2008, 110; James 2011, 118-119). He believed weaker individuals should be weeded out for the more developed ones. So a community should simply let the weaker members of a given society, e.g. individuals that have special needs or older family members, die off so that stronger members of a community can flourish (Spencer 1851, 151):

Blind to the fact that under the natural order of things, society is constantly excreting its unhealthy, imbecile, slow, vacillating, faithless members, these unthinking, though well-meaning, men advocate an interference which not only stops the purifying process but even increases the vitiation - absolutely encourages the multiplication of the reckless and incompetent by offering them an unfailing provision, and discourages the multiplication of the competent and provident by heightening the prospective difficulty of maintaining a family.

In other words, Spencer's philosophy is to let nature take care of itself in which the strongest ultimately survive and progress. As can be seen, this kind of narrative can and was used to justify various problematic ideologies including eugenics, racism, colonialism, etc. (Peters and Hewlett 2003, 55-58). Some thinkers like Julian Huxley - also known as Darwin's bulldog - disagreed that this was the moral lesson to be taken from evolution 


\section{Metaphysical considerations}

(Huxley 2009). It is true, he believed, that evolution has led to the creation of man, but it doesn't mean that man cannot transcend his natural impulses and origins (Huxley 1900, 285): "Of moral purpose I see not a trace in nature. That is an article of exclusively human manufacture - and very much to our credit." Furthermore, the golden rule - treat unto others how you'd wanted to be treated - was (and still is) a famous stock objection against leaving the less fortunate behind. The argument of having a duty to tend to the sick, the poor, the elderly could simply not be dismissed (Mizzoni 2009; Beck 2017). Even Darwin $(2009,106)$ himself believed in this:

The moral sense perhaps affords the best and highest distinction between man and the lower animals; but I need not say anything on this head, as I have so lately endeavoured to shew that the social instincts, the prime principle of man's moral constitution - with the aid of active intellectual powers and the effects of habit, naturally lead to the golden rule, 'As ye would that men should do to you, do ye to them likewise;' and this lies at the foundation of morality.

In addition to the aforementioned intuitive moral friction, there are also two fundamental philosophical problems with taking evolution and applying it to the ethical domain. The first, is David Hume's (2007) infamous "is-ought" gap. Hume's famous dictum states that we cannot derive how we should behave (the ought) simply from what we observe (the is; James 2011, 132-142). Consider a gene, a fossil, a group of monkeys, and a primitive society. Say that you are analysing all four of these things as a scientist. Hume claims that no matter how much you observe them, you cannot derive a moral idea from them. Genes and fossil do not come with moral prescriptions, and neither does studying primates or human societies from a distance tell you how you should behave. The only thing you can claim from studying such things is a descriptive account. So the natural world and the moral world seem to be occupying two different kinds of spaces. Assuming that there is a straightforward, derivable bridge from the natural world to the moral world is what Hume claims is problematic.

A closely related second problem is G.E Moore's (2000) naturalistic fallacy. This fallacy states that we cannot conflate the morally good and bad with natural properties that are also deemed good and bad, like pleasure or pain, since they are categorically different (James 2011, 143-149). To make this clearer, consider the game of chess. Both players are trying to instrumentalise their pieces to win the game. So any move that advances that goal would be considered a good move. But it would be incorrect to state that such moves would also be morally good. It doesn't make sense to equate a good chess move for a good moral move. Similarly, Moore points out that moral properties can't be equated to natural ones. Underlying both Hume's and Moore's claims is the idea that morality cannot be reduced to nature or described in natural terms. It is precisely at this juncture where 
ethicists disagree over how and whether we can get NEE from DEE (James 2011, 150-160).

While Social Darwinism may have fallen out of favour, some thinkers have gone further to suggest that evolution affects EM. The discussion of evolutionary ethics was livened again with the publication of Sociobiology: The New Synthesis by Edward Osborne Wilson in 1975. In it, he writes (Wilson 1975, 1):

The biologist, who's concerned with questions of physiology and evolutionary history, realises that self-knowledge is constrained and shaped by the emotional control centers in the hypothalamus and limbic system of the brain. These centers flood our consciousness with all the emotions - hate, love, guilt, fear, and others - that are consulted by ethical philosophers who wish to intuit the standards of good and evil. What, we are then compelled to ask, made the hypothalamus and limbic system? They evolved by natural selection. That simple biological statement must be pursued to explain ethics and ethical philosophers ... at all depths.

Wilson makes it clear that he wants to put the foundations of sociology in biological terms. In other words, individual and societal moral makeup must be grounded in the process of evolution. This entails that evolution has somehow given us a moral-making capacity, but these capacities, alongside their moral content, are simply by-products of historical evolutionary pressures. If we replay the tape of life, and if humans are produced again, we may acquire very different moral-making capacities and ideas of right and wrong. Michael Ruse (2017), Sharon Street (2006), and Richard Joyce (2006; 2017) argue for the same thing with differences in the details. The implication of this line of argument is straightforward: evolution makes it clear that there is no such thing as objective morality. So Wilson, Ruse, Street, and Joyce are moral antirealists. The contrast with Social Darwinism should be apparent (James 2011, 159):

Unlike the work of traditional Social Darwinists, contemporary evolutionary ethicists are using the evolutionary story not to prop up a moral system, but to destroy it. 'New wave' evolutionary ethicists have turned Social Darwinism on its head. For they assert that the story of human evolution shows that there are, ultimately, no objective moral duties.

So unlike Social Darwinism that instrumentalised evolution to provide rational justifications for certain socio-political arrangements of human civilisations, moral antirealists are using evolution to undermine the entire edifice of morality.

Of course, this has not gone unchallenged. Hume's is-ought fallacy and Moore's naturalistic fallacy are still relevant for EM. Both challenge 


\section{Metaphysical considerations}

whether moral facts can be determined from natural ones. If not, then perhaps it seems moral facts have an independent autonomy of their own. We can use mathematics as an example. There are multiple philosophical interpretations of mathematics (Horsten 2019). One famous position is known as mathematical platonism (Linnebo 2018). According to this perspective, regardless of whether the universe existed or not, or if the universe was arranged in a radically different way to ours, mathematical facts wouldn't change. So $1+1=2$ would be true regardless of whether the universe existed or not, or if it had different configurations. If correct, this would suggest that mathematics isn't reducible to the natural world. ${ }^{7}$ Similarly, perhaps morality isn't reducible to the natural world. ${ }^{8}$ To be sure, the idea of moral realism has been deliberated throughout history in philosophical and theological circles independent of evolution (Sayre-McCord 2020). The debate over moral realism has been reignited within an evolutionary context because of the potential metaphysical implications of evolution. ${ }^{9}$

We shall end our tour of evolutionary ethics here. The key thing to take from all of this is how evolutionary ethics has had distinctive strands of thought within its domain. As we have seen, there is some understanding of how evolution may have led to morally conscious beings (DEE). However, at times, evolution has been used to justify entire moral and political systems, as was with the case of Social Darwinism (NEE). Others, like moral antirealists, believe that evolution makes morality entirely contingent on evolutionary pressures, which land us to a form of moral antirealism and relativism (EM).

\section{Al-Ghazālī’s moral framework}

In the previous section, we had a quick tour of evolutionary ethics. To determine whether POE or POM are problematic in al-Ghazālī's framework, we first need to determine his specific ideas on morality. To this end, we shall be looking at how al-Ghazālī understands moral goodness followed by certain objections one may pose to al-Ghazālī's ideas.

It should be stated from the onset that al-Ghazāli is a divine command theorist and a (moral) content non-nativist. This is being pointed out because these positions have their associated theological contentions, which can easily be found in the literature. It is beyond the scope of this chapter to critique these arguments. As stated at the beginning of this book, Ash'arite ideas as prescribed by al-Ghazālī are being adopted for the sake of juxtaposing them with evolution. Whether one agrees with them or not is not the purpose of this work. However, it should be highlighted that, at times, certain defences will be provided insofar they add clarity for the aims of this chapter.

\section{Al-Ghazālī's understanding of the good}

Al-Ghazālī defines the good largely in teleological terms. In other words, being good is based on the end purpose. He distinguishes between three 
kinds of good. In the first kind of good, call it G1, he defines it as an act related to the agent's purpose. So for instance, if someone intended to work today to get paid, and they go ahead and do the work to earn that money, then this is considered a good thing. Within the same definition, al-Ghazāli also says that this purpose can be designated externally on the agent. If a boss wants an employee to work over the weekend to meet a deadline, then it is considered a good thing that he does so according to the boss' purpose. In other words, G1 is relational and relative (Al-Ghazālī 2013, 161):

If it is in accordance with one person's purpose but not another's, it is called 'good' for the first and 'bad' for the other. For the terms 'good' and 'bad' are based on whether there is accord or contrariety, and these are relational matters that vary with people. They even vary with the states of a single person, and they vary with the purposes attached to a single state. An act might be in accordance with a person in one way and contrary to him in another way; hence it would be good for him in one way and bad for him in another way. He who has no religion may deem it good to commit adultery with the wife of another and consider winning her a blessing; and he would deem bad the act of the one who exposes his secret and would call him 'a slanderous person who has done a bad deed.' The devout, on the other hand, would call him [the exposer of the secret] 'a righteous person who has done a good deed.' Each one of them uses the terms 'good' and 'bad' according to his purpose. Indeed, a king might be killed; all of his enemies would deem the act of the killer good, and all of his supporters would deem it bad.

Under the same rubric, al-Ghazāli's's second definition of good, call this G2, is of similar nature but is related to eschatological (or otherworldly) goals, i.e. heavenly rewards or salvation (Al-Ghazāli 2013, 161-162). However, what distinguishes G1 and G2 is that the latter is grounded solely on revelation and cannot be determined by reason. So G1 may be determined by reasons alone, i.e. in the absence of revelation, but G2 is completely unknowable until revelation arrives. To be clear, this doesn't mean that there is no potential overlap between the two. In the absence of revelation, a person may very well do things that may synchronise with revelational commands once it is received, e.g. helping your fellow neighbour, but what changes the moral evaluation of an act is the purpose attached to it. This falls in line with the broader understandings of Islam, particularly a well-known hadīth which says that actions are valued by the intentions behind them. ${ }^{10}$

Let us explore G1 a bit more now that we've cleared the distinction between it and G2. A key question relevant to unpacking al-Ghazālī's divine command theory is how these values of goodness in G1 come about in the first place. After all, there must be something that makes people think that a certain act is good or bad before the act itself. Al-Ghazālī has interesting ideas on the human being's psychology, but only three points are relevant for us. 


\section{0}

First, he believes that a human being's knowledge makeup has two components, each supplying different things but work together. There is a priori knowledge or self-evident principles embedded within the soul, e.g. the law of non-contradiction. Then there is acquired knowledge that is obtained $a$ posteriori (Umaruddin 2010, 111). Second, al-Ghazālī believes that moral principles are not axiomatic but are instead acquired (Griffel 2012, 29), which implies that humans aren't born with any innate ideas of morality. Third, given that moral principles are acquired, what humans eventually come to consider as good or bad are derived from two (appreciably differentiated) human experiences that usually work in tandem. The first is based on universalisation of ideas, and the second is predilections. An agent gets accustomed to thinking that a particular act is good or bad due to consistent recurrences (implicit or explicit) that can either come from repetitive social inculcation (be it cultural or religious instruction), personal observations, and experiences with societal members (Hourani 1985, 159), or personal preferences based on how they are hardwired. Consider how a mother consistently scolding a child for playing with fire can lead to the impression that fire is bad; or how when a child sees that fighting leads to being hurt and is, therefore, a bad thing; or how emotional instigations like the tenderness of the heart lead to thinking that killing animals is bad. According to al-Ghazālī $(2013,166)$, such instances end up crystallising an individual's understanding of the good and bad as per the definition outlined in G1: "The source of all of this is being accustomed to approving or disapproving [of certain things] and acquiring certain morals since early youth.”

Collectively, these ideas lead al-Ghazāli to believe that there are no such things as objective or universal morality, i.e. there is nothing that is intrinsically absolutely good or bad. He gives several reasons for making his case, but a few shall be mentioned. First, morality fails to pass the test of universality (Hourani 1985, 155). What human agents end up conceiving as universal rules are, in fact, incomplete inductions. By taking individual instances as moral ontological units in of themselves, humans mistakenly end up identifying them as universal moral rules. Al-Ghazālī $(2013,164)$ expresses this using the example of lying (though this can work with universalising any principle, for good or bad):

For example, he might deem that lying is absolutely bad in all cases, and that its badness is due to its essence alone as lying, and not due to an additional notion. The reason [for this judgment] is his unawareness of how many beneficial matters depend on lying under certain circumstances. Even if such circumstances take place, he might be, by nature, averse to considering lying good because he is fully accustomed to considering it bad. For his nature, since early youth, is averse to lying due to discipline and good upbringing; he is taught that lying is bad in itself and that he should never lie. Lying is bad, indeed, under 
a certain condition, which always accompanies lying except in rare cases; because of this he has not been made aware of that condition. Thus the badness of lying and his absolute aversion to it become rooted in his nature.

In other words, al-Ghazāli would reject the notion of categorical imperatives as developed by Immanuel Kant (Abdullah 1992). It is because of this reason we sometimes see clashes between G1 and G2. Say that a person adopts a universal moral principle of not lying. However, while lying is generally not permitted in Islamic thought, Islamic scripture allows a person to lie in certain circumstances, e.g. to make peace between people or to avoid a war. Or consider the issue of drinking alcohol or eating pork. Under G1, they may be considered perfectly normal consumables. However, Islamic scripture strictly prohibits both of them but allows exceptions, e.g. they can be consumed in life and death situations where they are the only options that one has. So the general rules and exceptions are grounded by revelation, either of which may clash with G1 depending on what is being compared (Al-Ghazālī 2016, 34).

Second, and this is closely linked to the previous point, al-Ghazāli believes that morality is not indubitable (Hourani 1985, 155; Griffel 2012, 29). Morality is largely dependent on externally fed social circumstances and personal temperaments, as discussed earlier, and thus subjective, as they can vary from one community to another. If a person was born in the absence of society, for instance, his/her understanding of good and bad would be somewhat different. He/she may not consider certain moral stances to be definite which would be thought to be otherwise in certain communal settings. Hourani $(1985,155)$ makes the following point on this issue:

... if you were to come into existence fully rational but without experience of society or instruction, having only sense experiences and images, you would be able to doubt such premises such as 'killing a man is evil,' or at least hesitate about them, but you could not doubt 'negation and affirmation cannot be true of the same thing' or ' 2 is great than $1 . '$

Consider another example but of predilections. Individuals are emotionally, culturally, and biologically wired differently, leading them to have different temperaments. One individual might be emotionally softer than another. In such a scenario, the individual might end up believing that killing animals is a bad thing because he may empathise with the animal (Hourani 1985, 155; Al-Ghazālī 2013, 166). This is another instance where G1 and G2 would clash. Al-Ghazālī points out how Islamic scriptures permits killing animals (for food), which may conflict with someone who believes otherwise under G1. In other words, both examples intend to illustrate how morality isn't necessary as are logical axioms. 


\section{Metaphysical considerations}

Jackson $(2014,84)$ aptly summarises the Ash 'arites' position on morality:

... the Ash 'arites insisted that (1) prior to revelation, humans were morally bound by nothing; 2 ) outside the dictates of revelation, there was no reliable, objective index of morality; and 3) even with the scope of revelation, it was the divine address and not any inherent qualities, either in acts themselves or in the human psyche, that established the moral status of human deeds.

Finally, the third definition of good, which will be called G3, refers to the acts of God (Al-Ghazālī 2013, 162):

'An act of God is good ${ }^{11}$ no matter what it is, although God has no needs.' The meaning of this is that there are no repercussions to God or blame of Him because of the act, for He is the agent in His kingdom, in which no one else has a share.

Since al-Ghazālì's general understanding of the good is firmly rooted in teleology, i.e. a thing is good according to its purpose, in al-Ghazālîs's framework, God is an unbounded being, which entails He has no deficiency. There is nothing that He needs nor wants, and thus He has no needs nor purposes, i.e. He has no teleology. For this reason, He does things without purpose because He doesn't need reasons to do things. Furthermore, God cannot be attributed with senses of good as in G1 and G2 because $\mathrm{He}$ is sovereign and ontologically independent. He cannot be harmed for failing to do something, and has no adverse consequences awaiting Him for His actions. ${ }^{12}$ So God is always good regardless of what He chooses to do. In other words, His goodness is an invariant no matter what He commands and manifests (Yaqub 2012). For al-Ghazālī, it would be the inevitable outcome of an unbounded being, which is what God is. To summarise:

G1 - an act that relates to the agent's purpose;

G2 - an act that gets an agent heavenly rewards and eschatological salvation;

G3 - an act of God no matter what it is.

\section{Potential objections}

A critic could raise two objections at this point. First, the Qur'ān itself mentions purposes mandated by God. Consider the following two verses:

We were not playing a pointless game when We created the heavens and earth and everything in between (Qur'ān 44:38)

I created jinn and mankind only to worship Me (Qur'ān 51:56) 
Second, the way al-Ghazālī has defined good when predicated of God is actually meaningless and vacuous. It doesn't really explain good the way we intuitively understand it. Given these two objections, how would al-Ghazālī respond? Let us consider them in order.

As for the first objection, one needs to understand the placement of teleology in those verses carefully. The first verse is implicit but elicits the reader to ponder over life's purpose (and thus suggesting there is one). By contrast, the second verse is clearly explicit in mentioning that man's purpose is to worship God. While these may seem like apparent objections to al-Ghazālī's thesis, they are not substantial. There is a fundamental difference between having a creation for a purpose (gharad) and having a purpose for creation (maqsad). The former is a reason for the creator to create his creation, and the latter is the purpose assigned to the creation. Consider the following analogy. If a game producer wanted to make a board game for the purpose of making money, that would be the assigned purpose in creating the game. However, the players' purposes in playing the game are to win it. Thus the players' purposes in the game are not the same as the creator's purpose for making the game. Similarly, God created the world but with the difference being that He has no purpose for the reasons outlined earlier, i.e. He has no intrinsic teleology. As an unbounded being, there is nothing that He needs, and thus He has no reasons for doing things. However, God created the world with the purpose for its inhabitants to attain salvation in the eschaton, and $\mathrm{He}$ has outlined how this is possible through His moral commands (as He deems fit to choose), i.e. extrinsic teleology. The verses above discuss the latter type of purposes and not the former. Thus, this objection is not a defeater for al-Ghazālī's thesis.

As for the second objection, we need to come back to the theological worldview which al-Ghazālī espoused. The fundamental axiom in the Ash'arite paradigm is God's omnipotence. God is the absolute free agent and has total sovereignty, and this trumps over any axiological considerations. Anything that limits God's capability raises an immediate red flag in the Ash arite framework. So when it is said that God cannot mandate cruel commands like killing innocents, al-Ghazâlī could respond by saying that this objection is premised on a frail human perspective (also see Farahat 2019, 27-65). God's transcendence (tanzi $h$ ) is such that He isn't bound by any moral duty towards His creation, and therefore does as He pleases according to His wisdom. ${ }^{13}$ So al-Ghazālī is saying God, in fact, transcends the human categories of good and bad (Campanini 2019, 62-63). One way of seeing this is by the analogy of a computer designer and the games he makes. A designer could create a game where a particular action is equal to a good thing. But he could equally replicate the same game with the exact action being a bad thing. The "moral framework" of either game is not something which the computer designer himself comes under. $\mathrm{He}$ assigns the framework as he sees fit according to the game's purposes that he has determined, but he himself isn't bound to or by it. So it would be 


\section{Metaphysical considerations}

incorrect to call the designer good or bad from the internal framework of either game.

Winters $(2017,242)$ summarises the Ash'arites (and thus al-Ghazālî̀'s) position aptly:

God is ... not 'morally good' in any human sense but habitually and validly acts according to wisdom ... Divine acts are unlike human acts, not least because they are not axiologically shaped by the values of obedience and disobedience. On this conclusion, divine omnipotence includes the capacity to impose suffering that by human measuring is certainly unjust or unbearable, but this cannot compromise the principle of divine wisdom.

To be sure, this understanding of God is vastly different from the Christian understanding of God being all-loving. ${ }^{14}$ While some schools of thought in Islamic history have had similar affinities to the Christian worldview, e.g. Mu'tazilites, it is not one that al-Ghazālī (nor the Ash'arites) subscribed to (Farfur 2010; Campanini 2019, 61-62). In sum, the second objection's response is simply that God doesn't come under human evaluative frameworks, i.e. He is axiologically transcategorical. ${ }^{15}$

Much more can be said of al-Ghazālī's ideas on ethics, but this is sufficient for the purposes of this chapter (for more details see Malik 2021). With the basic idea outlined here, we can now turn our attention to how al-Ghazālī would deal with the POE and POM.

\section{Al-Ghazālī, the problem of evil, and the problem of objective morality}

\section{Problem of evil}

It should be clear from the preceding section that al-Ghazālī adopts a form of divine command theory, which is the idea that only God, ultimately, indexes morality through revelation. It then follows that good and bad are decrees mandated by God, and so He cannot be subservient to his own moral commandments. Al-Ghazālī's entire point is that God is such a unique being that $\mathrm{He}$ cannot be subjugated to any moral framework; $\mathrm{He}$ transcends these relative notions. Furthermore, as stated earlier, God is not governed by a requirement of omnibenevolence in the Ash'arite paradigm. In fact, al-Ghazālī $(2013,157)$ makes it very clear that God isn't bound by any moral considerations, and is absolutely free in what He can or cannot do:

We claim that it is possible for God (Exalted is He) not to assign obligations to His servants, that it is possible for Him to assign obligations to them beyond their ability, that it is possible for Him to bring suffering 
upon them without compensating them and through no fault of theirs, that it is not obligatory for Him to care for their well-being, that it is not obligatory for Him to reward obedience and punish disobedience, that nothing is made obligatory for a person by virtue of reason but only by virtue of the revelation ...

Accordingly, evil and suffering are artefacts of God's creation. They are real, and they exist according to God's mandate (Jalajel 2010). Even the Qur'ān clarifies that this life has been made as a test where creation will face trials and tribulations, i.e. suffering, and contains episodes that may rub against our moral intuitions, e.g. Qur'ān (2:155). Apart from these divine instructions, humans are not privy to the totality of His divine plan. Collectively, these points make it clear that Ash'arism doesn't really see evil nor suffering as a problem. Even if evolution amplifies the POE because of the endless suffering of animals in the history of life, ${ }^{16}$ it would not be something that would be theologically problematic. It is why the Ash arite perspective on the POE is referred to as an anti-theodicy, i.e. does not vindicate God of evil and suffering (e.g. Winter 2017, 43).

Furthermore, it should also be pointed out that it is not that God simply allows evil to occur, but God is, in fact, the creator of evil. Al-Ghazālî's occasionalism (recall Chapter 6) alongside his adoption of divine command theory makes this an inescapable conclusion. Since God is the sole cause of everything, God is responsible for all things that endure suffering and evil. Al-Ghazālī has no qualms with this outcome seeing that he wants to preserve God's omnipotence above all else.

\section{The problem of objective morality}

Two things need to be mentioned regarding the POM concerning al-Ghazālī's framework. First, there is the issue of the underlying naturalism that some of the thinkers we looked at earlier seem to adopt. They assume that morality is contingent upon evolutionary pressures because they deem it necessary to explain everything via natural explanations (Kitcher 2006; Flanagan et al. 2008). But as highlighted before, and keeping Hume's and Moore's fallacies in mind, perhaps the natural world and moral world occupy different kinds of ontological spaces, making it difficult to determine morality from nature or ground it in nature. If so, morality may be causally independent of nature such that no matter how many times the tape of life was to be replayed, it would not change. In this case, morality would remain objective and would be independent of the history of life. But even setting aside the discussion of the relationship between the moral and natural world, it was made clear in Chapter 6 that al-Ghazāli doesn't adopt philosophical naturalism, and given what was discussed earlier in this chapter, the ultimate good and bad come entirely from revelation which is supernatural in origin, i.e. from God. So al-Ghazālī wouldn't 


\section{Metaphysical considerations}

look to nature for moral prescriptions given that he believes morality is ultimately what God decides to be good and bad, and therefore beyond natural origins.

The second point is that al-Ghazāli has no problem with accepting the POM for what it is. Since he believes that God is a completely free agent, $\mathrm{He}$ can assign the morally good and bad with whatever He pleases. So if this entails that morality is subjective, then so be it. It is interesting to note that both al-Ghazāli and the moral antirealists we looked at earlier agree that objective morality doesn't exist. However, the difference lies in their ontological foundations. Al-Ghazālī is a moral antirealist because of theism, while thinkers like Wilson, Street, Ruse, and Joyce are moral antirealists because of naturalism. They arrive at the same position but due to different metaphysical foundations.

In short, in al-Ghazālī's paradigm, the natural world and the moral world aren't causally connected, but both are entirely determined by God. This entails that whether evolution occurred or not, it would make no difference to the POM. Similar to the POE, the POM isn't an issue in the Ash'arite paradigm.

\section{Conclusion}

This chapter sought to look at the moral dimension of the discussion. The POE and POM are two key issues raised as problems in the discourse in science and religion within the context of evolution. These were evaluated through al-Ghazālī's framework and were found to be unproblematic. The POE is only an issue if there is a stress on God being omnibenevolent. But as was shown in this chapter, this conception doesn't strictly exist in the Ash arite paradigm. God transcends any axiological categories, and so the terms good and bad don't apply to Him. Accordingly, evil exists because it is what God wills. As for the POM, given that al-Ghazāli is a divine command theorist, he believes that morality is ultimately whatever God wills. Accordingly, there isn't anything intrinsically morally good and bad save for what God commands through revelation. The loss of objective morality is, therefore, a natural consequence of al-Ghazālī's framework. As for content nativism, al-Ghazālī doesn't believe humans have innate moral principles. For him, moral principles are adopted and learnt from experiences and the environment. So, it wouldn't matter even if there is no universality of moral norms as suggested by some thinkers that we looked at earlier. Content nativism might be important if one believes in objective morality, and this may be one way of supporting this point empirically, but under the combined perspective of occasionalism and divine command theory, which Ash arites adopt, whether one is a content nativist or non-nativist is irrelevant, at least in al-Ghazālī’s framework. Given these points, al-Ghazālī's metaethics and moral psychology could align with evolution. ${ }^{17}$ 


\section{Notes}

1 I am using morals and ethics synonymously in this chapter.

2 Summary of abbreviations used in this chapter.

\begin{tabular}{lc}
\hline Name & Abbreviation \\
\hline Problem of Evil & POE \\
Problem of Objective Morality & POM \\
Descriptive Evolutionary Ethics & DEE \\
Normative Evolutionary Ethics & NEE \\
Evolutionary Metaethics & EM \\
\hline
\end{tabular}

3 These are not always the terms used to refer to each domain. Ruse (2017, 92-99) for instance, refers to NEE as Darwinian substantive ethics and EM as Darwinian metaethics.

4 Some make a distinction between innatism and nativism. I am following Nielsen's $(2013,188)$ : approach here: "People sometimes distinguish between (moral) innatism and (moral) nativism, with innatism being the doctrine that the human mind is born with certain ideas and knowledge, and nativism being a specific modern version of this doctrine, which uses genetics, cognitive science and evolutionary biology to explain the existence of such innate ideas/knowledge. In this paper I use nativism indiscriminately to refer to all theories which take the human mind to be endowed with innate ideas/ principles/mechanisms."

5 Evolutionary psychologists usually posit entities known as "modules" for the brain. These are hypothesised mental domains responsible for our capabilities like speech and mathematics alongside other cognitive traits. So it should be of no surprise to highlight that moral modules are being discussed and debated over in evolutionary psychology (Prinz 2008, 387-391).

6 Recall from Chapter 1 that contemporary evolutionists suggest factors beyond genes that should be considered in the evolutionary narrative. One of them is cultural evolution which is being alluded here (see Jablonka and Lamb 2006). However, it is important to note the appreciable difference between evolutionary psychologists and cultural evolutionary theorists (Lewens 2020): “Theories of cultural evolution need to be distinguished from theories within evolutionary psychology, even though both may involve an application of evolutionary ideas to the explanation of cultural phenomena. The evolutionary psychologist ... tends to assume that the most important inheritance mechanism in all species - our own included - is genetic inheritance. Evolutionary psychology regards the human mind as evolving through a conventional process of natural selection acting on genetically inherited variation. For example, an evolutionary psychologist might explain the widespread taste among humans for fatty foods in terms of the importance in our species' distant past of consuming as much fat as possible on those rare occasions when the circumstances presented themselves. Such a hypothesis can also help to explain novel cultural trends: the recent increase in obesity is explained as the result of a novel environmental change - the increased availability of cheap, high-fat foods - acting in concert with a once-adaptive, now dangerous, gustatory preference. So evolutionary psychology is hardly silent about culture and cultural change. Even so, cultural evolutionary theorists tend to place far more stress on the role of non-genetic inheritance, and specifically of cultural inheritance mediated via learning, as a factor playing 
a positive, creative role in adapting species to their social and biological environments."

7 For the interested reader, Gould (2014) is a valuable resource for looking at the various perspectives on the relationship between God and abstract objects like mathematics.

8 This shouldn't be taken to imply that morality and mathematics are absolutely analogous. See Gill (2019).

9 For an excellent treatment on how evolution might be juxtaposed with various metaethical and normative theories, see Mizzoni (2017). For a critique of socio-biology, see Bennett (2015).

10 The hadith that is being referred to is the following: "The deeds are considered by the intentions, and a person will get the reward according to his intention. So whoever emigrated for God and His Messenger, his emigration will be for God and His Messenger; and whoever emigrated for worldly benefits or for a woman to marry, his emigration would be for what he emigrated for" (Bukhārī 1).

11 I agree with Yaqub's $(2012,171)$ observation of al-Ghazālī's insistence of using good here: "As we will see, al-Ghazālī thinks that in a certain sense it is correct to say that the acts of God are all good, but this sense has nothing to do with the moral good ..." I can only guess but I believe that al-Ghazālì' is saying this more out of respect for God than anything. As we shall see shortly in the following passages, it's apparent that al-Ghazāli sees God as beyond good and bad.

12 This aligns with Messer's (2009, 145-146) observations who cautions us of the dangers of treating God as an accountable one from a Christian standpoint: "If we attempt such judgements, we are in effect assuming that God is an agent of the same kind as us, only greater. Now if we find ourselves speaking of God in that way, we will no longer be speaking of the God of Christian theology. At best we might be speaking of the greatest being in the universe, not the transcendent Creator of the universe. This reduced 'god' can be more than a participant in the processes of physical cause and effect in the universe, albeit the greatest and most powerful participant ... Furthermore, the language of 'theodicies' and 'defences' makes clear what kind of judgement about God we have in view. Our moral evaluation of God has a forensic aspect to it: we are in a courtroom drama in which God stands accused of culpable negligence, wanton cruelty or worse. Theologians who develop theodicies and defences within such a frame of reference act as God's counsel, trying to get God acquitted of all charges. It is worth nothing the oddness of this way of speaking from the perspective of the Christian tradition, which is more accustomed thinking of God as our Judge. Even if it is sometimes necessary engage on its own terms with the kind of God-talk on trial ... we need to remain constantly aware that this is not Christian theology's characteristic mode of speaking - and at the very least, it has significant intellectual and spiritual dangers."

13 For al-Ghazālī's understanding of God's attribute of being al-Hakīm (The All Wise), see al-Ghazālī $(2015,116-118)$.

14 As a further qualification, while God being omnibenevolent is central to the Christian paradigm, I don't mean to imply that all Christians hold this position. Some Christian theologians come very close to al-Ghazālī's position, e.g. William of Ockham (Osborne 2005).

15 It could be asked how the commands of such a God is possible to understand within human categories. This is a conflation of understanding God himself through religious language versus the commands of God. Both are intelligible, but the former is linguistically and conceptually inexhaustible since God 
is an infinite and transcendent being. It is al-Ghazālī's point entirely that God Himself can never be completely reduced to humanly expressed terms. For further exposition on his thoughts on religious language, see al-Ghazāli (2015) and Malik (2021).

16 To be clear, this doesn't entail that animals are to be oppressed. Divine command theory is a metaethical position. By contrast, in Sharīa a a body of normative and applied ethics, it is clear that animals have welfare rights that Muslims need to uphold (Foltz 2006; Masri 2009).

17 Of course, there are a host of issues with divine command theory, at least when situated in the broader Ash'arite paradigm. The most serious contention is divine deception. The conjunction of God being able to do anything logically possible unbound by moral parameters allows the possibility of God being able to lie. For an excellent critique of the Ash'arite paradigm on this particular point, see El-Rouayheb (2014).

\section{References}

Abdullah, M. Amin. 1992. The Idea of Universality of Ethical Norms in Ghazāli and Kant. Ankara: Türkiye Diyanet Vakfi.

Al-Ghazālī, Abū Ḥāmid. 2013. Moderation in Belief. trans. by Aladdin M. Yaqub. Chicago, IL: The University of Chicago Press.

Al-Ghazālī, Abū Hāamid. 2015. The Ninety-Nine Beautiful Names of God. trans. by David Burrell and Nazih Daher. Cambridge: The Islamic Texts Society.

Al-Ghazālī, Abū Hāmid. 2016. Kitāb Qawāi id Al-'Aqāìd: The Principles of the Creed - Book 2 of the Ihyya' 'Ulūm al-Dīn. trans. by Khalid Williams. Louisville, KY: Fons Vitae.

Beck, Naomi. 2017. "Social Darwinism and Market Morality: A Modern DayView." In Michael Ruse, and Robert J Richards, eds. The Cambridge Handbook of Evolutionary Ethics. Cambridge: Cambridge University Press, 58-71.

Bennett, Franklin Roy. 2015. Evolution and Ethics: A Critique of Sociobiology. New York, NY: Palgrave Macmillan.

Campanini, Massimo. 2019. Al-Ghazālī and The Divine. Abingdon: Routledge.

Carter, Gerald G., and Gerald S. Wilkinson. 2013. "Food Sharing in Vampire Bats: Reciprocal Help Predicts Donations More Than Relatedness or Harassment." Proceedings of the Royal Society B: Biological Sciences, 280: 20122573.

Clark, Kelly James. 2014. Religion and the Sciences of Origins: Historical and Contemporary Discussions. New York: Palgrave Macmillan.

Clark, Kelly James. 2019. God and The Brain: The Rationality of Belief. Grand Rapids, MI: William B. Eerdmans Publishing Company.

Darwin, Charles. 2009. The Descent of Man and Selection in Relation to Sex. Volume 1. Cambridge: Cambridge University Press.

Dawkins, Richard. 2006. The Selfish Gene. Oxford: Oxford University Press.

Dwyer, Susan. 2008. "How Not to Argue That Morality Isn't Innate: Comments on Prinz.” In Walter Sinnott-Armstrong, ed. Moral Psychology Volume 1: The Evolution of Morality: Adaptations and Innateness. Cambridge, MA: The MIT Press, 407-418.

El-Rouayheb, Khaled. 2014. "Must God Tell Us the Truth? A Problem in Ash'arī Theology.” In Asad Q. Ahmed, Behnam Sadeghi, Robert G. Hoyland, and Adam Silverstein, eds. Islamic Cultures, Islamic Contexts Essays in Honor of Professor Patricia Crone. Leiden: Brill, 411-429. 
Farahat, Omar. 2019. The Foundation of Norms in Islamic Jurisprudence and Theology. Cambridge: Cambridge University Press.

Farfur, Muhammad Salih. 2010. The Beneficial Message and the Definitive Proof in the Study of Theology. trans. Wesam Charkawi. London: Azhar Academy Ltd.

FitzPatrick, William. 2016. "Morality and Evolutionary Biology." The Stanford Encyclopedia of Philosophy. Accessed 7th of September 2020. Available at: https:// plato.stanford.edu/archives/spr2016/entries/morality-biology/

Flanagan, Owen, Hagop Sarkissan, and David Wong. 2008. "Naturalizing Ethics." In Walter Sinnott-Armstrong, ed. Moral Psychology Volume 1: The Evolution of Morality: Adaptations and Innateness. Cambridge, MA: The MIT Press, 1-26.

Foltz, Richard C. 2006. Animals in Islamic Tradition and Muslim Culture. Oxford: Oneworld Publications.

Francescotti, Robert. 2013. "The Problem of Animal Pain and Suffering." In Justin P McBrayer, and Daniel Howard-Snyder, eds. The Blackwell Companion to The Problem of Evil. Hoboken, NJ: Wiley-Blackwell, 113-127.

Gill, Michael B. 2019. "Morality Is Not Like Mathematics: The Weakness of the Math-Moral Analogy." The Southern Journal of Philosophy, 57(2): 194-216.

Gould, Paul M., ed. 2014. Beyond the Control of God? Six Views on The Problem of God and Abstract Objects. New York, NY: Bloomsbury.

Griffel, Frank. 2012. “Al-Ghazālī’s Use of 'Original Human Disposition' (Fitra) and Its Background in the Teachings of al-Farābī and Avicenna." The Muslim World, 102(1): 1-32.

Harman, Gilbert. 2008. "Using a Linguistic Analogy to Study Morality.” In Walter Sinnott-Armstrong, ed. Moral Psychology Volume 1: The Evolution of Morality: Adaptations and Innateness. Cambridge, MA: The MIT Press, 345-352.

Hamilton, W. D. 1964. “The Genetical Evolution of Social Behaviour. II.” Journal of Theoretical Biology, 7(1): 17-52.

Hickson, Michael W. 2013. “A Brief History of Problems of Evil.” In Justin P McBrayer and Daniel Howard-Snyder, eds. The Blackwell Companion to The Problem of Evil. Hoboken, NJ: Wiley-Blackwell, 3-18.

Horsten, Leon. 2019. "Philosophy of Mathematics." The Stanford Encyclopedia of Philosophy. Accessed 12th of September 2020. https://plato.stanford.edu/archives/ spr2019/entries/philosophy-mathematics/

Hourani, George F. 1985. Reason and Tradition in Islamic Ethics. Cambridge: Cambridge University Press.

Hume, David. 2007. A Treatise of Human Nature. Volume 1. David Fate Norton and Mary J. Norton, eds. Oxford: Oxford University Press.

Huxley, Leonard. 1900. The Life and Letters of Thomas Henry Huxley. London: Macmillan.

Huxley, Thomas Henry. 2009. Evolution and Ethics. Cambridge: Cambridge University Press.

Jablonka, Eva, and Mariion J. Lamb. 2014. Evolution in Four Dimensions: Genetic, Epigenetic, Behavioural, and Symbolic Variation in the History of Life. Cambridge, MA: The MIT Press.

Jackson, Sherman A. 2014. Islam and the Problem of Black Suffering. Oxford: Oxford University Press.

Jalajel, David. 2010. "Ethical Objections to Evolution in Contemporary Muslim Thought.” American Journal of Islam and Society, 27(3): 79-92. 
James, Scott M. 2011. An Introduction to Evolutionary Ethics. West Sussex: Wiley-Blackwell.

Mikhail, John. 2008. "The Poverty of the Moral Stimulus.” In Walter SinnottArmstrong ed. Moral Psychology Volume 1: The Evolution of Morality: Adaptations and Innateness. Cambridge, MA: The MIT Press, 353-360.

Jones, James W. 2016. Can Science Explain Religion? The Cognitive Science Debate. Oxford: Oxford University Press.

Joyce, Richard. 2006. The Evolution of Morality. Cambridge, MA: The MIT Press.

Lewens, Tim. 2020. “Cultural Evolution.” The Stanford Encyclopedia of Philosophy. Accessed 7th of September 2020. Available at: https://plato.stanford.edu/archives/ sum2020/entries/evolution-cultural/

Joyce, Richard. 2017. "From an Empirical Puzzle to a Metaethical Puzzle” In Michael Ruse, and Robert J Richards eds. The Cambridge Handbook of Evolutionary Ethics. Cambridge: Cambridge University Press, 101-113.

Kitcher, Philip. 2006. "Four Ways of 'Biologicizing' Ethics.” In Elliott Sober, ed. Conceptual Issues in Evolutionary Biology. Cambridge, MA: The MIT Press, 575-586.

Linnebo, Øystein. 2018. "Platonism in the Philosophy of Mathematics." The Stanford Encyclopedia of Philosophy. Accessed 23rd of December 2020. Available at: https://plato.stanford.edu/archives/spr2018/entries/platonism-mathematics/

Malik, Shoaib Ahmed. 2021. "Al-Ghazālīs Divine Command Theory - Biting the Bullet." Journal of Religious Ethics, revised and resubmitted.

Masri, Al-Hafiz Basheer Ahmad. 2009. Animal Welfare in Islam. Markfield: The Islamic Foundation.

Messer, Neil. 2009. "Natural Evil After Darwin.” In Michael S. Northcott and R. J. Berry, eds. Theology After Darwin. Milton Keynes: Paternoster.

Mizzoni, John. 2009. “'The Social Instincts Naturally Lead to the Golden Rule:' The Ethics of Charles Darwin.” Teorema: Revista Internacional de Filosofía, 28(2): 123-133.

Mizzoni, John. 2017. Evolution and the Foundations of Ethics: Evolutionary Perspectives on Contemporary Normative and Metaethical Theories. New York, NY: Lexington Books.

Moore, G. E. 2000. Principia Ethica. Thomas Baldwin eds. Cambridge: Cambridge University Press.

Murray, Michael J. 2008. Nature Red in Tooth and Claw: Theism and the Problem of Animal Suffering. New York, NY: Oxford University Press.

Nagasawa, Yujin. 2018. “The Problem of Evil for Atheists.” In Nick N Trakakis, ed. The Problem of Evil: Eight Views in Dialogue. Oxford: Oxford University Press, 151-175.

Nielsen, Carsten Fogh. 2013. "It's Complicated - Moral Nativism, Moral Input and Moral Development.” In Bert Musschenga Anton van Harskamp, ed. What Makes Us Moral? On the Capacities and Conditions for Being Moral. Netherlands: Springer, 187-206.

Okasha, Samir. 2020. "Biological Altruism." The Stanford Encyclopedia of Philosophy. (Summer 2020 Edition), Accessed 7th of September 2020. Available at: https://plato.stanford.edu/archives/sum2020/entries/altruism-biological/

Osborne, Thomas M. 2005. "Ockham as a Divine-Command Theorist." Religious Studies, 41(1): 1-22. 


\section{Metaphysical considerations}

Peters, Ted, and Martinez Hewlett. 2003. Evolution from Creation to New Creation: Conflict, Conversation, and Convergence. Nashville: Abingdon Press.

Prinz, Jesse J. 2008. "Is Morality Innate? In Walter Sinnott-Armstrong, ed. Moral Psychology Volume 1: The Evolution of Morality: Adaptations and Innateness. Massachusetts: The MIT Press, 367-406.

Prinz, Jesse J. 2009. “Against Moral Nativism.” In Dominic Murphy and Michael A. Bishop eds. Stich and His Critics. Wiley-Blackwell, 167-189.

Rose, Hilary, and Steven Rose eds. 2000. Alas, Poor Darwin: Arguments Against Evolutionary Psychology. New York, NY: Harmony Books.

Ruse, Michael. 2008. Darwinism and Its Discontents. Cambridge: Cambridge University Press.

Ruse, Michael. 2017. "Darwinian Evolution Ethics.” In Michael Ruse and Robert J Richards, eds. The Cambridge Handbook of Evolutionary Ethics. Cambridge: Cambridge University Press, 89-100.

Samet, Jerry, and Deborah Zaitchik. 2017. "Innateness and Contemporary Theories of Cognition." The Stanford Encyclopedia of Philosophy. Accessed 8th of September 2020. https://plato.stanford.edu/archives/fall2017/entries/innateness-cognition/

Samet, Jerry. 2019. "The Historical Controversies Surrounding Innateness." The Stanford Encyclopedia of Philosophy. Accessed 8th of September 2020. https:// plato.stanford.edu/archives/sum2019/entries/innateness-history/

Sayre-McCord, Geoff. 2020. "Moral Realism." The Stanford Encyclopedia of Philosophy. Accessed 12th of September 2020. https://plato.stanford.edu/archives/ fall2020/entries/moral-realism/

Scher, Stephen J., and Frederick Rauscher, eds. 2003. Evolutionary Psychology: Alternative Approaches. New York: Springer.

Smith, Subrena E. 2020. "Is Evolutionary Psychology Possible?” Biological Theory, 15: 39-49.

Spencer, Herbert. 1851. Social Statics; Or the Conditions Essential Human Happiness Specific and the First of Them Developed. London: J. Chapman.

Street, Sharon. 2006. "A Darwinian Dilemma for Realist Theories of Value." Philosophical Studies, 127: 109-166.

Sripada, Chandra, and Stephen Stich. 2006. "A Framework for the Psychology of Norms.” In Peter Carruthers, Stephen Laurence, and Stephen Stich, eds. The Innate Mind, Volume 2: Culture and Cognition. Oxford: Oxford University Press, 280-301.

Sripada, Chandra Sekhar. 2008a. "Nativism and Moral Psychology: Three Models of the Innate Structure That Shapes the Contents of Moral Norms.” In Walter Sinnott-Armstrong, ed. Moral Psychology Volume 1: The Evolution of Morality: Adaptations and Innateness. Cambridge, MA: The MIT Press, 319-344.

Sripada, Chandra Sekhar. 2008b. "Reply to Haman and Mikhail." In Walter Sinnott-Armstrong, ed. Moral Psychology Volume 1: The Evolution of Morality: Adaptations and Innateness. Cambridge, MA: The MIT Press, 361-366.

Tiberius, Valerie. 2008. "The Nativism Debate and Moral Philosophy: Comments on Prinz.” In Walter Sinnott-Armstrong, ed. Moral Psychology Volume 1: The Evolution of Morality: Adaptations and Innateness. Cambridge, MA: The MIT Press, 419-426.

Trivers, Robert L. 1971. “The Evolution of Reciprocal Altruism.” Quarterly Review of Biology, 46: 35-57. 
Trivers, Robert L. 2002. Natural Selection and Social Theory Selected Papers of Robert Trivers. Oxford: Oxford University Press.

Umaruddin, M. 2010. The Ethical Philosophy of al-Ghazālī. New Delhi: Adam Publishers and Distributors.

Wilson, Edward O. 1975. Sociobiology: The New Synthesis. Cambridge, MA: Harvard University Press.

Wilson, Edward O. 1995. “The Morality of the Gene.” In Paul Thompson, ed. Issues in Evolutionary Ethics. New York, NY: State University of New York Press, 153-164.

Winter, Tim. 2017. "Islam and the Problem of Evil." In The Problem of Evil, eds. Chad Meister and Paul J. Moser. Cambridge: Cambridge University Press, 230-248.

Yaqub, Aladdin M. 2012. “Al-Ghazālī’s Ethical Egoism and Divine Will.”. In Y. Tzvi Langermann ed. Monotheism \& Ethics: Historical and Contemporary Intersections Among Judaism, Christianity and Islam. Leiden: Brill, 163-196. 


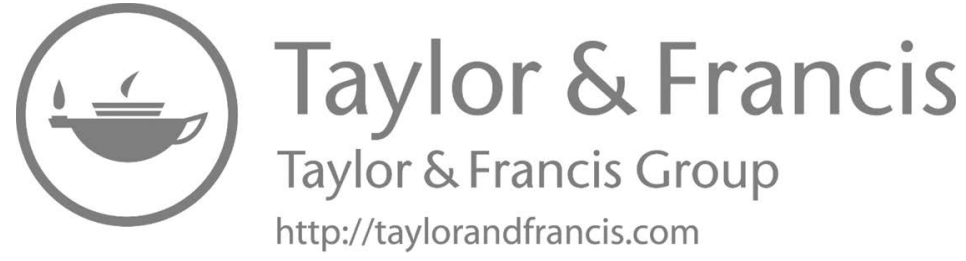


Part 4

Hermeneutic considerations 


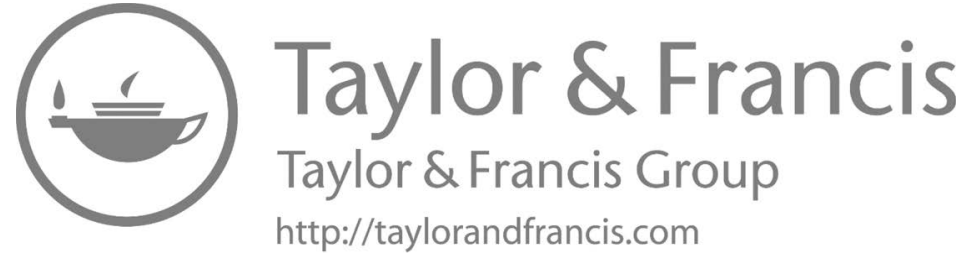




\section{Al-Ghazālī’s hermeneutics}

\section{Introduction}

In the previous quarter of this book, we looked at the metaphysical issues surrounding evolution, and how they could be responded to from an Ash'arite perspective. It was concluded that none of those problems raise serious contentions when situated in the Ash arite framework and qualified with nuances. In this last quarter of the book, we shall analyse the scriptural aspects of the discussion, in which the discussion of evolution is juxtaposed with the Qur'ān and hadīths. To this end, this chapter will try to highlight the relevant principles of scriptural interpretation from al-Ghazālī’s writings. This is more challenging than it seems. Since al-Ghazālī doesn't have any significant exegetical corpus to his name, or at least not one that has passed the test of time, we will have to rely on various treatises where he spells out his interpretive ideas that we can then apply to Islamic scripture in the context of evolution (Hourani 1984; Griffel 2009).

However, a challenge that comes with this approach is understanding the context of each work, and which "hat" al-Ghazāli is wearing in each one. As stated in the Introduction of this book, al-Ghazāli is sometimes a problematic thinker to pin down because he entertains different kinds of discourses in his corpus. Sometimes he writes as a theologian, at times as a jurist, and as a mystical thinker (Sufi) in others. The following is a useful way of understanding their differences. As a theologian, one is primarily concerned with explaining and defending matters of belief or dogma. Part of this discourse is to identify what is deemed orthodox, heterodox, and unbelief. As a jurist, one is preoccupied with legal matters. It looks at the combination of normative and applied ethics, which, in the case of Islam, involves utilising the scriptural sources of Islam, i.e. the Qur'ān and hadìth, to deriving juristic principles and developing a methodology that can be consistently applied in a variety of different settings. This includes laws related to personal worship, e.g. prayer and fasting, and transactional affairs that people deal with daily, e.g. wills and financial transactions. A mystical thinker is primarily concerned with gnosis. Through supplications and acts of worship, one can reach mystical heights and understand God in 
a manner that is beyond ratiocination and sense impressions. Given these differences, the emphasis and kind of content, scope, language, and the methodology varies between each type of discourse, which is why sometimes thinkers have noted internal tensions in the large corpus of al-Ghazālī (Gianotti 2000; Moosa 2005; Griffel 2009).

Since the purpose of this work is to determine how much Islam and evolution can embrace one another, the focus here will primarily be on al-Ghazālī as a theologian. In other words, how compatible is evolution with Islamic scripture from a creedal point of view? This seems to be a sensible approach since doctrines of creed demand a very high threshold in terms of certainty in both scriptural transmission and clarity in the text, elements which we shall expand on shortly. This high threshold entails that if Islamic scripture isn't clear enough on specific details in Adam's creation, which is the most crucial aspect of this entire discussion, then it cannot be stated that evolution and Islam are in conflict. However, if clear hermeneutic readings are forced with an interpretation that isn't scripturally warranted, they become theologically problematic. To be clear, al-Ghazālī highlights there are there are degrees of theological (in)acceptability. The most extreme degree is when an interpretation takes one outside of the fold of Islam. For instance, if a Muslim reads polytheism into Islamic scripture, wherein strict monotheism is repeatedly and unambiguously asserted, they are subject to being outside the fold of Islam. On the less severe end of the spectrum, if a Muslim gives a figurative reading to a verse that is irrelevant to the fundamentals of faith, then no such charge is warranted. Accordingly, primary and secondary matters affect what can or cannot be accepted theologically in al-Ghazālī's hermeneutic framework.

The structure of this chapter is as follows. In the first section we shall review a short work called The Universal Rule for Interpretation

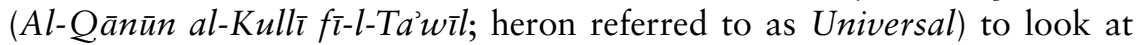
al-Ghazālī's framing of the reason and revelation debate. This will help with the context for when understanding his hermeneutic framework. The second discussion focuses on how al-Ghazālī views the relationship between science and the Qur'ān, which he briefly discusses in his Jewels of the Qur'ann (Jawāhir al-Qur'ān; hereon referred to as Jewels). The third section will introduce how al-Ghazālī understands hermeneutics in relation to his theological framework. This will be important to illustrate what he finds is at stake theologically when interpreting Islamic scripture. The fourth section goes through his methodological process. He differentiates literal readings from non-literal ones in The Decisive Criterion for Distinguishing Islam from Masked Infidelity (Fayșal al-Tafriqa bayna al-Islām wa al-Zandaqa; hereon referred to as Criterion). As we shall see shortly, he identifies a fivetier reading of Islamic scripture. In the fifth and final section, we shall look at the role of hadīths in al-Ghazālī's hermeneutic process as a theologian. This section will also highlight the different sensitivities specialists have with hadīths. As we shall see, theologians, legal jurists, hadīth specialists, 
and mystics have different epistemic standards for evaluating and applying hadīths. This will be important to understand what makes al-Ghazālì's theological perspective distinctive in comparison to him as a jurist and as a mystical thinker. This chapter will collectively help us navigate the Qurānic verses and hadīths relevant to evolution in Chapter 10. More importantly, it will help us appreciate where and how al-Ghazālī might agree or disagree with some of the opinions we reviewed in Chapter 4.

\section{Reason and revelation}

Al-Ghazālī describes five stances (without mention of any particular names and groups he is referring to) when it comes to understanding the relationship between reason and revelation in the Universal. ${ }^{1}$ These can be put on a spectrum, as shown in Table 9.1.

Table 9.1 Al-Ghazālî’s spectrum on the reason-revelation dichotomy. The table is organised with the stress on revelation on the left with increasing importance given to reason as one moves to the right. Also, note that the group names are not al-Ghazālī’s terminology. They have been used here to help better navigate this spectrum.

\begin{tabular}{lllll}
\hline $\begin{array}{l}\text { Revelation } \\
\text { Absolutists }\end{array}$ & $\begin{array}{l}\text { Revelation } \\
\text { Optimists }\end{array}$ & Moderates & $\begin{array}{l}\text { Reason } \\
\text { Optimists }\end{array}$ & $\begin{array}{l}\text { Reason } \\
\text { Absolutists }\end{array}$ \\
\hline Group 1 & Group 4 & Group 5 & Group 3 & Group 2 \\
\hline
\end{tabular}

Starting from the left, the first group (revelation absolutists) represents individuals who give absolute authority to revelation. Al-Ghazālī stresses that individuals in this camp are so absorbed and committed to the scriptural corpus, that they would go to the extent of rejecting reason even if it would involve entertaining contradictions: "And perhaps they would not even shrink from saying that a person's being in two places at once is within the power of God" (Al-Ghazālî 1998, 49). As stated in Chapter 6, logical impossibilities are not within God's power to enact according to al-Ghazālī. Since he sees that a person cannot be in two places simultaneously, as it entails a logical contradiction, and thus impossible for God to do, this, in turn, is hermeneutically impossible. Advocates of this position give such supreme authority to revelation that they would accept such things if mentioned in scripture.

The second group (reason absolutists) is on the other end of the spectrum. In this position, reason presides and dictates revelation entirely (Al-Ghazālī 1998, 49):

They confined their studies to reason and did not concern themselves with scripture. If they hear something in scripture that is agreeable to them, they accept it. On the other hand, if they hear something that 
is in conflict with their reason, they claim that it is something that has been imagined by the prophets, for the prophets were required to descend to the level of ordinary people, and sometimes it was necessary for them to describe things in a way that did not conform with reality. Thus anything that did not agree with their reason they interpreted in this way. They exaggerated rationality to the extent of becoming unbelievers inasmuch as they ascribed lying to the prophets, may God's blessing and peace be upon them, for the sake of the general welfare.

Al-Ghazāli doesn't give an example of what kind of opinions this group could have in this particular work. But one can surmise that he is referring to the Muslim philosophers (thinkers who follow the Hellenic tradition such as Avicenna) who he critiques in one of his most critical works, The Incoherence of the Philosophers (Tahāfut Al Falāsifa). In that work, al-Ghazālī criticises seventeen articles adopted by Muslim philosophers he believes are heterodox, and three articles that he deems are worthy of the charge of unbelief. The latter include their belief in the eternity of the world, denial of bodily resurrection, and God not knowing particulars (Al-Ghazālī 2000a). Concerning scripture in particular and our discussion of evolution, al-Ghazālī's criticism of their (philosophers') account of miracles is pertinent. Miracles are possible in al-Ghazālī's occasionalist framework (recall Chapter 6). But some might reject such things because it doesn't work with their metaphysical framework. As discussed in Chapter 4, al-Ghazālī is famous for critiquing Avicenna because he rejected the idea of miracles. Part and parcel of Avicenna's framework is the idea that laws of nature are fixed, which precludes the possibility of miracles (Richardson 2020). This led him to reinterpret miracles in Islamic scripture metaphorically. The following is al-Ghazālî̀s summary of Avicenna's stance on miracles (Al-Ghazālī 2000a, 163):

Whoever renders the habitual courses [of nature] a necessary constant makes all these [miracles] impossible. [The philosophers] have thus interpreted what is said in the Qur'ann about the revivification of the dead metaphorically, saying that what is meant by it is the cessation of the death of ignorance through the life of knowledge. And they interpreted the staff devouring the magic of the magicians as the refutation by the divine proof, manifest at the hand of Moses, of the doubts of those who deny [the one God]. As regards the splitting of the moon, they often deny the existence [of this occurrence] and claim that there has been no soundly transmitted, indubitable reporting of it.

In response to such claims, al-Ghazālī (2000a, 165) retorts with the following:

We ... deny ... their denying the possibility of the changing of the staff into a serpent, the revivification of the dead, and other [miracles of the 
kind]. For this reason, it becomes necessary to plunge into this question to affirm miracles and [to achieve] something else-namely, to support what all Muslims agree on, to the effect that God has power over all things.

Here we clearly see that rejecting or reinterpreting miracles in Islamic scripture is not warranted for al-Ghazālī since they are logically possible, and thus within divine power. This is a perfect example of how one's theological or metaphysical background affects one's hermeneutic stances. This relationship between eisegesis and exegesis will be essential to note when we review the various ways people have tried to accommodate evolutionary readings in Chapter 10.

It is also vital to note al-Ghazālī's comment on the integrity of the prophets in relation to the second group. It plays an important role in the Universal, which we will analyse shortly. But in brief, unnecessarily resorting to non-literal readings is a serious theological matter for al-Ghazālī. It suggests or entails that the prophets were either entirely or partially lying to their recipients after getting revelation from God. Ascribing any kind of falsehood to the prophets is a red line for al-Ghazālī. It is then of no surprise that al-Ghazālī $(1988,49)$ indicates the second group is more problematic than the first one.

The third group ${ }^{2}$ (reason optimists) gives some merit to revelation, but reason still is the main factor in interpretation (Al-Ghazāli 1998, 50):

The third group made reason fundamental and investigated it at length. However, they paid little attention to scripture, and did not encounter those passages that at first glance and initial impression seem to be contradictory and in conflict with each other or contrary to reason. They did not plunge into the heart of the problem, but when they did hear passages that conflicted with reason they rejected and ignored them or accused their transmitters of lying, except when the transmission was by tawātur, like the Qur'ān, or when the words of the hadīth were easy to interpret. They rejected what they found difficult to interpret in order to avoid making far-fetched interpretations. It is clear how dangerous this position is in its rejection of sound traditions that have been transmitted by those trustworthy persons through whom scripture has reached us.

This comment requires some unpacking. Al-Ghazālī seems to raise two criticisms against this group. The first criticism is mere negligence. Perhaps they didn't investigate Islamic scripture thoroughly enough on a given point. The second criticism is specifically related to hadiths. To help appreciate this comment, we need to distinguish between the historical transmission of the Qur'ān and the historical transmission of hadīths. The Qur'ān is believed to be historically and numerically transmitted by so 


\section{Hermeneutic considerations}

many people in each stage of the transmission that to believe the content of the Qur'ān was a conspired project by independent individuals is farcical. Such transmission is known as tawātur, and news that arrives to us through such channels is known as mutawattir. ${ }^{3}$ To put this in perspective, consider Antarctica. Most of us have never been to this continent. However, we know of it through our teachers, books, the internet, photos, and various other channels of information. It is known to us by so many independent channels that to question its existence would be silly. The knowledge of Antarctica is mutawātir, but the multiple independent sources that corroborate this knowledge is tawātur. Similarly, there is a robust historical record of the Qur'ān's transmission through the ages, which is why Muslims haven't questioned its historical veracity. While this may be the case for Qur'ān, the same cannot be said of hadīths. Hadīths are accompanying scriptural resources for Muslims, but not all of them have the sturdiness of the Qur'ān's historical integrity. This is why there is a whole independent discipline known as $u s \underline{u} l$ al-hadìth (principles of hadīth) through which strong hadīths are sifted out from the weak ones, as alluded to in Chapter 3. The Qur'ān and some hadīths are mutawātir. However, there are hadīths which aren't mutawātir, and they are called $\bar{a} h \bar{a} d$ (also known as khabar al-wāhid or khabar ahād $\bar{\imath})$. They are epistemically weaker. However, these hadīths aren't necessarily useless nor rejected. Hadīth specialists have various methodological principles through which they can substantiate these hadīths to a very strong level. For example, hadīths relay the similar content but are individually weak can become stronger when corroborated with one another leading to a higher epistemic status. With this in mind, al-Ghazālī's complaint against this group is that when they find things that conflict with reason in these kinds of hadīths, they either reject them or re-appropriate their meanings to fit their predesignated opinions. In other words, they treat such hadīths in a very rash manner, and do not give such kind of scripture their due methodological attention. Much more on hadīths can be mentioned (and it will be shortly), but this sufficient for the purposes of explaining this statement.

The fourth group (revelation optimists) is contrasted with the third group. Here reason is entertained when looking at scripture but often neglected (Al-Ghazālī 1998, 50):

The fourth group made scripture fundamental and dealt with it at length. They were familiar with a large number of scriptural passages ..., but they avoided reason and did not plunge into it. The conflict between reason and scriptural passages was apparent to them only in some fringe areas of the rational sciences. However, since their involvement with reason was not extensive nor did they plunge into it, rational impossibilities were not obvious to them, for some impossibilities are perceived only after careful and extended investigation built on many successive premises. 
The main criticism al-Ghazālī is charging against this group is they don't know how certain verses need to be re-assessed through principles of reason. This is why they end up having absurd beliefs. Al-Ghazālī $(1998,51)$ uses the example of verses which mention God in directional terms to illustrate the errors of the fourth group: "They resemble someone who does not know that God's being in a location is impossible and who can therefore dispense with the interpretation of 'above' and 'mounting' and all such words that indicate location." Since God is known to be non-spatial from theo-philosophical proofs, which may take time to appreciate in the form of dialectic arguments, ${ }^{4}$ the absence of this knowledge allows people in this category to make errors such as attributing directionality to Him.

Finally, the fifth group (moderates) is one which tries to balance both reason and revelation, and understands their importance with respect to one another. According to al-Ghazālī, one who has mastered the sciences related to both domains will be able to reach easy interpretations at moments of conflict. However, al-Ghazālī $(1998,52)$ believes that there will be inevitable moments that may be difficult to reconcile, which force people to make one of two moves:

... there inevitably remain two situations [in which interpretation is difficult]: the first is the situation in which one is forced to employ far-fetched interpretations from which [rational] minds shrink, and the other is the situation in which one cannot determine how to make any interpretation at all ... Anyone who thinks that he has escaped from these two situations does so either because of his deficiency in the rational sciences and his ignorance of rational impossibilities, so that he considers possible what he does not know to be impossible, or because of his deficiency in reading traditions, so that he has not encountered many individual traditions which contradict reason.

For individuals who arrive at this juncture, he lends three pieces of advice. The first is accepting one's limits and being humble with this task, as one may not know everything (Al-Ghazālī 1998, 52):

The first recommendation is that one not aspire to know all of that, and this was the purpose to which I was directing my discourse. Such knowledge is not something to be aspired to, and one should recite [the verse from the Qur'ān in which] God says, 'And of knowledge you have been vouchsafed but little' [Qur'ān 17:85].

The second advice is never doubting reason (Al-Ghazālī 1998, 52):

The second recommendation is that one should never deny the testimony of reason, for reason does not lie. Were reason to lie, it might lie in establishing scripture, for it is by reason that we know scripture to be true. 
In this point, al-Ghazāli is alluding to the idea that scripture itself is grounded by reason. When God sends prophets to people, He gives them miracles to help them establish their integrity as authentic prophets of God. This demands the use of reason. So to question the veracity of reason after scripture is predicated on reason is fallacious. He gives the example of a hadīth which effectively states that death will be brought in the form of a ram which will be killed in the eschaton. Al-Ghazāli makes the point that death is a state of being and not a tangible thing, and so death can never really be "executed," which is why this hadīth cannot be taken at face value. Instead, this hadīth should be interpreted with the idea that our lives in the hereafter will be never-ending, as we will never die, and the ram's death represents this as a symbol. Therefore, reason does have an important role to play in assessing what is and isn't determinable in scripture (Al-Ghazālī 1998, 53).

The third advice is deferring judgement (tafwì ticular verse or hadīth may have multiple and sometimes incompatible interpretations (Al-Ghazālī 1998, 53):

The third recommendation is that one refrain from specifying an interpretation when the [various] possibilities [of interpretation] are incompatible. Judgment concerning the intention of God or of His Prophet by means of supposition and guessing is dangerous. One knows the intention of a speaker only when he reveals his intention. If he does not reveal his intention, how can one know it, unless the various possibilities are limited and all but one of them is eliminated.

The reason why he stresses this point is because guessing what God intended with ambiguous scriptural references has eschatological implications. If one goes beyond his way to make a particular interpretation as the interpretation, then that person might be questioned by God on the day of judgement. It is why it is better to defer interpretation than to force an interpretation based on guesswork (Al-Ghazālī 1998, 54):

It ... provides more security for the day of resurrection, since it is not improbable that on the day of resurrection he will be questioned [about his judgments] and held accountable for them and be told, 'You made a judgment about Us [God] by supposition.'

There are several verses related to the idea that one's deeds or works in this life will be weighed in the hereafter, e.g. Qur'ān (7:8). He uses this as an example to show there can be more than one interpretation for which we can't really have a decisive opinion on (Al-Ghazālì 1998, 53-54):

For example, if it is clear to you that works cannot be weighed, and the tradition concerning the weighing of works comes up, you must interpret either the word 'weighing' or the word 'works.' It is possible that 
the word used metaphorically is 'works' and that it was used in lieu of the register of works, in which they are recorded, and it is these registers of works which are weighed. On the other hand, it is also possible that the word used metaphorically is 'weighing,' and that it was used in lieu of its effect, that is, the determination of the amount of work, since that is the virility of weighing, and weighing and measuring are ways of determining [amounts]. If you conclude at this time that what is to be interpreted is the word 'works' rather than the word 'weighing,' or 'weighing' rather than 'works,' without relying on either reason or scripture, you are making a judgment about God and His intention by guessing, and guessing and supposition are tantamount to ignorance.

In short, al-Ghazālī is comfortable with having uncertain hermeneutic positions.

In relation to this point, it might also be helpful note al-Ghazālī also employs theological tawaqquf (recall this concept was discussed in Chapter 4). This is the position of abstaining from judgement altogether since scripture is silent on a matter, which is different to when scripture is ambiguous on a matter. In other words, someone cannot claim anything either for or against a matter if it is not mentioned in scripture. Al-Ghazāli doesn't discuss this in the Universal, but one can find an example in his magnum opus, Revival of the Religious Sciences (Ihya ' 'Ulüm al-Dīn; hereon referred to as the Revival). In one section, he discusses the concept of major and minor sins in Islam. Minor sins are forgivable through prayer and supplication, but major sins may require punishment in the Hellfire for a period of time. ${ }^{5} \mathrm{Al}$-Ghazālī argues that whether a sin is major or minor can only be known with certainty from scriptural evidence since this distinction pertains to whether our performing the daily prescribed prayers will atone for them in the hereafter. So this isn't a legal ruling that is accountable in the worldly life, which has its prescriptions, but one that has implications in the eschaton. Accordingly, if the scriptures are silent on this point, we are obliged to abstain from judging whether the $\sin$ in question is major or minor. Interestingly, he concludes that obscurity on such matters is better since not knowing this information might help believers be more cautious with their sinful activities (Al-Ghazālī 2018, 23):

... what is meant by a 'major sin' is where [performing] the prescribed prayers do not atone for [the sin], as determined by Islamic Law. This is divided into [sins] where it certain that [the prescribed prayers] do not atone for them, [sins] they should atone for, and [sins] about which we must exercise tawaqquf. Where tawaqquf is exercised, in some cases it is speculation to either negate or assert [atonement through prayer], and in some cases there is [complete] doubt about it. The only way to remove this doubt is with textual evidence from the Qurān or Sunna [prophetic tradition], and since this cannot be obtained, it is impossible to try and dispel the doubt. 
If you were to say: 'This is arguing that it is impossible to know its definition, so how can Islamic Law propose something that is impossible to define?' You should know, then, that all matters unrelated to worldly rulings can accommodate obscurity, since the domain of legal accountability is the worldly domain. The ruling that something is specifically a 'major sin' is not a worldly ruling about that major sin. Indeed, everything that necessitates a prescribed punishment is known by name, like theft, fornication, and the like, whereas the ruling that something is a major sin is precisely that [performing] the five prayers does not atone for it. This pertains to the hereafter, and obscurity is better for it, so people will be scrupulous and cautious. Otherwise they would commit minor sins and rely on their prayers [to atone for them]. ${ }^{6}$

So, suspending judgment on issues not mentioned scripture is a hermeneutic principle that al-Ghazālī seems to adopt. This ends al-Ghazālī's discussion on the balance between reason and revelation.

It's clear that al-Ghazāli favours the middle group (the moderates). Despite this, he conveys and explains his reservations with how far they can go when it comes to arriving at an absolute harmony between reason and revelation. This brief survey of this work allows us to conclude with three important points. First, al-Ghazālī clearly sees both reason and revelation as being important and constitutive in the hermeneutic process. Second, al-Ghazālī has no problem with not having decisive answers. When needed, one has to admit that there are, at times, different interpretive possibilities for a particular scripture, and one should one not be eager to force a specific opinion in the absence of clear evidence that favours either opinion. Thus, al-Ghazālī shows epistemic humility in this regard, but more importantly, he links it to eschatological accountability. Saying something definitively on behalf of God when scripture isn't clear may have eschatological consequences. Third, al-Ghazālī happily employs theological tawaqquf. If scripture is silent on a given matter, then scripture cannot be used to make either a positive or a negative claim.

\section{Science and hermeneutics}

Another aspect of al-Ghazālī's hermeneutic process relevant to the discussion is his attitude towards what we today call the natural sciences, and how he saw Islamic scripture in light of them. In Chapter 6, we saw that physical causation isn't intrinsically necessary in his occasionalist worldview, but rather the constant conjunction of natural phenomenon. It is why he accepts the reality and possibility of miracles as we saw earlier. However, in al-Ghazālī's epistemology, the regular perception of constant conjunction in the natural world is a robust form of belief, and it doesn't entail a rejection of science. One can find this in several statements to this effect (Al-Ghazālī 1987, 553-554; Al-Ghazālī 2013a, 19). In one place, he 
even stresses that one should not reject the natural sciences like astronomy to attest the authority of religion (Al-Ghazālī 2000a, 7):

The greatest thing in which the atheists rejoice is for the defender of religion to declare that these [astronomical demonstrations] and their like are contrary to religion. Thus, the [atheist's $\left.{ }^{7}\right]$ path for refuting religion becomes easy if the likes [of the above argument for defending religion] are rendered a condition [for its truth].

Clearly, he doesn't see the natural sciences as a threat or incompatible with religion (Malik 2021). In fact, he uses the natural phenomenon mentioned in the Qur'ann to show the respective authority of scientific experts on the relevant subject matters. He makes this explicit in his Jewels. Consider the following Qur'ānic verse (26:80): "He who cures me when I am ill." Al-Ghazāli $(2013 b, 30)$ comments on this verse and says:

This single work can only be known by him who knows the science of medicine completely, for this science means nothing but the knowledge of all aspects of diseases with their symptoms, and the knowledge of their cures and means.

Another verse refers to the precision of celestial bodies: "The sun and the moon follow their calculated courses" Qur'ān (55:5). Regarding this verse and other verses on the movement of celestial bodies, al-Ghazāli $(2013 \mathrm{~b}, 31)$ makes the following remark:

The real meaning of the movement of the sun and the moon according to a fixed reckoning ... can only be known by him who knows the manner of the composition of the heavens and the earth, and this itself is a science [i.e. astronomy].

These quotations clearly suggest that al-Ghazāli is not anti-scientific and, in fact, sees a correlational (but not a definitive) engagement between Islamic scripture and the natural sciences. However, it should be made clear that in his Jewels al-Ghazālī discusses various disciplines that can be instrumentalised to appreciate the vast depths of the Qur'ān. These include, but are not restricted to, theology, jurisprudence, philology, the science of recitation, mystical sciences, and the natural sciences among others (Al-Ghazāli 2013b, 18-28; Tamer 2015). Accordingly, al-Ghazālī sees science as one out of several ways in understanding the Qur'ān. This is important to point out because there is a strand of thought that views the Qur'ān as containing "scientific miracles" that sees scientific ideas being readily available in the Qur'ān (Guessoum 2011; Bigliardi 2014). This isn't something that al-Ghazāli would approve of. Between pinning down science to the Qur'ān and rejecting the natural sciences entirely, he struck a balance of 
correlation. The Qur'ann instigates one to look into the natural world to understand God's works, but in of itself contains no scientific details (Tamer $2015,74)$. Since God is the creator of everything, and a major portion of the Qur'an asks readers to ponder and reflect over the natural world, the Qur'ān acts as a focal point through which Muslims view the world (Tamer $2015,72)$. For instance, al-Ghazālī talks about God's mercy when reflecting over a verse from the first chapter in the Qur'ān to illustrate how each animal has been perfectly designed for its purpose. In the case of the bee, for instance, al-Ghazāli (2013b, 52-53) asks the reader to reflect over the geometry of the hive that provides the maximum spacing in comparison to other shapes it could have. Following this, he says (Al-Ghazālī 2013b, 53): "This is a sample from the wonders of God's works and His kindness and mercy to His creation ..." It is why Campanini $(2011,35)$ aptly notes that al-Ghazālī sees the Qur'ān as a guiding lens rather than a repository of all sciences: "the Qur'ān does not contain 'all the sciences' but it undoubtedly contains the keys giving access to all the sciences." So we can clearly see that for al-Ghazāli science and scripture are interdependent, and can help each better understand one another (also see Al-Ghazālī 1982).

That said, how can al-Ghazāli be consistent with reading miracles on the one hand and allude to scientific phenomena? This is where his process of interpreting scripturally literally versus figuratively comes into play, which shall be dealt with in the next section.

\section{Theology and hermeneutics}

In his Criterion, al-Ghazālī outlines his method for when Islamic scripture should be taken literally and non-literally. However, to understand the context of this framework, looking into his theological underpinnings for this method will be helpful. In fact, one cannot but understand his hermeneutic methodology except when it is viewed through his theological commitments. The whole treatise is predicated on determining when a person can be charged with unbelief $(k u f r)$, i.e. having left the fold of Islam, in relation to scripture or hermeneutic judgements. For al-Ghazālī (2002, 92), the definition of unbelief is when someone attributes a lie to the Prophet Muhammed. By contrast, having belief (imān) is to accept wholeheartedly what the Prophet Muhammed revealed to be true.

Since the Qur'ān was revealed as the word of God to the Prophet Muhammed, and the fact that Prophet Muhammed is believed to be a truthful person who never lied, scripture should be read on its apparent meaning (at face value) until and unless there are good grounds to read it otherwise (with qualifications as we shall come to see later). Al-Ghazālī maintains that if one has no apodictic reason to move on to non-literal readings, they have erred (Al-Ghazālī 2002, 104; Griffel 2009, 112). So if Islamic scripture is read in an arbitrary fashion, and without very strong reasoning, then this is an invalid move. However, and this is a significant 
point, the charge of unbelief is only applicable when one reads the fundamentals of faith non-literally (Al-Ghazālī 2002, 107): "If their figurative interpretation pertains to a matter that is not connected with the basic principles and requirements of creed, we do not brand them unbelievers."

The obvious question then is: what are the basic principles of creed? Al-Ghazālī $(2002,112)$ lists three things which he deems to be the fundamentals of faith: "The fundamentals principles acknowledging the existence of God, the prophethood of his Prophet, and the reality of the Last Day." So long as one does not reinterpret these as metaphors in Islamic scripture, al-Ghazāli deems one to be safe from the charge of unbelief. However, what about secondary matters? In this regard, al-Ghazālī $(2002,112)$ adds one qualification:

Know that there should be no branding any person an unbeliever over any secondary issue whatsoever, as a matter of principle, with one exception: that such a person reject a religious tenet that was learned from the Prophet and passed via diffusely congruent channels (tawātur).

This point is related to our discussion earlier regarding historical transmission. The Qur'ān and some hadīths have reached the level of tawātur such that their historical veracity is indubitable. So if a person rejected these, they would be charged with unbelief since rejecting them is equivalent to considering the Prophet to have lied (Al-Ghazālī 2002, 113):

... anyone who claims that the Prophet lied must be condemned as an unbeliever, even if this claim of his involves a secondary issue. Thus, for example, were some to say that the House at Mecca is not the Ka ba to which God commanded people to perform pilgrimage, this would constitute an act of unbelief. For this claim is contradicted by that which has been established on the authority of the Prophet via diffusely congruent channels (tawätur). And were this person to deny (in order to avoid censure) that the Prophet ever gave any explicitly testimony to the effect that this very House was the Ka'ba, this would not avail him.

However, al-Ghazālī $(2002,112-113)$ shows lenience even with this concern: "Even here, regarding some matters he may simply be subject to being deemed wrong ... Or he may be subject to condemnation for unsanctioned

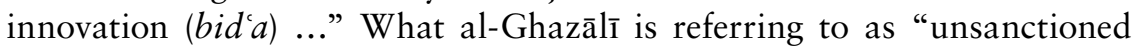
innovation" (bid'a) is heterodoxy, i.e. between orthodoxy and unbelief. So rejecting a non-fundamental belief that can be obtained through scripture that has mass transmission (tawātur), and hence is mutawātir, may still not agree with orthodoxy but still doesn't warrant the charge of unbelief. Finally, al-Ghazālī makes his stance on the $\bar{a} h \bar{a} d$ hadīths corpus crystal clear: "To be sure, were a person to deny the truth of an isolated report (khabar ahī $\bar{\imath} \bar{l})$, there would be no duty to brand him an unbeliever." 
With these points cleared, al-Ghazālī $(2002,114)$ summarises his perspective:

As for the first three fundament principles (i.e. God, the Prophet, and the Last Day) and those texts that have been transmitted via diffuse congruence and are not in and of themselves open to figurative interpretation and for which one cannot conceive of any logical proofs that would contradict their content, to contradict these is to say that they constitute lies, pure and simple, as, for example, with the resurrection of bodies, paradise, hell ... Regarding those texts, however, that are open to figurative interpretation, albeit even remove allegorical interpretation, here we examine the logical proof (adduced to justify the figurative interpretation). If this is definitive it must be accepted ... If, on the other hand, the logical proof is not definitive but gives rise to preponderance of probability while not posing any threat to religion ... then this constitutes an unsanctioned innovation, not an act of unbelief. As for those matters that appear a threat to religion, determining their ... status is subject to scholarly discretion (ijtiha $\bar{a})$ and speculative inquiry. They may constitute a basis for branding a person an unbeliever, and they may not.

Clearly, al-Ghazāli maintains that belief in the three primary principles God, the Prophet, and the eschaton - have to be held on to alongside any text that is mutawatir, which is not open to figurative interpretation. Otherwise, they may face the charge of unbelief. Apart from this, there are other grey areas that need to be dealt with on a case-by-case basis.

This, then, sets the theological context for al-Ghazālī's hermeneutic framework. As can be seen, al-Ghazālī seems to set a somewhat minimalistic but straightforward criterion for when the charge of unbelief is applicable. ${ }^{8}$ This is an important point to note. Recall from Chapter 4, some thinkers declared that belief in human evolution entails that one has left the fold of Islam (Keller 2011). Al-Ghazālī's framework allows for flexibility as long as they don't contradict the three fundamentals of faith and scripture that is mutawātir. The creation story of Adam doesn't contradict the fundamentals of faith as outlined by al-Ghazālī. So if there were theological problems with evolution, it would have to be with scripture that is mutawätir, and even then, it must not be open to figurative speech. Whether this is the case will be determined in Chapter 10.

\section{Al-Ghazālī’s methodology for figurative reading}

At this point, it seems befitting to introduce al-Ghazālī's elaborate, interpretive schema. As mentioned before, his interpretive strategy has five layers, which seems to break down existence into five degrees. One is supposed 
to start with the first level, the most apparent reading (zāair) until there are convincing reasons to go down to lower levels. These include (Bello 1989, 53-57; Al-Ghazālī 2002, 94-100; Griffel 2004; Sands 2006, 56-57; Whittingham 2007, 16-20):

1 Ontological (al-wujūd al-dhātī) - In this level, Islamic scripture is understood according to the terms' apparent meaning, and devoid of any figurative interpretation. For these entities exist in their own right regardless of whether the senses or the imagination apprehends them or not. In other words, these are understood noumenally. One example that al-Ghazāli uses is the mention of seven heavens in the Qur'ān $(20: 25)$. It may not be clear what they may be, but they can be accepted at face value since there is nothing inherently contradictory in them.

2 Sensory/phenomenological (al-wujūd al-hissī) - In this layer, things are conceived as empirical sense impressions. For instance, an image formed of a man in our minds by actually seeing a man in front of us. In contrast to the ontological layer, this second level treats scriptural references phenomenally. As an example of this kind, al-Ghazāli quotes a hadith in which the Prophet claimed that paradise was presented to him in a wall he was looking at (Bukhārī 6468). Al-Ghazālī argues that such a statement cannot be taken at face value, i.e. the first level, because the size of paradise cannot be fitted into a limited wall. Accordingly, what the Prophet may have seen was an image of paradise in the wall.

3 Conceptual (al-wujūd al-khayāli ) - This layer refers to the images of the things that can normally be perceived through the senses but do not have an immediate physical correlation. An example would include imagining an elephant in your mind which you can't actually see in front of you. Al-Ghazāli gives the example of a hadīth in which the Prophet Muhammed sees Prophet Jonah enact something (Muslim 166a). Since the hadīth mentions "as if ...," it indicates that the Prophet Muhammed didn't actually see Prophet Jonah, but rather it was an even that was being played out in his mind. He further argues for this interpretation's sensibility given the fact that Prophet Jonah didn't exist in Prophet Muhammed's time.

4 Noetic (al-wujūd al-aqlī) - This level signifies mental extractions of the essence of objects which can be understood beyond their physical forms. For example, a pen has a specific physical form, but its essence can be understood as being the recorder or holder of knowledge. As a scriptural example, al-Ghazālī discusses a hadīth which goes to the effect of relaying that anyone who exits Hellfire (after being punished and cleansed for their sins) will be given a portion of paradise that is equivalent to ten times the size of the world (Bukhārī 806). This isn't meant to be a literal understanding in terms of height, breadth, and 
width, but rather a value judgement. Since paradise is the most sought thing by Muslims, its value essentially supersedes anything. Hence the reference to ten times the size of the world, which implies that whatever portion an individual gets of paradise will be worth a lot.

5 Analogical (al-wujūd al-shabāhī al-majāzī) - This final level refers to instances wherein a thing itself does not strictly exist ontologically and neither as an image as such. Rather, it has an analogous structure that possesses some quality or attribute that can be related between two things by the mind. In other words, this isn't an analogy based on the essences of what is being compared like the fourth level, but rather one based on accidents or properties that two things might possess. An example of this type of analogy would include calling a person a lion in connection with his braveness (Moosa 1995, 135). ${ }^{9}$ Since braveness is not essential to a lion nor a person, i.e. you can have cowardice in both, it is a quality or attribute that they could possess but don't necessarily have to. Al-Ghazālī uses the example of God's anger (e.g. Qur'ān 20:81) to make this point. Anger, at least how al-Ghazālī defines it, represents a boiling of the blood to seek out vengeance. This is impossible for God since He isn't equivalent to a human being, and hence cannot have emotions like human beings (Al-Ghazālī 2008; Al-Ghazālī 2013a; Al-Ghazālī 2015). It is why the previous levels are inapplicable to such ideas. But we can understand it to imply that God's anger may have connotations like punishing. Hence there is an analogical crossover from what we can understand of God in human terms without committing to complete isomorphism.

Al-Ghazālī devised this hierarchal scheme to ensure that it would not lead to hermeneutic anarchism and relativism, i.e. when scripture is interpreted erroneously or arbitrarily. When reading scripture, the verse or hadīth need to be taken as-is on the apparent level and then judged in accordance with this schema. One starts with the highest tier, which is the ontological level. If a reading doesn't make sense in this category, then one should move to the phenomenological tier. An interpreter should keep on descending until a reading concords with a tier in the list. He believed that if one wanted to move away from a literal interpretation towards a figurative one, which in this schema means descending from the ontological level towards the analogical level, the interpreter would need to provide logical proof (burhān) for doing so. Only when a literal sense is thought to be impossible or incoherent could there be justification in descending towards a more figurative interpretation (Whittingham 2014, 25-27). If one moves to a lower level without the proper justification, it would be considered an unsanctioned move $\left(b^{\prime} d^{\prime} a\right)$. If all of these are rejected, then it would constitute unbelief (kufr; Bello 1989, 62).

A further point needs to be clarified. Al-Ghazālī doesn't deny the possibility of multiple interpretations. Whatever tier a particular reading 
occupies, the readings below it could provide additional interpretations (Griffel 2009, 113):

It should be stressed that for al-Ghazālī, the text of revelation can have more than one meaning. The 'rule of interpretation' establishes the most authoritative reading of the text, the one referring to the highest possible of the five levels of beings. It determines what kind of descriptive information the passage conveys. Once this reading is established, it allows all lower levels. These levels establish additional meanings of the text.

As long as the most authoritative reading based on the highest level isn't jeopardised, these additional readings can yield other interpretations that may further help appreciate scripture. As an example, consider the incident of Moses when God spoke to him. There is a verse in the Qur'ān (20:12) where God commands him to take off his sandals that he was wearing at the time. Sufis could interpret this in mystical terms. For instance, the sandals could be understood as symbols of this world and the hereafter, and Moses was instructed to leave both behind to give himself fully to God (Griffel 2009, 113). These are, of course, speculative, which al-Ghazālī $(2002,108)$ acknowledges, but this interpretation is still perfectly compatible with the apparent meaning of the verse, so there is no harm. It is why we see al-Ghazālī being lenient with Sufi interpretations, so long as they are in the boundaries outlined earlier (Al-Ghazālī 2002, 109): "And perhaps they should be given the benefit of the doubt regarding such interpretations that are not connected to with basic principles of creed ... They should neither be branded unbeliever nor deemed guilty of unsanctioned innovation." This, then, is al-Ghazālī's process of interpretation (qanūn al-ta'wīl).

It is important to note that this mechanism cannot be applied without qualification. There are two particular elements that are important, which are familiarity with the Arabic language and context (Al-Ghazālī 2000b, 185):

Understanding comes by way of a pre-existing knowledge of the language conventions in which the communication takes place. Then, if [the communication] is decisive in meaning (nașs), knowing the language is sufficient for understanding. If it is open to possibilities, then the meaning of the utterance cannot truly be known except in conjunction with a contextual indicator (qarina). The contextual indicator will either be a revealed utterance, like with God's statement: 'Paying what is due on the day of harvest' ${ }^{\text {'10 }}$ where the 'due' is a tenth; or it will be a rational indicator like with God's statement: 'The heavens will be rolled up in His right hand,'11 and the Prophet's statement: 'The heart of the believer is between the two fingers of the Merciful;'12 or the contextual indicators will be from the circumstances, like gestures, indications, movements, or what comes before and after [the utterance], and these are countless. 


\section{Hermeneutic considerations}

In this statement we see we al-Ghazālī referring to different kinds of indicators. The first reference - the quotation mentioning harvest - is part of a larger Qur'ānic verse which talks about different types of agricultural produce. The instruction of paying what is due is God mandating to set a portion of that for charity, which al-Ghazāli interprets to be a tenth (for more details on the technicalities of this point, see Shafi 2010, 483-490). As for the rational indicators, the references to God's hands and fingers cannot be taken literally, as al-Ghazālī (2013a, 55-62) does not interpret God to have such entities, i.e. they are anthropomorphic. Let us unpack the considerations and nuances of language and context a bit more.

\section{Classical Arabic}

Arguably the most important prerequisite is understanding classical Arabic, the source language which the Arabs at the time of the Prophet Muhammed spoke in (Al-Ghazālī 2002, 116-117):

... knowing what is and what is not open to figurative interpretation is not an easy matter. On the contrary, the only people who can make such determinations are those who are proficient and well-versed in the (Arabic) language, knowledgeable of its fundamental structures, and well-acquainted with the customs of the Arabs in using metaphors and figures of speech and the various ways in which they construct similes.

To illustrate this point, consider the following examples. In the Qur'ān, there are several indicators which can be referred to when interpreting scripture metaphorically or allegorically. There is the explicit kind which employs the use of simile particles such as $k a$ and mithl:

He [God] created mankind out of dried clay, like $(k a)$ pottery (Qur'ān 55:14)

Those who take protectors other than God can be compared (kamathalu) to spiders building themselves houses- the spider's is the frailest of all houses - if only they could understand. (Qur'ān 29:41).

Other verses don't have any such particles but could be read non-literally based on the thematic context and content. Consider the following example related to customary usage:

Believers, do not push yourselves forward (bayna yaday) in the presence of God and His Messenger - be mindful of God: He hears and knows all. (Qur’ān 49:1).

The literal translation of bayna yaday is the human's two hands, but it is an Arabic idiom that means in "front of" or "put forward" (Shafi 2008, 114). 
It probably stems from the notion of merchants who when making a transaction would lean out their hands. This concept is used here and in several other verses where God instructs humankind not to make bad transactions or choices by giving in to one's immoral desires (Mir 1989, 268), e.g. lust, and instead abiding by God's law, hence the mention of God and His Messenger as the standard reference.

Another example, and one that will prove to be very useful later in Chapter 10, is hyperbole in the Arabic language. In contemporary English, we use a hundred, a thousand or a million to convey an exaggerated claim, e.g. I washed the car like a million times. We don't literally mean those numbers but only use them to overstate a point. In classical Arabic, however, the numbers associated with hyperbole in classical Arabic revolve around 7, e.g. 70 and 700 (Lane 2010, 1297-1298; Omar 2010, 245-246)..$^{13}$ Given this point, it allows one to appreciate the following verse:

Those who spend their wealth in God's cause are like grains of corn that produce seven ears, each bearing a hundred grains ... (Qur'ān $2: 261)$.

In effect, this verse says that giving charity to please God is like getting 700 hundred rewards (grains) in return, i.e. it is hyperbolic language. Depending on the language and the theme, there are indications when to take a certain verse (or part of it) literally or metaphorically.

Finally, it might also be helpful to note that semantic openness of words can sometimes lead to multiple interpretations for a given verse. We shall review one example to illustrate this point. There is a famous verse which entertains polar opposite opinions because it contains a contronym (Al-Ghazālī 1987, 471): "Divorced women must wait for three monthly periods (qurü) ...” (Qur'ān 2:228). The word for periods is qurü, and can mean two things which completely contradict one another. It can either mean menstruation in which case the verse says that divorced women should wait for three menstruation periods, or it can mean the time between two menstruations in which case the verse reads as waiting for three non-menstruation periods. Both are valid interpretations, which is why we see two different religious edicts over this issue in Islamic jurisprudence (Kamali 2008, 134). So multiple meanings can be catered for provided that the language permits it. When exegetes or jurists tried to understand the ambiguity in certain verses or words, they did so within the confines and rules of the language.

It is with these considerations in mind that Shah $(2012,593)$ makes the following comment:

[Muslims'] ... metaphorical interpretations ... were bound by strictly fixed linguistic rules with regards to the language, to which they had to adhere, and their metaphorical interpretations were further limited 
by the fixed number of linguistic meanings governing each term. In other words, interpretation was controlled by clearly defined linguistic parameters, forcing ... [Muslims] to employ one of the already existing linguistic meanings of the term under question as an appropriate or intended meaning, preventing the invention of far-fetched facts of speculative suppositions to fit or prove whatever was wanting proven from the text. Moreover, this fixation was further substantiated by the usage of the same meanings in established Arabic metaphors. Although there was scope to arrive at a number of different yet mutually related interpretations with different scholars perhaps emphasising different aspects or meanings out of the few commonly used meanings of a phrase, nevertheless this was a far cry from free and open speculation, closing the doors to fanciful and absurd interpretations.

Accordingly, the language and culture of the Arabs at the time of the Prophet Muhammed limit the scope of interpretation.

\section{Contextual indication}

Finally, another point worthy of highlighting concerning reading things figuratively is the idea of looking at things with the context (qara in) in mind, which can be linguistic or extra-linguistic in nature, e.g. history (Al-Ghazālī 2008). This entails that Islamic scripture should not be read in an isolated and atomistic fashion. It involves thematising the verses being scrutinised within their proximity, i.e. looking at verses that immediately come before or after. Otherwise, one might lose context. For example, the Qur'ān (107:4) says: "So woe to those who pray." This may seem contradictory since Muslims are commanded to pray. But when read with the succeeding verses, the concerned verse instinctively becomes contextualised:

So woe to those who pray but are heedless of their prayer; those who are all show and forbid common kindnesses. Qur'ān (107: 4-7)

The verses that follow explain that those who pray but are heedless in their prayers, show off, and don't offer assistance to those in need, may be nullifying their prayers.

Sometimes distant verses need to be looked at collectively as well. The Qur'ān frequently employs and conveys the same ideas or themes in different areas. As noted in Chapter 3, Adam's story is mentioned a few times sporadically in the Qur'ān. However, if each part is read in an isolated and localised manner that radically differs and contradicts the other parts, something has gone wrong. This is why Ali $(2000,5)$ notes how "the Qur'ān must be treated as a complete text" to ensure there is no contradiction in 
its overall coherency. ${ }^{14}$ Even the Qur'ān (4:82) alludes to this by stating that had this scripture been from other than God, it would have had many contradictions.

The same goes for analysing the ḥadīth corpus (Al-Ghazālī 2002, 117):

As for (texts) other than the Qur'ann, making such a determination is extremely difficult. And only those who study the books of history, the conditions of bygone generations, the books of hadīth, the status and conditions of transmitters of reports, as all well as their objectives in transmitting the doctrines they transmit, can successfully undertake such a task.

For example, consider the following hadīth of a statement uttered by the Prophet:

If bad luck were true, it would be in the horse, the woman, and the house (Muslim 2225-2226; Bukhārī 5093).

This can be seen as a very concerning hadith because it seems that the Prophet is insinuating that the common denominator in the horse, woman, and house is unluckiness. The conditional at the beginning ("If ...") may give readers some relief, but even then it may trouble the reader why this was even mentioned. However, we have a historical record wherein Aisha, the Prophet's wife, commented on this hadīth and clarified this misconception (quoted from Khan 2010, 70): "Arabs of the pre-Islamic times ... used to say that the woman, the house, and the animal were the source of bad luck." So having all the relevant source material on a given topic is incredibly important for contextualisation.

\section{Theology and hadīths}

The discussion of hadīths has intentionally been left for the end even though they have been mentioned throughout this chapter. This is for a good reason. The study of hadīths (ușul al-hadìth) is in of itself a complex subject, which is why it is a specialised discipline like other Islamic domains, e.g. theology, jurisprudence, exegesis, etc. We differentiated between mutawātir and $\bar{a} h \bar{a} d$ hadīths throughout this chapter. The former refers to hadīths which have been transmitted so extensively that they are deemed to be epistemically certain. The Qur'ann and some hadīths fit this standard. However, a large part of the hadīth corpus is $\bar{a} h \bar{a} d$, and mutawātir don't need to be historically verified since they are so well-known. Accordingly, hadīth specialists ${ }^{15}$ found no practical value in viewing and treating hadīths in a mutawātir-ăhād dichotomy (Hansu 2020, 254). ${ }^{16}$ To help better navigate the ăhād hadīth corpus, they took it upon themselves to differentiate strong hadīths from weak 
ones. There are usually five main principles they utilise to assess a hadīth (Brown 2009, 67-122; Khan 2010, 31-35):

1 Chain of continuity (ittisāl al-sanad)

2 The integrity of narrators' characters (al-'adāla)

3 The Precision of the report (al- dabt)

4 Non-deficiency (ghayr al-illa)

5 Non-aberrance ('adm al-shudhüdh)

The chain of continuity requires that the hadith must retain an unbroken chain back to the original narrator for it to be acceptable. Furthermore, every transmitter must have heard directly from the preceding transmitter. So if the Prophet is the initial transmitter and the hadith was passed on to three more generations, the chain would look like this:

Prophet Muhammed (Transmitter 1) $\rightarrow$ Transmitter $2 \rightarrow$ Transmitter $3 \rightarrow$ Transmitter $4^{17}$

If the chain has a missing link or more, it will weaken the status of the hadīth. The following is the example of a hadīth in which the transmitter between the Prophet and the third transmitter is missing, and is referred to as mursal (this particular example will be important for when we look at a particular hadīth in Chapter 10):

\section{Prophet Muhammed (Transmitter 1) $\rightarrow$ Missing person $\rightarrow$ Transmitter $3 \rightarrow$ Transmitter 4}

The second principle requires that each individual in the transmission line must have been a truthful and pious character. Since the Prophet's heritage was being carried forward from one generation to the next by hadīth transmitters, the hadīth specialists were very careful in determining who was worthy of this endeavour. Accordingly, they developed compendiums containing detailed biographies of every person from every generation to keep a record of their character profile. This included identifying elements of hypocrisy or unbelief. The report's precision is similar to the second principle, but it had less to do with the character of the narrator and more to do with his or her skill and studious nature. This involved analysing a narrator's memory or the number of recorded mistakes he or she made. The more errors one narrator was found to have, the lower he or she was graded. The principle of non-deficiency was to ensure that nothing was lacking in a hadīth either in content or transmission. This principle was useful in flushing out hadīths that were initially deemed authentic but then later own were found to have some errors. Finally, non-aberrance would involve looking at a hadīth from a certain narrator being at variance in wording 
Table 9.2 Summary of hadīth differentiations.

\begin{tabular}{|c|c|c|}
\hline & Mutawātir & $\bar{A} h \bar{a} \bar{d}$ \\
\hline $\begin{array}{l}\text { Possible classifications } \\
\text { according to hadīth specialists }\end{array}$ & Șahịịn & $\begin{array}{l}\text { Sahịh } \\
\text { Hasan } \\
\text { Da'îf }\end{array}$ \\
\hline
\end{tabular}

from other hadīths recorded by better narrators. This was done to identify if there were any errors or dissimilarities between them. Though much more can be said of these five principles, what is provided here is sufficient for our purposes. ${ }^{18}$

Following this evaluative scheme, three broad categories were used to determine whether an $\bar{a} h \bar{a} \bar{d}$ hadīth was authentic or not. They were deemed as being either authentic or strong (sahīh), good (hasan), or weak (da'iff). Mutawātir hadīths are categorically șaḥịh. For the hadīth specialists, the main purpose of this classification was to demarcate between hadiths that were usable for doctrinal or jurisprudential purposes, i.e. along the șahīhhasan spectrum, and those that weren't, i.e. da'îf (Brown 2009, 100-103). ${ }^{19}$ This has been summarised in Table 9.2. ${ }^{20}$ With this clear, we can now elucidate the different epistemic roles that hadīths play in al-Ghazālì's framework.

As noted earlier, al-Ghazāli maintains that the only kind of scriptures which are theologically binding are the ones which are mutawatir. Accordingly, a point of essential theological doctrine cannot be based on $\bar{a} h \bar{a} d$ hadiths. This does not mean they are rejected; rather, it is only binding doctrinal commitments that cannot solely be based on ăhād hadīths. So $\bar{a} h \bar{a} d$ hadīths that are authentic (sa $h \bar{i} h)$ are generally to be reckoned with, and this is especially the case if they are already affirmed through sources that are mutawätir (Hansu 2020, 253). The reason for this is the probability associated with the epistemic status of $\bar{a} h \bar{a} d$ hadīths. Matters of essential doctrine on which belief and unbelief are determined can only be based on absolute certainty (yaqin ), which mutawätir sources provide. By contrast, $\bar{a} h \bar{a} d$ hadīths are not certain and, at best, can only yield strong likelihood of being true $(z a n n \bar{\imath})$. It is why if someone does dismiss an $\bar{a} h \bar{a} d$ hadìth, such a person cannot be charged with unbelief (Al-Ghazālī 2002, 114).

That said, $\bar{a} h \bar{a} d$ hadīths cannot be just brushed aside, and are not to be categorically rejected; one must have very good reasons to question or dismiss them, even when the matter in question is one of belief, especially in matters of the unseen (ghayb; recall this discussion in Chapter 4), such as descriptions of heaven and hell, and the events that will take place in the eschaton (Jalajel 2009, 23-24). Also, rejecting $\bar{a} h \bar{a} d$ hadīth can lead to several problems in jurisprudence. Many rituals are predicated on $\bar{a} h \bar{a} d$ hadiths, which are treated as forms of evidence in Islamic jurisprudence (Hansu 2020, 252). 
It is then of no surprise that al-Ghazāli discusses how to assess $\bar{a} h \bar{a} d$ hadīths in his legal work, On the Legal Theory of Muslim Jurisprudence (Al-Mustașfa min ' Ilm al-Ușül), which, if they pass the criteria of assessing hadīths, can be used in determining legal matters (Al-Ghazālī 1987, 541-661). ${ }^{21}$ So from a juristic perspective, al-Ghazālī accepted qualified $\bar{a} h \bar{a} d$ hadīths, and even argued that they should be acted upon.

We also see the utilisation of weak hadīths in al-Ghazālī's more spiritually inclined works such as the Revival. In this material, he sometimes uses very weak hadīths for which he has been criticised (Brown 2009, 112; Palmer 2020, 271). However, it is not entirely a work of jurisprudence, nor an exclusive work of theology; rather, it seems to be a work that teaches Muslims how to practice their religion with a clear exposition of its spiritual merits. So it accommodates a shade of spirituality (Garden 2013). The threshold for hadiths in the Sufi discourse is much more relaxed (Brown 2009, 184-195). To be clear, this does not mean that Sufis were against the strictures of the theologians and hadīth specialists; rather, they were instrumentalising weak hadīths in a particular way (Palmer 2020, 272). Hadīths which discuss and promote virtues and supererogatory acts, as long as their weakness does not lead one to expect fabrication, and if they didn't go against theology or legal practice, were comfortably used by Sufi thinkers (Brown 2011a). Thus, it shouldn't be a surprise that al-Ghazālī adopted some weak hadīths in his magnum opus.

We can draw two conclusions from these observations. First, we can appreciate that al-Ghazālī differentiates the epistemic role of hadīths according to the disciplinary vantage point, e.g. theological, juristic, and spiritual. ${ }^{22}$ Second, al-Ghazāli generally seems to be inclined towards treating $\bar{a} h \bar{a} d$ hadīths carefully and respectfully. This is despite their weaker status in comparison to scripture that is mutawätir. So rejecting or dismissing $\bar{a} h \bar{a} d$ hadīths must be based on good reasons and evidence. This tendency to retain $\bar{a} h \bar{a} d$ hadīths as much as possible will be a guiding principle in Chapter 10.

\section{Conclusion}

Having completed our survey of al-Ghazālī's ideas on hermeneutics, we can summarise our findings. First, al-Ghazālī definitively adopted a position which gives equal epistemic weight to both reason and revelation. Second, al-Ghazāli clarifies that when a position is reached where there is an apparent conflict between them, one shouldn't bend the text to suit one's presuppositions. In the situation where there might be more than one hermeneutic possibility, and if all of them have equal traction, then one should defer in making a judgement since making suppositions about God's intent may have eschatological consequences. Third, al-Ghazālī has no qualms with abstaining from judgement altogether when scripture is silent on an issue, i.e. tawaqquf. Fourth, al-Ghazālī appreciates possible correlations between science and scripture. Science can help understand 
aspects of scripture which point to natural phenomena in general terms. But al-Ghazālī doesn't reduce the Qur'ān to scientific facts; science is but one way of further appreciating the Qur'ān, but it isn't the only way of understanding it. Fifth, al-Ghazālī’s hermeneutic ideas are closely linked to his theological beliefs. Scripture should be read on its apparent meaning unless there are apodictic reasons to do otherwise. He establishes a five-tier system starting from the ontological down to the analogical. If an interpreter reads into scripture a lower tier without justification, then this would be a form of heterodoxy. If an interpreter rejects all of these interpretations, then it would warrant the charge of unbelief. In relation to science, al-Ghazālī's hermeneutic method happily allows him to consistently read miracles alongside natural phenomena that the Qur'ān alludes to, which fits in with his theological outlook. Sixth, familiarity with Arabic and context (linguistic and historical) is important. Both of these are important to determine the reasons for interpreting scripture non-literally when needed. Finally, the discussion on hadīth helped us determine that al-Ghazālī uses hadīth according to the epistemic demands of the frame of reference he is adopting. From his theological standpoint, which is the perspective that has been adopted here, mutawätir hadīths are epistemically certain, which is why they form the basis of developing creedal points. A $h \bar{a} \bar{d}$ hadìths don't occupy that epistemic certainty even though they might be șahīh. However, $\bar{a} h \bar{a} d$ hadīths are not to be dismissed or rejected unless there are good reasons for doing so. These points will be collectively used to evaluate the various ways people have tried to read evolution into Islamic scripture in Chapter $10 .{ }^{23}$

\section{Notes}

1 For an excellent historical and contextual overview of the Universal, see Griffel (2015). It also discusses the connection between the Universal and Criterion.

2 This is probably referring to a theological group known as the Mu'tazilites. It is well-known that the Ash'arites extensively criticised this group because they stressed reasons more than revelation. One can find many references to this group even in al-Ghazālî’s works. In fact, in the Criterion, he compares them to the philosophers who we looked at in the second group (Al-Ghazāli 2002, 111): “... the approach of the Mu'tazilites comes close to that philosophers, with one exception, namely, that the Mu'tazilites do not hold it to be permissible for the Prophet to lie ... Instead, they figuratively interpret the apparent meaning of scripture whenever it appears to them to contradict some logical proof. The philosopher, on the hand, in going beyond the apparent meaning of scripture, does not confine himself to texts that might accommodate figurative interpretation, obvious or remote."

3 For an overview of al-Ghazālī's understanding of tawātur, see Weiss (1995).

4 See al-Ghazālī $(2008 ; 2013 a)$.

5 Of course, this does not preclude the possibility of God forgiving one's major sins through sincere acts of worship.

6 I am indebted to David Solomon Jalajel for identifying, translating, and sharing this quotation with me (Jalajel, David Solomon. 2020. E-mail message to author, November 11). 


\section{Hermeneutic considerations}

7 This should be treated with caution. Most likely, this means unbelievers. See my distinction between atheism and disbelief in Malik (2018, 7). Al-Ghazālī could have in mind eternalists, i.e. individuals who believe the universe was eternal, and materialists, both of whom he criticises in his works.

8 This, however, should be taken with some caution. In an earlier part, al-Ghazālī $(2002,92)$ does not fail to mention that a full exposition would require some length, which is why he suffices his reader(s) with a simple framework: "Know that a full explanation of this matter would be quite long, and the means through which it might be fully apprehended are quite subtle and elusive. But I will provide you with a sound criterion which you should apply evenly across the board ..."

9 He uses this example in his al-Mustașfā.

10 Qur'ān $(6: 141)$.

11 Qur'ān (39:67).

12 The mention of Merciful here is referring to a name of God. Another variation that relays content very similar to this hadīth is in Muslim (2655): "Verily, the hearts of all the sons of Adam are between the two fingers out of the fingers of the Compassionate Lord as one heart ...”.

13 Another is the number 1000. See Lane 2010, 80), Omar (2010, 25), and Qur'ān (97:3).

14 For an excellent treatment of this subject, see Bhutta (2017).

15 What I am referring to as hadīth specialists is a category of individuals who are expert in assessing and classifying hadīths, and they are not to be confused with a theological group known as partisans of hadīth (ahl al-hadīth). This particular group disagreed with Ash arite theologians over the epistemic status of ăhād hadīths (Brown 2009, 180-182; Brown 2011a).

16 To be clear, this doesn't entail they didn't value mutawätir hadīths; rather, since the bulk of the hadīths corpus was $\bar{a} h \bar{a} d$, they saw little practical utility with the mutawātir-ähäd dichotomy.

17 The transmissions of hadiths can become very complicated with several kinds of interrelations and networks. Accordingly, hadīths should not be though simple as linear chains as depicted here. See the diagram in Brown (2009, 114) as an example.

18 For excellent resources on hadīths, see Siddiqui (2008), Brown (2009), Khan (2010), Brown (2011b), Brown (2014), and Davidson (2020).

19 I should add that there are many more internal subdivisions and classifications within the discipline of hadīth scholarship. This is but a mere summary. See Al-A'żamī (2002).

20 There is a third category of hadīths which are referred to as either mustafi or mashhūr (Siddiqui 2008, 110; Brown 2009, 179). These are $\bar{a} h \bar{a} d$ hadīths which were initially isolated reports but quickly became widely transmitted reports, so they have the appearance of being mutawatir. Interestingly, al-Ghazāli $(2002,117)$ makes it very clear that even here one should be scrupulous with such hadīths: "Indeed, a report that is simply widely known (mustafī $d$ ) may be mistakenly thought to be diffusely congruent [, i.e. mutawātir]."

21 For an overview of the relationship between law and hadīths, see Melchert (2020).

22 To be sure, al-Ghazāli is not alone in this position. Other theologians treated $\bar{a} h \bar{a} \bar{d}$ hadīths this way too. See Jalajel (2009, 11-34) and Brown (2009, 150-183).

23 One limitation of this developed framewok of al-Ghazālī's hermeneutics might be the absence of scholarly consensus $\left(i j m \bar{a}^{c}\right)$. This is a valid form of theological proof and can hold strong weight for grounding one's creedal and jurisprudential positions in Sunnī Islam (Kamali 2008, 228-263; Hasan 2009). 
Thus, going against scholarly consensus could have theological repercussions, e.g. the charge of unbelief, which may partially explain some Muslims' sensitivities with reconciling Islam with evolution. However, this was not considered for this particular study because of al-Ghazālī's $(2002,114)$ own reservations about it regarding secondary matters: "To be sure, were a person to deny the truth of an isolated report (khabar aha $\bar{a} \bar{\imath})$, there would be no duty to brand him an unbeliever. Were he to deny, on the other hand, that upon which there was unanimous consensus $\left(i j m \bar{a}^{c}\right)$, his case would be unclear. For knowledge of whether or not consensus is itself a definitive proof is fraught with ambiguities the like of which only those who have mastered the discipline of legal theory $(u s \underline{u} l$ al-fiqh) can bring into relief ... Thus, the status of consensus as a valid proof is itself disputed (mukhtalaf $f \bar{l} h)$. This, then, is the ruling regarding secondary matters.” For more information on al-Ghazālī’s understanding of scholarly consensus, see al-Ghazālī (1987, 662-739) and Bello 1989 (17-43).

\section{References}

Al-A'ẓamī, Muhammad Mușțafā. 2002. Studies in Hadīth Methodology and Literature. Kuala Lumpur: Islamic Book Trust.

Al-Ghazālī, Abū Hāmid. 1982. The Recitation and Interpretation of the Qurāan: Al-Ghazali's Theory. trans. by Muhammad Abul Quasem. London: Kegan Paul International.

Al-Ghazālī, Abū Ḥāmid. 1987. "Al-Mustașfā min 'Ilm al-Uṣūl.” In Ahmad Zaki Mansur Hammad. "Abū Hāmid al-Ghazālìs's Juristic Doctrine in al-Mustașfā min 'Ilm al-Ușūl with a Translation of Volume One of al-Mustașfā min 'Ilm al-Ușull." PhD Diss. Chicago, IL: The University of Chicago.

Al-Ghazālī, Abū Ḥāmid. 1998. “The Canons of Ta’wīl.” trans. by Nicholas Heer. In Abū Hāmid, and John Renard, eds. Windows on the House of Islam. California: University of California Press, 48-54.

Al-Ghazālī Abū Hāmid. 2000a. The Incoherence of the Philosophers. Utah: Brigham University Press.

Al-Ghazāīị, Abū Ḥamid. 2000b. Al-Mustaṣfā min 'Ilm al-Ușūl. Beirut: Dār al-Kutub al-'Ilmiyya.

Al-Ghazālī, Abū Haàmid. 2002. On the Boundaries of Theological Tolerance in Islam. trans. by Sherman Jackson. Oxford: Oxford University Press.

Al-Ghazālī, Abū Ḥāmid. 2008. A Return to Purity in Creed. trans. by 'Abdullah bin Hamid 'Ali. Philadelphia, PA: Lamp Post Productions.

Al-Ghazālī, Abū Ḥāmid. 2013a. Moderation in Belief. trans. by Aladdin Yaqub. Chicago: The University of Chicago Press.

Al-Ghazālī, Abū Ḥāmid. 2013b. The Jewels of the Qur'ān: Al-Ghazali's Theory. trans. by Muhammad Abul Quasem. Kuala Lumpur: Islamic Book Trust.

Al-Ghazālī, Abū Hāmid. 2015. The Ninety-Nine Beautiful Names of God. trans. by David Burrell and Nazih Daher. Cambridge: The Islamic Texts Society.

Al-Ghazālī, Abū Ḥāmid. 2018. Ihyyà 'Ulūm al-Dīn. Volume 4. Beirut: Dār al-Fikr.

Ali, Mohamed Mohamed Yunus. 2000. Medieval Islamic Pragmatics: Sunni Legal Theorists' Models of Textual Communication. Abingdon: Routledge.

Bello, Iysa A. 1989. The Medieval Islamic Controversy Between Philosophy and Orthodoxy: Ijmā and Ta'wīl in the Conflict Between al-Ghazālī and Ibn Rushd. Leiden: Brill. 


\section{Hermeneutic considerations}

Bhutta, Sohaib Saeed. 2017. "Intraquranic Hermeneutics: Theories and Methods in Tafsīr of the Qur'ān Through the Qur'ān." PhD Diss. London: School of Oriental and African Studies.

Bigliardi, Stefano. 2014. Islam and the Quest for Modern Science: Conversations with Adnan Oktar, Mehdi Golshani, Mohammed Basil Altaie, Zaghloul El-Naggar, Bruno Guiderdoni and Nidhal Guessoum. Istanbul: The Swedish Research Institute.

Brown, Jonathan A. C. 2009. Hadith: Muhammad's Legacy in the Medieval and Modern World. Oxford: One World.

Brown, Jonathon A. C. 2011a. "Even If It's Not True It's True: Using Unreliable Hadīths in Sunni Islam." Islamic Law and Society, 18(1): 1-52.

Brown, Jonathan A. C. 2011b. The Canonization of al-Bukhārī and Muslim: The Formation and Function of the Sunnī Hadīths Canon. Leiden: Brill.

Brown, Jonathon A.C. 2014c. Misquoting Muhammad: The Challenge and Choices of Interpreting the Prophet's Legacy. London: Oneworld Publications.

Campanini, Massimo. 2011. The Qur'ān: Modern Muslim Interpretations. trans. by Caroline Higgitt. Abingdon: Routledge.

Davidson, Garrett. 2020. Carrying on the Tradition: A Social and Intellectual History of Hadith Transmission across a Thousand Years. Leiden: Brill.

Garden, Kenneth. 2013. The First Islamic Reviver. Ab̄u Hāmid al-Ghazāl̄̄ and His Revival of the Religious Sciences. New York, NY: Oxford University Press.

Gianotti, Timothy J. 2001. Al-Ghazālı’s Unspeakable Doctrine of the Soul: Unveiling the Esoteric Psychology and Eschatology of the Ihya $\vec{a}$. Leiden: Brill.

Griffel, Frank. 2004. "Al-Ghazālī's Concept of Prophecy: The Introduction of Avicennan Psychology into Ash'arite Theology." Arabic Sciences and Philosophy, 14: 101-144.

Griffel, Frank. 2009. Al-Ghazali's Philosophical Theology. New York, NY: Oxford University Press.

Griffel, Frank. 2015. "Al-Ghazālī at His Most Rationalist: The Universal Rule for Allegorically Interpreting Revelation (Al-Qānūn al-Kullī fī-l-Ta’wīl).” In Georges Tamer, ed. Islam and Rationality: The Impact of al-Ghazālı Papers Collected on His 900th Anniversary. Volume 1. Leiden: Brill, 89-120.

Guessoum, Nidhal. 2011. Islam's Quantum Question: Reconciling Muslim Tradition and Modern Science. London: I.B. Tauris.

Hasan, Ahmad. 2009. The Doctrine of Ijma $\bar{a}^{\mathrm{i}}$ in Islam: A Study of the Juridical Principle of Consensus. New Delhi: Kitab Bhavan.

Hansu, Hüseyin. 2020. “Theology.” In Daniel W. Brown, ed. The Wiley Blackwell Concise Companion to the Hadith. West Sussex: Wiley Blackwell, 241-264.

Hourani, George F. 1984. “A Revised Chronology of Ghazālī’s Writings.” Journal of the American Oriental Society, 104(2): 289-302.

Jalajel, David Solomon. 2009. Islam and Biological Evolution. Western Cape: University of the Western Cape.

Kamali, Mohammad Hashim. 2008. Principles of Islamic Jurisprudence. Cambridge: Islamic Texts Society.

Keller, Nuh Ha Mim. 2011. Sea Without Shore: A Manual of the Sufi Path. Amman: Sunna Books.

Khan, Israr Ahmad. 2010. Authentication of Hadith: Redefining The Criteria. Herndon: International Institute of Islamic Thought.

Lane, Edward William. 2010. Arabic English Lexicon. New Delhi: Kitab Bhavan. 
Malik, Shoaib Ahmed. 2018. Atheism and Islam: A Contemporary Discourse. Abu Dhabi: Kalam Research and Media.

Malik, Shoaib Ahmed. 2021. “Al-Ghazālē.” In Michael Ruse and Stephen Bullivant, eds. Cambridge Companion to the History of Atheism. Cambridge: Cambridge University Press, forthcoming.

Melchert, Christopher. 2020. “Law.” In Daniel W Brown, ed. The Wiley Blackwell Concise Companion to the Hadith. West Sussex: Wiley Blackwell, 205-222.

Mir, Mustansir. 1989. Verbal Idioms of the Quran. Ann Arbor: University of Michigan.

Moosa, Ebrahim. 1995. “The Legal Philosophy of al-Ghazāli: Law, Language and Theology in al-Mustașfā.” PhD Diss. Cape Town: University of Cape Town.

Moosa, Ebrahim. 2005. Ghazāli and the Poetics of Imagination. Chapel Hill, NC: The University of North Carolina Press.

Omar, Abdul Mannan. 2010. Dictionary of the Holy Quran, Arabic-English. Noor Foundation International.

Palmer, Aiyub. 2020. "Exegesis." In Daniel W Brown, ed. The Wiley Blackwell Concise Companion to the Hadith. West Sussex: Wiley Blackwell, 265-280.

Richardson, Kara. 2020. "Causation in Arabic and Islamic Thought." The Stanford Encyclopedia of Philosophy. Accessed 10th of November 2020. Available at: https://plato.stanford.edu/archives/fall2020/entries/arabic-islamic-causation/

Sands, Kristen Zahra. 2006. Süfū Commentaries on the Qur'ān in Classical Islam. Abingdon: Routledge.

Shafi, Muhammad. 2008. Ma'ariful Qurān: A Comprehensive Commentary on the Holy Qur'ān. Volume 8. trans. by Muhammad Taqi Usmani. Karachi: Maktaba-e-Darul-Uloom.

Shafi, Muhammad. 2010. Ma'ariful Qur'ān: A Comprehensive Commentary on the Holy Qur'ān. Volume 3. trans. by Muhammad Taqi Usmani. Karachi: Maktaba-e-Darul-Uloom.

Shah, Zulfiqar Ali. 2012. Anthropomorphic Depictions of God: The Concept of God in Judaic, Christian Ad Islamic Traditions: Representing the Unrepresentable. London: The International Institute of Islamic Thought.

Siddiqui, Muhammad Zubayr. 2008. Hadith Literature: Its Origin, Development and Special Features. Cambridge: The Islamic Texts Society.

Tamer, Georges. 2015. "Revelation, Sciences and Symbolism al-Ghazālī's Jawāhir al-Qur'ān.” In Georges Tamer, ed. Islam and Rationality: The Impact of al-Ghazāl̄ Papers Collected on His 900th Anniversary. Volume 1. Leiden: Brill, 49-88.

Weiss, Bernard. 1985. "Knowledge of the Past: The Theory of 'Tawātur' According to Ghazālī." Studia Islamica, 65: 81-105.

Whittingham, Martin. 2007. Al-Ghazālī and the Qur'àn: One Book, Many Meanings. Abingdon: Routledge. 


\section{Creationism or evolution in Islamic scripture?}

\section{Introduction}

In Part 3 of this book, we saw how al-Ghazālī’s thoughts could deal with the metaphysical objections which some associate with evolution. In this chapter, we will see how al-Ghazālî̀s hermeneutic framework, which was reviewed in Chapter 9, can be used to evaluate the proposals we reviewed in Chapter 4. This chapter works with the presumption that non-human evolution is a non-issue. There are verses and hadiths on plants and animals, but they are too ambiguous to have any clear stance on the matter, as indicated in Chapters 3 and 4, and so the crux of the issue is squarely with human evolution. Accordingly, the strategy adopted here will be to use al-Ghazālî̀'s hermeneutic framework outlined in Chapter 9 to determine where and how it might (dis)agree with current strategies to either negate or accept readings of human evolution in Islamic scripture. This will include assessing the arguments and the methodologies that can be determined of each thinker when applicable. However, before we start any evaluative procedures, it might be helpful to summarise the principles outlined in Chapter 9.

Principle 1 - All interpretations must conform to Classical Arabic;

Principle 2 - Interpretations must be considerate of the thematic and historical context (qarä in);

Principle 3 - Figurative readings can only be taken up if they conform to al-Ghazālî's rule of figurative interpretation (qanūn al-ta'wīl);

Principle $4-A h \bar{a} d$ hadīths will be maintained as valid scriptural references for matters of belief that do not constitute binding creed, as long as they are robust $(s a h \bar{\imath} h)$, and are not contradicted by evidence of similar or stronger epistemic certainty; ${ }^{1}$

Principle 5 - If there are compossible opinions, one should acknowledge them, observe epistemic humility and not force one over the other(s), and thus defer judgement to God (tafwīd al-maina);

Principle 6-In areas where there are compossible opinions, the matter cannot be a point of doctrine; ${ }^{2}$ 
Principle 7 - If scripture is silent on a matter, one should not claim any stance on behalf of scripture (tawaqquf).

As a point of reference, these principles will be mentioned alongside critiques or arguments put forward during the course of this chapter. This is to help link how each principle plays out in the discussion. Undoubtedly, there are various principles involved with interpreting scripture at any given moment, but the references are only there to highlight the primary ones involved in a particular critique or argument.

This chapter is divided into six parts. First, we shall highlight the methodological differences between al-Ghazālī's hermeneutic framework and some modern attempts that try to reconcile Islam with evolution. In particular, we will review Nidhal Guessoum's approach. This comparison will parallel Chapter 6 in which it was noted there are theological differences between the Divine Action Project (DAP) and the Ash'arite perspective, with the former being considered a form of scientism from the latter's viewpoint. Guessoum's approach treats science and scripture unidirectionally in that science gets to completely determine what is and isn't valid. As we shall see, al-Ghazālī would find this a problematic approach due to its inherent scientism. The second and third sections will evaluate three criticisms made against human evolutionary readings followed by an assessment of three attempts which try to reconcile Islamic scripture with human evolution, respectively. The fourth section will involve a comparison of Caner Taslaman's proposal with David Solomon Jalajel's. Since both of their positions involve a suspension of judgement (referred to as theological agnosticism by Taslaman and tawaqquf by Jalajel), it will be helpful to see how their differences in the application of this principle might fare through al-Ghazālī's hermeneutic framework. The penultimate section will look at the discussion of hadiths. The final section reviews the stances of human exceptionalism as argued by Yasir Qadhi and Nazir Khan, and David Solomon Jalajel's Adamic exceptionalism. It is concluded that al-Ghazālī's hermeneutic framework is compatible with creationism, human exceptionalism, and Adamic exceptionalism but not with the no exceptions stance. This is primarily due to al-Ghazāli permitting miracles in his metaphysics as well as his hermeneutics.

To help guide the reader with the discussions to follow, all the important Qur'ānic verses are referenced, e.g. Verse 1, Verse 2, Verse 3, etc. Finally, while this chapter is primarily about hermeneutics, some of the metaphysical discussions looked at in earlier chapters will be brought up to help evaluate the proposals looked at here.

\section{Hermeneutic scientism}

In Chapter 9, we saw al-Ghazālī occupies a methodological framework for interpreting Islamic scripture which starts with reading it apparently until an apodictic justification can be provided to go to a more figurative 
reading. However, some approaches stress that all hermeneutic readings must be looked at through a scientific narrative. So if Qur'ānic verse or hadīths seem unscientific, they must be reinterpreted to make them scientifically friendly.

Two proponents who advance this type of thinking are Nidhal Guessoum and Rana Dajani, both of whom we have encountered earlier in Chapter 4. Guessoum (2010) seems to have a serious problem with scriptural literalism. He believes that "creationism is a literalistic religious movement" (Guessoum 2010, 828). As a response to this issue, he suggests that Muslims should accommodate multiple and multi-layered meanings, i.e. interpretive pluralism (Guessoum 2008, 425). More importantly, his solution to the entire problem seems to be that once it is established that evolution is, in fact true, all conflicting scripture must be deemed metaphorical (Guessoum 2010). His entire approach is predicated on the no-conflict principle, which he adopts from Ibn Rushd. ${ }^{3}$ This is the self-evident position that there can be no conflict between science and scripture. Dajani (2016) adopts a somewhat similar method which, as highlighted in Chapter 4, seems to think that because evolution is true, Adam's creation narrative is just a metaphor. But since Guessoum has written much more extensively on the subject, we shall exclusively focus on his approach.

There are three issues with this method that need highlighting. First, it is true that creationists are framed by a literalistic outlook, but it would be incorrect to state that it is the only reason why they adopt creationism. As pointed out in Chapters 1 and 4, evolution is considered (though not necessarily correctly) as an atheistic or a materialistic ideology by some Muslim creationists (Jalajel 2009, 162-163; Howard 2011, 6-7). So care needs to be taken in that literalism does not take the entire blame for creationism as it could be a means or an end. In other words, Muslim creationists can reject evolution for non-scriptural reasons and then use literal readings of scripture to justify their position (the means), or they can reject evolution because of their literal readings of scripture (the end). This is being pointed out to add nuance to the role and kinds of literalism that partake in this discourse.

Second, as with literalism, Guessoum overstates the case of emphasising the need for interpretative pluralism. Muslim scholars have appreciated a variety of intelligible readings when the situation permits it. Recall from Chapter 9, al-Ghazāli himself alludes to this with the example of two possible interpretations regarding how one's deeds are weighed on the day of judgement. We also noted the example of qur $\vec{u}$ and how it led to two polar opposite jurisprudential outcomes. Finally, there is nothing problematic with adopting a metaphorical reading as Muslim scholars have invoked such readings when the situation requires it. As we saw in Chapter 9, al-Ghazālī happily allows a range of non-literal readings in his methodology. So there are appreciable overlaps between Guessoum's and al-Ghazālī's hermeneutic approaches.

However, the scope of these hermeneutic agreements is significantly affected by their different theological frameworks. The broader difference between 
Guessoum and al-Ghazālī is that the former rejects miracles due to differences understanding of God and His relationship with the natural world. This is something Guessoum himself acknowledges (Bigliardi 2014, 176):

In the famous example of al-Ghazālī, you throw cotton into the fire and it may not burn if God would decide to do so at that moment. I think that is the fundamental difference of understanding; it is really a serious, fundamental theological issue. Understanding, conceptualising how God relates to the world, how He created the world, its purpose according to Him, and how we related to Him.

To be clear, Guessoum admits that God is capable of interfering with the laws of nature, but it wouldn't make sense for Him to do so (Bigliardi 2014, 175):

... because $\mathrm{He}$ is omnipotent it does not mean that He is just going to violate His own laws. So I am not saying that God cannot; I am saying that God put together the laws so that things function in an orderly manner. Otherwise what is the point of putting together laws, and then doing one wants every now and then? The world is ordered and harmonious; the Qur'ān itself emphasises that. On the contrary, God is saying 'I am omnipotent but even I, omnipotent, put together laws by which creation proceeds, and I want you to follow laws, and I want you to be orderly, to follow the order.'

It is with this framework that Guessoum asserts that Prophet Muhammed himself did not perform any miracles, which if indeed is the case, provides further impetus for reading miracle events mentioned in scripture as moral lessons instead of real events (Bigliardi 2014, 174):

I am saying that even in the Islamic tradition there is a large tradition of not calling upon miracles for the Prophet himself. Now, if the last and greatest Prophet did not perform miracles, why do you think that there must have been physical miracles in the past? Maybe people saw something or were convinced, maybe the supposed miracles did not even occur like this, maybe the stories that are related in the Qur'ān are not to be taken literally, maybe they didn't happen historically exactly like this, it is just told to convey a moral, to convey an idea about God and humanity, and injustice ... Probably we are not talking about physical miracles at all, they are just parables about the fact that God can intervene, can help and so on.

Otherwise, miracles are incredibly lucky incidents (Bigliardi 2014, 175):

... putting together all these ideas of how to read he Qur'ān, how to understand the stories of the Prophets, what is the meaning of God's 
order, what are the laws of God and nature etc., all of this for me rules out the idea of miracle as a violation of laws. Miracles are very lucky events, providence, coincidences.

However, while Guessoum believes God doesn't violate physical laws, God can interfere with spirits (Bigliardi 2014, 176): "My current position is that God interacts with us through the spirit, meaning our mental connection with Him, not thorough physical mechanisms."

From al-Ghazālî̀s standpoint, Guessoum's hermeneutic would be in the same position as the DAP, which we looked at in Chapter 6. The DAP was an exercise to determine how far participants could come up with theological models that safeguard the sciences on the one hand while catering for God's autonomy on the other. It was concluded that al-Ghazālī would see the parameters of the DAP as a form of scientism; it straitjackets God too much. In the Ash arite paradigm, God isn't bound by the laws of nature and/or science. In responding to the Guessoum's specific claim of God's insensibility in creating an ordered world and then disrupting its laws, al-Ghazālī would simply say that God has His reasons. We don't have epistemic insight into everything that $\mathrm{He}$ does and thinks about. So curtailing what God can't and can do according to human frameworks is a limitation on God, which, as highlighted in Chapter 6, Ash 'arites don't entertain.

These theological differences spill over to the hermeneutic plane, which inevitably leads to significant differences of opinions. How each thinker reads miracle stories is a clear case in point. ${ }^{4}$ Guessoum does not read miracle stories literally or considers them to be very rare, natural, law-abiding events, while al-Ghazālī has no problem reading such events at face value whether they conform to science or not. As we will come to see during the course of this chapter, Guessoum utilises his adopted hermeneutic principles to conform Islamic scripture to the demands of science. So if there is something in scripture that isn't scientifically possible, it will be read in a way such that it safeguards science. In other words, if there is an interface between science and scripture, the flow of engagement seems to be unidirectional from science to scripture rather than being bidirectional where science and scripture are equally dissected, discussed and integrated as is the approach of al-Ghazālī. It would not be a stretch to assert that al-Ghazālī would see Guessoum's approach as a form of hermeneutic scientism, i.e. appropriating scripture to the demands of science. ${ }^{5}$

To be clear, this is not a new debate and, in fact, has a historical footprint. As we noted in Chapter 3, when reviewing human exceptionalism as outlined by Qadhi and Khan, and in Chapter 9, al-Ghazālī had issues with Avicenna's thoughts for similar reasons. Avicenna occupied a metaphysical framework known as emanationism within which creation is a necessary production. So God did not create the universe and its constituents through any volition of His own. As part of this framework, miracles aren't possible, which is why Avicenna resorts to claiming that scriptural indications of such events should 
be taken symbolically rather than literally (Al-Ghazālī 2000a; Richardson 2020). Given al-Ghazālī's metaphysical framework, he was at complete odds with Avicenna's line of thinking. Guessoum is not an emanationist, but he is tightly welded to a scientific framework which does not allow him to cater for any kind of unscientific readings. It is why any kind of creationist reading is impossible for him to entertain, whereas from al-Ghazālī's perspective both creationism and evolution are equally possible. These disagreements will become more apparent as we progress in this chapter.

\section{Criticisms raised against human evolution}

In Chapter 4, we noted three main criticisms that were brought up against human evolutionary readings. The first is the notion that Adam was created and fell from the heavenly garden, which some suggest nullifies any reconciliation whatsoever. Second, there is the issue of man's nobility. Some have used verses in the Qur'ān to determine that because humans are a noble being or were created with dignity, they could not have come about by evolutionary processes. The biological link of animals with a "lower status" in comparison to humankind seems to ground this claim. Third, there is a reference to God's hands in Adam's creation, which people have used to suggest a miracle reading. Let us review each of these in order.

\section{Heavenly or earthly garden?}

It was noted in Chapter 4 that the garden from which Adam fell is generally understood to be as the eternal garden of heaven. Seyyed Hossein Nasr (2006), Nuh Ha Mim Keller (2011), and Yasir Qadhi and Nazir Khan (2018) are some of the proponents who have utilised this argument to reject human evolution. Two things can be said on this particular point. First, it seems that scripture itself seems to be unclear on the matter. Exegetes seem to have debated over this issue. Classical exegetes debated over the nature of the garden from which Adam fell. According to the classical exegete, Ibn Kathīr (2018, 350-359), the majority sided with the heavenly interpretation while a minority sided with the earthly interpretation. In Chapter 4, we saw how Keller seems to advocate the heavenly interpretation as if it's the position on the matter. This doesn't seem to be the case. For instance, Ibn Kathīr himself didn't commit to any particular position, possibly indicating a non-committal stance. Furthermore, other well-known exegetes such as Ibn 'Ashūr $(1984,428-431)$ also acknowledged the different opinions with the heavenly interpretation being dominant. However, he stated that these positions rested on likelihoods rather than certainty, and one's position on the matter doesn't affect one's doctrine, i.e. this isn't a matter that is theologically binding. Al-Rāzi $(2000,1)$, one of the most revered exegetes in Islamic intellectual history, also concludes that the evidence on the matter is contradictory and unresolvable, i.e. there are valid arguments 


\section{2}

for a heavenly garden as well as an earthly one. Given that we are utilising al-Ghazālī's hermeneutic framework from a theological angle, if there is a lack of clarity or ambiguity in Islamic scripture, it cannot be a point of doctrine, and so he would agree with stances of Ibn 'Ashūr and al-Rāzī (Principle 6). Furthermore, since there are competing interpretations over this issue, one should not unnecessarily force an opinion on the matter. Given al-Ghazālī's principle of epistemic humility, when there are viable competing interpretations, it is perfectly valid to defer judgement just like Ibn Kathīr (Principle 5). So, resorting to a heavenly garden and utilising it as if it were a definitive reading does not warrant a disqualification of human evolution given that there is a case to be made for the earthly interpretation.

Second, even if the garden was in heaven, it does not directly entail that human evolution is false. It is logically possible that Adam fell from the heavenly garden and then recreated on earth through evolutionary processes. So relying on a heavenly garden reading does not automatically disqualify human evolution as a possibility. A further hermeneutic constraint would be needed to arrive at this strong conclusion. As suggested in Chapter 3, the verse of similitude between Jesus and Adam provides this constraint (Qur'ān 3:59). So the discussion of the nature of the garden in of itself doesn't undermine human evolution.

\section{The nobility of man}

The second argument against human evolution is an axiological appeal to the nobility of humans that is mentioned in the Qur'ann, which seems to entail that humans cannot be the output of evolution. Ramaḍann al-Būṭi (2017) is one example who adopts this line of argument.

Undoubtedly, the Qur'ān has a few verses that give humans a lofty status. The following are some examples which are quoted when making this point:

Verse 1 - We create man in the finest (ahsan) state ... (Qur'ān 95:4)

Verse 2 - We have honoured the children of Adam and carried them by land and sea; We have provided good sustenance for them and favoured them specially above many of those We have created. (Qur'ān 17:70)

The question is: are the quoted verses sufficient to deny human evolution? This doesn't seem to be the case. First, when the previous two verses are looked at thematically with the verses that follow them, the quoted verses' meanings become apparent. Consider Verse 1, followed by the verses that follow it:

We create man in the finest state then reduce him to the lowest of the low, except those who believe and do good deeds. (Qur'ān 94:4-6) 
Similarly, consider Verse 2 with what succeeds it:

We have honoured the children of Adam and carried them by land and sea; We have provided good sustenance for them and favoured them specially above many of those We have created. On the Day when We summon each community, along with its leader, those who are given their record in their right hand will read it [with pleasure]. But no one will be wronged in the least. (Qur'ān 17:70-71)

When both verses are thematically contextualised, it immediately reveals how the honour given to humankind seems to be linked with believing in God, and abiding by good deeds and refraining from bad ones through free will, i.e. following God's commandments ascetically and volitionally (Principle 2).

Second, when the Qur'ān is viewed holistically one can also find verses that speak negatively of humans including them being hasty (Qur'ān 21:36), niggardly (Qur'ān 17:100), greedy (Qur'ān 70:19) and weak (Qur'ān 4:28). So it seems to be a lopsided argument when the positive qualities are presented in the absence of the negative ones (Principle 2). So how can these positive qualities of humans be interpreted in light of the negative ones? Similar to the first point, the honour given to humans in these verses are due to their potential of fulfilling their purpose by worshipping God, and attempting to reach a high state of spirituality by fighting against these negative qualities and base desires. This is succinctly highlighted by al-Ghazālī $(2008,34)$ :

If he [man] throws the alchemy of (spiritual) happiness upon the essence of his soul, he will travel from the degree of beasts to the degree of the angels. If he turns to the world and the appetites of the world, a dog or a pig will be superior to him tomorrow ... So when he has come to know his ability, he must recognise his own deficiencies, baseness, and helplessness. In this way, that self-knowledge is one of the keys to the knowledge of God ...

Thus, based on his spiritual merit, man has the potential to become a being of nobility, but he is also susceptible to becoming a loathsome creature. This neatly balances the positive and the negative qualities of humans mentioned in the Qur'ān. Subsequently, none of these verses actually seem to conflict with evolution. Humans can still be the product of evolution and yet maintain a lofty status by following the commandments laid down by God.

Interestingly, but also paradoxically, these verses and their likes have been used by some to argue for human evolution. Recall from Chapter 4, Rana Dajani (2012) reviews Verse 1 and makes the following comment:

In the verse in $\mathrm{Al}$ teen [Verse 1], Allah states that man was created to be fit for his environment. To me, this supports evolution and is an 
example of misinterpretation of the meaning of words in religious texts for lack of the scientific knowledge on the issue by the interpreters.

She also used the word ahsan to argue for an evolutionary reading in the Qur'ān. However, it seems that it is both thinly argued and overstated. In lexicons, one finds that ahsan can etymologically mean beauty, be or become beautiful, improve, adorn, goodness, charity, favour, act properly, deem good, and approve, to appreciate (Badawi and Haleem 2008, 209). So the idea of ahsan meaning the most fit for the environment as Dajani believes isn't strictly a strong reading. Still, it could weakly resonate with the idea of being created to act properly or created perfectly that may align with evolution (Principle 1). But more importantly, Dajani has interpreted it atomistically without considering the thematic context. The qualification by exception (... except those who believe and do good deeds ...) clearly indicates that isn't referring to the physical part of the human being. Thus, stretching this to an evolutionary reading completely misses the mark (Principle 2).

It seems, then, that even though Adam and humankind are specially referred to in the Qur'ān with a lofty status, none of these are clear rebuttals against human evolution. If anything, these verses remain neutral on the topic when thematically contextualised.

\section{God's hands}

The final argument that is sometimes used to argue against human evolution is the reference of God's Hands (Qur'ān 38:75): “God said, 'Iblīs, what prevents you from bowing down to the man I have made with My own [two] hands? Are you too high and mighty?'” Keller refers to this when arguing against human evolution. However, Keller is mistaken to think that mere mention of God's hand(s) is exclusive to Adam. As we noted in Chapter 3, there is another verse where God mentions His Hands in the plural form (jam') about livestock: "Do they not see that We have created for them from what Our hands have made, grazing livestock, and [then] they are their owners?" (Qur'ān 36:71). In another place God's Hand is mentioned in the singular form (mufrad) with respect to His allegiance: "Those who pledge loyalty to you [Prophet] are actually pledging loyalty to God Himself - God's hand is placed on theirs ...” (Qur'ān: 48:10). Given this point, the claim of Adam's exclusivity as a special creation is lost if it is only based on the mere mention of God's hand(s). To give credit to Keller, the mention of Adam's creation with respect God's Hands in the dual form (muthanna) is exclusive to Adam, and, in the context of the verse, it suggests that Adam is in some way unique which is why Satan (Iblīs) was asked to bow down to him. ${ }^{6}$ Also, al-Ghazālī doesn't interpret any verses that depict God anthropomorphically literally, as noted in Chapter 9. God is transcendent and cannot have entities like hands (Shah 2012, 399-654; 
Kars 2019). Subsequently, it is unlikely he would read this verse to mean God literally creating Adam with a pair of hands, but most probably would understand it as Adam's creation being a significant event. However, even if this option carried with it some kind of exclusivity, it remains unobvious as to how this would contradict human evolution (Principle 1; Principle 2).

As far as can be told, the basis for Adam's uniqueness (and humans) has been interpreted to be the soul, which demarcates him from other beings (e.g. see Chittick 1989; Al-Ghazālī 2008; Coppens 2018). Even Keller $(2011,361)$ alludes to this:

The locus of this attachment and this knowledge is not the mind, but rather the subtle faculty within one that is sometimes called the heart, sometimes the $r \bar{u} h$ or spirit. Allah's special creation of this faculty has been mentioned above in connection with the Qurānic words and breathed into him of My spirit. According to masters of the spiritual path, this subtle body is knowledgeable, aware, and cognizant, and when fully awakened, capable of transcending the opacity of the created universe to know Allah.

As we saw in Chapter 4, Israr Ahmad links this point to Adam's creation in the context of evolution and the mention of God's hands. In his view, it is reasonable to think that one advanced member of the Homo species was chosen within whom the soul was infused into and became Adam (Ahmad 2013, 45-46). He suggests that when God mentions creating Adam with His two hands, it possibly alludes to this moment where the soul was infused into Adam's physical template, which could easily be consistent with evolution (Ahmad 2013, 47). ${ }^{7}$ Given this possibility, simply relying on the verse which mentions God's two hands to deny human evolution is not necessarily a robust argument (Principle 5; Principle 6). ${ }^{8}$

Finally, it has been pointed out that in order "for this verse to be evidence against human evolution, one must first assume that 'God's hands' are not involved in natural biological development, but, again, this assumption is not obvious" (Majid 2015, 100). In other words, the special attention the verse indicates is being given to Adam does not negate the biological dimension. This is particularly important to note in light of al-Ghazālîs's metaphysics. If occasionalism is true, isn't God directly maintaining and sustaining every single entity? And couldn't this include evolution? For all these reasons, the reference to God's hands doesn't make it clear that human evolution is to be rejected.

\section{Arguments by the no exceptions camp}

There are three broad ways this is done. One is by reading the creation narrative of Adam non-literally. The second is by utilising the bashar-insān distinction. The third approach is by reading evolution into verses that 
either in themselves or when coupled with other verses lead to a pro-evolution reading. Let us review each approach in the stated order.

\section{Metaphorical readings of Adam's creation narrative}

As we saw in Chapter 4, Rana Dajani and Muhammad Iqbal interpret the creation narrative of Adam non-literally. Dajani $(2016,146)$ thinks the creation narrative of Adam is a metaphor, and the purpose of this metaphorical story is to convey moral lessons:

The story of Adam in the Qur'àn as well as other stories should not be taken literary $[s i c]$. They are metaphors to learn lessons. The process of human evolution was gradual and concerned groups of humans who evolved from former ancestors.

Iqbal $(2012,66)$ suggests that Adam is more of a symbol of humanity rather than a historical individual:

Indeed, in the verses which deal with the origin of man as a living being, the Qur'ān uses the words Bashar or Insān, not Adam, which it reserves for man in his capacity of God's vicegerent on earth. The purpose of the Qur'ann is further secured by the omission of proper names mentioned in the Biblical narration - Adam and Eve. The word Adam is retained and used more as a concept than as the name of a concrete human individual.

Both believe that the verses mentioning Adam cannot be taken literally. Given al-Ghazālī's five-tiered system for interpreting scripture, as highlighted in Chapter 9, he would differ with both of their approaches. Dajani, and perhaps Iqbal, read the verses non-literally because they see evolution as conflicting with this narrative. In their case, it seems that science is a very salient operational feature in their hermeneutic process. Al-Ghazālī, however, is not so much constrained by scientific measures. This isn't because he is antiscientific or unscientific. As we saw in Chapter 9, al-Ghazālī respects the authority of scientists to be able to deliver high-resolution explanations of natural phenomena that are briefly alluded to in the Qur'ān on their own terms. Al-Ghazālī's hermeneutic framework works in tandem with his metaphysical framework, i.e. occasionalism, within which miracles are permitted realities. It is why miraculous events are not taken non-literally by al-Ghazālī. While Dajani and Iqbal may not be operating in the same framework as Avicenna, using science to curtail to what is(n't) metaphysically and hermeneutically possible would warrant the same concerns. As with Guessoum's case discussed earlier, this approach could be seen as a form of hermeneutic scientism when looked at from al-Ghazālì's framework. 
Apart from these methodological differences, there are other issues with taking this route even on its own merits. First, there is no contextual indicator that metaphors are intended by the text, either as events (the fall of Adam and Eve from the garden) or as actors (Adam, Even and satan; Principle 1; Principle 2). Second, the Qur'ān as a whole also does not indicate that Adam should be read non-literally even implicitly because references to him are simply too well-corroborated (Principle 2). Consider the following verses:

Verse 3 - When We told the angels, 'Bow down before Adam,' they all bowed. But not Iblīs, who refused and was arrogant: he was one of the disobedient. (Qur'ān 2:34)

Verse 4 - We said, 'Adam, live with your wife in this garden. Both of you eat freely there as you will, but do not go near this tree, or you will both become wrongdoers.' (Qur'ān 2:35)

Verse 5 - [Prophet], tell them the truth about the story of Adam's two sons: each of them offered a sacrifice, and it was accepted from one and not the other. One said, 'I will kill you,' but the other said, 'God only accepts the sacrifice of those who are mindful of Him.' (Qur'ān 5:27)

Verse 6 - God chose Adam, Noah, Abraham's family, and the family of Imran, over all other people (Qur'ān 3:33-34)

In Verse 3, God commands the angels to prostrate to Adam, and they did except for Satan. In Verse 4, God speaks to Adam in the first person and tells him to dwell in heaven with his wife. In Verse 5, Adam's two specific sons are being referred to, i.e. Cain and Able. In Verse 6, Adam is mentioned alongside Prophet Noah and Prophet Abraham as those whom God chose to follow a connected lineage. The specific references to God talking with Adam, his wife, his sons, which are also corroborated in multiple places in the Qur'ān and hadīths, are simply too numerous to reinterpret as metaphors with a simple stroke. Of course, it is conceded that this in of itself doesn't necessitate that they cannot be metaphorical readings, even if en masse. But the following two contentions give this argument some weight.

Verse 6 raises a third contention, which is the argument by implication. Verse 6 is but one example in which Adam is mentioned alongside other well-known prophets. If Dajani's or Iqbal's reading were to be applied to consistently throughout the Qur'ān, it would suggest that if Adam is a metaphor/symbol, and thus Noah and Abraham should be too (recall the argument by Mohammed Shihabuddin Nadvi in Chapter 4). 
There is also the verse which likens Adam to Jesus (Qur'ān 3:59), which raises similar concerns. These verses collectively make it very difficult to maintain and believe that Adam was simply a metaphor/symbol, as it potentially questions the truthfulness of other prophetic stories discussed in the Qur'ān. Applied consistently, if Noah and Abraham are metaphors/symbols because of being mentioned in the same verse as Adam, then it would imply that they are still just metaphors whenever they are mentioned independently, too. The same goes for any other prophets mentioned alongside Adam and the ones discussed here. This would create several theological problems because it would suggest that a large portion of the Qur'ān contains fictitious fables which the Qur'ān itself doesn't seem to suggest is the case (Qur'ān 6:25; 4:164; 11:120; 18:13; 20:99; 40:78). Thus, because of the downstream implications of Adam being a metaphor or a symbol, the entire Qur'annic corpus potentially becomes fictitious and incoherent if applied consistently (Principle 2).

The fourth and final issue is the problem of arbitrariness, which is intrinsically tied up with the previous contention. In response to the third contention, it could be argued that Adam is referred to as a metaphor/symbol in some parts while he should be read as a real person in other parts. This would eliminate the charge of making the whole Qur'ān a book of fictitious fables. However, without giving us a proper hermeneutic mechanism whereby we can determine when the mention of Adam should read metaphorically and literally, which has not been provided, it makes it too arbitrary of an interpretation. Going back to Adam's verse mentioned alongside Noah and Abraham again, Verse 6, if Dajani or Iqbal wanted to be consistent with their reading, it would entail interpreting the first part of the verse as metaphorical/symbolic and the latter half as literal. But how would this work if not non-arbitrarily? Without a clear and consistent hermeneutic framework, their methodology would be considered capricious (Principle 2; Principle 3). Dajani, in particular, has a very confusing methodology. She asserts that the Qur'ān is not a book of science, but then tries to find evolution-friendly readings in certain words and verses (recall her reading of ahsan reviewed earlier and in Chapter 4). This makes for a confusing and inconsistent method.

To be clear, the story of Adam can be read metaphorically in al-Ghazālī's framework. It could be taken to symbolise the power of repentance for humanity, for instance, - because God forgave Adam for eating from the tree after asking for forgiveness (Qur’ān 7:23) - but this would have to be maintained in conjunction with the literal reading rather than instead of it. As we noted in Chapter 10, al-Ghazālī doesn't deny metaphorical readings so long as they are read in tandem with apparent readings (Principle 3). His problem would only be when a perfectly valid, apparent reading is easily dismissed for a more figurative one in the absence of clear proofs. 


\section{The bashar and insān distinction}

The second approach rests on the bashar-insān dichotomy, which we reviewed in Chapter 4. Nidhal Guessoum and Israr Ahmad adopt this narrative. To dissect this particular claim, let us requote Guessoum's apt summary of this position, which he adopts from Mohammed Shahrour's narrative (Guessoum 2011b, 313-314):

He [Shahrour] starts by declaring that the Arabic/Qur'ānic words insān, usually understood as 'man', and bashar, usually rendered as 'human being', must be distinguished; they refer to two very different stages of human evolution. Indeed, in reviewing the story of Adam in the Qur'ān, he shows that each time the word insān ('man') is used, there is a clear connotation of 'comprehension' (mental capacity), 'abstract conception' (of metaphysical entities, in particular) and 'intelligence.' By contrast, the word bashar is used only in the context of its creation, well before it has evolved to insān and become mentally capable. One could simply say that Shahrour wants to identify the bashar stage with hominid (or even Homo) and insān with modern man. He finds support for this idea in the fact that the Qur'ān refers to the 'breathing of God's Spirit' into the hominid/homo ... Shahrour summarises the whole story by emphasising two things: (1) there were many hominid/homo creatures before Adam; (2) God then 'selected' Adam and breathed into him from His Spirit; this later action is the transformative act that produced the jump from the animal state to the human one.

This position has been extensively criticised (Ayoub 2005; Elshahat et al. 2019; Saeed 2019). Critics raise two key objections raised against this approach. First, it has been argued that the way the words have been utilised is idiosyncratic (Ayoub 2005, 188). Lexicons seem to suggest that both have been generally used for referring to humans/humanity. But this suggestion is predicated on it being usable for predecessors of modern human beings (Principle 1). The second criticism is that this new usage is not uniform across the Qur'ān (Principle 2). For example, the following verses raise some difficulties for this approach:

Verse 7 - That is because their messengers came to them with clear signs, yet they said, 'Should we take guidance from mere mortals (absharun)?', rejected the message, and turned away. But God had no need for them: He is all sufficient, worthy of all praise. (Qur'ān 64:6)

Verse 8 - They say, 'We will not believe for you [Muhammad] until you make a spring gush out of the ground for us; or until you have a garden of date palms and vines, and make rivers pour through them; or make the sky fall on us in pieces, as you claimed will happen; or bring God and 
the angels before us face to face; or have a house made of gold; or ascend into the sky - even then, we will not believe in your ascension until you send a real book down for us to read.' Say, 'Glory be to my Lord! Am I anything but a mortal (basharan), a messenger?' (Qur'ān 17:90-93)

Verse 9 - So eat, drink, be glad, and say to anyone (al-bashar) you may see: 'I have vowed to the Lord of Mercy to abstain from conversation, and I will not talk to anyone (insiyya) today.' (Qur'ān 19:26)

In Verse 7, God records the complaint of the people who rejected the prophets sent by God (including Prophet Muhammed) because of him being a man compared to a "nobler" creature like an angel. This is captured in their question: "Should we take guidance from mere mortals (absharan)?" In Verse 8 verse, God commanded Prophet Muhammed to declare his humanness because of his inability to follow up with the absurd requests of the people who disbelieved him. Such verses may be problematic for Guessoum, Shahrour, and Ahmad because the Prophet Muhammed is being referred to as bashar (implicitly in the first one and explicitly in the second one), which somewhat contradicts their claims if bashar is being exclusively reserved for hominids before humans who were without or had little mental cognition relative to what humans may possess (Principle 2). Furthermore, Verse 9 describes the event of Mary's virgin birth. On giving birth to Jesus, she was provided with food and drinks to ease her pain after which she was instructed by God to not speak to any person. The interesting point here is that conjugations of bashar and insān are both mentioned when referring to humanity/humans. It is why some have suggested the possibility of them being equivalent terms rather than carrying any significant distinction as seen in Guessoum's quotation (Saeed 2019, 128-129; Elshahat et al. 2019; Principle 2).

While the first criticism may have some validity, the second criticism completely misses the mark. Rather than understanding bashar as pre-humans and insān as humans exclusively, i.e. there is no mutual overlap, they may be treated as relational categories. Guessoum and those who agree with him understand bashar as a wider category, which includes any entity that could be identified as Homo, while insān is a subcategory of bashar which refers to entities that are identified as humans. Accordingly, all bashar are insān but not all insān are bashar. Treated this way, the preceding problems can be avoided, e.g. by suggesting that when bashar is being used it's is merely emphasising their physical aspect rather than the intellectual one. However, despite this suggestion, one potential problem with this approach is that some advocates of the bashar-insān dichotomy seem to disagree over the relational order. For instance, Hasan Hamad 'Ațiyya (1999, 109-111) also adopts this narrative, but suggests that it is, in fact, insān that's the broader category while bashar is the subcategory for humans. If anything, this shows how there isn't a clear consensus on the semantic loading of 
either of the terms involved, and with such semantic flexibility, this argument loses potency.

The bigger problem with this proposal is it misses out on the more relevant verses to the creationist-evolutionist divide. They are the following two:

Verse 10 - People, be mindful of your Lord, who created you from a single soul (nafsin wăhidatin), and from it created its mate, and from the pair of them spread countless men and women far and wide; be mindful of God, in whose name you make requests of one another. Beware of severing the ties of kinship: God is always watching over you. (Qur'ān 4:1)

Verse 11 - In God's eyes Jesus is just like Adam: He created him from dust, said to him, 'Be', and he was. (Qur'ān 3:59)

As noted in Chapter 3, both of these verses are taken to support that Adam was a special creation of God and was created from no prior biological process, i.e. instantaneously (Majid 2015).

However, it is worth pointing out that while Guessoum doesn't directly review these verses, he does deal with the idea of Adam's miraculous creation in a book review of David Solomon Jalajel's Islam and Biological Evolution: Exploring Classical Sources and Methodologies. Some of the criticisms he raises against Jalajel's book are telling. Pertinent to our discussion is Guessoum's rejection of miracles (Guessoum 2011c, 303-341). Jalajel $(2009,149-156)$ analyses classical Islamic exegesis and concludes that all classical commentators agree Adam had no parental agency. He adopts the methodology of classical Islamic theologians, and he concludes that Adam was a miraculous creation. Jalajel explains $(2009,123-131)$ that this was a comfortable conclusion for classical exegetes and theologians because miracles are permissible realities in their worldviews. Accordingly, miracles that are mentioned in the Qur'ān were unproblematic for them, and thus were taken at face value. Guessoum (2011c, 478) says the following with regards to this point:

[Jalajel] insists that Adam be regarded as a miraculous creation. In his 'orthodox' view, first we only observe general patterns in God's action in the world, not any rigid laws of nature, hence God can break them or suspend them whenever He wishes, and secondly 'Science can never hope to be able to determine the manner in which a single human being, Adam ... was specifically created ... What the sacred texts say about the creation of Adam has led classical scholars to the conclusion that his creation was unique, even miraculous' ... He adds: 'there is no reason to assume that the creation of Adam had to follow the same pattern as the creation of other life forms'. Needless to say, this fully contradicts not only the whole scientific perspective on the subject, but tons of empirical evidence as well. 


\section{Hermeneutic considerations}

Two points can be said of this remark. First, it is unclear how science can contradict either human exceptionalism as argued by Qadhi and Khan (2018), or Adamic exceptionalism as argued by Jalajel (2018). In the former case, if Adam did indeed descend to earth with all the right biological properties as expected of evolution, which gives it a look of seamless continuation, and were then passed on to all of his descendants, how can Guessoum produce empirical evidence to deny this scientifically? In the case of Adamic exceptionalism, what scientific test can be done to demonstrate that there was an individual called Adam that appeared miraculously on earth from non-existence however long ago and who, moreover, neither negates common ancestry nor contributes anything discernible to human biology? Neither of these possibilities seem to be incompatible with a scientific explanation through evolution.

Second, arguably, some miracles can be interpreted in a way that safeguards scientific sensibilities. For example, there is a famous verse in the Qur'ān (54:1) which refers to the moon being split, a case which Guessoum (2011b, 9-13) discusses in his book. It can be interpreted either as an event that occurred in the past or an event that will take place on the day of judgement (Mourison 2002, 130). The latter would not conflict with science, but the former would due to lacking scientific evidence. Both are hermeneutically plausible. As put by Haleem $(2005,350)$ :

The Arabic uses the past tense, as if that Day were already here, to help the reader/listener imagine how it will be. Some traditional commentators hold the view that this describes an actual event at the time of the Prophet, but it clearly refers to the end of the world.

By contrast, it would be difficult to see how one could interpret other prophetic miracles mentioned in Islamic scripture, e.g. the event of Moses parting the seas, any other way within the confines of the language (Qur'ān 26:63). Aside from the theological and hermeneutic differences between Guessoum and al-Ghazālī, Islamic scripture contains references to God, angels, and demons, heaven, and hellfire, all of which are not part and parcel of the observable, natural world. If science is the defining perspective through which one should interpret scripture, it seems unclear how these entities, which are fundamental tenets of Islamic faith, could be accepted. So, on the one hand, Guessoum's science-governed hermeneutics rejects miracles. On the other hand, his approach faces the lingering worry with how to deal with supernatural entities like the ones just mentioned. Despite Guessoum claiming that not everything in scripture is a metaphor, by completely sidestepping any restraints offered by the language, thematic analyses, historical analyses, there doesn't seem to be a nonarbitrary methodology through which one can stop interpreting anything to be read as a metaphor (Bigliardi 2014, 175; Principle 1; Principle 2; Principle 3). 
There is another related critique which can be made of the no-conflict thesis that Guessoum seems to adopt. It assumes a priori that conflict is not an option. While it is true that nature and scripture are both products of God, and thus there should be no conflict between them, they are however mediated by human constructs and methods, and therefore fallible and open to potential conflict (Haarsma 2010, 112-114). Moreover, his stance misses out the possible position of either deferring judgement (tafwi $d$ al-mán $\bar{a})$ when one reaches a potential conflict between science and scripture, or abstaining from judgement (tawaqquf) when scripture is silent altogether on a matter, i.e. there is nothing to interpret (Principle 5; Principle 6; Principle 7). Though these may not necessarily be seen as satisfactory positions, deferring and suspending judgements are valid positions. As we saw earlier in Chapters 4 and in 9, strictly within the confines of scriptural analysis, Muslim scholars have sometimes resorted to deferring judgement on occasions where there is an apparent contradiction in scripture. So if deferring judgement can and has been used for scriptural interpretations, then one should be even more open to adopting it to address conflicts in the interface of science and scripture, as there are many more possibilities and considerations that might be missing from one's analysis. This is even more the case for abstaining from judgement (tawaqquf) when scripture is altogether silent on a matter of scientific relevance, since this means that there is no scriptural claim being made to contradict a scientific one.

The worry with Guessoum's no conflict thesis is that it could lead to neglecting or ignoring methodological principles or facts of either science or hermeneutics in trying to force a harmonious reading. This can easily be seen in Guessoum's proposal in which he ignores several hermeneutic considerations to reach some kind of compatibility. Furthermore, using the presumption of harmony, and possibly to the dismay of Guessoum, one can conceive of a reverse situation where a creationist theologian says that science actually points towards a creationist narrative by reinterpreting science or relying on non-mainstream science (or even pseudoscience). Both are problematic outcomes, which is why the options of deferring or reserving judgement should not be ruled out beforehand. To be clear, the no-conflict thesis is not being criticised because it's an ideal, but rather this a criticism of its application if it ends up ignoring or bypassing the methodological concerns of either scripture or science. In other words, just as scientists expect non-scientists to appreciate the nuances and sophistication of science, so does the theologian expect non-theologians to appreciate the nuances and sophistication of theology.

\section{Readily available readings of evolution in the Qur'ān}

The approaches in this category don't adopt a metaphorical reading, nor do they necessarily employ the bashar-insān distinction. Rather, the thinkers in this category find other creative means to suggest that evolutionary 


\section{Hermeneutic considerations}

readings are readily available in the Qur'ann. Some of them are open to the same charge of neglecting the important verses as was advanced against Guessoum. For example, Basil Altaie (2018) discusses three stages of man's creation which could align with evolution. However, his strategy completely ignores Verse 10 and Verse 11, which is where the real divide between creationists and evolutionists seems to be (Principle 2).

Others follow Altaie's strategy, but also engage with either Verse 10 and/ or Verse 11. T.O Shanavas $(2005,156)$ interprets Verse 10 referring to spirits for instance and not as concrete, physical individuals. This allows him to bypass the claim that humankind's physical origin is Adam, and therefore needn't conflict with human evolution. It is with this interpretation he then claims that the creation narrative was a mental blissful stage. Taken together, he believes in a kind of ensoulment interpretation similar to Israr Ahmad.

It is possible to interpret that the word nafsin - the word translated as "soul" in Verse 10 - as an immaterial body but could also mean an individual and one's affective states (Badawi and Haleem 2008, 954). So the word on its own may help with Shanavas' reading. However, taking the verse as a whole, it doesn't seem to be the case it is referring to spiritual beings. It was noted in Chapter 3 that Verse 10 does indeed have two potential interpretations regarding Adam and Eve. One was that a part of Adam was used to created Eve, another was that Adam and Eve were made from the same kind or essence (Haleem 2011, 135). So it is conceded that there is more than one interpretation of this verse. However, when read in its context, if nafsin is understood as a spiritual being, it does not seem to follow coherently with the latter half of the verse, which is referring to physical men and women: "People, be mindful of your Lord, who created you from a single soul, and from it created its mate, and from the pair of them spread countless men (rijäl) and women (nisäan) far and wide ..." (Qur'ān 4:1). The words used for men and women in this verse are specifically designated for physical beings. Accordingly, it seems to be unclear how can we non-arbitrarily read the first half as spiritual entities and the latter half as physical ones. Finally, there are other verses which clearly refer to a single couple in reference to Adam and Eve: "People, We created you all from a single man and a single woman, and made you into races and tribes so that you should recognise one another ..." (Qur'ān 49:13). Given these collective points, Shanavas' reading of this verse seems somewhat forced (Principle 2).

This impression is further corroborated by his attempts to read other verses with definitive evolutionary readings. One of the verses he quotes from is: "While He has created you in stages (ațwāran)?" (Qur'ān 71:14). On this, he comments: "The ... verse unequivocally states that the creation of mankind was not a magical ex nihilo instant event but a step-by-step transformation" (Shanavas 2010, 135). However, the word atwäran translated as "stages" in the quoted verse is not the only rendition in English. 
The word also connotes ideas like conditions, different forms or dispositions (Badawi and Haleem 2008, 575-576; Lane 2010a, 1890). With such ambivalence, it could imply a temporal progression or a non-temporal description, i.e. referring to people's various conditions at a given time (Principle 1). Nonetheless, even if one wanted to choose the temporal progression interpretation, one still has to justify whether progression here is referring to evolution in the modern sense or the progression of a human being from embryo to human as is done in other parts of the Qur'ān (23:1214; Principle 2). The verses that precede the quoted verse discuss the bounties of God, such as weather, family, and property (Qur'ān 71:11-13). The succeeding verses discuss the various layers of heaven, celestial bodies, and the earth (Qur'ān 71:15-20). When situated thematically, this verse seems to imply a general account of various stages and forms of creation in toto. Nonetheless, it could plausibly encompass the step-by-step transformation which Shanavas suggests, but not with the certainty nor high plausibility he is making it out to be (Principle 2). Moreover, while Shanavas engages with Verse 10, there isn't any engagement with Verse 11 (Principle 2).

Daud Abdul-Fattah Batchelor engages with both Verse 10 and Verse 11 with a very creative reading. Batchelor $(2018,496)$ believes that one can infer from Verse 11 that since Jesus was born from Mary, i.e. Mary was his blood mother, Adam also had a blood mother albeit a pre-Adamic one. This reading completely reverses reading found in Chapter 3. Exegetes have identified various similarities between Adam and Jesus. One exegesis provides us with fifteen similarities (all of which are compatible with each other; Al-Gharnāṭī 2020a; Al-Gharnāṭ̂̄ 2020b):

1 In configuration;

2 Creation from the material of the world God used to form them;

3 Servitude;

4 Prophethood;

5 Trials: Jesus on the hands of the Jews and Adam on the hands of Satan;

6 Consumption of food and drink;

7 Need for God;

8 Features;

9 Elevation to the heavens and descent from it to earth;

10 Inspiration;

11 Adam sneezed and he was inspired to say "All praise belongs to God," and when Jesus came out from his mother's womb, he said: "I am the servant of God;"

12 Knowledge: He said: "He taught Adam all the names" and "He taught him [Jesus] the Book and Wisdom;"

13 Blowing the spirit in them: "I blew from my spirit in him [for Adam]," "We blew in it from our spirit [for Jesus];"

14 Death;

15 Lack of father. 
As can be seen from this list, there is no mention of Adam having a mother as a common similarity. Recall, the Qur'ān itself states that Mary conceived Jesus asexually, i.e. without a father:

Verse 12 - Mention in the Qur'ān the story of Mary. She withdrew from her family to a place to the east and secluded herself away; We sent Our Spirit to appear before her in the form of a perfected man. She said, 'I seek the Lord of Mercy's protection against you: if you have any fear of Him [do not approach]!' but he said, 'I am but a Messenger from your Lord, [come] to announce to you the gift of a pure son.' She said, 'How can I have a son when no man has touched me? I have not been unchaste,' and he said, 'This is what your Lord said:' 'It is easy for $\mathrm{Me}$ - We shall make him a sign to all people, a blessing from Us.' (Qur’ān 19:16-21)

The "spirit" mentioned in this scenario is usually understood to be the Archangel Gabriel, who came to Mary in the form of a man (Nasr 2015, 768). Mary's very own statement recorded in the Qur'ān makes it clear that Jesus was born without a father: "How can I have a son when no man has touched me? I have not been unchaste." So even if one wanted to maintain a parental similarity between Jesus and Adam in light of this point, the analogical crossover is on Jesus and Adam not having a father.

However, one could still maintain that Adam having a mother is not ruled out at this point. This position loses potency once we review the context of Verse 11 thematically and historically. As we saw in Chapter 3, the entire chapter in which Verse 11 is located in is a critique of the Christian doctrine. It contains criticisms levied against Christianity on how it ascribes divinity to Jesus. Furthermore, the immediate verses that follow it mention how divinity exclusively belongs to God (Qur'ān 3:62), i.e. no man or prophet shares divinity with God. Similarly, the verses that come before this also mention Jesus calling his supporters who believe in the unitary God (Qur'ān 3:52). Looking at the Qur'ān as a whole, and given the various verses in the Qur'ān about Adam's creation in conjunction with this verse, suggests that this is a comparative point in which Jesus' miraculous birth, which is without a mother, is less miraculous than Adam's parentless creation. The ending of the verse, "then He said to him, 'Be,' and he was," which is a common motif throughout the Qur'ān, is meant to illustrate God's omnipotence in that He isn't by bound by laws of nature and can do as He pleases. Accordingly, it doesn't make thematic sense to interpret this verse referring to Adam having a mother. Of course, this would not be a permissible reading for those who reject miraculous creations like the one suggested here.

Historically, the comparison with Adam is being made because there was a particular Christian sect which believed that Jesus was divine because he was born miraculously, i.e. without a father. Understood collectively, 
the whole point of this verse is rhetorically to demonstrate that if Jesus is considered to be divine because he had no father, there is Adam who should be deemed even more miraculously because had no mother and no father (Principle 2). However, it does need to be stated that this historical context is based on an ahād hadīth, and, more specifically, in the terminology of hadīth specialists, it comes under mursal (Al-'Awnī 1997, 452-453). This is the classification applied to hadit ths where the name of the narrator between the Prophet Muhammed and the third narrator is missing, as shown below.

\section{Prophet Muhammed $\rightarrow$ Missing person $\rightarrow$ Third transmitter}

Hadīth scholars have generally been critical of the authenticity of such hadīths (Brown 2009, 91-92). In al-Mustașfā, a work of jurisprudence which we briefly discussed in Chapter 9, al-Ghazālī (1987, 650-656) states that mursal hadīths could be accepted under a few conditions. While ahād hadīths aren't theologically binding, they can be substantiated by scripture that is mutawatir. So if it is understood that Adam was created miraculously through the Qur'ān, this hadīth could be used to provide the historical context for this particular verse. But even if this was hadith was not considered reliable, the argument of thematic inconsistency would remain. Given these points, Batchelor's interpretation seems to be strained.

In addition to Verse 11, Batchelor provides a very creative account of how Verse 10 can be interpreted in light of his pre-Adamic mother narrative (2018, 496-497):

Use of nafsin wahidatin in this verse suggests that Adam's zygote (fertilised egg) appeared first and the Eve (as zawjaha) separated from him. By calling in this seminal 'creation' verse to respect the wombs that bore you, God appears to infer here that Adam and Eve were created within a womb. This writer draws attention to the fact that 'nafsin wahidatin' is grammatically feminine and also highlights the double usage of the feminine pronoun ' $h \bar{a}$ ' in both 'minh $\bar{a}$ ' and 'zawjaha In line ... with orthodoxy Islamic teachings and scholarly consensus ... 'nafsin wahidatin' refers to Adam. The proposed explanation for the divine designation of the word 'nafs' as feminine, accompanied by use of the feminine ' $h \bar{a}$ ' suggests that nafsin wabidatin is not yet fully human, which is explained by the fact that the 'nafsin wabidatin' is in a zygote stage. God would have only 'blown' in the rüh (to make a complete spiritual being) subsequently at the advanced stage. This seems to be the most logical explanation.

The upshot of Batchelor's perspective is that nafsin wähidatin, which is translated as a single soul, is for him a fertilised egg, or, in other words, a zygote. He then explains that the best scientific explanation for humanity being created from a single soul is that Adam and Eve formed as 
monozygotic twins in a pre-Adamic entity. Others have put forward similar views. ${ }^{9}$

However, there is something deeply problematic with how Batchelor has transmogrified the word "nafsin" (soul). In Arabic, it is commonly known that nouns are either masculine or feminine. There are specifically three kinds of distinctions by which words are either male or female, including semantic gender, morphemic gender, and grammatical gender (The Qur'ānic Arabic Corpus 2009). Semantic gender is an ascription due to either being genuinely gender-based or because they are artefacts of the language (Principle 1). For example, if someone wanted to refer to Ellie, say a female colleague, with an adjective in Arabic, they would do so with a feminine conjugation because she is a biological female being. However, in Arabic, femininity is also ascribed to objects even though they are biologically gender-neutral, such as the sun, i.e. grammatical gender. The sun has no inherent feminine qualities like a woman, yet in Arabic, the sun is always written with feminine grammatical correspondences..$^{10}$ The word "nafsin" is like that. It is a feminine word due its semantic gender. As stated earlier, it generally means soul or a person but in of itself does not have a biological gender (Badawi and Haleem 2008, 954-955; Lane 2010b, 2826). Following this, the pronoun " $b \bar{a}$ " - the corresponding pronoun for feminine words - is used because of grammatical gender. Once the subject is determined to be either male or female, all the corresponding pronouns must grammatically follow that specific gender. Thus, the feminine reference to "it" or "its" is because of the semantic prescription of nafsin in the Arabic language, which entails the grammatical enforcement of the following pronouns. Accordingly, Batchelor's interpretation of nafsin in contrast to $r \bar{u} h$, based on gender differences in the language, is thinly argued, and does not seem to conform to its standard usage, i.e. interpreting it as a zygote (Principle 1).

\section{Suspension of judgement}

In Chapter 4, we saw that Caner Taslaman and David Solomon Jalajel occupy very similar strategies. Both of them rely on the principle of abstaining from judgement if the details are simply unavailable in scripture to be able to make a case for or against evolution. While Jalajel argues that Adam's miraculous creation is to be accepted at face value, Taslaman seems to suggest that even Adam can be explained without resorting to miracles. There are two primary strategies that Taslaman uses to make his case.

First, Taslaman argues that one should be agnostic about miracles. His main point is that God could have performed miracles through existing laws of nature that were unknown at the time, or he could have violated them. Either way, we cannot be sure so one cannot take any firm stance on the matter (Taslaman 2020, 93):

Whether or not the laws of nature were suspended is a matter of philosophical debate. In order to properly answer the question 'Does God 
suspend the laws of nature?' we need to perfectly understand the laws of nature; however, we are still far from such a complete understanding. Religious believers can agree that divine intervention can happen with or without the suspension of laws. Whichever position is chosen, the other remains a possibility. A Muslim cannot sensibly claim that 'God cannot create species by suspending the laws of nature;' nor can a Muslim sensibly claim that 'God cannot create species without suspending the laws of nature.' Both options are possible and, since we lack epistemic access to God's intentions, we should withhold belief about which is actual. The content of the Qur'ān does not force us to make a choice.

This point can be conceded to Taslaman. God may have very well performed miracles which people may not have recognised as laws of nature due to the limited scientific knowledge at the times they were performed in. It is also possible for God to perform miracles that are very improbable events. But in Ash'arite theology, God can perform miracles that are event beyond current conceptions and improbabilities. Recall from Chapter 6, Ash arites claim God can do anything that is logically possible, which is a broader set of possibilities than what is scientifically possible (recall Figure 6.1 in Chapter 6). So even if we scientifically advanced to radically new heights such that we could get a "complete understanding," that doesn't have any bearing on the question of God performing miracles beyond those limits. The very function of miracles is to show God's absolute power by manifesting events that run counter to natural regularities. Just as God may perform miracles that were beyond past civilisations' scientific knowledge, so too God may perform miracles that are beyond our current knowledge, no matter how advanced. The issue of miracles is tightly linked with Taslaman's hermeneutic positions, which leads us to his second strategy.

The second strategy which Taslaman utilises is to show that the Qur'ān is silent on the creation of everything, including Adam and humans. In comparison to Jalajel's Adamic exceptionalism, which entails that Adam was born miraculously, Taslaman claims that does not have to be the case. $\mathrm{He}$ makes a few points regarding Verse 10. First, he rejects the interpretation of Eve possibly being created as a part of Adam (Taslaman 2020, 65):

Some Muslim theologians interpret 'one living kind/entity' (nafsi wahida) in this and other verses as the creation of Eve from Adam's rib, and descent of all humankind from this couple. However, the Qur'ān does not imply anything about the creation of Eve from Adam's rib. This belief snuck into the Muslim world from the Judeo-Christian tradition [Isrāiliyāt]. Muslim scholars hold that [Isrāiliyāt] contains many apocryphal narratives; thus, Muslims should not base their religious views about creation on such narratives. 
In short, he is criticising the hadiths that suggest Eve was created from Adam's rib, as they belong to a genre of a hadīths which contain Judaic and Christian narratives, what is referred to as Isräiliyāt, which are known to be weak in their integrity. This criticism has been shared by others (Nasr 2015, 189). But of course, this argument doesn't in of itself hermeneutically invalidate the possibility of Eve being created from a part of Adam, rib or otherwise. But Taslaman (2020, 65-66) goes further and makes a case against Eve being created from a part of Adam from a moral standpoint:

This narrative is also exploited in the denigration of women - woman's creation from and for man is used to attribute ontological inferiority to women. Some go so far as to claim that since woman was created from an errant rib, she has an inborn tendency to go astray. Again, the Quran neither contains nor tolerates any such sexist arguments.

This may very well be the case, but this a socio-political argument and problem, not a hermeneutic one. So while there may be sexist applications of Eve's interpretation being created from Adam, rib or otherwise, it doesn't necessarily undermine this hermeneutic reading.

Taslaman then goes on to argue for a reading of this verse in which he interprets the single soul (nafsin wähidatin) as an essence or a natural kind:

If we understand the term 'creation out of one kind/entity (nafsi wahida)' the same way-as members of the same, human species-as in the two verses above, all confusion is clarified ... the claims of these verses extend to all of humanity; the verse ... begins with the exclamation "O Humankind!" goes on to say that God '...has created you (khalaqakum) out of one living kind/entity.' 'You,' then, refers to the whole of humankind, including the first human (Adam).

Unlike the second reading of this verse that we looked at earlier in Chapter 3 , in which the essence argument was restricted to Eve, i.e. Eve was made in the same essence as Adam, Taslaman stretches this argument to all of humanity. This seems to be a forced reading. The main problem with this reading is that the verse makes it quite clear that the men and women being referred to in the second half of the verse come from a pair: "... and from the pair of them (minhumā) spread countless men and women far and wide." To claim that this verse reads as an essence for all humanity, as opposed to an initial individual or pair, is a stretch. Taslaman needs to account for how people were created from the pair of Adam and Eve. (Principle 1; Principle 2).

Finally, he goes on to assert the grammatical form should be different to what is mentioned in the verse if it indeed is referring to Adam (Taslaman 2020, 67): “If, as some have claimed, 'one living kind/entity' referred solely to Adam, the Arabic word should have begun with the definite article 'al' (al nafsi wahida)." To be clear, Taslaman suggests that for this verse to be 
referring to a single being, it should have had the definite article such as to read the single soul, so it's referring to a specific individual. This is a problematic claim because the verse's usage is the correct one to convey the commonly understood meaning. There is nothing wrong in the verse that warrants Taslaman's suggestion. Interpreted as it is, the verse is perfectly compatible with it referring to a single individual or a single essence: "who created you from a single soul." Had the phrase been definite, it would read "who created you from the single soul," which would imply there was only one soul or essence in existence, not just that from which humanity was created, or it would have to refer to a soul or essence that was already mentioned in the discussion immediately beforehand. Furthermore, Taslaman's suggestion is in of itself syntactically problematic because the word order he suggests (al-nafsi wähida) is no longer an adjective phrase but a sentence in itself, giving the verse a syntactically impossible structure that would be reflected in English translation as follows: "People, be mindful of your Lord, who created you from the soul is one, and from it created its mate, and from the pair of them spread countless men and women far and wide." It seems, then, that Taslaman's proposal is grammatically invalid, and thus renders a convoluted reading (Principle 1).

As for Verse 11, he reverses the general understanding of the verse. He is quoted a length to illustrate his argument (Taslaman 2020, 63-64):

Some claim that 'the nature of Jesus is as the nature of Adam;' implies the fatherless creation of Adam; since Jesus was created without parents, Adam was also created without parents (hence did not evolve from pre-existing species). Yet, according to the Qur'ān, Jesus had a mother and was born through the normal and natural processes of pregnancy and delivery. If Adam is in all ways like Jesus, Adam must also have been born from a mother through very normal and natural processes. The similarity of Adam to Jesus, then, cannot simply imply coming into existence without processes.

Given this verse's narrative context concerning Jesus and Christians, the subject of the verse is not Adam but Jesus, aiming to correct misbeliefs about Jesus. According to the Islamic faith, the common misbelief about Jesus is the attribution of divine nature to him. Therefore, the verse proceeds as follows: 'You attribute divinity to Jesus, yet his essence is but dust just as Adam; like Adam, Jesus does not have a godlike nature.' The verse, taken in context, says nothing about the parent-less creation of Adam. Instead, it aims to correct a mistaken belief about the nature of Jesus. Hence, its reference to Adam does not indicate his fatherless creation; instead, it reveals the very ordinary creation of Jesus from the dust and thereby stresses that he has no extraordinary nature.

In short, Taslaman maintains that the Qur'ān itself indicates that Jesus was born through natural processes. If this is the case, Verse 11 could 


\section{Hermeneutic considerations}

be read with this as the analogical crossover to Adam, i.e. he was born from a mother. This argument is fundamentally flawed for one main reason. As seen earlier with Verse 12, while Mary might have had a natural pregnancy and labour, but it is, in fact, Jesus' conception that's miraculous, i.e. he is born without a father that is being highlighted here. In other words, he is a miraculous creation because he was created asexually, which is impossible for humans to do (Nasr 2015, 769). This is evident by Mary's own words: "How can I have a son when no man has touched me? I have not been unchaste." Unless Taslaman wants to claim that Mary has spoken untruthfully here, he has either misunderstood or neglected this event's miraculous component (Principle 2; Principle 3). As stated earlier when we reviewed Batchelor, Verse 11 refers to a comparative point in that if Christians believe in the divineness of Christ because of his miraculous creation, i.e. asexual production, then there is Adam who is no less even more miraculous because he was born neither from a mother nor a father.

Given these two points, Taslaman has one of two options. If he wants to maintain a theological agnostic stance on miracles and evolution, he must explain how human asexual reproduction is scientifically possible and give us a valid hermeneutic reading of Mary not being a virgin. If he cannot, then his claim about theological agnosticism on evolution loses warrant (Principle 2; Principle 3). Jalajel doesn't succumb to this error. For Jalajel, Adam's miraculous creation is taken to be a given because scripture is clear on the matter for him. The only thing he suspends judgement on is the notion of pre/co-Adamic human beings; there is nothing explicit in the Qur'ān nor the hadīths, as we shall see in the next section, that negates nor affirms this idea. Accordingly, he suspends judgement precisely on this point. This allows him to maintain Adam's miraculous reading with a connecting lineage to modern humans, and the possibility of all people on earth today having a lineage that predates Adam (see Figure 4.2 in Chapter 4). Between Taslaman and Jalajel, al-Ghazālī's framework would agree with the latter on the application of suspending judgement (Principle 7).

\section{Ḥadīths and evolution}

As noted in Chapter 3, there are a few hadīths which are relevant to our discussion on evolution. In this section we shall review those hadiths to assess what status those hadīths have, and how they could be engaged with in the context of al-Ghazālī's theological framework.

\section{Theological stance on hadiths}

In Chapter 9, we saw how al-Ghazālī does not find $a h \bar{a} d$ hadīths to be doctrinally binding for essential belief. So if evolution is deemed to be a strong reason enough reason, or if there are several problems with the hadìths, 
Table 10.1 Summary of hadīths relevant to evolution (these were identified in Chapter 3).

\begin{tabular}{|c|c|c|c|}
\hline Hadìth Content & Hadith Source & $\begin{array}{l}\text { Transmission } \\
\text { Rating }\end{array}$ & $\begin{array}{l}\text { Strength } \\
\text { Rating }\end{array}$ \\
\hline Adam is 60 cubits ( 30 metres) & Bukhārī (6277) & Aḥ̄àd & Șaḥīḥ ${ }^{11}$ \\
\hline God created Adam on Friday & Muslim (2789) & Ahāād & Șaḥị̣̣̂n \\
\hline $\begin{array}{l}\text { God took a handful of soil } \\
\text { from the earth and fashioned } \\
\text { Adam's lifeless body }\end{array}$ & Muslim (2611) & Ahād & Șaḥīḥ ${ }^{13}$ \\
\hline Adam was created from dust & Tirmidhī (3955) & Ahāād & Hasan $^{14}$ \\
\hline Your father is one & Ahmmad (23479) & Ahāād & Șahịị̣̂ ${ }^{15}$ \\
\hline
\end{tabular}

the hadīths can be rejected. But if they discuss points already established in strong sources, e.g. mutawātir scripture, then they cannot be dismissed (Principle 4).

Table 10.1 summarises all the hadiths we have looked at thus far that are generally considered to be problematic in the discussion of evolution (see Chapter 3). As it can be seen, all these hadīths are ahād, which means that they aren't theologically binding despite most of them being sahīh. However, three of the hadīths align with or are corroborated by the narratives of the Qur'ān. These include the hadīth about Adam being created from the soil of the earth (Muslim 2611), the hadīth about Adam being created from dust (Tirmidhī 3955), and the hadīth which mentions humanity's father is one (Ahmad 23479). So these cannot be dismissed as they are substantiated independently by scripture that is mutawatir (review verses discussed in Chapter 3 if needed). These three hadīths are perfectly acceptable from the perspective of creationism, human exceptionalism, and Adamic exceptionalism, as all three camps believe in the parentless creation of Adam and Eve, and that all humanity can be traced to these two individuals. By contrast, the no exceptions camp will likely see these as being problematic scripture because they conflict with their narrative of nothing being an exception to the process of evolution.

The hadīth about Adam being created on Friday has no mention nor reference in the Qur'ān. Furthermore, this hadīth was discussed in Chapter 3 (when discussing the issue of chronology of creation) where it was noted that it has several variations with different wordings, which reduces its epistemic status. However, even if it were taken on face value, it would not be a problem for creationism, human exceptionalism, and Adamic exceptionalism. It would also not be problematic for the no exceptions camp, as the hadīth only mentions a creation date of Adam and not that he was created miraculously. So this hadīth needn't be dismissed by any camp. But if this is understood as Adam being created on a specific date miraculously in light 


\section{Hermeneutic considerations}

of other Qur'anic verses and hadīths, then it could be problematic for the no exceptions camp.

This leaves us with the hadīth about Adam being 30 metres tall. As mentioned in Chapter 3, this hadīth remains problematic even if evolution is untrue; the hadīth is only important because it has been raised as an issue in the literature of Islam and evolution. The notion that Adam is of that height conflicts with the general understanding of physics and human anatomy, which is why this hadīth needs to be scrutinised further. This is done in the following section.

\section{Hadīth analysis}

This analysis is primarily based on the work of Muntasir Zaman (2020) called, At The Crossroads of Science and Scripture: An Analysis of the Hadìths on Prophet Adam's Height, which is one of the most detailed and exhaustive analysis of this particular hadīth, and will suffice for our purposes. As a start, Zaman takes the epistemic conflict very seriously. He acknowledges that the sciences limit how far human height can go, which then raises problems for the concerned hadith. This becomes the starting point for assessing the veracity of this hadīths through which he identifies three distinctive positions: harmonisation $\left(t a^{\prime} w \bar{l} l\right)$, prioritisation (tarjīh), and suspension of judgement (tawaqquf). ${ }^{16}$

In the harmonisation category, Zaman identifies some scholars who can reconcile the hadīths with the natural sciences. This is done by understanding Adam's height as his description in heaven and not on earth. So one can still maintain a surface level reading of the hadīths. As a point of comparison, this differs with the direct metaphorical track adopted by Guessoum, as we saw in Chapter 4. He offers no suggestions from the language which may support his conclusion. The hadīths of Adam having a certain height mentions a number, i.e. 60 cubits ( 30 metres). One could look into this specific detail and see if this a number of exaggeration or hyperbole in classical Arabic. As noted in Chapter 9, the numbers of exaggeration in classical Arabic are associated with 7, e.g. 70 and 700 (Omar 2010, 245-246; Lane 2010a, 1297-1298). This point is important because if 60 was a number of exaggeration or hyperbolic language, then Guessoum could have made a case that Adam was probably really tall rather than literally having a height of 60 cubits ( 30 metres). But this consideration was ignored. The recurring problem with Guessoum's approach is that he does not acknowledge nor entertain a wider set of hermeneutic principles or internal constraints that come with understanding Islamic scripture.

In the prioritisation category, Zaman asserts that a careful reading of all variants of this hadīths, i.e. different transmission lines, lead to the startling conclusion that not all of the hadīth transmitters mention a numerical value of Adam's height. This collective analysis weakens the epistemic value given to the specific mention of the numerical height of Adam. Accordingly, 
because the scriptural side is epistemically weaker, one can happily give credence to the natural sciences in this particular instance.

The final stance is simply the suspension of judgement. Sometimes scholars are happy to suspend judgement. Zaman gives the example of Ibn Hajar Asqalāni, one of the most authoritative scholars on hadīths, particularly on Bukhārī's hadīth corpus in which the concerned hadīth is located in. Ibn Hajar acknowledged that the archaeological demands of this day didn't align with the hadīth, but did not attempt reject the hadīth nor reinterpret it; he simply left it as it is. There may be several reasons for doing so, one of which could be due to the thinker's sensitivities and respect for Islamic scripture. If one finds a conflict, it doesn't necessarily mean that scripture is necessarily wrong, but it may reflect one's capabilities.

Through this study, Zaman's fundamental message is to give hadīths their due attention and not dismiss them swiftly. Just as there are epistemic impressions provided by the natural sciences, so is the case with Islamic scripture. The critical attention given to the methodologies of the natural sciences must equally be replicated and emulated with the methodological framework of hadīths studies. Given these three different takes on the matter, it should be noted that al-Ghazāli could easily accept one of these positions. Furthermore, these possibilities also illustrate why ahăd hadīths do not establish theologically binding doctrine according to al-Ghazālī, even though they must still be engaged with showing full consideration and respect. While the other hadīths were not looked at in this level of detail in this study, one could entertain similar conclusions for them, which will be left for others to look into.

In short, all the hadiths that we looked at in this study are completely acceptable under creationism, human exceptionalism, and Adamic exceptionalism. However, some hadīths might be problematic for the no exceptions group.

\section{Human and Adamic exceptionalism}

Strictly from a hermeneutic point of view, al-Ghazālī would not have a problem with creationism. Given the ambiguity of non-human creation in scripture, as noted in Chapter 3, al-Ghazālī's framework is compatible with creationism. Al-Ghazālī would, however, disagree with the no exceptions camp for the reasons outlined earlier. His framework permits the possibilities of miracles and, therefore, does not see the need to reinterpret Adam's miraculous creation (Principle 3). This leaves us with human exceptionalism as argued by Yasir Qadhi and Nazir Khan, and Adamic exceptionalism as argued by David Solomon Jalajel, which will be evaluated in this section.

Both proposals follow methodological principles as outlined by classical Sunnī scholars. Jalajel takes a broad denominator of all orthodox Sunnī 
schools of doctrine. This includes Ash'arism, Māturīdism, and the Atharism. Using this denominator as his working framework, he suggests that an alignment between Islamic scripture and evolution can be made with Adam being excluded from the process. Qadhi and Khan argue specifically argue from an Athari perspective, particularly from the lens of the well-known Islamic scholar from that tradition, Ibn Taymiyya. For brevity, the Atharī school is more theologically sensitive when it comes to hadīths. So the epistemic weight given to hadiths would not be as lax as it is with the Ash'arite (and Māturīdite) school. Accordingly, even if a hadīth is ahăd, it doesn't mean it is theologically non-binding. This is one point of difference between al-Ghazālī and/or Ash'arism, and the Atharī school and/or Ibn Taymiyya (among others). Regardless, Qadhi and Khan are open to evolution, but not for humans, which is why they believe humans are excluded from evolutionary processes. ${ }^{17}$ Obviously, Jalajel's proposal is closer to what no exceptions camp would deem appropriate.

Qadhi and Khan's proposal hermeneutically involves taking the verses as they are (as does Jalajel). That means Adam was created miraculously. Furthermore, they take it that Adam is the starting point of humanity, which is why Adam and by extension all humans are excluded from the process of evolution. For them, this is implied by all the Qur'annic verses and hadīths that were reviewed in Chapter 3. However, Qadhi and Khan face three issues with their proposal. These are the issues of divine deception, incest, and the genetic bottleneck. Let us review each of these to see if these are problematic from the perspective of Ash'arism.

\section{Divine deception}

Qadhi and Khan already address this contention, as we saw in Chapter 4, but it is helpful to raise this again here for better evaluating between human and Adamic exceptionalism. One problem with Qadhi and Khan's proposal is that if science gives us one understanding of how humans came about, and Islamic scripture is giving us a different account altogether, the conjunction of these two points could be used to assert that God is deceptive. Why would God give us faculties that can be used to determine the laws of nature on the one hand and yet inform us of events that go against those laws in Islamic scripture? This objection does not apply to Adamic exceptionalism, since what nature shows is that the human species evolved from prior species. This is exactly what happened under the scenario of Adamic exceptionalism, with Adam and Eve not impacting upon natural history or common descent of humans in any way. Still, Qadhi and Khan make it clear this is not a problematic concern. Their case rests on the epistemic differences between science and revelation. Science works with the presumption that the laws of nature are fixed. Miracles challenge this presumption. Accordingly, miracles, like the creation of Adam (and Eve), that were performed in the past are indeterminable from a scientific perspective. 
Qadhi and Khan make it clear that Adam and Eve could have been created with all the right biological properties such that whatever was demanded by evolutionary processes was maintained. This is theologically plausible and scientifically undeniable. Under these considerations, revelation, which is considered to contain true historical accounts, is simply filling in our scientific blind spots. This line of reasoning is unproblematic from an Ash'arite perspective.

To be sure, this argument could extend to Adamic exceptionalism insofar that any miraculous event violates the appearance of a world where all the natural laws are fixed and immutable. However, this is a different order of reasoning than the argument of God placing deceptive patterns in nature to indicate that the human species evolved when it did not. There is an appreciable difference in degree between humans exclusively originating from a couple who were created miraculously, and an excluded couple being created miraculously alongside other humans created through evolutionary processes. So Adamic exceptionalism has a relative benefit over human exceptionalism with respect to this particular point.

\section{Incest}

If Adam and Eve were the first couple of humankind, and if there were no other humans at the time, it entails that Adam's immediate descendants must have practised incest. This could be raised as a morally objectionable concern. After all, the Qur'ān (4:23) makes it explicitly clear that incestual relationships are forbidden. How can these two points be reconciled?

It is generally accepted by Muslims jurists that moral commands revealed to the earlier prophets are not necessarily identical to the commands revealed to Prophet Muhammed. Al-Ghazālī $(2000 \mathrm{~b}, 98,165)$ himself discusses this point in his work of jurisprudence, al-Mustașfā. Indeed, al-Ghazālī emphasises that God could have given any law He wishes to any faith community of the past (Al-Ghazālī 2000b, 165):

God can require His servants to follow whatever previous or new Divine Law ( $\operatorname{Sharī}^{\circ} a$ ) He wishes, or some of it being previous and some of it being new. None of this is impossible for Him in and of itself nor for any harm it might entail.

Accordingly, the objection of incest wouldn't hold weight in the Ash arite perspective. Given the position of divine command theory espoused by Ash'arism, which we reviewed in Chapter 8, moral commandments are entirely dependent on the will of God. It is then entirely conceivable that God allowed certain things in the past that are no longer permissible; Adam's sons and daughters could have been allowed to marry one another, which, if they did, would not pose a moral objection or concern in the Asharite 
paradigm (Eissa 2017; Malik 2021). By contrast, Adamic exceptionalism doesn't necessarily raise this problem.

\section{Genetic bottleneck}

The biggest issue with their proposal is the genetic bottleneck problem. This is the scenario in which a population is significantly reduced such that the species involved loses an immense amount of genetic variation, which is important because it entails that a species will suffer the challenges of disease and reproductive issues, and might end up going extinct (Futuyma and Kirkpatrick 2017, 173-174). If humanity started with a single couple, i.e. Adam and Eve, as suggested by Qadhi and Khan, this makes for the improbable scenario of having successful, i.e. healthy, offspring through which humanity came about (though it is theoretically possible for plants, e.g. see Losos 2014, 308). In other words, this outcome is scientifically challenging and very questionable if not impossible. Whether such a possibility is scientifically plausible will be left to the scientists to determine. Another possibility for Qadhi and Khan is to explain this through miracles. Perhaps God safeguarded the offspring of Adam such that they would be protected from health problems while practicing incest. This would allow human diversity to progress and blossom, leading to humans all the way to modern times. However, this position would not be based on any clear scriptural text, but rather a rationalisation after accepting Adam's miraculous creation based on the text. So it is a speculation that fills in the gaps. This is where Jalajel's proposal does better. Recall, Jalajel argues that the creation of Adam is indeed miraculous due to textual proof. But scripture does not deny the possibility of there being pre/co-Adamic human beings. If this is the case, then Adam and Eve were not the only human beings. This bypasses the genetic bottleneck issue if Adam and Eve's descendants intermingled and procreated with other humans. Jalajel's thesis includes no other position that Qadhi and Khan might have an issue with, save Adam being the first member of humankind, and therefore could align with Jalajel's proposal. With this particular issue, then, Jalajel's proposal fares better by avoiding the genetic bottleneck problem.

To be clear, Jalajel's framework is compatible with Qadhi and Khan's proposal. Jalajel simply makes it the case that Adam's miraculous creation must be maintained due to the scriptural evidence. Furthermore, scripture only points out that our lineage can be traced back to him, which can be inferred from Verse 10 and some hadīths we looked at earlier, e.g. Ahmad (23479). But scripture is silent on whether there were humans on Earth before his appearance. ${ }^{18}$ So he could or couldn't have been the first of humankind, which is why one has to do tawaqquf (Principle 7). Given this point, Jalajel's framework allows multiple possibilities to be catered for 
including human exceptionalism. What Jalajel himself argues for is that Adam is not necessary for humans to have come about. God could have created pre/co-Adamic human beings that were products of evolution. Adam was created miraculously and was made a prophet, an honour that was bestowed on him. In this scenario, he entered the community of humans that were already there at the time, the date of which is unknowable by scripture. Adam's descendants mingled and integrated with them, and through that process, all humans have a lineage that traces back to Adam and the origins of life that predate Adam. This way, Jalajel goes further than Qadhi and Khan by accommodating common ancestry for all humans today while explicitly exempting Adam from the evolutionary process.

Al-Ghazālī could happily align with either option. He could accept human exceptionalism, as suggested by Qadhi and Khan, despite the three concerns that were raised. Simultaneously, he could accept Jalajel's proposal and align himself with Adamic exceptionalism. Given that both are possible, and given his point in not forcing an assertion when equally valid possibilities are available, he would refrain from making a stern judgement (Principle 5; Principle 6). But in light of evolution, Adamic exceptionalism seems to be the closest alignment one can get with al-Ghazālî̀s framework.

\section{Conclusion}

In this chapter, we looked at some of the arguments creationists (and human exceptionalists) raise against human evolution as well as the proposals put forward by the no exceptions camp. Both of them were found wanting. In the hermeneutic arguments against human evolution, the verses they utilised or referred to don't strictly warrant a rejection of human evolution. The specific hermeneutic constraint that makes human evolution difficult to consider is Verse 10 and Verse 11. To be clear, those criticisms don't entail that al-Ghazālī would hermeneutically reject creationism. His proposal is entirely compatible with creationism if it were true. It is only the specific arguments we reviewed in this section that do not warrant a rejection of human evolution.

The proposals for trying to reconcile the creation narrative of Adam with human evolution equally had issues. They either led to idiosyncratic readings that defied the language, either by entertaining metaphorical readings when scripture doesn't warrant it, or infusing new meanings into some of the words, or neglecting Verse 10 and/or Verse 11 in their analyses. Excluding some exceptions, the general motivation seems to be a complete harmony between science and scripture, which entails rejecting miracles. However, the problem here is that we see more of a disagreement over God and his relationship over the natural world that is then seeping over to the hermeneutic discussion. If a thinker cannot accept miracles, they will have to resort to one or more of the strategies looked at in that discussion. 
But al-Ghazālī’s framework disagrees with the metaphysical presumptions of this approach as well as the hermeneutics.

On the discussion of suspending judgement (tawaqquf), we noted how Taslaman's proposal isn't coherent. He seems to strain the reading of Verse 10. Furthermore, by treating Jesus' conception as a natural one, he transposes this to Adam and states that he had a mother too. This argument in conjunction with his agnostic stance on miracles allows him to reason that there is nothing explicit in the Qur'ann that warrants a rejection of evolution, and hence one should theologically suspend judgement over this issue. However, as we noted earlier, Taslaman's reading neglects that Mary herself testifies Jesus' miraculous conception. This undermines his position. By contrast, Jalajel maintains Adam's miraculous creation but suspends judgement over pre/co-Adamic humans. Comparatively, Jalajel's thesis fares better.

In the hadīths section, we determined that all hadīths can be easily accepted in al-Ghazālī's hermeneutic framework. Three of the hadīths cannot be readily dismissed because they are corroborated by the Qur'ān, i.e. Adam's miraculous creation from earthly materials. The other hadīths don't share this advantage, but can easily be accepted given the nuances discussed therein. All of them are perfectly compatible with creationism, human exceptionalism, and Adamic exceptionalism. It is only the no exceptions camp that might find some of them problematic.

Finally, we reviewed Qadhi and Khan's proposal of human exceptionalism and Jalajel's Adamic exceptionalism. Given al-Ghazālī's framework, both are possible scenarios. They cater for miraculous events which don't end up straining other verses or words beyond their hermeneutic limits.

Given this analysis, it seems al-Ghazālī’s framework is hermeneutically compatible with creationism, human exceptionalism, and Adamic exceptionalism. He would reject the no exceptions stance because of hermeneutic problems they encounter. Consequently, it seems that the closest alignment one can get with evolution would be Adamic exceptionalism as argued by Jalajel.

\section{Notes}

1 Al-Ghazālī discusses that mutawātir hadīth establish binding tenets of creed in Criterion (Al-Ghazālī 2002, 117, 128), and he enumerates the conditions for mutawātir hadīth and how they convey certainty of knowledge in al-Mustașfā (Al-Ghazālī 2000b, 105-108, 112). He discusses how aḥād hadith cannot provide certainty in al-Mustașfa al-Ghazālī 2000b, 115-116), and how as a consequence their rejection does not entail unbelief in Criterion (Al-Ghazālī 20002, 117). He discusses how aḥa d hadith are to be relied upon for devotional purposes in al-Mustașfā (Al-Ghazālī 2000b, 116-123), and elaborates on the conditions for their reliability, i.e. their being sahīh, in al-Mustașfā (Al-Ghazālī 2000b, 123-137). 
2 But, of course, a mutawätir source has to be accepted regardless of the difference of opinions on interpretation.

3 For a comparison of Ibn Rushd and al-Ghazālī's hermeneutics, see Wohlman (2010).

4 This is also expressed by Guessoum $(2011 \mathrm{a}, 16)$ with a hint of disagreement with theologians: "The question of miracles constitutes perhaps the clearest bone of contention between science and religion today, and it will still be for some time, until scientists have developed a better understanding of many such occurrences ..., and theologians have developed a reasonable standpoint on the concept."

5 It should be noted that hermeneutic scientism was not known to al-Ghazālī. This is a modern conception which is being discussed in light of al-Ghazālī’s framework.

6 This point may be lost to the reader unfamiliar with Arabic. Unlike English which has singular and plural words, words in Arabic can be mentioned in singular, dual and/or plural forms.

7 This position has some parallel with Denis Alexander's (2008, 236-239) idea of Homo divinus.

8 I do not claim Ahmad's interpretation is necessarily tenable. I only raise this point to show an alternative interpretation of the same verse being used by Keller by a well-known interpreter of the Qur'ān.

9 It seems that Batchelor refers to Shanavas' old book. However, Shanavas seems to have abandoned this specific point. In his older book he explicitly uses the same terminology as Batchelor (Shanavas 2005, 174): "In nature there are two kinds of twins - dizygotic and monozygotic. Dizygotic twins develop when two different sperm cells fertilise two different ova (eggs). In monozygotic twinning, a single sperm fertilises a single egg. Monozygotic twins emerge from the separation from a single developing embryo into two independent parts. Monozygotic twins are almost always the same sex. However, the Qur'ān states in verse one of chapter four that the first human being was created from a single living entity (nafsin wähidatin) from which God created a mate (zawj). Therefore, Adam and Eve were created from a single living entity (nafsin wāhidatin). The Qur'ān also states that humans originated from a single male and female. Therefore, Adam and Eve were monozygotic twins A transmutation occurred in the sex chromosome of one of the twins, making into a "mate (zawj)" for the other." However, in the same chapter or section in his new book, as far as the I can identify, no reference is made to any monozygotic twins. Implicit mention is made to the "seeds" of pre-Adamic entities but nothing else. For comparison, see Shanavas $(2010,129-152)$.

10 By contrast, the moon is grammatically considered a masculine object.

11 Șahīh by definition because it is in Bukhārî̀s (the hadīth compiler) collection.

12 Șahị hy definition because it is in Muslim's (the hadīth compiler) collection.

13 Șahị hy definition because it is in Muslim's (the hadīth compiler) collection.

14 Hasan according to al-Albān̄i $(2000,136)$.

15 Șahīh according to Sho'ayb Al-Arna'ūt, the editor of the hadīth compilation, Musnad al-Imām Ahmad Ibn Hanbal. See Chapter 3.

16 This is not theological tawaqquf, but the one that is used for hadīth and jurisprudence. Recall from Chapter 4, this kind of tawaqquf is temporary because of uncertainty or ambiguity in scripture. This is unlike theological tawaqquf, which is maintained when scripture silent altogether on a subject matter. 
17 However, in a recent open discussion with Jalajel and myself, the author, Qadhi made it very clear that he is open to Jalajel's position, but he personally prefers human exceptionalism. See Qadhi et al. (2020).

18 The following is a response from Jalajel to my request for an elaboration on Qur'ān (4:1), which he kindly allowed me to share in this book (Jalajel, David Solomon. 2021. E-mail message to author, February 28):

You have asked me to clarify how Qur'ān (4:1) is not proof that God did not create biological humans before Adam and Eve. I must begin by saying the question of Adam, Eve, and human origins is addressed by a number of Qur'ān verses and authentic hadīth, all of which must be taken into consideration to get a full picture. However, since you asked me specifically about Qur'ān (4:1), I will address it first, then relate it briefly to the other relevant textual evidence.

When approaching scripture as evidence for purely doctrinal questions in contrast to questions of religious law, ethics, and spirituality - the strictest, most conservative hermeneutical standards were applied by classical theologians. Each text must be accurately understood for what it is clearly saying, and just as importantly for what it is not saying. Speculative interpretations are not allowed. It is important to keep pre-existing assumptions and personal biases to a minimum when establishing something as a matter of religious belief. The question at hand is a claim about what God did or did not create, so it is one that directly pertains to our beliefs about God's actions. Therefore, the strictest hermeneutical approach of the theologians is the one I will attempt to demonstrate in my examination of Qur'ān (4:1) while addressing the concerns that you have raised.

\section{[1] The term "naas"}

The word "naas" means "people".

It is a plural word without a singular in its own utterance. It is a plural for "insaan", but not the plural for the category or kind (jins). That plural for "insaan" is "ins". The word "ins" refers to a categorical concept. You will notice it almost always appears in the Qur'ān along with "jinn", since it is addressing two distinct categories of beings. When the word "ins" is used, it's default meaning refers to all people categorically. "Naas", by contrast, is used to refer to any multiplicity of people. It can refer to a small or large group of people. This is best illustrated in 3:173: "Those to whom the people (al-naas) said: Indeed the people (al-naas) have gathered against you..." In this verse, the first mention of "naas" refers to a delegation of people (with some commentators specifying the person of $\mathrm{Nu}^{\prime}$ 'aym $\mathrm{b}$. Mas'ū ${ }^{\prime}$ al-Ashja $\left.{ }^{(} \overline{1}\right)$ while the second instance refers to Abu Sufyaan and his army. The point is that the scope of what the word "naas" indicates is fully dependent on the context.

\section{[2] The phrase "Yaa ayyuhan-naas"}

As Ibn Hayyaan and other scholars of language emphasise, "Yaa ayyuannaas" is an address, a khitaab. When it appears in the Qur'ān, it usually refers to all people who are addressed by the Qur'ān, near or far, present and future, believer or unbeliever. This is emphasized by the word "ayyuhaa" which, when it appears in an address, restricts the matter to those being addressed and not to others who might share in their category. Therefore, the phrase does not address or refer to people before the Qur'ān was revealed. The first time "Yaa ayyuhan-naas" appears in the Qur'ān (2:22). It reads, "O people! Worship your Lord who created 
you (khalaqakum) and those who came before you, perhaps you will fear God." This is clear that the phrase encompasses the people who are being addressed and not those who came before them. Indeed, this verse explicitly distinguishes between those who are being addressed by the phrase "Yaa ayyuhan-naas" and those people who came before them. The people who came before were certainly also "naas", but they are not included in the address nor are they included in the ruling $(\mathrm{bukm})$ of the address. The people who came before them are not being compelled to pray by this verse that came after their time, and they are not included in the consequence that perhaps they will come to fear God for their compliance with this command. Their account in this world is already over, as well as whether or not they feared God. Likewise, when God says in Qur'ān (7:158): “Say: O people! I am God's Messenger to all of you!", we can be certain that it is restricted to the people who exist from the time of Prophet Muhammad (pbuh), even though we can also be certain that the people of previous nations were also equally "naas". Therefore, when this phrase is used, the ruling indicated by what comes after to is restricted to the people being addressed and not to all humans who ever existed, unless the statement itself expressly indicates the inclusion of others.

\section{[3] The phrase: “khalaqnaaakum"}

This phrase applies the ruling of God's act of creation from a single soul and applies it to the pronoun "you". This pronoun is the second person plural pronoun, and refers back to the people being addressed by "yaa ayyuha-nnaas". Those people are the people to whom the Qur'ān was revealed, at that time and in the future, but not to the people of earlier times.

[4] The phrase: "wa bath-tha minhumaa rijaalan katheeran wa nisaa" It should be obvious that this phrase does not assert exclusivity of human beings to those who came after the single soul and its zawj.

\section{In summary:}

1 What is the verse saying?

a All people addressed by the Qur'ān - meaning all people from the time of revelation onwards - can with certainty and without exception, trace themselves back to the single soul and its $z a w j$.

2 What is the verse NOT saying?

a Who the single soul and its zawj are.

b When they existed.

c Who or what may or may not have existed before or during their time.

d How the single soul was created

3 What it is unclear about?

a Whether the zawj was created out of the essence of the single soul, or created independently from the same materials as the single soul. Both opinions were held by Qur’ān commentators.

Some of the matters that are unstated by the verse or that are unclear in the verse are indeed indicated by other verses and hadīth. The full body 
of textual evidence strongly indicates that the single soul and its mate are Adam and Eve. There is also a strong body of evidence that strongly indicates that Adam and Eve were created without parents.

When all the evidence is taken together, scripture clearly indicated that:

a Adam and Eve were created miraculously, without parents.

b All people on Earth today are the direct descendants of Adam and Eve.

However, the issue of who or what may or may not have existed before or during the time of Adam and Eve is not addressed by Qur'ān (4:1) or by any of the other scriptural texts. This means that Qur'an $(4: 1)$ cannot be used as evidence to resolve the question of whether God did, or did not, create biological human beings on Earth before Adam's appearance on Earth.

And God knows best.

\section{References}

Ahmad, Israr. 2013. The Process of Creation: A Qur'ānic Perspective. trans. by Absar Ahmad. Lahore: Shirkat Printing Press.

Al-Albānī, Muḥammad Nāṣir al-Dīn. 2000. Șaḥ̄ḥ al-Targh̄̄b wa al-Tarhīb. Volume 3. Riyadh: Maktabah al-Ma'ārif.

Al-`Awnī, As-Sharīf Ḥātim Ibn 'Ārif. 1997. Al-Mursal al-Khafī wa 'Alāqata Bi-Tadlīs. Riyadh: Dār al-Hijra.

Al-Būṭị, Muhammad Sa īd Ramaḍān. 2017. The Greatest Universal Sureties: The Creator's Existence and The Creature's Function. trans. by Nicholas Walter Mogiliansky Lock. Damascus: Dār al-Fikr.

Al-Gharnāṭī, Abū Ḥayyān Athīr ad-Dīn, 2002a. “Tafsīr al-Baḥr al-Muhịị̣.” Al-Tafāsīr. Accessed 8th of November. Available at: https://www.altafsir.com/ Tafasir.asp? tMadhNo=0\&tTafsirNo=19\&tSoraNo=3\&tAyahNo=59\&tDisplay $=$ yes $\&$ Page $=10 \&$ Size $=1 \&$ LanguageId $=1$

Al-Gharnāṭ̄i, Abū Hayyān Athīr ad-Dīn, 2002b. "Tafsīr al-Baḥr al-Muhị̂ṭ." Al-Tafāsīr. Accessed on 8th of November. Available at: https://www.altafsir. $\mathrm{com} /$ Tafasir.asp?tMadhNo=0\&tTafsirNo=19\&tSoraNo=3\&tAyahNo=59\&tDisplay=yes\&Page $=11 \&$ Size $=1 \&$ Language $\mathrm{Id}=1$

Al-Ghazālī, Abū Ḥāmid. 1987. "Al-Mustașfā min 'Ilm al-Uṣūl.” In Ahmad Zaki Mansur Hammad. "Abū Hāmid al-Ghazālī’s Juristic Doctrine in al-Mustașfā min 'Ilm al-Ușul with a Translation of Volume One of al-Mustașfā min 'Ilm al-Ușūl." PhD Diss. Chicago, IL: The University of Chicago.

Al-Ghazālī, Abū Hamid. 2000a. The Incoherence of the Philosophers. Utah: Brigham University Press.

Al-Ghazālī, Abū Ḥamid. 2000b. Al-Mustașfā min 'Ilm al-Ușūl. Beirut: Dār al-Kutub al-'Ilmiyyah.

Al-Ghazālī, Abū Hamid. 2002. On the Boundaries of Theological Tolerance in Islam. trans. by Sherman Jackson. Oxford: Oxford University Press.

Al-Rāzī, Muḥammad Ibn 'Umar (Fakhr al-Dīn). 2000. Mafātz̄h al-Ghayb. Volume 3. Beirut: Dār al-Kutub al-'Ilmiyya.

Alexander, Denis. 2008. Creation or Evolution? Do We Have to Choose? Michigan: Monarch Books. 
Altaie, Basil. 2018. The Divine Word and The Grand Design: Interpreting the Qur'an in the Light of Modern Science. Manchester: Beacon Books.

'Ațiyya, Hasan Hamad. 1999. Min al-Wahy ela Darwin Qadiyat al-Khalq. Beirut: Dār al-Khayyāl.

Ayoub, Mahmoud M. 2005. "Creation of Evolution? The Reception of Darwinism in Modern Arab Thought." In Zainal Abidin Bagir, ed. Science and Religion in a Post-Colonial World: Interfaith Perspectives. Hindmarsh: ATF Press, 173-190.

Badawi, Elsaid M., and Muhammad Abdel Haleem. 2008. Arabic-English Dictionary of Qur'ānic Usage. Leiden: Brill.

Batchelor, Daud Abdul-Fattah. 2018. "Adam and Eve's Origin: A Theory Harmonising Scientific Evidence With the Qur'ānic Text.” Theology and Science, 15(4): 490-508.

Bigliardi, Stefano. 2014. Islam and the Quest for Modern Science: Conversations with Adnan Oktar, Mehdi Golshani, Mohammed Basil Altaie, Zaghloul El-Naggar, Bruno Guiderdoni and Nidhal Guessoum. Istanbul: The Swedish Research Institute.

Brown, Jonathan A. C. 2009. Hadīths: Muhammad's Legacy in the Medieval and Modern World. Oxford: One World.

Chittick, William C. 1989. The Sufi Path of Knowledge: Ibn al-'Arabī's Metaphysics of Imagination. New York, NY: State University of New York.

Coppens, Pieter. 2018. Seeing God in Sufi Qur'ān Commentaries: Crossings Between This World and the Otherworld. Edinburgh: Edinburgh University Press.

Dajani, Rana. 2012. "Evolution and Islam's Quantum Question.” Zygon, 47(2): 343-353.

Dajani, Rana. 2016. "Evolution and Islam: Is There a Contradiction?” In Muslim World Science Initiative: Islam and Science: Muslim Responses to Science's Big Questions, Islamabad, February 12-13, 2015, 142-151.

Elshahat, Ibrahim, Abdullatif Ahmadi Ramchahi, Mohd Yakub, and Zulkifli Mohd Yusoff. 2019. "Theistic Evolutionists' Views of the Words Bashar and Insān in the Qur’ān: A Critical Analysis.” Afkār, 21: 103-140.

Eissa, Mohamed. 2017. The Jurist and the Theologian: Speculative Theology in Shāfī Legal Theory. Piscataway: Georgia Press.

Futuyma, Douglas, and Mark Kirkpatrick. 2017. Evolution. Sunderland, MA: Sinauer Associates Inc.

Guessoum, Nidhal. 2008. "The Qur'ān, Science and the (Related) Contemporary Muslim Discourse.” Zygon, 43(2): 411-431.

Guessoum, Nidhal. 2010. "Religion Literalism and Science-Related Issues in Contemporary Islam.” Zygon, 45(4): 817-840.

Guessoum, Nidhal. 2011a. Kalam's Necessary Engagement with Modern Science. Dubai: Kalam Research and Media.

Guessoum, Nidhal. 2011b. Islam's Quantum Question: Reconciling Muslim Tradition and Modern Science. London: I.B. Tauris.

Guessoum, Nidhal. 2011c. "Islam and Biological Evolution: Exploring Classical Sources and Methodologies by David Solomon Jalajel." Journal of Islamic Studies, 22(3): 476-479.

Haarsma, Deborah B. 2010. "Science and Religion in Harmony." In Melville Y. Stewart, ed. Science and Religion in Dialogue. Volume 1. West Sussex: WileyBlackwell, 107-119.

Haleem, Muhammad Abdel. 2005. The Qur'ān: A New Translation. Oxford: Oxford University Press. 


\section{6}

Haleem, Muhammad Abdel. 2011. Understanding the Qur'ann: Themes and Style. London: I.B. Tauris.

Howard, Damian A. 2011. Being Human in Islam: The Impact of the Evolutionary Worldview. Abingdon: Routledge.

Ibn 'Ashūr, Muḥammad al-Ṭāhir. 1984. Al-Taḥīr wa-l-Tanwīr. Volume 1. Tunis: Al-Dār al-Tūnisiyya lī al-Nashr.

Ibn Kathīr, Abū l-Fidā’ Ismā '̂̀l Ibn 'Umar. 2018. Tafsīr Al-Qur'ān al-'Az̄ìm. Volume 1. Riyadh: Dār Ibn al-Jawzi.

Iqbal, Muhammad. 2012. The Reconstruction of Religious Thought in Islam. New Delhi: Kitab Bhavan.

Jalajel, David Solomon. 2009. Islam and Biological Evolution. Western Cape: University of the Western Cape.

Jalajel, David Solomon. 2018. "Tawaqquf and Acceptance of Human Evolution.” Yaqeen Institute. Accessed 1st of January 2020. Available at: https://yaqeeninstitute. org/dr-david-solomon-jalajel/tawaqquf-and-acceptance-of-human-evolution/\#. Xgw_HxczbPA

Kars, Ardogan. 2019. Unsaying God: Negative Theology in Medieval Islam. Cambridge: Cambridge University Press.

Keller, Nuh Ha Mim. 2011. Sea Without Shore: A Manual of the Sufi Path. Amman: Sunna Books.

Lane, Edward William. 2010a. Arabic English Lexicon. Volume 1. New Delhi: Kitab Bhavan.

Lane, Edward William. 2010b. Arabic English Lexicon. Volume 2. New Delhi: Kitab Bhavan.

Losos, Jonathon B. 2014. The Princeton Guide to Evolution. Princeton, NJ: Princeton University Press.

Majid, D. S. Adnan. 2015. “Qur'ānic Interpretative Latitude and Human Evolution: A Case Study.” Al-Bayan - Journal of Qur'ān and Hadìths Studies, 12: 95-114.

Malik, Shoaib Ahmed. 2021. "Al-Ghazālīs Divine Command Theory - Biting the Bullet.” Journal of Religious Ethics, revised and resubmitted.

Mourison, Robert G. 2002. “The Portrayal of Nature in a Medieval Qur’ān Commentary.” Studia Islamica, 94: 115-137.

Nasr, Seyyed Hossein. 2006. "On the Question of Biological Origins." Islam and Science, 4(2): 181-197.

Nasr, Seyyed Hossein. ed. 2015. The Study Qur'ān: A New Translation and Commentary. New York, NY: HarperOne.

Omar, Abdul Mannan. 2010. Dictionary of the Holy Qur'ān, Arabic-English. Noor Foundation International.

Qadhi, Yasir, and Nazir Khan. 2018. "Human Origins: Theological Conclusions and Empirical Limitations." Yaqeen Institute. Accessed 19th of August 2020. Available at: https://yaqeeninstitute.org/nazir-khan/human-origins-theologicalconclusions-and-empirical-limitations/

Qadhi, Yasir, David Solomon Jalajel, and Shoaib Ahmed Malik. 2020. “(2/2) CLASSICAL ISLAMIC THEOLOGY AND THE QUESTION OF BIOLOGICAL EVOLUTION-David Jalajel, Yasir Qadhi.” YouTube. Debates in Modern Kalam. Accessed 29th of December 2020. Available at: https://youtu.be/iKk_96nG99M

Richardson, Kara. 2020. "Causation in Arabic and Islamic Thought.” The Stanford Encyclopedia of Philosophy. Accessed 10th of November 2020. Available at: https://plato.stanford.edu/archives/fall2020/entries/arabic-islamic-causation/ 
Saeed, Sohaib. 2019. "The Shāhīn Affair and the Evolution of Usūl al-Tafsīr.” Journal of Qur'annic Studies, 21(3): 114-144.

Shah, Zulfiqar Ali. 2012. Anthropomorphic Depictions of God: The Concept of God in Judaic, Christian Ad Islamic Traditions: Representing the Unrepresentable. London: The International Institute of Islamic Thought.

Shanavas, T. O. 2005. Creation And/Or Evolution: an Islamic Perspective. Philadelphia, PA: XLibris.

Shanavas, T. O. 2010. Islamic Theory of Evolution: The Missing Link between Darwin and the Origin of Species. USA: Brainbow Press.

Taslaman, Caner. 2020. Can a Muslim Be an Evolutionist? Istanbul: Istanbul Yayınevi.

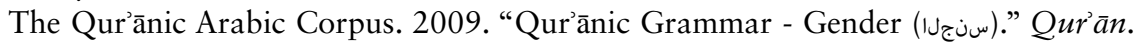
Accessed 22nd of June 2018. Available at: http://corpus.quran.com/documentation/ gender.jsp

Wohlman, Avital. 2010. Al-Ghazali, Averroës and the Interpretation of the Qur'ān. trans. by David Burrell. Abingdon: Routledge.

Zaman, Muntasir. 2020. At the Crossroads of Science and Scripture: An Analysis of the Hadith on Prophet Adam's Height (Unpublished manuscript). 


\section{Conclusion}

We have come a long way since the start of this book, so it will be helpful to pick up all the different strands discussed in the previous chapters with a conclusion.

In Part 1, we did the background work to help frame the discussion for the coming chapters. We looked at what evolution is and isn't scientifically in Chapter 1. This included going through the various, technical concepts that make up Neo-Darwinism. Furthermore, we reviewed the history of evolution through which we were able to appreciate the differences between Darwinism, Neo-Darwinism, and Lamarckism. The chapter also attempted to tease out and dispel the various misconceptions and negative connotations surrounding the topic of evolution. Chapter 2 looked at the Christian responses to evolution. Given that Christianity has had the most immediate and long-term engagement with the discussion, it was a necessary undertaking because it helped with appreciating how Christian thinkers have responded to this idea. We reviewed and highlighted the overlaps and differences of young-earth creationism, old-earth creationism, intelligent design, and theistic evolution. We also noted three particular hermeneutic issues that concerned some thinkers. These included the universe's/earth's age, Noah's flood, and prophetic lineage.

In Part 2, we saw numerous opinions on Islam and evolution. If anything, it reflects a growing maturity of the topic. Chapter 3 looked at the various Qurānic verses hadīths that were used to help draw a general narrative of creation in Islamic scripture. The most contentious part was Adam's creation. Additionally, the earth's age, Noah's flood, and prophetic lineages were concluded to be unproblematic in Islamic scripture compared to the hermeneutic concerns raised by some Christian thinkers in Chapter 2. In Chapter 4, we looked at a suggested classification that can potentially help the discourse. The classification is consciously unidimensional, i.e. focuses on only one thing, so comparing different thinkers is easier. It relies on distinguishing between what each thinker accepts and rejects part of common ancestry, and the reasons for why they do so. Accordingly, we obtained four distinctive positions:

1 Creationism - everything was created instantaneously, and so common ancestry is false; 
2 Human exceptionalism - everything has common ancestry except for Adam and humans;

3 Adamic exceptionalism - everything has common ancestry except for Adam;

4 No exceptions - nothing is an exception to common ancestry.

Sometimes people reached the same conclusion/position but for different reasons. Creationists and proponents of the no exceptions camp each had diverse arguments for their case, illustrating the several variables that affect the conversations, and the different motivations thinkers occupy in this discourse. Broadly, these can be divided into scientific, metaphysical, and hermeneutic. Since this book's focus is theological, the scientific issues were not entertained further than Chapter 4, after which the science was taken as a given, and the focus was entirely on the metaphysical and hermeneutic issues. We also noted the errors of modern thinkers trying to identify evolutionary ideas in the works of historical works written by medieval Muslim thinkers in Chapter 5. These were determined to be problematic readings because they relied on truncated texts.

There were six metaphysical concerns that were identified which were thought to be either problematic or problematised because of evolution in Parts 1 and 2:

1 Naturalism;

2 Chance;

3 Inefficiency;

4 Intelligent design;

5 Evil and suffering;

6 Objective morality.

These concerns were addressed in Part 3. Al-Ghazālī's presentation of the Ash'arite framework and the first three contentions were addressed in Chapter 6. We saw that evolution doesn't have to be interpreted naturalistically. Methodological naturalism is a comfortable position that Muslims can adopt while studying evolution (and any other science, in fact). Furthermore, chance is not an issue because physical processes that are either deterministic or indeterministic can be happily aligned with the Ash'arite worldview. Concerning this point, chance-like mechanics in creation don't undermine ultimate teleology, which is revelation-dependent in the Ash arite perspective. Finally, inefficiency is unproblematic in the Ash'arite paradigm. God is a boundless being, and therefore He cannot be compared to any barometer of efficiency. In Chapter 7, we saw that intelligent design's scientific status is uncertain, and it is ultimately up to the scientific establishment to determine its scientific status. It was concluded that if intelligent design is being used as a rival to evolution simply because it appears to be God-friendly, then this is simply unnecessary in 
the Ash arite perspective. What ultimately grounds the Ash'arite worldview is the radical contingency of creation and the necessity of God; whether creation conspicuously demonstrates design or not makes no difference. Finally, in Chapter 8, we concluded that the problem of evil and the problem of objective morality are non-issues in the Ash'arite paradigm. Axiological considerations don't bind God, and therefore evil and suffering are deemed unproblematic from the Ash arite perspective. Putting all these points together, from a metaphysical perspective, al-Ghazālī's Ash'arite framework is entirely compatible with creationism, human exceptionalism, Adamic exceptionalism, and no exceptions.

The hermeneutic component of the discussion was reserved for Part 4. We looked at al-Ghazālî̀s hermeneutic considerations in Chapter 9 followed by an evaluation of the various hermeneutic proposals that argue against and for evolution using scripture through al-Ghazālîs's hermeneutic framework in Chapter 10. Critics who argue against evolution through scripture use arguments related to Adam's garden, the mention of God's hands, and man's nobility. However, each of these arguments was found wanting. With the no exceptions camp, we saw that advocates adopt either the metaphor track, or the bashar-insann approach, or they find readily available evolutionary readings in the Qur'ān. These approaches were found to be problematic because they were either methodologically inconsistent, strained the semantic possibilities of the verses involved, or neglected some verses that are relevant to the discussion. The most important verse in the entire discussion is the similitude of Jesus and Adam (Qur'ān 3:59), which makes it difficult to assign parental agency to Adam. It was also found that the hadīths relevant to the discussion are $\bar{a} h \bar{a} d$, but they can easily be accommodated and aligned with creationism, human exceptionalism, and Adamic exceptionalism. The no exception camp may have issues with some of them, particularly the hadīths which discuss Adam's creation from earthly materials. Against these considerations, human exceptionalism as argued by Yasir Qadhi and Nazir Khan, and Adamic exceptionalism as argued by David Solomon Jalajel fared better. Qadhi and Khan's proposal might be metaphysically problematic on three fronts. The first is the problem of divine deception, the second is the issue of incest, and the third is the genetic bottleneck problem. All of them are entirely unproblematic when viewed from al-Ghazālī's metaphysical framework. However, Jalajel's proposal does better in this regard. It permits the possibility of pre/co-Adamic humans who could have come about through evolutionary processes, making Adam the only exception to the process. Subsequently, al-Ghazālī's framework is hermeneutically compatible with creationism, human exceptionalism, and Adamic exceptionalism but not with no exceptions. Al-Ghazālī’s metaphysical and hermeneutic compatibilities have been summarised in Table Conc. 1 in light of the preceding points.

It is then metaphysically possible that Adam and Eve were born with parents, but the hermeneutic considerations preclude the no exceptions 
Table Conc.1 Summary of al-Ghazālī’s compatibility with common descent

\begin{tabular}{lcc}
\hline Position & Metaphysical compatibility & Hermeneutic compatibility \\
\hline Creationism & $\boldsymbol{v}$ & $\mathbf{v}$ \\
Human exceptionalism & $\boldsymbol{v}$ & $\mathbf{v}$ \\
Adamic exceptionalism & $\boldsymbol{v}$ & $\mathbf{v}$ \\
No exceptions & $\boldsymbol{v}$ & $\mathbf{x}$ \\
\hline
\end{tabular}

scenario. Since scripture is a weighty import in al-Ghazālī's framework, the closest alignment one can get between Islam and evolution would be Adamic exceptionalism as argued by Jalajel.

\section{Future research}

This book isn't the last word on the matter, and nor should it be. There is still much stimulating work to be done in the discourse of Islam and evolution. The following are some non-exhaustive suggestions.

Limitations of this book - There are plenty of considerations that might have been missed from this analysis. Perhaps other crucial Qurāanic verse(s) and/or hadīth(s) were missed from the preceding chapters. Maybe there was an exegesis that was crucial to the conversation which was not reviewed here. Or perhaps how al-Ghazālī was interpreted or applied in this work might be at fault. The reader might not agree with reading al-Ghazālī as an Ash'arite thinker, nor how his hermeneutics was solely viewed from a theological lens. On another note, perhaps the adopted classification might be seen as being too restrictive, limited, or not useful. All of these are possible limitations of this study, and it is hoped that they can be picked up by future researchers who can then take this work into new directions.

Theological/Philosophical - In this work, we only looked at the Ash'arite perspective. How would evolution fare from the lens of other perspectives from Islamic intellectual history like Māturīdism, Atharism, Avicennism, Mu'tazilism, Sufism? ${ }^{1}$ How would Shi'ī perspectives of evolution look like? These are all exciting avenues that are waiting to be studied. There is also the question of theological anthropology, i.e. the study of humanity or human nature in light of theology. Are humans essentially the soul? Or are they the conjunction of body and soul? And how might these different answers impact the discussion of Islam and evolution? ${ }^{2}$

Philosophy of Science - The fascinating discussion of scientific (anti-) realism in the remit of philosophy of science might be an important area worthy of examination. These are generally discussed within the context of physics, e.g. the really tiny and inaccessible unobservables such as virtual particles or theoretical entities posed by theories and equations. However, and as far as I can tell, two recent works have looked at how historical 


\section{Conclusion}

sciences like evolution affect the conversation of scientific realism (Turner 2007; Currie 2018). How these ideas might intersect with reconciliation strategies between Islam and evolution could be a fruitful area to explore. ${ }^{3}$

Hermeneutic - Are there any hermeneutic attempts which completely allow evolutionary readings, including Adam, that bypass the criticism discussed in this work? Evolution may be a modern concept, but did any exegetes discuss the possibility of their being pre/co-Adamic human beings in history? Or was Adam being the first of humankind the standard hermeneutic narrative for the past 1,400 years since Islam's inception? It would also be interesting to see detailed analyses of other hadīths missed or not scrutinised further in this work.

Historical - Surveys of Muslims' perspectives on evolution are slowly coming to the fore, but these are largely focused on the Middle East and North Africa (MENA), and South-East Asian contexts (see references in Chapter 4). Are there any Muslim perspectives from other areas that could help understand how evolution was received and appropriated more broadly in the Muslim world? One fascinating inquiry would be to determine if Charles Darwin himself had any Muslim contemporaries he was in contact with, and how they understood and responded to his theory. Furthermore, as we saw in Chapter 5, some contemporary thinkers impose evolutionary reading on medieval Muslim scholars' historical works. While the reviewed historical thinkers in that chapter did not adopt evolutionary readings, there might be yet undiscovered manuscripts containing discussions of something similar. So it raises the question: were there any Muslim scholars that came close to ideas like deep time, common ancestry, and mechanics of speciation before Darwin?

Sociological - As seen in Chapter 4, the literature on the sociological studies on Muslims and evolution is slowly developing. Critical conversations over how questions are framed in surveys are being discussed, which, in turn, should increase our resolution of understanding Muslims' attitudes towards evolution. However, as far as I am aware, there isn't any survey that makes Adamic exceptionalism a category of choice. Perhaps this could be picked up in sociological studies that might aid or further develop our understanding of Muslim perspectives on evolution.

Interreligious - Evolution is an intriguing question for all religions, not just Islam. Where and how Muslim thinkers differ and overlap with intellectuals of other religious traditions over the question of evolution is an excellent space for fostering interreligious dialogue and learning. Potential analyses could involve juxtaposing modern thinkers. For instance, Sharp (2018) recently compared the thoughts of Keith Ward - a well-known Christian philosopher - and Nidhal Guessoum on theistic evolution. Other kinds of work could involve looking at how historical, intellectual traditions carried within and across religious traditions may overlap and differ, e.g. a comparison of Ash'arism and Aquinas-Aristotelian thought in the context of evolution. These are exciting but yet unchartered territories that 
will yield much-needed insight into how different religious communities grapple with questions pertaining to science and religion.

All of these suggestions are fruitful lines of inquiries that can help our understanding of the growing conversation of Islam and evolution in particular, and Islam and science more broadly. I can only hope the reader found this work helpful even if the adoption of al-Ghazālì's framework and the resulting conclusions were not agreeable. If I have been able to help systematise the discourse and clarify any misconceptions, I consider this to be a major milestone in the ongoing conversation of Islam and evolution.

Ultimately, God knows best (Allähu'a'lam).

\section{Notes}

1 To be sure, as we saw in the Introduction and Chapter 4, Jalajel's analysis was done from the broad denominators of the Ash 'arism, Māturīdism, and Atharism. Also, Qadhi and Khan briefly looked at evolution from an Athari perspective. The suggestion here is to perhaps advance the discussions by taking on the idiosyncrasies of each school and discussing all the relevant metaphysical and hermeneutic considerations in detail as was done for Ash'arism in this work.

2 The reader may have noted that I didn't address this particular idea in this work. Given the limitations of time and space, I prioritised what I felt were the primary issues of the discussion. Looking at theological anthropology in the context of evolution from the lens of al-Ghazālī's framework will a subject of future work. For the intrigued reader, Othman (1960) and Gianotti (2001) are excellent surveys on al-Ghazālì's ideas on the nature of man.

3 While this point was very briefly alluded to by Qadhi and Khan, it didn't contain any thorough engagement with the topic.

\section{References}

Currie, Adrian. 2018. Rock, Bone, and Ruin: An Optimist's Guide to the Historical Sciences. Cambridge, MA: The MIT Press.

Gianotti, Timothy J. 2001. Al-Ghazālì's Unspeakable Doctrine of the Soul: Unveiling the Esoteric Psychology and Eschatology of the Ihya $\vec{a}$. Leiden: Brill.

Othman, Ali Issa. 1960. The Concept of Man in Islam: In the Writings of al-Ghazali. Cairo: Dār al-Ma'ārif.

Sharp, James. 2018. "Theistic Evolution in Christianity and Islam: Two Approaches to Creation and Science in Historical Perspective." PhD Diss. Claremont: Claremont Graduate University.

Turner, Derek. 2007. Making Prehistory: Historical Science and the Scientific Realism Debate. Cambridge: Cambridge University Press. 


\section{Index}

Note: Page numbers in bold denote tables, and page numbers in italics denote figures.

Adam: hadīths 94-99, 317, 322-325; Qur’ànic verses 94-99, 301-322

Adamic exceptionalism 111, 113, 136; David Solomon Jalajel 7, 133-136, 144, 149n24, 149n25, 149n26, 311-312, 318-322, 325-330, 332n17, 332-334n18

Al-Ghazālī: Ash'arite metaphysics 180-187; differing opinions 10 ; hermeneutic framework 267-291

Al-Jāḥiz 158-159, 166-169

Creationism: broad and narrow meaning 78-79, 80n17; Harun Yahya 4, 14n2, 53, 54, 120-121, 148n11, 212, 226; Islamic creationism 111, 113, 114-121; Mohammed Shihabuddin Nadvi 119; Muḥammad Sa īd Ramaḍān Al-Būṭ̄i 118-119, 302; Muzaffar Iqbal 116-117, 148n8, 213; old-earth 70-73, 78, 109; Osman Bakar 114-116, 206n10; Seyyed Hossein Nasr 114-116, 206n10; Shaikh Mabud 117-118, 148n9, 149n23; young-earth 67-70, 78, 109; Zakir Naik 4, 47, 114

Divine action project 179, 187-193

Evolution: evidence 32-38; Extended Evolutionary Synthesis 45-46; history 38-46; Lamarckism and Darwinism 40-43; Neo-Darwinism 43-45; principles $22-32$

Great chain of being 39, 155-173 ḥadīth: āhād 145, 272, 279, 287-290, 296, 317, 322-325; 330-331n1; mashhūr 292n20; mustafīẹ 292n20; mutawātir 145, 272, 279-280, 287-290, 317, 323, 330n1, 331n2

Human exceptionalism 111, 113, 131;

Nazir Khan 7, 124-133, 147, 301-302, 312, 326-329; Nuh Ha Mim Keller 5, 50, 121-124, 147, 148n15, 194-195, 206n17, 301, 305-306, 331n8; Yasir Qadhi 7, 124-133, 147, 149n24, 301-302, $312,326-329,332 \mathrm{n} 17$

Ibn Khāldun 158-162 Ikhwān al-Ṣafā 158, 169-172 Intelligent design 73-75, 78, 109, 212-236: criticism 76-77, 225-230; irreducible complexity 215-219, 217; Michael Behe 73, 78, 117, 120, 215-219; scientific status 219-225; Stephen Meyer 73-75, 78

Laws of nature $53,72,76,98,144$, 146, 184-186, 188-193, 196, 201, 206n9, 206n15, 229, 231, 238, 270, 299, 300, 311, 316, 318-319, 326; miracle(s) 3, 7, 76, 99, 102n11, 126, 133, 135, 136, 145-146, 184, 187, 188-192, 196-197, 205n3, 270, 271, 274, 276, 277, 278, 291, 297-301, 306, 311-312, 318-319, 322, 325-330, 331n4

Metaphysical problems: chance and God 197-199; chance and teleology 200-203; inefficiency of evolution 
and God 203-204; naturalism and God 194-197; objective morality and evolution 255-256; problem of evil and evolution 254-255

Methodological naturalism 54, 80n12, 194-197

No exceptions evolution 111, 113: Basil Altaie 143-144, 314; Caner Taslaman 144-146, 318-322; Daud Abdul-Fattah Batchelor 144, 315318; Israr Ahmad 142-143, 305, 309-311; Mohamed Iqbal 138-139, 149n28, 173n6; 306-308; Nidhal
Guessoum 14n5, 139-141, 158, 164-166, 298-301, 309-314, 324, 331n4, 342; Rana Dajani 137-138, 173n6, 298, 303-304, 306-308; T.O. Shanavas $143,158,314-315$, $331 n 9$

Rūmī 159, 162-166

Scientism 3, 4, 192, 197, 204, 206n14, 297, 300, 306, 331n5

Theistic evolution 59n33, 76-77, 78, 109 